Making the Medieval Relevant 


\section{Das Mittelalter \\ Perspektiven mediävistischer Forschung}

Beihefte

Herausgegeben von

Ingrid Baumgärtner, Stephan Conermann und Thomas Honegger

\section{Band 6}




\section{Making the Medieval Relevant}

How Medieval Studies Contribute to Improving our Understanding of the Present

Edited by

Chris Jones, Conor Kostick, and Klaus Oschema

\section{DE GRUYTER}


The publication of this book has been generously supported by a British Academy Rising Star Engagement Award, by the Mediävistenverband e.V., and by open access grants from the University of Canterbury (Christchurch, New Zealand) and the Ruhr-University Bochum (Germany).

ISBN 978-3-11-054530-2

e-ISBN (PDF) 978-3-11-054631-6

e-ISBN (EPUB) 978-3-11-054648-4

\section{(c) BY-NC-ND}

This work is licensed under a Creative Commons Attribution-NonCommercial-NoDerivatives 4.0 International License. For details go to http://creativecommons.org/licenses/by-nc-nd/4.0/.

\section{Library of Congress Control Number: 2018958050}

\section{Bibliographic information published by the Deutsche Nationalbibliothek}

The Deutsche Nationalbibliothek lists this publication in the Deutsche Nationalbibliografie; detailed bibliographic data are available on the Internet at http://dnb.dnb.de.

(C) 2020 Chris Jones, Conor Kostick, Klaus Oschema, published by Walter de Gruyter GmbH, Berlin/Boston.

The book is published with open access at www.degruyter.com.

Typesetting: Integra Software Services Pvt. Ltd.

Printing and binding: $\mathrm{CPI}$ books $\mathrm{GmbH}$, Leck

www.degruyter.com 


\section{Contents}

Chris Jones, Conor Kostick, and Klaus Oschema

Why Should we Care about the Middle Ages? Putting the Case for the

Relevance of Studying Medieval Europe - 1

\section{Science}

Tobias Kluge and Maximilian Schuh

Providing Reliable Data? Combining Scientific and Historical Perspectives on

Flooding Events in Medieval and Early Modern Nuremberg (1400-1800) — 31

Conor Kostick and Francis Ludlow

Medieval History, Explosive Volcanism, and the Geoengineering Debate - 45

Jörg Feuchter

The Middle Ages in the Genetics Lab - 99

Freya Harrison and Erin Connelly

Could Medieval Medicine Help the Fight Against Antimicrobial Resistance? — 113

\section{Education}

Julien Demade

The Contemporary Delegitimization of (Medieval) History - and of the Traditional University Curriculum as a Whole — 135

Chris Jones and Madi Williams

Pacific Perspectives: Why study Europe's Middle Ages in Aotearoa New

Zealand? 151

Laura Grazia Di Stefano

How to be a Time Traveller: Exploring Venice with a Fifteenth-Century Pilgrimage Guide -171 


\section{Society}

Klaus Oschema

Heaven Can Tell ... Late Medieval Astrologers as Experts - and what they can

Teach us about Contemporary Financial Expertise — 191

Elva Johnston

Eoin MacNeill's Early Medieval Ireland: A Scholarship for Politics or a Politics of Scholarship? - 211

Hélène Sirantoine

What's in a Word? Naming 'Muslims' in Medieval Christian Iberia — 225

Niamh Wycherley

The Enduring Power of the Cult of Relics - an Irish Perspective - 239

Ben Jervis

Resilience and Society in Medieval Southampton: An Archaeological Approach to Anticipatory Action, Politics, and Economy — 255

\section{Reflections}

Pierre Monnet

Studying the Middle Ages: Historical Food for Thought in the Present Day -277

Notes on Contributors -289

Index 293 


\title{
Why Should we Care about the Middle Ages? Putting the Case for the Relevance of Studying Medieval Europe
}

\begin{abstract}
This introductory chapter puts forward a case for the continuing importance of studying the European Middle Ages. The early twenty-first century is witness to a boom in popular interest in the medieval, one which is playing a significant role in shaping both politics and popular culture. Paradoxically, while this boom has led to increasing study of 'medievalism', investment in the disciplines that involve the study of the Middle Ages themselves is in relative decline with questions frequently raised about the value of such research. This chapter begins by examining the challenges that necessitate a defence of research whose key focus is the period between the fifth and the fifteenth centuries. It goes on to consider the nature of the relationship that has developed between Modernity and the Middle Ages and reflects on the changing role that medieval scholars have played in society since History emerged as a professional discipline in the nineteenth century. It poses the important question of what a focus on the medieval might offer contemporary society, arguing that a significant distinction should be drawn between 'usefulness' and 'relevance'. It contends that not only does the medieval remain relevant but that that relevance is to be found in surprising, frequently overlooked, areas that range from advancing modern medical knowledge and assessing the impact of climate change to informing contemporary political and social discourse.
\end{abstract}

Keywords: Medieval Studies, historiography, medievalism, History and Society, popular history, ideology, contemporary and modern nationalisms

There is a growing ambivalence concerning the relationship between modern (western) societies and the medieval world from which they sprang. The experience of the first decades of the twenty-first century suggests that attempts at critical reflection on the state of the study of Europe's Middle Ages, and on the relationship between the medieval period and contemporary society in particular, often involve paradoxes,

\footnotetext{
Chris Jones, Department of History, University of Canterbury, Private Bag 4800, Christchurch 8140, New Zealand, chris.jones@canterbury.ac.nz

Conor Kostick, Department of History, School of History \& Humanities, Trinity College Dublin, Dublin 2, Ireland, conorkostick@gmail.com

Klaus Oschema, Geschichte des Mittelalters (insb. des späten Mittelalters), Ruhr-Universität Bochum, Historisches Institut, Universitätsstr. 150, 44801 Bochum, Germany, klaus.oschema@rub.de
}

¿ Open Access. ( 2020 Chris Jones et al., published by De Gruyter. (c) BY-NC-ND This work is licensed under a Creative Commons Attribution-NonCommercial-NoDerivatives 4.0 International License. 
contradictions, and ideological conflicts. ${ }^{1}$ This is, in part, the result of an abuse of the period by those intent on fabricating a mythical 'golden age' to justify abhorrent, racist ideologies. Tragically, on 15 March 2019, a horrifying example of such abuse was evident in connection with the massacre of fifty-one people attending Friday prayers at two mosques in Christchurch, New Zealand: the alleged perpetrator made use of a cycle of medieval images that white supremacists have sought to associate with their repugnant ideology. This dialectic, however, is also a consequence of the way in which the period between the fifth and the fifteenth centuries has proved a fecund source for shaping wider popular culture. The influence of images, concepts, and ideas that are - correctly or wrongly - identified with 'the Middle Ages' can, for example, be felt in the pseudo-medieval, pseudo-Shakespearian world constructed by Kenneth BRANAGH for Marvel Studio's 'Thor' (2011). It informs the re-imagining of Aotearoa New Zealand as J. R. R. TolkIEN's Middle Earth (2001-2014) by Peter JACKSON. And it strongly marks the dark fantasy that is both George R. R. MARTIN's novels and their adaptation by HBO as 'Game of Thrones' (2011-). ${ }^{2}$ Without doubt, these latter are less reprehensible than the twisting of history to create a sense of identity for neo-Nazi groups. But even if these creations are clearly fictional, they have the power to convey images and ideas that shape the attitudes and beliefs of their audiences in the 'real' world.

In recent years, there has been a marked shift in scholarship to focus on popular culture's increasing embrace of the Middle Ages. The trend is termed, by academics at

1 See, for example, Peter RAEDTS, Die Entdeckung des Mittelalters. Geschichte einer Illusion, Darmstadt 2016 (Dutch orig. 2011); Tommaso DI CARPEGNA FALCONIERI, Medioevo militante. La politica di oggi alle prese con barbari e crociati, Turin 2011 (English translation in preparation; we refer to the French translation: Médiéval et militant. Penser le contemporain à travers le Moyen Âge, transl. Michèle GrÉvin, Paris 2015); Valentin GroEBnER, Das Mittelalter hört nicht auf. Über historisches Erzählen, Munich 2008; Jacques LE GofF, Faut-il vraiment découper l'histoire en tranches?, Paris 2014; K. Patrick FAzioli, The Mirror of the Medieval: An Anthropology of the Western Historical Imagination, New York 2017. Inspiring older contributions include: Peter voN Moos, Gefahren des Mittelalterbegriffs. Diagnostische und präventive Aspekte, in: Joachim HEINZLE (ed.), Modernes Mittelalter. Neue Bilder einer populären Epoche, Frankfurt, Leipzig 1994, pp. 33-63.

2 For a detailed study of the latter: Carolyne LARRIngton, Winter is Coming. The Medieval World of Game of Thrones, London, New York 2015 (German transl. by Jörg FüNDLING, Stuttgart 2016); Zita RoHR / Lisa BENZ (eds.), Queenship and the Women of Westeros: Female Agency and Advice in Game of Thrones and A Song of Ice and Fire, Cham 2019 (forthcoming). For a more general perspective see Andrew B. R. ELLIOTT, Medievalism, Politics and Mass Media. Appropriating the Middle Ages in the Twenty-first Century (Medievalism 10), Cambridge 2017. Further studies on constructions of the Middle Ages in popular culture can be found in Tobias ENSELEIT / Christian PETERS (eds.), Bilder vom Mittelalter. Vorstellungen von einer vergangenen Epoche und ihre Inszenierung in modernen Medien (Wissenschaftliche Schriften der WWU Münster. Reihe X, 26), Münster 2017. William BLANc, Winter is Coming. Une brève histoire politique de la fantasy, Montreuil 2019, proposes an interpretation of medievalisms in fantastic literature that underlines the intimate relation with the respective political and social environment and its preoccupations. 
least, 'medievalism'. ${ }^{3}$ While the study of medievalism and the social phenomenon that it represents is laudable, this collection of essays springs from a different interest. Its focus is the continuing social and wider value of research into the Middle Ages themselves, that is the literary, historical, archaeological, and other scholarship that we will group here under the label 'Medieval Studies'.

This volume has a simple objective: to demonstrate why expertise in the field of the Middle Ages remains important to contemporary society. The case is worth making, in part, because there is a real danger that a popular enthusiasm for medievalism may obscure the distinction between the 'real' Middle Ages and modern fantasy, whether the latter is considered dangerous or merely diverting. The potential problem is compounded by the internet, which, while laudably enabling an unprecedented democratization of access to knowledge (in spite of all the barriers that continue to exist), has also removed much of the traditional quality assurance performed by publishers via the process of academic peer review. Professional scholars, and not just those of the Middle Ages, find themselves in increasing danger of being marginalized as irrelevant in a world where few among the wider public see any issue with the primary point of access for an understanding of the past being Wikipedia. ${ }^{4}$

An important issue that arises from the removal of traditional 'gatekeepers' to knowledge is that the line between 'opinion' and 'fact' may become increasingly blurred. So much so, indeed, that Kellyanne ConwAY, then Counsellor to the US President, once - laughably - could claim that she possessed "alternative facts" in the face of convincing evidence concerning the numbers attending Donald TRUMP's

3 For the growing importance of medievalism, see Richard UtZ, Medievalism: A Manifesto (Past Imperfect), Kalamazoo 2017; Louis D'ARCENS (ed.), The Cambridge Companion to Medievalism, Cambridge 2016; Elizabeth EMERY / Richard Utz (eds.), Medievalism. Key Critical Terms, Cambridge 2014, and Bettina BiLDHAUER / Chris Jones (eds.), The Middle Ages in the Modern World, Oxford 2017. Please note, the Chris JONES who edited the latter is not to be conflated with the editor of this volume. For reflections on more political phenomena, see the important collection of articles in János BAK / Jörg JARNuT / Pierre MONNET / Bernd SCHNEIDMÜLLER (eds.), Gebrauch und Missbrauch des Mittelalters, 19.-21. Jahrhundert / Uses and Abuses of the Middle Ages: 19th-21st Century / Usages et Mésusages du Moyen Âge du XIX ${ }^{\mathrm{e}}$ au XXI ${ }^{\mathrm{e}}$ siècle (MittelalterStudien des Instituts zur Interdisziplinären Erforschung des Mittelalters und seines Nachwirkens, Paderborn 17), Munich 2009.

4 For some discussion of the advantages and disadvantages of Wikipedia with regard to history: Roy Rosenzweig, Can History be Open Source? Wikipedia and the Future of the Past, in: Journal of American History 93(1) (2006), pp. 117-146; republished online: https://rrchnm.org/essay/canhistory-be-open-source-wikipedia-and-the-future-of-the-past/ (last accessed 15/05/2019). See also Maren LORENZ, Geschichtsdarstellung und Geschichtsverhandlung in Wikipedia oder: Die Sehnsucht nach Beständigkeit im Unbeständigen, in: Barbara KoRTE / Sylvia PALETSCHEK (eds.), History goes Pop. Zur Repräsentation von Geschichte in populären Medien und Genres, Bielefeld 2009, pp. 289-312, and EAD., Wikipedia - ein Modell für die Zukunft? Zur Gefahr des Verschwindens der Grenzen zwischen Information und Infotainment, in: Marco JoRIo / Cindy EGGS (eds.), “Am Anfang ist das Wort.” Lexika in der Schweiz, Baden / CH 2008, pp. 91-109. 
inauguration as President of the United States. ${ }^{5}$ Europe's Middle Ages are actually a long-suffering victim of an ideological agenda that can confuse oft-stated opinion with reality. The trend began with the 'reporting' of the period by Renaissance scholars, who first applied the label 'the Dark Ages' to the centuries that preceded them. As Peter BURKE once noted, a key error of the nineteenth-century Swiss historian Jacob BURCKHARDT, whose legacy still shapes our conception of the Renaissance and its significance, was to accept these scholars and artists "at their own valuation". ${ }^{6}$ Today, the problem is exacerbated by the fact that we live in a period of growing populism in which politicians, when confronted with unpalatable facts, have a tendency to denigrate the source of those facts by arguing that the public "have had enough of experts". ${ }^{7}$ In such a world, scholars face the danger of being reduced to the role of mere entertainers who, when challenging popular opinion, are considered to offer little more than their own "alternative facts", facts from which the public is entitled to pick and choose as it sees fit.

The above state of affairs makes it necessary to begin by underlining that while the practitioners of Medieval Studies certainly do not lack their own opinions, what constitutes them as members of a professional discipline is that their conclusions, whatever they may be, are based on informed analysis and are subject to rigorous peer review. Western society has reached a crossroads at which it needs to reflect with care on this important distinction. Do we really wish to set the assessments of trained Egyptologists alongside the pronouncements of the YouTuber who declares that the pyramids were built by aliens? Or to entertain the views of those who continue to argue that the Earth is flat, a position ably disproved by, amongst many, Conrad of Megenberg? Conrad even supplied an illustrated proof of the planet's curvature in his mid-fourteenth century 'Deutsche Sphaera'! ${ }^{8}$ To take an apocryphal example, should

5 The phrase was first used by ConwAY in an interview with NBC's "Meet the Press" (22 January 2017), online: https://www.nbcnews.com/meet-the-press/video/conway-press-secretary-gave-alternative-facts -860142147643 (last accessed 15/05/2019).

6 Peter BuRKE, The Renaissance, New York 1997, pp. 2-3 (quote: p. 3). For a sample of Renaissance 'spin' in translation: Loys LE Roy, The Excellence of this Age (1575), in: James B. Ross / Mary M. MCLAUghlin (eds.), The Portable Renaissance Reader, New York 1953, pp. 91-108.

7 This particular statement was made by the then British Justice Secretary, Michael Gove, MP during the BREXIT debate when he was asked to name an economist who supported Britain's exit from the European Union. Henry MANCE, Britain has had enough of experts, says Gove, in: The Financial Times (3 June 2016), online: https://www.ft.com/content/3be49734-29cb-11e6-83e4-abc22d5d108c (15/05/2019). The problem is not limited to the situation in the UK, as witnessed by publications such as Marc E. Fitch, Shmexperts. How Ideology and Power Politics are Disguised as Science, Washington / DC 2015; see also the chapter by Klaus OsCHEMA in this volume.

8 For a recent example concerning the pyramids: Jon Austin, Time Travel Shock: Speed of light is 'final proof aliens built pyramids' claims researcher in: The Express online (2 April 2018), online: https://www.express.co.uk/news/weird/940347/Time-travel-speed-of-light-prof-aliens-built-pyramids -UFO (last accessed 15/05/2019). For a (sceptical) overview of key sites often associated with alleged alien architects: Nadia DRAKE, 7 Ancient Sites Some People Think Were Built by Aliens, in: National 
we accord equal weight to the pronouncements of the oft-anonymous blogger who, having taken a sentence out of its original context, reads it in a poor translation, and subsequently 'reveals' a conspiracy that has been concealed for centuries?' ${ }^{9}$ While the freedom to hold an opinion is a praiseworthy feature of western society, by the same token, it is worth recognizing that not every opinion is an informed one. Or, to put it more simply, in the company of Conway's interviewer, Chuck ToDD, the editors of this volume do not consider "alternative facts" to be facts at all.

Yet, in making an argument for the continuing importance of expertise in Medieval Studies and for the value of studying the 'real' Middle Ages, the editors have no appetite to join the ranks of hapless populist politicians. This volume will not, for example, assert that essential aspects of modern, twenty-first century living, such as the internet, owe their origin to the Middle Ages. ${ }^{10}$ Nor, at the opposite end of the spectrum, will it put the hackneyed argument that the medieval is worth studying simply for its own sake. Make no mistake, we believe that it is. We also recognize that such an argument is unlikely to convince tax payers who, understandably, wonder why they should contribute towards supporting the Humanities as a whole. What, the public might - and should - ask, do the historians do for us? 'Art for art's sake' is an argument only ever likely to convince three groups: an elite who take pleasure in patronage; a fragment of the political establishment who believe in patronizing everyone else with their view of what constitutes 'Culture'; and, of course, practitioners of the Humanities. Our intention is to put a different case based on 'relevance'. ${ }^{11}$ It is a case inspired by a particular concern: that there is a possibility that an understanding of the

Geographic (26 October 2017), online: https://www.nationalgeographic.com/travel/travel-interests/artsand-culture/ancient-sites-built-by-aliens/ (last accessed 15/05/2019). For the continuing popularity of the hilarious - albeit disturbing - view that the Earth is flat: 2018 Flat Earth International Conference, online: https://fe2018.com/about/about-us/ (last accessed 15/05/2019). For the medieval understanding of the Earth's spherical shape: Rudolf SIMEK, Heaven and Earth in the Middle Ages: The Physical World before Columbus, transl. Angela HALL, Woodbridge 1996 (German orig. 1992), pp. 24-38, and for Conrad's proof specifically, p. 32. On the creation of the myth of the "flat earth" see also Jeffrey Burton RuSSEL, Inventing the Flat Earth. Columbus and Modern Historians, Westport / CT, London 1991, and Louise M. BISHOP, The Myth of the Flat Earth, in: Stephen J. HARRIS / Bryon L. GRIGSBY (eds.), Misconceptions about the Middle Ages (Routledge Studies in Medieval Religion and Culture 7), New York, London 2008, pp. 97-101.

9 For a series of essays that debunk widespread popular myths about the Middle Ages, see HARRIS / GRIGSBy (note 8).

10 One example of such populism is the claim in April 2018 by Biplab DeB, chief minister of the north-eastern Indian state of Tripura, that the internet was a product of ancient Indian civilization. He cited the ancient Hindu epic 'Mahabharata' as proof and was, rightly, much ridiculed: Minister ridiculed for saying ancient India invented internet, in: BBC News (18 April 2018), online: http://www.bbc.com/news/world-asia-india-43806078 (15/05/2019).

11 It is worth noting that one peer reviewer of this introduction expressed his / her disgust at this approach. The discipline, they stated, justified itself through its own scientific results, no more, no less; there was no reason to consider its 'relevance' beyond that. While we appreciate the 
'real' Middle Ages may be lost as a result of the enthusiasm with which the medieval has been embraced as a source for the fantastical. Without wishing to argue in favour of a new positivism, this volume will therefore look at some of the broader social and scientific benefits to implementing Leopold VON RANKE's famous, if now somewhat clichéd, dictum that the historian's task is to explore "how things actually were" (wie es eigentlich gewesen). ${ }^{12}$

Is studying the Middle Ages in Europe - and increasingly beyond ${ }^{13}$ - relevant in the twenty-first century? We believe that not only does the medieval remain relevant but that its relevance is to be found in some surprising places. In this volume, which, of course, represents only a sample of the possible approaches, we have selected what we consider to be a series of powerful case studies that demonstrate the way in which Medieval Studies can contribute solutions to urgent challenges. These challenges include two of the greatest faced by our species: the threat posed by anti-microbial resistance to drug treatments and the impact of climate change. At the same time, the volume contains chapters intended to contribute to informing contemporary political and social discourse.

argument, we consider adopting such a perspective to be blinkered. We hold that we live and work in specific social contexts and that we have a duty to the societies we are a part of (and that enable us to do our work) to reach out and explain the worth of our scientific endeavour. And there is also an element of self-interest here for failure to do so might very well result in the - perhaps even justified - suppression of our (worthwhile) specializations. We cannot help but feel that an inability or unwillingness to recognize this is more than a little naïve.

12 The famous dictum is to be found in the preface to Leopold vON RANKE, Geschichte der lateinischen und germanischen Völker von 1494 bis 1514, Leipzig 1885, p. vii. For discussion of the philosophy of history it embodies and its relationship with positivism: Michael BENTLEY, Modern Historiography. An Introduction, London 1999, pp. 36-42.

13 By employing the expression 'the Middle Ages' as a convenient shorthand for the period between the fifth and the fifteenth century, we do not intend to imply that we subscribe to arguments that researchers should refrain from developing a globalized perspective. For the most recent expression of such views: Thomas BAUER, Warum es kein islamisches Mittelalter gab: Das Erbe der Antike und der Orient, Munich 2018. We consider such arguments to be based on an erroneously 'realistic' understanding of the ontological status of historical periods. In our view, an overwhelming number of contributions with a 'global' focus demonstrate the value of adopting a wider perspective. See, for example, SociéTÉ DES Historiens MÉdiÉVISTES DE l'ENSEIGNEMENT SupÉRIEUR PUBLIC (ed.), Histoire monde, jeux d'échelles et espaces connectés (Publications de la Sorbonne. Série Histoire ancienne et médiévale 151), Paris 2017 (with further bibliographical references). For a more theoretical argument against the use of the term 'Middle Ages' see Bernhard JussEN, Richtig denken im falschen Rahmen? Warum das 'Mittelalter' nicht in den Lehrplan gehört, in: Geschichte in Wissenschaft und Unterricht 67(9-10) (2016), pp. 558-576, and ID., Wer falsch spricht, denkt falsch: Warum Antike, Mittelalter und Neuzeit in die Wissenschaftsgeschichte gehören, in: Spekulative Theorien, Kontroversen, Paradigmenwechsel: Streitgespräch in der Wissenschaftlichen Sitzung der Versammlung der Berlin-Brandenburgischen Akademie der Wissenschaften am 25. November 2016 (BBAW Schriftenreihe 17), Berlin 2017, pp. 38-52. 
We begin, however, by considering the circumstances that have engendered an increasing degree of self-reflection amongst scholars of Medieval Studies: the paradoxical relationship between Modernity and the Middle Ages and the rise and fall of the 'useful' medievalist in western society. We will subsequently explore the important distinction that should be drawn between the 'usefulness' and 'relevance' of Medieval Studies, in the process establishing why trained medieval scholars remain a genuinely valuable asset to the societies of which they are a part.

\section{Modernity \& the Middle Ages: The Conflicted Relationship}

The late German historian Otto G. OEXLE (d. 2016) repeatedly analysed the relationship between medieval cultures, their legacies, and contemporary society. He described the resulting image of the medieval period as "entzweites Mittelalter", a nearly untranslatable notion that might approximate as the "disunited Middle Ages". In doing so, he was alluding to an almost schizophrenic underlying principle. ${ }^{14}$ According to OEXLE, the very essence of Modernity is defined by its ambivalent relationship with the Middle Ages. The latter serve as a necessary and indispensable negative foil for the positive self-assessment of 'modern culture': they were a dark and brutal period in which everything positive that characterizes the progressive developments that allow us to live in the bright age of Modernity had yet to come into existence. Seen from this perspective, the Middle Ages were a (regrettably) uncivilized period that we had to overcome. Today, according to the Panglossian modernist, this task is accomplished.

Celebrating Modernity via a complacent comparison with the medieval period is, of course, by no means simple and straightforward, especially since people living in western societies have felt, since the dawn of Modernity, that something has been lost along the way. Modern life is replete with negative experiences that can easily make people feel alienated..$^{15}$ It is hard, for instance, to find the answers to quite fundamental questions: 'What's it all for?', 'Where do we come from?', and 'Where are we going?'. As a consequence, there have always been those, from the eighteenthcentury Romantics to the present day, who looked back to earlier periods with a

\footnotetext{
14 Otto G. OExLE, Das entzweite Mittelalter, in: Gerd Althoff (ed.), Die Deutschen und ihr Mittelalter. Themen und Funktionen moderner Geschichtsbilder vom Mittelalter (Ausblicke. Essays und Analysen zu Geschichte und Politik), Darmstadt 1992, pp. 7-28 and 168-177; ID., Die Moderne und ihr Mittelalter. Eine folgenreiche Problemgeschichte, in: Peter SEGL (ed.), Mittelalter und Moderne. Entdeckung und Rekonstruktion der mittelalterlichen Welt. Kongreßakten des 6. Symposiums des Mediävistenverbandes in Bayreuth 1995, Sigmaringen 1997, pp. 307-364; ID., Die Gegenwart des Mittelalters (Das mittelalterliche Jahrtausend 1), Berlin 2013.

15 See, for example, Anthony GIDDENS, The Consequences of Modernity, Cambridge 1990.
} 
feeling of loss and nostalgia: was the world of our forefathers not wonderfully simple and meaningful in comparison to our own?

In the end, it does not really matter which of the two modes of relating to the Middle Ages the individual prefers. ${ }^{16}$ Both are inextricably linked to the development of Modernity: having a sense of what it means to live in the Modern era requires a sense of what it means to live in the medieval era.

For medievalists, however, OEXLE's analysis could not be more attractive, since its implications offer an indisputable justification for research into the distant period that we label 'medieval'. While it might be suggested such knowledge is nice to have, it would be easy to argue that medieval scholarship is not indispensable for us to function in the present day. It is, of course, interesting to know, for example, that modern glasses, pizza, or the fork constitute medieval inventions, yet it seems hardly necessary to know about these distant origins in order to produce excellent glasses or pizza. ${ }^{17}$ According to OEXLE's argument, understanding this period provides us with far more than just knowledge about the emergence of our modern societies, rather, the Middle Ages are indelibly imprinted into Modernity's 'genes', which means that knowledge of the medieval is of immediate consequence for our understanding of our own contemporary societies.

Thus far OEXLE. But we believe matters to be even more complicated than the above sketch would suggest. The presence and effects of medieval objects and motifs in the modern world cannot be neatly categorized: in fact, the more one reflects on the situation of Medieval Studies and medievalism in contemporary societies, the more one realises the enormous multiplicity of situations, contexts, and meanings that need to be taken into account. As was noted above, the early twenty-first century is witness to an overwhelming interest in things medieval in popular culture. ${ }^{18}$ Some of the products that witness this success are intimately connected with Medieval Studies, even though their aim is, principally, popularization. One notable

16 The situation is, of course, far more complex than this simplified distinction of two modes might imply: While the position towards the Middle Ages was rapidly used as an argument, for example, in the debates between Catholics (who tended to underline tradition and continuity) and Protestants (who preferred to reach back to early Christianity, perceiving the Middle Ages as a period of decadence and decline) - see Coen MAAS, Medievalism and Political Rhetoric in Humanist Historiography from the Low Countries (1515-1609) (Proteus 7), Turnhout 2018, pp. 35-36 - there is no entirely clear-cut distinction along these major ideological fault-lines, see the examples given in RAEDTS (note 1), pp. 54-60. An analogous case can be made for the widespread preconception that only conservative or even nationalist political positions tend to use references to the Middle Ages: As DI CARPEGNA FALCONIERI (note 1), pp. 111-128, demonstrates, the period between the 1960s and 1980s in particular witnessed the creation of the image of an 'anarchic' (and thus politically left-leaning) Middle Ages.

17 See the wonderfully narrated account by Chiara FruGonI, Books, Banks, Buttons, and Other Inventions from the Middle Ages, transl. William McCuAIG, New York 2003 (Ital. orig. 2001).

18 See above, note 2 . 
example is exhibitions on medieval topics, which have had an astonishing success in the course of the last two decades. ${ }^{19}$ Others are more loosely linked to academia: one might think of leisure activities ranging from re-enactment and living-history movements to medieval markets. ${ }^{20}$ And the list goes on.

Contemporary political discourse is marked by a similar interest in the medieval. With the (re-)awakening of nationalistic political movements after the fall of the Berlin Wall and the re-organization of the political landscape of Eastern Europe and beyond, allusions to historical events and medieval developments have become increasingly prominent. ${ }^{21}$ The Middle Ages are considered the alleged 'cradle' of many nation-states. ${ }^{22}$ Absurd as their practices might seem, one can hardly ignore the fact that movements like the so-called 'Alt-Right' in the United States and beyond use symbolism mis-appropriated from the medieval to create and claim a (racist) identity and to pursue identity politics. ${ }^{23}$

Eighteen of the many terms scrawled in white writing on the body armour and weapons of the alleged perpetrator of the March 2019 New Zealand mosque attacks were references to medieval figures and events, prominent among them being

19 On German exhibitions since the late 1990s, Simone HeImann, Das Mittelalter endet gestern. Überlegungen zum Mittelalter in Sonderausstellungen, in: Sascha BÜTOW / Peter RIEDEL / Uwe TRESP (eds.), Das Mittelalter endet gestern. Beiträge zur Landes-, Kultur- und Ordensgeschichte. HeinzDieter Heimann zum 65. Geburtstag (Studien zur brandenburgischen und vergleichenden Landesgeschichte 16), Berlin 2014, pp. 366-373. One British example is the 2015 exhibition "Magna Carta: Law, Liberty, Legacy", which was described as "the most successful paid exhibition the [British] Library has ever staged, attracting 126,283 visitors (against a target of 80,000)”, see British Library Annual Report and Accounts 2015/16, London 2016, p. 21, online: https://www.bl.uk/abou tus/annrep/2015to2016/annual-report2015-16.pdf (last accessed 15/05/2019).

20 For one prominent example of the former, see the "Society for Creative Anachronism", whose website claims "over 30,000 members residing in countries around the world", online: http://www.sca.org/ (last accessed 15/05/2019).

21 BAK et al. (note 3); see also Patrick GEARY, Writing the Nation: Historians and National Identities from the Nineteenth to the Twenty-First Centuries, in: BILDHAUER / JONES (note 3), pp. 73-86, and the essays in Len SCALES / Oliver ZIMMER (eds.), Power and the Nation in European History, Cambridge 2005. For a critical reaction to the recent revival of nostalgic and uncritically affirmative presentations of national history in France, see William BLANC / Aurore CHÉRY / Christophe NAUDIN, Les historiens de garde, 2nd ed. Paris 2016 (the 3rd ed. was published while this chapter was in press).

22 This has, of course, also to do with the establishment of Historical Studies, and particularly Medieval History, as an academic discipline in the 19th century, see below, note 49.

23 Kimberly A. KuIMEK's paper "At the Front of the Storm: Teaching the Multicultural Middle Ages in the Age of the alt-Right”, delivered at the joint 2018 Medieval Association of the Pacific / Rocky Mountain Medieval \& Renaissance Association (MAP-RMMRA) conference held in Las Vegas offers the latest research on the misappropriation of medieval symbolism by right-wing groups during the 2017 clashes in Charlottesville, Virginia. More generally, see: Daniel WoLLENBERG, Medieval Imagery in Today's Politics (Past Imperfect), Leeds 2018. 
Charles Martel and also the crusades. ${ }^{24}$ By intertwining references to Hitler and twentieth-century fascism with medieval warriors, a white supremacist agenda is tied to a narrative where horrific deeds are intended to appear heroic and part of an (entirely invented) tradition of a racial and religious war stretching back centuries, rather than a foul and unspeakably brutal slaughter of unarmed people. Clearly, these medieval references are acquiring a potency of meaning in our times, even if the potency is derived entirely from contemporary concerns rather than any justifiable legacy of their historical medieval creation.

It quickly becomes clear that medieval names and symbols are used not only to propagate racist positions, but also that their use in this context is just absurd to the professional scholar. ${ }^{25}$ Perhaps one of the oddest cases is the erroneous transformation of the Anglo-Saxon epic poem Beowulf into a translation (allegedly from a Scandinavian original) and, more bizarre still, its adoption as a 'sacred' text by rightwing followers of Odinism. ${ }^{26}$ As a consequence, medievalists find themselves frequently torn between their desire, as citizens, to engage in public discourse - and debunk this sort of fatuous nonsense - and the need to focus on the academic activities that will both maintain their scholarly reputations and meet the standards of an academic profession increasingly dominated by - slightly surreal - metrics. ${ }^{27}$ The

24 Gillian BRockelL, The accused New Zealand shooter and an all-white Europe that never existed, in: Washington Post (16 March 2019), online: https://www.washingtonpost.com/history/2019/03/16/ accused-new-zealand-shooter-an-all-white-europe-that-never-existed/ (last accessed 15/05/2019). Please note this article contains still images taken from the alleged gunman's self-shot live stream. The Chief Censor of the New Zealand Office of Film and Literature Classification has deemed footage from this film and the alleged perpetrator's manifesto, "The Great Replacement", objectionable publications and banned possession, reading, or viewing of them in Aotearoa New Zealand. While it is possible to apply for an exemption to read the manifesto on grounds of legitimate academic research, permission to view the document had not yet been received at the time of writing. It was therefore illegal for the New Zealand-based author to view it. Its content is therefore not considered here.

25 On the immediate aftermath of the events at Charlottesville in August 2017, see, for example, the blog entries by Paul B. Sturtevant, Leaving “Medieval” Charlottesville. Race, Racism, and the Middle Ages, in: The Public Medievalist (17 August 2017), online: https://www.publicmedievalist.com/leav ing-medieval-charlottesville/ (last accessed 15/05/2019), and Mark BRUCE, The Alt-Right is Hijacking the Middle Ages: Medievalists Aren't Going to Let Them, in: surfingedges (18 August 2017), online: https://surfingedges.com/2017/08/18/the-alt-right-is-hijacking-the-middle-ages-medievalists-arentgoing-to-let-them (last accessed 15/05/2019).

26 This topic was discussed as part of Donald BURKE's paper “That's Not the Story I Remember: The Adoption and Interpretation of Beowulf by Far-Right Racialist Groups", delivered at the 2018 MAP-RMMRA conference (see note 23).

27 For this characteristic tension see, for example, Celia Chazelle / Simon Doubleday / Felice LIFSHITZ / Amy G. REMENSNYDER, Introduction, in: ID. (eds.), Why the Middle Ages Matter. Medieval Light on Modern Injustice, Abingdon, New York 2012, pp. 1-14, esp. pp. 5-6. The classic description of this particular tension was, of course, furnished by Max WeBER, Wissenschaft als Beruf, 1917 / 1919. Politik als Beruf, 1919, ed. Wolfgang J. MommSEn / Wolfgang SCHUCHTER / Birgitt MorGEnBRod, 
importance of public engagement is, however, highlighted by the furore that has engulfed Christchurch's rugby team since the March mosque attacks. Since its establishment as part of New Zealand's Super Rugby League in 1996, the team has been known as The Crusaders. At the time of writing, no decision had yet been made concerning the future of the name but the boards of both New Zealand Rugby and the team itself had already begun a process to examine the appropriateness of retaining it. Reflecting on the nature of the religious wars with which the term was inextricably associated, the team had already decided to abandon permanently their traditional pre-game entertainment, which had included knights on horseback wearing crosses and wielding swords. ${ }^{28}$ The issue of a name change has, however, proved extremely contentious in New Zealand society. While many, including the authors, consider the original decision to adopt the name to be, to say the least, naïve, there have been those keen to defend its retention. ${ }^{29}$

The above might lead to the impression that at least the 'popular' Middle Ages are very much 'alive and kicking', a development that would probably have surprized any critical observer between the mid-twentieth century and the 1980 s. $^{30}$ Paradoxically, in spite of the period's evident popularity, funding for academic research on medieval subjects remains under permanent threat. While positions in Medieval History seem relatively stable, other related disciplines are suffering enormously from this trend. This is especially true of Philology and Linguistics, but also of Art History, Literature, and other disciplines, which traditionally reserved an important place for the Middle Ages. ${ }^{31}$ All are under constant pressure to focus more and more on the modern aspects of their objects of study. And today, as the historian Valentin GROEBNER described so

Tübingen 1994, who focussed on a clear distinction between the production of knowledge / truth and values / opinion.

28 Mat KeRmEEn, Super Rugby: Seeking Muslim feedback on Crusaders name 'not fair' so soon after terror attacks, in: Stuff (3 April 2019), online: https://www.stuff.co.nz/sport/rugby/super-rugby /111750672/super-rugby-crusaders-and-nzr-engage-research-company-on-branding-dilemma?rm=a (last accessed 15/05/2019).

29 For some of the varying views expressed in the New Zealand media, see Kevin NoRQUAY, Super Rugby: The time for the Crusaders to put their name to the sword has arrived, in: Stuff (4 April 2019), online: https://www.stuff.co.nz/sport/opinion/111790180/super-rugby-the-time-forthe-crusaders-to-put-their-name-to-the-sword-has-arrived? $\mathrm{rm}=\mathrm{m}$ (last accessed 15/05/2019), and Duncan GARNER, Crusaders should hold the line, and keep their name, in: Stuff (5 April 2019), online: https://www.stuff.co.nz/sport/rugby/super-rugby/111832155/crusaders-should-hold-the-lineand-keep-their-name (last accessed 15/05/2019).

30 Hence František GrAUS, Lebendige Vergangenheit. Überlieferung im Mittelalter und in den Vorstellungen vom Mittelalter, Cologne, Vienna 1975, p. 392, asserted (for post-war western Germany): "Nach 1945 gibt es in der Bundesrepublik de facto kein populäres Mittelalterbild mehr; [...]." ("After 1945 there is, de facto, no longer a popular image of the Middle Ages in the Bundesrepublik; [...]”).

31 Many medievalists in higher education find themselves to be the only representative of the period in their departments, see the essays in Kisha G. TRACY / John P. SEXTON (eds.), The Ballad of the 
well in a 2008 essay on the "never-ending Middle Ages", one frequently feels, as an adult citizen, a little socially awkward when admitting to studying the Middle Ages. ${ }^{32}$ As the editors can testify, in the context of dinner parties the confession 'I am a medieval historian' more often than not elicits superficial recognition and limited curiosity only to be followed by a rapid end to the exchange. Indeed, it often seems that only children of five or under - imbued, it would appear, with an enduring fascination with knights and castles, battles and dragons - fail to see the revelation of a career choice in Medieval Studies as a conversation stopper. They alone consider 'medievalist' a socially acceptable occupation, albeit alongside 'astronaut' and 'princess'.

\section{The Role of the Medievalist in Society}

It seems to the editors that this state of affairs is far from satisfactory. While it is certainly good to be placed in the company of explorers and royalty by one sector of society, as both professional historians of the Middle Ages and adult members of that society - and thus 'responsible citizens' - we feel that we cannot avoid asking: what is it all actually good for? Or, to put it another way: why study medieval history? It is not a new question, and provided the famous starting point for Marc BLOCH’s 1949 “Apologie pour l'histoire ou métier d'historien”. ${ }^{33}$ Such questions are only superficially one-dimensional. They are motivated by a range of - sometimes contradictory - factors, and the answers they can generate are equally multifaceted. As professional medievalists, we are, of course, interested in sound answers that can justify the future of the discipline we belong to. But an insider's perspective cannot - and should not - prevent us from thinking about further contexts: as members of contemporary society, we are also interested in assigning our discipline an appropriate place in the world we inhabit. And, as citizens, we are inclined to ask ourselves what our expertise can contribute.

Lone Medievalist, [s. 1.] 2018 (eBook). The particular threat posed to Medieval Studies within Literature departments in the United States was highlighted at the joint 2018 MAP-RMMRA conference during a round table discussion, "Challenges and Strategies: Valuing the PreModern in the 21st Century”: it was noted that the University of Oregon's administration had recently over-ruled a decision by department faculty to appoint to a tenure-track position with a medieval specialism in favour of a modernist.

32 Groebner (note 1), pp. 16-17.

33 Marc Bloch, Apologie pour l'histoire ou métier d'historien [1949], ed. Étienne Bloch, Paris 1993, p. 69: “Papa, explique moi donc à quoi sert l'histoire.” Various scholars have posed a similar question. See, for example, Ali Benmakhlouf, Pourquoi lire les philosophes arabes, Paris 2015 (referring to medieval Arab philosophers, whose contribution to the history of philosophy the author underlines); Didier MéHu / Néri de Barros Almeida / Marcelo CÂndido da Silva (eds.), Pourquoi étudier le Moyen Âge? Les médiévistes face aux usages sociaux du passé, Paris 2012. 
Their respective careers have led the editors, collectively, to practise their craft in a number of countries ranging across Europe - including Germany, the United Kingdom, Ireland, France, and Switzerland - to North America and to the relative remoteness of Aotearoa New Zealand. In each we have been confronted with the tension between contemporary needs and our seemingly detached and remote area of study. So, how are professional medievalists supposed to react to the recent developments and what would an appropriate response be? Of course, as in any other academic field, the merits and rewards of our discipline reside first and foremost in the new insights we can offer, recognition by our peers, and our readers' interest. At the same time, we have been - and remain - supported in our work by public funding. We are all, in some sense, the servants of the tax payer. If we assume that Medieval Studies should in fact be funded by the public, which we believe is the best means of preventing the research agenda being dominated by any one special interest group, how can we justify this position in a political landscape that is increasingly defined by ideologies of practical application ${ }^{34}$

In current debates, which are widely dominated by questions of utility and pragmatics, of economics and impact, the notion of 'usefulness' often plays an important role. ${ }^{35}$ This is hardly surprising in a world that is increasingly governed by the logic of growth, the accumulation of wealth, and the monetization of every aspect of life. The idea is encapsulated in "Priority 1" of the New Zealand Ministry of Education's long-term strategy for tertiary education, headed, tellingly: "Delivering skills for industry". It outlines what was the then centre-right government's key aim for the tertiary sector in the following terms: "The priority is to ensure that the skills people develop in tertiary education are well matched to labour market needs". It is a strategy that has little room for Medieval Studies unless we interpret such a field as a pathway to "ensuring tertiary education supports development of transferable skills". ${ }^{36}$ Such utilitarian policies may well be mocked by academics who might -

34 Obviously, this question applies not only to the field of Medieval Studies, but is equally important, as can be seen in Julien DEMADE and Pierre MONNET's contributions to this volume, in a number of other disciplines in the Humanities and the Social Sciences.

35 See its prominence in the contributions to Florian KIESINGER / Steffen SEISCHAB / Markus MÜLLER / Timo LANG / Angelika STEINACHER / Christine WÖRNERE (eds.), Wozu Geisteswissenschaften? Kontroverse Argumente für eine überfällige Debatte, Frankfurt am Main 2003; cf. Beat SITTER-LIVER, Der Einspruch der Geisteswissenschaften. Ausgewählte Schriften, ed. Rainer J. SchwEIZER, Freiburg i. Üe. 2002, p. 294. The "VIIIth International Conference of Theory and Philosophy of History" (Viña del Mar, Chile, 30 August-1 September 2017) was dedicated to the question of "The Usefulness of History", online: http://www.inth.ugent.be/news/conference-usefulness-history (last accessed 15/05/2019).

36 At the time of writing, the policy remains in place under the centre-left coalition elected in 2017. It defines the required skills as: "addressing new and emerging shortages in specific areas, such as information and communications technology (ICT) and the science, technology, engineering and mathematics (STEM) skills needed for innovation and economic growth.” New Zealand Ministry of Education Te Tāhuhu o Te Mātauranga, Tertiary Education Strategy 2014-2019 (9 July 2015), online: 
rightly, we believe - argue that the purpose of tertiary education is to develop the ability of the next generation to think critically, ${ }^{37}$ rather than to create economically productive automata with predictable voting habits. We could go so far as to argue that such policies are in fact a danger to democracy.

Yet, even if we consider the - immediate as well as the ultimate - goal of research not to be the production of 'useful' knowledge, but rather of 'truth', ${ }^{38}$ we, personally, would not want to argue for a complete disconnect between the 'real world' and an academy that claims the privilege to retire to oft-vilified 'ivory towers'. But the relationship between the disinterested quest for scientific truth and knowledge and the possible usefulness of its results is by no means as simple and straightforward as one might think. Not least with this in mind, Abraham FLEXNER, the first director of the Institute for Advanced Study (IAS) at Princeton, New Jersey, made a strong case for the pursuit of 'useless' knowledge in science at least as early as 1939. His position was based on the argument that the apparently useless often turned out to become the basis on which useful applications could then be developed. ${ }^{39}$

Perhaps the best example of 'pure' research with 'useful' consequences for modern society is that branch of Physics known as quantum mechanics. Amongst other things, it is only the latter's explanation of semiconductors that enabled the development of the silicon chips on which the bulk of our modern technology is based. ${ }^{40}$ Similarly, research in Mathematics has often run ahead of any obvious deliverable for industry. In Dublin, there is a bridge made famous by the mathematician William Rowan HAMILTON, who, while out walking on 16 October 1843, lacking any writing materials at a moment of inspiration, paused and carved the formula

www.education.govt.nz/further-education/policies-and-strategies/tertiary-education-strategy (last accessed 15/05/2019).

37 See below, note 61, for the important reflexions by Martha Nussbaum.

38 See the famous characterisation of the university by Karl JASPERS, Die Idee der Universität (Schriften der Universität Heidelberg 1), Berlin, Heidelberg 1946, p. 9: "Die Universität ist die Stätte, an der Gesellschaft und Staat das hellste Bewußtsein des Zeitalters sich entfalten lassen. Dort dürfen als Lehrer und Schüler Menschen zusammenkommen, die hier nur den Beruf haben, Wahrheit zu ergreifen. Denn daß irgendwo bedingungslose Wahrheitsforschung stattfinde, ist ein Anspruch des Menschen als Menschen." ("The university is the location where society and state let the brightest consciousness of the age unfold itself. There people may come together as teachers and students, who have only one occupation, namely to seize truth. Because that somewhere the unconditional research of truth should take place, is a claim of mankind as mankind.")

39 Abraham FLEXNER, The Usefulness of Useless Knowledge, in: Harper's Magazine 179 (October 1939), pp. 544-552; see ID., The Usefulness of Useless Knowledge. With a companion essay by Robbert DiJKGRAAF, Princeton 2017.

40 For a layman's guide to the 'usefulness' of quantum mechanics: James KaKaLIos, The Amazing Story of Quantum Mechanics: A Math-Free Exploration of the Science That Made Our World, London 2010. 
for quaternions $\left(\mathrm{i}^{2}=\mathrm{j}^{2}=\mathrm{k}^{2}=\mathrm{ijk}=-1\right)$ into the stone. ${ }^{41}$ Quaternions only really came into their own a hundred and fifty years later, as a tool for 3D modelling.

On foundations rooted in the belief that there was a usefulness in useless knowledge, FLEXNER justified the orientation of the IAS as an institution that was entirely dedicated to pure and theoretical research, without any conscious orientation towards the production of 'useful' results: FLEXNER himself spoke of "a paradise for scholars". ${ }^{42}$ Yet, while the existence of institutions like the IAS might be desirable and welcome, they certainly do not represent the majority of academic institutions, which are increasingly driven by ideas of 'usefulness' and profitability. ${ }^{43}$ The question thus becomes: should the Humanities in general - and Medieval Studies in particular - heed the call to become more 'useful'?

Some might argue that such a reaction in fact constitutes an inevitable necessity, one which might even help the Humanities to re-establish their profile: they have much to offer that needs only to be adequately pointed out. Yet, others remain profoundly negative. At the 2007 meeting of the French SHMESP (the Société des Historiens Médiévistes de l'Enseignement Supérieur Public), for example, a round table discussed the potential for a dialogue between (medieval) historians and the Social Sciences, with an implicit underlying discourse concerning the question of medievalists' social engagement. ${ }^{44}$ While some argued for the inherent moral obligation of historians to make their work relevant to the societies in which they live, ${ }^{45}$ others insisted on their right to analyse meticulously their objects of

41 See online: https://en.wikipedia.org/wiki/Broom_Bridge (last accessed 15/05/2019).

42 FLEXNER (note 36), Usefulness, p. 552. On the role of the IAS as sanctuary for refugee scholars see Laura SMITH PORTER, From Intellectual Sanctuary to Social Responsibility. The Founding of the Institute for Advanced Study, 1930-1933, Ann Arbor 1988.

43 For a recent survey, see: Ron SRIGLEy, Whose University Is It Anyway?, in: Los Angeles Review of Books (22 February 2018), online: https://lareviewofbooks.org/article/whose-university-is-itanyway/ (last accessed 15/05/2019).

44 The question of social engagement and the dialogue between historical research and contemporary society was addressed explicitly during the discussions. This specific aspect of the debate is, however, only partly documented in the proceedings of the conference, see SocIÉTÉ DES Historiens MÉdiÉvistes de l’Enseignement Supérieur Public (ed.), Être historien du Moyen Âge au $\mathrm{XXI}^{\mathrm{e}}$ siècle. XXXVIII ${ }^{\mathrm{e}}$ Congrès de la SHMESP, Paris 2008, esp. Nicolas OFFENSTADT, L'“histoire politique” de la fin du Moyen Âge. Quelques discussions, in: ibid., pp. 179-198, and Jean-Patrice BOUdET / Nicolas WEILl-PAROT, Être historien des sciences et de la magie médiévales aujourd'hui: apports et limites des sciences sociales, in: ibid., pp. 199-230.

45 Amongst the most active, one might mention Nicolas OFFENSTADT, presently maitre de conferences (lecturer) at the Université Paris 1 (Panthéon-Sorbonne). Enjoying a strong media presence, mostly as a specialist of the First World War, OFFENSTADT was also a founding member of the "Comité de Vigilance face aux Usages Publics de l'Histoire", created in 2005. For the current activities of this group of French historians, see online: http://cvuh.blogspot.de/ (last accessed 15/05/2019). See also Laurence DE COCK / Mathilde LARRĖRE / Guillaume MAZEAU, L'Histoire comme émancipation, Marseille 2019, here pp. 52-53. 
scientific predilection in a manner entirely disconnected (as they argued) from any possible link to modern society. After all, had not Lucien Febvre already asserted as long ago as 1919 that "a History that serves is an enslaved History" ("une histoire qui sert est une histoire serve")? ${ }^{46}$

One might, of course, ask whether a total disconnect between two historically connected cultures is ever really possible. One response would be that it is not - for the simple reason that the past is always understood and shaped via the lens of the present. At its most extreme, this perspective has led some post-modernists, most notably Hayden WHITE, to characterize History as a discipline as nothing more than a particular form of narration, a point we will return to. ${ }^{47}$ In any case, it is curious to see one of the protagonists of the 'detached' position fervently argue against the recent rise of global history (especially in Medieval Studies), on the grounds that pupils and students should first learn the historical facts and information that concern their own country. ${ }^{48}$ Not only does this kind of argument ignore the importance of migration as an historical factor, ${ }^{49}$ but it actually undermines the claim for the total independence of the field from society. To take but the French example: large numbers of pupils whose forebears migrated into the country over the course of the last century (to leave it at that), would have a hard time describing either the Gauls or the Merovingians as 'their predecessors', people with whom they should, according to traditional curricula, develop a

46 Quoted in François HARTOG, Régimes d'historicité. Présentisme et expériences du temps. Édition augmentée, Paris 2012, p. 186.

47 Hayden White, The Content of the Form: Narrative Discourse and Historical Representation, Baltimore 1987. For an overview: BENTLEY, Modern Historiography (note 12), pp. 137-148; see also Otto G. OeXLE, 'Das Mittelalter' - Bilder gedeuteter Geschichte, in: BAK et al. (note 3), pp. 21-43 and 345-349, here pp. 22-24, 39, and Paul Veyne, Comment on écrit l'histoire. Essai d'épistémologie, 2nd ed. Paris 1996, pp. 23-26.

48 Nicolas WeILL-PAROT, Recherche historique et "mondialisation": vrais enjeux et fausses questions. L'exemple de la science médiévale, in: Revue historique 316 (2014), pp. 655-673. WeILL-PAROT’s critical comments concern, most explicitly, the publications by his fellow French historians Patrick BOUCHERON and Jérôme BASCHET (ibid., pp. 657-658). Interestingly, WEILL-PAROT stresses the importance of history as a means to 'know yourself' (along the lines of the ancient Greek locution attributed to Socrates), but at the same time decries "les risques d'une histoire utilitariste" ("the risks of a utilitarian history"), see ibid., pp. 671-673. It should be noted that WEILL-PAROT's research represents an important contribution on the impact of Arabic scientific knowledge on high and late medieval astrology and science, see, for example, Nicolas WeILL-PAROT, Les "images astrologiques" au Moyen âge et à la Renaissance: spéculations intellectuelles et pratiques magiques, $\mathrm{XII}^{\mathrm{e}}-\mathrm{XV}^{\mathrm{e}}$ siècle (Sciences, techniques et civilisations du Moyen âge à l'aube des Lumières 6), Paris 2002.

49 Current popular debates, which often combine a notable lack of information with extremely polemical attitudes, serve to illustrate the importance of pertinent knowledge in establishing an historical and transcultural perspective. For relevant recent contributions by medievalists in this particular arena see Michael BoRGolte (ed.), Migrationen im Mittelalter. Ein Handbuch, Berlin, Boston 2014, and Dominique GARCIA / Hervé Le BRAS (eds.), Archéologie des migrations, Paris 2017. 
privileged relationship. ${ }^{50}$ If there really was a complete disconnect between the work of historians and current social practices, there would be no reason to be concerned about the replacement of traditional 'national' narratives and content with more 'globalized' perspectives. The exception would be if an author wished to argue that History should actually serve the - quite utilitarian - aim of furnishing pupils and students with a sense of national belonging rather than being a pathway via which the capacity for critical historical analysis and thinking are developed. We prefer to call this latter what it is: the socially acceptable face of a resurgent nationalism.

The above example can, of course, not claim to be universally representative: in fact, French historical culture and the debates it generates are vivid and important, especially in comparison with countries like Germany. But even if France constituted a unique case, its debates do illustrate recent trends that can be observed, to a greater or lesser degree, in other countries as well. There is undeniably a growing tension between different attitudes towards History, and in particular to national histories. While a number of authors insist on the need to innovate in Medieval Studies by, for example, including elements of global history, others underline the importance of more traditional positions for the development of 'national identity'. ${ }^{51}$ The origin of these tensions lies, in part, in the profound change that took place in attitudes towards the Middle Ages after 1945; to a certain degree, they are also a result of the internal debates that began in the closing decades of the twentieth century, and that continue to shape the profession's understanding of itself.

Medieval History's emergence as an academic discipline in the early nineteenth century was intrinsically linked to Europe's 'national projects'. ${ }^{52}$ Seen from the

50 This observation lies behind the publication of William BLanc / Christophe NaUdin, Charles Martel et la bataille de Poitiers. De l'histoire au mythe identitaire, Paris 2015, who propose deconstructing the historical myth built up around the battle of Poitiers, which has painted the battle as the crucial moment that allegedly saved Christian Europe from the dangers of a Muslim onslaught. During a speech to commemorate the hundredth birthday of Nelson MANDELA, the former US President, Barack OBAMA, turned an analogous observation into an efficient pun when he observed, with regard to the positive effects of diversity in a society: "And if you doubt that, just ask the French football team that just won the World Cup. Because not all of those folks - not all of those folks look like Gauls to me. But they're French. They're French.” Online: https://www.nelsonmandela.org/news/entry/nelson-mandela-annual -lecture-2018-obamas-full-speech (last accessed 15/05/2019).

51 In France, where this debate draws an important public, the two poles were represented at the time of writing by Patrick Boucheron (ed.), Histoire mondiale de la France, Paris 2017, on the one hand, and Nicolas WeILL-PARot / Véronique SaLeS (eds.), Le vrai visage du Moyen Age. Au-delà des idées reçues, Paris 2017, on the other.

52 See, for example, Isabelle GuYot-BAchy / Jean-Marie MoEglin (eds.), La naissance de la médiévistique. Les historiens et leurs sources en Europe (XIX ${ }^{\mathrm{e}}$-début du XX $\mathrm{XX}^{\mathrm{e}}$ siècle) (École Pratique des Hautes Études, Sciences Historiques et Philologiques 5 / Hautes études médievales et modernes 107), Geneva 2015. With a stronger focus on the ideological implications, see the publications in the series "Writing the Nation", for example, Stefan BERGER / Chris LoRENZ (eds.), 
perspective of those keen to defend the integrity of the emerging nation-state, an important task of History consisted in furnishing the basis for a nation's legitimacy by providing a narrative of its venerable age and the heroic deeds of its founders, its people, and its ruling dynasties. The medieval period thus became of the utmost importance as an element in nation building. It led to the construction of the Middle Ages as the crucible in which nations such as Britain, France, and Germany were forged. Historians of the Middle Ages furnished detailed and elaborate master narratives: they were, in a sense, the chief 'myth makers' of Europe's national projects. $^{53}$

In the course of the twentieth century, a series of quite different developments profoundly unsettled the privileged position of the Middle Ages in the popular consciousness: on the one hand, the shocking experience of two world wars, and of the reactionary nationalism that accompanied the second in particular, largely discredited the category of the 'nation-state' as a fundamental framework for the writing of history. This was especially true in Germany, but there were also repercussions beyond the German borders. ${ }^{54}$ Myths of 'national character' forged in a distant medieval past had served the nineteenth-century imperialists of Britain, Germany, and France well; yet, with their focus on the distinctive origins of 'peoples' and the relationship between those peoples and specific territories, it was an uncomfortable truth that they also played their part in shaping the mentalities that had led to the Holocaust. At the same time, a series of theoretical and methodological debates within the

Nationalizing the Past: Historians as Nation Builders in Modern Europe (Writing the Nation 4), Basingstoke 2010 (2nd ed. 2015).

53 See Patrick GEARY, The Myth of Nations. The Medieval Origins of Europe, Princeton 2002. It is curious to note that the critical deconstruction of the nation-state as the 'default' category for historical interpretation may have given way to the creation of new myths (in the form of new master-narratives) in which 'Europe' replaces the nation-state as the fundamental and enduring cultural unit allegedly created in the Middle Ages. On this point, see Klaus OschemA, Ein Karl für alle Fälle Historiographische Verortungen Karls des Großen zwischen Nation, Europa und der Welt, in: Gregor Feindt / Félix KRAWATzek / Daniela Mehler / Friedemann Pestel / Rieke TRIMÇEV (eds.), Europäische Erinnerung als verflochtene Erinnerung. Vielstimmige und vielschichtige Vergangenheitsdeutungen jenseits der Nation (Formen der Erinnerung 55), Göttingen 2014, pp. 39-63, here p. 41.

54 See Winfried Schulze, Deutsche Geschichtswissenschaft nach 1945 (Historische Zeitschrift. Beihefte N. F. 10), Munich 1989. In the immediate aftermath of the Second World War, some individual authors were already calling for a new history written within a European framework; others underlined the importance of 'universal history', see Klaus OschEMA, Bilder von Europa im Mittelalter (Mittelalter-Forschungen 43), Ostfildern 2013, pp. 51-60. On the (possible) conceptual distinctions between the 'universal history' envisaged in the 1950s and the more recent developments that favour a 'global history' of the Middle Ages, see Michael BoRGolTE, Wie Weltgeschichte erforscht werden kann. Ein Projekt zum interkulturellen Vergleich im mittelalterlichen Jahrtausend, in: Zeitschrift für Historische Forschung 43(1) (2016), pp. 1-25, and ID., Mittelalter in der größeren Welt. Eine europäische Kultur in globaler Perspektive, in: Historische Zeitschrift 295 (2012), pp. 35-61. 
historical disciplines in the second half of the twentieth century unsettled the very foundations of the writing of History itself. These latter have certainly made classes in historiography more interesting, but they have also had important consequences for historians' relationship with the broader public. ${ }^{55}$

A series of so-called 'turns' - including the 'linguistic' turn - coupled with the critical perspective of (radical) constructivism and findings in the field of neurosciences forced professional historians to doubt the certainty of their reconstructions of the past. $^{56}$ While these important developments provided essential methodological and theoretical insights, one unfortunate side-effect was to distance much of the historical profession from the broader public by removing a key attribute that had made them so valuable to the nineteenth century's national projects: their ability to convey 'truth' with certainty.

If past reality is, for the most part, only accessible through the means of texts that have gone through the distorting filter of the human mind, with all the uncertainties of the influence of perception, let alone of varying interests, it seems hardly possible to develop one singular 'true' narrative of past reality. In spite of popular assumptions to the contrary, history is not just there to be 'found' in ancient manuscripts and other evidence. While these artefacts do connect us with the past in the sense that they have been produced by individuals in times long gone, they do not contain 'history' in a pure state that can readily be 'discovered'. All they can do is provide data that enable us today to write an evidence-based narrative. ${ }^{57}$ The - sometimes quite fierce - debates concerning these insights and observations doubtless fertilized and enriched academic discourse. They invited professional historians to develop new perspectives and to criticize the well-established narratives that they had become fond of. At the same time,

55 The pertinent developments concern methodological questions as well as questions of scope and the choice of subjects. For the former see, for example, the brief overview by Hans-Jürgen GoERTZ, Unsichere Geschichte. Zur Theorie historischer Referentialität, Stuttgart 2001; for the latter Nicolas OfFEnSTADT, L'historiographie (Que sais-je? 3933), Paris 2011, esp. pp. 83-97. For an introduction to the topic, see the essays in parts IV and V of Michael BENTLEY (ed.), Companion to Historiography, London 1997, and Georg G. IGGERS, Historiography in the Twentieth Century: From Scientific Objectivity to the Postmodern Challenge, 2nd ed. Middleton / CT 2005, esp. part III: "History and the Challenge of Postmodernism". Concerning the history of Medieval Studies in North America and the implications of these developments in particular: Gabrielle M. SPIEGEL, In the Mirror's Eye: The Writing of Medieval History in America, in: Anthony MoLHo / Gordon S. WOOD (eds.), Imagined Histories: American Historians Interpret the Past, Princeton 1998, pp. 238-262.

56 See GOERTZ (note 52) and Otto G. OEXLE, Von Fakten und Fiktionen. Zu einigen Grundsatzfragen der historischen Erkenntnis, in: Johannes LAUDAGE (ed.), Von Fakten und Fiktionen. Mittelalterliche Geschichtsdarstellungen und ihre kritische Aufarbeitung, Cologne, Weimar, Vienna 2003, pp. 1-42, and ID., "Facts and Fiction". On the Current Fundamental Crisis in History, in: Salvador Rus RuFINO (ed.), Historia, filosofía y política en la Europa moderna y contemporánea. Conferencias inaugurales del acuerdo Universidad de León, León 2004, pp. 101-117.

57 OEXLE, 'Das Mittelalter' (note 44), p. 39; VEYNE (note 44), p. 23: "L'histoire est un récit d'événements vrais." ("History is the account of true events.") 
they threatened the standing of professional historians who embraced them in the eyes of the wider public: those who engaged with these debates could no longer lay claim to the historian's traditional role as the source of an absolute historical 'truth'.

The recent popularity of histories that adopt an air of nostalgia for the traditional narrative, such as those of Melvyn BRAGG, Lorànt DEUTSCH, or Jean-Christian PETITFILS, suggests that a significant section of the wider public have become increasingly unsettled and dissatisfied with an academic discourse that risks dissolving many of the established narratives of society's past. ${ }^{58}$ Where is the 'true' narrative? Where is the account of 'what happened'? While critical innovations might force historians to tread much more carefully, it is worth noting that they do not exclude the possibility of demonstrating the defectiveness of certain presentations of the past. Yet this type of 'negative certainty' is by no means identical with an attempt to create some kind of 'new positivism' that would enable the reestablishment of old-fashioned 'definitive' narratives. In a curious turn of events, proponents of the political right have been able to turn these methodological advancements and critical instruments against professional historians, who, in questioning traditional narratives, often came to be perceived as far too left-wing and liberal from the point of view of conservative groups. ${ }^{59}$ If professional historians

58 For example: Melvyn BRAGG, The Book of Books: The Radical Impact of the King James Bible 1611-2011, London 2011; Lorànt DEuTsCH, Métronome, Neuilly-sur-Seine 2009; Jean-Christian PETITFILS, Histoire de la France. Le vrai roman national, Paris 2018. The latter positions himself explicitly against recent approaches that globalize and deconstruct the well-established older masternarratives in order to defend the latter, ibid., p. 11: "L'Histoire n'est pas l'instrumentalisation de petits récits éclatés, mise au service d'une vision communautariste et multiculturelle, ainsi que l'ont présentée Patrick BOUcheron et son équipe (Histoire mondiale de la France, 2017), vision critiquée aussi bien par l'Obs (Pierre NORA) que par Le Figaro (Ran HALEVI) comme une défiguration de la vérité par l'idéologie." The very fact that PETITFILS continues by underlining that "Or, c'est la conception même de la nation qui est en jeu" ("the very concept of the nation is at stake") demonstrates the absurdity of his criticism: he justifies his efforts with reference to exactly the same ideological foundation that he criticizes in his 'adversaries'. For a critical survey see DE COCK / LARRÈRE / MAZEAU (note 45).

59 An anti-intellectual stance frequently characterizes right-wing positions: hence proponents of the Swiss right-wing party SVP (Schweizerische Volkspartei) frequently defame academic historians as notoriously left-wing and thus 'anti-national'. Critical analyses that tend to deconstruct scientifically widespread popular myths, such as, for example, Guy MARCHAL, Schweizer Gebrauchsgeschichte. Geschichtsbilder, Mythenbildung und nationale Identität, Basel 2006, are systematically denigrated. The remarkable rift between the left and right's images of history in Switzerland is clearly visible in the agitated debates that surrounded the five-hundredth anniversary of the battle of Marignano: while right-wing presentations insist that Marignano represents the beginning of Swiss neutrality, academic historians underline the necessity to differentiate, amongst others, between contemporary perspectives and later developments and interpretations. See, for example, Thomas MAISSEN, Schweizer Heldengeschichten - und was dahintersteckt, Baden 2016, pp. 104-115 (ch. 6), and ID., Seit wann ist die Schweiz "neutral seit Marignano"? Zu den Wurzeln eines nationalpädagogischen Topos, in: Schweizerische Zeitschrift für Geschichte 68(2) (2018), pp. 214-239, esp. pp. 235-239. 
claimed that they could not produce certainty about the past, why bother listening to them at all? The historians who side-stepped or attacked these debates could now claim, seemingly unchallenged, the validity of their own 'common sense' version of the past. ${ }^{60}$

Confronted with nostalgic and conservative renderings of the past as simple and attractive (a counter-weight to the complexity of the modern world), professional scholars who engage in the debates that continue to re-shape the discipline risk losing ground to populists happy to provide the public with a 'straightforward' account of history. It is undeniable that professional historians have done a remarkably poor job of engaging the public in their complex internal debate. Instead, unaccountably disappointed that wider society appears disinterested, at least some have retreated to the ivory tower and pulled up the drawbridge by employing a vocabulary, often borrowed from literary criticism, that few understand. Others have withdrawn into the comforting pseudo-intellectual hair-splitting and barely disguised name-calling of the reviews' column of their favourite journal. The overall effect is particularly threatening to professional Medieval Studies. On the one hand, there are genuine academic developments that force us to recognize that apprehending the past is only partially feasible; on the other, the Middle Ages are suffering a progressive loss of importance as the object of serious research because professional medieval scholars no longer serve the traditional social function that they once did.

One might argue that the Middle Ages' role as a romantic otherworld that allows us to flee the increasing complexity of a globalized and confusing Modernity only becomes a problem for Medieval Studies because professional medievalists are, in fact, excellent representatives of their respective disciplines: they take the implications of the theoretical debates and the insights those debates furnish seriously. To take but one example: we have learned to understand individual and collective identities as constructed entities in, for example, the case of nations. This does not mean that 'nations' did not in fact exist. ${ }^{61}$ However, as a consequence, it becomes impossible to satisfy the quest of some parts of the public to find a reassur-

\footnotetext{
60 One example of this backwards-oriented, anti-intellectual tendency that argues strongly against methodological and thematic innovations is furnished by WEILL-PAROT / SALES (note 48). It has to be said, though, that many of the contributors who were interviewed for this collection seem to have tried to provide a more nuanced picture than the quite tendentious questions allow, see, for example, Philippe Contamine, La France, une idée anachronique au Moyen Âge?, in: ibid., pp. 9-25. It is hardly a coincidence that a series of recent conservative publications choose to include the word 'truth' in their titles, see, for example, PETITFILs (note 55).

61 The much cited and influential study of reference is Benedict ANDERSON, Imagined Communities: Reflections on the Origin and Spread of Nationalism, rev. ed. London 1991 (orig. 1983).
} 
ing stability in the history of 'their' origin. ${ }^{62}$ If unsettled members of contemporary societies turn towards history in order to obtain a reassuring sense of stability, and this entails the highly problematic side-effect of excluding other members of society not considered part of that imagined past, professional scholars simply cannot provide them with the reassurance they seek and at the same time continue to take their job seriously. And yet this brings us to the crux of the problem, the gap between the public's expectations and scholars' ability to provide answers that take account of the principles that define their profession. The failure of scholars to bridge that growing chasm contributes to the popular impression that modern research in Medieval Studies - but also more generally in the Humanities and sometimes also the Social Sciences - are essentially 'useless' to society in general.

It is thus hardly surprising that the international academic world is witness to a number of initiatives that seek to diminish funding for allegedly useless Humanities or Social Science subjects. In the United States, in particular, recent cuts in funding have been either proposed by politicians or implemented based on the argument that the disciplines in question, and the insights they furnish, are practically useless and do not promote the national interest. ${ }^{63}$ This ongoing debate illustrates the dangers of an argument based on 'usefulness', which does not furnish a level playing field with the so-called 'hard' sciences. The latter can often (but by no means always) argue in favour of the practical benefits of insights and inventions that result from their work. The Humanities and Social Sciences have a much harder time providing concrete arguments for their (positive) practical effects. This, of course, does not mean that those effects do not exist: as Martha NuSSBAum convincingly points out, the Humanities and the way of thinking that they teach us, can (and, indeed, must) be regarded as an important basis for the education of mature and able citizens who will become competent members of modern democracies. ${ }^{64}$ Thus they fulfil a vital condition for the existence of a system of political order that most countries deem to be the best and most adequate choice for a modern and enlightened society. One cannot stress this enough,

62 This 'problem' becomes even more evident when one includes data from the 'hard' sciences, such as DNA-analyses. See, for example, Alistair MofFat, The Scots: A Genetic Journey, Edinburgh 2011, a work intended for a popular readership, which demonstrates the Scottish population's high level of genetic diversity.

63 See, for example, the timeline and quotations provided by Social Science Space, online: https:// www.socialsciencespace.com/2016/01/timeline-of-us-government-and-socialbehavioral-science (last accessed 15/05/2019). Cf. for a defence of Social Sciences, Jonathan MicHIE / Cary L. COOPER (eds.), Why the Social Sciences Matter, Basingstoke 2015.

64 Martha Nussbaum, Not For Profit. Why Democracy needs the Humanities, Princeton 2010. This debate is, of course, ongoing; for a contribution in the context of recent developments in US politics and media: Paula Marantz Cohen, The Humanities' Decline Makes Us Morally Obtuse, in: The Wall Street Journal (21 September 2018), online: https://www.wsj.com/articles/the-humanities-declinemakes-us-morally-obtuse-1537566941 (last accessed 15/05/2019). See also, with a focus on History, DE COCK / LARRĖRE / MAZEAU (note 45). 
especially since this ongoing project of education and of the transmission of the vital critical spirit to future generations is not only a never-ending story, but, moreover, because its effects tend to be much less spectacular than the new insights and techniques derived from the hard sciences that have given us computers, smartphones, etc. In contrast to dazzling technological innovations, the outcome of successful education in the disciplines that form the Humanities and the Social Sciences will contribute primarily to upholding, and perhaps even improving, a political system that is worth living in (something that many western politicians benefit from but seem to take for granted). There are, in addition, further beneficial insights that critical engagement with medieval subjects can entail once they are brought into a comparative perspective with contemporary phenomena, and these doubtless merit further attention. ${ }^{65}$

\section{From Usefulness to Relevance}

Research in the fields of the Humanities and the Social Sciences should not be a limited endeavour: far beyond the need to give future generations a chance to become mature and critical citizens, these fields effectively help to identify and understand a broad range of problematic areas in our societies and thus contribute to providing solutions. And it is on this particular and constructive contribution of the Humanities, or, more precisely, of the discipline of Medieval Studies, that we will focus in this volume. Given the - rightly - controversial debates about the dangers of the quest to make scientific research 'useful', we have opted consciously for the vocabulary of 'relevance'. We are aware that the distinction is not always clear-cut. ${ }^{66}$ Nevertheless, we would argue that 'relevance' conveys an idea of importance that surpasses the notion of immediate application as evoked by 'usefulness'. We feel this has the major advantage of inviting both readers and contributors to identify effects and connections that may already be there but that have eluded us because we have not focussed sufficiently on recognizing them. In addition, the notion of relevance conveys a particular idea of importance and applicability that does not boil down to immediate practical 'use'. Rather, it leaves room for inspiration and the insight that some elements of knowledge may need to be further refined and transformed before the benefits become apparent.

65 See above, note 26.

66 See, for example, the critical remarks by Mahmood MAmDANI, The African University, in: London Review of Books 40(14) (19 July 2018), pp. 29-32, online: https://www.lrb.co.uk/v40/n14/ mahmood-mamdani/the-african-university (last accessed 15/05/2019). 
This latter idea can be illustrated by a simple example. When confronted with the contemporary tensions and conflicts that are mostly, and to a large extent erroneously, formulated in religious terms, such as the conflicts between Christians in Europe and the Muslim minorities that have made the continent their home, one might be tempted to turn to high medieval Sicily or to the famous convivencia of Christians, Jews, and Muslims in medieval Iberia in order to establish how peaceful coexistence might be organized efficiently. ${ }^{67}$ But this approach inevitably leads to disappointment: not only was the 'multi-religious' past far less conflict-free than is often claimed, but the fundamental parameters of highly religious pre-modern societies make the hope of learning anything useful from an immediate comparison nothing less than futile. In addition, the societies in question were organized as monarchies and feudal societies, which did not cultivate the idea of human rights, but rather attributed a very specific place, with specific privileges, duties, and handicaps, to every individual. These comments are not supposed to imply, however, that critical analysis of the distant past is useless per se. To the contrary, we hold that it can make us aware of specific differences, of alterities, that make us realise that some of the culturally constructed ideas and conceptions we take for granted are in fact highly contingent. And the potential insights are by no means limited to the identification of alterities. We might also be able to identify structural analogies between medieval societies and cultures and our own, which, in turn, force us to rethink drawing a strict dividing line between the medieval and the modern. One example would be the potential relevance of concepts of legal pluralism in Magna Carta for contemporary debate in Aotearoa New Zealand concerning indigenous rights. ${ }^{68}$

As will have become clear, our approach to the question of the 'relevance' of the Middle Ages does not seek to provide yet another series of reflections on the well-established motif of the importance of History - and by implication Medieval History - for the creation of identity. In fact, in a world that becomes ever more globalized and that witnesses migrations that might well exceed anything humans have hitherto experienced, we feel that such 'identity-based' arguments are inevitably bound to lose their force. Nationalist fairy tales might satisfy those who feel the need for something reassuring, but this does not make them any less simplistic

67 Amongst the numerous publications on these questions see, for example, the critical analysis by Mark R. CoHEN, Under Crescent and Cross: The Jews in the Middle Ages, Princeton 1994; cf. the contributions in Matthias M. TISCHLER / Alexander FIDORA (eds.), Christlicher Norden Muslimischer Süden. Ansprüche und Wirklichkeiten von Christen, Juden und Muslimen auf der Iberischen Halbinsel im Hoch- und Spätmittelalter (Erudiri Sapientia 7), Münster 2011. For Italy, see Alex MetCaLfe, The Muslims of Medieval Italy (The New Edinburgh Islamic Surveys), Edinburgh 2009.

68 Chris Jones, Mana and Magna Carta: Locating New Legacies in a Post-Colonial Society, in: Stephen WinTER / Chris Jones (eds.), Magna Carta and New Zealand - History, Law and Politics in Aotearoa, Cham 2017, pp. 229-251. 
fantasies. It was never true that the 'Germans', the 'French', the 'English', the 'Russians', the 'Swiss', or the 'Chinese' formed stable groups with a common ancestry that lived from the dawn of time on the ground they now inhabit. In this regard, a large number of the peoples that lived in medieval Europe were in fact closer to the truth than modern adherents of the idea of a stable national history: the idea of migration and the acquisition of new homelands is one of the most widespread motifs in medieval origo gentis narratives. ${ }^{69}$ As a consequence, the 'real' story about anyone's past is inevitably a story of migration and of the blending of different influences over time. ${ }^{70}$ Our origin stories are necessarily fragmented. You are, as Kurt WEILL and Ogden NASH very neatly put it, a stranger here yourself.

While we consider the more limited argument of 'identity' to be unpromising, we feel that there are several other approaches the medievalist can furnish and contribute to answering contemporary questions. And they may even offer solutions to contemporary problems. This volume cannot claim to give a comprehensive overview of the areas to which Medieval Studies is potentially (or actually) relevant. Instead, we want to achieve two things: to present a limited, but, we believe, representative choice of different contexts and backgrounds that demonstrate the fertility and relevance of Medieval Studies; and to begin a wider debate that invites further reflection within the academy. And if this book achieves a wider audience - although we recognize that is an unlikely fate for an academic collection of essays! we hope it may make some small contribution to encouraging the broader public to consider the value of our field.

\section{What to Expect from this Collection}

Our choice of topics has been limited from the outset as this publication is principally intended to unite a series of contributions to two academic events: in November 2015, with the support of the British Academy's Rising Star Engagement Award, Conor

69 For an excellent introduction to the topic, Susan REYnOLDS, Medieval Origines Gentium and the Community of the Realm, in: History 68 (1983), pp. 375-390; see more recently Alheydis PlassmanN, Origo gentis. Identitäts- und Legitimitätsstiftung in früh- und hochmittelalterlichen Herkunftserzählungen (Orbis mediaevalis 7), Berlin 2006, pp. 360-362, and Michael BERNSEN / Matthias BECHER / Elke BRÜGGEN (eds.), Gründungsmythen Europas im Mittelalter, Göttingen 2013.

70 For a strictly 'scientific' perspective, although conveyed in a popular narrative, see MOFFAT (note 59). For the British case, see also Stephen LesLIE / Bruce Winney / Garrett HellenthAL / Dan DAvison / Abdelhamid BoumerTit / Tammy DAy / Katarzyna HutniK / Ellen C. RoYRVIK / Barry Cunliffe / Wellcome Trust Case Control Consortium 2 / International Multiple Sclerosis Genetics Consortium / Daniel J. Lawson / Daniel Falush / Colin FreEman / Matti Pirinen / Simon Myers / Mark Robinson / Peter Donnelly / Walter BodmeR, The fine-scale genetic structure of the British population, in: Nature 519 (19 March 2015), pp. 309-314. 
KosticK organized a two-day conference on "Making the Medieval Relevant" at the University of Nottingham. Happily, he accepted an invitation to contribute to two sessions and a round table discussion organized by Chris JonEs and Klaus Oschema at the International Medieval Congress at Leeds in July 2016, "Are the Middle Ages Relevant?", held under the aegis of Australasia's ANZAMEMS and the German Mediävistenverband. The contributions to these two events now form the backbone to the present volume. In order to present a tableau that truly demonstrates the wide-ranging relevance of Medieval Studies, however, the editors invited further papers and were pleased to receive a number of important contributions covering fields that range from climate science and genetics to education. ${ }^{71}$

The volume has been divided into three sections: 'Science', 'Education', and 'Society'. These divisions are primarily intended to enable the reader to navigate the collection more easily, but they also indicate the key areas where we believe Medieval Studies is most relevant today. We begin, in 'Science', with the component of our case for the relevance of Medieval Studies that is most likely to convince an audience beyond the Humanities. In a series of four essays our contributors demonstrate the value of medieval scholarship to the so-called 'hard' sciences by examining the way in which medievalists can contribute to exploring and resolving some of the key issues that confront the contemporary world. In two very different essays, first Tobias KLUGE and Maximilian SCHUH and then Conor KostiCK and Francis LUDLOW illustrate the varied and important contributions that medieval scholars make to the ongoing exploration of climate science, study of which fundamentally effects our continued existence on this planet. In spite of what many choose to believe, 'hard scientists' do, indeed, need to cooperate with historians in order to make sense of their evidence: this begins with questions of chronological calibration and continues with the task of broader contextualization that makes the social and cultural repercussions of climatic events and developments visible. With a very different focus, Jörg FEUCHTER then considers the value of knowledge of the Middle Ages in the genetics lab: while DNA-analysis can certainly contribute to solving a number of medievalists' questions, FEUCHTER plausibly argues that the relationship between DNA-researchers and historians is by no means a one-way street. To the contrary, medievalists can contribute important material and the necessary knowledge to provide insights into questions of immediate contemporary importance, beginning with data on migration, but also including questions of epigenetic change. Finally, Freya HARRISON and Erin CONNELLY demonstrate the real potential benefits of analysing medieval knowledge for modern medicine. Contrary to popular portrayals of medieval medical practice as fantastical and bizarre,

71 With regard to genetics, see also Elsbeth BösL, Doing Ancient DNA. Zur Wissenschaftsgeschichte der aDNA-Forschung, Bielefeld 2017. 
centuries of careful observation on the healing properties of various plants when prepared in a variety of ways contributed to the development of effective medicines in the Middle Ages. Reviving these recipes and improving them using modern techniques offers a new way to derive cures for conditions where anti-microbial resistance has undermined what used to be our most effective treatments.

Our section on 'Education' comprises three discrete perspectives. The first two focus on the tertiary sector: Julien DEMADE considers the changing place of the medieval in French higher education and what it might tell us about society more generally. He applies a deliberately structural perspective, which enables him to underline that the relative loss in importance of Medieval Studies is by no means unique to this discipline. Rather, DEMADE claims, it constitutes merely one example of a veritable landslide that orientates capitalist elites towards more lucrative and specialized, albeit younger disciplines, for their education. Chris JoNES and Madi Williams choose, on the other hand, to focus on the contribution that the teaching of Europe's Middle Ages can make to Aotearoa New Zealand's bicultural policy. While exploring the broader significance of medieval scholarship in addressing colonial legacies, the chapter argues that medieval history is an excellent vehicle for better integrating Aotearoa's official policy of biculturalism into university curricula. However, it also suggests that in order to do this effectively the way in which the subject is taught in universities requires adjustment to integrate comparison with indigenous Māori culture and values. Laura DI STEFANO, meanwhile, considers a case study in medieval travel writing that may improve the modern tourist's understanding of their encounter with medieval Venice.

In 'Society' we look at five case studies, each of which reflects on what exploring a medieval topic may - and actually should - tell us about ourselves and the world in which we live, beginning with Klaus OsCHEMA's examination of 'expert culture'. His contribution takes up an idea that is axiomatic to this volume, namely that expertise in Medieval Studies is valuable to a better understanding of contemporary society and its workings. Analysing the social role of late medieval astrologers, whom he proposes to compare to modern financial and economic experts, OsCHEMA characterizes the Middle Ages as a 'laboratory'. This enables us to better calibrate the sometimes erroneous self-descriptions of our own societies provided by the Social Sciences, descriptions which focus on modern societies as 'rationally' organized and as being peopled by individuals who act 'rationally'. Exploring the medieval culture of expertise provides a valuable point of reflection on this concept. Then, in the company of Elva JoHNSTON and Hélène SiRANTOINE, we consider two very different case studies, one focussed on the relationship between medieval history and early twentieth-century Irish nationalism, the other on the issue of religious tensions in contemporary Europe and the oftidealized image of cooperation between Muslims and Christians in medieval Iberia. Both illustrate the importance of understanding what can be said about what actually happened in the Middle Ages. We then explore, with Niamh WYCHERLEY and Ben JERVIS, the way in which medieval expertise can provide a different window on to 
modern problems. WYCHERLEY considers our understanding of the enduring power of relics and what it might say about the culture of celebrity in contemporary society, while JERVIS examines what a case study that looks at archaeological evidence from a medieval town can tell us about the idea of resilience.

We close the volume by returning, with Pierre MONNET, to some broader reflections on the value of Medieval Studies in today's world. Like the collection as a whole and the Leeds round table that helped inspire it, this latter contribution does not seek to provide the reader with definitive answers to the relevance of Medieval Studies. Nor have the editors sought to present every conceivable example of the way in which studying the Middle Ages may be relevant to the contemporary world. We largely exclude, for example, the kind of 'therapeutic' and cathartic value attributed to history by, for example, Patrick BOUCHERON. ${ }^{72}$ Other problems and subjects that we will not explicitly engage with include the important relationship between historical knowledge and questions of social justice ${ }^{73}$ and the intensively scrutinized question of the 'abuse of history' for ideologically charged political purposes. ${ }^{74}$

The attentive reader will doubtless note the absence of further fields that would merit discussion. These include the question of what historians of the pre-modern period might contribute to the current debate concerning the crises that endanger cultural heritage in politico-religious conflicts ${ }^{75}$ as well as the fiercely debated question of Medieval Studies' own tendency to marginalize certain peoples and groups. ${ }^{76}$ Finally, there are also different views on the question of the very notions of the 'Middle Ages' and 'medieval'. Are these not, in fact, misleading terms that actually impede the development of new insights that might be gained, for example, by adopting more globalized perspectives? ${ }^{77}$ As editors of this volume, we are acutely

72 Patrick Boucheron, Ce que peut l'histoire (Leçons inaugurales du Collège de France 259), Paris 2016, p. 69: "Nous avons besoin d'histoire car il nous faut du repos." ("We need history, because we need rest.”)

73 On this topic, see the volume by CHAZELLE / DOUBLEDAY / LiFSHITZ / REMENSNYDER (note 26).

74 For a selection of pertinent contributions see above, note 3, 21, and 50.

75 One might cite the efforts of Columba STEWART, OSB (Saint John's Abbey and University, Collegeville, Minnesota) to save manuscripts in and from conflict zones: Matteo FAGoTTo, The Monk Who Saves Manuscripts from ISIS. Why a Christian Wants to Rescue Islamic Artifacts, in: The Atlantic (23 February 2017), online: https://www.theatlantic.com/international/archive/2017/02/ the-monk-who-saves-manuscripts-from-isis/517611/ (last accessed 15/05/2019). The project "Premodern Manuscripts and Early Books in Conflict Zones" has been awarded the CARMEN Projectprize in 2018, online: http://www.carmen-medieval.net/project-prize/ (last accessed 15/05/2019).

76 For one aspect of these debates, concerning race and its impact on the North American academy in particular, see a statement by the group Medievalists of Color, online: http://medievalistsofcolor.com/ statements/on-race-and-medieval-studies/ (last accessed 15/05/2019). For brief comments on the influence of lived experience on the construction of the subjects of scientific inquiry in this context see Geraldine HENG, The Invention of Race in the European Middle Ages, Cambridge 2018, pp. 1-5. 77 See above, note 13. 
aware of all these lacunae, and it is not least due to this awareness that we consider this volume primarily to be an attempt to encourage further debate.

Our project has a relatively limited objective: to present a representative sample of some of what we consider to be the more important ways in which Medieval Studies can contribute to advancing our understanding of important social and scientific questions. It, inevitably, involves a degree of subjective judgement about what should be considered 'important'. We have, in some instances, excluded proposals - occasionally even whole essays - not because they were intrinsically uninteresting, but because they did not speak to what we consider to be the core themes of the volume. The most vociferous objection of reviewers may remain our decision to exclude medievalism.

While we fully embrace the importance and dynamism of medievalism as a field, we do not share the opinion put forward by Tommaso DI CARPEGNA FALCONIERI, who identified it as the most important arena for the future of Medieval Studies. ${ }^{78}$ To the contrary, we believe that experts in medievalism need a different set of instruments to do their important work to those employed by medievalists. Transforming Medieval Studies into studies of medievalism would, from a certain point of view, amount to nothing less than the abolition of the former - and this is something we would like to avoid. This book is a manifesto for something quite different: it is the case for the value of the study of the Middle Ages in and of themselves and what such doubtless esoteric pursuits may still tell us about the world in which we live. In keeping with the dictum of the modern discipline of History's founding father, we submit it remains worthwhile to focus on "what actually happened", even if we remain conscious that we will never be in a position to give an entirely satisfactory answer. While we would agree with VON RANKE that our task is not to seek to judge the past or "instruct" the present, where we would depart from his view is that we remain convinced that the contemporary world can be informed by study of the Middle Ages, and that such study may benefit the future. ${ }^{79}$

78 DI CARPEGNA FALCONIERI (note 1), pp. 27, 250-251.

79 VON RANKE's full comment, from which the dictum wie es eigentlich gewesen is often extracted, reads, vON RANKE (note 12), p. vii: "Man hat der Historie das Amt, die Vergangenheit zu richten, die Mitwelt zum Nutzen zukünftiger Jahre zu belehren, beygemessen: so hoher Aemter unterwindet sich gegenwärtiger Versuch nicht: er will bloss sagen, wie es eigentlich gewesen." (“To history has been assigned the office of judging the past, of instructing the present for the benefit of future ages. To such high offices this work does not aspire: it wants only to show what actually happened”, transl. Fritz STERN, The Varieties of History: From Voltaire to the Present, 2nd ed. New York 1973, p. 57.) 



\title{
Providing Reliable Data? Combining Scientific and Historical Perspectives on Flooding Events in Medieval and Early Modern Nuremberg (1400-1800)
}

\begin{abstract}
Extreme weather events or climate phases and their consequences were a common threat to premodern societies. Detailed analysis of specific periods and societies requires profound knowledge of the political, economic, social, and climatic background. As a consequence, a single discipline can hardly study the interdependency of natural impacts and human and societal reactions adequately. Interdisciplinary approaches are thus essential for a more precise and comprehensive understanding. This paper discusses the relevance of historical research on extreme weather events and climate phases in the medieval and early modern period for the calibration and interpretation of proxy data, which environmental physicists and chemists draw from the 'archives of nature'. Preliminary results of an ongoing research project will show how the close examination of administrative records offers a far more accurate perspective on flooding events in Nuremberg than narrative sources, which have, hitherto, dominated our understanding. These precise findings help the natural sciences to evaluate proxy climate data drawn from the analysis of stalagmites situated in proximity to the Nuremberg area. On the other hand, the natural sciences provide clues from the environmental proxies that help to explain the impact strength of extreme weather events and severe climate phases on society. Additionally, this collaborative case study allows reflection on the advantages and problems of interdisciplinary research in the humanities and the natural sciences.
\end{abstract}

Keywords: interdisciplinary study, climate and society, extreme weather and climate, administrative records, stalagmites, chronicles, imperial city, Nuremberg, water and river management

\section{Introduction}

The Middle Ages were a period of significant societal development and differentiation. From the twelfth century onwards, the number of villages and towns in the Holy Roman Empire grew significantly from about 50 towns to approximately 3000 around

Tobias Kluge, Universität Heidelberg, Institut für Umweltphysik, Im Neuenheimer Feld 229, 69120 Heidelberg, Germany, tkluge@iup.uni-heidelberg.de

Maximilian Schuh, Freie Universität Berlin, Friedrich-Meinecke-Institut, Geschichte des Mittelalters, 14195 Berlin, Germany, maximilian.schuh@web.de

Ә Open Access. (C) 2020 Tobias Kluge and Maximilian Schuh, published by De Gruyter. (c) BY-NC-ND This work is licensed under a Creative Commons Attribution-NonCommercial-NoDerivatives 4.0 International License.

https://doi.org/10.1515/9783110546316-002 
1300 and 4000 in the later Middle Ages. ${ }^{1}$ This development was concomitant with generally strong population growth: in the Holy Roman Empire, for example, the population increased from around 5-6 million around the year 1000 to between 13 and 15 million around $1300 .^{2}$ Smaller towns, like Nördlingen, had about 5000 inhabitants, while contemporary censuses indicate between 20000 and 30000 people lived in the city of Nuremberg during the fifteenth century. ${ }^{3}$ But even as they flourished, these towns were under constant threat from earthquakes, extreme weather events, severe epidemics, or political unrest and war. These exceptional events include, for example, the devastating earthquake at Basel in 1356 and famines in the beginning of the fourteenth century and during the $1430 \mathrm{s.}^{4}$

Whereas in most territories princely rule was the standard, in certain autonomous cities an oligarchic craft or merchant elite was able to take over administrative control in the course of the thirteenth and fourteenth centuries. ${ }^{5}$ In Nuremberg, for example, the decline of imperial and royal power after the Staufen rule was the starting point of a continuously growing legal and economic independence for the city, which was fully developed by the beginning of the sixteenth century. ${ }^{6}$

In this contribution, we focus on the interconnection between societal developments, the governance issues specific to a medieval and early modern Reichsstadt in the Holy Roman Empire situated on a river, and the influence of climatic extremes. The study of this premodern setting is particularly instructive, on the one hand, as it is characterized by the fast development of the city and its society as well as the corresponding production of written documents. On the other hand, the period witnessed a strong increase in the impact of natural disasters and climatic extremes. In addition, a high population in a limited space increased the potential vulnerability of the urban society and thus the impact of the catastrophic events induced by adverse weather conditions. The effects and consequences these events

1 Eberhard Isenmann, Die deutsche Stadt im Mittelalter, 1150-1550. Stadtgestalt, Recht, Verfassung, Stadtregiment, Kirche, Gesellschaft, Wirtschaft, 2nd ed. Vienna, Cologne, Weimar 2014, pp. 39-40.

2 Andreas WEIGEL, Bevölkerungsgeschichte Europas, Vienna, Cologne, Weimar 2012, pp. 68-70.

3 ISENMANN (note 1), pp. 58-61.

4 Gerhard FouQuet / Gabriel ZeILINGER, Katastrophen im Spätmittelalter, Darmstadt 2011, pp. 58-83.

5 IsENMANn (note 1), pp. 295-304.

6 Ernst PITZ, Die Entstehung der Ratsherrschaft in Nürnberg im 13. und 14. Jahrhundert (Schriftenreihe zur bayerischen Landesgeschichte 55), Munich 1956; Michael DIEFENBACHER, Nürnberg, Reichsstadt. Verwaltung, in: Historisches Lexikon Bayerns, online: http://www.historisches-lexikon-bayerns.de/ Lexikon/Nürnberg,_Reichsstadt:_Verwaltung (last accessed 15/05/2019); ID., Nürnberg, Reichsstadt. Politische und soziale Entwicklung, in: Historisches Lexikon Bayerns, online: https://www.histori sches-lexikon-bayerns.de/Lexikon/Nürnberg,_Reichsstadt:_Politische_und_soziale_Entwicklung (last accessed 15/05/2019); Carla MEYER-SCHLENKRICH, The Imperial city - the example of Nuremberg, in: Graham A. Loud / Jochen Schenk / Deutsches Historisches Institut London (eds.), The Origins of the German Principalities, 1100-1350. Essays by German Historians, London, New York 2017, pp. 68-82, here pp. $75-80$. 
had on the city were well documented by the municipal administration and by the sums of money it spent to repair damages caused by flooding and to counter their social consequences.

Environmental and climatic conditions are imprinted in natural archives, as, for example, in speleothems. ${ }^{7}$ Speleothems are carbonates that grow quasi-continuously in caves and record changes in climate and environment in their growth layers. Within the carbonate and its structure various proxies, such as isotopes or trace elements, can be used to infer details of climatic and environmental changes. Of the carbonate proxies, isotopes of oxygen and carbon that reflect changes in temperature and rainfall (oxygen isotopes) or temperature and vegetation (carbon isotopes) are amongst the most important and frequently used. ${ }^{8}$ Elements that are incorporated in the carbonate have proven to be useful in deducing changes in the hydroclimate and mineral growth characteristics. ${ }^{9}$ New developments in radiometric dating methods now allow us to assign relatively precise ages to stalagmite layers with uncertainties on the order of 1-10 years (for ages up to a few millennia) ${ }^{10}$ in the case of the U-Th disequilibrium dating method, and a few decades in the case of radiocarbon (C-14) dating. ${ }^{11}$ With high-resolution methods for isotope and element analyses, which allow us to resolve even seasonal and monthly events, ${ }^{12}$ a comparative assessment of historically-documented occurrences becomes possible.

Whereas the two relevant dating methods evolved rapidly, the interpretation of stalagmite proxy data remains challenging. In spite of its potential, proxy data in speleothems can be influenced by several factors ${ }^{13}$ and thus necessitates a detailed investigation of the actual proxy-environment relationship. For example, carbonate $\delta^{18} \mathrm{O}$ inherits the oxygen isotope signal from the drip water that is typically dominated by rainfall; in addition, it contains a component that is related to the

7 Frank McDeRmotT et al., Isotopes in Speleothems, in: Melanie J. LenG (ed.), Isotopes in Palaeoenvironmental Research, Berlin 2006, pp. 185-225.

8 Ian J. FAIRChILD / Andy BAKER, Speleothem Science. From Process to Past Environments, Chichester 2012, p. 450.

9 Ian J. FAIRCHILD / Pauline C. TREBLE, Trace Elements in Speleothems as Recorders of Environmental Change, in: Quaternary Science Reviews 28(5-6) (2009), pp. 449-468.

10 Hai CHENG et al., Improvements in ${ }^{230} \mathrm{Th}$ dating, ${ }^{230} \mathrm{Th}$ and ${ }^{234} \mathrm{U}$ Half-Life Values, and U-Th Isotopic Measurements by Multi-Collector Inductively Coupled Plasma Mass Spectrometry, in: Earth and Planetary Science Letters 371-372 (2013), pp. 82-91.

11 Quan Hua et al., Robust Chronological Reconstruction for Young Speleothems Using Radiocarbon, in: Quaternary Geochronology 14 (2012), pp. 67-80.

12 David P. MAtTEy et al., Seasonal Microclimate Control of Calcite Fabrics, Stable Isotopes and Trace Elements in Modern Speleothems from St. Michaels Cave, Gibraltar, in: Geological Society, London. Special Publications 336 (2010), pp. 323-344; Pauline C. TREBLE et al., Comparison of High Resolution sub-annual Records of Trace Elements in a Modern (1911-1992) Speleothem with Instrumental Climate Data from Southwest Australia, in: Earth and Planetary Science Letters 216 (2003), pp. 141-153.

13 MCDERMOTT et al. (note 7). 
temperature-dependent fractionation between water and carbonate. Fractionation refers to the preferential enrichment or depletion of isotopes in phase transitions (e. g. the change from liquid to vapour), during transport (for example by diffusion) or related to reaction processes. Furthermore, a reaction-kinetic component can alter the signal and mask both contributions. ${ }^{14}$ The detection of extreme events in speleothems is thus only possible under special conditions: 1) the speleothem grows under a drip site connected to the surface with a flow path that exhibits mean residence times on the order of months or less; this ensures that the signal is not completely averaged to an annual mean but shows some meaningful deviations from longterm signals; 2) the speleothem grows continuously and records all seasons; 3 ) the speleothem is not dominated by erratic kinetic components.

The comparative assessment of the data gathered by the analysis of speleothems with data from historical archives makes it possible to evaluate the extent to which extreme events may be imprinted in stalagmite carbonate. In a positive and quantitative case, the natural speleothem archive may provide neutral background information for the assessment of extreme events in the past; it can be used to evaluate historical documents in this context.

\section{Methods and Study Outline}

In our study, the natural sciences benefit from the specific dating of single weatherinduced flooding events gathered from historical documents. Conversely, proxy data for paleoclimate studies drawn from the analysis of stalagmites allow us to assess the value of written sources. The interdisciplinary approach makes new insights possible in two directions:

- Assessment if and to what extent climatic extremes documented in written sources are visible in selected 'natural archives'.

- Assessment of the value and precision of written documents concerning climatic extremes and their consequences.

Furthermore, in a final synthesis, the societal and administrative response to environmental challenges can be evaluated on the basis of the long-term environmental evolution, provided by the natural sciences component of the study, and the political, economic, and societal evolution, as deduced by scholars working in the humanities.

Our case study is the city of Nuremberg, situated at the river Pegnitz, and its $1200 \mathrm{~km}^{2}$ catchment area. Flooding events in premodern Nuremberg mainly occurred during the last months of winter, February and March (Figure 1), and were caused by

14 Matthew S. LACHNIET, Climatic and Environmental Controls on Speleothem Oxygen Isotope Values, in: Quaternary Science Reviews 28 (2009), pp. 412-432. 
meltwater and ice drift. Structures crossing the river within the city, such as bridges, caught the ice, blocked, and dammed up the water flow, thereby causing flooding of the city.

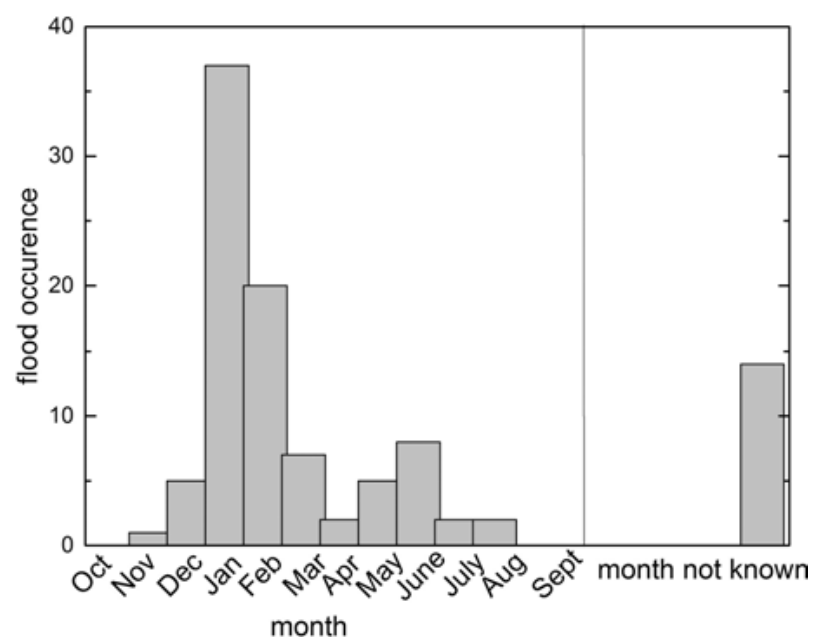

Figure 1: Occurrence of flooding events in Nuremberg $1400-1800$ by month.

Historical research on past climate and weather extremes and their consequences in Nuremberg hitherto focussed mainly on narrative sources such as annals and chronicles. ${ }^{15}$ There are, however, several problems with the analysis of this source type: the sources for these historiographical works are mainly unknown and it is, therefore, difficult to verify the events described. On the other hand, the city chronicles often take a tendentious perspective on events that highlight the actions taken by Nuremberg's ruling elite. Furthermore, early modern chronicles of flooding events seem to stress floods that happened in close temporal proximity to their time of writing. The growing body of administrative writing that was created from the end of the fourteenth century, ${ }^{16}$ in contrast, offers a more contemporary and unbiased perspective on flooding events and other environmental challenges. Records kept by the city's official administration are of high value in this context. For the identification of relevant documents, in-depth knowledge of Nuremberg's structure of administration is thus essential, ${ }^{17}$ starting with the identification of the city's office that dealt with the consequences of flooding. The

15 Rüdiger GLASER et al., Zur Temperatur- und Hochwasserentwicklung der letzten 1000 Jahre in Deutschland, in: DWD Klimastatusbericht 2003 (2004), pp. 55-67, here p. 66.

16 For a comprehensive overview see Paul SANDER, Die reichsstädtische Haushaltung Nürnbergs. Dargestellt auf Grund ihres Zustandes von 1431 bis 1440, Leipzig 1902.

17 Peter Fleischmann, Die Nürnberger Ämterbüchlein, in: Michael DiEFENBACHER / Wiltrud FischeRPACHE (eds.), Das Nürnberger Buchgewerbe. Buch- und Zeitungsdrucker, Verleger und Druckhändler 
most important administrative documents are the 'Ratsverlässe' (“council's decisions”) that shed light on day-to-day business in premodern Nuremberg. Since the end of the fifteenth century, the 'Ratsverlässe' have remained preserved in the municipal archives at Nuremberg. They keep account of the resolutions made by the Innere Rat (the higher administrative council) in its weekly sessions. ${ }^{18}$ A collection of the most important decrees was noted in the 'Ratsbücher' ("council books") and the 'Bürgermeisterbücher' ("mayor's books"). A second important group of documents was created by the city's administrative officers and by commissions that were created in order to solve specific problems within the city. Close examination of the administrative documents allows a relatively unbiased view of flooding events in Nuremberg during the period studied and helps to create an absolute chronology, which can be correlated with data obtained from the analysis of climate proxies.

Close to Nuremberg, well-known and studied caves that contain dated speleothems with up to annual resolution exist in the Jurassic limestone and dolomite of the Fränkische Alb, the 'Franconian Jura'. Annual resolution is provided by visible layers that reflect single years (verified by U-Th and ${ }^{14} \mathrm{C}$ measurements). ${ }^{19}$ For our purposes, it is important that part of the groundwater and river water of the Franconian Jura drains via the Pegnitz that flows through Nuremberg. One cave location that has been investigated in detail is the Zoolithen Cave, approximately $40 \mathrm{~km}$ from Nuremberg. ${ }^{20}$ In the course of an ongoing project (HEiKA "Check Extrema”, funded for 2016 by the Heidelberg University and Karlsruhe Institute of Technology research partnership) new stalagmites have been taken from the Zoolithen Cave and a cave close by, the Kleine Teufelshöhle, in order to close gaps in the data on growth periods of the stalagmites, thereby allowing for a complete comparison of historical documents with the geological archive during the medieval and early modern period. A selection of environmental tracers were analysed in these stalagmites at very high resolution (trace elements such as strontium [Sr] or magnesium $[\mathrm{Mg}]$ and isotopes such as ${ }^{13} \mathrm{C}$ and ${ }^{18} \mathrm{O}$ ) and investigated to determine what they may tell us about climatic extremes. The proxy analysis in the stalagmites has been complemented by a unique high-resolution monitoring of the caves. Physical information (humidity and temperature) together with water drip rates are collected continuously, while water

vom 16. bis zum 18. Jahrhundert (Quellen und Forschungen zur Geschichte und Kultur der Stadt Nürnberg 31), Nuremberg 2003, pp. 560-569.

18 Walter BAUERNFEIND, Innerer Rat, in: Michael DiEFENBACHER / Rudolf ENDRES (eds.), Stadtlexikon Nürnberg, 2nd ed. Nuremberg 2000, p. 477.

19 Dana F. C. Riechelmann et al., Annual-Resolution Carbon and Oxygen Isotope Time Series from Three Stalagmites from Zoolithencave (Southern Germany) and their Potential for Climate Reconstruction, in: Geophysical Research Abstracts 19 (2017), EGU2017-13520.

20 Georg WURTH et al., Der hierarchische Aufbau des Laminationsgefüges eines spät/postglazialen Kerzenstalagmiten aus der Zoolithenhöhle bei Burggaillenreuth (Fränkische Schweiz), in: Detlev K. RICHTER / Georg WURTH (eds.), Beiträge zur Speleologie I (Bochumer Geologische und Geotechnische Arbeiten 55), Bochum 2000, pp. 131-151. 
samples are taken in weekly intervals for isotope and elemental analyses. This kind of high-resolution monitoring has the potential to detect short-term weather-induced variations in the modern proxy data. Modern conditions and related events can serve as an example for past variations and are essential for the interpretation of past proxy data. In addition, the dating of the available and newly taken stalagmites was improved to achieve accuracy with uncertainties on the order of years to decades. For example, three stalagmites of the Zoolithen Cave were dated at the top using ${ }^{14} \mathrm{C}$. The atomic bomb tests of the 1960 s with a unique atmospheric ${ }^{14} \mathrm{C}$ spike provide a precise age marker that allows a good correlation with visible layers and age uncertainties of only a few years. Furthermore, for older growth periods U/Th was measured that provides absolute age tie points with uncertainties on the order of a few decades. Layer counting based on colour changes and fluorescence by humic acid layers (where possible) was applied to suitable stalagmites, which enabled us to adopt an approach that allows a year to year correlation with written documents.

\section{Results}

The study of the period between 1400 and 1800 in this short and focussed research project has already furnished highly interesting insights into climatic extremes, their perception and communication, and the societal responses to them. Of special interest was the assessment of historical documents for their objectivity and the study of stalagmite proxies with regard to potential imprints of extreme climate phases and weather events.

For the city of Nuremberg a 'flood chronology' that covers the period from 1300 to 2000 had already been composed by Rüdiger GLASER and others. ${ }^{21}$ The critical assessment of the existing historical flood chronology for Nuremberg showed that the information used was mainly drawn from the chronicle 'Wassergüß in Nürnberg', written around $1700 .{ }^{22}$ Drawing information only from one source, the chronology's reliability regarding specific details and its comprehensiveness have to be questioned. Many flooding events recorded in the chronicle for the second half of the seventeenth century, for example, were probably common knowledge at the time of its creation or even experienced by the writer himself. On the other hand, no clearly identifiable sources are known for the description of the events from the eleventh to the sixteenth centuries in GLASER's flood chronology. Furthermore, there is no hint as to which sources provide information for flooding events after 1690 in the chronology,

21 Rüdiger GlaSER, Thermische Klimaentwicklung in Mitteleuropa seit dem Jahr 1000, in: Geowisssenschaften 13 (1995), pp. 302-312; ID., Hochwasser, in: DIEFENBACHER / ENDRES (note 18), p. 452; ID. et al. (note 15), p. 66.

22 Nuremberg Staatsarchiv, Rst. Nürnberg, Hs. 434: 'Wassergüß in Nürnberg'. 
when the 'Wassergüß' chronicle ends. As far as the details are concerned, false replication of events, a failure to adjust dates following the introduction of the Gregorian calendar, and the incorrect assignment of dates to events were identified in "tambora. org". ${ }^{23}$ Taken together, these findings cast considerable doubt on the existing flood chronology for Nuremberg.

Our own in-depth historical analysis focussed on the well-known events in 1551, 1595, 1682, 1746, and 1784 that are labelled as 'catastrophic' in current research. These events are not only densely documented in the 'Ratsverlässe' and the records of the various municipal offices, but they also appear in a wide range of additional sources, such as official reports on damage caused by flooding and statutes aiming at preventing future damage and deaths. A detailed study of the available source material shows different intensities in the documentation of the five events. These differences cannot be satisfactorily explained simply by the changes in administrative practices over the centuries. Obviously, the five floods were very different in their extent and had extremely varied impacts on the buildings and the society of Nuremberg. In 1595, for example, it was not only the environmental impact that led to the destruction of the Henkersteg (a bridge inside the city), but inept human reactions played an important role, too: two craftsmen disregarded the orders given by the city official and broke the ice on the river on the wrong side of the Henkersteg. The loose ice then damaged the overpass and led to its collapse. ${ }^{24}$ So it was not only the ice itself that was responsible for this catastrophe, but first and foremost its inadequate handling by the craftsmen. In February 1595, however, the city was flooded twice by the Pegnitz (on the 23rd and the 26th) and the resulting destruction was massive. The council's decrees of the following weeks describe in detail the damaged bridges, mills, and other buildings of the city. ${ }^{25}$ Furthermore,

23 The results of the search with the terms "Hochwasser" and "Nürnberg" in https://www.tam bora.org/ were compared with the original entries in Nuremberg, Staatsarchiv, Rst. Nürnberg, Hs. 434: 'Wassergüß in Nürnberg'.

24 Nuremberg, Staatsarchiv, Rep. 60a, $\mathrm{n}^{\mathrm{o}}$ 1642, fol. $34^{\mathrm{r}-\mathrm{v}}$ (1595 January 18): Uff Meister Petter Carls verordenten waßer grafen, Ansag, was die zween schleuffer bey S. Catharina Closter, als er dieselben Ires uff dem Pegnitz fluß beschehenen Eissens halben, gutlichen zum stilstandt [fol. $\left.34^{\mathrm{V}}\right]$ biß zuvor das Eiß von den untern Mühlen nach einander ledig gemachet und fortt getrieben wurde, vermanet, Ime dagegen fur unnutze böse wortt gegeben, greulich aus gemachet, und mitt schmach wortten uber die Schutt nachgeschrien p., und das sie mitt Irem stettigen Eisen nicht wenig ursecher des erbermblichen schadens bey dem henckerssteg sein möchten $p$.

25 Ibid., $\mathrm{n}^{\mathrm{O}}$ 1643, fol. $40^{\mathrm{r}}$ (1595 February 26): Dieweiln die Schwaben Mühl durch die Itzige grosse wasser gieß sehr grossen schaden gelitten, soll man der aigen frawen, der Erberen Appolonia Sebastian Schleuderspachin, Als zu einem Notpaw, die notturfft Pawholtz geben lassen. Ibid., fol. $49^{\mathrm{r}}$ (1595 March 1): Weilen die waßer Inn dieser Statt noch zimblich groß, unndt die Brucken uber die Pegnitz zum teil gar eingefallen, zum teil sonsten bußwürdig worden, undt also die Jenigen, so über der Pegnitz Jenseits, und herwarts wohnen, schwerlich zusammen kommen können, darauß dann leichtlich ein weittleufftigkeit erfolgen möcht, wann sonnderlich leichtferttiges böses gesindlein sich zusammen rottieren, undt hernach zue früe unvermerckter sachen, sich herein schleichten solt, Alß ist 
they elaborate specific measures taken to respond to the catastrophic events. The main effort was to re-establish the water flow by removing debris from the riverbed with heavy machinery. ${ }^{26}$ Dealing with the economic consequences of the flooding, the focus lay on securing the availability of bread within the city, as the destruction of mills severely hindered the production of flour. ${ }^{27}$ Many more details on the damages and their consequences were noted in the 'Ratsverlässe' of the following weeks. In contrast to the description of the 1595 flood in the 'Wassergüß in Nürnberg' chronicle, that highlights the weather conditions and the flooded area, ${ }^{28}$ we find far more details on the political and societal reactions to the flooding events in the administrative sources.

befolchen die Thor vor dem garaus, undt biß es Tag würdte, biß uff weittern beschaidt, nit zusperren Deßgleichen die strainende Landtsknecht nit herrein Inn die Statt zulasßen, sondern sie der gepür nach abzuweisen.

26 Ibid., $\mathrm{n}^{\circ}$ 1643, fol. $47^{\mathrm{v}}$ (1595 March 1): Die werckhleut, so Inn der feuergehorsam begriffen, soll man alle zu sammen erfordern, undt vonn Inen vernemmen, welcher gestalt durch uffrichtung eines Zugs oder Kränichs die eingefallene Brucken undt Heusser ettlicher maßen auß dem Strom der Pegnitz geraumbt, undt dem Waßer sein freier lauff gemacht werden möchte, damit man uff das ehist wiederumb mahlen könn, waz sie nun also für guett ansehen, das soll man also Inns werckh richten, undt es daneben Inn die verordenten Herren setzen, ob sie Inn mangel gesindts undt Taglöner ettliche Handtwercker uffmahnen losßen wöllen, oder nicht.

27 Ibid., $\mathrm{n}^{\mathrm{o}}$ 1643, fol. $47^{\mathrm{v}}$ (1595 March 1): Dieweil die Yetzo ettlich Tag aneinander geweste große waßergüß ettliche gepeu undt die fürnembsten Mühlwerckh angegriffen, undt zerrisßen, also das man sobalden, undt biß dieselben wieder referiert undt erpauet werden, mit dem mahlen alhie nit würdt vortkommen können, auch dahero albereit mangel undt klemme an brott erfolgt, zu Altorff aber, Neuenmarckht, undt anderer umbgelegener ort die Waßer sich nichts sonnderlichs ergoßen haben sollen.

28 Nuremberg, Staatsarchiv, Rep. 52a, Hs. $\mathrm{n}^{\circ} 434$, fol. $16^{\mathrm{v}}$ : Den 23. February, am St. Matthaiabendt, nachdem es innerhalb vier Wochen, und seit her deß Jüngst geweßenen grosen gewßers und Eyßes, einem großen und tieffen Schnee gelegt, darauff dem gebürg eines Manns hoch war, als dießer nach eingefallen Leim Wetter zerging, kam auff obgemelten tag ein groses und erschröckliches grausames gewäßer alhero, wuchs gegen der Nacht biß umb acht uhr, da stundt es still; biß umb ein gen tag, gieng eine gute Ellen hoch über das Mesene Täffelein gegen dem Sandbadt am Eck der Neuengaßen, rieße zu Wehrd den Langen Steeg ein, wie auch den Steeg auff der Schütt, da die Mühlterstätten ist, mehr stieß es ein stück von der steinern Mauren am St. Catharina Clostergarten ein, gegen der Schütt $z u$, und führet hinweg den Steeg bey der Catharina Schleiffmühl, und den Steeg bey der Pfannenmühl, der Neue Spittal und die Kirchen daselbst, litten große noth, dann das Waßer hette nur noch eine Staffel bevor, das es nicht gar in die Kirchen floß, es gabe sich der Altar bey der Sacristey in der mitt von einander, und wurde das Pflaster in der Kirchen alles auffgehoben, und wurde hernach dieße Kirchen vier Wochen zugespert, die steinerne Parfüßer Brucken, sencket und zerkloh sich, das man solche wegen anlauffung der Leuthe mit Brettern verschlagen muste, es reißet auch eine ganze Seiten Wandt an der Schwabenmühl gegen dem Schleiffersteeg hinweg, in Summa es ist nicht alles zuerzählen, was dießes gewäßer an Heußern, Brucken, Mühlen, un Krämen Gewölbern, umb den Marckt unter deß Rieders Hauß im Spittal, in den Kellern, Badstuben, und den Burigern, so am Waßer gewohnt, am Haiußrath und andern Sachen; für einen unaußsprechlichen Schaden gethan hat, dann sich niemandt eines so großen Waßer beförchtet, und nicht hoch genug auffgeraümet hatte, und 
As a reaction to the regular flooding events and their consequences, several administrative measures were taken in Nuremberg in order to reduce the dangers of the natural hazard. Between 1464 and 1475, for example, Endres Tucher compiled the 'Baumeisterbuch' (“master builder's book”), a manual that collected various preventive measures that could contribute to reducing the flooding risk at neuralgic points in the city, such as the riverbanks, mills, and bridges. Tucher even outlined an emergency action plan in his work. This plan allocates craftsmen with specific skills to specific locations where they could fight the imminent dangers most effectively. Carpenters, for example, were assigned to guard bridges and were to use their tools to destroy sheets of ice that blocked the water flow. Furthermore, an alarm system was installed along the river Pegnitz that helped to anticipate upcoming floods. ${ }^{29}$ According to the account of the contemporary chronicler Sigismund Meisterlin, this organized handling of the environmental impact helped to reduce the damages caused by floods in Nuremberg much more effectively. ${ }^{30}$

From a paleo-climatic perspective, the redaction of the 'Baumeisterbuch' coincided with deteriorating climatic conditions and lower mean annual air temperatures. $^{31}$ Based on the current chronology of the Hölloch stalagmite (Allgäu, Southern Germany) ${ }^{32}$ the climate from 1400-1800 was rather dry (generally high Sr concentration and low Fe concentration) punctuated by a few prominent layers with extremely low Sr concentration (for example, during the sixteenth century). The generally high Sr concentrations coincide with the strongest negative $\delta^{18} \mathrm{O}$ excursion of the last 7000 years in the same stalagmite, which may indicate relatively cold conditions. The flood occurrence chronology including the five investigated

wurde was dießes gewäßer alhier, so einem Erbarn Rath, und gemeinder Burgerschafft Schaden gethan, in drey Thönnen goldtes werth geschäzet.

29 Endres Tucher, Baumeisterbuch der Stadt Nürnberg, 1464-1475, ed. Matthias LEXER, Stuttgart 1862. Cf. Stefanie RÜTHER, Zwischen göttlicher Fügung und herrschaftlicher Verfügung. Katastrophen als Gegenstand spätmittelalterlicher Sicherheitspolitik, in: Christoph KAMPMANN / Ulrich NIGGEMANN (eds.), Sicherheit in der Frühen Neuzeit. Norm, Praxis, Repräsentation, Cologne 2013, pp. 335-350. Contemporary background to LEXER's edition of the 'Baumeisterbuch' is provided by Jürgen PETERSOHN, Geschichtswissenschaft engagiert sich für Germanistik. Franz Xaver Wegele und die Berufung des Kärntners Matthias Lexer an die Universität Würzburg (1868/1869), in: Mitteilungen des Instituts für Österreichische Geschichtsforschung 124 (2016), pp. 430-435.

30 Sigismund Meisterlin's Chronik der Reichsstadt Nürnberg. 1488, in: Karl HEGEL (ed.), Die Chroniken der fränkischen Städte. Nürnberg, vol. 3 (Die Chroniken der Deutschen Städte 3), Leipzig 1864, pp. 1-178, here p. 169: Anno domini 1379 jar. Zu diesen zeiten tet die Pegnitz unaussprechenlichen großen schaden der stat Nurenberg, wann der fluß was nit eingefast, noch mit mauren versorgt, noch mit brucken von felsen gemacht, als nun bei unsern tagen.

31 Michael E. ManN et al., Proxy-Based Reconstructions of Hemispheric and Global Surface Temperature Variations over the Past Two Millennia, in: Proceedings of the National Academy of Sciences 105(36) (2008), pp. 13252-13257.

32 Georg WuRTH et al., The Younger Dryas and Holocene Climate Record of a Stalagmite from Hölloch Cave (Bavarian Alps, Germany), in: Journal of Quaternary Science 19 (2004), pp. 291-298. 
'catastrophic' floods mimic the curve based on $\delta^{18} \mathrm{O}$ (Figure 2). This coincidence could be due to the importance of winter floods and ice blockages for Nuremberg. Thus, an increasing number of days with freezing temperatures may have increased the risk of damage caused by rafting ice; this may consequently have triggered the composition of the 'Baumeisterbuch'.

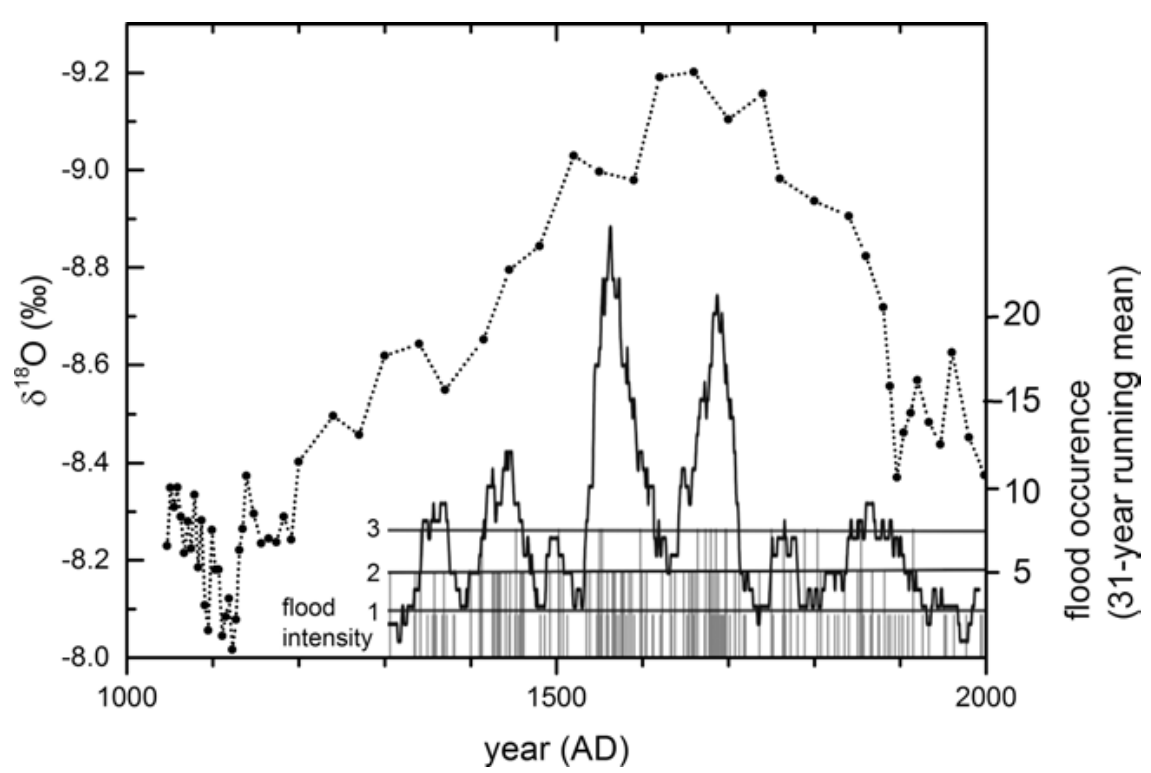

Figure 2: Flood occurrence chronology of Nuremberg (continuous line, right axis; modified from GLASER et al. [note 15], p. 66) relative to the oxygen isotope evolution of the Hölloch stalagmite (dotted line, left axis). Colder periods in this stalagmite are related to more negative $\delta^{18} 0$ values. The stalagmite $\delta^{18} 0$ values were measured and provided by Prof. Dr. Christoph SPÖTL from Innsbruck University.

As repeated references in administrative records and the existence of several copies demonstrate, the 'Baumeisterbuch' was annotated with comments and remained in use in the seventeenth century. ${ }^{33}$ In combination with the inhabitants' legally binding obligation to keep the river free of ice, such precautions apparently helped to improve the situation significantly. By the end of the eighteenth century, and heavily influenced by the experience of the 1784 flood, an ordinance was created and published by the city council that contained clearly defined measures and rules for flood protection. ${ }^{34}$

33 For example, the copy Nuremberg, Stadtarchiv, B 1/I, $n^{\circ} 17$, fol. $209^{\mathrm{v}}-244^{\mathrm{r}}$.

34 Ordnung, wie es allhier zu Nürnberg mit den Anstalten zu Abwendung der Gefahr bei außerordentlicher Ergießung des Pegnizflußes, gehalten werden solle, [Nuremberg] 1785. 
Shortly before the end of the autonomy of the city in 1806, modern forms of state government can be detected. ${ }^{35}$ The constant threat of flooding prompted the city's ruling elite to create and implement effective strategies to reduce the risks and damages caused by these natural hazards. Nevertheless, these actions did not suffice to contain the consequences of the four mentioned major floods, and environmental impacts repeatedly challenged the premodern city society that lived on the river.

\section{Implications and Outlook}

Finally, it is worth asking, how the interdisciplinary study of flooding events in medieval and early modern Nuremberg might be relevant today. On a scientific level, both the natural sciences and the humanities involved in this project benefit from an integrated approach. The project's design is based on mutual understanding of the research methods in each field. This requires intensive and fundamental exchange of the insights that can be gained on both sides. Geoscience and historical research thus have to discuss their ways of creating knowledge. In the course of this discussion, it became clear that both sides are ultimately interpreting information, drawn on the one side from documents and on the other side from stalagmites. In the end, their methods of achieving scientific insights are based on similar groundwork. Once one engages in this process of discussion and exchange, the differences between the natural sciences and the humanities tend to become far less important.

As far as our immediate object is concerned, the historical analysis of the administrative records in Nuremberg allows us to compile a reliable chronology of flooding events in the city during the premodern period. This chronology can, in turn, help the natural sciences to calibrate their climate proxy data drawn from the analysis of stalagmites. As no other similarly reliable data points for calibration exist, cooperation involving historical research entails profound advantages for the geosciences. For historical research, on the other hand, the analysis of the climate proxy data provides an unbiased reconstruction of past climate change and extreme weather events. This reconstruction is not based on human perceptions but on signals in the 'archives of nature'. Although the analysis of the signals also requires interpretation, they provide a completely different perspective on the past than historical documents. This helps to evaluate the perceptions of environmental impacts in the written sources.

35 Helge WeInGÄRTNER, Die Selbstverwaltung der Reichsstadt Nürnberg, in: Michael DiEFENBACHER / Gerhard RECHTER (eds.), Vom Adler zum Löwen. Die Region Nürnberg wird bayerisch 1775-1835 (Ausstellungskataloge des Stadtarchivs Nürnberg 17), Nuremberg 2006, pp. 29-42; DIEFENBACHER, Entwicklung (note 6). 
Reactions to the flooding events in Nuremberg between 1400 and 1800 show that the ruling elite and the population of the city were not helpless victims of the environmental challenges. Already in the fifteenth century the "Baumeister" ("master builder") as city official and his craftsmen identified ice as the main reason for flooding during the winter months and developed adaptive strategies. In consequence, many of the responses to the danger of flooding aimed at destroying ice and preventing it from blocking the water flow of the river. The knowledge and the related expertise were written down in the 'Baumeisterbuch', a work that remained in use until the seventeenth century and formed the basis for later regulations and legislation concerning the river. The recurring environmental challenges for a city situated at a river were met with considered measures that addressed the primary cause of something that might otherwise have potentially fatal consequences.

Overall, an awareness of the environmental challenges and their main dangers is discernible. Out of self-interest, but also out of responsibility for the community, the ruling city elite created a system that helped to tackle the problems that arose from the river. ${ }^{36}$ This system was cultivated and improved over the centuries, although it could not prevent the catastrophic consequences of extreme floods. Nevertheless, its sheer existence attests to a willingness to address the imminent threat on a basis that outlasted the lives of individual persons.

In order to conclude this preliminary report on our research, we would like to highlight that we are facing several institutional problems arising from the interdisciplinary approach we have adopted to the study of flooding events in medieval and early modern Nuremberg. It must be underlined that gathering data from stalagmites in caves and from documents in archives both represent time-consuming activities. Funding for this kind of long-term project that involves complex research for all the participating disciplines is difficult to obtain. Unfortunately, the traditional programmes financed by the German Science Foundation or similar institutions are not designed with collaborative projects that bring together the (natural) sciences and the humanities in mind. As a consequence, we must rely on smaller grants in order to pay for particular aspects of our research. This is an additional obstacle to the execution of an already challenging endeavour. Yet another problem is publishing our results, as we have to identify options that are equally attractive to all the researchers who participate in the project. There is little common ground to be found between academic publications in geosciences and history. Consequently, we have to look for alternative formats. This is a case in point. Being part of this innovative volume on the relevance of the Middle Ages

36 Andrea Bendlage / Peter Schuster, Hüter der Ordnung. Bürger, Rat und Polizei in Nürnberg im 15. und 16. Jahrhundert, in: Mitteilungen des Vereins für Geschichte der Stadt Nürnberg 82 (1995), pp. 37-55. 
allows us to present our research to researchers from the humanities; for an audience from the (natural) sciences we will have to find another forum for publication. The fruitful exchange that enriches our respective work, however, continues to motivate us, all the while enabling us to broaden our perspective in unexpected ways.

Acknowledgment: The HEiKA (Heidelberg-Karlsruhe Research Partnership Heidelberg University, Karlsruhe Institute of Technology (KIT), Germany) Project team "Check Extrema" consisted of Thomas Neumann, Elisabeth Eiche, Philipp Holz, Arno Hartmann (all Institute of Applied Geosciences, KIT), Tobias Kluge (Institute of Environmental Physics, Heidelberg University), Gabriel Meyer, and Maximilian Schuh (Historisches Seminar, Heidelberg University). We acknowledge the joint effort of the whole team for the investigation and assessment of the research topic and are grateful for funding provided by HEiKA. 


\title{
Medieval History, Explosive Volcanism, and the Geoengineering Debate
}

\begin{abstract}
One of the most important issues facing humanity is the rise in temperature of the planet. One current line of investigation for the reversal of global warming is that of using one or more of a suite of geoengineering (or climate engineering) techniques known as solar radiation management (SRM) in order to reflect sunlight back into space. The Paris Agreement of 2015, COP21, invited further research into this kind of geoengineering solution. One idea is to artificially emulate the effect of large volcanic eruptions, which can certainly lead to global cooling. Here, medieval history offers a perspective from which to help understand the challenges that geoengineering may present and inform our choices. The closest natural parallel to stratospheric aerosol injection (SAI) geoengineering are volcanic eruptions and case studies of their climatic (and subsequent societal) impacts are much needed.

By studying historical explosive volcanism, medieval history provides a laboratory for understanding the climatic and societal impacts of geoengineering in the form of reports of extreme weather and societal stresses such as subsistence crises and even conflict arising from scarcity induced resource competition. We argue that this history must be taken seriously in the discussion about whether to proceed with solar geoengineering. The twentieth and twenty-first centuries have been volcanically quiescent relative to earlier centuries, but this can change at any time. In particular, advocates of a geoengineered solution have to appreciate the relevance of the question: what will happen if the planet experiences another period in which one or more sulphur-rich VEI 5 to 7 eruptions occur, if we have already laden the stratosphere with sulphates artificially? The medieval experience of such eruptions can point to an answer that serves as a warning.
\end{abstract}

\footnotetext{
1 This publication represents a contribution to the "Historical Dynamics of Violence, Conflict and Extreme Weather in Medieval Ireland" (CLIMCONFLICT) project. This project has received funding from the European Union's Horizon 2020 research and innovation programme under the Marie Skłodowska-Curie grant agreement No. 709185. Francis acknowledges additional support and input from the Trinity Centre for Environmental Humanities, Trinity College Dublin, and the Volcanic Impacts of Climate and Society (VICS) Working Group of PAGES. Both Conor and Francis acknowledge the contribution of Chaochao GAO and Or AMIR in an earlier collaborative work from which this paper draws, with permission of Elsevier, see Chaochao GAO / Francis LuDLow / Or AMIR / Conor KosTick, Reconciling Multiple Ice-Core Volcanic Histories. The Potential of Tree-Ring and Documentary Evidence, 670-730 CE, in: Quaternary International 394 (2016), pp. 180-193, online (DOI): https://doi. org/10.1016/j.quaint.2015.11.098 (last accessed 15/05/2019).
}

Conor Kostick and Francis Ludlow, Department of History, School of History \& Humanities, Trinity College Dublin, Dublin 2, Ireland, conorkostick@gmail.com / ludlowf@tcd.ie 
Keywords: geoengineering, sulfate aerosol injection, global warming, explosive volcanism, early medieval, annals, chronicles, climate history, historical climatology

\section{Explosive Volcanism and Geoengineering}

Record-breaking weather extremes, from hurricanes to flooding and drought, continue to occur at a pace greater than expected under natural climate variability, ${ }^{2}$ consistent with a warming climate system. It has thus become increasingly attractive among scientists and policymakers to consider counteracting global warming, and hence hopefully its more deleterious impacts, through technological means. In the near future it will likely become technologically feasible for society to lower global annual average temperatures by artificially blocking a fraction of sunlight from reaching the planet's troposphere or surface, using one or more of a suite of geoengineering (or climate engineering) techniques known as solar radiation management (SRM). These techniques are under increasingly intensive research by climate scientists and engineers, with a growing discussion among economists and policymakers regarding their potential implementation as a remedy to global warming.

Among existing SRM proposals, perhaps the most prominent and (in the near term) technologically and financially feasible is that of the stratospheric aerosol injection (SAI) of chemical compounds that would act to reduce average tropospheric temperatures by changing the Earth's albedo (i. e., reflectivity). Sulphur dioxide $\left(\mathrm{SO}_{2}\right)$ gas injected into the stratosphere would, for example, oxidize to form sulphate aerosol particles known to efficiently back-scatter incoming solar direct (shortwave) radiation to space. Geoengineering the climate in this manner is an idea that ultimately derives from long-standing yet still evolving understandings of the atmospheric and climatic consequences of explosive volcanism. ${ }^{3}$ Historically, a suggestive link was posited by the ancient Roman author, Virgil, between the explosive release of materials from an eruption of Etna (Sicily) in 44 BCE and a widely noted episode of diminished and discoloured sunlight and other unusual

2 Christopher B. Field / Vincente BARRos / Thomas F. STOCKER / Quin DAHE / David Jon Dokken / Kristie L. Ebi / Michael D. Mastrandrea / Katharine Mach / Gian-Kasper Plattner / Simon K. AlLen / Melinda Tignor / Pauline M. Midgley (eds.), Managing the Risks of Extreme Events and Disasters to Advance Climate Change Adaptation. Special Report of the Intergovernmental Panel on Climate Change, Cambridge 2012.

3 Alan Robock / Douglas G. MacMartin / Riley Duren / Matthew W. Christensen, Studying Geoengineering with Natural and Anthropogenic Analogs, in: Climatic Change 121(3) (2013), pp. 445-458; see also Alan Rовоск, Stratospheric Aerosol Geoengineering, in: Roland HeSTER / Roy M. HARRISON (eds.), Geoengineering of the Climate System (Issues in Environmental Science and Technology), Cambridge 2014, pp. 162-185. 
atmospheric optical phenomena. ${ }^{4}$ Other authors such as Pliny the Elder variously described the atmospheric phenomena seen in the Mediterranean region at the time or the severe cold weather in this and the next several years, ${ }^{5}$ with Plutarch explicitly noting a link between the diminished sunlight and its impact on climate and agriculture. ${ }^{6}$ Thus Plutarch describes how:

all that year [i. e., 44 BCE] the [sun's] disk was pale and without radiance. The heat that came down from it was feeble and reduced. By reason of the weakness of the warmth penetrating it, the atmosphere became thick, murky and heavy. Grain and fruits withered and shrivelled on account of the ambient coldness. ${ }^{7}$

Later, in 1784, Benjamin Franklin conjectured that the prolonged eruption of the Icelandic fissure volcano Lakagigar (translatable as "craters of Laki" and more often just called "Laki") that began in the previous year (8 June) explained the unusual cold in Europe and North America in the year that followed. ${ }^{8}$ A more significant advance in modern understanding occurred after the great 1883 eruption of Krakatau, Indonesia, especially in the work of geologist and mining engineer Rogier D. M. VERBEEK in a classic report commissioned by the Dutch government. This detailed the atmospheric ef-

4 See Virgil's 'Georgics' 1.466-73, as cited by Philis Y. ForsYTH, In the Wake of Etna, 44 B. C., in: Classical Antiquity 7(1) (1988), pp. 49-57, here p. 50. Note that new ice-core-based volcanic forcing histories suggest that the atmospheric phenomena (or 'dust veil') at this time is likely to have originated in a major tropical eruption, c. 44 BCE, being perhaps the third largest of the past 2,500 years on the evidence of sulfate levels deposited within polar ice sheets. This is supported by observations of diminished and discoloured sunlight in Chinese sources from the period. This does not, however, necessarily mean that the probable eruption of Etna in 44 BCE made no contribution, see Michael Sigl / Mai Winstrup / Joseph R. McConnell / Kees C. Welten / Gill PlunketT / Francis Ludlow / Ulf Büntgen / Marc W. Caffee / Nathan Chellman / Dorthe Dahl-Jensen / Hubertus Fischer / Sepp Kipfstuhl / Conor Kostick / Olivia J. MASELLI / Florian MEKHALdi / Robert MulVANEY / Raimund Muscheler / Daniel R. PASTERIS / Jonathan R. PILCHER / Martin SAlZER / Simon SCHÜPBACH / Jorgen Peder Steffensen / Bo M. Vinther / Thomas E. WoodRufF, Timing and Climate Forcing of Volcanic Eruptions for the Past 2,500 Years, in: Nature 523 (2015), pp. 543-549.

5 FORSYTH (note 4).

6 See Plutarch ('Caesar' 69), as cited in Peter Bicknell, Blue Suns, the Son of Heaven, and the Chronology of the Volcanic Veil of the 40s B. C., in: The Ancient History Bulletin 7(1) (1990), pp. 2-11.

7 Translation after ibid., p. 9, and we follow BicknelL's determination that Plutarch refers here to 44 BC. Plutarch does not, however, appear to have connected the eruption of Etna to the atmospheric phenomena he describes.

8 Alexandra WiTZE / Jeff KANIPE, Island on Fire. The Extraordinary Story of Laki, the Volcano that Turned Eighteenth-Century Europe Dark, London 2014, p. 125. Franklin mistakenly attributed the eruption to 'Hecla' rather than Laki; see Sigurdur THORARINSSON, Greetings from Iceland. Ash-Falls and Volcanic Aerosols in Scandinavia, in: Geografiska Annaler 63A(3/4) (1981), pp. 109-118; see also Benjamin FrankLIN, The Meteorological Imaginations and Conceptions, in: Memoirs of the Literary and Philosophical Society of Manchester 3 (1785), pp. 173-177. 
fects of the eruption, including changes in atmospheric clarity and opacity caused by high-altitude aerosol particles of volcanic origin that had encircled the globe within two weeks of the eruption. ${ }^{9}$ Through the twentieth century, and particularly with the advent of meteorological satellite observations since the $1960 \mathrm{~s}^{10}$ and other groundbased remote sensing techniques (lidar, radar), the process by which volcanic aerosol clouds can trigger hemispheric and even global-scale average cooling has become increasingly understood. ${ }^{11}$ The bulk of this cooling arises from the creation of sulphate aerosol particles (when volcanic $\mathrm{SO}_{2}$ or $\mathrm{H}_{2} \mathrm{~S}$ explosively injected into the stratosphere oxidize to form $\mathrm{H}_{2} \mathrm{SO}_{4}$ ) that can efficiently backscatter incoming solar radiation to space, thereby reducing tropospheric temperatures. ${ }^{12}$

An oft-cited 2006 essay by Nobel Laureate Paul CRUTZEN provided considerable additional impetus to research into geoengineering via stratospheric aerosol injection (SAI), ${ }^{13}$ by clearly articulating an imperative and rationale for research into such technology as a potential means of counteracting catastrophic global warming, hence breaking a perceived taboo around research into such technologies. ${ }^{14}$ Present estimates of the cost of implementing SAI suggest it would be relatively inexpensive for a large country or group of countries to engage in this form of geoengineering, from "a few billion dollars" per year up to US $\$ 10$ billion. ${ }^{15}$ This is a modest amount when set against declared national military budgets (e. g., $\$ 595.5$ billion in 2015 by the USA). ${ }^{16}$ Already - backed by Bill Gates - millions of dollars have been spent in developing an

9 Jelle ZeILInga DE BoER / Donald Theodore SANDERS, Volcanoes in Human History. The FarReaching Effects of Major Eruptions, Princeton 2002, p. 158.

10 The first weather satellite was released in 1959, but not considered as successful as planned. More successful launches occurred throughout the 1960s, see William J. BURROUGHS / Bob CROWDER / Ted ROBERTSON / Eleanor VAlliER-TALBot / Richard WhitaKeR, The Nature Companions Weather Watching, San Francisco 2003, pp. 80-81.

11 Also see important early twentieth-century work by William Jackson HUMPHREYs, Volcanic Dust and Other Factors in the Production of Climatic Changes, and their Possible Relation to Ice Ages, in: Bulletin of the Mount Weather Observatory 6 (1913), pp. 1-34.

12 Alan Rовоск, Volcanic Eruptions and Climate, in: Reviews of Geophysics 38 (2000), pp. 191-219. 13 Paul J. CRUtzen, Albedo Enhancement by Stratospheric Sulfur Injections: A Contribution to Resolve a Policy Dilemma?, in: Climatic Change 77(3-4) (2006), pp. 211-219.

14 So described by Mark G. LAWREnCE / Paul J. CRUtzen, Was Breaking the Taboo on Research on Climate Engineering via Albedo Modification a Moral Hazard, or a Moral Imperative?, in: Earth's Future 5(2) (2007), pp. 136-143. Research into SAI existed before CRUTZEN's 2006 essay and the wider special section of "Climatic Change" that it prefaced, but the essay was certainly followed by a rapid expansion of publications on the topic. For examples of earlier relevant work, particularly pertaining to SAI, see Robert E. Dickinson, Climate Engineering: A Review of Aerosol Approaches to Changing the Global Energy Balance, in: Climatic Change 33 (1996), pp. 279-290.

15 Ryo Moriyama / Masahiro Sugiyama / Atsushi Kurosawa / Kooiti Masuda /Kazuhiro Tsuzuki / Yuki Isнiмото, The Cost of Stratospheric Climate Engineering Revisited, in: Mitigation and Adaptation Strategies for Global Change 22 (2017), pp. 1207-1228.

16 Figure from https://www.nationalpriorities.org/campaigns/military-spending-united-states (last accessed 15/05/2019). 
active research program into SAI geoengineering. China's Ministry of Science and Technology has announced that it will invest \$ 3 million and employ fifteen researchers (and accept forty students) at Beijing Normal University, Zhejiang University and the Chinese Academy of Social Sciences to develop a geoengineering research programme. This will not be an experimental programme, rather it will explore the theoretical possibilities as well as the related legal and policy implications. ${ }^{17}$

By contrast, the Harvard-based research funded by Bill Gates and other philanthropists is designing experiments into the subject. David KeITH and Frank KEUTSCH are constructing a 'StratoCruiser', a collection of sensors and spraying devices attached to a high-altitude balloon. Their intention is to launch the balloon from a site in Tucson, Arizona. The StratoCruiser will test the impact of various particles (sulphur dioxide, alumina, and calcium carbonate) it has sprayed to examine the extent to which the stratosphere becomes more reflective, determine what chemical reactions have taken place and identify whether the aerosol mists disperse or coalesce. World View Enterprises have already begun to construct and test the balloon. ${ }^{18}$ The locations of many other geoengineering projects (from research to experimentation, and not restricted to SAI) are shown at map.geoengineeringmonitor.org, with $800+$ projects in 2017 versus 300 in 2012. ${ }^{19}$

In July 2017, about 100 scientists gathered at the Grand Summit Hotel near Boston to discuss climate engineering. Hosted under the auspices of the Gordon Research Conferences, this event was held under 'Chatham Rules', in other words, in privacy and without a record being taken to facilitate an open dialogue among participants on what is a generally controversial topic, though the agenda and keynote speakers were publicly available. Subsequent interviews with delegates at the conference suggested a broad acceptance that of all the possible approaches to geoengineering considered, SAI is likely to be the easiest to model and, in the event that it proves problematic, to reverse. ${ }^{20}$

Several key concerns have been repeatedly expressed over the prospect of SAI geoengineering. Most common is that it does not address the underlying increase in atmospheric greenhouse gas concentrations and hence does not address other

17 James Temple, Harvard Scientists Moving Ahead on Plans for Atmospheric Geoengineering Experiments, in: MIT Technology Review, 27/03/2017, online: https://www.technologyreview.com/ s/603974/harvard-scientists-moving-ahead-on-plans-for-atmospheric-geoengineering-experiments (last accessed 15/05/2019).

18 Ibid.

19 This map (https://map.geoengineeringmonitor.org/ [last accessed 15/05/2019]) is provided by the ETC Group and the Heinrich Böll Foundation, with the caveat that there is no fully complete record of geoengineering projects available.

20 Robinson MEYER, To Stop Global Warming, Should Humanity Dim the Sky? The world's top geoengineering researchers met off the record to discuss the possibility in Maine last month, in: The Atlantic, 07/08/2017, online: https://www.theatlantic.com/science/archive/2017/08/geoengineersmeet-off-the-record/536004/?utm_source=feed (last accessed 15/05/2019). 
associated deleterious impacts such as ongoing ocean acidification as these waters continue to absorb $\mathrm{CO}_{2}$. Indeed, it seems possible that research into SAI and other geoengineering technologies may even militate against emissions reductions. This is the much-discussed 'moral hazard' problem. Here it has been argued that progressing not only toward actual implementation, but even primary research into SAI, may hamper efforts to achieve a more definitive solution through greenhouse gas emissions reduction and cessation. It is certainly plausible to consider that any development potentially allowing the continuance of current economic practices (whilst avoiding global average temperature increase) may be highly attractive to politicians and policy makers who have struggled with conflicting imperatives (perceived trade-offs between short to medium term economic growth goals versus climate action $)^{21}$ and have often been successfully influenced by vested interests via lobbying or regulatory capture. These interests (e. g., fossil fuel and petrochemical companies) would thus not only profit from continuing to externalize the costs of greenhouse gas emissions, but also potentially profit from public-borne costs of implementing SAI or other geoengineering. ${ }^{22}$

If research and the development of practical SAI technologies do indeed serve to diminish the drive for emissions control, this may contribute to a 'lock in' effect in which the implementation of SAI or related SRM geoengineering becomes an increasingly credible proposition to counteract the deleterious impacts of global warming, and once implemented, becomes essential to continue as emissions reductions fail to be achieved at the necessary level. Such concerns can be countered by pointing, legitimately, to the ongoing failure to deliver truly meaningful (i. e., globally agreed, legally binding and effective at limiting warming to under $2^{\circ} \mathrm{C}$ ) emissions reductions. LAWRENCE and CRUTZEN thus suggest that while geoengineering research may pose a moral hazard, there simultaneously exists a moral imperative to understand the possibilities, costs and benefits of such technologies and facilitate the potential for their deployment. ${ }^{23}$ Such a view is further supported by genuine concern over the existence of both unanticipated and anticipated-but-uncertain thresholds, tipping points, feedbacks and surprises in climate and related ecological processes responding to continued global warming, ${ }^{24}$ and which may shift public and political perceptions towards acceptance of the need for a rapid geoengineering intervention if the technology has developed to allow this. This argument is bolstered by modelling that suggests, in a scenario in which rising temperatures and associated impacts required emergency

21 Failure to act on climate change will in the longer term likely prove a greater impediment to economic growth as climate change impacts continue to magnify.

22 Here, for example, regarding the costs of producing immense volumes of $\mathrm{SO}_{2}$ or other SRM geoengineering prerequisites.

23 LaWrence / CRutZen (note 14).

24 For a review, see National Research Council, Abrupt Impacts of Climate Change: Anticipating Surprises, Washington / DC 2013. 
intervention, even rapid emissions cuts (i. e., more severe than cuts presently optimistically foreseen) would not bring climate back under 'control' as rapidly as SAI. ${ }^{25}$

Just as there are uncertainties and unknowns associated with the impacts of continued global warming, however, these also exist for SAI geoengineering. Here, the discussion is more speculative, in part because of incomplete understandings of the climate system and its linkages to related earth and ecological systems, and because the majority of research into the impacts of geoengineering necessarily depends upon climate or earth system modelling. These models are becoming increasingly sophisticated, capturing earth system processes in ever more detail, and certainly provide a valid means of exploring the consequences of geoengineering at a broad level (such as estimating the reduction of mean global temperatures). But they remain models, with inherent uncertainties, ${ }^{26}$ and challenges remain in simulating climate responses to forcings such as sulphate aerosols, ${ }^{27}$ including on finer spatial (local to regional) scales. This is critical because it is at local to regional scales that individuals and societies must experience climate and plan for extreme weather, and at this scale that societies will experience the variable impacts of possible SAI geoengineering. ${ }^{28}$ Of particular concern in this respect are impacts from geoengineering on regional precipitation and hydroclimates.

While temperature impacts have historically been the dominant focus of volcanic climatic impact studies, recent work using improved climate modelling and

25 Detlef P. van Vuuren / Elke StehFEST, If Climate Action Becomes Urgent: The Importance of Response Times for Various Climate Strategies, in: Climatic Change 121(3) (2013), pp. 473-486. More specifically, the authors find (ibid., p. 473) that "reduction rates [...] [of] up to $6 \%$ [per year] [...] could effectively reduce climate change, but only with a noticeable delay" and with "temperatures [...] above those in the year of policy introduction for more than 70 years [...]" while "a strategy based on SRM is shown to have much shorter response times [. . .]".

26 For relevant discussion, see Sajjad EGHDAMIRAD / Fiona JOHNSON / Ashish SHARMA, How Reliable are GCM Simulations for Different Atmospheric Variables?, in: Climatic Change 145(1-2) (2017), pp. 237-248. See also Section 6.2.2 of Tamsin L. EDWARDS, Hydrometeorological Hazards Under Future Climate Change, in: Jonathan ROUGIER / Steve SPARKS / Lisa HiLl (eds.), Risk and Uncertainty Assessment for Natural Hazards, Cambridge 2013, pp. 151-189.

27 As example, KASHIMURA et al. note a "high uncertainty in modelled processes of sulfate aerosols and clouds" (p. 3339) in their assessment of results from the G4 experiment of the Geoengineering Model Intercomparison Project (GeoMIP), which represents a major effort to model the likely impacts of SRM geoengineering, see Hirokie KaSHIMURA / Manabu ABE / Shingo WaTANABE / Takashi SEKIYA / Duoying JI / John C. MOORE / Jason N. S. Cole /Ben KRAVITZ, Shortwave Radiative Forcing, Rapid Adjustment, and Feedback to the Surface by Sulfate Geoengineering: Analysis of the Geoengineering Model Intercomparison Project G4 Scenario, in: Atmospheric Chemistry and Physics 17(5) (2017), pp. 3339-3356; cf. http://climate.envsci.rutgers.edu/GeoMIP (last accessed 15/ 05/2019).

28 As stated in Francis Ludlow / Alexander R. Stine / Paul Leahy / Enda Murphy / Paul A. MAYEWSKi / David TAYLOR / James KilLEN / Michael G. L. BAilLIE / Mark HenNessy / Gerard Kiely, Medieval Irish Chronicles Reveal Persistent Volcanic Forcing of Severe Winter Cold Events, 431-1649 CE, in: Environmental Research Letters 8(2) (2013), L024035. 
paleoclimatic proxies such as precipitation-sensitive tree rings have shown significant impacts on global to regional precipitation and hydrology following volcanic eruptions. ${ }^{29}$ These impacts arise from both the direct radiative impact of volcanic sulphate aerosols (in which lower average surface temperatures can lead to a net decrease in evaporation and hence a net decrease in global average precipitation) and a dynamical impact that may be even more important (leading to notable changes in the regional distribution of precipitation). These responses are complex and much depends upon the location of stratospheric sulphate aerosol loading. High-latitude eruptions in the Northern Hemisphere (e. g., Icelandic, Alaskan, Kamchatkan) alter the Earth's radiative balance by primarily cooling the Northern Hemisphere where the aerosols are concentrated. This then diminishes the boreal (i. e., Northern Hemispheric) summertime heating that drives the northward migration of monsoon winds and associated rainfall each summer. ${ }^{30}$ Some $70 \%$ of global population now live in monsoon dependent regions, ${ }^{31}$ including some of the Earth's poorest peoples whose livelihoods may be profoundly affected by monsoon weakening. An awareness of the hydroclimatic impacts of past volcanic eruptions already acts as a caution in

29 Prominent examples are Charles E. ILEs / Gabriele C. HegerL / Andrew P. SCHURER / Xuebin ZHANG, The Effect of Volcanic Eruptions on Global Precipitation, in: Journal of Geophysical Research 118 (2013), pp. 8770-8786; Brendan M. BuCKLEY / Roland Fletcher / Shi-Yu Simon WANG / Brian ZotToli / Christophe PotTiERE, Monsoon Extremes and Society over the Past Millennium on Mainland Southeast Asia, in: Quaternary Science Reviews 95 (2014), pp. 1-19; Charles E. ILES / Gabriele C. HegERL, The Global Precipitation Response to Volcanic Eruptions in the CMIP5 Models, in: Environmental Research Letters 9 (2014), 104012; Martin Wegmann / Stefan BRÖnNimanN, Volcanic Influence on European Summer Precipitation through Monsoons: Possible Cause for "Years without Summer", in: Journal of Climate 27 (2014), pp. 3683-3691; Charles E. ILES / Gabriele HEGERL, Systematic Change in Global Patterns of Streamflow Following Volcanic Eruptions, in: Nature Geoscience 8 (2015), pp. 838-842; Fei LiU / Jing ChAI / Bin WANG / Jian LIU / Xiao Zhang / Zhiyuan WANG, Global Monsoon Precipitation Responses to Large Volcanic Eruptions, in: Scientific Reports 6 (2016), 24331; Mukund Palat RaO / Benjamin I. CooK / Edward R. CooK / Rosanne D’ArRigo / Paul Krusic / Kevin J. Anchukaitis / Allegra N. LeGrande / Brendan M. Buckley / Nicole K. DAvi / Caroline Leland / Kevin Lee Griffin, European and Mediterranean Hydroclimate Responses to Tropical Volcanic Forcing over the Last Millennium, in: Geophysical Research Letters 44 (2017), 55894.

30 See note 29; see also Luke Oman / Alan RoBock / Georgiy L. StEnCHIKov / Thorvaldur THORDARSON, High-Latitude Eruptions Cast Shadow over the African Monsoon and the Flow of the Nile, in: Geophysical Research Letters 33 (2006), L18711; Brian ZAMBRI / Alan Roвоск, Winter Warming and Summer Monsoon Reduction after Volcanic Eruptions in Coupled Model Intercomparison Project 5 (CMIP5) Simulations, in: Geophysical Research Letters 43 (2016), pp. 10,920-10,928, and Joseph G. MAnNing / Francis LudLow / Alexander R. Stine / William R. Boos / Michael Sigl / Jennifer R. MARLON, Volcanic Suppression of Nile Summer Flooding Triggers Revolt and Constrains Interstate Conflict in Ancient Egypt, in: Nature Communications 8 (2017), A900.

31 Mahyar Mohtadi / Matthias Prange / Stephan SteInKE, Palaeoclimatic Insights into Forcing and Response of Monsoon Rainfall, in: Nature 533 (2016), pp. 191-199. 
this respect, ${ }^{32}$ with the potential for similar impacts from SAI geoengineering being frequently cited as a key area requiring further research.

The likelihood of unequally distributed hydroclimatic impacts implies that there may be both winners and losers from potential SAI geoengineering implementation. Modelling suggests that a scenario in which SAI geoengineering preferentially loads the Southern Hemisphere stratosphere with sulphate may, for instance, enhance precipitation in the African Sahel and produce a potentially beneficial 'greening' of a region known for prolonged and often socially catastrophic drought. ${ }^{33}$ This greening may, however, come at the expense of other regions such as parts of South America that may experience a drying from the same shifting precipitation patterns that would benefit the Sahel. ${ }^{34}$ Modelling work has begun to test strategies in which SAI injection would be tailored (e. g., with multiple injection locations, varied seasonally) to serve multiple climatic goals, not just a reduction of average global surface temperatures. ${ }^{35}$

32 See for examples Kevin E. TRENBERTh / Aiguo DAI, Effects of Mount Pinatubo Volcanic Eruption on the Hydrological Cycle as an Analog of Geoengineering, in: Geophysical Research Letters 34 (2007), L15702; Zhihong ZHuo / Chaochao GAO / Yuqing PAN, Proxy Evidence for China's Monsoon Precipitation Response to Volcanic Aerosols over the Past Seven Centuries, in: Journal of Geophysical Research 119 (2014), pp. 6638-6652; Jim M. HAYwood / Andy Jones / Nicolas BELLouin / David STEPHENSON, Asymmetric Forcing from Stratospheric Aerosols Impacts Sahelian Rainfall, in: Nature Climate Change 3 (2017), pp. 660-665.

33 The proposed mechanism involves a more pronounced northward boreal summer migration of the Intertropical Convergence Zone (ITCZ) allowing a greater penetration of the related monsoon winds and rainfall in the Sahel region, see HAYWOOD et al. (note 32). Historical documentary and tree-ring evidence of monsoon variability in China over the past seven centuries also suggests that eruptions occurring in the Southern Hemisphere are associated with increased monsoon precipitation, as per ZHUO / GAO / PAN (note 32).

34 HAYwOod et al. (note 32).

35 See as examples Zhenyu DAI / Debra K. WeISENSTEIN / David W. KeITH, Tailoring Meridional and Seasonal Radiative Forcing by Sulfate Aerosol Solar Geoengineering, in: Geophysical Research Letters 45(2) (2018), pp. 1030-1039, online (DOI): https://doi.org/10.1002/2017GL076472 (last accessed 15/05/ 2019); Simone Tilmes / Jadwiga H. RichteR / Ben Kravitz / Douglas MacMartin / Michael M. Mills / Isla R. Simpson / Anne S. GLANVILLE / John T. FASUlLo / Adam S. PHilLIPS / Jean-Francois LAMARQUE / Joseph TRIBBia / Jim EdWARDS / Sheri MickelSon / Siddharta Gosh, CESM1(WACCM) Stratospheric Aerosol Geoengineering Large Ensemble (GLENS) Project, in: Bulletin of the American Meteorological Society 99 (2018), pp. 2361-2371, online (DOI): https://doi.org/10.1175/BAMS-D-17-0267.1 (last accessed 15/05/ 2019); Ben Kravitz / Douglas G. MacMartin / Michael J. Mills / Jadwiga H. RichteR / Simone Tilmes / Jean-Francois LAMARQUE / Joseph J. TRIBBIA / Francis VITT, First Simulations of Designing Stratospheric Sulfate Aerosol Geoengineering to Meet Multiple Simultaneous Climate Objectives, in: Journal of Geophysical Research: Atmospheres (2017), online (DOI): 10.1002/2017JD026874 (last accessed (15/05/ 2019); Anton LAAKSO / Hannele KoRHONEN / Sami ROMAKKANIEMI / Harri KoKKOLA, Radiative and Climate Effects of Stratospheric Sulfur Geoengineering Using Seasonally Varying Injection Areas, in: Atmospheric Chemistry and Physics 17(11) (2017), pp. 6957-6974; Xiaoyong Yu / John C. MooRE / Xuefeng CuI / Annette RinKE / Duoying Ji /Ben KRAvitz / Jin-Ho Yoond, Impacts, Effectiveness and Regional Inequalities of the GeoMIP G1 to G4 Solar Radiation Management Scenarios, in: Global and Planetary Change 129 (2015), pp. 10-22. 
Such work can hopefully lead to understandings of how unequal impacts can be minimized for both precipitation and temperatures. It appears unlikely, however, that all adverse climatic impacts can be negated or equally distributed, ${ }^{36}$ and political choices (dense with moral and ethical considerations) will hence need to be made regarding trade-offs between costs and benefits of different strategies. ${ }^{37}$ Even, indeed, if an equal distribution of climatic impacts were somehow ultimately achievable, disparities in the wealth and adaptability of regions are still likely to promote unequal socioeconomic impacts that may be as difficult, if not more so, to model and plan for as the climatic impacts.

The above provides further reason why many scholars, including proponents of geoengineering research, stress that emissions reductions must accompany any SRM geoengineering, so that the causes and not only the symptoms of global warming are treated (though we may wonder how effective such emphasis from geoengineering researchers on the need to prioritize emissions reductions can be). It is also why there have been urgent calls for considerations of how the deployment (and even basic research into) SRM technologies will be governed. Achieving widely binding and effective governance is, however, likely to prove challenging. Jesse REYNOLDS' study of the evolution of nuclear power governance as a parallel for geoengineering concludes "that climate engineering research will most likely be promoted and will not be the subject of a binding multilateral agreement in the near future", ${ }^{38}$ while Olaf CURRY suggests that "ideas about global governance of geoengineering rely on heroic assumptions about state rationality and a generally pacific international system". 39 Related concerns range from the possibility of larger nations 'going rogue' in implementing geoengineering unilaterally if to their own benefit, ${ }^{40}$ or others in implementing counter-geoengineering schemes, ${ }^{41}$ if reaching consensus under situations

36 Katharine L. Ricke / Morgan Granger / Myles R. Allen, Regional Climate Response to SolarRadiation Management, in: Nature Geoscience 3(8) (2010), pp. 537-541.

37 Douglas G. MacMartin / David W. Keith / Ben KraviTz / Ken CaldeiRA, Management of TradeOffs in Geoengineering through Optimal Choice of Non-Uniform Radiative Forcing, in: Nature Climate Change 3(4) (2013), pp. 365-368.

38 Jesse REYNOLDS, The International Regulation of Climate Engineering: Lessons from Nuclear Power, in: Journal of Environmental Law 26(2) (2014), pp. 269-289, here p. 269.

39 Olaf CuRry, The International Politics of Geoengineering. The Feasibility of Plan B for Tackling Climate Change, in: Security Dialogue 48(4) (2017), pp. 297-315, here p. 297.

40 Florian RABITZ, Going Rogue? Scenarios for Unilateral Geoengineering, in: Futures 84 (2016), pp. 98-107; see also John C. Moore / Ying CHEN / Xuefeng CuI / Wenping YuAN / Wenjie Dong / Yun GAO / Peijun SHI, Will China be the First to Initiate Climate Engineering?, in: Earth's Future 4(12) (2016), pp. 588-595.

41 Andy PARKer / Joshua B. Horton / David W. KeIth, Stopping Solar Geoengineering Through Technical Means: A Preliminary Assessment of Counter-Geoengineering, in: Earth's Future 6(8) (2018), pp. 1058-1065, online (DOI): doi.org/10.1029/2018EF000864 (last accessed 15/05/2019). 
in which regional equality of impacts proves impossible, ${ }^{42}$ or if designing an effective mechanism for compensating regions most adversely affected by SRM geoengineering proves too difficult. Providing compensation for those nations now affected most severely by global warming (often those that are not historically responsible for the greatest greenhouse gas emissions) continues to prove contentious, with existing provisions and proposals largely deemed inadequate. ${ }^{43}$ There is little reason to think that designing successful compensatory mechanisms for SAI impacts will prove easier, nor designing and implementing successful international emergency aid in the event of adverse (especially if novel and unexpected) consequences.

Scholars have indeed suggested the potential for novel harmful consequences, foremost of which is known as the 'termination effect'. This describes a return to pre-SAI temperatures occurring rapidly due to the short (one to two year) residence time of sulphate aerosol in the atmosphere, and making for potentially unpredictable impacts on ecological, agricultural, and economic systems unable to adapt to the sudden change. ${ }^{44}$ Such a scenario has been posited under conditions of political or economic uncertainty, or as part of a 'double catastrophe' in which a first catastrophe (e. g., pandemic disease) triggers a second catastrophe from the sudden cessation of geoengineering.

As the potential of geoengineering responses to global warming are examined, can medieval history offer a perspective from which to help understand the challenges that geoengineering may present and inform our choices? We believe so. As the closest natural parallel to SAI geoengineering, ${ }^{45}$ improvements to our knowledge of volcanic climatic impacts are still needed. The number and size of eruptions occurring during the twentieth and twenty-first centuries for which satellite and instrumental observations are available is limited, representing a key constraint. Even the modelling of temperature impacts from explosive eruptions, generally less complex

42 RiCKE / GRANGER / ALLEN (note 36).

43 A set of essays that addresses the issue of climate justice and its intersection with geoengineering is Christopher J. PRESTON (ed.), Climate Justice and Geoengineering. Ethics and Policy in the Atmospheric Anthropocene, London, New York 2016.

44 H. Damon Matthews / Ken Caldeira, Transient Climate-Carbon Simulations of Planetary Geoengineering, Proceedings of the National Academy of Sciences 104(24) (2007), pp. 9949-9954; Seth D. BAUM / Timothy M. MAHER Jr. / Jacob HAQQ-MisRA, Double Catastrophe: Intermittent Stratospheric Geoengineering Induced by Societal Collapse, in: Environment Systems and Decisions 33 (2013), pp. 168-180; Andreas OSCHILES, Temperature Debt of Solar Geoengineering, in: Nature 554 (2018), p. 423; Christopher H. Trisos / Giuseppe AmATULLI / Jessica GuREvitch / Alan Roвоcк / Lili XIA / Brian ZAMBRI, Potentially Dangerous Consequences for Biodiversity of Solar Geoengineering Implementation and Termination, in: Nature Ecology \& Evolution 2 (2018), pp. 475-482, online (DOI): https://doi.org/10.1038/s41559-017-0431-0 (last accessed 15/05/2019); Andy PARKER / Peter J. IRVINE, The Risk of Termination Shock from Solar Geoengineering, in: Earth's Future 6(3) (2018), pp. 456-467, online (DOI): https://doi.org/10.1002/2017EF000735 (last accessed 15/05/2019).

45 Rовоск et al. (note 3). 
than precipitation responses, can prove challenging to reconcile with historical observations. ${ }^{46}$ While the best-known hemispheric to global-scale response to major explosive volcanism is a summer season cooling, scrutiny of instrumental data and natural archives are increasingly revealing a marked spatial variation in the aftermath of major explosive eruptions. ${ }^{47}$ Variation in response can be influenced by the season and location of an eruption, its chemical composition, as well as by interactions between the climatic influences of eruptions and pre-existing modes of atmospheric and climatic variability, including the state of the North Atlantic Oscillation and El Niño-Southern Oscillation. ${ }^{48}$ These complexities must be more fully understood and strategies developed to achieve a more uniform response under SAI. Human-environmental interactions (including interactions with disease environments perturbed by climatic shocks) are even more difficult to model. It is by turning to the past that we can begin to sketch an answer.

\section{The Role and Sources of Medieval Historical Climatology}

Historical Climatology straddles the divide between history and climatology, ${ }^{49}$ and provides an evolving methodology for extracting evidence of past climatic conditions

46 Climatic responses observed after several major tropical eruptions in the modern period in clude, for example, a dynamically induced winter warming over Northern Hemispheric continental landmasses, which has proven challenging to reproduce in climate models. See recent progress by Brian ZAmBri / Allegra N. LeGrande / Alan RoBock / Joanna SlawinsKa, Northern Hemisphere Winter Warming and Summer Monsoon Reduction after Volcanic Eruptions over the Last Millennium, in: Journal of Geophysical Research: Atmospheres 122 (2016), pp. 7971-7989.

47 Sébastien Guillet / Christophe Corona / Markus Stoffel / Myriam Khodri / Franck Lavigne / Pablo ORTEga / Nicolas Eckert / Pascal Dkengne Sielenou / Valérie Daux / Olga V. ChuRakova (Sidorova) / Nicole Davi / Jean-Louis EdouARd / Yong Zhang / Brian H. LucKman / Vladimir S. Myglan / Joël Guiot / Martin Beniston / Valérie Masson-Delmotte / Clive OppenheImer, Climate Response to the Samalas Volcanic Eruption in 1257 Revealed by Proxy Records, in: Nature Geoscience 10 (2017), pp. 123-128, and Francis LudLow, Volcanology: Chronicling a Medieval Eruption, in: Nature Geoscience 10(2) (2017), pp. 77-78.

48 Alan Rовоск, Volcanic Eruptions and Climate, in: Reviews of Geophysics 38 (2000), pp. 191-219; Jihong CoLE-DAI, Volcanoes and Climate, in: Wiley Interdisciplinary Reviews: Climate Change 1(6) (2010), pp. 824-839; Ben Kravitz / Alan Roвocк, Climate Effects of High-Latitude Volcanic Eruptions. Role of the Time of Year, in: Journal of Geophysical Research: Atmospheres 116 (D1) (2011), online (DOI): https://doi.org/10.1029/2010JD014448 (last accessed 15/05/2019); Allegra N. LEGRande / Kostas TSIGARIDIS / Susanne E. BAUER, Role of Atmospheric Chemistry in the Climate Impacts of Stratospheric Volcanic Injections, in: Nature Geoscience 9 (2016), pp. 652-655.

49 Christian PFISTER, Climatic Extremes, Recurrent Crises and Witch Hunts. Strategies of European Societies in Coping with Exogenous Shocks in the Late Sixteenth and Early Seventeenth Centuries, in: The Medieval History Journal 10 (2007), pp. 33-73. 
from historical archives and, increasingly, for combining this with evidence from natural archives, often especially high-resolution proxy sources such as tree-rings and ice cores. ${ }^{50}$ Although a comparatively young discipline, ${ }^{51}$ its contribution to understanding the human impacts of past extreme weather events has already been important. ${ }^{52}$ The integration of evidence from written and natural archives is particularly crucial for the medieval period in which human records are relatively scant compared to the wealth of information available from the abundance of texts available after $1500 \mathrm{CE}$, the period that has to date received the greatest attention from historical climatologists. ${ }^{53}$ Using methodologies developed within the discipline, we can examine past cases of climatic perturbations forced by the injection of sulphates into the stratosphere by major explosive volcanic eruptions and any ensuing societal impacts, thereby contributing to understandings of the potential consequences of SAI geoengineering. In undertaking such research, the medievalist is catapulted into the heart of a research field and debate that has important consequences for the future of humanity.

Historical Climatological research into the high and particularly early medieval periods has until recently been hampered by (1) concerns over the reliability of ice-

50 For overviews, see Christian PFISTER / Rudolf BRÁzDIL / Mariano BARRIEndos, Reconstructing Past Climate and Natural Disasters in Europe Using Documentary Evidence, in: PAGES News 10(3) (2002), pp. 6-7, and Rudolf BRÁzDIL / Christian PFISTER / Heinz WANNER / Hans VON STORCH / Jürg LUTERBACHER, Historical Climatology in Europe - The State of the Art, in: Climatic Change 70 (2005), pp. 363-430.

51 The discipline has grown in prominence since the 1990s (see works such as Hubert H. LAMB, Climate, History and the Modern world, 2nd ed. London 1995, and Astrid E. OGILviE / Graham FARMER, Documenting the Medieval Climate, in: Mike HulME / Elaine BARRow [eds.], Climates of the British Isles: Past, Present and Future, London, New York 1997, pp. 112-134), but important framing works were published in the 1960s and 1970s (e. g. Emmanuel Le Roy LADURIE, Times of Feast, Times of Famine. A History of Climate since the Year 1000, London 1971, and Wendy T. BELL / Astrid E. OGILVIE, Weather Compilations as a Source of Data for the Reconstruction of European Climate During Medieval Period, in: Climatic Change 1 [1978], pp. 331-348), while further relevant work is recognizable in earlier decades still (e. g., Charles E. P. ВRоoKs, Historical Climatology of England and Wales, in: Quarterly Journal of the Royal Meteorological Society 54 [1928], pp. 309-317).

52 This is an increasing focus of historical climatologists (as advocated by Christian PFISTER, The Vulnerability of Past Societies to Climatic Variation. A New Focus for Historical Climatology in the Twenty-first Century, in: Climatic Change 100 [2010], pp. 25-31) and complements work by a growing number of climate historians, who generally place less emphasis on climate reconstruction and more on the role of climate in human history; see, e. g., Sam White, The Climate of Rebellion in the Early Modern Ottoman Empire, Cambridge 2011, and ID., A Cold Welcome: The Little Ice Age and Europe's Encounter with North America, Cambridge 2017.

53 As per classic works of historical climatology such as Raymond BRADLEY / Philip D. JonEs (eds.), Climate Since A.D. 1500, rev. ed., London 1995; Francis Ludlow / Charles TRAvis, STEAM Approaches to Climate Change, Extreme Weather and Social-Political Conflict, in: Armida DE LA GARZA / Charles TRAvis (eds.), STEAM: Transdisciplinary Approaches to Science, Arts, Humanities \& Technology Studies, New York 2018, pp. 33-65. 
core chronologies from which to identify the timing of past eruptions, (2) a relative paucity of well replicated tree ring chronologies, with generally fewer tree-ring samples available compared to the later medieval and early modern periods, and hence a potentially less reliable ('noisier') climate signal preserved within these chronologies, and (3) the scarcity (actual and perceived) of historically reliable written evidence. These challenges have now been either resolved, or are in the process of being so, and we elaborate upon each in turn below.

Ice core data on past volcanic activity comes to us from glaciers and ice sheets that provide a record of acidity and other chemical and physical traces that have been preserved by the compression of annual snowfall into layers of ice. This annual layering (Figure 1), most easily visible in high snowfall accumulation sites, allows ice-core scientists to count layers backwards and create a history of past explosive volcanism that can pinpoint the timing and volume of fallout of volcanic sulphate and tephra (i. e., volcanic glass) to specific calendar years. There are, however, several reasons why a volcanic signal might not be accurately preserved in the ice. The complexities of broader scale atmospheric circulation patterns as well as local weather conditions will influence the specific timing and volume of sulphate deposited, ${ }^{54}$ while post-depositional processes such as drifting and wind scouring of fallen snow may also bias a signal. ${ }^{55}$ The use of multiple ice-cores from dispersed locations can thus improve estimates of the volume of sulphate released by any given eruption and help to prevent over- or under-estimation of likely climatic impacts. ${ }^{56}$

54 Gregory A. ZIELINSKI / Jack E. DibB / Qinzhao YANG / Paul A. MAYewski / Sallie WhitLow / Mark S. TWICKLER / Mark S. GeRMANI, Assessment of the Record of the 1982 El Chichón Eruption as Preserved in Greenland Snow, in: Journal of Geophysical Research 102(D25) (1997), pp. 30,031-30,045; Chaochao GAO / Luke OMAN / Alan RoBock / Georgiy L. STENCHIKov, Atmospheric Volcanic Loading Derived from Bipolar Ice Cores. Accounting for the Spatial Distribution of Volcanic Deposition, in: Journal of Geophysical Research 112(D9) (2007), online (DOI): https://doi.org/10.1029/2006JD007461 (last accessed 15/05/2019); Christoph T. Plummer / Marc A. CurRan / Tas D. van Ommen / Sune Olander Rasmussen / Andrew D. Moy / Tessa R. Vance / Henrik B. Clausen / Bo Vinther / Paul A. Mayewski, An Independently Dated 2000-yr Volcanic Record from Law Dome, East Antarctica, Including a New Perspective on the Dating of the 1450s CE Eruption of Kuwae, Vanuatu, in: Climate of the Past 8 (2012), pp. 1929-1940.

55 David A. Fisher / Nils ReeH / Henrik B. Clausen, Stratigraphic Noise in Time Series Derived from Ice Cores, in: Annals of Glaciology 7 (1985), pp. 76-83; ZIELINSKI et al. (note 54).

56 See examples of this approach by Thomas CRowley / Gregory A. ZielinsKi / Bo VinTHeR / Roberto Udisti / Karl KreutZ / Jihong Cole-Dai / Emiliano CASTELlano, Volcanism and the Little Ice Age, in: PAGES News 16 (2008), pp. 22-23; Chaochao GAo / Allan RoBock / Caspar AmmanN, Volcanic Forcing of Climate Over the Past 1500 Years. An Improved Ice Core-Based Index for Climate Models, in: Journal of Geophysical Research. Atmospheres 113(D23) (2008), online (DOI): https://doi.org/10.1029/2008JD010239 (last accessed 15/05/2019; see also the correction by ID., Correction to "Volcanic forcing of climate over the past 1500 years: An improved ice core-based index for climate models", in: Journal of Geophysical Research. Atmospheres 117[D16] [2012], 


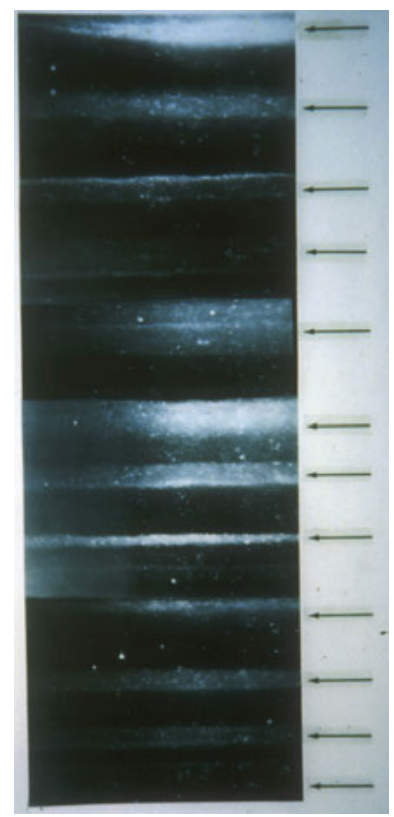

Figure 1: One metre section of the Greenland Ice Sheet Project 2 (GISP2) ice-core from 1885 metres depth. This section of the core is dated to c. 16,880 YBP (years before present) and the beginning of each annual layer is denoted by an arrow. The GISP2 site (Summit, Greenland, 3207m elevation, $72.6 \mathrm{~N}, 38.5 \mathrm{~W}$ ) experiences sufficiently high snowfall accumulation to facilitate annual layer identification. Picture courtesy of Deb Meese.

A key consideration when employing ice-core evidence relates to the accuracy and precision of the chronologies (or timescales) available. ${ }^{57}$ As well as visual inspection of the ice, measurements of seasonally varying levels of dust and chemical species provide additional parameters for identifying and counting annual layers. ${ }^{58}$ Even with multiple parameters available, the identification of individual annual layers involves some subjectivity. A landmark study on the GISP2 Greenland ice-core that

online (DOI): https://doi.org/10.1029/2012JD018052 [last accessed 15/05/2019]); Michael SIGL / Joseph R. McConnell / Lawrence Layman / Olivia Maselli / Ken MCGwire / Daniel PASTERIS / Dorthe Dahl-Jensen / Jørgen Peder StefFensen / Bo Vinther / Ross EdWards / Robert Mulvaney / Sepp KIPFSTUHL, A New Bipolar Ice Core Record of Volcanism from WAIS Divide and NEEM and Implications for Climate Forcing of the Last 2000 Years, in: Journal of Geophysical Research. Atmospheres 118(3) (2013), pp. 1151-1169, online (DOI): https://doi.org/10.1029/2012JD018603 (last accessed 15/05/2019), and Matthew TooHey / Michael SigL, Volcanic Stratospheric Sulfur Injections and Aerosol Optical Depth from 500BCE to 1900CE, in: Earth System Science Data 9 (2017), pp. 809-831.

57 Accuracy here relates to whether a volcanic signal registered in an ice core falls on or within (in the cases where estimates are provided as ranges) a chronology or timescale's cited age or date estimate. An accurate date may be more or less precise, e. g., an age estimate for a volcanic signal of say, $853 \mathrm{CE}+/-5$ years is less precise than $853 \mathrm{CE}+/-2$ years.

58 Such chemical species include nitrates, calcium, and chloride; further discussion is provided by Claus U. HAmmeR, Ice-Core Chronology, in: Peter G. KnIGHT (ed.), Glacier Science and Environmental Change, Malden 2006, pp. 398-403. 
compared results from independent layer counters was thus able to group counters into 'splitters' and 'lumpers', with splitters tending to identify a greater number of annual layers than actually existed by artificially dividing individual layers, and lumpers the opposite, though less divergence occurred between counters of greater experience. ${ }^{59}$ Uncertainties in annual layer counting may be estimated and controlled for by the use of chronological reference horizons in the ice, with such horizons including volcanic sulphate signals tied to eruptions of historically (and hence independently) known date, ideally corroborated by tephra in the ice corresponding to known tephra chemistries from the presumed source volcano and eruption. In cases where reference horizons are erroneous but unknowingly used to adjust or constrain ice-core timescales, the accuracy of estimated dates will be compromized. This is particularly the case when the dates offered by ice-core timescales claim a high precision, in which the actual date of an event will more easily fall outside of its estimated date-range if the relevant time-scale has been influenced by erroneous reference horizons. The utility of volcanic dates for climatic or societal impact analyses grows with increasing precision, but there is a clear trade-off between accuracy and precision, and precise dates can be actively misleading in serving to obscure links between volcanism, climate and society if they are inaccurate.

An undiagnosed error of approximately seven years in the first millennium CE of the important Greenland Ice Core Chronology 2005 (GICC05) timescale was in fact identified by Mike BAILlE in 2008. ${ }^{60}$ This timescale was developed based upon layer counting and synchronization of three major Greenland ice cores, the GRIP, NGRIP and Dye-3. ${ }^{61}$ An error of less than a decade in dating is in some senses small. It is negligible for studies examining climatic changes on multimillennial time-scales, for example, but is of sufficient magnitude to have hampered efforts to assess the role of explosive volcanism as a driver of climatic variability on inter-annual timescales in the early medieval period, and to understand

59 Richard B. Alley / Christopher A. Shuman / Debra A. Meese / Anthony J. Gow / Kendrick C. TAYloR / Kurt M. Cuffey / Joan J. FitZPatrick / Pieter M. Grootes / Gregory A. Zielinski / Mar RAM / Glenn SPINELLI / Bruce C. ELDER, Visual-Stratigraphic Dating of the GISP2 Ice Core. Basis, Reproducibility, and Application, in: Journal of Geophysical Research 102(C12) (1997), pp. 26367-26381.

60 Michael G. L. BAILLIE, Proposed Re-Dating of the European Ice Core Chronology by Seven Years prior to the 7th Century AD, in: Geophysical Research Letters 35(15) (2008), online (DOI): https:// doi.org/10.1029/2008GL034755 (last accessed 15/05/2019).

61 Bo M. Vinther / Henrik B. Clausen / Sigfus J. Johnsen / Sune O. Rasmussen / Katrine K. Andersen / Susanne L. Buchardt / Dorthe DAhL-Jensen / Inger K. SeIERSTAD / Marie-Louise SigGAARd-ANDERSEn / Jorgen P. STEFFEnSEn / Anders SvensSon / Jesper W. Olsen / Jan HeinEMEIER, A Synchronized Dating of Three Greenland Ice Cores Throughout the Holocene, in: Journal of Geophysical Research. Atmospheres 111(D13) (2006), online (DOI): https://doi.org/10.1029/ 2005JD006921 (last accessed 15/05/2019). 
the impact of such variability on early medieval society. It is regrettable that with compelling evidence of an error presented in 2008, and reinforced in 2010, ${ }^{62}$ that timescales were not more rapidly revised. This issue was compounded both by the rescaling of independent ice-core chronologies onto the GICC05, ${ }^{63}$ and the counting of new ice-cores on the assumption that the GICC05 was correct, having an error of at most $+/-1$ year during the Common Era, and a claimed tree-ring-like precision. ${ }^{64}$ Work led by Michael SIGL and published in 2015 supported the veracity of BAILLIE's proposed chronological corrections and established a revised icecore timescale and associated volcanic history for the past 2,500 years. ${ }^{65}$ This work identified errors accumulating from approximately the mid-thirteenth century, before the great 1257 Samalas eruption (which provides a clear global marker event in polar ice-cores). This correction was achieved thanks in part to the recent identification of two cosmic events, one in $775 \mathrm{CE}$ and another at $994 \mathrm{CE}$ that registered through anomalous ${ }^{10} \mathrm{Be}$ levels in ice cores and ${ }^{14} \mathrm{CO}_{2}$ in tree rings. ${ }^{66}$

If the compact layering of ice provides one of the most valuable sources of natural proxy data, its worth is matched by that available from tree rings. Of all available natural archives, tree-rings provide one of the most important means of understanding how past climatic conditions varied on a year-to-year (interannual) timescale. ${ }^{67}$ Since the growth of trees is strongly controlled by climate, variations

62 Michael G. L. BAILLIE, Volcanoes, Ice-Cores and Tree-Rings: One Story or Two?, in: Antiquity 84 (2010), pp. 202-215.

63 Bo M. Vinther / Henrik B. Clausen / David A. Fisher / Roy M. Koerner / Sigfus J. Johnsen / Katrine K. Andersen / Dorthe Dahl-Jensen / Sune O. RASmussen / Jorgen P. StefFensen / Anders M. Svensson, Synchronizing Ice Cores from the Renland and Agassiz Ice Caps to the Greenland Ice Core Chronology, in: Journal of Geophysical Research 113(D8) (2008), online (DOI): https://doi.org/10.1029/2007JD009143 (last accessed 15/05/2019)

64 HAMMER (note 58), p. 398.

65 SigL et al. (note 4).

66 Fusa MiYAKE / Kentaro NAGAYA / Kimiaki MASUdA / Toshio NAKAMURA, A Signature of Cosmic-Ray Increase in $A D$ 774-775 from Tree Rings in Japan, in: Nature 486 (2012), pp. 240-242; Ilya G. Usoskin / Bernd Kromer / Francis Ludlow / Juerg BeER / Michael Friedrich /Gennady Kovaltsov / Sami K. Solanki / Lukas Wacker, The AD775 Cosmic Event Revisited. The Sun is to Blame, in: Astronomy \& Astrophysics 553 (2013), L3, online (DOI): https://doi.org/10.1051/00046361/201321080 (last accessed 15/05/2019).

67 Peter D. Jones / Keith R. BRIFFA / Timothy J. Osborn / Janice M. Lough / Trang D. van OMmen / Bo M. VinTHER / Juerg LUTERBACHER / Elizabeth R. WAHL / Francis W. ZwiERS / Mark E. MAnN / Gregory A. SCHMidT / Caspar M. AMmAnN / Brendan M. BuCKLEy / Kim M. CoBB / Jhonatan EsPeR / Hugues Goosse / Nicol Graham / Emily JANSEn / Thorsten KIEFER / Christian KulL / Michael KütTel / Ellen MosLey-THompson / Jonathan T. OverPeck / Nadja RiEdwyl / Mauro Schulz / Alexander W. TudHOPE / Ricardo VilLALba / Helen WANNER / Elisabeth WoLfF / Elena XoPlAKI, High-Resolution Palaeoclimatology of the Last Millennium. A Review of Current Status and Future Prospects, in: The Holocene 19 (2009), pp. 3-49. 
in the widths of annual growth rings have allowed climatic conditions to be inferred for past centuries, and increasingly, millennia. It is thus possible to examine the climatic impacts of major explosive eruptions using tree-ring data, with pronounced growth minima (and sometimes visible physical damage in the form of 'frost rings') often following such eruptions. ${ }^{68}$ Even, however, if volcanic climatic impacts were evenly distributed in space and time, tree-ring responses would likely vary by species and location, sometimes over quite short distances. ${ }^{69}$ The complexities of treering evidence and how it registers climatic influences must thus be understood for its credible interpretation by medieval historical climatologists. An eruption that has left a strong signal in ice-cores and/or in the historical record may not, for example, find a clear expression in 'complacent' trees growing in favourable environmental locations. ${ }^{70}$ Human disturbances affecting tree growth (e. g., forest management practices such as coppicing) or natural disturbances from insect or fungal pathogen outbreaks may also complicate the identification of any climatic response. ${ }^{71}$ Sensitive ('stressed') trees that grew at or near their environmental limits, such as in arid or cold high-altitude or high-latitude locations, are thus often favoured when making climatic inferences, as are those from locations less likely to be influenced by human activity. If volcanic climatic impacts are experienced by the tree mainly

68 Matthew SALZER / Malcolm Hughes, Bristlecone Pine Tree Rings and Volcanic Eruptions over the Last 5000 Years, in: Quaternary Research 67 (2007), pp. 57-68; see also Keith R. BRIFFA / Philip D. Jones / Fritz H. SchweIngRUBER / Timothy J. OSBoRn, Influence of Volcanic Eruptions on Northern Hemisphere Summer Temperature over the Past 600 Years, in: Nature 393 (1998), pp. 450-455; Rosanne D. D'ARRIGo / Gordon C. JACOBY, Northern North American tree-ring evidence for regional temperature changes after major volcanic events, in: Climatic Change 41 (1999), pp. 1-15.

69 Divergence in climate-growth responses can occur in particular circumstances over even comparatively small distances if trees are sampled across an area with a steep altitudinal gradient, or in nearby sites but with a different aspect, or between comparatively water-logged (e. g., lake margin) locations versus those further inshore; see discussion by Carolyn COPENHEAver / Laura E. HENDRICK / John W. Houchins / Christopher D. PEARCE, Changes in Growth and Dendroclimatic Response of Trees Growing Along an Artificial Lake, in: The American Midland Naturalist 163 (2010), pp. 134-145; Ernst VAN DER MAATEN, Climate Sensitivity of Radial Growth in European Beech (Fagus sylvatica L.) at Different Aspects in Southwestern Germany, in: Trees 26 (2012), pp. 777-788, and Elisabeth DÜTHORN / Lea SCHNEIDER / Oliver KonTER / Philipp SCHÖN / Mauri TIMONEN / Jan ESPER, On the Hidden Significance of Differing Micro-Sites on Tree-Ring Based Climate Reconstructions, in: Silva Fennica 49(1) (2015), Article 1220, online (DOI): https://doi.org/10.14214/sf.1220 (last accessed 15/05/2019).

70 A straightforward discussion of sensitive versus complacent trees is given in Marvin A. STOKES / Terah L. SmiLEY, An Introduction to Tree-Ring Dating, Chicago 1968, pp. 10-11. More recent isotopic and densitometric analyses have, however, made improved use of 'complacent' tree-ring data; for a summary see Raymond S. BRADLEY, Palaeoclimatology. Reconstructing Climates of the Quaternary, 3rd ed. Oxford 2015, pp. 456-458.

71 Kristof Haneca / Ilse Boeren / Joris VAn ACKer / Hans BEeCKMAn, Dendrochronology in Suboptimal Conditions: Tree Rings from Medieval Oak from Flanders (Belgium) as Dating Tools and Archives of Past Forest Management, in: Vegetation History and Archaeobotany 15 (2006), pp. 137-144. 
during the spring-summer growing season, the response is likely to be of greater magnitude than for other seasons when the tree is partially or fully dormant. A lagged or multi-year growth responses can also occur in response to extreme weather, potentially in cases when trees are able to temporarily sustain themselves through stored energy reserves (carbohydrates), and soil or bedrock moisture reserves. ${ }^{72}$ It follows that responses to explosive volcanism may be potentially influenced by preceding conditions - reduced precipitation following a major eruption may be less impactful if this followed a period of abundant precipitation, and vice versa.

Using large numbers of trees (and multi-tree 'chronologies') from dispersed sites allows broader climate signals to be extracted by minimizing influences from local site-specific environmental and micro-climatic influences. Improvements in the temporal and spatial coverage of tree-ring data (from ongoing field campaigns and improved sharing of sometimes closely guarded earlier-collected data) is thus of great importance. So too is the development of new means of extracting climatic data from these tree-rings, most prominently measurement of the density of each year's latewood growth, which can often be more strongly correlated to climate. Thus, the increasing availability of tree-ring chronologies spanning several millennia has led to the creation of a number of robust chronologies such as the 3512-year Qilian juniper (Juniperus przewalskii) precipitation-sensitive ring-width chronology from the Tibetan plateau, ${ }^{73}$ or the 4064-year Siberian larch (Larix sibrica) temperature-sensitive chronology, also from a high latitude in the Yamal Peninsula, western Siberia. ${ }^{74}$ Other important series include a 2140-year Scots pine (Pinus sylvestris) maximum latewood density

72 Nathalie BrÉDA /Vincent BADEAU, Forest Tree Responses to Extreme Drought and Some Biotic Events: Towards a Selection According to Hazard Tolerance?, in: Comptes Rendus Geoscience 340 (2008), pp. 651-662; Flurin BABST / Marco CARRER / Benjamin POUlTER / Carlo URBINATI / Burkhard NeUwirth / David Frank, 500 Years of Regional Forest Growth Variability and Links to Climatic Extreme Events in Europe, in: Environmental Research Letters 7(4) (2012), 045705; Christian Pfister / Oliver Wetter / Rudolf BRÁzdil / Petr DOBRovolný / Rüdiger GlaSER / Jürg LutTERBach / Sonia I. SENEviRATnE / Eduardo ZoRITA / Maria-Joao AlCoforado / Mariano BARRIENDos / Ursula BiEber / Karl H. Burmeister / Chantal CAMEnisch / Antonio Contino / Uwe Grünewald / Jürgen HeRget / Iso Himmelsbach / Thomas LabBÉ / Danuta LimanówKa / Laurent LitzenbuRger / Andrea Kiss / Oldřich KotyZa / Øyvind NoRdLi / Kathleen PRibYl / Dag Retsö / Dirk Riemann / Christian ROHR / Werner SIEGFRIED / Jean-Laurent SpRING / Johan SöDERBERg / Sebastian WAGNER / Johannes P. WERnER, Tree-Rings and People - Different Views on the 1540 Megadrought. Reply to Büntgen et al. 2015, in: Climatic Change 131 (2015), pp. 191-198; Daniella M. REMPE / William E. DiETRICH, Direct Observations of Rock Moisture: A Hidden Component of the Hydrologic Cycle, in: Proceedings of The National Academy of Sciences 115(11) (2018), pp. 2664-2669.

73 Bao YANG / Shuyuan KANg / Fredrik Charpentier LjungQvist / Minhui HE / Yan ZHAO / Chun QIN, Drought Variability at the Northern Fringe of the Asian Summer Monsoon Region over the Past Millennia, in: Climate Dynamics 43(3-4) (2014), pp. 845-859.

74 Rashit M. Hantemirov / Stepan G. Shiyatov, A Continuous Multimillennial Ring-Width Chronology in Yamal, Northwestern Siberia, in: The Holocene 12(6) (2002), pp. 717-726. 
temperature-sensitive chronology from Northern Scandinavia, ${ }^{75}$ and a 2407 -year Pedunculate and Sessile oak (Quercus robur and Quercus petraea) precipitationsensitive chronology from Central Europe. ${ }^{76}$ This latter tree-ring sequence is particularly important because it comes from the same region as many of our European documentary sources. These chronologies and others are now being increasingly employed in creating spatialized temperature and precipitation (or related hydroclimatic) reconstructions, ${ }^{77}$ and we return to these chronologies in the following section.

Where medieval historical climatologists fit into this picture is in applying their expertise in accessing and interpreting the evidence of written sources and, indeed, in understanding the contingencies of human history, the motivations for human behaviours and the interplay of forces that have driven historical change. ${ }^{78}$ Medieval texts often provide accounts of weather and (frequently associated) societal stresses such as famine and plague, but the many reasons that might motivate medieval scribes to include such accounts highlights the need to treat all such material critically. ${ }^{79}$ The prospective reliability of any given account is often related to the genre of the source text. Consider a text that celebrates the life of a saint and describes a drought that was ended by parading the saint's relics or otherwise invoking his or her intercession, as is the case with Adso's of Montier-en-Der 'Miracles of Saint Mansuy' or Adomnan's of Iona 'Life of Saint Columba'. ${ }^{80}$ Or perhaps an author wished to praise the deeds of a king and emphasize a military

75 Jan ESPER / David C. Frank / Mauri Timonen / Eduardo ZoRita / Rob J. S. WiLSON / Jürg LUTERBACHER / Steffen HOlZKÄMPER / Nils Fischer / Sebastian WAGneR / Daniel Nievergelt / Anne VeRSTEGE / Ulf BÜNTGEN, Orbital Forcing of Tree-Ring Data, in: Nature Climate Change 2 (2012), pp. 862-866.

76 Ulf BÜNTGEN / Willy TEGEL / Kurt Nicolussi / Michael MCCORMICK / David FrANK / Valerie TROUET / Jed O. KAPLAN / Franz HeRZIG / Karl-Uwe HeUSSNER / Heinz WANNER / Jürg LuTERBACHER / Jan ESPER, 2500 years of European Climate Variability and Human Susceptibility, in: Science 331 (2011), pp. 578-582.

77 See for example the use of European oak ring width chronologies by Edward R. Cook et al., Old World Megadroughts and Pluvials during the Common Era, in: Science Advances 1(10) (2015), e1500561. Spatialized reconstructions covering the entirety of the Early Medieval period are, as yet, rare.

78 Relevant work for the early medieval period includes Michael MCCoRMick / PAUL E. DUTTON / Paul A. MAYEwSKI, Volcanoes and the Climate Forcing of Carolingian Europe, A.D. 750-950, in: Speculum 82 (2007), pp. 865-895, and Timothy P. NewFIELD, Domesticates, Disease and Climate in Early Post-Classical Europe: The Cattle Plague of c. 940 and its Environmental Context, in: Journal of Post-Classical Archaeologies 5 (2015), pp. 95-126.

79 See the summary discussion regarding the assessment of source reliability in BRÁzDIL et al. (note 50).

80 Francis Ludlow / Conor Kostick, European Climate History, 400-1000 CE, in: Timothy P. NEWField / Richard ORAM / Philip SLAVIN (eds.), Handbook of Medieval Environmental History, vol. 1: The Early Middle Ages, Leiden (in preparation). 
success in the face of adversity from a river in flood. A whole range of motives, likely to distort actual events or even invent them entirely, must be considered and an assessment made as to the reliability of both the text as a whole, and particular accounts therein.

Even with annals and chronicles, often more straightforward than hagiography, the subjective interests of the authors mean that they are not suitable to derive the kinds of lengthy reconstructions that historical climatologists often seek. One author, writing for a period of twenty years might have a keen interest in whether the crops did well or poorly, another might have a fascination with celestial events. ${ }^{81}$ And if a text comes to us in the hand of one, later, compiler, it is usually challenging to identify when a new chronicler has taken over the record keeping. While such a text might appear to indicate that a period of unpredictable harvests was followed by one of relative stability, it might, in fact, be indicating only that the author has changed. The silences in such records must therefore be treated with great caution, though it is important to recognize that collective silences may be more meaningful as the medieval era progresses and sources become more abundant. Just as evidence cannot be uncritically accepted, nor, however, should it be uncritically dismissed, even for saint's lives, and there are cases in which independent dendrochronological evidence supports the evidence of extreme weather reported in saints' lives. ${ }^{82}$ Historical Climatology can only be successful by utilising the source-criticism and language skills of the medieval historian.

For much of the medieval period then, the historical sources are often best used not as a basis for long quantitative sequences of climate information but as qualitative evidence for specific events in narrow periods. And in this they can be spectacularly valuable. Our particular interest in this chapter is in the early medieval period, which has sometimes been dismissed as being impenetrable for a climate and social history due to the difficulty of working with the sources of the period. It has been argued that due to the relative paucity of European written sources in the period following the collapse of the Western Roman Empire, it is not possible to obtain accurate climate information from the 'imprecise', 'exaggerated', and 'unreliable' material that is available. ${ }^{83}$ The U.S. National Research Council's assessment of the issue is that "there are [...] weather records preserved in Irish and Norse

\footnotetext{
81 Francis LudLow, Assessing Non-Climatic Influences on the Record of Extreme Weather Events in the Irish Annals, in: Patrick J. Duffy / William Nolan (eds.), At the Anvil: Essays in Honour of William J. Smyth, Dublin 2012, pp. 93-133.

82 LudLOW / KOSTICK (note 80).

83 LAMB (note 51); Christian Pfister / Jürg Luterbacher / Gabriela Schwarz-ZanetTi / Milène Wegmann, Winter Air Temperature Variations in Western Europe during the Early and High Middle Ages (AD 750-1300), in: Holocene 8(5) (1998), pp. 535-552.
} 
annals back to the middle of the first millennium [...] but their dating is imprecise and descriptions of weather and climate are often exaggerated." ${ }^{84}$ An artificial horizon has therefore been raised, which discourages entry into the past by medieval historical climatologists beyond a certain point.

We believe that there is, in fact, sufficient historical material to reach useful conclusions about the impact of explosive volcanism on early medieval society (and therefore to raise questions about the extent to which our contemporary social structures and technologies are vulnerable). But in making such assessments, it is important to stress that extreme weather does not impact on communities in a crude or deterministic fashion. Rather, the particular social structures and even ideologies of different societies mediate their vulnerabilities, leading to potentially different outcomes for different polities in the face of the same stressors. ${ }^{85}$ Pre-existing instabilities, such as periods of warfare, may make a region more vulnerable to the impact of volcanic cooling, while a robust system of state-organized relief, such as occurred in China in 704, can mitigate the societal consequence of a major climate stressor. ${ }^{86}$ Again, the relationship between the atmospheric changes following a significant volcanic eruption and the outbreak of epidemics and epizootics is not a straightforward one. ${ }^{87}$ There is considerable variation in the importance of extreme cold weather to the spread of certain pathogens and there may well be important steps in the emergence of a major epidemic event that are not always met. For instance, famine and mass migration may be essential prerequisites for a major outbreak of disease, yet whether a climatic shock arising from a major eruption leads to these events will depend on the societal context.

\section{Case Study: 670-730 CE}

One period that we have previously looked at in some detail is that of 670-730 $\mathrm{CE},{ }^{88}$ being frequently overlooked by historical climatologists and yet also witness to a sequence of substantial explosive volcanic eruptions with sulphate deposition

84 National Research Council, Surface Temperature Reconstructions for the Last 2,000 Years, Washington / D.C. 2006.

85 Katiuscia FARA, How Natural Are "Natural Disasters"? Vulnerability to Drought of Communal Farmers in Southern Namibia, in: Risk Management 3 (2001), pp. 47-63; Monica JunEJA / Franz Mauelshagen, Disasters and Pre-Industrial Societies. Historiographic Trends and Comparative Perspectives, in: Medieval History Journal 10 (2007), pp. 1-31; Geoffrey PARKER, Global Crisis: War, Climate Change and Catastrophe in the Seventeenth Century, New Haven 2013.

86 For further examples, see Lillian M. LI, Fighting Famine in North China. State, Market, and Environmental Decline, 1690s-1990s, Stanford 2007.

87 See the important work of Timothy NEWFiELD on early medieval disease and climate, e. g. NEWFIELD (note 78).

88 GAO et al. (note 1). 
evident in multiple Greenland ice-cores. The period thus provides a useful case study both for illustrating the application of medieval historical climatology and for examining the societal impact of past volcanic climate forcing. Our goals in originally examining this period were (1) to assess the veracity of the above-discussed ice-core chronological corrections proposed by BAILLIE and MCANENEY, using both tree-ring and documentary evidence, and (2) to highlight the value of and challenges inherent in reconciling multiple signals of explosive volcanism in the available Greenland ice-cores for this period (Figure 2). Our analysis supported the veracity of BAILLIE and MCANENEY's proposed corrections in work that again highlights the value of the sources and skillset of medieval historians in addressing major scientific challenges. ${ }^{89}$ In our present essay, we emphasize the extent to which our analysis also revealed the climatic impact of these eruptions and the related vulnerability of society across multiple regions despite their different social systems and variable resilience to climatic shocks.

Adjusted according to BAILLIE and MCANENEY's proposed chronological corrections, ${ }^{90}$ greater agreement can be observed between volcanic signals from Greenland ice-cores, resulting in a more coherent volcanic history for this period, in which at least six climatically significant volcanic events can be deemed to have occurred, datable approximately to 681, 684-6, 692-3, 697, 706-7 and 730-3 (see Figure 2). ${ }^{91}$ While multiple volcanic eruptions occur each year, ${ }^{92}$ even very explosive events may not have a significant climatic impact if they are not particularly sulphurous or if most material is ejected laterally rather than into the high atmosphere, as per the major May 1980 eruption of Mt. Saint Helen's, Washington, USA. ${ }^{93}$ These six eruptions are of significance, therefore, in having deposited notable volumes of sulphate in Greenland. We can further assess their climate-altering potential by comparing the size of their ice-core sulphate signals against those of known highVEI and climatically impactful eruptions such as Tambora in 1815 and Krakatau in 1883. After adjusting its chronology by adding seven years, the NEEM S1 dataset registers the largest individual sulphate signal in our period for the year $681 \mathrm{CE}$, with a measured sulphate deposition of $117 \%$ of the Tambora and $246 \%$ of the Krakatau eruptions. This suggests an immense sulphur-rich eruption capable of

89 The substance of these corrections was also independently confirmed and has been incorporated in state-of-the-art ice-core-based volcanic forcing reconstructions; see SIGL et al. (note 4).

90 The dating of the volcanic signals in Figure 2 reflects the proposed chronological corrections of BAILLIE and MCANENEY, namely an adjustment of +7 years to signals on the GICC05 chronology (i. e., Dye3, GRIP, NGRIP, NEEM) and, for parity, a correction of +5 years to Crête.

91 GAO et al. (note 1). In generating this list, only events identified in at least two independent cores are selected, to increase confidence in the credibility of the volcanic eruptions identified, after the approach of GAO et al. (note 56).

92 Lee Siebert / Tom Simkin / Paul Kimberly, Volcanoes of the World, 3rd ed. Berkeley 2010.

93 Alan Roвоск, The Mount St. Helens Volcanic Eruption of 18 May 1980: Minimal Climatic Effect, in: Science 212 (1981), pp. 1383-1384. 

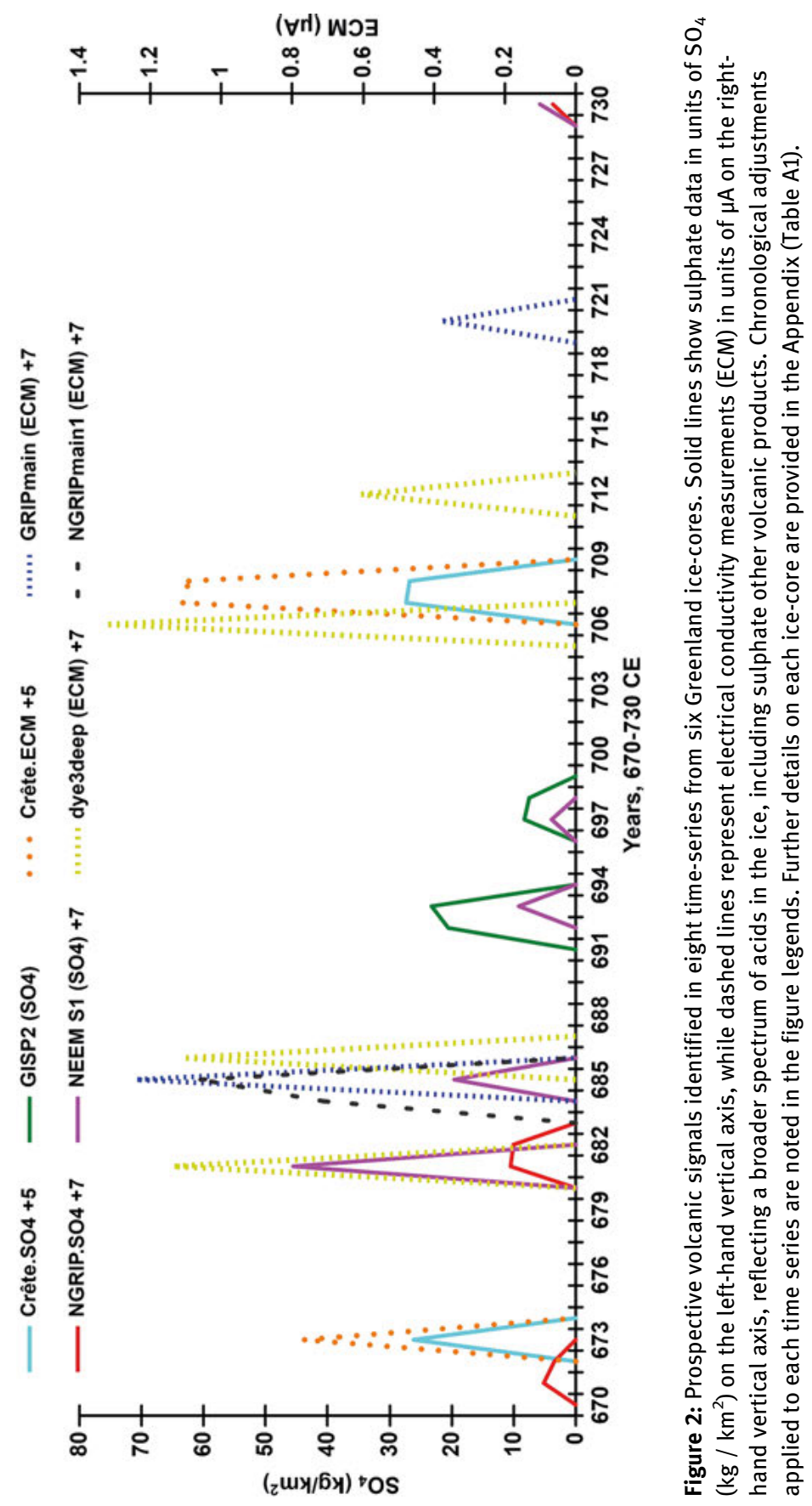
bringing about extensive and severe global cooling, with Antarctic ice-cores also registering a major sulphate signal at this time and hence identifying the eruption as likely having occurred in the tropics. ${ }^{94}$ Such high-magnitude sulphur-rich eruptions are infrequent and when they do occur can provide important examples of the challenges societies experience in the face of sudden severe alterations to climate and underlying ecosystems. ${ }^{95}$

The largest ice-core sulphate signal of the past 2,500 years was the product of a VEI 7 'Super-colossal' scale eruption of Samalas volcano on Lombok island, Indonesia, in $1257,{ }^{96}$ an event that induced severe and spatially complex patterns of cooling in the Northern Hemisphere. ${ }^{97}$ Comparing the six events signalled in the Greenland ice for 670-730 CE to Samalas, we can calculate the following comparative magnitudes for their sulphate deposition: 681 (44\%), 684-6 (24\%), 692-3 (14\%), 697 (5\%), 706-7 (17\%) and 730-3 (7\%). Starting in approximately 681, therefore, the planet experienced a major injection of sulphate into the atmosphere, with a notable clustering of subsequent eruptions that would have likely sustained the cooling effect of the initial eruption. Few scholars have appreciated this period as one likely to have seen dramatic temperature drops, following closely after the cessation of the recently proposed Late Antique Little Ice Age (c. 536-660 CE). ${ }^{98}$ Our research suggests that the period $670-730 \mathrm{CE}$, and particularly c. $680-710$, is one that holds potentially valuable insights into the climatic and societal responses to sustained explosive volcanism, with relevance to concerns over the climatic and societal consequences of geoengineering.

An examination of relevant tree ring sequences confirms that these sixty years were unusual in experiencing a downturn in temperature. Figure 3 depicts two long tree-ring-based temperature reconstructions for continental Europe and the Southern Colorado Plateau, each registering a sustained temperature decrease beginning in

94 SIGL et al. (note 4). In this forcing reconstruction, the date of the 681 event is given as 682, a date that can be considered highly accurately to within $+/-1$ year.

95 For historians and other scholars, such eruptions can be considered historiographical tools or diagnostic tests of societal vulnerability and resilience to sudden climatic change, as outlined by LUDLOW (note 47).

96 Franck Lavigne / Jean-Philippe DegeaI / Jean-Christophe Komorowski / Sébastien Guillet / Vincent Robert / Pierre Lahitte / Clive OpPenheimer / Markus Stoffel / Céline M. Vidal /Surono Indyo Pratomo / Patrick Wassmer / Irka Hajdas / Danang Sri Hadmoko / Edouard DE Belizal, Source of the Great A.D. 1257 Mystery Eruption Unveiled, Samalas Volcano, Rinjani Volcanic Complex, Indonesia, in: Proceedings of the National Academy of Sciences 110(42) (2013), pp. 16742-16747.

97 GuilLet et al. (note 47); LuDLOw (note 47).

98 Ulf BÜNTGEN / Vladimir S. MygLAn / Fredrik Charpentier LJungqvist / Michael McCoRmick / Nicola Di Cosmo / Michael Sigl / Johann Jungclaus / Sebastian Wagner / Paul J. KRusic / Jan ESPER / Jed O. KAPLAN / Michiel A. C. DE VAan / Jürg LuTERBACHER / Lukas WACKER / Willy TeGeL / Alexander V. KiRDYAnov, Cooling and Societal Change During the Late Antique Little Ice Age from 536 to around 660 AD, in: Nature Geoscience 9 (2016), pp. 231-236. 


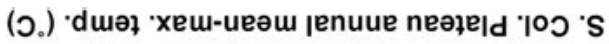

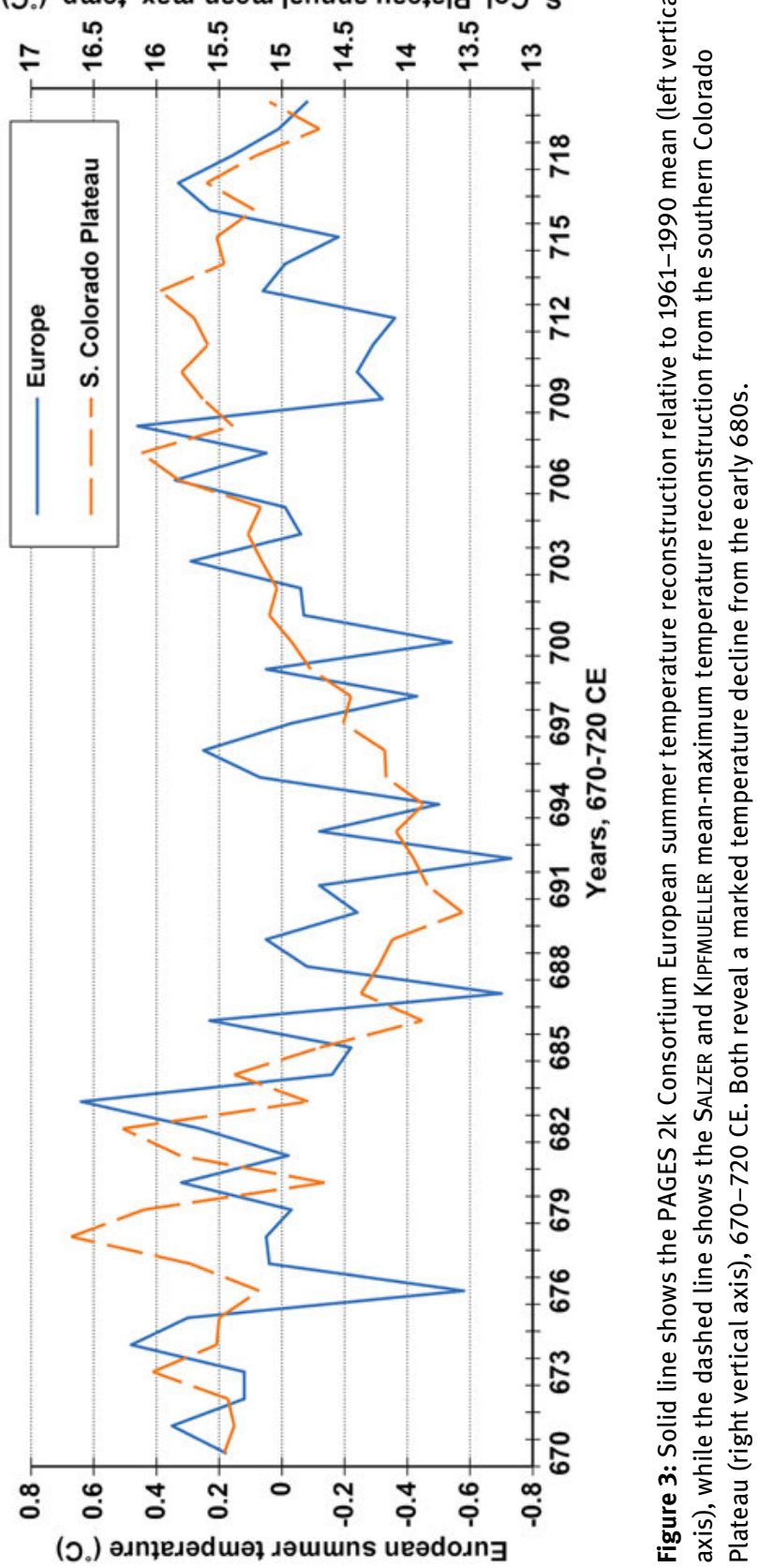


the early 680 s and continuing variably into the first decade of the 700s. ${ }^{99}$ SALZER and KIPFMUELLER have, moreover, specifically highlighted the years 683-700 as the coldest period in their 2262-year temperature reconstruction for the southern Colorado Plateau. ${ }^{100}$ In addition to long multi-millennium temperature reconstructions, which are still comparatively rare, we may draw upon the previously discussed precipitation-sensitive tree-ring-chronologies available for the Tibetan Plateau and Central Europe, in addition to the chronologies from Northern Scandinavia and Yamal that exhibit a dominant sensitivity to growing season temperature. Using these four chronologies, we can identify ten years of notably reduced tree-ring growth that distinguish themselves by co-occurring in at least two of the four regions. The dates of these years of pan-regional growth minima, shown in Table 1, frequently match the timing of volcanic signals in the ice. It is possible to quantify this. Between 670 and $730 \mathrm{CE}$ (inclusive), the average number of tree-ring minima in years associated with volcanic signals is $0.31,{ }^{101}$ while the average number of minima in years not associated with volcanic activity is 0.09 . In other words, there exists a much greater (more than three times) average incidence of tree-ring minima occurring within a small number of years of volcanic signals than otherwise. We have confidence, therefore, in drawing the conclusion that the explosive volcanism identified in the chronologically adjusted ice-core evidence notably perturbed hydroclimatic patterns in far flung regions of the Northern Hemisphere.

What do the available written records tell us of these events and their consequences? Between 670 and $730 \mathrm{CE}$, our survey identified relevant reports of extreme weather and major societal stresses (subsistence crises, epidemic or epizootic disease, and mass human or animal mortality) which occur 29, 16, and 31 times in sources for Europe, the Near East and China, respectively. Events were included or excluded from our analysis according to a scale of historical reliability shown in Table 2. This is a filtering system devised in order to avoid the errors of earlier compilers of extreme weather events and indications of social stress, who simply listed all the reports they came across, without any attempt to weigh them for reliability. ${ }^{102}$ Our scale prioritizes eyewitnesses, but even the evidence of such observers cannot be used uncritically. For the purposes of our analysis, we included data only from categories 1 and 2, ranked as most reliable, and excluded those from 3

99 PAGES 2k Consortium, Continental-Scale Temperature Variability during the Past Two Millennia, in: Nature Geoscience 6 (2013), pp. 339-346.

100 Matthew W. SAlzer / Kurt KipfMUELLER, Reconstructed Temperature and Precipitation on a Millennial Timescale from Tree-rings in the Southern Colorado Plateau, U.S.A., in: Climatic Change 70 (2005), pp. 465-487.

101 By 'associated', we mean here any minima occurring within -1 to +3 years (inclusive) of the dates of our volcanic signals, a margin that allows for small remaining uncertainties in the dating of our volcanic signals, and the possibility of a lagged or multi-year climatic and tree-ring-growth response to the eruptions.

102 See discussion in BELL / OGILVIE (note 51), and OGILVIE / FARMER (note 51). 
Table 1: Sets of co-occurring tree-ring minima (widths and/or maximum latewood densities) in which growth is at least 1.25 standard deviations below the 670-730 CE mean of each series, in the same or directly consecutive years in two or more regions. *

\begin{tabular}{ll}
\hline Years & Series or chronology region and minima years \\
\hline $675-676$ & Qinghai-Tibet (675), Yamal (675), N. Scandinavia (676) \\
\hline 681 & Qinghai-Tibet (681), N. Scandinavia (681) \\
\hline $683-684$ & Central Europe (683), Yamal (684) \\
\hline 687 & N. Scandinavia (687), Central Europe (687) \\
\hline 692 & N. Scandinavia (692), Central Europe (692) \\
\hline 696 & Qinghai-Tibet (696), Central Europe (696) \\
\hline 700 & Qinghai-Tibet (700), Yamal (700), N. Scandinavia (700), Central Europe (700) \\
\hline $705-707$ & N. Scandinavia (705), Central Europe (706), N. Scandinavia (707) \\
\hline 711 & Qinghai-Tibet (711), Central Europe (711) \\
\hline $724-725$ & Central Europe (724), Qinghai-Tibet (725) \\
\hline
\end{tabular}

* Table adapted from GAO et al. (note 1).

Table 2: Scale for ranking the prospective reliability of source material.*

\begin{tabular}{ll}
\hline $\begin{array}{l}\text { Data Rating } \\
\text { Confidence } \\
\text { Level }\end{array}$ & Rationale \\
\hline 1 & Eyewitness or contemporary with a reliable chronology. \\
\hline & $\begin{array}{l}\text { Eyewitness or contemporary but with some chronological uncertainty. } \\
\text { Or } \\
\text { Neither eyewitness nor contemporary but has a reliable chronology and } \\
\text { accurately conveys the information from earlier sources. }\end{array}$ \\
\hline 3 & $\begin{array}{l}\text { Eyewitness or contemporary but with evidence of errors or fabrications. } \\
\text { Or }\end{array}$ \\
& Neither eyewitness nor contemporary and with an unreliable chronology. \\
\hline & Neither eyewitness nor contemporary and with evidence of errors or \\
&
\end{tabular}

* This ranking system is also employed in SIGL et al. (note 4).

and 4. This is a simple enough statement to make, but what lies behind it is important for making clear the contribution medievalists make to issues such as the potential societal and climatic consequences of geoengineering. In order to access the 
historical documentation, the training in source criticism that a medievalist receives is necessary in order to carry out such an evaluation of a text. Even within the same text there can be variation in how it scores on our scale, from passage to passage. For example, we exclude some material found in Hermann of Reichenau (d. 1054), which we ranked 3, as we can see that in several instances he erroneously re-dated the information from his sources. As Hermann came closer to writing about his own times, however, his entries score a 1. Sometimes it becomes possible to assess the dating system of a text against independently dated natural events, such as a report of a solar or lunar eclipse, or well attested human events, such as the death of a leading noble. But always it proves necessary to examine the level of certainty for each source dynamically, through time.

In further analysing the available evidence, the medieval historical climatologist must invest considerable effort in the meteorological interpretation of events, and in our case in particular to identify events of only localized significance (such as smallscale or isolated flash flooding) with the potential to occur in any year given the large spatial domain examined, regardless of any volcanic climatic perturbation. Such events are excluded from Tables 3 to 5 below, which we provide as a research resource detailing prospective large-scale extreme weather events and societal stresses for Europe, the Near East and China for the volcanically active years 670-730 CE. A further key consideration in constructing these tables has been to identify events duplicated between the extant sources, and which may (owing to chronological errors introduced in the copying and transmission of texts, for example) be found under distinct years and hence appear as potentially separate events. ${ }^{103}$ The level of duplication of events in the extant Irish annalistic sources is highlighted in Figure 4 as an example, which, if not accounted for would artificially inflate the apparent number of extreme events and societal stresses identified through time. ${ }^{104}$ It is also of clear importance to understand that some silences in Tables 3-5 arise from discontinuities in the available records, relating to their differing periods of coverage, as well as lacunae in the manuscripts. There may be a meaningful difference between a year or period for which scant evidence exists of extreme weather or societal stresses if that period is densely covered by many versus few sources, or indeed if the sources available are comparatively numerous but provide only a thin coverage in terms of events reported per year. ${ }^{105}$ Figure 4 shows the degree to which the extant Irish annalistic sources exhibit discontinuities in their coverage of the 670-730 CE period. Variable levels of coverage is a consideration that should be made more explicit in work drawing the written heritage remaining from the medieval era.

103 See discussion in LudLOW / TRAVIS (note 53).

104 LudLow et al. (note 28); ID. / TRAvis (note 53).

105 A more complete consideration of this issue in the case of the Irish Annals may be found in LuDLOW (note 81). 


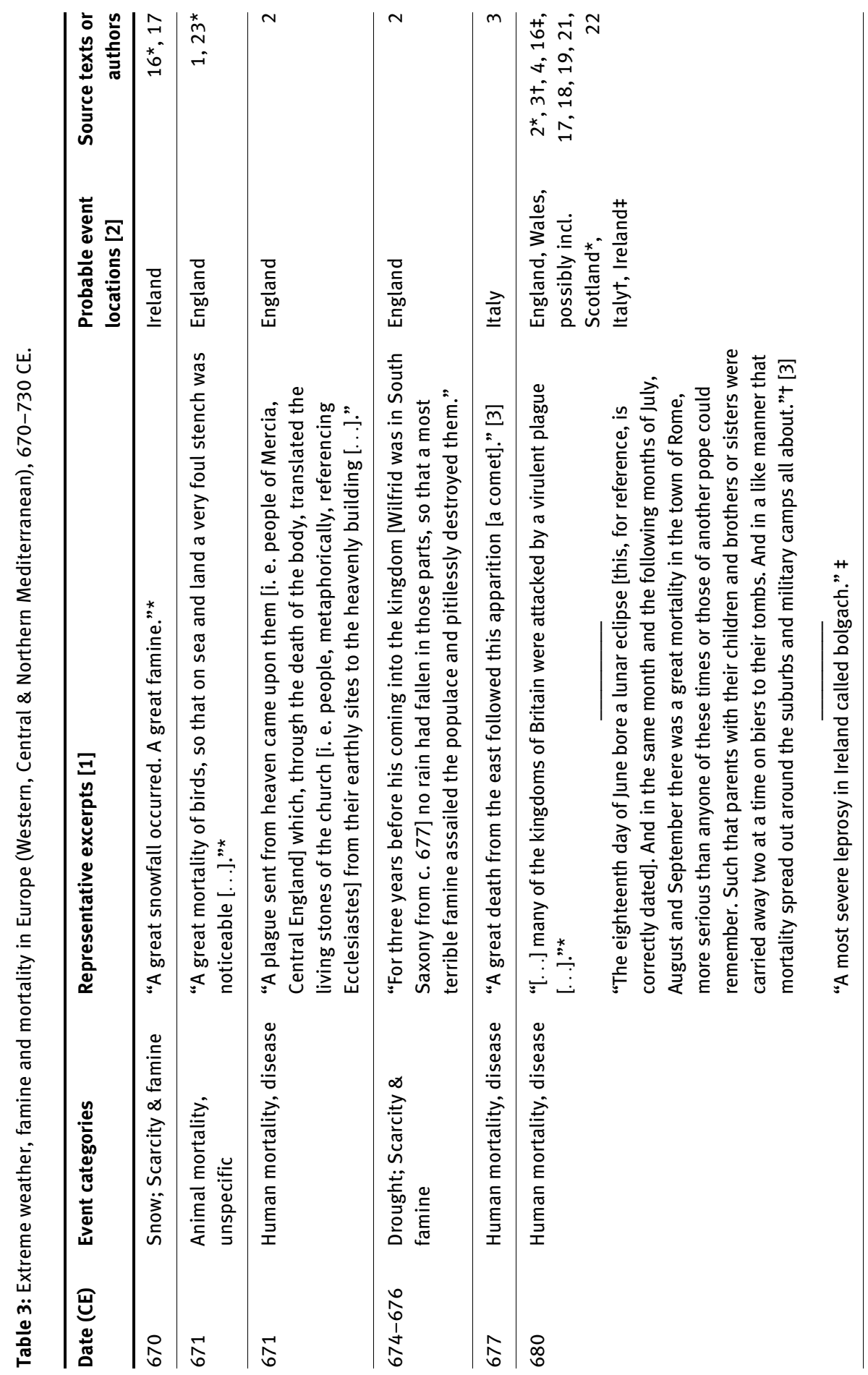




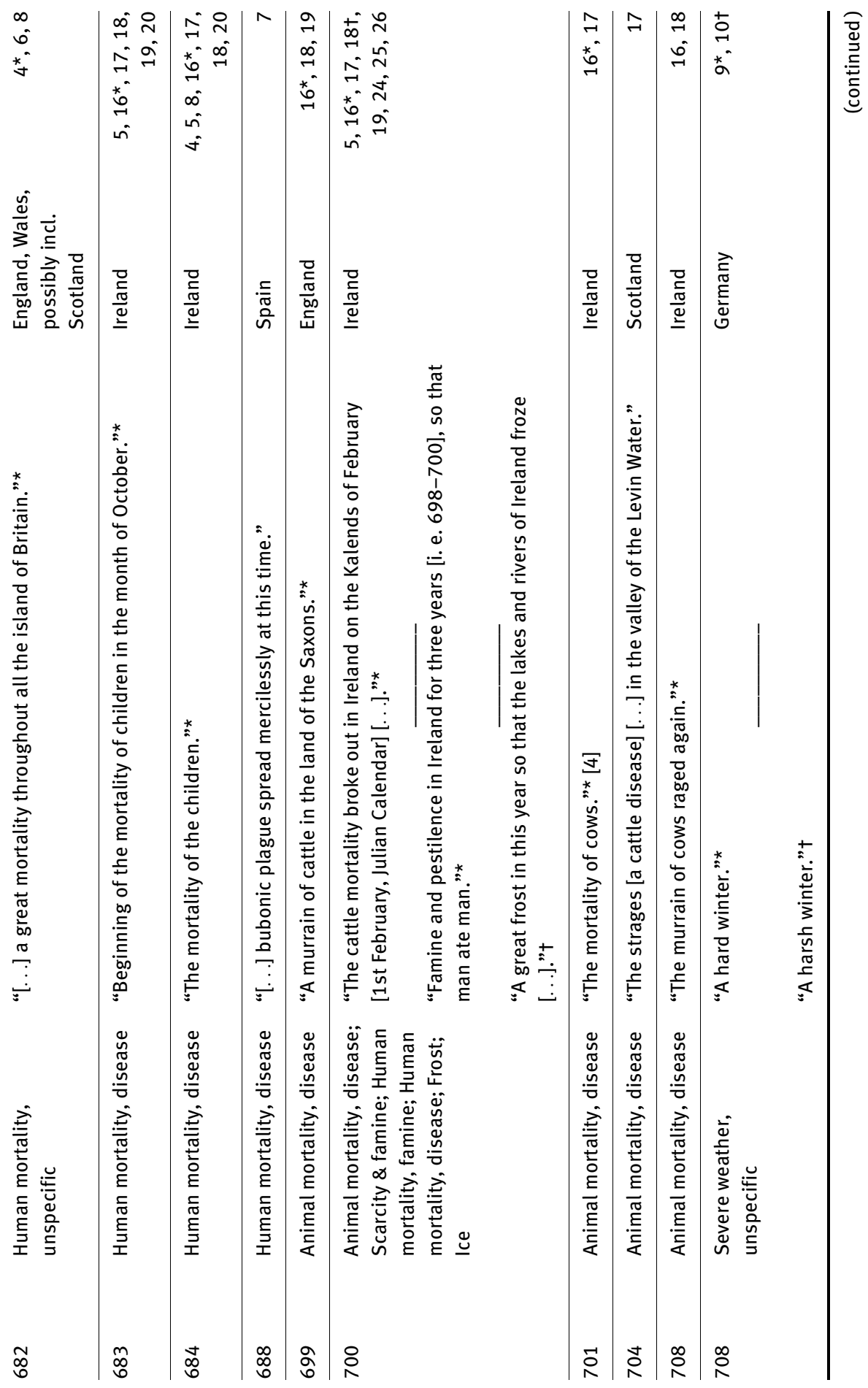




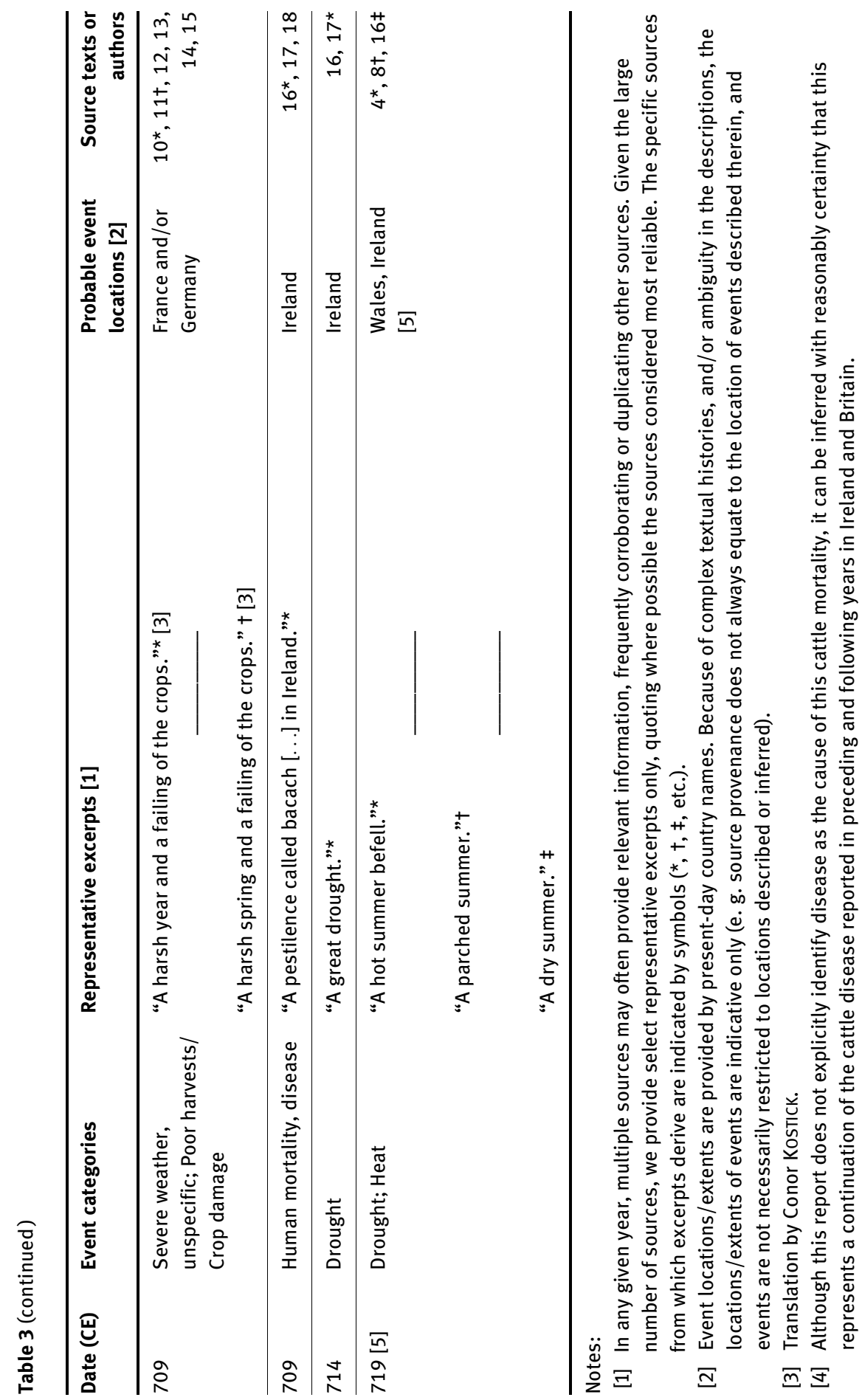




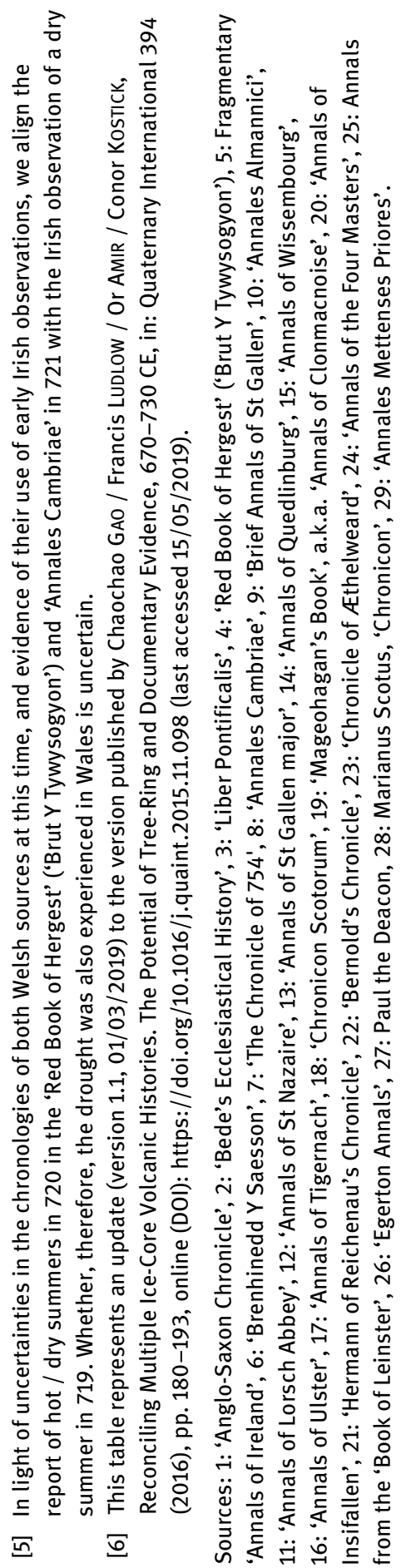




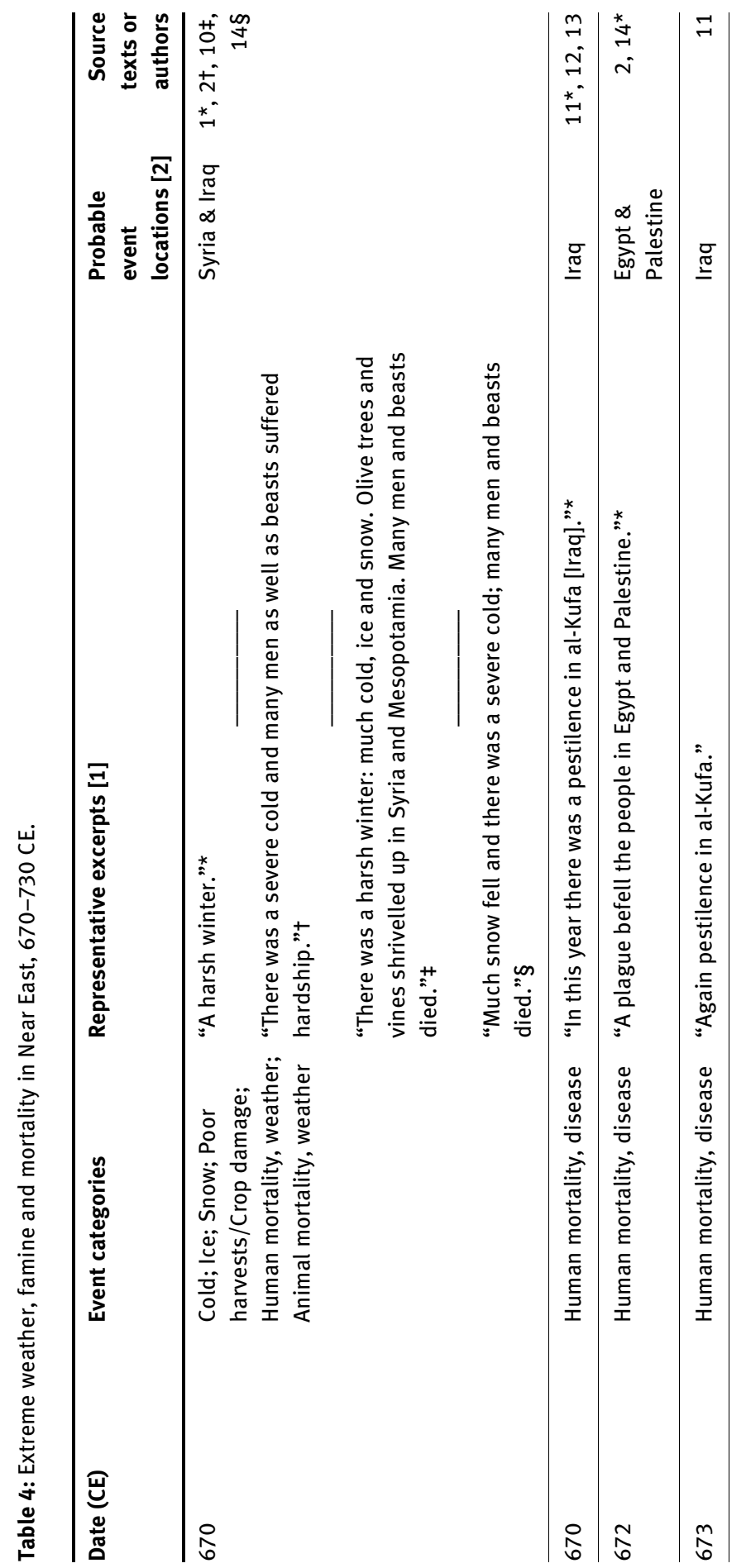




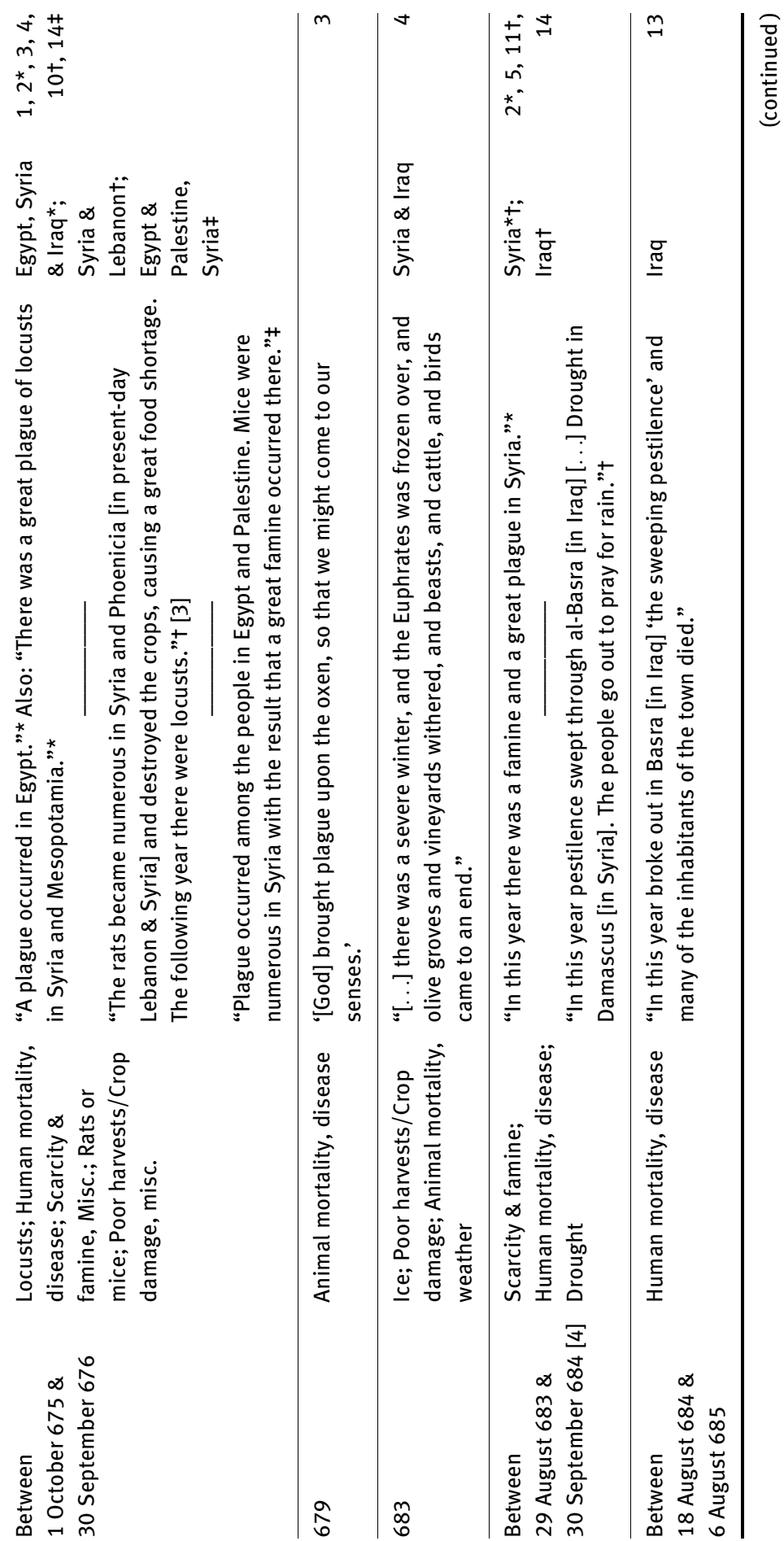



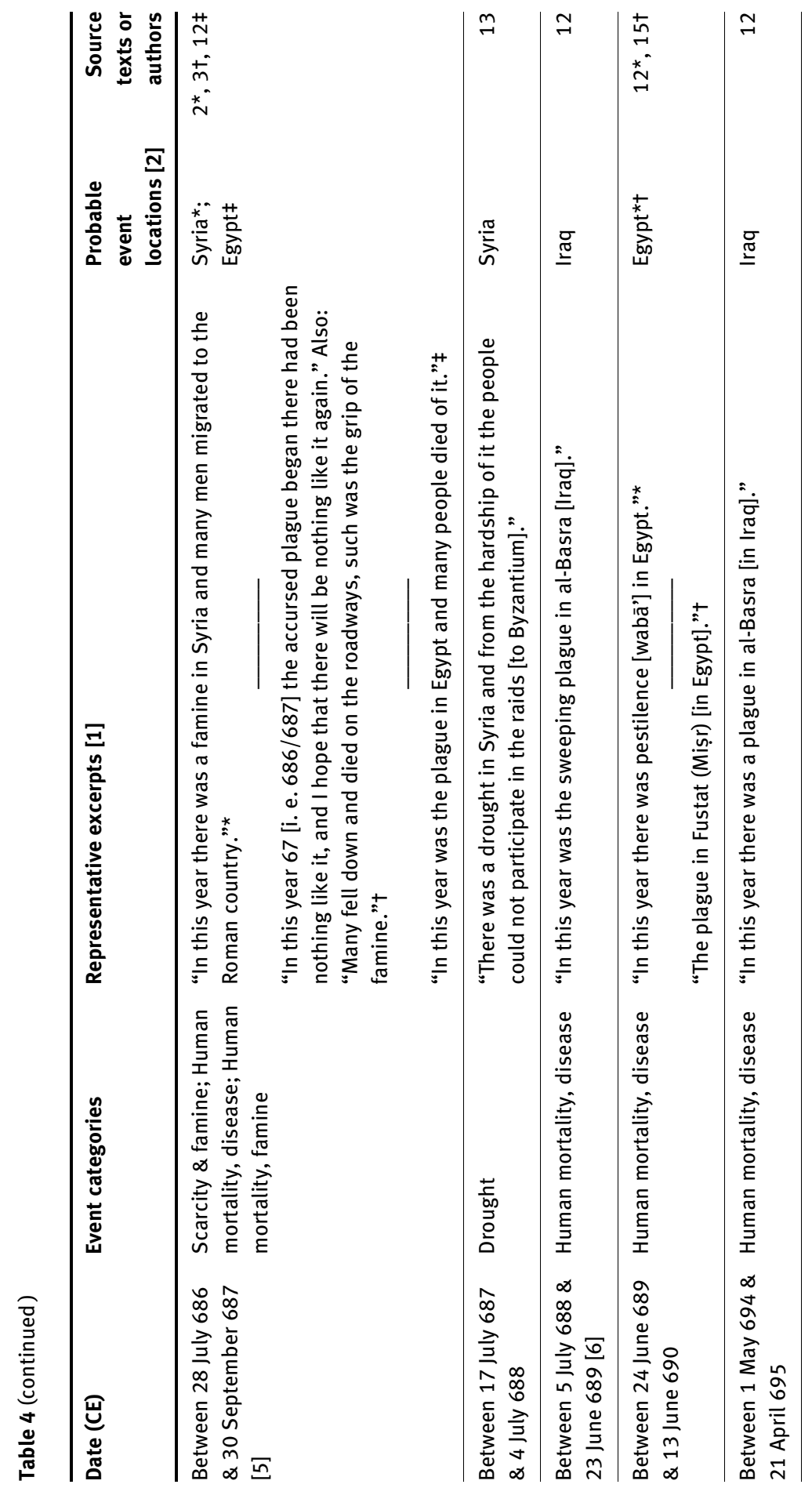


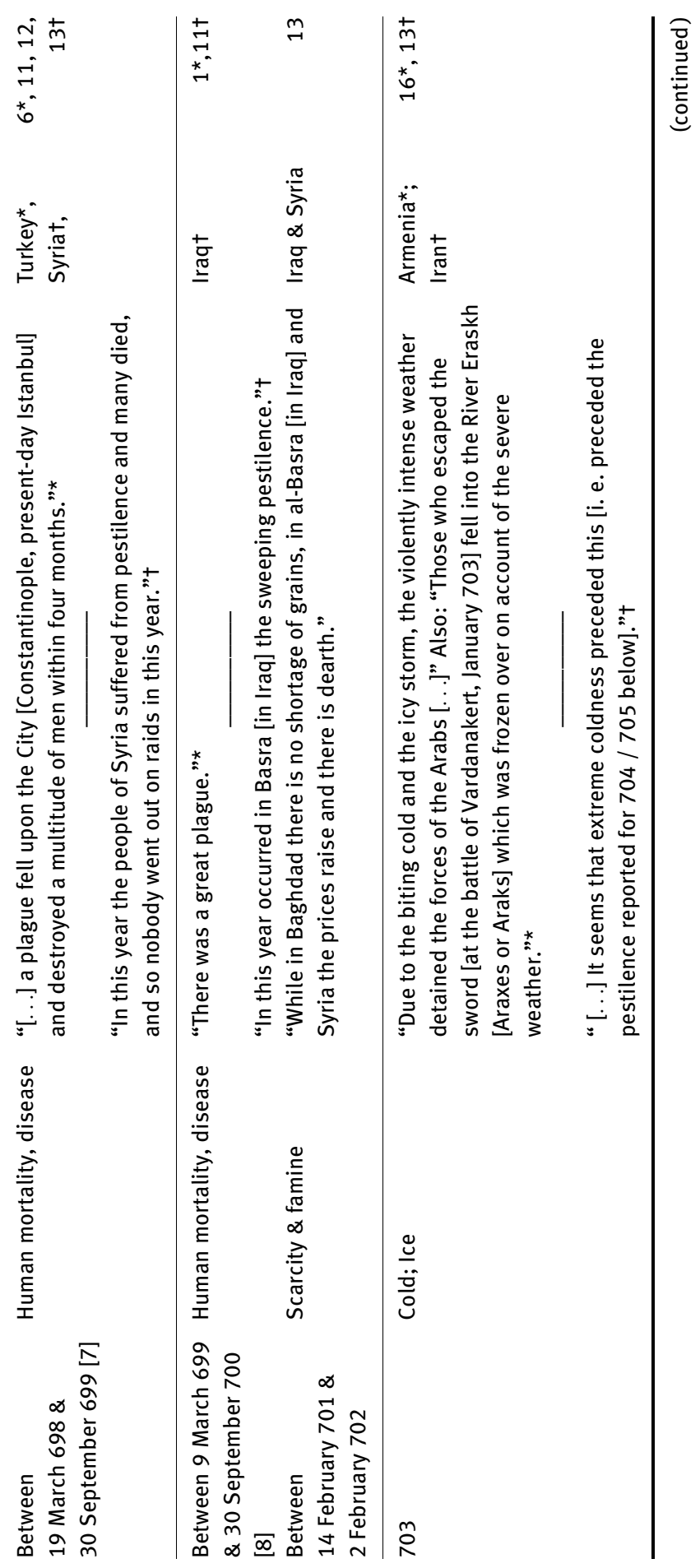




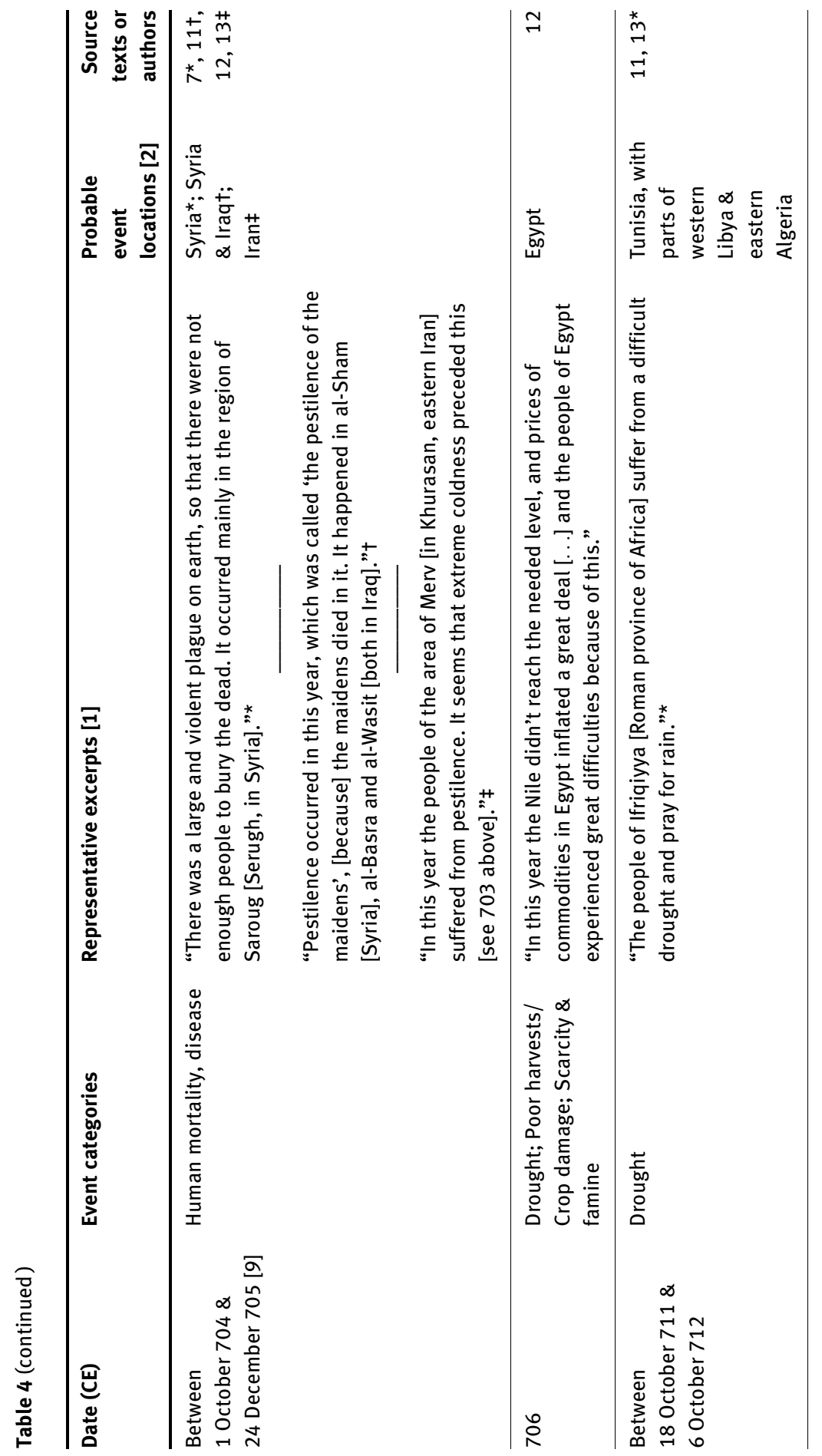




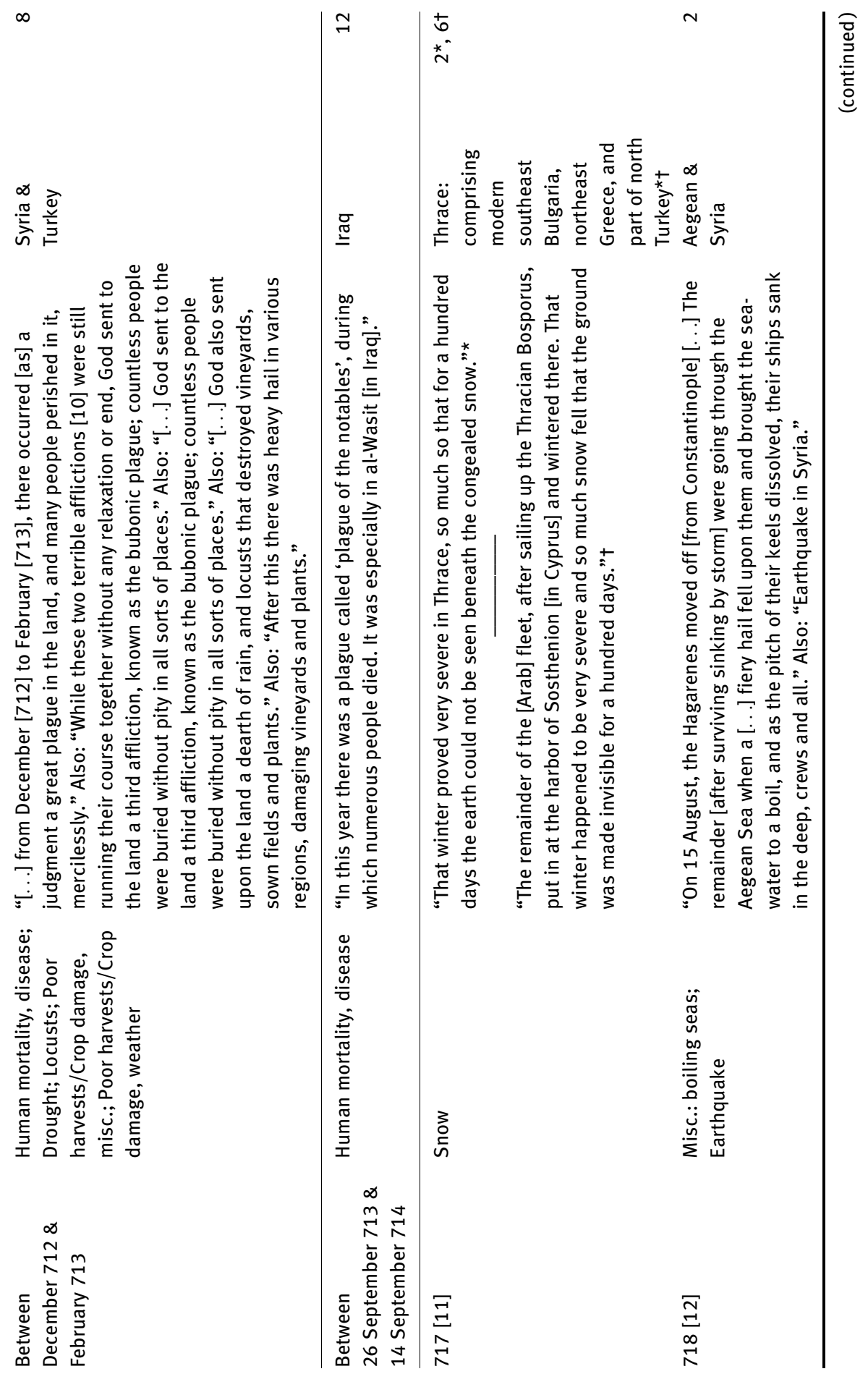




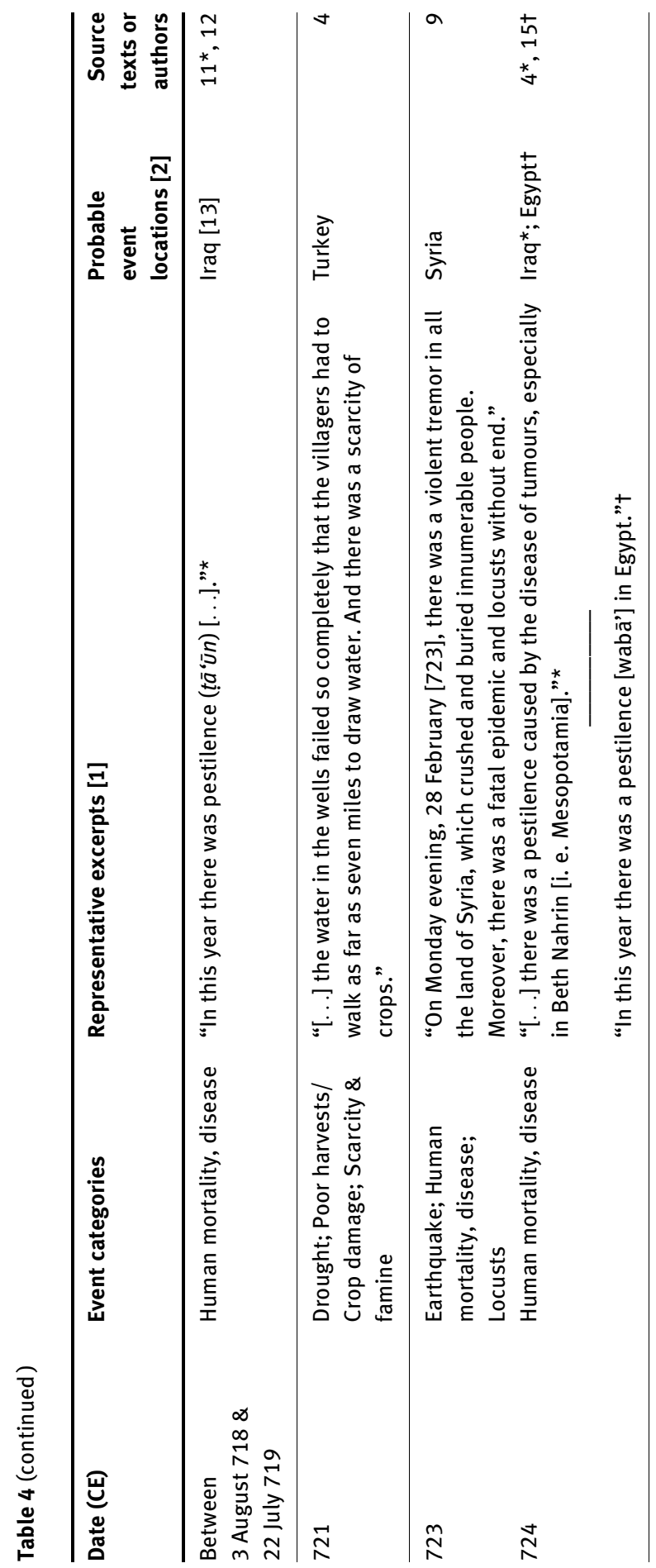




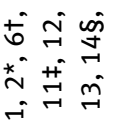

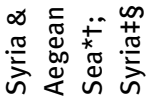

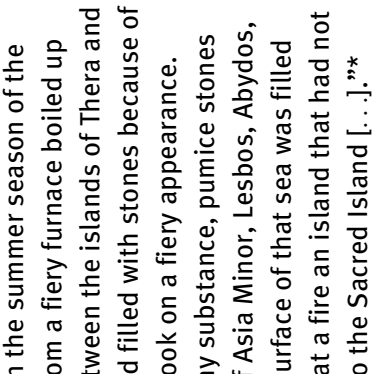

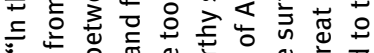

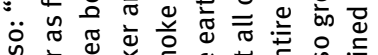

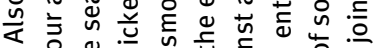
$\therefore$ : $\because$ 证

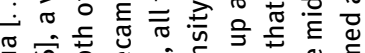

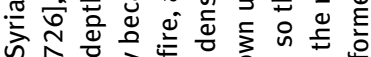

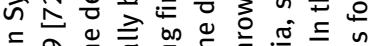

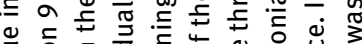

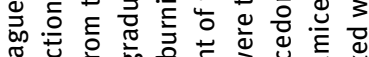

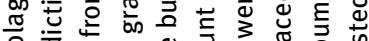
r.

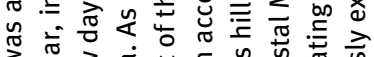

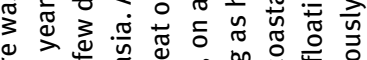

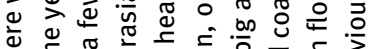

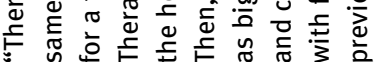

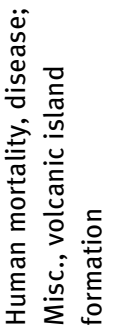

$\stackrel{\sim}{N} \stackrel{0}{N}$

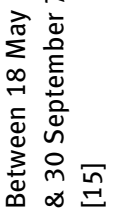

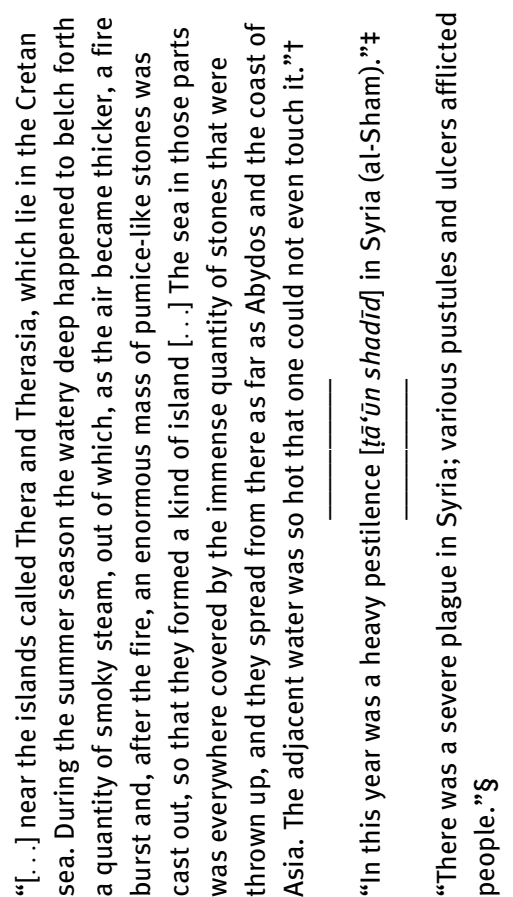

站的

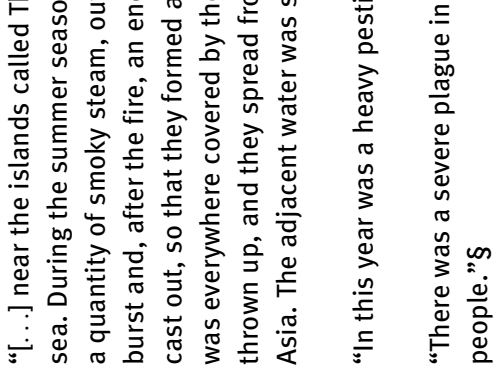

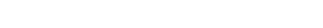

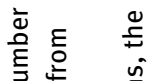

至总证产

कั

出

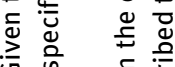

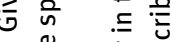

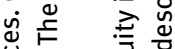

जे .ำ

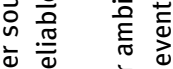

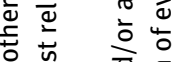

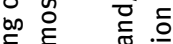

莺 ⿺辶寸

음 훙

ป ᄃ

엉

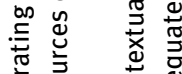

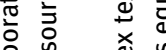

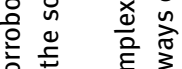

ㅎํㅇํㅇ

焉 प눙

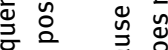

बㅇ 웡 윰

$=\frac{\square}{3} \quad 0$

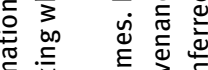

है

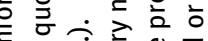

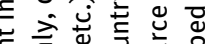

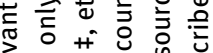

业

ब

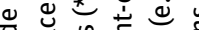

শ 능 离

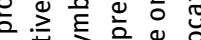

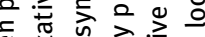

ब

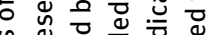

凹 巳

๘

i

纯

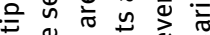

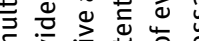

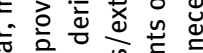

ฐ

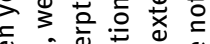

ऐ

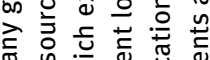

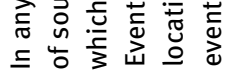

$\ddot{g}$

혼 


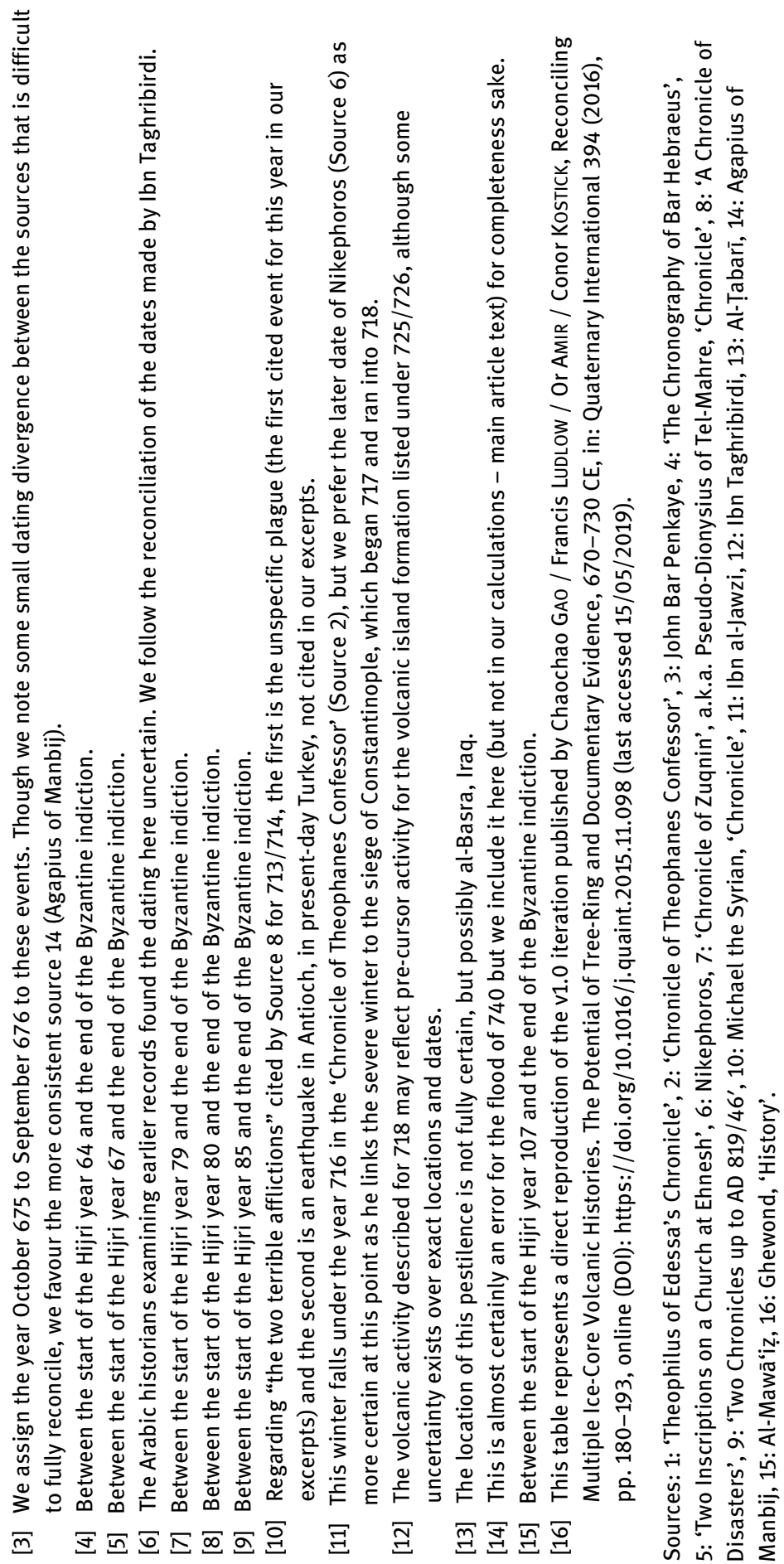




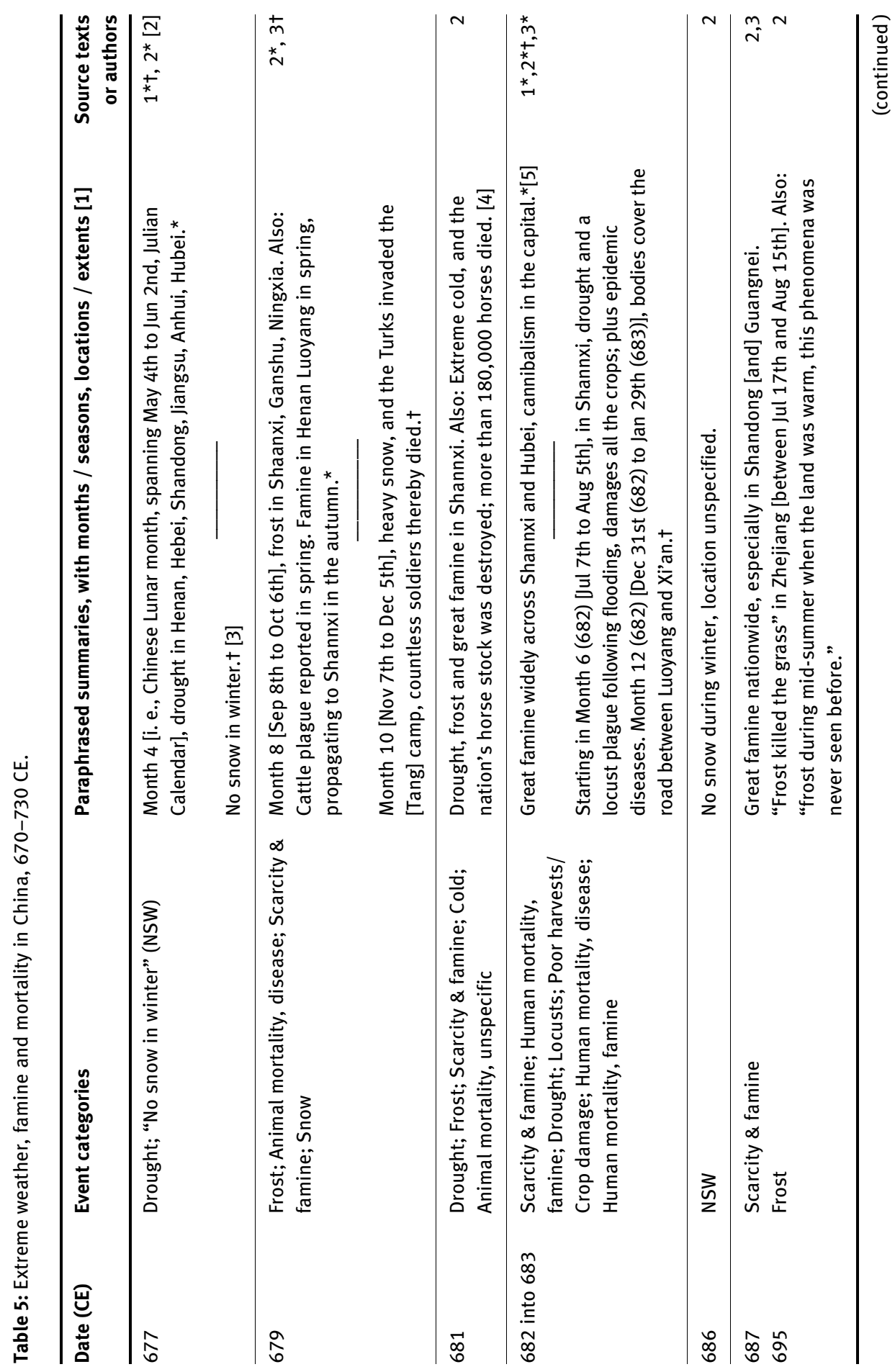




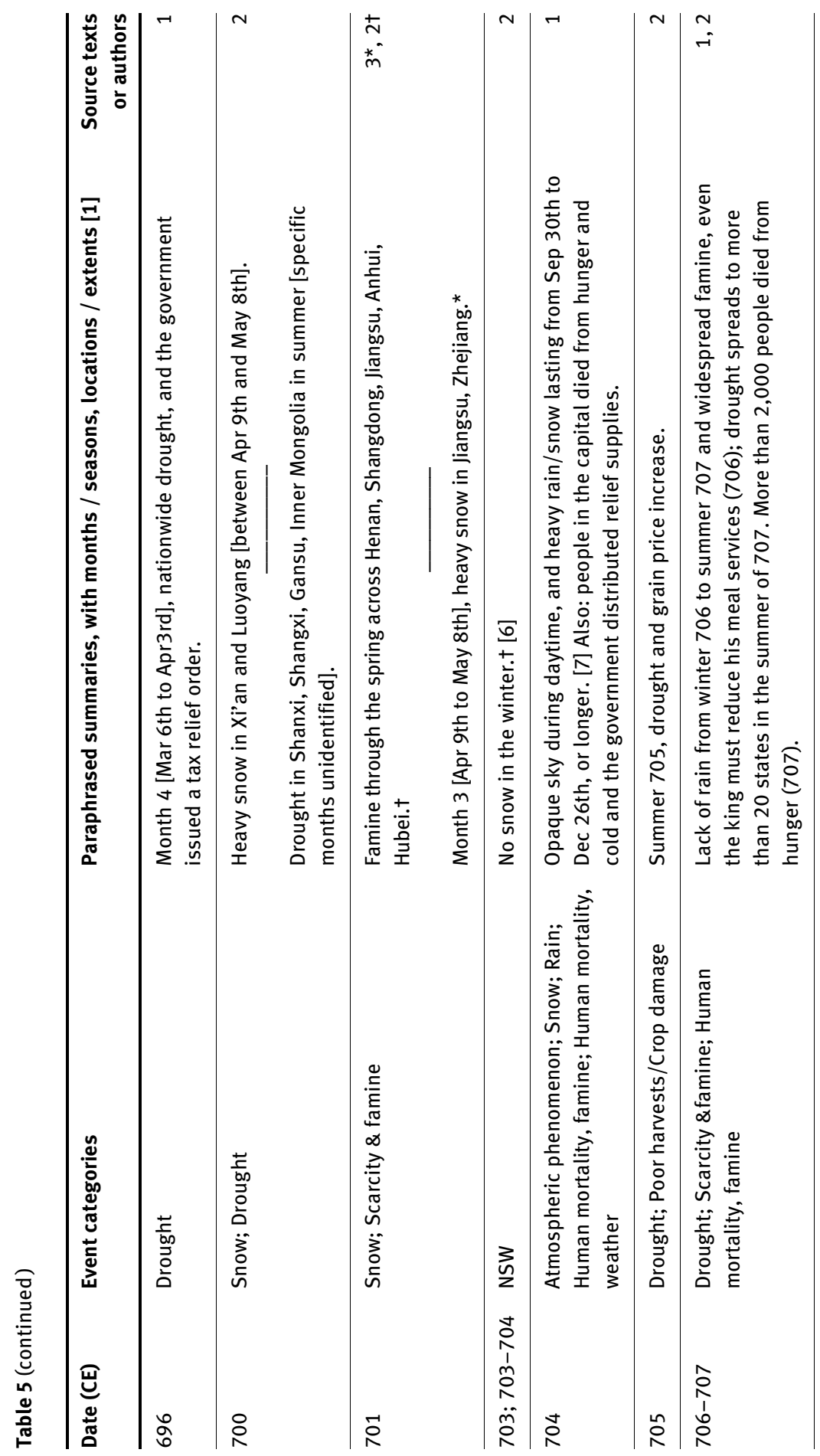




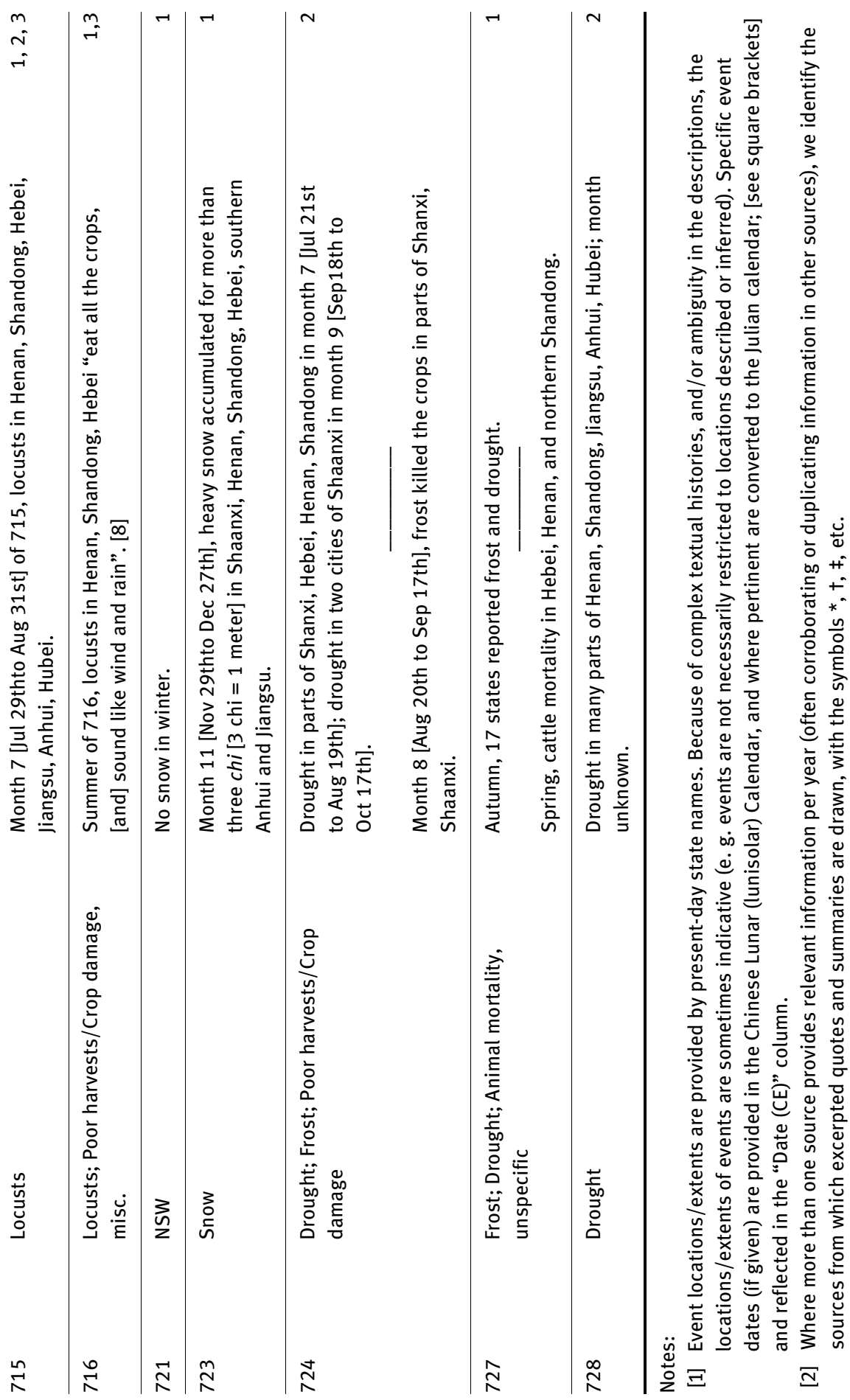




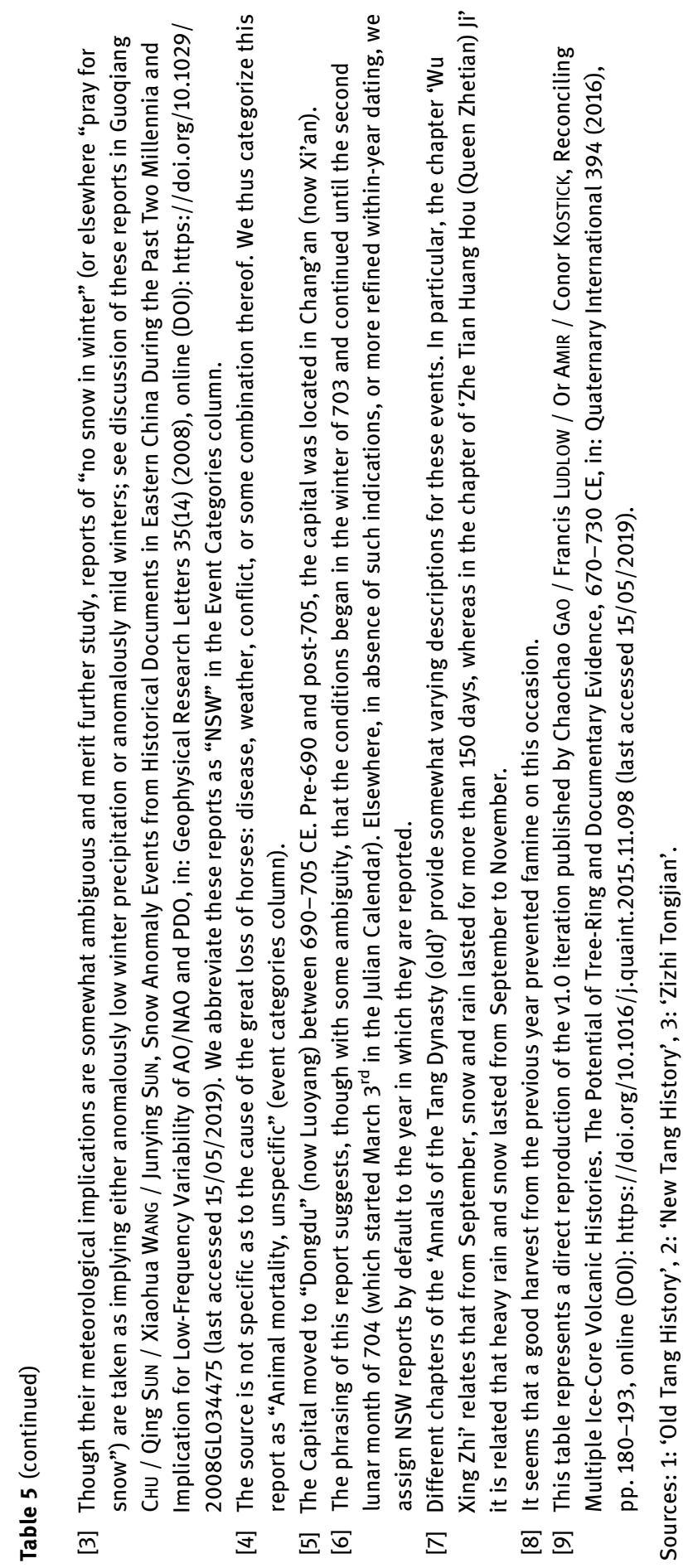




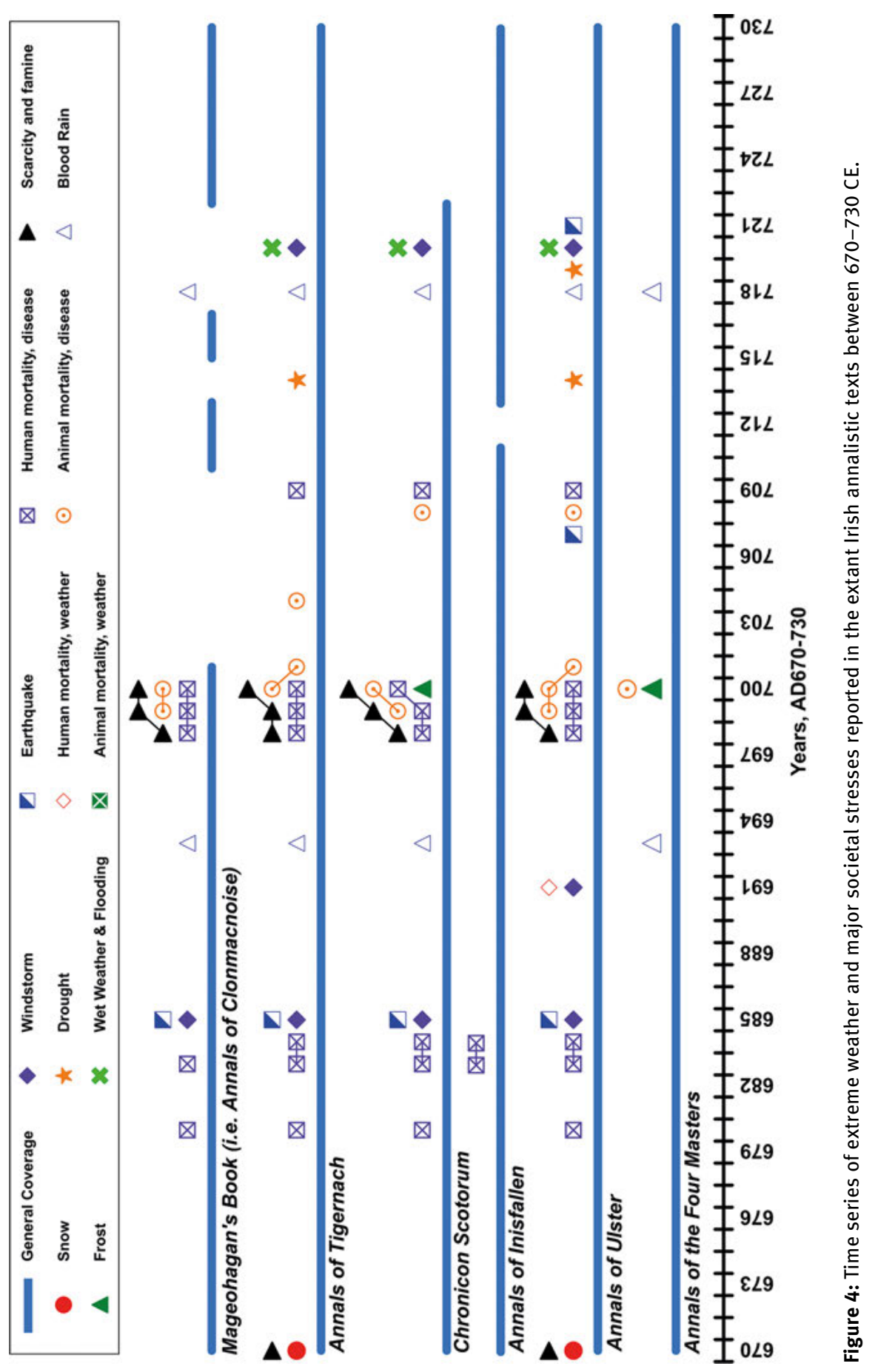


In Figure 4, many reported events are duplicates (rather than independent accounts) arising from the shared textual ancestry, and must be placed on a unified time-scale to assist in distinguishing separate events from duplicates assigned to incorrect years. The years covered by each available text (defined as at least one event reported per year) are also shown in the horizontal blue lines, with several texts exhibiting clear lacunae. Applying the chronological corrections of MCCARTHY also relocates some events into apparent lacunae in the coverage provided by some texts. $^{106}$

In our 61-year period of investigation then, extreme cold - as evidenced by reports of heavy or prolonged snowfall and long-lasting frosts - occurred in one or more of the three regions thirteen times $(21.3 \%)$. There were even more years with instances of drought, namely 27 (44.3\%). In terms of the challenges facing human societies in this period, mass human mortality occurred with extraordinary frequency. It is reported in at least one region for 36 (59\%) years and arose from various documented causes: indirectly as a result of scarcity and famine, or directly from extreme weather, or the outbreak of disease. In 10 years $(16.4 \%)$ there were poor or damaged harvests and in 20 (32.8 \%) scarcity and famine. Epizootics struck with surprising frequency too. Eleven (18\%) years have reports of mass animal mortality resulting from unusual weather and disease (the mass animal mortality in 671 in Europe and 681 and 727 in China are not explicitly linked to any particular cause in the texts).

In any comparison of events from three different regions, some clustering might arise by chance, especially if the data run over several centuries. But here it is striking that we see multiple distinct moments when crises grouped between distinct regions in this comparatively short study period. More significantly, they do so around years that the ice-cores and tree-rings indicate experienced major explosive eruptions with severe climatic perturbation. As depicted in Figure 5, particularly notable years for multiple societal crisis are 681-4, 686-8, 698-701 and 704-7. These correspond well with the two largest volcanic signals identified in the Greenland ice-cores for this period, namely 681 and $684-6$ at $44 \%$ and $24 \%$ the sulphate deposition volume of the great 1257 Samalas eruption, but perhaps more surprisingly also correspond to smaller volcanic signals in 697 (5\%) and 706-7 (17 \%). This is an important observation regarding the vulnerability of early medieval society to even comparatively smaller eruptions, particularly if those eruptions compound the impacts of preceding larger events, and suggests that a further concern requiring detailed consideration is

106 The evolution of the Irish annalistic tradition is detailed most fully in Daniel McCARTHY, The Irish Annals: Their Genesis, Evolution and History, Dublin 2008. A ground-breaking unified 'synchronized' chronology for Irish annalistic texts has been developed by ID., Irish Chronicles and their Chronology, 4th ed. online: www.cs.tcd.ie/Dan.McCarthy/chronology/synchronisms/annalschron.htm (last updated 14/12/2011, last accessed 15/05/2019). 


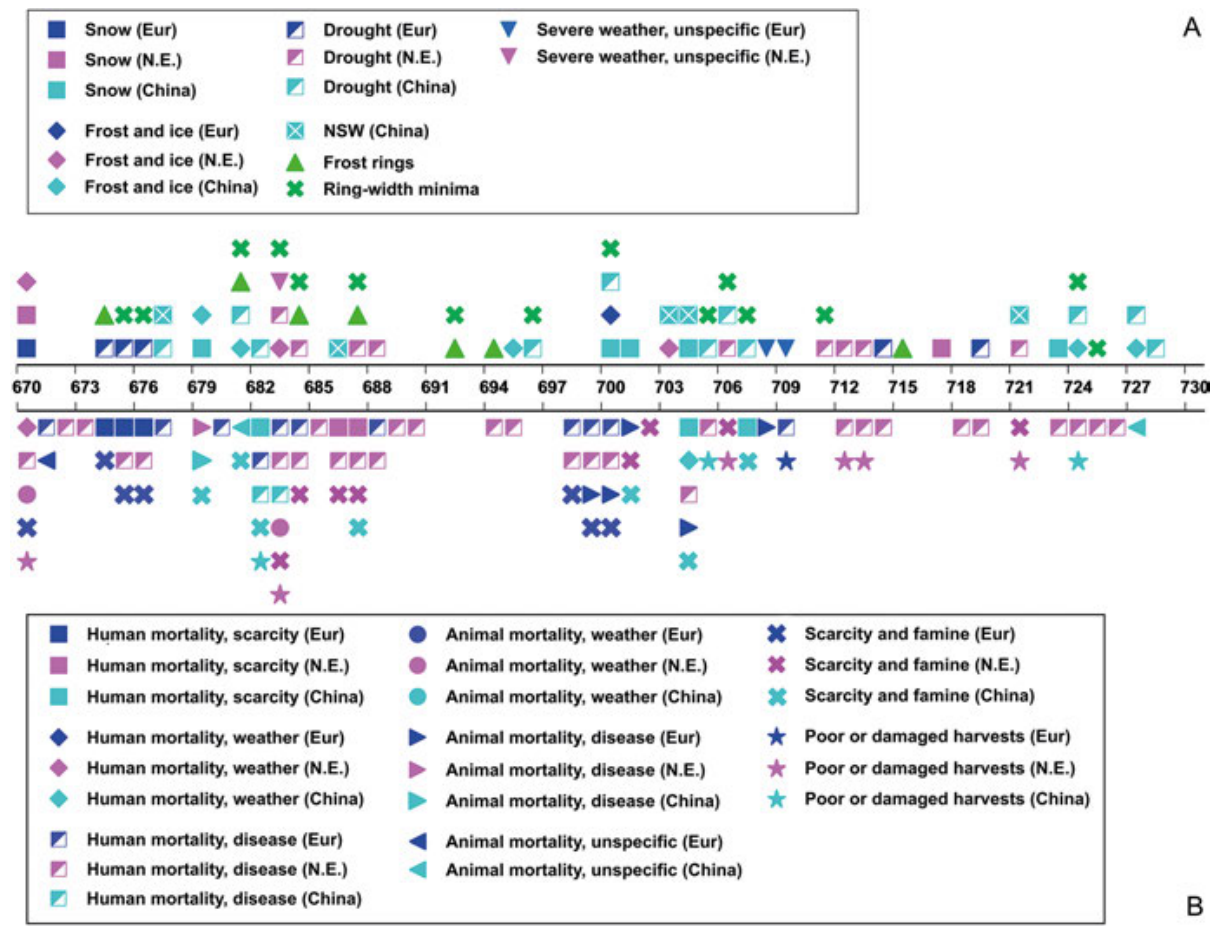

Figure 5: Historically documented meteorological extremes (panel A) and societal stresses (panel B) from 670-730 CE (horizontal axes) colour-coded by region (Europe [blue], Near East [pink] and China [aquamarine]). Frost-ring dates are taken from the compilation of SALZER and HUGHES (note 68), as well as dates of inter-regional tree-ring minima, for comparison in the top panel (Table 1 specifies the regions from which the minima originate). Figure reproduced from GAO et al. (note 1).

the potential for a compounding of adverse consequences from even comparatively small explosive eruptions if occurring whilst SAI geoengineering is ongoing.

\section{Conclusion}

By studying historical explosive volcanism, medieval history provides a laboratory for understanding the possible climatic and societal impacts of geoengineering in the form of reports of extreme weather and societal stresses such as subsistence crises and even conflict arising from scarcity induced resource competition. ${ }^{107}$ We argue that this history must be taken seriously in the discussion about whether to proceed with solar geoengineering. The twentieth and twenty-first centuries have been

107 LudLOW / TRAVIS (note 53). 
volcanically quiescent relative to earlier centuries, in terms of large climatically impactful eruptions, but this can change at any time. In particular, advocates of a geoengineered solution must appreciate the relevance of the question: what will happen if the planet experiences another period in which one or more sulphur-rich VEI 5 to 7 eruptions occur, if we have already laden the stratosphere with sulphates artificially?

The story our research tells is, in sum, that beginning with a massive eruption in 681, the climate of the planet was perturbed across a wide region, bringing about major social stress. Before the climate and human activity could recover, another large eruption took place, which combined with several other smaller but still notable eruptions to compound the climate effects and the human impact. For early medieval societies, whose resilience in the face of several years of extreme cold was precarious, this was a disaster that lead to mass human mortality, as attested by the sources. The period can, moreover, be seen as a parallel of the better-known climatic anomaly of c. 536-550, an event now also generally considered the product of multiple closely spaced volcanic eruptions, and coincident with the outbreak of the great Justinian plague. ${ }^{108}$

Contemporary society can be deemed immensely more resilient than the early medieval world. We recognize that, for example, with grain yields at 30 per seed rather than the 3 per seed that was typical for the period we discuss here, there is a far larger cushion between humanity and famine caused by crop failure (famines caused by war, sanctions, or an over-dependence on cash crops are another matter entirely). Yet there are features of modern society that render it more vulnerable in some ways than our medieval predecessors. Just-in-time production and a dependency of so many economies on rapid international trade creates a situation where, for example, if air traffic is heavily impeded across a wide region for several months, the consequences may be severe. Moreover, modelling of global tradeflows under climate shocks suggests that even apparently insulated western societies may face strain in cases of monsoon failure or other episodes of extreme weather in apparently far distant regions. ${ }^{109}$

108 Conor Kostick / Francis Ludlow, The Dating of Volcanic Events and their Impacts upon European Climate and Society, 400-800 CE, in: European Journal of Post-Classical Archaeologies 5 (2015), pp. 7-30; Matthew TOOHEY / Kristin KRÜGER /Michael SIGL / Frode STORDAL / Henrik SvenSEN, Climatic and Societal Impacts of a Volcanic Double Event at the Sawn of the Middle Ages, in: Climatic Change 136(3-4) (2016), pp. 401-412.

109 David SeEkell / Joel CARR / Jampel Dell’Angelo / Paolo D’ODorico / Marianela Fader / Jessica Gephart / Matti Kummu / Nicholas Magliocca / Miina PorkKa / Michael Puma / Zak RatajCzak / Maria Cristina Rulu / Samir SuweIs / Alessandro TAVonI, Resilience in the Global Food system, in: Environmental Research Letters 12(2) (2017), 025010, online (DOI): https://doi.org/10.1088/17489326/aa5730 (last accessed 15/05/2019); Michael J. PumA / Satyajit BoSE / So Young CHON / Benjamin I. Соок, Assessing the Evolving Fragility of the Global Food System, in: Environmental Research Letters 10(2) (2015), 024007, online (DOI): https://doi.org/10.1088/1748-9326/10/2/024007 (last accessed 15/05/2019); Philippe Marchand / Joel A. CARR / Jampel Dell’Angelo / Marianela 
Our conclusion then is that as the geoengineering option becomes more appealing in the face of increasingly damaging consequences arising from global warming and the fear that we might cross a tipping point that imperils humanity, we must nevertheless appreciate the historical perspective. And what this perspective demonstrates is that along with a strategy for pumping sulphates into the stratosphere, the unpredictability of explosive volcanism means that we must also develop one for mitigating their societal (and, if possible, even their climatic) impacts with extreme rapidity.

\title{
Appendixes
}

Table A1: Reference and attribute table of major ice-core datasets in Greenland. ${ }^{\mathrm{A}}$

\begin{tabular}{|c|c|c|c|c|c|}
\hline $\begin{array}{l}\text { Data-set } \\
\text { name }\end{array}$ & Location & $\begin{array}{l}\text { Period } \\
\text { covered }\end{array}$ & $\begin{array}{l}\text { Approx. } \\
\text { resolution }\end{array}$ & $\begin{array}{l}\text { Measurement } \\
\text { type }^{\text {B }}\end{array}$ & Units \\
\hline NEEM S1 & $77.5^{\circ} \mathrm{N}, 5^{\circ} \mathrm{W}$ & $78-1997$ & $1 / \mathrm{a}$ & $\mathrm{NSS} \mathrm{SO}_{4}$ & $\mathrm{ng} / \mathrm{g}$ \\
\hline NGRIPmain1 & $75.1^{\circ} \mathrm{N}, 42.3^{\circ} \mathrm{W}$ & 190-1969 & $2 / a$ & $\mathrm{ECM}$ & \\
\hline NGRIP.SO ${ }_{4}$ & $75.1^{\circ} \mathrm{N}, 42.3^{\circ} \mathrm{W}$ & 190-1969 & $1 / a$ & Total $\mathrm{SO}_{4}$ & 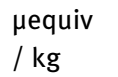 \\
\hline GISP2 & $72.6^{\circ} \mathrm{N}, 38.5^{\circ} \mathrm{W}$ & $1-1984$ & $0.5 / a$ & $\mathrm{NSS} \mathrm{SO}_{4}$ & $\mathrm{ppb}$ \\
\hline Dye3deep & $72.6^{\circ} \mathrm{N}, 37.6^{\circ} \mathrm{W}$ & $1-1768$ & $4 / a$ & ECM & \\
\hline GRIPmain & $71.3^{\circ} \mathrm{N}, 26.7^{\circ} \mathrm{W}$ & $1-1642$ & $4 / a$ & ECM & \\
\hline Crête & $71.1^{\circ} \mathrm{N}, 37.3^{\circ} \mathrm{W}$ & $553-1778$ & $4 / a$ & ECM & \\
\hline Crête. $\mathrm{SO}_{4}$ & $71.1^{\circ} \mathrm{N}, 37.3^{\circ} \mathrm{W}$ & $553-1778$ & $4 / a$ & $\mathrm{NSS} \mathrm{SO}_{4}$ & $\mathrm{~kg} / \mathrm{km}^{2}$ \\
\hline
\end{tabular}

A Table adapted from GAO et al. (note 1 ).

${ }^{B}$ ECM, electrical conductivity measurement; $\mathrm{NSS} \mathrm{SO}_{4}$, non-sea-salt sulphate; NSS-conductivity, non-sea-salt conductivity.

\section{Primary Sources}

\author{
Abbreviations: \\ MGH SS Monumenta Germania Historica, Scriptores \\ MGH SRG Monumenta Germania Historica, Scriptores Rerum Germanicarum
}

FAder / Jessica A. Gephart / Matti Kummu / Nicholas R. Magliocca / Miina PorkKa / Michael J. Puma / Zak RatajCzaK / Maria Cristina Rulli / David A. SEeKEll / Samir Suweis /Alessandro TAVoni / Paolo D’ODorico, Reserves and Trade Jointly Determine Exposure to Food Supply Shocks, in: Environmental Research Letters 11(9) (2016), 095009, online (DOI): https://doi.org/10.1088/ 1748-9326/11/9/095009 (last accessed 15/05/2019). 
A Chronicle of Disasters, trans. Sebastian P. BRock, in: Andrew PALmer / Sebastian P. BRock / Robert Hoyland (eds.), The Seventh Century in the Western Syrian Chronicles, Liverpool 1993, pp. 45-47.

Agapius of Manbij, Kitab al-'Unvan, ed. Alexander A. VASILIEv (Patrologia Orientalis 38 [8.3]), Paris 1912.

Al-Mawā'iẓ, al-Mawā'iz wa'l-i'tibār bi-dhikr al-khițațwa'l-athār, 3 vols., eds. Muhammad ZAYNHum / Madiha AL SHARQĀWĪ, Beirut 1997-1998.

Al-Ṭabarī, Ta'rīkh al-rusul wa'l-mulūk, 11 vols., ed. Muhammad Abū AL-FADL IBRAHIM, Beirut 1967-1968.

Anglo-Saxon Chronicle, trans. George N. GaRMONSWAY, London 1975.

Annales Alamannici, ed. Georg H. PERTZ (MGH SS 1) Hanover 1826, pp. 22-30, 40-44, 47-60.

Annales Cambriae. A Translation of Harleian; PRO E.164/1; Cottonian Domitian, A 1; Exeter Cathedral Library MS. 3514 and MS Exchequer DB Neath, PRO E, ed. and trans. Paul M. REMFRY, Shrewsbury 2007.

Annales Mettenses Priores, ed. Bernhard Eduard von SIMSON (MGH SRG 10), Hanover 1905, pp. 1-98.

The Book of Leinster sometime called the Book of Glendalough with introduction, analysis of contents, and index, ed. Robert ATKINSON, Dublin 1880.

Annals of Insifallen, ed. and trans. Seán MAC AIRT, Dublin 1944.

Annals of Lorsch Abbey, ed. Georg H. PERTZ (MGH SS 1), Hanover 1826, pp. 7, 9, 10, 12, 15, 52-55.

Annals of Quedlinburg, ed. Georg H. PERTZ (MGH SS 3), Hanover 1839, pp. 22-90.

Annals of St Gallen major, ed. Ildefons von ARX (MGH SS 1), Hanover 1826, pp. 73-85.

Annals of St Nazaire, ed. Georg H. PeRTz (MGH SS 1), Hanover 1826, pp. 40-4.

Annals of the Four Masters, ed. John O'Donovan, Dublin 1851.

Annals of Tigernach, 2 vols., ed. Whitley STOKES, Felinfach 1993.

Annals of Ulster (to A.D. 1131). Part I: Text and Translation, ed. and trans. Séan MAC AIRT / Gearóid MAC NIOCAILL, Dublin 1983.

Annals of Wissembourg, ed. Georg H. PERTZ (MGH SS 3), Hanover 1839, pp. 33-72.

Bar Hebraeus, Chronicon Syriacum, ed. Paul Bedjan, Paris 1890.

Bede, Ecclesiastical History, ed. Bertram Colgrave / Roger A. B. Mynors, Oxford 1969.

Bernold of St Blasien (Constance), Chronicon, in: Die Chroniken Bertholds von Reichenau und Bernolds von Konstanz 1054-1100 (MGH SRG N.S. 14), ed. Ian S. RoBINSON, Hanover 2003, pp. 383-540.

Brenhinedd Y Saesson, or, The King of the Saxons: BM Cotton MS Cleopatra B v, and The black book of Basingwerk, NLW MS. 7006, ed. and trans. Thomas JONES, Cardiff 1971.

Brief Annals of St Gallen, ed. Georg H. PERTZ (MGH SS 1), Hanover 1826, pp. 64-5.

Chronicle of Æthelweard, ed. Alistair CAMPBELL, Edinburgh 1962.

Chronicle of Zuqnin, a.k.a. Pseudo-Dionysius of Tel-Mahre Chronicle, ed. Witold WITAKowsKI, Liverpool 1996.

Chronicon Scotorum, ed. and trans. William M. HENNESSY, London 1866.

Fragmentary Annals of Ireland, ed. Joan N. RADNER, Dublin 1978.

Ghewond, History, ed. Zaven ArzoumanIAN, Philadelphia 1982.

Hermann of Reichenau, Chronicon, ed. Georg H. PERTZ (MGH SS 5), Hanover 1844.

Ibn al-Jawzi, al-Muntaẓam fī ta’rīkh al-umam wa’l-mulūk, 19 vols., ed. M.A.Q. 'ĀṬ̂̄ et al., Beirut 1992.

Ibn Taghri Birdi, al-Nujum al-Zahira fī mulūk Mișr wa'l-Qāhira, 5 vols., ed. William PoPPER, Berkeley 1936.

John Bar Penkaye, Riš Melle, in: Sebastian P. BRock (ed.), North Mesopotamia in the Late Seventh Century: Book XV of John Bar Penkaye's Riš Melle, in: Jerusalem Studies in Arabic and Islam 9 (1987), pp. 57-74. 
Liber Pontificalis, ed. Theodor Mommsen (MGH Gesta Pontificum Romanorum 1), Berlin 1898. Mageohagan's Book, a.k.a. Annals of Clonmacnoise, ed. Denis MURPHY, Dublin 1896.

Marianus Scotus, Chronicon, ed. Georg WAITZ (MGH SS 5), Hanover 1884, pp. 481-562.

Michael the Syrian, Chronique de Michel le Syrien, Patriarche Jacobite d'Antioche (1166-1199), 4 vols., ed. and trans. Jean Baptiste СНАВот, Paris 1916-1920.

New Tang History, 20 vols., ed. Ouyang XIU / Song QI, Beijing 1975.

Nicephorus Callistus Xanthopoulos, Historia Ecclesiastica, ed. Jacques Paul MIGNE, in: ID. (ed.), Patrologia Graeca, vols. 145-147, Paris 1865, vol. 145, cols. 559-1332, vol. 146, vol. 147, cols. 449-634.

Old Tang History, 16 vols., ed. Liu Xu, Beijing 1975.

Paul the Deacon, Historia langobardorum, ed. Ludwig BetHMAnN / Georg WAITZ (MGH SRG 48) Hanover 1878.

Red Book of Hergest (Brut Y Tywysogyon), ed. and trans. Thomas JONES, Cardiff 1955.

The Chronicle of 754, ed. Eduardo LóPez PereiRA, Zaragoza 1980.

Theophanes, Chronographia, 2 vols., ed. Carl De Boor, Leipzig 1883-1885.

Theophilus of Edessa's Chronicle, trans. Robert G. HoYLAND, Liverpool 2011.

Two Chronicles up to AD 819/46, trans. Andrew PALmeR, in: Andrew PALMER / Sebastian P. BRoCK / Robert HoYLAND (eds.), The Seventh Century in the Western Syrian Chronicles, Liverpool 1993, pp. 75-82.

Two Inscriptions on a Church at Ehnesh, trans. Andrew PALMER, in: Andrew PALMER / Sebastian P. BRock / Robert Hoyland (eds.), The Seventh Century in the Western Syrian Chronicles Liverpool 1993, pp. 71-73.

Widukind of Corvey, Rerum Gestarum Saxonicum, ed. Paul HIRSCH / Hans-Eberhard LoHmAnN (MGH SRG 60), Hanover 1935.

Zizhi tongjian, ed. Sima GuANG, Beijing 1956. 



\title{
Jörg Feuchter
}

\section{The Middle Ages in the Genetics Lab}

\begin{abstract}
In the twenty-first century the medieval ended up in a place where - only a few decades ago - no one would have expected to find it: the genetics lab. Today, highly specialized state-of-the-art research institutes are busy analysing medieval DNA samples. The objects they scrutinize represent the entire Middle Ages. Sometimes the scientific objective of the analysis resides primarily in the realm of history/archaeology; sometimes the questions asked are of a biological nature. A rapidly growing field of more or less intertwined genetic, historical, and archaeological knowledge production is developing, and the medieval has become relevant to genetics, as well as the other way around. Given the breath-taking pace of research, it is virtually impossible to keep track of all pertinent developments. This paper demonstrates the relevance of the medieval for genetics in several contexts: medieval pandemics constitute a source of important data for today's medical research; medieval migrations are both showcases and test cases for the tools of population genetics, and the medieval millennium (500-1500 AD) might well become an essential period for studies in recent human evolution. Even such much-studied medieval objects as parchments have the potential to reveal a whole field of previously hidden data by providing polyvalent source material. Yet real interdisciplinary cooperation between geneticists and medievalists remains rare. There is an urgent need for more critical engagement, which should hopefully also provide us with more complete overviews of the growing field of which the present contribution is only intended to give some initial insights.
\end{abstract}

Keywords: ancient DNA, archaeology, genetics, migrations, evolution, pandemics, parchment

\section{Introduction}

In the twenty-first century, the medieval ended up in a place where - only a few decades ago - no one would have expected to find it: the genetics lab. Today, highly specialized state-of-the-art research institutes ${ }^{1}$ are busy analysing medieval DNA samples. The objects they scrutinize represent the entire Middle Ages, ranging from

\footnotetext{
1 For an overview of the facilities see Ann GibBons, Ancient DNA Divide, in: Science 352, 6292 (2016), pp. 1384-1387. On one of the most prominent and prolific ones among them, the Max-Planck-Institute for the Science of Human History in Jena (Germany), see Jörg FEUCHTER, Die DNA der Geschichte, in: Frankfurter Allgemeine Zeitung, 05 November 2014, p. N4, online: http://www.faz.net/aktuell/feuille
}

\footnotetext{
Jörg Feuchter, Berlin-Brandenburg Academy of Sciences and Humanities, Regesta Imperii Regesten Kaiser Friedrichs III., Jägerstr. 22-23, 10117 Berlin, Germany, feuchter@bbaw.de 
burial sites which were occupied during the so-called 'barbarian invasions' (that is, the period marking the beginning of the Middle Ages), to late-medieval plague cemeteries. Scientists even feed charters written on parchment, the epitome of the traditional object medievalists study, into their sequencing machines. Sometimes the scientific objective of the analysis resides primarily in the realm of history/archaeology; sometimes the questions asked are of a biological nature. A rapidly growing field of more or less intertwined genetic, historical, and archaeological knowledge production is developing, and the medieval has become relevant to genetics, as well as the other way around. Given the breath-taking pace of research, it is virtually impossible to keep track of all pertinent developments and the task becomes even more difficult as historians of the Middle Ages and geneticists are only just beginning to talk to each other. Real interdisciplinary cooperation remains rare. There is an urgent need for more critical engagement, ${ }^{2}$ which should hopefully also provide us with more complete overviews of the growing field of which the present contribution is only intended to give some initial insights.

The research areas which I have chosen to highlight are connected with the following phenomena: 1) pandemics, 2) migrations, 3) recent human evolution, and 4) parchment. Each of these areas will be outlined only very briefly. In addition, I want to make clear from the very outset that my own perspective is, throughout, that of a scholar who is trained and who works in the field of medieval history, not in biology. This disciplinary background inevitably limits my understanding of geneticists' research methods and purposes and, as a consequence, my own view of the intersection between genetics and Medieval Studies is necessarily conditioned by my disciplinary perspective.

\section{Pandemics}

The so-called 'Black Death' of the mid-fourteenth century took the lives of large swathes of the European population ${ }^{3}$ and was connected to a huge wave of antiJewish pogroms and displays of public penance, such as the flagellant

ton/geisteswissenschaften/neues-max-planck-institut-zur-dna-in-der-geschichte-13246120.html (last accessed 15/05/2019).

2 This case is made by Stefanie SAmida / Jörg Feuchter, Why Archaeologists, Historians and Geneticists Should Work Together - and How, in: The Genetic Challenge to Medieval History and Archaeology $=$ Medieval Worlds 4 (2016), pp. 5-21, and by ID., Für einen kritischen Dialog zwischen Geschichtswissenschaft und Genetic History, in: NTM Zeitschrift für Geschichte der Wissenschaften, Technik und Medizin 26(3) (2018), pp. 34-40.

3 For a recent critical overview of Black Death mortality estimates see Joris Roosen / Daniel R. CURTIS, The 'Light Touch' of the Black Death in the Southern Netherlands: An Urban Trick?, in: The Economic History Review 71 (2018), pp. 1-25, esp. pp. 1-2. 
movement. ${ }^{4}$ It is also one of the fields of research in which it hardly comes as a surprise that genetics and Medieval Studies intersect: genetics is, after all, closely connected to medical studies and the plague represents one of the greatest and most devastating pandemics in history. And indeed, during the past years, geneticists have made huge steps forward in establishing knowledge not only about the late medieval pandemic, but also about the recurrent appearances of the plague in all periods of history. A notable example is the so-called Justinian Plague, the early medieval precursor of the fourteenth-century Black Death. In addition, not only have the early modern outbreaks of the disease been analysed but there are also projects which delve even further back in time in order to find occurrences of plague bacteria in much earlier periods. ${ }^{5}$

As new research and its insights continue to be published, the following remarks will be limited to a very general overview of some pandemics from the perspective of our question regarding the relevance of the medieval. First of all, it should be underlined that recent genetic research has removed any doubt that the Black Death really was the plague, i. e. that the pandemic was caused by the pathogen that is known as yersinia pestis. The key breakthrough in solving this particular problem was furnished by a study based on DNA taken from human remains in a London cemetery, which successfully led to the reconstruction of the full genome of the medieval plague bacterium. ${ }^{6}$ In follow-up studies, the pathogen's phylogeny has been traced in more detail, both for later and for earlier periods. ${ }^{7}$

\footnotetext{
4 See the classic monograph František GraUS, Pest - Geissler - Judenmorde. Das 14. Jahrhundert als Krisenzeit (Veröffentlichungen des Max-Planck-Institutes für Geschichte 86), Göttingen 1987.

5 Simon RASmuSSEN et al., Early Divergent Strains of Yersinia Pestis in Eurasia 5,000 Years Ago, in: Cell 163(3) (2015), pp. 571-582.

6 Kirsten I. Bos / Verena J. Schuenemann / Geoffrey Brian Golding / Hernán A. BuRBano / Nicholas WAGLeCHNer / Brian K. Coombes / Joseph B. MCPheE / Sharon N. DeWitte / Matthias MeYeR / Sarah SCHMEDES / James W. Wood / David J. D. EARN / Donald HERRING / Peter BAUER / Hendrik N. PoinaR / Johannes KRAUSE, A Draft Genome of Yersinia Pestis from Victims of the Black Death, in: Nature 478, 7370 (2011), pp. 506-510; Kirsten I. Bos / Philip Stevens / Kay Nieselt / Hendrik N. PoinaR / Sharon N. DEWITTE / Johannes KRAUSE, Yersinia Pestis: New Evidence for an Old Infection, in: PLoS One 7(11) (2012), e49803.
}

7 See Maria A. Spyrou / Rezeda I. Tukhbatova / Michel Feldman / Joanna Drath / Sacha Kacki / Julia Beltrán de HeRedia / Susanne ARnold / Airat G. Sitdikov / Dominique CAStex / Joachim WaHL / Ilgizar R. GazimzYanov / Danis K. NuRgaliev / Alexander Herbig / Kirsten I. Bos / Johannes KRAUSE, Historical Y. Pestis Genomes Reveal the European Black Death as the Source of Ancient and Modern Plague Pandemics, in: Cell Host Microbe 19(6) (2016), pp. 874-881; Michal Feldman / Michaela HARBECK / Marcel Keller / Maria A. SPYRou / Andreas RotT / Bernd TRAutmann / Holger Christian Scholz / Bernd Päffgen / Joris Peters / Michael McCormick / Kirsten I. Bos / Alexander Herbig / Johannes Krause, A High-Coverage Yersinia Pestis Genome from a Sixth-Century Justinianic Plague Victim, in: Molecular Biology and Evolution 33(11) (2016), pp. 2911-2923; Kirsten I. Bos / Alexander Herbig / Jason W. SAHL / Nicholas WAGlechner / Mathieu Fourment / Stephen A. Forrest / Jennifer Klunk / Verena J. Schuenemann / Debi Poinar / Melanie Kuch / G. Brian Golding / Olivier J. Dutour / Paul S. Keim / David M. WAGner / Edward C. Holmes / Johannes 
In spite of first appearances, it has to be stressed that this research is not only of historic relevance, that is, it provides us with insights that are far broader than simply an improved understanding of the situation in the Middle Ages. ${ }^{8}$ Given the persistence of the plague bacteria today and the similitude of the medieval pathogen to its modern descendant, the analysis of the disease's earlier history is of some interest to pandemic research today. As Monica H. GREEN, a leading historian in the study of medieval pandemics, has put it: "The medieval Black Death, therefore, is far more than a mere historical curiosity; it is, in all its complexity, the source of vital data that can help us to establish scenarios for pandemic disease now and in the future." ${ }^{9}$ With GREEN, we can also conclude more generally that genetics is "A New Player in Disease History": ${ }^{10}$ genetic research has also provided new insight into further diseases that have proven to be persistent since (at least) medieval times, e. g. leprosy, although the state of our knowledge seems to be less advanced in these cases. ${ }^{11}$ A further example would be tuberculosis, yet another old scourge of humanity that still remains a threat even today. Geneticists have recently established that some strains of TB bacteria had reached the American continent long before the European conquerors arrived. The strain that made landfall in pre-Columbian America was, as has been demonstrated, transmitted by seals crossing the Atlantic from Africa to South America in, at

Krause / Hendrik N. PoInAR, Eighteenth Century Yersinia Pestis Genomes Reveal the Long-term Persistence of an Historical Plague Focus, in: Elife (2016), 5:e12994. For an earlier perspective from a historian who formulates research problems that concern the early medieval plague see Michael McCoRmick, Toward a Molecular History of the Justinianic Pandemic, in: Lester Knox LiTTLE (ed.), Plague and the End of Antiquity. The Pandemic of 541-750, Cambridge 2007, pp. 290-312.

8 This is, of course, not only true for the Middle Ages: quite recently the importance of connections between late medieval climate change, the history of the plague (on the basis of new genetic evidence), and the rise of Europe in the modern period have been stressed by Bruce CAMPBELL, The Great Transition. Climate, Disease and Society in the Late-Medieval World, Cambridge et al. 2016. For a critique, notably of Campbell's conclusions from genetic research, see Monica H. GREEN, Black as Death, in: Inference. International Review of Science 4(1) (2008), online https://inferencereview.com/article/black-as-death (last accessed 15/05/2019)

9 Monica H. GreEn, Editor's Introduction, in: ID. (ed.), Pandemic Disease in the Medieval World. Rethinking the Black Death (The Medieval Globe 1/2014), pp. 9-26, here p. 20.

10 ID., Genetics as a Historicist Discipline. A New Player in Disease History, in: Perspectives on History. The Newsmagazine of the American Historical Association (December 2014), pp. 30-31, online: www.historians.org/publications-and-directories/perspectives-on-history/december-2014/ge netics-as-a-historicist-discipline (last accessed 15/05/2019).

11 Tom A. Mendum / Verena J. Schuenemann / Simon Roffey / G. Michael TaYlor / Huihai Wu / Pushpendra Singh / Katie TucKer / Jason Hinds / Stewart T. Cole / Andrzej M. KiERzEK / Kay NiESElt / Johannes KRAUSE / Graham R. STEWART, Mycobacterium Leprae Genomes from a British Medieval Leprosy Hospital: Towards Understanding an Ancient Epidemic, in: BioMed Central Genomics 15 (2014), p. 270; Helen D. Donoghue et al., A Migration-driven Model for the Historical Spread of Leprosy in Medieval Eastern and Central Europe, in: Infection, Genetics and Evolution 31 (2015), pp. 250-256. 
the latest, the early medieval period. ${ }^{12}$ Recently, a research project dedicated to finding out about pathogen exchange between "New and Old World peoples" before and after 1492 has been funded by the European Research Council. ${ }^{13}$ Moreover, connections have been drawn between the distribution of some distinctive strains of TB and the Mongol expansion to the West in the thirteenth century. ${ }^{14}$ In fact, many studies of historical pandemics touch upon the issue of human migration, which will be treated in the following paragraph. At this point, however, we can summarize that 'the medieval' is particularly relevant to genetic pandemic research in two distinct contexts: a) in research concerning the earlier development of current pathogens and b) in research about ways of global transmission.

\section{Human Migration}

While pandemics already constitute a core subject at the intersection of genetics and medieval history, migrations possibly play an even more central role. And again, this does not come as a surprise. Firstly, the concept of 'migration' counts among the essential ideas of Population Genetics. Next to 'mutation', 'recombination', 'selection', and 'drift', it occupies an important place among the key elements which determine the general evolutionary processes that influence the genetic diversity of human - amongst other - populations. ${ }^{15}$ Secondly, the idea that DNA research could contribute substantially to the reconstruction of the history of human migrations became evident quite early on: already in 1987 the

12 Kirsten I. Bos et al., Pre-Columbian Mycobacterial Genomes Reveal Seals as a Source of New World Human Tuberculosis, in: Nature 514, 7523 (2014), pp. 494-497. For a general and accessible overview of historical plague and leprosy research in genetics see Anne GiBBons, On the Trail of Ancient Killers, in: Science 340, 6138 (2013), pp. 1278-1282.

13 “Communicable Disease Exchange in the Age of Seafaring”, online: http://www.shh.mpg.de/ 1019351/bos-warinner-erc-starting-grants (last accessed 15/05/2019). The principal investigator is Dr. Kirsten I. Bos, group leader at the Max-Planck-Institute for the Science of Human History in Jena (Germany).

14 Guislaine REFRÉGIER / Edgar AbAdÍA / Tomoshige MATSUmoto / Hiromi Ano / Tetsuya TAKASHIMA / Izuo Tsuyuguchi / Elif AKTAŞ / Füsun Beğendik Cömert / Michel Kiréopori Gomgnimbou / Stefan Panaiotov / Jody Phelan / Francesc Coll / Ruth Mc Nerney / Arnab Pain / Taane G. Clark / Christophe SolA, Turkish and Japanese Mycobacterium Tuberculosis Sublineages Share a Remote Common Ancestor, in: Infection, Genetics and Evolution 45 (November 2016), pp. 461-473, and, more recently, Igor Mokrousov / Egor A. SHITIKov / Yuriy A. SkIBA / Sergey KolChENKo / Ekaterina N. ChERNYAEVA / Anna A. VYAZOVAYA, Emerging Peak on the Phylogeographic Landscape of Mycobacterium Tuberculosis in West Asia: Definitely Smoke, Likely Fire, in: Molecular Phylogenetics and Evolution 116 (2017), pp. 202-212.

15 See Mark A. Jobling / Mattthew E. Hurles / Chris Tyler-Smith, Human Evolutionary Genetics. Origins, Peoples \& Disease, New York, Abingdon 2004, pp. 141-143. 
'Out-of-Africa' (II) or 'Recent African Origin' hypothesis - i. e. the idea that the anatomically modern human, which ultimately spread all around the world, came from a single African region of origin - was strongly supported by findings from population genetics. ${ }^{16}$ In order to understand why (apart from Prehistory) the Middle Ages are the one period most intensively scrutinized by geneticists interested in past human migrations, we have to take a closer look.

One reason why the Middle Ages are so attractive to some geneticists has to do with the general history of migrations, or rather modern assumptions about them. Many geneticists consider the medieval period to represent the last 'pristine' era before the early modern - post-1492 - colonization movements, which thoroughly mixed up the 'original' population compositions on a word-wide scale for the first time. As a consequence, pertinent data concerning the Middle Ages tend to be used as an indicative baseline that can indicate everything that had happened during the process of the dispersal of modern humans around the world. In other words: medieval populations are valuable for geneticists, since (as they claim is the case) they can be used as a model for the entire time since the global dispersal of anatomically modern humans. ${ }^{17}$ The validity of these assumptions cannot in fact be taken for granted at all.

Another reason why geneticists are particularly interested in medieval migrations consists in the relative scarcity of written sources in this period, at least during the Early and High Middle Ages. Results from genetic analyses thus seem to offer a much sought-after alternative approach that might help to answer difficult questions which are perceived to deserve modern science's attention: the Middle Ages doubtless play an essential and continuing role in contemporary modern discourses about historical identities. ${ }^{18}$ In other words, by 'solving' medieval mysteries, scientists demonstrate the power and capability of genetic approaches while guaranteeing public interest in their research and its results by linking both to the 'fashionable' Middle Ages.

There are also much more practical reasons for the interest of geneticists in the Middle Ages. One of the most obvious is that the ritual of earth burial was more

16 Rebecca L. Cann / Mark Stoneking / Allan C. WiLSON, Mitochondrial DNA and Human Evolution, in: Nature 325, 6099 (1987), pp. 31-36; Chris B. StRInGER / Peter ANDREWS, Genetic and Fossil Evidence for the Origin of Modern Humans, in: Science 239, 4845 (1988), pp. 1263-1268. See also Marianne Sommer, History in the Gene. Negotiations Between Molecular and Organismal Anthropology, in: Journal of the History of Biology 41(3) (2008), pp. 473-528, here pp. 510-511.

17 This assumption is particularly explicit, for example, in a highly controversial study mixing Molecular Anthropology with Economic Macroanalysis and (Animal) Behavioral Science: Quamrul ASHRAF / Oded GALOR, The 'Out of Africa' Hypothesis, Human Genetic Diversity, and Comparative Economic Development, in: American Economic Review 103 (February 2013), pp. 1-46.

18 Patrick J. GEARY, The Myth of Nations. The Medieval Origins of Europe, Princeton 2002. See also Jörg FEuChTER, Mittelalterliche Migrationen als Gegenstand der "Genetic History", in: Felix Wiedemann / Kerstin Hofmann / Hans-Joachim GeHRKe (eds.), Vom Wandern der Völker. Migrationserzählungen in den Altertumswissenschaften (Berlin Studies of the Ancient World 41), Berlin 2017, pp. 347-370, here pp. 354-55. 
widespread in this period than in Antiquity, when cremation was more widely practiced. As a consequence, a high number of medieval skeletal remains can still be found and - thanks to the revolutionary progress made in the analysis of ancient DNA (aDNA) in recent years - the genetic information contained in those bones is becoming increasingly easy to access. Until quite recently, geneticists and their research had to focus on DNA from living people. Any reconstruction of the situation in earlier periods thus inevitably remained hypothetical since it had to rely on the interpretation of recent genetic material and the assumption of continuity between modern populations and medieval ones. In recent years, however, the possibilities for sampling aDNA have improved breathtakingly: today, they make it possible to work on the original remains of medieval individuals. ${ }^{19}$

Although the quantity of studies from genetic history that touch on the question of medieval migrations has become quite impressive, more general surveys are not yet available. ${ }^{20}$ Nevertheless, we can tentatively identify two geographical foci of interest in this research: one of them is north-western Europe, including the North Atlantic, the other is the Western Mediterranean. Research concerning the former region mostly focusses on the Germanic migrations to the British Isles (Vikings from Scandinavia $^{21}$ and Anglo Saxons from the continental coast, ${ }^{22}$ probably the most

19 Overviews are provided by Montgomery SLATKIN / Fernando RACIMO, Ancient DNA and Human History, in: Proceedings of the National Academy of Sciences of the United States of America 113 (23) (2016), pp. 6380-6387; Anne GibBons, Revolution in Human Evolution, in: Science Magazine 349, 6246 (2015), pp. 362-366. The development of aDNA-studies has also been thoroughly analysed in a brilliant recent study from the perspective of the history of science, see Elsbeth BösL, Doing Ancient DNA. Zur Wissenschaftsgeschichte der aDNA-Forschung, Bielefeld 2017.

20 But see FEUCHTER (note 18).

21 Sara GOOdACRE / Agnar HeLGASOn / Jane M. NiCHOLSOn / Lorraine SOUTHAM / Lee FERGUSOn / Erin Hickey / Ernesto VEGA / Kári StEFÁnsSon / Ryk WARD / Bryan SyKES, Genetic Evidence for a Familybased Scandinavian Settlement of Shetland and Orkney During the Viking Periods, in: Heredity (Edinburgh) 95(2) (2005), pp. 129-135; Brian McEvoy / Ceiridwen J. EdwARDS, Human Migration: Reappraising the Viking Image, in: Heredity (Edinburgh) 95(2) (2005), pp. 111-112; Georgina R. BowdEn, Excavating Past Population Structures by Surname-based Sampling. The Genetic Legacy of the Vikings in Northwest England, in: Molecular Biology and Evolution 25(2) (2008), pp. 301-309; Brian McEvoy / Claire Brady / Laoise T. MOORE / Daniel G. BRADY, The Scale and Nature of Viking Settlement in Ireland from Y-chromosome Admixture Analysis, in: European Journal of Human Genetics 14(12) (2006), pp. 1288-1294.

22 James F. Wilson / Deborah A. Weiss / Mandy Richards / Mark G. Thomas / Neil N. BRAdman / David K. GolDSTEIN, Genetic Evidence for Different Male and Female Roles During Cultural Transitions in the British Isles, in: Proceedings of the National Academy of Sciences of the United States of America 98(9) (2001), pp. 5078-5083; Michael E. WEALE / Deborah A. WEISS / Rolf F. JAGER / Neil N. BRADMAN / Mark G. Thomas, Y Chromosome Evidence for Anglo-Saxon Mass Migration, in: Molecular Biology and Evolution 19(7) (2002), pp. 1008-1021; Mark G. THOMAS / Michael P. STUMPF / Heinrich HÄRKE, Evidence for an Apartheid-like Social Structure in Early AngloSaxon England, in: Proceedings of the Royal Society, Biological Sciences 273(1601) (2006), pp. 2651-2657; Ana L. TöPf / M. Thomas P. Gilbert / Jack P. DumbacheR / A. Rus Hoelzel, Tracing 
intensively scrutinized migration in Genetic History ${ }^{23}$ to Iceland, Greenland, ${ }^{24}$ or even Newfoundland. ${ }^{25}$ In the second region, the Western Mediterranean, geneticists have been mostly interested in Arabic and Jewish migrations. ${ }^{26}$ In both instances, the majority of studies have sought to quantify the number of people who were 'on the move' and to establish their 'legacy' in the gene pool of today's populations in the regions in question. Genetics is thus trying to answer popular modern questions about identity rooted in history by defining the proportions of a people's ancestry more precisely. Obviously there are many pitfalls to this approach: while the assumption that genetics has anything to do with individual identity is already quite dubious in itself, ${ }^{27}$ its application and the techniques that accompany the entire debate are prone to be abused, be it by public institutions or private groups or individuals. ${ }^{28}$

An example of a very careful and reflective approach that is avoiding the abovementioned pitfalls is a project led by medievalist Patrick GEARY (Institute for Advanced Study, Princeton) on Migrations between Pannonia and Italy at the beginning of the Middle Ages. GEARY and his team are not looking for 'ethnicity' in the aDNA from

the Phylogeography of Human Populations in Britain Based on 4th-11th century mtDNA Genotypes, in: Molecular Biology \& Evolution 23(1) (2006), pp. 152-161; Mark G. THOMAS / Michael P. STUMPF / Heinrich HäRKE, Integration Versus Apartheid in Post-Roman Britain. A Response to Pattison, in: Proceedings of the Royal Society, Biological Sciences 275 (2008), pp. 2419-2421.

23 See treatment in Feuchter (note 18), and SAmida / Feuchter (note 2).

24 Elena Bosch / Francesc Calafell / Zoë H. Rosser / Søren NøRBy / Niels Lynnerup / Matthew E. HuRLES / Mark A. Jobling, High level of Male-biased Scandinavian Admixture in Greenlandic Inuit Shown by Y-Chromosomal Analysis, in: Human Genetics 112(4) (2003), pp. 353-363.

25 Eleanor P. Jones / Heidi M. EAGER / Sofia Isabel GABRIEL / Fríða JóHANNESDótTiR / Jeremy B. SEARLE, Genetic Tracking of Mice and Other Bioproxies to Infer Human History, in: Trends in Genetics 29(5) (2013), pp. 298-308.

26 Maria Jose CASAS / Erika Hagelberg / Rosa Fregel / José María LaRRuga / Ana Maria Gonzalez, Human Mitochondrial DNA Diversity in an Archaeological Site in al-Andalus: Genetic Impact of Migrations from North Africa in Medieval Spain, in: American Journal of Physical Anthropology 131(4) (2006), pp. 539-551; Susan M. ADAMS et al., The Genetic Legacy of Religious Diversity and Intolerance: Paternal Lineages of Christians, Jews, and Muslims in the Iberian Peninsula, in: American Journal of Human Genetics 83(6) (2008), pp. 725-736; Cristian CAPELLI / Valerio ONOFRI / Francesca BRISIGHELLI / Ilaria Boschi / Francesca SCARNICCI / Mara Masullo / Gianmarco FeRRI / Sergio Tofanelli / Adriano TAGLIABRACCI / Leonor Gusmão / António AmoRIM / Francesco GatTo / Mirna KirIN / Davide MerLITTI / María BRión / Alejandro Blanco Verea / Valentino Romano / Francesco CaLì / Vincenzo Lorenzo PASCALI, Moors and Saracens in Europe. Estimating the Medieval North African Male Legacy in Southern Europe, in: European Journal of Human Genetics 17(6) (2009), pp. 848-852.

27 For a more detailed critical discussion see FEUCHTER (note 18).

28 See e. g. Marianne SOMmER, 'Do You Have Celtic, Jewish, Germanic Roots?' - Applied Swiss History Before and After DNA, in: Katharina SCHRAmm / David SkINNER / Richard ROTTENBURG (eds.), Identity Politics and the New Genetics: Re/Creating Categories of Difference and Belonging, Oxford 2012, pp. 116-140, esp. pp. 130-131, and Lorna-Jane RICHARDSON / Tom BоotH, Response to 'Brexit, Archaeology and Heritage: Reflections and Agendas', in: Papers from the Institute of Archaeology 27 (2017), pp. 1-5. 
gravesites they are analysing, but rather for data about demographics, kinship relations, and migratory patterns, with very promising and interesting first results. ${ }^{29}$

\section{Recent Human Evolution}

With the above-mentioned progress in aDNA sampling, considerable improvements have also been made in the study of recent developments and stages in human evolution $^{30}$ : Geneticists are now able to observe evolutionary processes in humans that have taken place not in a distant prehistory, but in historical times, that is in the last few thousand years. ${ }^{31}$ Among the many traits that have been studied by geneticists (including such controversial aspects as body height and skin pigmentation), I want to focus on only one, namely lactose tolerance, i. e. the ability to digest milk and fresh dairy products without experiencing intestinal problems.

Lactose is a sugar that is present in milk and young children are generally able to digest it by cracking it with the help of lactase, an enzyme. The production of this enzyme gets switched off in humans after a certain age. This deactivation of lactase production, however, does not occur in lactose tolerant people: they are thus 'lactase persistent'. Seen on a global level, lactose tolerance is a genetic trait that is not present among most adults in the world, but highly common in some

29 On the project see Patrick J. GEARY, Rethinking Barbarian Invasions Through Genomic History, in: Hungarian Archaeology. Online Journal (Autumn 2014), pp. 1-8, online: http://www.hungarianarch aeology.hu/wp-content/uploads/2014/11/eng_geary_140.pdf (last accessed 15/05/2019); Stefania VAi / Silvio GHIRoTto / Elena PILLI / Francesca TASSI / M. Taheri LARI / Ermanno RizZI / Laura MATASLALueza / Oscar RAmirez / Carles LaluezA-Fox / Alessandro Achilli / Anna Olivieri / Antonio TORRONI / Hovirag LANCIONI / Caterina GIOSTRA / Elena BEDINI / Luisella Pejrani BARICCO / Giuseppe Matullo / Cornelia Di Gaetano / Alberto Piazza / Krishna R. Veeramah / Patrick J. Geary / David CARAmelli / Guido Barbujani, Genealogical Relationships between Early Medieval and Modern Inhabitants of Piedmont, in: PLoS One 10(1) (2015), e0116801; and Carlos Eduardo G. AMORIM / Stefania VAI / Cosimo Posth / Alessandra Modi / István KonCZ / Susanne HAKENBECK / Maria Cristina LA RocCA / Balazs Mende / Dean BoBo / Walter PoHL / Luisella Pejrani BARICCo / Elena Bedini / Paolo FranCALACCI / Caterina Giostra / Tivadar Vida / Daniel Winger / Uta von FreEDEN / Silvia GHIROTTO / Martina LaRi / Guido Barbujani / Johannes Krause / David CARAmelli / Patrick J. GeARY / Krishna R. VEeRAMAH, Understanding 6th-Century Barbarian Social Organization and Migration through Paleogenomics, in: Nature Communications 9(1) (2018), 3547, reviewed by Jörg FeUCHTER, Aber diese Fremden da sind nicht von hier!, in: Frankfurter Allgemeine Zeitung, 12/19/2018.

30 For overviews see Shaohua Fan / Matthew E. B. HAnSEn / Yancy Lo / Sarah A. Tishroff, Going Global by Adapting Local: A Review of Recent Human Adaptation, in: Science 354, 6308 (2016), pp. 54-59; Mark STONEKING, An Introduction to Molecular Anthropology, Hoboken 2017, pp. 321-332.

31 The commonplace definition of 'historical times' is based on the development of writing and thus the production of written records of history - which cover the period of only a few thousand years. There are, however, other views, which are equally justifiable, see, for example, Manfred K. H. EGGERT, Zwischen Paläolithikum und Gegenwart. Überlegungen zum historischen Universum, in: Saeculum 63 (2013), pp. 7-51. 
populations, including most populations living in Europe, and especially in NorthWestern Europe (but there are also populations in certain African regions that are overwhelmingly lactose tolerant). ${ }^{32}$ Since milk and derivative products are an attractive source of protein- and energy-rich nutrition, the capacity to consume them even as an adult certainly provides an important evolutionary advantage. At the same time, it has quite fundamental repercussions on cultural practices as far as the cultivation of particular animal species are concerned.

In view of these important effects, it is hardly surprising that considerable effort is being put into finding out when the decisive genetic mutations (they are not the same everywhere) for lactose tolerance have occurred, when they spread, and how exactly this process is connected to the husbandry of dairy-producing animals (cattle, sheep, goats). ${ }^{33}$ Pertinent research and its results are not only interesting in the context of medical or nutritional issues, where milk is often an important element, but they are of more general interest. In fact, the distribution of lactose tolerance is considered to be a prime example of 'gene-culture-coevolution', ${ }^{34}$ i. e. the mutual interference of cultural habits and genetic traits in a population in a longer-term evolutionary selection process. In other words, while the accidental development of lactose tolerance among adults might have increased the motivation to develop husbandry of specific animals, the latter might also, in turn, have influenced the selective genetic advantage of lactose tolerance.

Currently it can be considered an established scientific fact that lactose tolerance is exclusively acquired via genetic transmission. Recent studies convincingly demonstrate that this trait must have spread among the European populations in the relatively short period of the last 4,000 years. Thus - given it is nowadays so prevalent among people of North-Western Europe - it spread at a staggering pace. ${ }^{35}$ In fact, it might even be the most highly selective genetic trait ever observed among humans. A recent study ${ }^{36}$ has now confirmed - or rather, radicalized - this finding:

32 Annina KRuttli / Abigail S. Bouwman / Guelfirde AKGuel / Philippe Della CaSA / Frank RÜHLI / Christina WARINNER, Ancient DNA Analysis Reveals High Frequency of European Lactase Persistence Allele (T-13910) in Medieval Central Europe, in: PloS One 9(1) (2014), e86251.

33 See e. g. a new research project dedicated to "Cultures of Dairying: Gene-culture-microbiome Evolution and the Ancient Invention of Dairy Foods", funded by the European Research Council, online: http://www.shh.mpg.de/1019083/bos-warinner-erc-starting-grants (last accessed 15/05/ 2019). The principal investigator of this project, which focusses on Mongolia, is Dr. Christina WARINNER, group leader at the Max-Planck-Institute for the Science of Human History.

34 For an outline of the general theory see Linda Stone / Paul F. LURQUin / Luigi Luca CavalLISFORZA, Genes, Culture, and Human Evolution: A Synthesis, Malden / MA 2007.

35 Ian MATHIESON et al., Genome-wide Patterns of Selection in 230 Ancient Eurasians, in: Nature 528 (2015), pp. 499-503.

36 Yair Field / Evan A. Boyle / Natalie Telis / Ziyue Gao / Kyle J. Gaulton / David Golan / Loic Yengo / Ghislain RochelEAu / Philippe Froguel / Mark I. MCCARTHY / Jonathan K. PRITCHARD, Detection of Human Adaptation During the Past 2000 Years, in: Science 354, 6313 (2016), pp. 760-764. 
its authors have come to the conclusion that the entire process of the spread of lactose-tolerance among Europeans occurred in no more than the last 2,000 years. This result puts a particular focus on the Middle Ages. If the geneticists' findings and the assumptions derived from them are accurate, the millennium between 500 and $1500 \mathrm{AD}$ might in fact have been a key period in the spread of lactose tolerance. There is indeed one local study which suggests that the current level of lactose persistence in western central European populations was reached in exactly the period we are interested in. ${ }^{37}$ If we accept this suggestion, we might ask in turn whether families with parents that carried the specific mutation causing lactase persistence in European peoples were at a considerable selective advantage over other families during the Middle Ages? In order to study this question in sufficient depth, we must not only retrieve and analyse aDNA from medieval individuals, all related data from historical sources concerning dairy production, cattle husbandry, consumption of milk, cheese and other dairy produce is also highly relevant. ${ }^{38}$ Medieval historians obviously would have much to contribute from their traditional sources, the texts, but obviously also from images that show animals, farming conditions, and practices, etc. Finally, there is even a type of source where both kinds of information - DNA and textual - combine, which will be treated below.

\section{Parchment Studies}

Parchment was, by and large, the most important writing material for most of the European Middle Ages. Papyrus played only a very minor role (and mostly only at the beginning of the era), while paper was only introduced in the course of the last centuries of Middle Ages, even though it quickly replaced parchment in many fields. ${ }^{39}$ Wax tablets, another medium for text, were usually only employed for nonpermanent writing, although there are some exceptions.

But how does this widely used writing medium come to be of value when exploring the relationship between genetics and history? First of all, parchment is made from animal skin (cattle, sheep, or goat) and the idea of extracting DNA from it has been around for some years. ${ }^{40}$ Yet only recently have very promising technological

37 KRUTTLI et al. (note 32).

38 See ibid., Abstract: "A history of dairying is presumed to be a prerequisite."

39 See Carla MeYer / Sandra Schulz / Bernd SCHNeidMülLER (eds.), Papier im mittelalterlichen Europa. Herstellung und Gebrauch (Materiale Textkulturen 7), Berlin 2015.

40 Cf. Timothy L. STINSON, Knowledge of the Flesh. Using DNA Analysis to Unlock Bibliographical Secrets of Medieval Parchment, in: Papers. Bibliographical Society of America 103(4) (2009), pp. 435-453. See also the overview in Matthew D. Teasdale / Nienke L. van Doorn / Sarah Fiddyment / Christopher C. WeBb / Terry O’Connor / Michael Hofreiter / Matthew J. Collins / Daniel G. BRAdLEy, Paging Through History. Parchment as a Reservoir of Ancient DNA for Next 
advances been made: most importantly, the problem of contamination by DNA from other individual animals or by human DNA - be it in the process of preparation of the parchment or afterwards - has been solved by using a modern sequencing technique called 'Next Generation Sequencing'. This technique, which has replaced the earlier Polymerase Chain Reaction method, finally made it possible to retrieve mitochondrial $^{41}$ aDNA from seventeenth- and eighteenth-century sheep-skin parchment, to fully sequence it, and to attribute this material to specific breeds. ${ }^{42}$ The technological development thus opens up spectacular possibilities, since, as has already been indicated, medieval parchment combines two kinds of information: not only does it contain the DNA geneticists are looking for as their primary material, but in many cases the material object includes a precise date. Such dates appear, for example, as part of the text of charters. In these cases, the objects provide us with "a [chronological] level of resolution not readily achievable with any other historic DNA source." 43 Moreover, charters usually also mention the name of the place where the document was created and although there are inaccuracies in some cases, such indications are generally correct. If we are right in assuming that skins did not travel long distances and were not kept in stock for long periods before being used (at least not in general), this particular combination of information makes chronological and spatial attribution of the animal that was used for the production of the parchment possible and even very easy. There is thus no need for expensive and much less exact methods like radiocarbon dating or isotope analysis, which are usually employed to ascertain the date and region of origin of medieval artefacts. This makes parchment an ideal resource for serial information about medieval animals, their husbandry and breeding. ${ }^{44}$

\section{Conclusion}

The relevance of the medieval for genetics can be demonstrated in several contexts: medieval pandemics constitute a source of important data for today's medical

Generation Sequencing, in: Philosophical transactions of the Royal Society of London. Series B, Biological sciences 370, 1660 (2015), 20130379, p. 2.

41 Mitochondrial DNA is different from nuclear DNA. It is contained not in the nucleus of the cell, but in the mitochondria (the cell's energy reservoirs). Mitochondrial DNA is transmitted only through females.

42 TEASDAlE et al. (note 40).

43 Ibid.; as the authors remark, even undated writing on parchment can easily be narrowed down to a century by palaeographic evidence.

44 See also a new study by the same laboratory, which managed to glean even more biological information from much older parchment material: Matthew D. TEASDALE / Sarah FidDYMENT / Jiri VNOUCEK / Valeria Mattiangeli / Camilla Speller / Annelise Binois / Martin Carver / Catherine Dand / Timothy P. NEWField / Christopher C. WebB / Daniel G. BRAdLEy / Matthew J. Coldins, The York Gospels: a 1000year biological palimpsest, in: Royal Society Open Science 4(10) (2017), 170988. 
research; medieval migrations are both showcases and test cases for the tools of population genetics and the medieval millennium (500-1500 AD) might well become an essential period for studies in recent human evolution. Even such much-studied medieval objects as parchments have the potential to reveal a whole field of previously hidden data by providing polyvalent source material. Thus, the relevance of the medieval for genetics cannot seriously be doubted here.

Yet there is another problem, which lies elsewhere, and which some might consider to be the real question: are medievalists still relevant? Will they and their skills still be needed and sought for, once the medieval becomes the serious focus of geneticists? If we consider the minuscule number of medieval historians who figure among the authors of studies in the field(s) where genetics and Medieval Studies intertwine - or who are at least noticed and quoted - one might seriously doubt that medievalists are really prepared for this future. ${ }^{45}$

But even if things progress and historians finally decide to participate in a common endeavour and engage in this field of research and its debates, several caveats should be kept in mind. First and foremost amongst them, it seems important that historians do not accept to become mere contributors of data, but that they seek to be involved actively in the fundamentals of the research design process: currently, the way many geneticists work with history has been aptly described by Mark JoBling, himself a geneticist, as "cherry-picking" those facts from history that fit the hypothesis built from the DNA findings, while other facts are left out! ${ }^{46}$ Historians should certainly not be content with being better suppliers of cherries; nor should they take the geneticists' results at face value just because they are the products of quantifiable science. In order to be able to cooperate in a fertile way, that is conceptually, with geneticists - but also in the spirit of mutual correction through insight into each other's disciplinary limitations - historians should inform themselves thoroughly about genetics' methods both in general, but also in particular when they are applied to medieval objects and questions of medieval history. Not every historian needs to do this, of course, but more should do so than is currently the case. ${ }^{47}$

45 On this see FeUCHTER (note 18), and SAMIDA / FEUCHTER (note 2).

46 Mark A. Jobling, The Impact of Recent Events on Human Genetic Diversity, in: Philosophical Transactions of the Royal Society of London. Series B, Biological sciences 367, 1590 (2012), pp. 793-799, here p. 794: "An additional problem is that geneticists who observe a pattern in their data and seek an explanation for it tend to visit a library, take out a history book and read about a past event that seems to explain the pattern they see. This kind of historical cherry-picking leads to a lack of objectivity in asking what kinds of past events could have given rise to modern genetic diversity."

47 Bibliographical note: After the present text has been edited, the following emerging field essay was published: Elsbeth BöSL / Jörg FEUCHTER, Genetic History - eine Herausforderung für die Geschichtswissenschaften, in: Neue Politische Literatur 64(2) (2019), pp. 237-268. 



\title{
Could Medieval Medicine Help the Fight Against Antimicrobial Resistance?
}

\begin{abstract}
The emergence of antibiotic-resistant bacteria, combined with a severely stalled discovery pipeline for new antibiotics being developed, has the potential to undo the advances in infection control achieved in the last century. One way around this impasse might be to re-explore the medicinal practices of the medieval world. Why? This is because although the medieval world was ignorant of so much of modern theory, it seems that centuries of practice by medieval doctors could have produced some treatments for infections that were effective. These could contain antimicrobial compounds suitable for development into antibiotics. Our interdisciplinary team, initially based at the University of Nottingham, tested an eyesalve described in the tenth century Anglo-Saxon 'Bald's Leechbook' with startling results. By following the recipe as closely as possible, we created a cocktail that can kill one of the most common causes of eye infections, the bacterium Staphylococcus aureus. More significantly, Bald's eyesalve can kill a range of antibiotic-resistant bacteria. This chapter details our team's initial findings and places them in the context of an interdisciplinary analysis of how medieval doctors used the materia medica available to them. We present novel results confirming the reliability of Bald's eyesalve as an anti-Staphylococcal agent. Further, we demonstrate the potential of 'big data' approaches to turn medical texts into predictive databases for selecting natural materials for antibiotic testing. Finally, we present our work as an example of how interdisciplinary dialogue can significantly advance scholarship.
\end{abstract}

Keywords: medieval medicine, antimicrobial resistance, AMR, interdisciplinary

\section{The Past and Present of Infectious Disease}

Chronic infections are often multi-antibiotic resistant, expensive to manage and can be lethal. Soft tissue infections (e. g. surgical wounds, pressure sores or diabetic ulcers) can be particularly problematic, persisting for months or years. Major contributing pathogens include the so-called ESKAPE bacteria (Enterococcus faecium, Staphylococcus aureus, Klebsiella pneumoniae, Acinetobacter baumannii, Pseudomonas aeruginosa, Enterobacter spp.), which can co-colonize soft tissue to

\footnotetext{
Freya Harrison, School of Life Sciences, Gibbet Hill Campus, University of Warwick, Coventry, CV4 7AL, United Kingdom, f.harrison@warwick.ac.uk

Erin Connelly, Schoenberg Institute for Manuscript Studies, University of Pennsylvania, Philadelphia, PA, 19104, United States, erincon@upenn.edu
} 
form multicellular biofilm: communities of bacteria protected by a sticky slime layer that protects against immune clearance and antibiotic penetration. ${ }^{1}$ Further, antibiotic over-use has led to bacteria evolving genetic strategies to become resistant to the drugs in our armoury. The problem of recalcitrant chronic infection will likely worsen due to a scarcity of new antibiotics in development. ${ }^{2}$

An innovative pipeline for discovering new antimicrobials could have its roots in ethnopharmacology. Pre-modern European medical texts contain abundant remedies for soft tissue (wound, eye and skin) infections, and use many ingredients shown to possess antimicrobial qualities in in vitro tests. These include garlic and other Allium species, ${ }^{3}$ other native plants, ${ }^{4}$ honey, ${ }^{5}$ breast milk, ${ }^{6}$ and metals. ${ }^{7}$ A few of these individual materials have been developed into clinically-useful products (e. g. medical-grade honey), but individual materials generally fail to deliver positive results in clinical trials. ${ }^{8}$

Unlike modern drugs containing a single active ingredient, medieval remedies are typically complex preparations of several ingredients. This could be crucial for producing antimicrobial activity. If this is the case, then this would strongly suggest an element of 'rational drug design' on the part of medieval doctors. It would also

1 Jack N. Pendleton / Sean P. Gorman / Brendan F. Gilmore, Clinical Relevance of the ESKAPE Pathogens, in: Expert Review of Anti-Infective Therapy 11 (2013), pp. 297-308; Francesca L. SHORT / Sarah L. Murdoch / Robert Patrick RYAN, Polybacterial Human Disease. The Ills of Social Networking, in: Trends in Microbiology 22 (2014), pp. 508-516.

2 The Review on Antimicrobial Resistance, Antimicrobial Resistance. Tackling a Crisis for the Health and Wealth of Nations (2014), online: https://amr-review.org (last accessed 15/05/2019).

3 Virginia LAnzotTi / Felice Scala / Giuliano Bonanomi, What Makes Allium Species Effective Against Pathogenic Microbes?, in: Phytochemistry Reviews 12 (2013), pp. 751-772.

4 Frances WATKINS / Barbara PENDRY / Olivia CoRCoran / Alberto SANCHEZ-MEdinA, Anglo-Saxon Pharmacopoeia Revisited. A Potential Treasure in Drug Discovery, in: Drug Discovery Today 16 (2011), pp. 1069-1075; Frances WATKInS / Barbara PENDRY / Alberto SANCHEZ-MEdinA / Olivia CoRCoRAN, Antimicrobial Assays of Three Native British Plants Used in Anglo-Saxon Medicine for Wound Healing Formulations in 10th Century England, in: Journal of Ethnopharmacology 144 (2012), pp. 408-415.

5 Peter C. Molan, Potential of Honey in the Treatment of Wounds and Burns, in: American Journal of Clinical Dermatology 2 (2001), pp. 13-19.

6 Kyle H. RAMSEY / Christoffer E. Poulsen / Peter P. Motiu, The in vitro Antimicrobial Capacity of Human Colostrum against Chlamydia trachomatis, in: Journal of Reproductive Immunology 38 (1998), pp. $155-167$.

7 Gregor GRASS / Christopher RENSING / Marc Solioz, Metallic Copper as an Antimicrobial Surface, in: Applied and Environmental Microbiology 77 (2011), pp. 1541-1547; Svitlana CHERNOUSOVA Matthias EPPLE, Silver as Antibacterial Agent: Ion, Nanoparticle, and Metal, in: Angewandte Chemie. International Edition 52 (2013), pp. 1636-1653.

8 E. g. garlic: Alan Robert SMYTH / Paramita M. CifELli / Catharina A. ORTORI / Karima RighETTI / Sarah N. LEWIS / Penny ERSKine / Elaine D. Holland / Michael C. GivsKov / Paul Williams / Miguel CÁmara / David A. BARRETT / Alan J. Knox, Garlic as an Inhibitor of Pseudomonas aeruginosa Quorum Sensing in Cystic Fibrosis - a Pilot Randomized Controlled Trial, in: Pediatric Pulmonology 45 (2010), pp. 356-362. 
mean that tests of individual medical materials are limited in their power to reveal any useful biological effects of medieval remedies. Experiments that test the activities of entire remedies could reveal molecular cocktails with real clinical potential, but these are few and far between. ${ }^{9}$ If medieval cures can kill pathogens, and if this activity relies on the combined action of several compounds, this could make it harder for bacteria to evolve resistance and so produce unusually robust antibiotics. ${ }^{10}$ As well as bactericidal compounds, medieval remedies could yield compounds that make infections less virulent, or more susceptible to treatment with standard antibiotics. Garlic, for example, may reduce tissue damage caused by $P$. aeruginos $a$ and enhance the ability of antibiotics to clear P. aeruginosa infections in mice. ${ }^{11}$ Additionally, extracts from Plantago major leaves (a traditional herbal treatment) may have a significant synergistic effect when combined with the antibiotic gentamicin and applied against $P$. aeruginosa, $S$. aureus and other bacteria. ${ }^{12}$

We and our colleagues in the Ancientbiotics consortium - an international team of researchers based in the arts, humanities and sciences - have instigated a project to explore how medieval Europeans perceived, described and treated infection. In a pilot study, we found that an Anglo-Saxon remedy for bacterial eye infections can kill a range of ESKAPE pathogens, including antibiotic-resistant clinical isolates, in synthetic wounds and an animal model. The remedy's efficacy depends on preparing and combining ingredients as specified in the text. ${ }^{13}$ This could explain why in vitro antibacterial activity of individual ingredients (e. g. garlic) does not reliably translate into clinical potential. ${ }^{14}$ Antibiotic activity may rely on a cocktail of bioactive molecules and/ or on chemical reactions that take place during preparation. This result represents a paradigm shift about medieval medicine, which has - with very few

9 For a rare example, see Barbara BrennESSEL / Michael D. C. Drout / Robyn Gravel, A Reassessment of the Efficacy of Anglo-Saxon Medicine, in: Anglo-Saxon England 34 (2005), pp. 183-195.

10 Tobias Bollenbach, Antimicrobial Interactions: Mechanisms and Implications for Drug Discovery and Resistance Evolution, in: Current Opinion in Microbiology 27 (2015), pp. 1-9.

11 Thomas Bjarnsholt / Peter Østrup Jensen / Thomas Bovbjerg Rasmussen / Lars Jackie Christophersen / Henrik CAlum / Morten Hentzer / Hans-Petter Hougen / Jørgen RygaARd / Claus Moser / Leo Eberl / Niels Høiby / Michael Christian GivsKov, Garlic Blocks Quorum Sensing and Promotes Rapid Clearing of Pulmonary Pseudomonas aeruginosa Infections, in: Microbiology 151 (2005), pp. 3873-3880.

12 Saffidine KARIMA / Sahli FARIDA / Zerroug Mohamed MiHoub, Antioxidant and Antimicrobial Activities of Plantago major, in: International Journal of Pharmacy and Pharmaceutical Sciences 7 (2015), pp. 58-64.

13 Freya Harrison / Aled E. L. ROBERTs / Rebecca GABriLsKa / Kendra P. Rumbaugh / Christina LeE / Stephen P. Diggle, A 1,000-Year-Old Antimicrobial Remedy with Antistaphylococcal Activity, in: mBio 6 (2015), e01129-01115.

14 SмYтн et al. (note 8). 
exceptions - been dismissed as superstition or placebo. ${ }^{15}$ Our results suggest that targeted exploration of the medieval pharmacopeia could suggest a wealth of possibilities for developing new antimicrobials.

In this chapter, we will discuss our team's qualitative and quantitative analysis of medieval texts, with the aim of exploring patterns of material usage which may reflect the construction of effective cocktails. Focussed datamining of medieval medical texts, informed by historical/cultural understanding, modern microbiological and pharmacological knowledge, and techniques for analysing information within the texts, could open a new pipeline for the discovery of desperately-needed antibiotics. The ethnopharmacology of Europe has been understudied relative to that of other continents, so potentially useful compounds could lie hidden within the medieval pharmacopeia. We conclude our chapter by venturing some suggestions for smoothing the way towards successful and impactful research across the traditional arts/sciences divide.

\section{Approaches to Studying Medieval Infectious Disease}

Infectious diseases are constant companions of human populations. Throughout history, people have contended with a range of acute and chronic infections, as evidenced by the survival of numerous medical texts and bioarchaeological evidence. ${ }^{16}$ These include specialized human pathogens that are transmitted from person to person; pathogens that normally infect livestock or wild animals but which can occasionally make the jump into humans (zoonoses); or so-called opportunistic pathogens which normally live in soil, water, or as commensals on and in the human body, but can switch to a pathogenic lifestyle if they encounter a human host whose normal immune defences are compromized (for example, by an open wound or severe burn). In trying to understand the social and medical history of infectious disease in the medieval period, we can define two general categories of research question.

First, we can ask questions about aetiology and epidemiology. Which microbes caused problems for medieval people? Were these the same species that continue to cause important health problems today, or were there differences? For example, it is

15 Peregrine HoRDEN, What's Wrong with Early Medieval Medicine?, in: Social History of Medicine 24 (2000), pp. 2-25; Audrey L. MEANEY, The Practice of Medicine in England about the Year 1000, in: Social History of Medicine 13 (2000), pp. 221-237; BRENNESSEL / Drout / GRAVEL (note 9).

16 See, for instance, Charlotte A. ROBERTS / Francisca Alves CARDOSO / K. BERNOFSKY / Charlotte Yvette Henderson / Tina JaKob / K. Plomp / Paola Ponce / Jennifer Sharman / R. SPencer, Palaeopathology: Studying the Origin, Evolution and Frequency of Disease in Human Remains from Archaeological Sites, in: UNESCO Encyclopedia Life Support Systems (online) (2012), https:// www.eolss.net/Sample-Chapters/C04/E6-59-51.pdf (last accessed 15/05/2019). 
possible that medieval people experienced higher levels of zoonoses than their modern descendants because they tended to live in closer association with livestock following the domestication with the introduction of farming in the Neolithic. Second, we can ask questions about how people responded to infection. Were these diseases recognized as being caused by influences external to the body, something perhaps transmissible from one person to another? How did people treat symptoms which we now recognize as microbial infection, and can any of these treatments successfully kill exemplar pathogenic bacteria?

None of these questions is trivial to answer. We must use a range of insights and tools from different disciplines - arts, humanities and sciences - to even begin to dissect the relationships between medieval people and their pathogens.

\subsection{Recognising Medieval Infections}

Aside from a few notable exceptions (leprosy, tertiary syphilis, tuberculosis, and some chronic respiratory tract infections), microbial pathogens generally do not cause diagnostic damage to bones and teeth, and a person would need to develop the chronic stages of infectious disease anyway to develop characteristic bone changes that are recognisable. ${ }^{17}$ Soft tissue lesions, microbial toxins and sepsis are invisible killers when trying to assign causes of death to people solely represented by their skeletal remains. Recent advances in genetic technology have allowed researchers to isolate fragile and fragmented microbial DNA from samples taken from archaeological human remains and determine the genus, species and even infectious strain present, and such studies are becoming more common. Other biomolecular markers of infection available to archaeologists include microbes entombed in dental calculus and structural molecules derived from bacterial cell envelopes. Studies using the combined skills of bioarchaeologists and microbial geneticists have provided insights into the epidemiology of the plague and leprosy, and glimpses into the infection-related deaths of a small number of medieval people. ${ }^{18}$ But

17 Charlotte A. RoBerts, Human Remains in Archaeology. A Handbook (Practical Handbooks in Archaeology 19), York 2012.

18 For plague: Verena J. Schuenemann / Kirsten Bos / Sharon DeWitTE / Sarah Schmedes / Joslyn JAmieson / Alissa MitTniK / Stephen Forrest / Brian K. CoOmbes / James W. Wood / David J. D. EARN / William WhITE / Johannes KrauSE / Hendrik N. PoINAR, Targeted Enrichment of Ancient Pathogens Yielding the $p P C P 1$ Plasmid of Yersinia pestis from Victims of the Black Death, in: Proceedings of the National Academy of Sciences 108 (2011), pp. e746-e752; Marie A. SPYROU / Rezeda I. TukHBATovA / Michal FELdMAN / Joanna DRATH / Sacha KACKI / Julia BELTRÁN DE HEREdIA / Susanna ARNOLD / Airat G. Sitdikov / Dominique CASTEX / Joachim WaHL / Ilgizar R. GazimzYanov / Danis K. NuRgaliev / Alexander Herbig / Kirsten I. Bos / Johannes KRAUSE, Historical Y. pestis Genomes Reveal the European Black Death as the Source of Ancient and Modern Plague Pandemics, in: Cell Host \& Microbe 19 (2016), pp. 874-881; Cheryl P. ANDAM / Colin J. Worby / Qiuzhi Chang / Michael G. Campana, Microbial 
despite these captivating snapshots of past microbial disease, this work is not without challenges and caveats, ${ }^{19}$ and it remains difficult to find physical evidence of identifiable pathogens that infected medieval people.

Textual evidence goes some way to filling this gap. If a medical text describes recognisable symptoms of infection, we can use what we know about the aetiology of those symptoms in the modern world to make an educated guess at the likely causative agents. A recipe for a wen or lump in the eye in the Anglo-Saxon 'Bald's Leechbook' most likely describes a sty: an infection of an eyelash follicle that causes an irritated swelling. Today, most stys are caused by the bacterium $S$. aureus. As this species is a normal inhabitant of the skin and mucous membranes of healthy people, but can break out of this quiescent lifestyle to cause a range of unpleasant infections, it seems sensible to assume that $S$. aureus was also responsible for many stys in medieval times. Similarly, in the modern world many opportunistic infections of wounds are caused by P. aeruginosa: as this species is ubiquitous in natural soils and water sources, it makes sense to assume that medieval people were similarly at risk from colonisation when they had open wounds. By combining expertises of people versed in philology and in microbiology, we can take a qualitative approach to suggesting likely causes of symptoms described in texts.

The nature of medieval recognition of, and responses to, pathogens is a complex area to address and demands a broad-ranging, interdisciplinary approach. Medieval medical texts contain descriptions of diseases that could be considered infectious, but, to fully explore contemporary social and medical perceptions, patterns and processes relating to contagion and disease, we need expertise and input from at least five areas of knowledge:

Genomics of Ancient Plagues and Outbreaks, in: Trends in Microbiology 24 (2016), pp. 978-990. For tuberculosis, see Janet E. REDMAN / Matthew J. SHAW / Anthony I. MalLET / Ana Luisa SANTos / Charlotte A. RoBerTS / Angela M. GERnAEY / David E. MinNIKIN, Mycocerosic Acid Biomarkers for the Diagnosis of Tuberculosis in the Coimbra Skeletal Collection, in: Tuberculosis 89 (2009), pp. 267-990. For leprosy, see Verena J. Schuenemann / C. Avanzi / B. Krause-Kyora / A. Seitz / Alexander Herbig, Ancient Genomes Reveal a High Diversity of Mycobacterium leprae in Medieval Europe, in: PLOS Pathogens 14 (2018), e1006997. For others, see Gemma L. KAY / Martin J. SERGEANT / Valentina GIUfFRA / Pasquale BANDIERA / Marco Milanese / Barbara BRAMANTI / Raffaella BianucCi / Mark J. PALLEN, Recovery of a Medieval Brucella melitensis Genome Using Shotgun Metagenomics, in: mBio 5 (2014), e01337-e01314; Alison M. Devault / Tatum D. MoRTimer / Andrew Kitchen / Henrike KieSEwetTer / Jacob M. EnK / G. Brian Golding / John R. Southon / Melanie Kuch / Ana T. Duggan / William Aylward / Shea N. GARDNER / Jonathan E. ALLEN / Andrew M. King / Gerard D. WRiGHT / Makoto KuRODA / Kengo Kato / Derek E. G. Briggs / Gino FornaCiari / Edward C. Holmes / Hendrik N. Poinar / Caitlin S. PePPERELL, A Molecular Portrait of Maternal Sepsis from Byzantine Troy, in: eLife 6 (2017), e20983.

19 See e. g. Romy MÜLLER / Charlotte A. ROBERTS / Terence A. BRown, Complications in the Study of Ancient Tuberculosis: Non-specificity of IS6110 PCRs, in: STAR: Science \& Technology of Archaeological Research 1 (2015), pp. 1-8, and Romy MÜLLER / Charlotte A. ROBERTS / Terence A. BRown, Complications in the Study of Ancient Tuberculosis: Presence of Environmental Bacteria in Human Archaeological Remains, in: Journal of Archaeological Science 68 (2016), pp. 5-11. 
- Cultural and social history: to explore perceptions and contexts of disease as people experienced it and as physicians approached it. $^{20}$

- Manuscript studies: to determine how diseases were described in contemporary written sources. These include annals (which tell us about spatiotemporal patterns of endemic and epidemic disease, death tolls and general public perceptions) and medical texts (which give us contemporary descriptions of the symptoms and perceived aetiology of infections, and details of what was prescribed to treat them). ${ }^{21}$

- Microbiology and immunology: to determine which diseases most likely are being described by contemporary observers and suggest the likely causative agents.

- Ethnobotany: to understand which natural medical materials were used and how they were processed. ${ }^{22}$

- Medicinal chemistry: to determine which - if any - biologically active compounds are contained within contemporary materia medica. ${ }^{23}$

Combining these perspectives, and the specialized analytical tools that each specialism can contribute, makes it possible to improve our knowledge of medieval rationality and pre-modern 'science'. This approach also allows us to bring the study of medieval European medicine within the realm of ethnopharmacology.

\section{The Ethnopharmacology of an Anglo-Saxon Infection Remedy}

\subsection{A Potential 'Ancientbiotic' from 'Bald's Leechbook'}

With these questions in mind, our team set about conducting an interdisciplinary study of a remedy from a tenth-century Old English medical text known as 'Bald's

20 See e. g. Sally Crawford / Christina LeE (eds.), Social Dimensions of Medieval Disease and Disability (Studies in Early Medicine 3), Oxford 2014.

21 See e. g. Conor Kostick / Francis LudLow, Subsistence Crises, Mass Mortality, Epidemic Disease and Drought in Early Medieval Europe and the Near East, 750-1000 CE, in: Timothy NEWFIELD (ed.), Mortality Crises Between the Plagues, c. 800-c. 1300 CE, Cambridge (in preparation); Malcom Laurence CAMERon, Anglo-Saxon Medicine, Cambridge 2008; CRAWford / LeE (note 20).

22 See e. g. Youyou Tu, The Discovery of Artemisinin (Qinghaosu) and Gifts from Chinese Medicine, in: Nature Medicine 17 (2011), pp. 1217-1220, online (DOI): 10.1038/nm.2471 (last accessed 15/05/2019); WATKINS et al. (2011, 2012) (note 4).

23 See e. g. Lanzotti / Scala / Bonanomi (note 3); Watkins / PendRY et al. 2011 and Watkins / PendRY et al. 2012 (note 4); Cassandra L. QuAve / James T. LyLes / Jeffery S. Kavanaugh / Kate Nelson / Corey P. Parlet / Heidi A. Crosby / Kristopher P. Heilmann / Alexander R. HoRswill, Castanea sativa (European Chestnut) Leaf Extracts Rich in Ursene and Oleanene Derivatives Block Staphylococcus aureus Virulence and Pathogenesis without Detectable Resistance, in: PLoS One 10 (2015), e0136486. 
Leechbook'. A colophon states that the text was compiled for an enigmatic figure called Bald. The part of the book that survives to the present day is held by the British Library (London, British Library, Royal MS 12 D XVII) and contains many hundreds of remedies for all manner of ailments. One remedy stands out as particularly interesting to microbiologists (Figure 1A):

Make an eyesalve against a wen: take equal amounts of [an Allium species] and garlic, pound well together, take equal amounts of wine and oxgall, mix with the alliums, put this in a brass vessel, let [the mixture] stand for nine nights in the brass vessel, wring through a cloth and clarify well, put in a horn and at night apply to the eye with a feather; the best medicine. (translation by Christina LEE)

As discussed above, a wen, or lump, in the eye is most likely a sty. But it is the ingredients list that made the microbiologists on our team take notice of this remedy. Allium species are remarkable among plants for the range of antimicrobial compounds they can make. Compounds isolated from garlic, leek, onion and other species within this genus have been shown to kill $S$. aureus and other troublesome bacterial species, to prevent them from sticking themselves together into protective biofilms and to interfere in the cell-cell signalling processes by which bacteria switch to a disease-causing mode. ${ }^{24}$ Bile is a surfactant that can punch holes in the fatty membranes that surround bacteria, and it also triggers human cells to defend themselves against bacterial invaders. ${ }^{25}$ Wine could provide various grape-derived antimicrobial small molecules, or simply act as a solvent to extract useful compounds from the plant tissues in the recipe. Finally, antimicrobial copper salts from the brass/bronze vessel could leach into the salve. ${ }^{26}$

Could this apparently multi-pronged attack on bacteria inside the wen really be "the best medicine"? An earlier study by BRENNESSEL, DROUT and GRAVEL concluded that the promise of the recipe was not borne out by its performance in laboratory tests, ${ }^{27}$ but these authors did not have the microbiological tools and techniques at our disposal. The original authors made their eyesalve, saturated small pieces of filter paper with the resulting liquid, placed these on petri dishes spread with bacteria, and then incubated the dishes to see if bacterial growth was inhibited in the vicinity of the filter paper. This is a standard method of

24 LANZOTTI / SCALA / BONANOMI (note 3).

25 Alan F. Hofmann / Lars Eckmann, How Bile Acids Confer Gut Mucosal Protection Against Bacteria, in: Proceedings of the National Academy of Sciences of the United States of America 103 (2006), pp. 4333-4334.

26 Grass / Rensing / Solioz (note 7); Kaveri S. Chaturvedi / Jeffrey P. HendERSon, Pathogenic Adaptations to Host-derived Antibacterial Copper, in: Frontiers in Cellular and Infection Microbiology 4 (2014), online (DOI): 10.3389/fcimb.2014.00003 (last accessed: 15/05/2019). Copper plates have been found associated with bones of skeletons, see note 17.

27 BRENNESSEL / DRout / GRAVEL (note 9). 
(A)

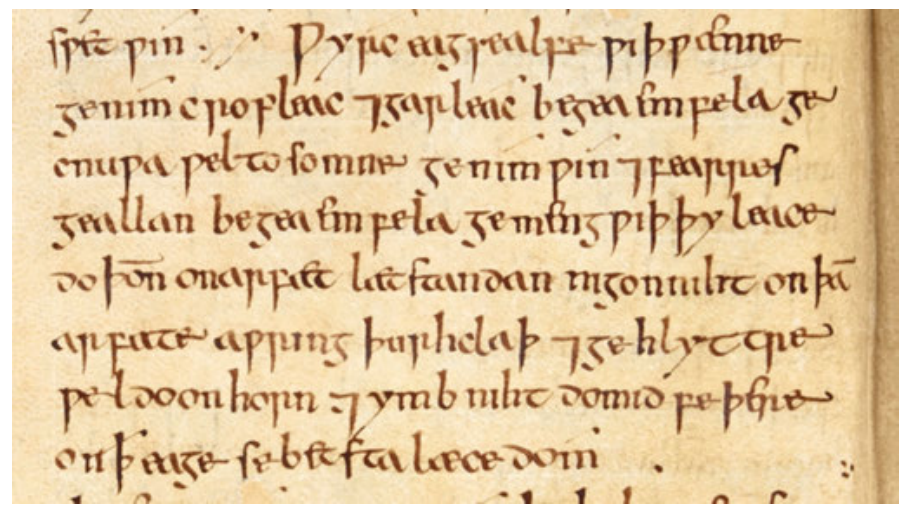

(B)

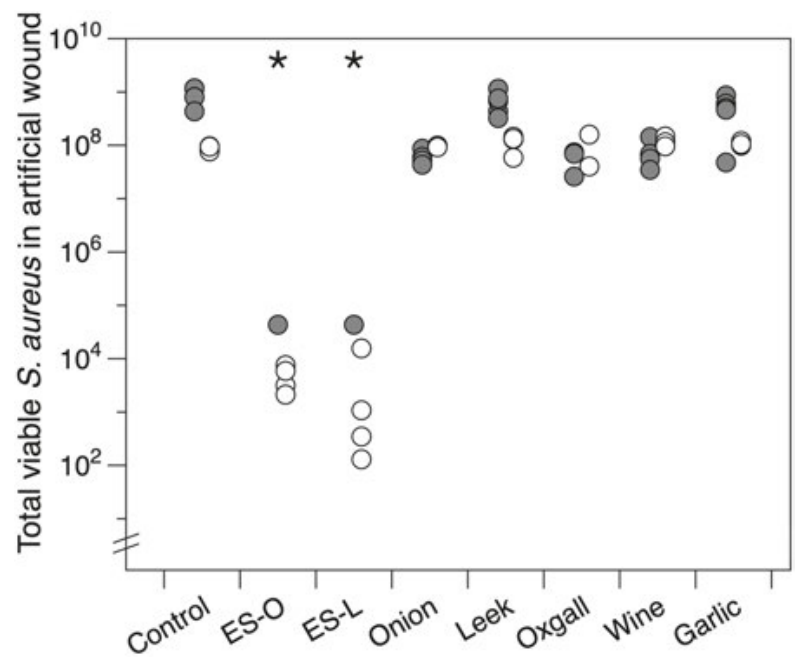

Figure 1: A) Facsimile of a recipe for an eyesalve against a wen, taken from 'Bald's Leechbook' (London, British Library, Royal 12 D XVII) @ The British Library Board, reproduced with permission. B) Two batches of eyesalve were made, using fresh ingredients each time (open and filled circles denote the two batches), with either onion (ES-0) or leek (ES-L) for cropleac. For each batch, two hundred microliters of eyesalve or of each individual ingredient preparation was added to five oneday-old cultures of $S$. aureus growing at $37^{\circ} \mathrm{C}$ in a synthetic wound. After $24 \mathrm{~h}$ of further incubation, the collagen in the synthetic wound was dissolved to recover bacterial cells. The control treatment was sterile distilled water left to stand for nine days in the presence of brass, which was also present in all other preparations, to simulate the presence of a copper alloy vessel. Asterisks denote treatments whose results were statistically significantly different from those of the control. (Reproduced with permission from HARRISON et al. [note 13]). 
testing modern antibiotics against bacteria taken from clinical samples, in order to determine which drugs to administer. But it delivers only a very small volume of the test substance to the bacteria - a few microliters - so it is likely to give false negative results when the concentration of antibacterial compounds present is low, or when they are volatile (i. e. evaporate readily).

We therefore decided to re-test Bald's eyesalve. We made two versions of the salve, using onion and leek respectively for the mysterious Allium species referred to as cropleac. We made our salve in sterile glass bottles, but added small squares of brass to simulate the copper alloy vessel. The first hint that the mixture could be antibacterial came when we attempted to culture bacteria from the mixture after its nine-day resting period. The bacteria initially present on the vegetables did not survive this period of time in the mixture: the salve was self-sterilising. We then grew $S$. aureus in a clinically realistic biofilm model - serum from blood, solidified with collagen to mimic soft tissue - and added drops of Bald's eyesalve to the mature biofilms. We were not prepared for the result: biofilms subjected to a 'mock' treatment (sterile water plus brass, left for nine days), or treated with individual recipe ingredients, contained a few hundred million to a billion live bacteria, but we could only retrieve a few hundred or a few thousand live bacteria from biofilms exposed to either version of the full recipe (Figure 1B).

That a millennium-old remedy could reduce bacterial viability by several orders of magnitude was unprecedented, and sufficiently significant to justify a test in animals. We went on to show that Bald's eyesalve could kill the antibioticresistant 'superbug' strain of $S$. aureus, MRSA, in infected animal tissue. Infected wound tissue was excised from mice, and exposed to the eyesalve for a short length of time ( 4 hours). In this experiment, the antibiotic of last resort against MRSA, vancomycin, kills approximately $50 \%$ of MRSA bacteria in the tissue, but the eyesalve killed approximately $90 \%$. We also verified that in vitro antibacterial activity required all ingredients to be present except for the brass, and was not present if the salve was used immediately after preparation (i. e. without the nineday waiting period). Further, we went on to test numerous batches of the eyesalve, made with fresh ingredients each time, and by different people, and found that the anti-staphylococcal effect in the in vitro model was reproducible. At time of writing, we are collating data on 56 batches of the eyesalve made by 11 different people and an analysis of reproducibility will be presented in a future publication.

We have since shown that Bald's eyesalve can kill a range of ESKAPE bacteria, including antibiotic-resistant clinical isolates, but it does not kill indiscriminately: some bacteria are impervious. ${ }^{28}$ This shows that whatever is present in the eyesalve

28 Freya Harrison / Rebecca GABRILSKa / Sheyda AzImi / Kendra P. Rumbaugh / Christina LeE / Stephen P. DIGgLe, The Potential of Medieval 'Ancientbiotics' in the Treatment of Chronic Biofilm Infection, Annual Conference of the Microbiology Society, Liverpool 2016. 
is not a non-specific biocidal agent. Rather, whatever happens when the various ingredients are combined produces a substance or substances with a specific mode of action to kill certain bacteria. This specificity is one thing that delineates a potential antibiotic from, say, bleach. These results have spurred us on to begin to explore the spectrum of the eyesalve's antibacterial activity (what can it kill?), its mechanism of action (how does it kill?), the pharmacological basis of its action (what active molecules does it contain?), and its likely safety (can it damage human cells?).

A recent publication by another research group attributes the antibacterial efficacy of the eyesalve to the compound allicin, present in garlic. ${ }^{29}$ However, this work addressed only killing of bacteria in planktonic culture and not in biofilms, where increased antibiotic tolerance may require the action of several antibacterial agents at once - and, critically, where garlic alone is not an effective anti-staphylococcal treatment (Figure 1B). Thus, more meticulous explorations are needed. Safety and toxicity testing using cultured human cell lines or live animals are key steps in the early scoping of any potential antibiotic, and the eyesalve ingredients contain a range of compounds that could cause moderate to severe allergic reactions when applied topically. Crushed garlic, in particular, can cause skin reactions ranging from contact dermatitis to chemical burns (partly attributable to allicin), so it is crucial to assess whether the eyesalve carries a safety risk. ${ }^{30}$ Chemically dissecting the eyesalve and carrying out safety testing is a significant undertaking, and we are delighted that the Ancientbiotics consortium has received research funding from Diabetes UK to begin this process. ${ }^{31}$ However, answering these questions fully will require us to work together for the foreseeable future.

Whether Bald's eyesalve could ever be turned into a standardized medicine is something we cannot predict at this moment. However, the fundamental result of our study is the discovery that the cocktail of ingredients in Bald's eyesalve is greater than the sum of its parts. By combining specific materia medica, none of which has significant antibacterial activity when used alone, an active mixture is created. This raises the tantalising suggestion that at least some of the cocktails constructed by medieval doctors were rationally designed (even if the initial stages of discovery relied on trial and error!). If this is true, then it means that a powerful new approach to drug discovery could lie in reconstructing and testing pre-modern

29 Amanda L. Fuchs / Alan J. Weaver, Jr. / Brian P. Tripet / Mary Cloud / B. Ammons / Martin TEINTZE / Valerie Copí,, Characterization of the Antibacterial Activity of Bald's Eyesalve against Drug Resistant Staphylococcus aureus and Pseudomonas aeruginosa, in: PLoS ONE 13 (2018), e020810.

30 Cem Kıvılcım KaÇAR / Ebru Tarıkçı Kiliç/ Hakan AKelma / Osman Uzundere / Ayhan KaYdu / Erhan GöкÇEK, Medical Folk Remedy: Two Cases of Garlic Burns, in: Journal of Burn Care \& Research 40 (2019), pp. 133-135.

31 "Assessing the potential of a medieval antibiotic to treat infected diabetic ulcers." PI: Dr Freya Harrison, University of Warwick. The Project runs from 2018-2020. 
remedies, rather than simply exploring individual traditional medical materials for potential activity. Our results suggest that to discount the antibacterial potential of individual traditional medical materials because they do not have significant clinical potential when used alone would be to throw the baby out with the bathwater. ${ }^{32}$ Perhaps it is to combinations of traditional materia medica that we must look for novel antibacterial treatment.

The results of our work led us to wonder whether Bald's eyesalve was a lucky stab in the dark. Is it the sole useful 'ancientbiotic' among a vast collection of placebos? Or does its existence reflect some empirical medical knowledge and method on the part of medieval physicians, and thus the existence of other potentially efficacious anti-infection remedies in the medieval pharmacopeia?

\subsection{Rational Drug Development? Patterns of Ingredient Usage in Medieval Leechbooks}

We cannot effectively answer the above questions with a small-scale approach to finding and testing infection remedies that look interesting: this would be laborious and doubtless lead us up many blind alleys. What we need instead is a top-down approach to analysing the data present in medical texts and predicting what sorts of remedies seem to be most promising: whether some ingredients were used repeatedly to treat symptoms that clearly suggest infection, and, more importantly, whether certain ingredients were repeatedly combined together to treat these symptoms. If such cocktails of ingredients exist, then these are where we must focus our research effort.

A small-scale analysis of the context of Bald's eyesalve within 'Bald's Leechbook' suggests this remedy was not simply thrown together using a random selection of ingredients that the compiler had to hand. We sought to find out how often the various ingredients present in the eyesalve co-occurred in other remedies in the same text. We therefore compared the frequency with which each possible pair of ingredients appeared together in a recipe with the frequencies with which ingredients appeared in any recipe, regardless of combination. In this manner, we were able to calculate the probability of observing $n$ recipes containing ingredients $A$ and $B$, if $A$ and $B$ were assigned randomly to remedies. Our methodology was to perform searches of the electronic text of 'Bald's Leechbook' held on the 'Dictionary of Old English Web Corpus $^{33}$ for each ingredient present in the eyesalve. We were aided here by two other carefully curated databases of Old English language, namely 'The Dictionary of

32 See note 8.

33 Antonette diPaolo Healey / John Price Wilkin / Xin Xiang, Dictionary of Old English Web Corpus. Toronto, Dictionary of Old English Project 2009, online: http://tapor.library.utoronto.ca/ doecorpus/ (last accessed 15/05/2019). 
Old English Plant Names' and 'A Thesaurus of Old English'. ${ }^{34}$ These allowed us to ensure that we included synonyms in our search, e. g. BIERBAUMER et al. give cipe, cipe-leac and ynne-leac for 'onion'. It also allowed us to exclude spurious results: e. g. a text search for the fragment leac returns not only Allium spp. containing this name element, but also leaccerse, which is translated by BIERBAUMER et al. as garlic mustard (Alliaria petiola) - a member of the Brassica family. ${ }^{35}$

Table 1 shows the number of recipes in 'Bald's Leechbook' containing each of the five ingredients in the eyesalve, the number of recipes we would expect to see containing each possible pair of ingredients if they are combined randomly, and the number of remedies that actually do contain each pair of ingredients - excluding the eyesalve itself. The Venn diagram in Figure 2 provides a pictorial representation of

Table 1: Calculating the probability that pairs of ingredients used in Bald's eyesalve were combined more often than expected under random chance.

\begin{tabular}{|c|c|c|c|c|c|c|}
\hline \multicolumn{2}{|c|}{$\begin{array}{l}\text { A) Occurrences of all } \\
\text { ingredients from the eyesalve } \\
\text { in Bald's Leechbook }\end{array}$} & \multicolumn{5}{|c|}{$\begin{array}{l}\text { B) Expected and observed co-occurrences (excluding the eyesalve } \\
\text { itself) }\end{array}$} \\
\hline \multirow[t]{2}{*}{ Ingredient } & \multirow[t]{2}{*}{ Remedies } & \multirow[t]{2}{*}{ Ingredient A } & \multirow[t]{2}{*}{ Ingredient B } & \multicolumn{2}{|c|}{$\begin{array}{l}\text { Remedies } \\
\text { with A \& B }\end{array}$} & \multirow[t]{2}{*}{ Probability } \\
\hline & & & & Exp. & Obs. & \\
\hline Copper vessel & 12 & Copper vessel & Garlic & 0 & 0 & \\
\hline Garlic & 14 & Copper vessel & Gall & 0 & 0 & \\
\hline Gall & 21 & Copper vessel & Other Allium spp. & 0 & 0 & \\
\hline Other Allium spp. & 25 & Copper vessel & Wine & 1 & 4 & 0.00125 \\
\hline Wine & 65 & Garlic & Gall & 0 & 0 & \\
\hline \multirow[t]{5}{*}{ Est. total recipes: } & 1493 & Garlic & Other Allium spp. & 0 & 4 & $<0.001$ \\
\hline & & Garlic & Wine & 1 & 0 & \\
\hline & & Gall & Other Allium spp. & 0 & 0 & \\
\hline & & Gall & Wine & 1 & 0 & \\
\hline & & $\begin{array}{l}\text { Other Allium } \\
\text { spp. }\end{array}$ & Wine & 1 & 1 & \\
\hline
\end{tabular}

34 Peter Bierbaumer / Hans Sauer / Helmut W. Klug / Ulrike KrischKe (eds.), Dictionary of Old English Plant Names, 2007-2017, online: http://oldenglish-plantnames.org (last accessed 15/05/ 2019); Jane Roberts / Christian Kay / Lynne Grundy, A Thesaurus of Old English, Glasgow, University of Glasgow 2015, online: oldenglishthesaurus.arts.gla.ac.uk (last accessed 15/05/2019). 35 Bierbaumer et al. (note 34). 


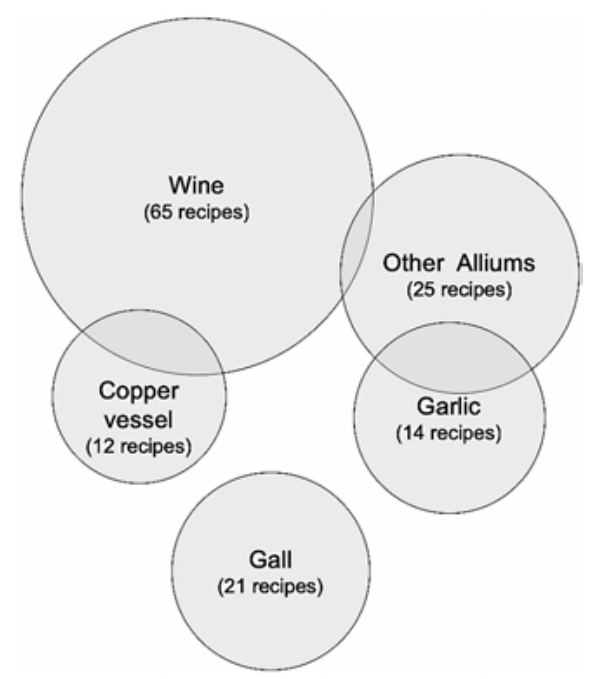

Figure 2: Venn Diagram showing co-occurrences of eyesalve ingredients elsewhere in 'Bald's Leechbook'. The size of each circle is proportional to the number of remedies containing each ingredient, and the size of each area of overlap is proportional to the number of remedies containing each pair of ingredients.

the frequencies of ingredient combination. Four remedies combine garlic with other Allium species, and four require the use of a copper alloy vessel and wine. Given the prevalence of each individual ingredient in the 'Leechbook', under the random allocation of ingredients to remedies we would expect to observe zero or one such remedy respectively. The probability of observing four such remedies under the assumption of random assortment is therefore quite low: using Fisher's Exact Test, the probability of four remedies including both garlic and another Allium species is less than one in one thousand, and the probability of four remedies containing both wine and a copper vessel by chance is one in eight hundred. A rule of thumb in science is to accept a probability of less than one in twenty as being unlikely to be due to chance; we suggest that these pairs of ingredients were deliberately put together.

The use of copper vessels is interesting, especially given that in our test of Bald's eyesalve, this was the one ingredient not required for antibacterial activity. All the remedies in 'Bald's Leechbook' that refer to copper alloys use this material for the vessel in which the remedy is prepared (as opposed to a direct ingredient), and of the twelve such remedies, nine are for eye complaints. Parallels are found elsewhere in medieval medicine, for example a remedy for blurred vision in a ninth/tenth-century Latin and Old Breton text held by the University of Leiden (MS Vossianus lat. f. 96A) contains a remedy that calls for the ingredients to be placed 
in a bronze box. ${ }^{36}$ Perhaps this was due to an observation that materials left in copper or copper alloy vessels were less likely to 'go off', as copper surfaces retard bacterial colonisation - or it could be due to some unknown magico-medical connection between copper and eye complaints, or to the placebo effect of receiving a medicine in fancy packaging. Even now, large numbers of people believe that generic drugs are not as effective as identical drugs supplied in branded packaging, and supplying placebo painkillers in branded packaging enhances the placebo effect. ${ }^{37}$ Finally, it is possible that a large copper vessel could leach sufficient copper into the eyesalve (Mike DrouT, personal communication) to further enhance the antibacterial effect, and that our failure to observe this was simply due to the much smaller surface area of brass we used to simulate the presence of the vessel.

Similar patterns of ingredient combinations are seen in other recipes used to treat infectious conditions in the medieval literature selected for preliminary analysis. For instance, throughout medical history various species of Plantago (in combination with vinegar or wine and other medicinal plants) are administered for a number of conditions, including wounds (and surgically induced wounds), skin infections, insect stings, oral conditions, abscesses in the gums, burns (caused by water or fire), nail infections, nosebleeds, digestive complaints, diarrhoea, liver problems, respiratory conditions (cough, throat infections), vomiting blood, kidney stones and blood in the urine. In the fifteenth-century Middle English 'Lylye of Medicynes' (Oxford, Bodleian Library MS Ashmole 1505), Plantago spp. often appear in recipes in co-occurrence with descriptions of cutaneous infections from the simple (the first sign of redness) to the severe (ulceration, purulence, and black crusts), including wounds, swellings, abscesses, lesions, carbuncles, pustules, and rashes. ${ }^{38}$ In these recipes, Plantago spp. is crushed (ground) and soaked or boiled in vinegar, wine or water, mixed with other medicinal plants and applied directly to the affected area. Due to its long history of use in traditional medicine, Plantago spp. is a popular candidate for laboratory studies investigating the efficacy of herbal remedies for the treatment of wounds or infection. In some of these studies, the species Plantago major and Plantago lanceolata have

36 Benjamin FrancKaERT, Santé et pratiques médicales des Bretons insulaires et continentaux du Haut Moyen Âge ( $\mathrm{V}-\mathrm{X}^{\mathrm{e}}$ siècles): revue de la littérature ouverte, analyse croisée des données historiques et archéologiques, Brest (Université de Bretagne occidentale, med. diss.) 2014, online: https://dumas.ccsd.cnrs.fr/dumas-01006406/document (last accessed 15/05/2019).

37 Sarah Colgan / Kate FaAsse / Leslie R. Martin / Melika H. Stephens / Andrew Grey / Keith J. PetRIE, Perceptions of Generic Medication in the General Population, Doctors and Pharmacists. A Systematic Review, in: BMJ Open 5 (2015), e008915; Kate FAASSE / Leslie R. MARTIN / Andrew GREY / Greg D. GAmBlE / Keith J. PETRIE, Impact of Brand or Generic Labeling on Medication Effectiveness and Side effects, in: Health Psychology 35 (2016), pp. 187-190.

38 Erin Connelly, A Case Study of Plantago in the Treatment of Infected Wounds in the Middle English Translation of Bernard of Gordon's Lilium medicinae, in: Erin CONNELLY / Stefanie KüNZEL (eds.), New Approaches to Disease, Disability, and Medicine in Medieval Europe, Oxford 2018, pp. 126-140. 
been associated with many beneficial properties, including antibiotic, antiviral, antioxidant, anti-inflammatory, anticancer, and hepatoprotective effects along with wound healing. ${ }^{39}$ Some researchers suggest that these species possess wound healing properties, ${ }^{40}$ or may be candidates for use in combination with conventional antibiotics or other medicinal plants in infection prevention. ${ }^{41}$ Many bioactive plant compounds are only active in freshly-crushed material (aucubin from Plantago spp. is an excellent example of this), and solvent extraction can capture less activity than lowtech extraction methods such as soaking in water (artemisinin from Artemisia spp. providing a high-profile example). The results of studies using dried leaves may therefore underestimate the antibacterial capacity of fresh whole-plant material.

Nettles (Urtica dioica / U. urens) also appear several times in medieval texts in connection with potentially infected wounds. Preliminary analysis of 'Bald's Leechbook', a tenth-century translation of the fourth-century 'Pseudo-Apuleius Herbarius' and works by later medieval practitioners, such as the fourteenth-century surgeon John Arderne,

39 Ricardo Gómez-Flores / Cesar L. CALDERon / Leonard William Scheibel / Patricia TAmez-GuerRa / Cristina Rodríguez-Padilla / Reyes Silvestre TAmez-GuerRa / Richard J. Weber, Immunoenhancing Properties of Plantago major Leaf Extract, in: Phytotherapy Research 14 (2000), pp. 617-622; Geir Hetland / Anne Berit C. Samuelsen / Martinus LøviK / Berit Smestad Paulsen / Ingeborg S. AAberge / E. C. Groeng / Terje E. Michaelsen, Protective Effect of Plantago major L. Pectin Polysaccharide Against Systemic Streptococcus pneumoniae Infection in Mice, in: Scandinavian Journal of Immunology 52 (2000), pp. 348-355; Lien-Chai CHIANG / Wen CHIANG / Mei-Yin CHANG / Chun-Ching Lin, In Vitro Cytotoxic, Antiviral and Immunomodulatory Effects of Plantago major and Plantago asiatica, in: The American Journal of Chinese Medicine 31 (2003), pp. 225-234; Lien-Chai CHIANG / Wen Chiang / Mei-Yin Chang / Lean-Teik Ng / Chun-Ching Lin, Antiviral Activity of Plantago major Extracts and Related Compounds in vitro, in: Antiviral Research 55 (2002), pp. 53-62; Idris TÜREL / Hanefi ÖZBEK / Remzi ERTEN / Ahmet Cihat ÖNER / Nureddin CENGIZ / Orhan YILMAZ, Hepatoprotective and Anti-Inflammatory Activities of Plantago major L., in: Indian Journal of Pharmacology 41 (2009), pp. 120-124; Suzanne NiLson / Fidji Gendron / Jody Bellegarde / Betty McKenna / Delores Louie / Geraldine MANSON / Harvey ALPHONSE, Preliminary Scientific Investigation of the Effectiveness of the Medicinal Plants Plantago major and Achillea millefolium Against the Bacteria Pseudomonas aeruginosa and Staphylococcus aureus in Partnership with Indigenous Elders, in: Global Journal of Research on Medicinal Plants \& Indigenous Medicine 3 (2014), pp. 402-415.

40 Ralph Gruppi Thomé / Hélio Batista Dos Santos / Fábio Vieira Dos Santos / Renato José Da SiLva Oliveira / Luis Fernando de Camargos / Mariana Nunes PEREIRA / Tamara Ribeiro LongatTi / Cássio Martins Souto / Carlaile Soares Franco / Raissa DE Oliveira Aquino SchÜFFnER / Rosy Iara Maciel DE AZAMBUja RiBEIRo, Evaluation of Healing Wound and Genotoxicity Potentials from Extracts Hydroalcoholic of Plantago major and Siparuna guianensis, in: Experimental Biology and Medicine 237 (2012), pp. 1379-1386; Ivan KovÁČ / Ján ĎURKÁČ / Martin HolLÝ / Katarína JAKUBČovÁ / Vlasta PeRŽELová / Pavel MuČajI / Emil ŠvajDlenka / František SABol / Jaroslav LEgáth / Jozef BeLÁK / Karel Smetana / Peter GÁL, Plantago lanceolata L. Water Extract Induces Transition of Fibroblasts into Myofibroblasts and Increases Tensile Strength of Healing Skin wounds, in: Journal of Pharmacy and Pharmacology 67 (2015), pp. 117-125, online (DOI): 10.1111/jphp.12316 (last accessed 15/05/2019).

41 Kemal Metinar / Oktay ÖZKAN / Seyyal AK, Antibacterial Effects of Ethanol and Acetone Extract of Plantago major L. on Gram Positive and Gram Negative Bacteria, in: Kafkas Üniversitesi Veteriner Fakültesi Dergisi 18 (2012), pp. 503-505; KARIMA / FARIDA / MiHouB (note 12). 
reveal a clear pattern of nettles being crushed and combined with salt and vinegar to make a salve for wounds likely to be infected: these include wounds described as foul or rotten, dog bites, frostbite, and surgical wounds. A small number of articles present results showing that extracts of nettle leaves and stems show antibacterial activity against various bacteria, including species that continue to cause chronic, antibioticresistant infections today, such as $S$. aureus, Klebsiella pneumoniae, Escherichia coli and Enterococcus faecalis. ${ }^{42}$ This is unsurprising as nettles contain a range of secondary metabolites known to have antibacterial activities, such as the flavonoids quercetin and kaempferol that are also significant bioactive components of Allium species. However, as with much research into Plantago spp. these results are based on solvent extracts of dried plant material and, as with most ethnopharmacological research, combinations of nettles with the salt and vinegar used by our pre-modern physicians have not been tested. As with Plantago, nettles are unlikely to trigger adverse effects when applied to the skin, or consumed: nettles are widely eaten as a vegetable and used to make beer, cheese, and shampoo. A combination of nettles with salt and vinegar both non-toxic substances known to have some bactericidal activity - could in theory lead to enhanced antibacterial activity of the three-part cocktail. The Ancientbiotics team is currently undertaking further research into nettles activity thanks to funding provided by the Royal Society APEX Award (Academies Partnership in Supporting Excellence in Cross-disciplinary Research Award). ${ }^{43}$

Our team has thus identified remedies containing plantains or nettles as useful focal groups of remedies which we would like to make in the lab and test for antimicrobial activity, and work is ongoing in this area. However, approaches that rely on our a priori knowledge of texts, ingredients and microbes to look for patterns radiating from a focal recipe, substance or symptom may have limited power. Going beyond this simple approach to attempt 'big data' analyses of medical texts requires working with yet another discipline: the field of data science can supply powerful analytical tools to find patterns of ingredient combination, and the mapping of groups of ingredients to symptoms, with no a priori assumptions about potential patterns or useful ingredients.

42 Nursel Dostbil / Sema Agaoglu / Suleyman Alemdar, The Antibacterial Activity of Common Nettle, in: Indian Veterinary Journal 82 (2005), pp. 492-494; Julia E. CHRUBASIK / Basil D. Roufogalis / Hildebert WaGner / Sigrun A. ChrubasiK, A Comprehensive Review on Nettle Effect and Efficacy Profiles, Part I: Herba Urticae, in: Phytomedicine 14 (2007), pp. 423-435; Amir MODARRESI-CHAHARDEHI / Darah IBRAhim / Shaida FaRIZA-Sulaiman / Leila MouSAVI, Screening Antimicrobial Activity of Various Extracts of Urtica dioica, in: Revista de Biología Tropical 60 (2012), pp. 1567-1576; Kais Kassim GHAIMA / Noor Makie HASHIM / Safaa Abdalrasool Ali, Antibacterial and Antioxidant Activities of Ethyl Acetate Extract of Nettle (Urtica dioica) and Dandelion (Taraxacum officinale), in: Journal of Applied Pharmaceutical Science 3 (2013), pp. 96-99, online (DOI): 10.7324/JAPS.2013.3518 (last accessed 15/05/ 2019).

43 "Nettles and Networks: New Ways to tackle Wound Infections." Principal Investigator: Dr Christina LEE, University of Nottingham. The Award runs from 2019 to 2021. 


\subsection{Looking to the Future: Datamining Medieval Texts for Antibiotic Discovery}

The success of the Bald's eyesalve pilot study and others, such as Tu YouYou's development of artemisinin (from Artemisia annua), a therapy for malaria derived from traditional herbal medical texts (awarded the Nobel Prize in Physiology or Medicine in 2015), have produced a series of questions relevant to the history of medicine and modern day research. Did medieval physicians follow a predictable rational method and how did they adapt and improve earlier remedies to use local ingredients, or to target different aetiologies? Where we see contingencies of different remedies for a condition, what conclusions can be drawn about the methodology of medieval practitioners? Finally, do ancientbiotic cocktails hold the key to discovering new natural compounds, or cocktails of compounds, that could form the basis of novel treatments for infection? Thus far research has been concentrated around single specific recipes from select medieval texts (e. g. 'Bald's Leechbook', 'Lylye of Medicynes') - a process which is limited by the availability and accessibility of medieval texts, as well as the constraints of researchers mining these texts by hand. Using digital technologies, specifically relational databases and network analysis from the field of data science, ${ }^{44}$ to conduct a large-scale survey of ingredients from multiple medieval texts may provide a foundation to build evidenced answers to such questions and unlock the medieval medicine cabinet.

This pipeline of data-driven exploration of texts, underpinned by qualitative knowledge from the arts and sciences with regard to manuscripts, cultural contexts and ingredients, will ultimately inform laboratory testing, with an aim to develop novel antibiotics. A small-scale pilot study in collaboration with a mathematician was performed to test the viability of this hypothesis. ${ }^{45}$ This study applied the tools of data science to the 'Lylye of Medicynes', as a base text, to analyse the interrelatedness and co-occurrence of the ingredients and relationship of the ingredients to

44 Réka AlBert / Albert-László BarabÁsI, Statistical Mechanics of Complex Networks, in: Reviews of Modern Physics 74 (2002), pp. 47-97; Mark E. J. NEwman, The Structure and Function of Complex Networks, in: SIAM Review 45 (2003), pp. 167-256; Sergey N. DoROGovTSEV / Alexander V. GolTSEv / José F. F. MENDES, Critical Phenomena in Complex Networks, in: Reviews of Modern Physics 80 (2008), pp. 1275-1335; Yong-Yeol AHn / Sebastian E. AHnERT / James P. BAGRow / Albert-László BARABÁSI, Flavor Network and the Principles of Food Pairing, in: Scientific Reports 1 (2011), p. 196, online (DOI): 10.1038/srep00196 (last accessed: 15/05/2019); Federico BoTTA / Charo DEL GENIO, Finding Network Communities Using Modularity Density, in: Journal of Statistical Mechanics (2016), online (DOI): 10.1088/1742-5468/2016/12/123402 (last accessed 15/05/2019).

45 Laboratory tests to complement the study are being analysed; for a preprint of the preliminary results of the datamining see Erin CoNNELLy / Charo I. DEL GenIo / Freya HARRISON, Datamining a medieval medical text reveals patterns in ingredient choice that reflect biological activity against the causative agents of specified infections, in: BioRxiv (16/07/2018), online (DOI): https://doi.org/ 10.1101/368779 (last accessed 15/05/2019). 
disease states, specifically infectious disease. This analysis suggests sets of ingredients that were repeatedly combined and used to treat specific infection symptoms: these are, we hypothesize, the sets of ingredients that are most likely to produce antibiotic effects when combined, and therefore those on which lab work should focus. This approach provides valuable data about potential ancientbiotic cocktails and the feasibility of a large-scale study involving multiple texts and a much larger dataset.

There are specific challenges to integrating medieval data with twenty-firstcentury digital technology, including medieval spelling and language variation, multiple synonyms for the same ingredient, translation of medieval ingredients into modern equivalents (many ingredients are ambiguous or have multiple possible interpretations), the variation within the modern system of botanical binomial nomenclature itself from the ongoing centuries-long process of classification, and avoiding the perils of retrospective diagnosis. The nascent pilot study serves as a model for the efficacy of the data pipeline hypothesis for a large-scale study, and it serves to work out solutions to these challenges, of which currently there is no established methodology. This insight into underlying patterns in medieval medical data revealed by modern technological methods may enable a move beyond testing individual recipes lifted from medieval texts to a process of creating new pharmaceuticals inspired by the ingredients of the past based on a system of quantitative measures of the likelihood of antibiotic activity when specific ingredients are combined.

\section{Approaches to Interdisciplinarity: Power and Pitfalls}

We conclude our chapter with an exploration of what we have learned from each other, and how we have had to think outside our usual disciplinary boundaries in order to make this project work.

\subsection{What Can We Learn and Achieve Through Interdisciplinary Working?}

Turning historical medical texts into a new drug discovery resource is only possible through dedicated interdisciplinary collaboration. It requires close working relationships, unity of conviction, good communication, digital accessibility and discoverability of data, and knowledge exchange between (a) experts in medieval medicine and manuscripts (for the analysis and translation of pre-modern texts), (b) experts in microbial pathogenicity and molecular microbiology, (c) experts in analytical and natural compound chemistry, and (d) experts in data science for the creation of 
databases and network visualizations, which reveal new patterns in medieval ingredient data. In the future, using this approach for comparative analyses of texts could also help us to explore how medieval physicians created and shared knowledge, and how their approaches varied across time and geography. In this way, we could better understand the medieval mind.

The sciences and humanities are often presented as diametric opposites; however, the Ancientbiotics collaboration suggests that interdisciplinary work can yield remarkable outcomes. As discussed in this chapter, interdisciplinary collaboration requires a willingness to step outside of the structures of one's own discipline and methodology in order to learn the skills and methodologies of another discipline. The scientists involved in the Ancientbiotics collaboration had to become familiar with the languages of the past (e. g. Old English, Middle English, Latin), as well as adjust a modern scientific worldview to differences in the way their predecessors thought about scientific principles (e. g. physicians of the past worked from an incorrect humoral understanding of disease). The medievalists and historians had to learn the methodologies of laboratory research and become familiar with principles of microbiology (e. g. biofilms, quorum sensing). With these shared understandings, it is easier to see the elements of medieval recipes which convey cultural and scientific merit and thus select viable candidates for testing.

\subsection{Impediments to Successful Interdisciplinary Research, and some Suggestions for Removing Them}

While 'interdisciplinary' is regarded ubiquitously as a positive attribute, collaborative efforts which unite disciplines that are traditionally regarded as diametric opposites (the arts and the sciences) are often considered high-risk by peer reviewers. ${ }^{46}$ The impediment is in creating an interdisciplinary proposal that speaks to the needs of reviewers from all disciplines, so that they each feel that their field has an adequate amount of focus. This is difficult within the space constraints of grants and because there is a need to keep everything accessible to everyone. It is possible that the main impediment with applying for funding involves the lack of training of peer reviewers in how to approach interdisciplinary grants. Perhaps the review process could benefit from more oversight by core funding body reviewers who can guide peer reviewers on how to approach the task (e. g. explicitly remind them that for an interdisciplinary grant application the level of detail and style of communication is necessarily different because it has to be understandable to people from different areas).

46 As we experienced during preparation of this chapter, which one professional vociferously refused to review. 
Furthermore, an impediment closely related to that of peer review, is resistance from within the disciplines to ideas that challenge traditional perspectives and collaborations that unite non-traditional elements, i. e. some academics believe that they must act as gatekeepers, which impedes movement across the disciplines as well as movement forward to meet common goals. However, we suggest that solving global problems, such as antimicrobial resistance, requires the application of global mindsets, or, stated another way, a solution may require the combined effort of individuals with diverse expertise working across disciplinary boundaries. Our preliminary results suggest that the outcome of such alliances can be greater than the sum of its parts. With further research in this spirit, it may be possible to show that the past could inform the future, and that the ancientbiotics of yesterday could have real implications for the antibiotics of today.

\section{Conclusions and Future Directions}

Relevance to multi-disciplinary concerns and wider societal issues is a current requirement for most academic research projects, especially for those in the humanities. At the "Making the Medieval Relevant" conference sponsored by the British Academy there was a range of international representatives from the fields of Economics, Microbiology, History, English, Archaeology, and Genetics, which demonstrates the multi-disciplinary significance of medieval topics, as well as the ability of medieval studies to shed light on both historical and present-day research when united with experts from the sciences, of which Bald's eyesalve is a successful example.

Many exciting discoveries remain to be made about medieval medical 'science'. Analysing and understanding medieval medicine and how it was practised will not just provide a window into the medieval mind. It could ultimately enhance ethnopharmacological research and - potentially - open new routes to drug discovery. To bring to fruition nascent work in this area, increased interdisciplinary participation and greater allocation of resources to arts/science collaborations that currently fall through the cracks of traditional disciplinary funding will be essential.

Acknowledgements: This chapter is one output of a large and diverse project undertaken by the wider Ancientbiotics consortium, which spans multiple disciplines, institutions and countries. We would therefore like to thank our colleagues Dr Christina LEE and Dr Steve DigGLE, who co-founded the team with us; Dr Aled Roberts, Dr Kendra Rumbaugh, Rebecca Gabrilska, Dr Lee Haines and Dr Álvaro ACOSTA SERRANO, who collaborated to design and conduct published and ongoing 
experimental work on Bald's eyesalve; Colman Ó Cathail, Jason Millington, Thorulf VARgSen, Gemma Lunn, Shajini Subhaskaran, Jenny LitTler, Callum PARSONS, and Navneet JANDU, who undertook student research projects to characterize ancientbiotics; Dr Stefanie KüNZEL for contributing expertise in Old English and Anglo-Saxon medicine; Dr James GuRNEY for his feedback on drafts of this chapter; Prof Dave BARRETT, Dr Cath ORTORI, Dr Jing Hu, and Dr Ricky CaIN who brought expertise in medicinal chemistry to the team; Dr Sheyda AzIMI, Jessica Furner-Pardoe, Dr Blessing AnOnYe, Dr Meera UnNikrishnan, and Prof Julie BrucE for beginning work towards safety and efficacy testing of the eyesalve; Dr Charo DEL GENIO for expertise in datamining and network analysis; and Emma RAYNER and Louisa SHEPARD for their expertise in helping us to promote our work to the wider world. We are very grateful to Dr Conor KosTiCK and the attendees at the 2015 "Making the Medieval Relevant" meeting for their feedback on the presentations that formed the genesis of this chapter, to Mike DROUT and Benjamin FRANCKAERT for useful discussion and to the editors and two anonymous reviewers of this volume for their feedback on drafts of our chapter. Finally, for financial support, we thank the Universities of Nottingham, Warwick and Pennsylvania, the Schoenberg Institute for Manuscript Studies, University of Pennsylvania Libraries, the Council on Library and Information Resources, Diabetes UK, the APEX Award scheme, the Microbiology Society, the Medical Research Council Doctoral Training Programme in Interdisciplinary Biomedical Research and 66 very generous members of the public who gave to a crowdfunding campaign. 


\title{
The Contemporary Delegitimization of (Medieval) History - and of the Traditional University Curriculum as a Whole
}

\begin{abstract}
The present delegitimization of History, and particularly of medieval History, is linked to the decline of the nation state, which ensured its own justification by referring to its own age and tradition. Nowaydays, economics, with its ahistorical logic, has become the ideology of a system in which multinational companies and transnational institutions have come to dominate. Seen in a broader perspective, the delegitimization of (medieval) History constitutes only one example of the loss of legitimacy that fundamental disciplines in general have suffered and that results from the fact that currently only monetary values are recognized as core values: advanced capitalism has succeeded in blending its ideology (i. e. its values), which is what enables it to reproduce itself, with the very mechanisms that form its core. As a corollary, the elite curriculum has shifted from fundamental to applied disciplines, leading to a qualitative increase in the recruitment of the latter; in addition, these applied disciplines have also been the main beneficiaries of the massification of higher education. This bifold increase, both qualitative and quantitative, has profoundly modified the relation of forces within the academic field and reversed it in favour of applied disciplines and the resulting social delegitimization has been translated into the academic delegitimization of the fundamental disciplines, of which the contemporary delegitimization of (medieval) History is only an illustration.
\end{abstract}

Keywords: Medieval Studies, tertiary education, France, social capital, capitalism, humanities, ideology

\section{Introduction: Why does a Discipline Question its Own Legitimacy?}

A discipline's capacity to ask why it exists has no intrinsic value. Instead, this value is inversely proportional to the capacity of the surrounding world to confront the

Note: Translated by Bruce L. VenARde (Pittsburgh) / Klaus OSChEmA (Bochum) / Chris JONES (Christchurch / NZ).

Julien Demade, chargé de recherches au CNRS, Laboratoire de médiévistique occidentale de Paris, 17 rue de la Sorbonne, 75005 Paris, France, demade@vjf.cnrs.fr 
discipline with this fundamental question. In other words, a discipline is strong if it can critically reflect on its own legitimacy when unchallenged, but also refuse to do so when its value is subject to external questioning. One might equally say that a discipline is strong when it can preserve its intellectual and scientific autonomy and that it functions well when it is able to question its function but not its existence.

As these initial observations demonstrate, it does not make much sense to ask the question of a discipline's relevance in an 'absolute' way. In order to discuss it in a meaningful way, we have to take into account the social context, implications, and effects of the individual discipline: it seems unlikely that a social organization, which an intellectual discipline certainly is, can ever really question its meaning without instrumentalizing that question. Therefore, it is appropriate, rather, to ask in concrete terms what social and intellectual conditions are likely to cause a discipline to question - or to allow others to question - its legitimacy.

It is hence necessary to set aside the question of value judgment in order to commence the analysis of observable social realities. Two different situations might bring a discipline to instrumentalize the question of its legitimacy. The first case occurs when the legitimacy of a discipline is challenged from the outside: the discipline finds it is called upon to justify itself. In reaction to such an exterior challenge, the question of legitimacy is addressed by the discipline only to avoid losing ground, to try to find a convincing answer - one that satisfies the 'outside' rather than itself. ${ }^{1}$ In the second case, a growing discipline seeks reasons that enable it to justify its expansion at the expense of other disciplines. These two situations refer not to the relative importance of a discipline but to its relative contraction or expansion - they concern trajectory, not standing. Thus, a very new discipline, one still developing and under-institutionalized, will create for itself a highly developed discourse of method to consolidate the positions it progressively gains (as in the case of Sociology in its Durkheimian phase). ${ }^{2}$ Conversely, a long-established and powerful discipline facing competition from newer and more dynamic disciplines will elaborate a self-justifying discourse.

It is clear that (medieval) History today finds itself in the second situation. The question, then, is not whether (medieval) History is now on the defensive; the question is how it has been forced into this position. Is the crisis only 'local', rooted in the growth of related disciplines? If so, this would affect only (medieval) History

1 See e. g. for the example of classical studies, Gilles Siouffi / Alain REy, De la nécessité du grec [ancien] et du latin, Paris 2016.

2 For the two successive moments in the establishment of Sociology in France, see Victor KaRADY, Stratégie de réussite et mode de faire-valoir de la sociologie chez les durkheimiens, in: Revue française de sociologie 20(1) (1979), pp. 49-82; John E. CRAIG, Sociology and Related Disciplines Between the Wars. Maurice Halbwachs and the Imperialism of the Durkheimians, in: Philippe BESNARD (ed.), The Sociological Domain: the Durkheimians and the Founding of French Sociology, Cambridge 1983, pp. 263-289. 
and be likely to preoccupy only (medieval) historians. Or is it instead a local effect of much larger transformations? If it is the latter, it is necessary to understand the situation of (medieval) History today by considering trends that appear to be very distant from it. ${ }^{3}$

\section{Loss of Ideological Utility}

In societies that relied on an ideology structured around the idea of the nation state, the study of history was self-evident: the study of history was an activity whose justification was so obvious one might say it was subconscious and therefore invisible. The image of the state, and still more that of the nation, was rooted in the past, which granted each state its legitimacy. In fact, the more distant that past, the better. It is revealing that, when history emerged as a modern academic discipline in France, at the beginning of the Third Republic (i. e. in the 1880s), most historians were trained medievalists ${ }^{4}$ who studied the history of France. In today's societies, however, the nation state has lost its status as the central component of ideology and has been replaced in this position by the transnational corporation. ${ }^{5}$ This new ideology is no longer structured according to its relationship with time, ${ }^{6}$ but instead

3 The following arguments mainly focus on the French case, with which I am most familiar due to my own training as a medievalist in France (and in Germany) and because I have spent most of my professional career in France (as well as in England and Spain). Wherever it seemed appropriate, however, I have chosen to point out similarities with other academic traditions and contexts.

4 Of those who held chairs in History at French universities in 1900, twenty-one had defended a dissertation in medieval History, ten in 'Modern History' (i. e. the period between the Middle Ages and the French Revolution), and eight in Ancient History, see Charles-Olivier CARBONNEL, Les professeurs d'histoire de l'enseignement supérieur en France au début du XX ${ }^{\mathrm{e}}$ siècle, in: ID. / Georges LIVET (eds.), Au berceau des Annales. Le milieu strasbourgeois: l'histoire en France au début du $\mathrm{XX}^{\mathrm{e}}$ siècle, Toulouse 1983, pp. 89-104. None of these professors had written his thesis on 'Contemporary History' (i. e. on a subject posterior to the French Revolution), because this period was still perceived as being a catalyst for national division rather than national unity. This becomes clear if one thinks of the - somewhat earlier - examples of Adolphe THIERS and François Guizot, who began as historians of the French Revolution and then went on to become influential and controversial politicians. The field was hence highly charged because of its clearly political dimension. 5 This demonstrates the efficiency of the present-day capitalist system. The structure that assures ideological reproduction has become identical with the structure that guarantees real domination, eliminating the possibility of contradiction between the two.

6 Therefore, it is not entirely correct to say that we live in a 'presentist' society, see François HARTOG, Regimes of Historicity. Presentism and Experiences of Time, trans. Saskia Brown, New York 2015 (French original Paris 2003), because this would imply a simple reversal of the once-dominant temporality. In fact, the relationship to time has, in a more essential way, been stripped of significance. HARTOG does not grasp this important point because he is exclusively interested in the uses of history, which prevents him from seeing the very change of history's status as 
tends towards timelessness. ${ }^{7}$ Ideology no longer finds its basis in the long term, but in a utilitarianism made eternal and natural through the sheer force of its logic.

If this loss of ideological utility is general to History, it is particularly notable in the case of medieval History. First, medieval History was once the dominant historical discipline because it performed the primary ideological function of telling the origin story of the nation state - be it the formation of the French territory from Hugh Capet to Joan of Arc, the creation of the German Empire with the Ottonians, the establishment of Spain's Catholic character with the so-called Reconquista, or the creation of the Swiss Confederacy, to name but a few examples. ${ }^{8}$ Secondly, if an ideological function remains for history, it has largely shifted to contemporary history ${ }^{9}$ - which certainly does not mean that medieval history has lost its ideological value entirely, ${ }^{10}$ but that this value is diminishing.

More generally, however, beyond the paradigmatic case of the disappearance of the immediate and central ideological function of history (medieval history in particular) lies the end of the indirect yet still central ideological function of intellectual activity in general. While intellectual life may once have served to signify - symbolically collective as well as individual value, ${ }^{11}$ today those functions are assumed by completely different social actors. These days, professional sports symbolize the

ideology. The matter is not merely a transformation in the functioning of history as ideology (that is, the periods on which it is based and the nature of the relationship it maintains to these periods), but more essentially, those transformations that affect the functioning of ideology and the diminished place history occupies in it.

7 In this regard, the evolution of Economics as a discipline, from its strongly historiographical origins (for example, in the work of Adam Smith, not to mention the subsequent dominance of the historische Schule in the second half of the 19th century) to its current interests in cognitive biology, is very revealing of much more general developments.

8 This general tendency does, of course, not preclude that other periods of history could, in specific countries, be the favored ones of the historicist ideology - for instance Roman antiquity in Italy.

9 There is no better indicator for this development than the evolution of secondary school curricula - if one accepts that these are by nature ideological -, which devote an ever more essential role to (ultra)contemporary history. But one might also think about what Germans at the end of the 20th century called, plain and simple, der Historikerstreit ("the historians' quarrel"), though the focus of this debate was entirely on 20th century history. It is equally striking that, when the Real Academia de la Historia published its monumental 50-volume "Diccionario Biográfico español", public debate arose only around figures linked to the Spanish civil war, see Tereixa CONSTENLA, La Real Academia cuenta su Historia, in: El País, 31 May 2011, online: https://elpais.com/diario/2011/05/31/cultura/ 1306792801_850215.html (last accessed 15/05/2019).

10 See, for example, the controversy surrounding Sylvain GouguenheIM, Aristote au Mont-SaintMichel. Les racines grecques de l'Europe chrétienne, Paris 2008, notably Philippe BüTTGEN et al. (eds.), Les Grecs, les Arabes et nous. Enquête sur l'islamophobie savante, Paris 2009; as well as, a little earlier, the extraordinary hype over the (putative) 1,500th anniversary of the baptism of Clovis, as organized by the very official "Comité pour la commémoration des origines" (created by the President of the French Republic - decree $n^{\circ}$ 96-180, 11/03/1996).

11 The first serving to mask internal contradictions, the second to justify domination. 
collective, and it is 'celebrities' (a group that notably includes athletes, but excludes intellectuals) ${ }^{12}$ who embody individual excellence: hence in France, for example, Zinedine Zidane and Johnny Hallyday have replaced Pasteur and Hugo in the pantheon of the venerated and honoured. ${ }^{13}$ The 'glitterati' have replaced the literati. Where governments and rulers once built universities to demonstrate their might and value (like Strasbourg for the German Second Reich and the Sorbonne for the French Third Republic), ${ }^{14}$ today they build stadiums, ${ }^{15}$ wasting immense sums in a process that is repeated every four years for the Olympic Games.

The loss of the ideological utility of intellectual activity in general and of (medieval) history in particular is all the more striking because of its context. The justificatory worth of ideological utility has diminished in favour of another kind of utility: the economic. Ideological value is now largely linked to economic value: a great soccer club is one that makes a lot of money, a great artist is one who has the largest revenues, a great university is one whose endowment is the largest ${ }^{16}$ and whose former students are the best paid once they start their professional career, and so on. Mature capitalism has managed to match its ideological values to monetary value, which is at the heart of its practical function. This coincidence is both a sign and a means of the efficiency attained by this mature system. For (medieval)

12 More precisely, the only 'intellectuals' who seek to belong to this group - and do so successfully - pay the price of getting out of touch with their originally academic milieu: hence only nonspecialists continue to consider figures like Bernard-Henri LÉvY or Claude ALLĖGRE as, respectively, philosopher and scientist.

13 "Johnny, it's Victor Hugo" reads a title in France's newspaper of reference, see Michel GuERRIN, Johnny, c'est Victor Hugo, in: Le Monde, 8 December 2017, online: http://www. lemonde.fr/idees/article/2017/12/08/les-champs-ce-sera-une-premiere-pour-un-chanteur-maisjohnny-c-est-victor-hugo_5226476_3232.html (last accessed 15/05/2019).

14 In Strasbourg, control over which was a central concern in the international politics of the Belle Époque, the whole cityscape constructed by the Hohenzollerns around the 'University Palace' was a counterpart to nothing less than the imperial palace. Each complex was built on the two opposites of the same monumental axis and served symbolically as the two essential elements, the one political and the other intellectual, of taking territory into possession. See John E. CRAIG, Scholarship and Nation Building. The Universities of Strasbourg and Alsatian Society (1870-1939), Chicago 1984.

15 This phenomenon, which took some time to become widespread and whose full effect is being felt only today, was the brainchild of the interwar fascists. Examples include the Stadio Benito Mussolini in Turin (1933) or, even more significant, the Reichssportfeld in Berlin (1936) and the Deutsches Stadion in Nuremberg (begun in 1937 but never completed). Both German stadiums were directly linked to properly political spaces (Maifeld, the parade ground in Berlin, and the Reichsparteitagsgelände complex in Nuremberg) and constituted one component of the urban axis structuring each city.

16 More generally, academia is currently turning into a system of "academic capitalism", in which, for universities, "achievement is measured, in the first instance, by the accumulation of capital, just as it is done for a capitalist business". See Richard MüNCH, Academic Capitalism, in: Oxford Research Encyclopedia of Politics, Oxford 2016, p. 12, online: DOI:10.1093/acrefore/9780190228637.013.15 (last accessed 15/05/2019). 
History, as for any other 'economically useless' discipline, the maturity of the system means these disciplines now stand at odds with the system, because it no longer really needs such disciplines to assure its reproduction. While it once simply used those disciplines ideologically in support of its own logic, the capitalist system, because it has matured, now aims to submit them directly to its own logic. It no longer allows them to survive, except to the extent that they respond to a sufficient demand for cultural formation and/or consumption ${ }^{17}$ - and it is precisely (medieval) history's loss of ideological function that brings about decreased demand. On the one hand, this loss means that (medieval) history ceases to be the object of major intellectual debates, which diverts the educated public from taking interest in it and lessens its cultural consumption. On the other hand, (medieval) history's loss of ideological function brings about a reduction in the state's emphasis on the educational value of the subject. (Medieval) history is no longer at the centre of national plans for ideological acculturation, and so reduced interest in (medieval) history brings with it shrinking numbers of secondary school teachers in this field. That decline, in turn, puts an end to students' primary job prospects and thereby generates a crisis in the recruitment of students to study (medieval) history.

\section{Divorce from the Elite Curriculum}

The recent decline in student numbers has first and foremost occurred in those 'useless disciplines' that have only an indirect ideological function, ${ }^{18}$ followed by those that once assumed a direct ideological function, including (medieval) History. As faculty numbers correlate to the number of students, it is, therefore, the very perpetuation of these fields that is at stake. However, it would be an error to think that this decline in student numbers is the most important indicator of the delegitimization of (medieval) History, along with other 'useless' disciplines. Because if we take the long view, what is most striking about student (and therefore faculty) numbers is in fact their extraordinary increase ${ }^{19}$ Consequently, should we choose to interpret

17 For English plans to stop subsidizing curricula in the Humanities, see Hannah RicHARDSON, Humanities to Lose English Universities Teaching Grant, in: BBC News, 26/10/2010, online: http:// www.bbc.com/news/education-11627843 (last accessed 15/05/2019).

18 For these disciplines, see Bernard ConverT, Les impasses de la démocratisation scolaire. Sur une prétendue crise des vocations scientifiques, Paris 2006.

19 While in 1952, there were 1,715 faculty members in faculties of arts and sciences in France, their number rose to 37,959 in 2005; the number of faculty in medieval History alone rose from 398 to 724 between 1986 and 2005. See Charles Soulí / Brice LE GALL, Massification, professionnalisation, et réforme du gouvernement des universités. Une actualisation du conflit des facultés en France, in: Charles Soullé / Christophe CHARLE (eds.), Les ravages de la modernisation universitaire en Europe, Paris 2007, tables 1, 2, and 4. 
these figures as a precise indicator of the value society attributes to disciplines, we would have to recognize a continuous long-term increase. The recent decline in numbers represents only a very minor correction in comparison to a long-term growth until the end of the twentieth century - an expansion that would have been unimaginable a hundred years ago.

Yet the fundamental indicator is not so much the quantitative but the qualitative evolution concerning the students who study the 'useless disciplines': this does not refer to the scholarly or intellectual quality of students, but rather to their social quality, which is characterized by their origins before their studies and by their future in the social arena after their studies. The observable development and its chronology are quite different from what has been described above for the quantitative dimension: the deterioration of the social status of the new recruits to the useless disciplines is quite significant and began earlier than the quantitative involution of the field. The extent of change that has affected the curriculum chosen by students of the social elite (and who are meant to reproduce it) is exemplified by the Hautes Études Commerciales (HEC) in Paris. Founded at the end of the nineteenth century as a second-rate school for 'Daddy's boys' who were unable to pass the baccalaureate exam (which explains the absence, at first, of an entrance exam), ${ }^{20}$ today this institution is the French school of higher education that has most alumni among the CEOs of the Fortune Global 500. ${ }^{21}$

In France, where since the nineteenth century technical schools have played an important role (although then clearly shared with universities) in the production of elites, ${ }^{22}$ the transfer of the elites' curriculum from the fundamental to the applied disciplines has been the least abrupt. In the Germany of Bildung, on the contrary, higher education was characterized by a social divide: on one side were old universities that, because they were devoted solely to traditional disciplines, were prestigious; on the other side, new institutions of higher education - the Technische Hochschulen - that, because they were restricted to applied disciplines,

20 The self-designated slang term for HEC students was "fistici" for "le fils est ici" ["the son is here"]. The HEC "was long considered a minor school [. . . offering to students whose birth destined them for social success a means to hide their academic failure”. See Pierre BourdiEU, La noblesse d'État: Grandes écoles et esprit de corps, Paris 1989, p. 236 n. 36 and p. 279; engl. trans. Pierre Bourdieu, The State Nobility. Elite Schools in the Field of Power, trans. Lauretta C. Clough, Cambridge 1996, pp. 168 n. 41 and p. 198.

21 Mines ParisTech, Classement international professionnel des établissements d'enseignement supérieur, enquête 2011, Paris 2011, p. 23, online: http://www.mines-paristech.fr/Donnees/data03/ 334-10.-Classements.pdf (last accessed 15/05/2019).

22 The Grandes Écoles were notably responsible for the education of civil servants and military officers, but their alumni also often held 'top-notch' positions in the private sector. 
were considered second rate. ${ }^{23}$ In the meantime, a radical change has taken place: today, the differentiation between the two types of institutions has not only been removed (since between the 1960s and the 1980s), but in addition the hierarchy of first and second rate has sometimes been reversed. ${ }^{24}$

The resulting question - which extends far beyond (medieval) History - is twofold: Why was it formerly considered necessary to include 'useless' disciplines as an essential element in the education of elites? And which changes in the structure of the elites and the economy enabled the disappearance of that necessity in favour of applied education $?^{25}$ Whatever the answer to these questions, a response that would identify as 'decline' what is in fact a sociological transformation, or that sees in it a development guided by values (in particular the loss of respect for useless knowledge) rather than sociological pressures, is unacceptable. This kind of answer would in fact lead to nothing other than the myth of a former 'golden age', one characterized by a beneficent, traditional national capitalism, in order to contrast it with its current, 'global', deviant incarnation. ${ }^{26}$ It is a myth, because it relies on an incorrect assumption: the fact that the classic curriculum of the elites lent a distinguished place to disciplines that were at once fundamental and, practically speaking, useless, does not enable us to assume that this must have been in recognition of the value of their very uselessness. Instead, beyond high-minded rhetorical flourishes concerning the value of the traditional curriculum lies a central fact: the mastery of fundamental knowledge served a specific purpose and it was hence not useless at all. The questions, then, are, what that 'usefulness of uselessness' could have been, at least in the education of elites, and why this 'usefulness of uselessness' has now vanished from

23 For comparison between higher education in Germany and France from 1850 to 1950, especially in terms of the history of ideas, see Fritz K. RINGER, Fields of Knowledge. French Academic Culture in Comparative Perspective, 1890-1920, Cambridge 1992.

24 In Germany, two of the first three universities which received the label of Eliteuniversität, created in 2006, were Technische Universitäten, while the traditional elite German universities of Heidelberg, Göttingen, and Berlin were excluded.

25 A medievalist is of course poorly equipped to respond to these questions, which instead call for a contemporary historian and sociologist specializing in education. Having myself done extensive research on both contemporary history and present-day society (see Julien DEMADE, Les embarras de Paris, ou l'illusion techniciste de la politique des déplacements, Paris 2015, and ID., Produire un fait scientifique. Beveridge et le Comité international d'histoire des prix, Paris 2018), I hope, however, that I might not be the worst-suited medievalist for such an endeavour.

26 To be convinced that such an argument is unacceptable, we need only note the impasses into which it drives us. It makes little sense to locate moral superiority in the larger role played by the fundamental disciplines in England or Germany of 1900 considering their manifestly inegalitarian and endogamous social structures, whose ties to the structures of higher education at the time are undeniable. See for instance, concerning the relationship between German academics and reactionary forces during and after the second Reich: Fritz K. RINGER, The Decline of the German Mandarins. The German Academic Community 1890-1933, Cambridge / MA 1969. 
the education of the elites (as it has, for that matter, from the education of other social groups)?

The explanation for the disappearance of 'useful uselessness' could, at first glance, be sought in the deepening division of labour, which, after affecting the dominated through 'scientific management', then reached the dominant, who have become specialists in clearly delineated operations of domination (financial services, marketing, human resources, and so on). Until the interwar period, the division of labour among the dominant remained largely limited to a division between engineers and all other members of the dominant group, with their less differentiated functions. The new delineations arose from the increased size of businesses through the process of concentration, something characteristic of the dynamics of the capitalist mode of production. Since, apart from the management of production, acts of domination were once general, this profile logically matched an equally general education. However, this explanation only shifts the problem: it is not obvious at all that this general education should have focussed on areas that had no link with business management, instead of providing insights into different activities (beyond the technical control of production) that were characteristic of it. ${ }^{27}$

In order to identify the reasons for the transformation of the elite curriculum, it thus seems more pertinent to address this basic transformation of mature capitalism: the replacement of capitalist owners with salaried managers at the top of businesses $^{28}$ - a transformation that just as well came about through the growth of the size of businesses, as concentration involved a dilution of capital. Because the capitalist owner assumed a general social function of domination, which was in no way limited to the management of his business, but potentially extended to all social fields, ${ }^{29}$ the specific competence of managing a business was only one element of

27 That was indeed the direction chosen around this time by the creators of the first Master of Business Administration (MBA) degree (at Harvard in 1908). But this kind of education, even though it was to have a great future in the curriculum of elites, took a long time to become widespread: as late as in 1930, there were still only three universities in the US offering this degree and it did not make its appearance in Europe until 1957. See Lars ENGWALL / Vera ZAMAGNI (eds.), Management Education in Historical Perspective, Manchester 1998.

28 Alfred Chandler, The Visible Hand. The Managerial Revolution in American Business, Cambridge / MA 1977; Hartmut KAELBLE, Long-term changes in the recruitment of the business elite: Germany compared to the U.S., Great Britain and France since the industrial revolution, in: Journal of Social History 13(3) (1980), pp. 404-423.

29 This was especially true in the political realm. Eugène $1^{\text {er }}$ Schneider, besides creating a family steel conglomerate, was a minister of Agriculture and Commerce, and a president of the French assembly, whilst in the 68 years between 1842 and 1910 one or another Schneider was elected as a deputy for 45 years; François de Wendel, besides managing a family mining and steel conglomerate, was a deputy and then a senator for more than thirty years; similar cases may be observed in Germany, for instance Hugo Stinnes. See for a general approach Jean GARRIGUES, Les patrons et la politique, de Schneider à Seillière, Paris 2002; for a case study see Jean-Noël JEANNENEY, François de Wendel en République. L'argent et le pouvoir (1914-1940), Paris 2004. Patronage, too, was an 
expertise among the many that were required of him. This array of demands was so varied that it could not be mastered by any one sort of practical education. The only solution was to rely on some sort of fundamental education that did not provide any specific expertise, but rather guaranteed a variety of general competences. ${ }^{30}$ For instance, graduates in History from Oxford between 1873 and 1929 "entered the highest levels of the civil, foreign, imperial and diplomatic services, politics, the Church, the military, law, journalism, letters, publishing, banking, economics, and university and secondary school teaching and administration; honours graduates in history were the product of a course of study intended explicitly to prepare them for important careers". ${ }^{31}$ Managers, on the other hand, based their legitimacy not only on the fact that they focussed exclusively on entrepreneurial matters (since the growth of the size of businesses left no time for other fields of action), ${ }^{32}$ but above all on the special expertise, vouched for by their academic credentials, that they had in running a business. The transformation of the curriculum of the elite thus indicates the transformation of the elite itself. Within the framework of internal struggles that resulted in the inversion of the dominant and dominated fractions, this was an essential instrument in the context of these struggles themselves.

The reasons why managers, in the field of domination as it was structured, stressed their special expertise (soon to be reinforced by academic credentials), should be clear: this was the only option they had when confronted with the generalist fashion in which capitalist owners carried out their functions. But how could this have turned into a winning strategy? Indeed, if the dominant fraction of the dominant class opted for a fundamental, and not 'applied' education, the reason lay not only in economic structures (that is, the limited size of businesses that

essential field of action for the reproduction of domination by means of justification, a field illustrated, for example, by the French branch of the Rothschilds or by Heinrich Thyssen. See Pauline Prevost-Marcilhacy, Les Rothschild. Une dynastie de mécènes en France, Paris 2016.

30 Another solution, adopted by textile manufacturers in the north of France, was also possible: all intellectual education was absent, replaced by on-the-job training from a very young age. Conversely, for steel manufacturers in eastern France, intellectual education, whether applied (notably through the School of Mines) or not, played a much more important role.

31 Reba SofFer, Nation, duty, character and confidence: history at Oxford, 1850-1914, in: Historical Journal 30(1) (1987), pp. 77-104, here p. 79.

32 It was not, of course, that capitalist power withdrew from them, but because more than ever before, it began to act via proxies within a framework of division of labour. The professionalization of politics (linked to particular types of higher education) went hand-in-hand with the professionalization of the management of businesses. For instance, whereas in the interwar period Maurice de Rothschild, first as deputy and then as a senator, directly fought for the interests of his bank in the political arena, after the Second World War this role fell to Georges Pompidou, a professional politician who had only briefly been director of the Rothschild bank (and hence to a man with a profile similar to that of another president of the French Republic: Emmanuel Macron). See Martine ORANGE, Rothschild, une banque au pouvoir, Paris 2012. 
allowed owners to invest in social fields other than the economic) but equally in the mechanisms of control over the reproduction of the elites themselves.

Between the second half of the nineteenth century and the first half of the twentieth, advanced study and membership of the dominant class went together to a considerable extent. ${ }^{33}$ Therefore, advanced study was not only, as today, a necessary condition for membership of the dominant class, but rather both necessary and sufficient at the same time. ${ }^{34}$ Hence control of access to this kind of study was vital for the reproduction of the dominant class. Those seeking social advancement tended to orient themselves toward practical education that allowed them to gain access to a profession, ${ }^{35}$ because fundamental education did not in itself allow them to secure a job while they lacked an appropriate network of (social) connections. Thus, it was very much the 'useless' character of fundamental education itself that made this field the preserve of elites: it could be used as an instrument to organize access to the dominant fraction of the dominant class by way of making it a simple matter of reproduction, whereas access to the dominated fraction of the dominant class was through applied education. Moreover, as the function of higher education consisted above all in social aggregation (since it was the sufficient condition of inclusion into the dominant class), studying fundamental disciplines could not be a problem because the function of education was not economic and did not aim at the acquisition of useful and practical expertise. Fundamental education, with the general competences it provided, was thus not only well adapted to the still little-differentiated exercise of power, but it facilitated cordoning off access to that power as well. ${ }^{36}$ Hence the

33 One should never forget that, for instance, in Germany in 1910 less than $1 \%$ of an age cohort entered university, and that in France in 1930 it still wasn't more than $2 \%$. See Fritz K. RINGER, Admission, in: Walter RÜEGG (ed.), A History of the University in Europe, vol. 3: Universities in the Nineteenth and Early Twentieth Centuries (1800-1945), Cambridge 2004, pp. 233-246, here pp. 238, 242.

34 England is peculiar in this respect, since it was rather secondary schooling, or more precisely the type of secondary schooling (the so-called public schools vs. the other forms of secondary schooling), that worked as the educational operator for belonging to the upper class. See W. D. RuBinstein, Education and the Social Origins of British Elites 1880-1970, in: Past \& Present 112(1) (1986), pp. 163-207, here pp. 174-175.

35 Just as well they tended to be oriented towards such practical disciplines: "In 1910 only 7 per cent of the students at English universities received grants, and these were mainly for technical training”. See Christophe CHARLE, Patterns, in: RÜEGG (note 33), pp. 33-80, here p. 63.

36 These two characteristics make clear that the 'useless' could not be 'useful', except when it concerned the production of members of the dominant fraction of the dominant class. Therefore, the usefulness of uselessness was an attribute strictly dependent on the social origin of students, which hence vanished with the transformation of this social background. This process thus undermined the legitimacy of fundamental disciplines, because the 'useless' became 'useless' indeed. 
fact that for instance at the university of Glasgow in 1913-1914 "as many as 79 percent of students were taking the general degree course, with its broad training"; even in the interwar period no less than 80 per cent of Oxford's students were still in the arts faculties. ${ }^{37}$

These observations should make clear that the success of the managers' strategy for joining the dominant fraction of the dominant class by highlighting their applied education was not a foregone conclusion. Of course, it relied on special expertise that was better and better calibrated to the growth in size - and thus in complexity - of businesses. But at the same time, the strategy made control of the reproduction of elites through higher education more difficult, since applied education allowed less economic segregation of new members of the elite. This difficulty was all the greater because advanced education continued to become more widely available, and thus could not function in itself as a sufficient means to control access to the dominant class. Therefore, conversely to the managers' strategy, it would have been necessary to maintain the privilege of fundamental education, which was the only branch of education that could ensure the perpetuation of the identical reproduction of elites through higher education, despite the drive to mass higher education.

Yet that is not at all what happened. The drive to mass higher education succeeded not only through some applied disciplines (in France, the Administration Économique et Sociale, the Instituts Universitaires de Technologie, and so forth). At the same time, the 'useless' disciplines became just as well characterized by considerable numbers of newcomers of middle-class origins and mediocre social prospects, whereas the elites' heirs henceforth focussed on certain applied disciplines from which the newcomers now found themselves excluded.

The transformation of the elites' curriculum was thus motivated by a more imperative reason than just the modification of business structures or the control of the reproduction of elites. That prevailing reason was the necessary correspondence between the elite curriculum on the one hand and the central figure of ideology on the other. Only on the basis of this correspondence could the dominant position of the elites be justified and thus made acceptable to the dominated. On the other hand, any fundamental lack of correspondence, that is, when the dominant form of ideology corresponds only to the curriculum of the dominated, would lead to a disruption of power relations: it would legitimate the dominated and therefore delegitimize domination, which would thus become impossible. ${ }^{38}$

37 Gillian Sutherland, Education, in: F. M. L. THompson (ed.), The Cambridge Social History of Britain 1750-1950, vol. 3: Social Agencies and Institutions, Cambridge 1990, pp. 119-170, here pp. $158,167$.

38 We must not confuse this fundamental imbalance with a secondary form of imbalance as it occurs when the curriculum of elites is no longer adapted to the dominant form of ideology. The curriculum adapted to this new form becomes the monopoly of another elite, hence this secondary form of a lack of correspondence results only in the substitution of one elite for another. It does not 
As I have already said, mature capitalism, in contrast to its earlier stages, is characterized by the convergence of the social function of reproduction and the ideology that ensures the possibility of that reproduction. We could sum this up as 'the monetarization of ideology': monetary value has become paramount for all other types of social values. As a result, the curriculum of elites necessarily had to reorient itself toward the applied study of the techniques of capitalist domination (management, marketing, law, public relations, economics, and so on), since they are the means of producing monetary value. The curricular reorientation had the additional advantage of reinforcing the elite's practical capacity to master the economic system. The outcome was thus doubly advantageous, both ideologically and practically, which makes it characteristic of mature capitalism. In this way, the rule of practice over theory was established, which relegates the latter - and along with it the fundamental disciplines and academic institutions ${ }^{39}$ that exemplify it - to the dominated fraction of the academic field. Thus the 'democratization' of student and faculty recruitment in these fields, meaning the negative change in their social attributes alongside those of these newly diminished disciplines, became possible as well as necessary.

Applied disciplines and training have benefited not only from the reorientation of elite curriculum towards them (qualitative advance) but also from the extraordinary rise in their numbers (quantitative advance). This is due to the drive to mass higher education - preferentially concentrated on applied disciplines and training -, that is, the process by which advanced teaching began to have as its chief function the production not of the dominant but the dominated, specifically the dominant fraction of the dominated, that is the middle management. ${ }^{40}$ This transformation is owed to the increase in labour productivity, which prompted a double transfer of labour formerly devoted to physical production: on the one

question the structures of domination, only their means of realization, as in the case of the transition from capitalist owners to managers.

39 There has indeed been, within the academic field stricto sensu (French as well as foreign), a change in the balance of power in favour of applied education. Emblematic in this regard is the case of the University of Paris-Dauphine (specializing in Business 'Sciences', which are simply techniques), which at its origin in 1971 was not even designed as a fully functioning university and which obtained the highest-ranking status of Grande École in 2014. In just over forty years, its trajectory has thus led it from the most dominated fraction of the academic field to the most dominant fraction. See http:// www.dauphine.fr/fr/universite/dauphine-historique.html (last accessed 15/05/2019).

40 The upheaval in the function of advanced education can be conveniently dated to the academic crisis brought about by it around 1968 in Germany, Italy, and the US as well as in France, see Pierre BourdiEu, Homo Academicus, Cambridge 1990, ch. 5. Between 1960 and 1970, student enrolment went from 240,000 to 695,000 in France, and from 268,000 to 682,000 in Italy, see Guy NEAVE, Patterns, in: Walter RÜEGG (ed.), A History of the University in Europe, vol. 4: Universities since 1945, Cambridge 2011, pp. 31-69, here p. 42. For the creation of middle management as a new social group, see Luc BolTANSKI, The Making of a Class. Cadres in French Society, Cambridge 1987. 
hand to the design and control of that physical production, and on the other hand to the creation of the intangible value of physical production through marketing and branding.

This transfer made higher education the production site for, first, the domination wielded over the dominated (as the dominated internalized and reproduced this domination) and secondly, the value of the dominated to the system of domination (ensuring that they fit into the process of production in a way profitable for the dominant). Both productions are ideally ensured by applied disciplines and training. They now transmit the very ideology of mature capitalism, justifying the domination over the dominated. ${ }^{41}$ Additionally, they strengthen the effectiveness of the workforce by making it incorporate techniques likely to ensure the enlarged practical reproduction of the system. The consequence of this change is that fundamental disciplines have suffered not only a qualitative decline in their recruitment, but also a relative quantitative decline, because within the framework of the drive to mass higher education their numbers have risen less rapidly. In France, for example, although between 1986 and 2005 faculty numbers rose considerably in French Literature (+31\%), Theoretical Chemistry (+54\%), Mathematics (+75\%), and Ancient and Medieval History (+82\%), the increase was much greater in Mechanical Engineering (+188 \%), Business (+280 \%), Computer Science (+291\%), and Communications $(+399 \%){ }^{42}$ The numbers of students as well as of faculty in the fundamental disciplines certainly rose, giving these disciplines a quantitative importance unimaginable at the time their social value was most unanimously acknowledged. That being the case, the decline of these disciplines, as clearly (if not easily perceptibly) indicated by the qualitative and (relative) quantitative decline in recruitment, could long go unrecognized.

41 If 'applied disciplines' nowadays are the privileged way to inculcate ideology among the dominated, this is by no means due to any inherent property they possess, but rather is owed to their congruence with the current stage of the development of capitalism. Hence it is completely futile to cultivate essentialist ideas that irreducibly contrast 'fundamental disciplines', which would further reflexivity and therefore emancipation, with 'applied disciplines', which would accustom their students to the passive application of unquestioned laws and therefore alienation. It is undeniable that, at present, the capacity for protest is concentrated among both students and instructors of the fundamental disciplines, incompatible as they are with the reproduction of the ideology of the capitalist system in its mature stage. In an earlier stage of capitalism, however, members of the fundamental disciplines were in harmony with the dominant ideology; the most devoted acolytes of the ruling order were among their representative members. An excellent illustration is the behaviour of German students and scholars under the Nazi regime. For the particular case of medieval History and more specifically medievalists studying rural areas, see Julien DEMADE, The Medieval Countryside in German-language Historiography since the 1930s, in: Isabel ALFONSO ANTON (ed.), The Rural History of Medieval European Societies. Trends and Perspectives (The Medieval Countryside 1), Turnhout 2007, pp. 173-206. Conversely, that great monument to applied disciplines, the Encyclopédie of Diderot and d'Alembert, was a protest against the last stage of the ecclesio-feudal system.

42 See Soulié / Le GALL (note 19), tables 3, 4, and 5. 
All in all, the lowering of the (social) quality of recruits to the fundamental disciplines has made possible their growth in absolute terms. This corresponds to a crucial transformation in the reasons which determine the students' decision to study those fundamental disciplines. Far from continuing to be chosen, as they formerly were, by heirs to the elites for the exclusively general skills they provided, the fundamental disciplines were now chosen by the new recruits for their ability to provide jobs in secondary education, which expanded quantitatively alongside tertiary education. Students of fundamental disciplines, because they were now new recruits to higher education, gravitated toward them precisely because of the immediate job prospects they offered - and ultimately behaved towards them just as their predecessors once did towards applied disciplines. Thus, the fundamental disciplines became, in the use students made of them, a 'practical' education like any other. Its place in the hierarchy of instruction corresponds to the place of the profession for which it prepares its students in the hierarchy of professions - a very low place, as it turns out, because it is not tied to an economic function.

As a consequence, the qualitative transformation in students' objectives made possible the absolute quantitative increase in their numbers - all the while aggravating the qualitative social decline of recruitment to the fundamental disciplines, as this decline was due not only to the disappearance of the heirs (a negative factor of deterioration) but also (and more so) to the massive influx of new recruits (a positive factor of deterioration). The combination of this absolute qualitative decrease and the relative quantitative decrease produced a twofold delegitimization of the fundamental disciplines ${ }^{43}$ and ended up bringing about, today, a quantitative decline in terms not only relative but indeed absolute - first of students, then of faculty -, which added a supplementary source of delegitimization. The decline will hence probably be both long and steep, leaving the academic field turned upside

43 In addition to the fundamental delegitimization linked to the loss of a central ideological role, loss which in itself brought about the two subsequent delegitimizations under discussion here. Regarding the latter, the essential factor is certainly qualitative decline, the hierarchy of disciplines being directly linked to the place of their students and faculty in the social hierarchy. Nevertheless, the relative quantitative decline is far from being without effect - not so much on the general perception of the fundamental disciplines, but rather on their place within the academic field: the transformation of the relative importance of disciplines brings about modifications to the power relations inside as well as between faculties. Seen from this perspective, applied disciplines are clearly in the ascendant: to the detriment of the fundamental disciplines, they now exceed the former in terms of numbers, position, and respectability (all of which were formerly privileges of the latter), and generally exercise increasing influence over the policy choices of each university to their own benefit. In France, for instance, in 1986 the number of university students in Geography was $15 \%$ higher than the number in Business; in 2005 it was $50 \%$ lower. The same goes for Philosophy versus 'Information and Communications Science': in the mid-1980s, there were twoand-a-half times more students in Philosophy than in the newer discipline; by 2005 that number had fallen to less than $40 \%$ of the number enrolled in 'Information and Communications Science', see SoUlí̂ / LE GALL (note 19), tables 3 and 4. 
down because it will give absolute domination to applied training to the detriment of fundamental disciplines. Such, at least, is the lesson to be derived from the American example, which one can rightly consider, as the most advanced capitalist system, a precursor of changes that Western Europe frequently faithfully reproduces after some delay. Based on a theoretical index of 100 as baseline for 1970, the number of masters' degrees awarded in the USA declined, 30 years later, to 59 in Mathematics, 80 in Physical Sciences, 83 in Social Sciences and History, while it exploded to 401 in Law, 448 in Business, and 759 in Medicine. ${ }^{44}$ The drive to mass higher education has hence been, for the fundamental disciplines, nothing but a temporary illusion.

\section{Conclusion}

The fundamental disciplines lost legitimacy as ideological reproducers of the social system, a role which was especially important in the case of (medieval) History. These same disciplines also lost the role they played in the reproduction of the dominant class, which reinforced their delegitimization, the academic hierarchy being based on the social position of students. This double delegitimization, in the sense of a twofold loss of function, ended up bringing about today's drop in recruitment - after a temporary explosion of numbers that did nothing but reinforce the illegitimacy of student recruitment and that finally was nothing more than a flash in the pan. The background and the effects of this decline in recruitment should prevent us from thinking that we might be able to compensate for the loss of the fundamental disciplines' ideological function by claiming some kind of economic justification that could be linked to student 'demand'. The fundamental disciplines, which have lost the traditional foundations of their social utility, have proved to be incapable of substituting a different form of social utility.

Could one thus imagine a better moment to ask if the justification and the meaning of intellectual disciplines (but also more broadly of any action) could not derive from something other than social utility? Or, perhaps even more importantly, are there not other forms of legitimization that have nothing to do with the reproduction of social forms whose own legitimacy it is perfectly justifiable to question ${ }^{45}$

44 CONVERT (note 18), p. 71, table 13.

45 For reflections of this sort carried out with exclusive reference to (medieval) History, see Julien DEMADE, L'histoire (médiévale) peut-elle exciper d'une utilité intellectuelle qui lui soit spécifique?, in: Didier MÉHu / Néri de BaRRos Almeida / Marcelo CÂNDIDO DA Silva (eds.), Pourquoi étudier le Moyen Âge? Les médiévistes face aux usages sociaux du passé (Histoire ancienne et médiévale 114), Paris 2012, pp. 15-60. 


\title{
Pacific Perspectives: Why study Europe's Middle Ages in Aotearoa New Zealand?
}

\begin{abstract}
It could be argued that the teaching of medieval history, while of intrinsic interest, is a colonial legacy that has very little relevance in the university curricula of a Pacific nation such as Aotearoa New Zealand. This chapter argues that, alongside the important role that an accurate understanding of Europe's past has to play in discrediting erroneous modern arguments, the teaching of medieval history remains relevant in Aotearoa for two key reasons. The first is that it enables a better understanding of New Zealand's colonial past and its legacies. The recent debate surrounding the naming of "The Crusaders" rugby team illustrates that understanding both the reality of the Middle Ages and the way in which the medieval was interpreted in the nineteenth and twentieth centuries is by no means unimportant. Similarly, the origins of New Zealand's legal and constitutional arrangements underline the continued relevance of establishing a sound understanding of the Middle Ages. Nevertheless, there is a second, possibly more important, reason for continuing to study the medieval in Aotearoa: the Middle Ages are, potentially, an excellent vehicle for better integrating Aotearoa's official policy of biculturalism into university curricula. To fulfil such a goal would require adjusting the way in which medieval history is taught at university to integrate comparison with Māori culture and values. By adopting such an approach, however, the chapter suggests that teaching Europe's Middle Ages will not only remain relevant to a society seeking to move beyond its colonial legacies but that it raises the possibility of introducing new and innovative approaches to medieval research.
\end{abstract}

Keywords: constitutional debate, common law, reception of the Middle Ages, teaching the Middle Ages, medieval legacies, Māori and Indigenous Studies, biculturalism, Christchurch (Aotearoa New Zealand), genealogy, Treaty of Waitangi, tertiary education

If we set aside the argument that the study of every subject is intrinsically interesting for its own sake, there seems, at least at first glance, very little reason why studying the history of medieval Europe should be relevant in the remote Pacific

\footnotetext{
Chris Jones, University of Canterbury, Christchurch, NZ, Department of History, Private Bag 4800, Christchurch 8140, New Zealand, chris.jones@canterbury.ac.nz Madi Williams, Ngāti Kuia, Ngāti Kōata, Ngāti Apa ki te Rā Tō; Ngāi Tahu Research Centre, University of Canterbury, Private Bag 4800, Christchurch 8140, New Zealand, madi.williams@canterbury.ac.nz 
nation of Aotearoa New Zealand. ${ }^{1}$ It would be difficult to argue, for example, that an understanding of the Middle Ages contributes in anything but the most tangential way to understanding the process of colonization. New Zealand was settled by Europeans relatively late. The immigrants who arrived in the nineteenth century were no less convinced of the superiority of their society than those who had arrived in the New World several centuries earlier. Yet, despite the influence of nineteenth-century evangelical movements, the values of New Zealand's colonizers were firmly defined by the Enlightenment and the Industrial Revolution, not the later Middle Ages and the Reformation. It could also be argued that, starting in the mid-twentieth century, and particularly since the 1970s, New Zealand has worked hard to shake off even that colonial legacy. The country has been particularly innovative in seeking to recognize and restore the rights of the indigenous Māori population, who had been subject to land confiscations and social marginalization in the previous century and a half. Indeed, the New Zealand of the twenty-first century increasingly looks to the Asia Pacific region rather than to Europe in general and - as it did up until the 1970s - to Britain specifically. China, alongside Australia and the European Union, is now one of the country's largest trading partners. ${ }^{2}$ And Aotearoa's demographic picture, while it remains dominated by Europeans and those of European descent, is shifting notably. Immigration and changing birth rates are projected over the next twenty years to lead to increases in the proportion of the population made up of those of Asian, Pacific Islander, and Māori descent. ${ }^{3}$ Why, then, should studying the Middle Ages matter in twenty-first century Aotearoa?

1 The authors are grateful for the ideas and comments they received from participants in the strand "Are the Middle Ages Relevant?" at the Leeds International Medieval Congress 2016 and the workshop "Teaching the European Middle Ages in Aotearoa New Zealand: Issues \& Opportunities" at the 2017 Tertiary Education Research in New Zealand conference held at Massey University. They would also like to thank Associate Professor Mike GRIMSHAW, Dr Valerie SoTARDI, and the anonymous peer reviewer for their helpful suggestions and comments. This article is an output of the project "Crossing Cultural Boundaries or the Embodiment of Colonialism? Teaching the Middle Ages in New Zealand", supported by a University of Canterbury Teaching Development Grant. Its publication was supported by a UC Open Access grant. Madi Williams' conference attendance was supported by the Ngāi Tahu Research Centre and School of Humanities \& Creative Arts.

2 Goods and services trade by country: Year ended December 2018, in: Stats NZ (4 March 2019), online: https://www.stats.govt.nz/information-releases/goods-and-services-trade-by-country-yearended-december-2018 (last accessed 15/05/2019).

3 "The medium projection indicates that between 2013 and 2038: The Māori, Asian, and Pacific ethnic populations will all increase their share of the total population in most regions, because their growth rates are higher than the region's total population." Subnational ethnic population projections: 2013(base)-2038 update, in: Stats NZ (3 October 2017), online: https://www.stats.govt.nz/in formation-releases/subnational-ethnic-population-projections-2013base2038-update (last accessed 15/05/2019). 
There are three reasons why understanding Europe's past not only matters but is important in a New Zealand context. The first was highlighted, tragically, by the Christchurch terror attacks of the 15 March 2019, which targeted two mosques and left fifty-one people dead. The country's initial response to the attack, embodied by its Prime Minister, Jacinda Ardern, was one of deep and genuine concern for the victims mixed with a rejection of the ideology that inspired such an atrocity. But the attacks also forced into the light a number of long-standing issues in New Zealand society. Most immediate was the country's inadequate firearms legislation, which had enabled the alleged perpetrator to purchase semi-automatic weapons. ${ }^{4}$ Another - perhaps more challenging - issue is racism, something Ardern herself acknowledged is a problem that exists in at least a section of New Zealand society. ${ }^{5}$ While the Middle Ages may appear to have very little immediate connection with such significant issues in a Pacific nation, it is worth highlighting that it is all too easy for those with racist ideologies to use medieval history to justify their own twisted goals. And, sadly, that appears to have been the case in this instance. ${ }^{6}$ The best way of combatting such misinterpretation is establishing a clear understanding of the reality of Europe's past.

The broader context in which the misuse of medieval imagery is employed by white supremacists is a subject highlighted in the introduction to this volume. This chapter will, however, focus on two other important issues. First, the Middle Ages remain a significant component of Aotearoa's constitutional, legal, and - notwithstanding the relative lateness of European settlement - its colonial history. Research into Europe's past can therefore provide clearer insight into some of the factors that have shaped - and continue to shape - debate and discussion around these issues in New Zealand society today. A second source of relevance is, however, to be found in the least likely of places: the study of the Middle Ages offers a potential pathway for New Zealanders to develop a clearer appreciation of the

4 A bill banning semi-automatic weapons was introduced within two weeks of the attack, on 1 April 2019. It passed its third reading on 10 April and became law on 11 April when it received royal assent: New Zealand Legislation, Arms (Prohibited Firearms, Magazines, and Parts) Amendment Bill, online: http://www.legislation.govt.nz/bill/government/2019/0125/6.0/LMS181180.html (last accessed 15/05/2019).

5 Racism 'something we're going to have to confront as a nation', in: 1News (18 March 2019), online: https://www.tvnz.co.nz/one-news/new-zealand/racism-something-were-going-have-confrontnation (last accessed 15/05/2019).

6 Gillian BRockwELL, The accused New Zealand shooter and an all-white Europe that never existed, in: Washington Post (16 March 2019), online: https://www.washingtonpost.com/history/2019/03/16/ac cused-new-zealand-shooter-an-all-white-europe-that-never-existed/ (last accessed 15/05/2019). The Chief Censor of the New Zealand Office of Film and Literature Classification has deemed footage from the film shot by the alleged perpetrator and his manifesto, "The Great Replacement", objectionable publications and banned possession, reading, or viewing of them in Aotearoa New Zealand. While it is possible to apply for an exemption on grounds of legitimate academic research, permission to view these items had not yet been received at the time of writing. 
principles that underpin the country's aspirations to develop a truly bicultural society in which Māori culture and values enjoy equal footing with those of Pākehā (New Zealanders of European descent). Paradoxically, medieval history's potential to contribute to the promotion of bicultural values is, perhaps, the most important reason why the study of Europe's Middle Ages remains relevant in Aotearoa today.

\section{Challenging Colonial Interpretations}

Following the 15 March attack, the name of Christchurch's local rugby team, "The Crusaders", and the question of whether or not that name should be changed, became the subject of intense debate in New Zealand. ${ }^{7}$ The team acquired its name in 1996 with the formation of the Super Rugby League. ${ }^{8}$ Its adoption was accompanied by a pre-match entertainment programme that evolved to include sword-wielding 'knights' astride horses decked out with crosses, flaming castles, and the use of Vangelis's "Conquest of Paradise" as theme music. It was a name and an identity that were chosen, at least in part, to reflect the city in which the team was based, in much the same way as the South Island's other Super Rugby team acquired the name "The Highlanders", a reflection of the city of Dunedin's strong Scottish roots. The controversy over the team's name is an excellent illustration of the relevance of the Middle Ages to the exploration of New Zealand's colonial history. It also provides an important tool for evaluating aspects of that history's legacy in contemporary society, and, in this case, the appropriateness or otherwise of retaining elements of it.

In the course of the nineteenth century, Christchurch became the key city in the Canterbury region, and remains today the South Island's largest population centre. ${ }^{9}$

7 For some of the varying views expressed in the New Zealand media: Kevin NoRQuAY, Super Rugby: The time for the Crusaders to put their name to the sword has arrived, in: Stuff (4 April 2019), online: https://www.stuff.co.nz/sport/opinion/111790180/super-rugby-the-time-for-the-crusaders-to-put-theirname-to-the-sword-has-arrived?rm=m (last accessed 15/05/2019); Duncan GARNER, Crusaders should hold the line, and keep their name, in: Stuff (5 April 2019), online: https://www.stuff.co.nz/sport/ rugby/super-rugby/111832155/crusaders-should-hold-the-line-and-keep-their-name (last accessed 15/ 05/2019). For an academic contribution to the debate see Geoff Troughton, Playing in overtime: why the Crusaders rugby team is right to rethink brand after Christchurch attack, in: The Conversation (4 April 2019), online: https://theconversation.com/playing-in-overtime-why-the-crusaders-rugby-team -is-right-to-rethink-brand-after-christchurch-attack-114826 (last accessed 15/05/2019).

8 For the establishment of Super Rugby: About Super Rugby, online: https://super.rugby/super rugby/about-super-rugby/ (last accessed 15/05/2019) and for "The Crusaders" franchise specifically: https://crusaders.co.nz/about-us/history (last accessed 15/05/2019).

9 For an overview: Geoffrey W. RicE, Christchurch Changing. An Illustrated History, 2nd ed. Christchurch 2008; for more detailed discussion, see the essays in: John Cookson / Graeme Dunstall (eds.), Southern Capital: Christchurch. Towards a city biography, 1850-2000, 
While the city's origins as a Church of England settlement did not immediately invoke the crusades, the prominence of the neo-gothic in its architecture, a feature that marked the city's skyline particularly strongly prior to the earthquakes of 2010-2011, was probably significant in cementing a connection between the city and Britain's Middle Ages in popular thought. This architecture, much of it the work of Benjamin MOUNTFORT (d. 1898), a pioneer of neo-gothic in New Zealand, defined the city's identity. ${ }^{10}$ Its legacy continues to be felt to this day: even though it collapsed in 2011, a stylized version of the city's Anglican cathedral, whose construction was supervised by MOUNTFORT, remains prominent in the logo of the Christchurch City Council.

The decision to embrace the neo-gothic in Christchurch's original civic plan reflected the way in which the Middle Ages came to be understood in popular nineteenth-century European thought. It was the same conception that inspired, on the one hand, William MORRIS, and, on the other, the statue of Richard I by Carlo MAROChETTI, which now stands outside the Palace of Westminster. The latter, in particular, represents the nineteenth-century's romanticized image of crusading, an image reinforced in the first half of the twentieth century by the contemporary colonial activities of Britain and France in the Levant. ${ }^{11}$ It certainly influenced the naming of two nineteenth-century English rugby clubs, "Saracens" (in 1876) and its local rival, the original "Crusaders". ${ }^{12}$ Historians, since at least the 1970s, and arguably before, have persistently sought to debunk these misrepresentations of both the Middle Ages and crusading in particular. Yet the image lingered on in Christchurch into the 1990s.

The decision to name Canterbury's rugby team "The Crusaders" was, then, shaped by a legacy of nineteenth-century colonial conceptions, conceptions that survived in an environment sheltered from the world in a pre-internet age by, to

Christchurch 2000. For the changing nature of the city following the 2010-2011 earthquakes: Katie PICKLES, Christchurch Ruptures, Wellington 2016.

10 For Mountfort specifically: Ian LochHeAd, A Dream of Spires: Benjamin Mountfort and the Gothic revival, Christchurch 1999. For the wider context: Chris BROoKs, The Gothic Revival, London 1999.

11 For a detailed introduction to this topic: Elizabeth SIBERRY, The New Crusaders. Images of the Crusades in the Nineteenth and Early Twentieth Centuries, Aldershot 2000.

12 The clubs merged into "Saracens" in 1878: Saracens, Saracens Club History, online: https://www. saracens.com/club/history/yourclub (last accessed 15/05/2019). The word 'Saracen' is Greek in origin and referred originally to a specific tribe; it was popularized in the medieval West as a generic term for Muslims: Bernard LEWIS, The Arabs in History, 6th ed. Oxford 1993, p. 4. For discussion of the medieval usage and for Christian attitudes towards Muslims and Islam more generally in the Middle Ages: John V. ToLAN, Saracens: Islam in the Medieval European Imagination, New York 2002. While undoubtedly also a colonial legacy, unlike "Crusaders", the name "Saracens" has fewer negative connotations today. 
borrow Geoffrey BLAINEY's phrase, the "tyranny of distance". ${ }^{13}$ Unchallenged by large-scale immigration from Muslim countries, these perceptions overshadowed modern scholarly assessments that underlined that the crusades were, in reality, an immensely complex form of religious warfare and one that often involved considerable brutality and bloodshed. ${ }^{14}$ This is despite the fact that, up until 2012, courses on the crusades were taught at the University of Canterbury by J. J. SAUNDERS (d. 1972), an internationally-recognized expert on the crusades and medieval Islam, and then by his student and successor, Geoffrey RicE, from 1974 to 2014. Both maintained an up-to-date curriculum and well-stocked library. Their influence was, however, limited to their students and a handful of teachers. Although RICE gave several public lectures on medieval Islam after 2001, the New Zealand public showed little appetite for engaging with modern scholarship on the crusades. Islam itself was also studied as part of the University's Religious Studies curriculum up until 2007; contemporary staff noted that, similarly, there was little interest in the topic. ${ }^{15}$ The decision to adopt the team's name can, in this light, be considered, at best, naïve; at worst, it demonstrates an alarming tendency to preference an accepted colonial narrative of the past over decades of scholarship. The extent to which outmoded attitudes linger on in New Zealand society today is indicated by the fact that when a recent 1News Colmar Brunton poll asked if people thought changing “The Crusaders's” name was the right thing to do following the mosque shootings, 76 per cent of respondents answered "no". ${ }^{16}$

The discussion concerning the suitability of the team's name in the wake of the events of the 15 March underlines why understanding Europe's medieval past, and the evolving scholarship connected with it, continues to be relevant in Aotearoa. It is a striking example that reveals the way in which long-standing misconceptions originating in the colonial era remain influential. Modern medieval scholarship has two things, in particular, to offer to this specific debate. First of all, it can reassure "The Crusaders" that in their choice of name they have not, inadvertently, been associating themselves with a racist agenda for the past twenty years (despite the ill-conceived and erroneous attempts of white supremacists to

13 BLAINEY coined the phrase in relation to Australia. While Aotearoa does not enjoy Australia's immense internal distances, many of his arguments are just as applicable: Geoffrey BLAINEY, The Tyranny of Distance. How distance shaped Australia’s history, 3rd ed. Sydney 2001.

14 With regard to the First Crusade, see, for example, Conor Kostick, The Siege of Jerusalem. Crusade and Conquest in 1099, London 2009.

15 The authors are grateful to Emeritus Professor Geoffrey RICE and Associate Professor Mike GRIMSHAW, who discussed these matters in private correspondence.

16 "The groups of people who were more likely to believe the Crusaders should keep the name included those living in Otago and Southland, National Party supporters and people aged 18-29." 'Striking' new poll indicates vast majority of Kiwis want Crusaders to keep their name, in: 1News (20 April 2019), online: https://www.tvnz.co.nz/one-news/new-zealand/striking-new-poll-indicatesvast-majority-kiwis-want-crusaders-keep-their-name (last accessed 15/05/2019). 
cast the crusades in racial terms). At the same time, the existence of the debate itself highlights the importance of a good understanding of supposedly arcane knowledge to modern social issues. It is not just about the need to unpick lingering, out-dated nineteenth-century colonial conceptions of the crusades; it draws underlying issues about racism to the surface. On the other hand, modern scholarship also suggests it is unlikely to be possible to 'reclaim' the name from a history steeped in religious conflict; the terms 'crusade' and 'crusaders' continue to resonate with the idea of western aggression in the Middle East today. ${ }^{17}$

While it is without doubt easy to be wise with hindsight, a deeper appreciation of what the crusades actually involved might well have led to different decisions when it came to naming the Christchurch rugby team. The issues facing "The Crusaders" highlight the value of understanding Europe's medieval past as part of a 'tool kit' that complements and deepens aspects of our understanding of Aotearoa's colonial history. It is an understanding that can help inform decisionmaking around how aspects of that past should be approached in the present day. Another example concerns the post-earthquake rebuild of Christchurch, in which efforts were made to locate synergies between Māori and western design features in the planning of a new convention centre for the city. ${ }^{18}$ Yet an appreciation of certain aspects of the Middle Ages also remains directly relevant to constitutional debates and the evolution of Aotearoa's legal system.

\section{Constitutional Debate \& Common Law}

The celebrations surrounding the eight-hundredth anniversary of Magna Carta in 2015 were a prominent reminder that New Zealand's legal and constitutional arrangements have strong roots in medieval Europe. Magna Carta was duly feted in Parliament, its anniversary marked by a number of events throughout the year, and the Charter and its relationship with Aotearoa the subject of considerable reflection in a volume published in 2017. ${ }^{19}$ The latter underlined the fact that while Magna

17 For discussion of the way in which these terms have come to be viewed in contemporary Islamic societies, see: Carole HILlENBRAND, The Crusades: Islamic Perspectives, Edinburgh 1999, pp. 589-616, and more recently the final chapter of Susanna A. Throop, The Crusades: An Epitome, Leeds 2019, pp. 177-186.

18 Chris Jones, The Great Hall, in: Te Maire TAU (ed.), Grand Narratives, Christchurch 2016, pp. 176-182.

19 For the - highly amusing - parliamentary debate: Motions - Magna Carta - 800th Anniversary, 16 June 2015, 706 NZPD 4385, online: https://www.parliament.nz/en/pb/hansard-debates/rhr/docu ment/51HansD_20150616_00000008/motions-magna-carta-800th-anniversary (last accessed 15/05/ 2019). For a summary of events throughout the anniversary year: Magna Carta $800 \mathrm{NZ}$, online: https://magnacartanz.wordpress.com/ (last accessed 15/05/2019). For a series of essays that reflect 
Carta has frequently failed to prove effective when cited by litigants-in-person, ${ }^{20}$ it is by no means irrelevant in New Zealand. Quite apart from its constitutional role - as interpreted by the seventeenth-century legal scholar and parliamentarian Sir Edward COKE - as a guarantor of freedom from arbitrary action by the state, the Charter offers at least one alternative pathway, legal pluralism, for the settlement of ongoing contention between the government and Māori. The significance of this pathway is that it is embedded within existing, albeit much neglected, constitutional structures. ${ }^{21}$

The 1988 Imperial Laws Application Act makes clear that Magna Carta, at least in the form it was enacted in 1297, is only one of a number of medieval statutes that remain in force in Aotearoa today. They range from the first Statute of Westminster (1275) to Edward III's 1368 legislation regarding the observation of due process. ${ }^{22}$ The 1988 act also includes the provision that: "the common law of England (including the principles and rules of equity), so far as it was part of the laws of New Zealand immediately before the commencement of this Act, shall continue to be part of the laws of New Zealand." 23 The latter places Aotearoa's legal system in a tradition with roots at least as deep as the thought of the twelfth- and thirteenthcentury jurists GLANVILL and BRACTON.

While it could be argued that an understanding of the Middle Ages remains relevant in Aotearoa because it has the potential to inform our understanding of contemporary law, few lawyers today are likely to find such esoteric knowledge necessary to go about their daily business. You do not, for example, need to understand the complexities of the origins of the modern trust to establish one. ${ }^{24}$ Where it would be difficult to

on the history of Magna Carta in New Zealand, its current status, and its possible future relevance see: Stephen WINTER / Chris Jones (eds.), Magna Carta and New Zealand - History, Law and Politics in Aotearoa, Cham 2017.

20 Lindsay BREACH, The Utility of a Medieval Charter in New Zealand Litigation: The Case of the Magna Carta, in: WinTER / Jones (note 19), pp. 161-180.

21 For its constitutional role: Chris Jones / Stephen WinTER, “ . . a document of our times.” Magna Carta in Aotearoa New Zealand, in: WINTER / JONES (note 19), pp. 3-20. For the Charter as a model for legal pluralism: Chris JoNEs, Mana and Magna Carta. Locating New Legacies in a Post-Colonial Society, in: ibid., pp. 229-251.

22 Following Schedule 1 of the act, the medieval statutes that remain in force are: "(1275) 3 Edw 1, c 1 - (Statutes of Westminster the First): so much of that Act as is stated in the words 'The King willeth and commandeth ... that common right be done to all, as well poor as rich, without respect of persons.', [being the English translation of part of the authentic text of that Act as it appears in the edition called Statutes of the Realm]; (1297) 25 Edw 1 (Magna Carta), c 29; (1351) 25 Edw 3, St 5, c 4; (1354) $28 \mathrm{Edw} 3$, c 3; (1368) $42 \mathrm{Edw} 3$, c 3.” Imperial Laws Application Act 1988 (reprint as at 26 March 2015), online: http://www.legislation.govt.nz/act/public/1988/0112/latest/whole. html\#DLM135078 (last accessed 15/05/2019).

23 Ibid.

24 Although such research is certainly worthwhile for its own sake: see, for one example, Lindsay BREACH, The development of the use and the origins of the modern trust: Maitland's thesis, the crusades, and beyond (unpublished PhD thesis, University of Canterbury, 2018). 
argue against the relevance of an understanding of the Middle Ages, however, is in constitutional debate. Although the 1840 Treaty of Waitangi between the Crown and Māori is rightly considered New Zealand's key founding document, ${ }^{25}$ the continued importance of Magna Carta alone justifies an engagement with the medieval context in which the latter was shaped. Indeed, one recent attempt to frame a new written constitution for the country, written by a former Prime Minister, begins by giving Magna Carta considerable prominence: "We the people of Aotearoa New Zealand: Express our desire to build upon our rich constitutional culture and heritage that includes the Magna Carta 1215 ... " ${ }^{26}$ And if the time limits set by the term 'medieval' are considered particularly elastic, one area beyond the 1988 act where otherwise abstruse knowledge appears relevant to constitutional issues is New Zealand's anomalous retention of the title "Defender of the Faith" as part of the style of its head of state. While it was excised from, for example, Elizabeth II's style as Queen of Australia, the title was consciously retained in New Zealand in 1974, as it was at an earlier date in the United Kingdom and Canada. ${ }^{27}$

While knowledge of the Middle Ages remains relevant to navigating the complexities of Aotearoa's unwritten constitution and legal system - perhaps to an extent that is sometimes underestimated - it would be reasonable to argue that for most New Zealanders such issues are unlikely to intrude heavily, if at all, into their daily lives. Aotearoa is such a state that you do not need to understand the technicalities - or even the broad brush stokes - of its constitutional arrangements to live here. ${ }^{28}$ While greater knowledge of constitutional matters among the population could be considered to contribute to the long-term health of any democracy, the fact that voter turnout in recent elections (77 \%) was well above the OECD average (69 \%) suggests that New Zealand's democratic institutions are in robust health. Similarly, the level of civic engagement is above the OECD average, and, while not comparable to its Australian neighbour, easily outstrips that of many European

25 Claudia ORANGE, The Treaty of Waitangi, Wellington 2011.

26 Geoffrey Palmer / Andrew ButleR, A Constitution for Aotearoa New Zealand, Wellington 2016, p. 34. For Aotearoa's current constitutional arrangements: Kenneth KeITH, An Introduction to the Foundations of the Current Form of Government (1990, updated 2008 and 2017), online: http://gg. govt.nz/role/constofnz/intro (last accessed 15/05/2019).

27 This particular constitutional quirk is discussed in more detail as part of an examination of the oldest New Zealand copy of Henry VIII's Assertio septem sacramentorum, the text in connection with which the title was originally granted: Chris JonES, Henry VIII, Defence of the Seven Sacraments, in: Chris JonEs / Bronwyn MATTHEws / Jennifer ClEMENT (eds.), Treasures of the University of Canterbury Library, Christchurch 2011, pp. 141-144 and 241-242.

28 One of the authors applied for and became a New Zealand citizen in 2015; the process did not involve any consideration of the country's constitutional arrangements beyond establishing that the applicant was aware that Elizabeth II was the head of state in her capacity as Queen of New Zealand. 
countries including France, Germany, and the United Kingdom. ${ }^{29}$ However, the decision of a 2015 referendum to reject any changes to the national flag is only one indicator that, despite the vibrancy of New Zealand's democracy, there is little appetite for constitutional change. As such, it seems likely that the relationship between certain elements of Aotearoa's constitution and their medieval origins will remain the preserve of a few specialists. However, there is one area in which knowledge of Europe's medieval past may yet prove to be of considerable relevance to a much broader demographic: the implementation of biculturalism.

\section{Biculturalism \& the University Curriculum}

New Zealand's official policy of biculturalism seems, initially, the most unlikely of places to locate the principal - or indeed any - relevance for the study of Europe's medieval past in Aotearoa. Biculturalism, as the term is understood in a New Zealand context, is uniquely connected with establishing parity between the culture of the indigenous Māori peoples and the settler culture; it is not to be confused with multiculturalism, which New Zealand embraces but which is a quite separate issue. The country's bicultural policy deliberately and consciously sets Māori culture apart as distinct from all other cultures. As a policy, biculturalism arose as part of wider attempts to redress the situation that resulted from the failure of New Zealand's government to honour the Treaty of Waitangi, the agreement between the British Crown and the islands' tribes that has come, as was noted above, to be regarded as the country's most important founding document. The policy can be defined broadly as "a partnership and respectful relationships between the two treaty partners, Māori and the Crown". ${ }^{30}$ The adoption of a bicultural policy has considerable implications for New Zealand society, which are reflected in ongoing debates concerning the nature of, for example, Māori rights to specific representation as Māori, and not simply as citizens. Its most obvious impact on contemporary poli-

29 Data from the OECD Better Life Index, New Zealand (2017), online: http://www.oecdbetterlifein dex.org/countries/new-zealand/ (last accessed 15/05/2019), which also notes "the level of stakeholder engagement [in Aotearoa] in developing regulations is 2.5 (on a scale between 0 and 4); slightly higher than the OECD average of 2.4."

30 Diane GoRDON-BuRNS / Leeanne CAMPBELL, Inakitia rawatia hei kakano mō apōpō: Students encounter with bicultural commitment, Ako Aotearoa (Southern Regional Hub) (May 2014), p. 10, online: https://ako.ac.nz/assets/Knowledge-centre/RHPF-s1101-Students-encounter-with-biculturalcommitment/c4468ed818/RESEARCH-REPORT-Inakitia-Rawatia-hei-Kakano-mo-Apopo-Students-Encounter-with-Bicultural-Commitment.pdf (last accessed 15/05/2019). 
tics is the maintenance of a separate Māori electoral roll, one whose membership is defined by tribal affiliation, and the continued reservation of seats in Parliament specifically for Māori. ${ }^{31}$

A key turning point in New Zealand's race relations occurred in the 1970s with the 'Māori Renaissance'. ${ }^{32}$ This saw an increase in advocacy - and subsequently awareness - of the dissatisfaction regarding the marginalization, culturally, economically, and politically, of Māori. This recognition was combined with an increasing drive to honour the promises of the Treaty. ${ }^{33}$ These factors pressured the government of the day into adopting an official "bicultural" approach in the 1980s. ${ }^{34}$ In fact, the situation in Aotearoa, as Keith SULLIVAN put it, "demands primarily a bicultural framework". ${ }^{35}$ The policy of biculturalism that emerged was defined by four key principles: it "is an equal partnership between two groups that values and supports cultural diversity, Māori are acknowledged as the tangata whenua, the original inhabitants of Aotearoa/New Zealand", and it has a focus on "redressing past injustices and re-empowering the indigenous people". ${ }^{36}$ The move to a policy of biculturalism was highlighted by the official adoption of 'Aotearoa / New Zealand', in place of 'New Zealand', as the name of the country. ${ }^{37}$ Greater emphasis was placed on the Treaty of Waitangi as a founding document, and the Treaty became a "focal point for biculturalism". 38

The move towards biculturalism is not embraced by all. One example is the ongoing debate over the existence of separate Māori seats in Parliament: New Zealand First, the party of the current Deputy Prime Minister, Winston Peters, favoured a referendum on their continued existence in 2018 and has, in the past, advocated their abolition. ${ }^{39}$ New Zealand could be characterized as a reluctantly bicultural nation, one that struggles to deal with the continuing effects of colonization. This is in part due to the fact that many New Zealanders are uncomfortable with the truth of

31 For an overview: Māori Representation, in: Electoral Commission New Zealand (14 August 2018), online: https://www.elections.org.nz/voting-system/maori-representation (last accessed 15/05/2019).

32 Steven Webster, Patrons of Maori Culture. Power, theory and ideology in the Maori Renaissance, Dunedin 1998, p. 28.

33 Neriko Musha DoERR, Meaningful inconsistencies. Bicultural nationhood, the free market, and schooling in Aotearoa/New Zealand, New York 2009, p. 9.

34 Aroha HARRIS (with Melissa Matutina WiLliAms), Rights and Revitalisation, 1970-1990, in: Tangata Whenua. An Illustrated History, Wellington 2014, pp. 416-451, here p. 437.

35 Keith Sullivan, Bicultural Education in Aotearoa / New Zealand. Establishing a Tauiwi Side to the Partnership, in: New Zealand Annual Review of Education 3 (1994), pp. 191-222, here p. 195.

36 Ibid.

37 DOERR (note 33), p. 10.

38 Ibid., p. 25.

39 Charlie DREAVER, Winston Peters wants 'two-part referendum' on Māori seats, in: Radio New Zealand (5 July 2018), online: https://www.radionz.co.nz/news/te-manu-korihi/361175/winstonpeters-wants-two-part-referendum-on-maori-seats (last accessed 15/05/2019). 
how New Zealand came to be and are consequently unwilling to engage with the past. History in New Zealand remains a contentious topic and involves, as Avril BELL put it, a strong desire to forget the "history of violence in the construction of the New Zealand nation-state." ${ }^{40}$ A denial of the truth of New Zealand's past is often accompanied by arguments in favour of the adoption of a multicultural, rather than a bicultural, approach. While no one would deny Aotearoa is becoming a society defined by more than simply two cultures - Māori and European for Māori the key role of the Treaty means that any first step remains establishing the bicultural relationship: "[no] other ethnic group here has had such an agreement [as the Treaty], so it has become a priority for Māori that, before issues of multiculturalism are addressed, the outstanding grievances of the tangata whenua, the original people of the land, must be settled."41

While New Zealand is officially a bicultural nation, it can be argued that there remains a lack of bicultural awareness and skills. Māori do not have a choice in whether or not to be bicultural due to the nature of contemporary Aotearoa, a country in which English is the primary language of communication and western culture predominates. Pākehā, on the other hand, have every choice, and many choose not to engage with biculturalism. This has created an ongoing problem for institutions such as Aotearoa's universities, all of which have a legal obligation to honour the Treaty of Waitangi. ${ }^{42}$ One approach to addressing this requirement is the incorporation of bicultural aims throughout the curricula, including into the study of medieval Europe.

The University of Canterbury, based in the city of Christchurch, has approached the challenge of meeting its Treaty obligations by officially recognizing "the special relationship with Ngāi Tahu and our commitment to explore opportunities to extend our common interest and strengths, for Ngāi Tahu and all Māori”. ${ }^{43}$ Ngāi Tahu are the tribe who hold the mana whenua over the majority of the South Island of New Zealand. Mana whenua is a broad concept that signifies territorial rights and authority over land. In addition to this, the University has created a series of graduate attributes, one of which is bicultural confidence and competence. This attribute has been defined as: "the ability to interact confidently and appropriately with persons

40 Avril Bell, We're Just New Zealanders, in: Paul Spoonley / David PeArson / Cluny MaCPHERSon (eds.), Nga Patai. Racism and Ethnic Relations in Aotearoa/New Zealand, Palmerston North 1996, pp. 144-158, here p. 152.

41 James RitchiE, Becoming Bicultural, Wellington 1992, pp. 7-8.

42 Section 181(b) of the Education Act 1989 (amended 1990) states that it is the duty of university councils: "To acknowledge the principles of the Treaty of Waitangi." Duties of Councils, Education Act 1989 (Reprint as at 21 December 2018), online: http://www.legislation.govt.nz/act/public/1989/ 0080/262.0/DLM184136.html (last accessed 15/05/2019).

43 Rautaki Whakawhanake Kaupapa Māori. Strategy for Māori Development, in: University of Canterbury (2012), online: https://www.canterbury.ac.nz/media/images/leadership-andgovernance/strategy_for_maori_development_2012.pdf (last accessed 15/05/2019). 
from a background that is different from one's own. It goes beyond an awareness of, or sensitivity to, another culture to include the ability to use that knowledge in cross-cultural situations." ${ }^{44}$ In theory, this attribute is intended to provide graduates with the transferable skills needed to engage and empathize with a variety of people from other backgrounds, both nationally and internationally. The adoption of this graduate attribute has led to the incorporation of bicultural aims throughout the University including into a range of courses. It is in this attempt to embed the attribute of bicultural competence at every level of the curriculum and to ensure students acquire it in the course of their time at university, that the study of Europe's Middle Ages becomes, potentially, highly relevant in a New Zealand context. Given the aims of the bicultural policy, such a claim undoubtedly appears, at first glance, paradoxical, if not perverse.

The 'natural' location in which to embed a bicultural component are courses offered by Māori and Indigenous Studies departments. Such departments can offer dedicated courses in this area. An example at Canterbury intended for first-year students would be the 100-level course MAOR108 Aotearoa: Introduction to New Zealand Treaty Society. ${ }^{45}$ A 100 -level course is a foundation course in a particular subject. However, while similar departments exist in all New Zealand universities, they sometimes struggle to attract a wide range of students. At Canterbury, the key groups that enrol in these classes are Māori themselves; international students, many of whom see such courses as an integral part of their 'New Zealand experience'; and students that are required to take the course as part of a specific degree. In 2017, enrolment data for Canterbury's MAOR108 course suggested that 71 per cent of students were Pākehā. ${ }^{46}$ While on the surface such a figure would suggest the University's efforts to inculcate bicultural competence and confidence as a graduate attribute is extremely

44 UC’s Bicultural Competence and Confidence Framework, in: Assistant Vice-Chancellor Māori’s Office, University of Canterbury (undated), online: https://www.canterbury.ac.nz/about/leader ship/senior-management-team/avc-maori/bicultural-competence-and-confidence-framework/ (last accessed 15/05/2019).

45 For the 2019 offering: MAOR108 Aotearoa: Introduction to New Zealand Treaty Society, online: https://www.canterbury.ac.nz/courseinfo/GetCourseDetails.aspx?course=MAOR108 (last accessed 15/05/2019). Although intended primarily for first years, students are able to take 100-level (introductory) courses at any time during their degree. Canterbury operates a points-based system, with the award of a Bachelor's degree based on the accumulation of 360 points from a mix of 15 and 30 point courses. While completion of a 100-level course in a particular topic area is usually a prerequisite to study that subject at a higher level, it is possible to 'add in' additional 100-level courses at any point in a degree.

46 Ethnicity has been determined based on the way students self-identify in University records. Two important caveats must be kept in mind. First, students often identify as members of more than one ethnicity; where one of those ethnicities was Māori the student has been counted as such. Second, where an enrolled student identified at least one ethnicity, that ethnicity has been taken into account even if they also ticked 'other' or 'not stated' (options that were allowed by the data collection tool). With this in mind, the percentages should be considered to indicate no more 
effective via this route, it is worth emphasizing that 78 per cent of the Pākehā students who took this particular course were in degree programmes where it was compulsory. Indeed, a rise in Pākehā students taking the paper is linked to degree schedules that make engagement with bicultural themes a requirement. For example, a large proportion of students taking MAOR108 in 2017 were enrolled in either the Bachelor of Criminal Justice or the Bachelor of Health Science, both of which require students to take a first-year Māori and indigenous Studies paper as part of their schedule. This is not to say that no Pākehā New Zealand students take these papers by choice, but this group are a minority. If the aim is to ensure that all students obtain the graduate attribute of bicultural competence and confidence, this creates a problem: while the necessary courses exist, many students do not choose to engage with them. If students are reluctant to take papers with a Māori and Indigenous focus, then one option is to introduce a requirement that all students take such a paper as part of their degree.

While the integration of required courses into degree programmes is certainly one approach that can address the University's aim of ensuring all students graduate with bicultural skills, it remains problematic: research indicates that compulsory courses are generally not well received by students. This is principally because, as Carol SCHICK put it, to "define something as compulsory is, in terms of the liberal discourse of freedom and human rights, to define it negatively. Compulsion is automatically rhetorically bad." 47 This point has been proven by SCHICK specifically in relation to a compulsory cross-cultural paper implemented in a Canadian university. ${ }^{48}$ An approach that incorporates compulsory papers presents particular challenges for the Bachelor of Arts where, traditionally, students in Aotearoa New Zealand have enjoyed considerable freedom of choice in the subjects they study. To date, the solution has been to assemble a list of courses that incorporate bicultural themes - Schedule $\mathrm{C}$ - and to require students to take at least one course from that list as part of their degree. ${ }^{49}$ Such an approach requires minimal engagement with biculturalism; it is inadequate for truly achieving the goal of ensuring all students engage meaningfully with the graduate attribute. A risk of this approach is the drawing of superficial links between one's own subject and biculturalism in order to adhere to institutional regulations. When this occurs it works against the aims of genuine biculturalism. There needs to be authentic engagement with the values of biculturalism for this approach to have any merit.

than general trends. The authors are grateful to Aotahi: School of Māori and Indigenous Studies for access to, and permission to use, course enrolment data for MAOR108.

47 Carol SснIск, Keeping the Ivory Tower White: Discourses of Racial Domination, in: Canadian Journal of Law and Society 15(2) (2000), pp. 70-90, here p. 73.

48 Ibid.

49 Schedule $\mathrm{C}$ to the Regulations for the Degree of Bachelor of Arts, Calendar, University of Canterbury (2019), online: https://www.canterbury.ac.nz/media/documents/regulations/academicregulations-2019-coa-BA.pdf (last accessed 15/05/2019). 
Further barriers to incorporating bi- or cross-cultural elements lie in the perceived threat such courses pose to students' own sense of self, identity, and nationhood. Might they not appear as a form of indoctrination and lead to concomitant resentment? An alternative may be to integrate bicultural skills and knowledge into existing courses. The integration approach has proven successful in relation to academic literacy skills; research has shown that "well-designed activities embedded within discipline based programmes are one highly effective way to promote acquisition of these skills." 50 The integration of the bicultural graduate attribute could take many forms. The bicultural competence and confidence mapping document outlines seven kaupapa (initiatives/concepts) that offer starting points to course designers: a process of self-reflection on the nature of 'knowledge' and 'norms'; the nature of contemporary Māori organizational structures; traditional and contemporary realities of Māori society; the Treaty of Waitangi and Aotearoa New Zealand's bicultural history; the processes of colonization and globalization; other indigenous models of development, knowledge, and behaviours; and application of bicultural competence and confidence in a chosen discipline and career. ${ }^{51}$ While some kaupapa may suit some courses more than others, the vital aspect to a successful programme would be to integrate ways of thinking that generate reflection. This is where the study of medieval Europe can play an important role; different ways of thinking and understanding the world can be explored and then applied to contemporary New Zealand society.

Māori culture and traditions remain strong in Aotearoa New Zealand. For those living and working in the country, it is essential to become familiar with and gain an understanding of that culture and traditions if for no other reason than it enjoys a unique, legally-protected position. However, there remain many New Zealanders who are unable, and/or unwilling, to understand Māori society on its own terms. While it would be preferable if all New Zealand students chose to engage in a positive manner with Māori culture, it is necessary to recognize three factors that militate against this. First, the continuing contention surrounding the colonization and subjugation of Māori; second, put simply, many Pākehā students do not consider the topic relevant and actively seek to avoid engaging with it; and, third, the way in which New Zealand history is taught in schools elides discussion of the wider context of history, culture, and colonization. ${ }^{52}$ It is here that the study of medieval Europe may offer a useful pathway to developing bicultural skills.

50 Cathy Gunn / Shari HeARne / Julie SibTHORPE, Right from the Start: A Rationale for Embedding Academic Literacy Skills in University Courses, in: Journal of University Teaching \& Literacy Practice 8 (1) (2011), online: https://ro.uow.edu.au/jutlp/vol8/iss1/6/ (last accessed 15/05/2019), p. 1.

51 UC's Bicultural Competence and Confidence Framework (note 44).

52 The authors are grateful to Associate Professor Mike GRIMSHAW for highlighting the importance of this third point. 


\section{Towards Teaching a History of Values}

If the study of medieval history is approached as an opportunity to learn about a different society on its own terms, rather than as an exploration of the origins of a distinctly western civilization and its development, then its relevance in a New Zealand context becomes clearer. Considered from such a vantage point, the study of medieval Europe has the potential to make a valuable contribution to the development of the skills needed to understand other cultures and societies. For it to do so, however, requires more than a conscious rejection of a 'whiggish' interpretation of 'history as progress'. The desirability of avoiding Herbert BUTTERFIELD's 'Whig' interpretation of history, laden with its tendency to distort our understanding of the past, is certainly something many - if by no means all - professional historians would keep foremost in their minds today. ${ }^{53}$ However, for medieval history to be relevant to biculturalism a deliberate decision is also required to move away from topics that are particularly prominent in the historiography, such as the history of institutions, administrative development, architectural evolution, etc.; indeed, any topic that is principally set by a potentially 'whiggish' modern agenda and in which the interests of historians, rather than the views of contemporaries, are the principal driver of enquiry. Instead, it requires a concerted effort to approach history from the perspective of those who lived it; its agenda must become the agenda of contemporaries, and history the reconstruction of the medieval mind-set to the extent such a thing is possible. Or, to put it another way, a medieval history that is relevant to biculturalism is an account that attempts to understand not what occurred and why, but what was perceived to be important by those who experienced it. Such an approach would certainly benefit from drawing on the new focus on topics such as race in a medieval context in recent historiography. ${ }^{54}$ This opens the door to understanding another society on its own terms, and it is this that is critical to establishing bicultural competence and confidence. In many ways, understanding any society that differs substantially from that of the modern western world, would be valuable in this regard. The world of medieval Europe, however, offers a particularly fruitful field for investigation because of the similarity between some aspects of the worldview of its inhabitants and Māori.

It is important to emphasize that there are no direct parallels to be established in a comparison of the medieval and the Māori. In fact, the greatest danger in an approach that employs medieval European history to explore biculturalism is that it may imply that Māori society can be explained by reference to medieval Europe.

53 For the 'Whig' interpretation of history as it has come to be understood: Michael BENTLEY, Modern Historiography. An Introduction, London 1999, pp. 62-70. And for BUTTERFIELD's original assessment: Herbert BuTTERFIELD, The Whig Interpretation of History, London 1931.

54 See for example: Geraldine Heng, The Invention of Race in the European Middle Ages, Cambridge 2018. 
This would be incorrect; the two societies evolved very differently and are distinct. Yet, at the same time, some of the values of medieval European society appear notably closer to those of the Māori world than they do to those of the modern West. ${ }^{55}$ By focussing on a 'history of values' or social norms that establishes that these differ from society to society, the medieval world can become a vehicle for understanding the concepts at the heart of bicultural competence. For the relevance of the study of the Middle Ages in this context to be realized fully, however, it is important to incorporate a 'layer' into the teaching process that explains the values of the medieval West to a New Zealand audience in terms of Māori values and concepts, highlighting the similarities and differences.

An exploration of European perceptions of genealogy in terms of the Māori concept of whakapapa offers one notable example of the type of approach that might be adopted. The University of Canterbury is fortunate to hold the only example in the southern hemisphere of a medieval genealogical roll. This fifteenthcentury, five-metre long English manuscript is a fascinating, unique item. It is certainly worthy of investigation in its own right. As such, it has been the focus of several recent published studies by Canterbury students and is the subject of the ongoing "Canterbury Roll Project", which, to date, has created a digital edition and translation. ${ }^{56}$ At the same time, its value as a teaching tool for bicultural competence is certainly as important as the rare opportunity it affords to introduce New Zealand students to a medieval manuscript. ${ }^{57}$ The roll functions as a window

55 For an introduction to the Māori worldview and further discussion of the value/dangers of drawing comparisons with medieval Europe: Madi WiLLIAMs, Polynesia, 900-1600, Leeds (forthcoming). 56 Christchurch, University of Canterbury, MS 1. See in particular: Maree SHIROTA, Royal Depositions and the 'Canterbury Roll', in: Parergon 32(2) (2015), pp. 39-61; Thandiwe PARKER, A Woman's Role. How Scribes Depicted Women On The Fifteenth-Century Canterbury Roll, in: Comitatus. A Journal of Medieval and Renaissance Studies 48(1) (2017), pp. 95-115. The new edition and translation, as well as introductory materials and a high definition digital facsimile, were created in collaboration with Canterbury University Press and UC's Arts Digital Lab. They are available, open access, as part of the ongoing Canterbury Roll Project, online: https://www.canterbury.ac.nz/canterburyroll (last accessed 15/05/2019). For the project: Mark BRIDGE, Medieval scroll gives up secrets from original Game of Thrones, in: The Times (29 January 2018), online: https://www.thetimes.co.uk/article/medieval-scrollgives-up-secrets-from-the-original-game-of-thrones-30z9mk0b3 (last accessed 15/15/2019); and for an academic assessment: Judith CollaRd, Review: Jones, Chris, Christopher Thomson, Maree Shirota, Elisabeth Rolston, Thandi Parker, and Jennifer Middendorf, eds, The Canterbury Roll - A Digital Edition, December 2017, <http://www.canterbury.ac.nz/canterburyroll>, Christchurch, Canterbury University Press, in: Parergon 35(2) (2018), pp. 215-216.

57 There are just over 180 manuscripts in New Zealand: Margaret M. MANion / Vera F. Vines / Christopher DE HAMEL, Medieval and Renaissance Manuscripts in New Zealand, Melbourne 1989. For a less complete earlier catalogue see: David M. TAYLOR, The Oldest Manuscripts in New Zealand, Wellington 1955. Detailed studies of New Zealand's holdings are limited, although the country's collectors are better served by contemporary scholarship. Two key volumes in which both manuscripts and collectors are explored are: Stephanie Hollis / Alexandra BARRATT (eds.), Migrations: Medieval Manuscripts in New Zealand, Newcastle 2007, and Chris JonEs (ed.), A Road 
onto the importance of genealogy in the medieval world and is, equally, a springboard to understanding the way in which the past was perceived in pre-Renaissance England. For Māori, the concept of whakapapa, that is the construction and tracing of genealogical relationships, remains part of the bedrock on which society is constructed: “At a simple level [whakapapa] means 'genealogy', but it also refers to the whole body of Māori knowledge and belief systems that reaches back to the 'atua' (gods), the archetypal heroes and tribal ancestors." 58 Every formal introduction continues to incorporate a mihi, in which the person introducing themselves establishes their whakapapa. While there are substantial differences between the spiritual importance (mana) attributed to a recorded whakapapa and a medieval genealogical document, study of the latter can introduce a key idea: the importance of genealogy and the tracing of genealogical roots to a society. Comparing that genealogy with the Māori conception of whakapapa, an approach that is today integrated into 200/ 300-level courses at Canterbury, establishes the importance of genealogy as a value across the two societies while creating an opportunity to discuss the differences and similarities in the way in which those values were - and are - understood.

Canterbury's 100-level introduction to medieval history, HIST133 Medieval Europe: From Rome to the Black Death, has remained a consistently popular 'gateway' course, maintaining, since 2014, the largest enrolment of any History course at Canterbury. It remains, simultaneously, non-compulsory and one of four History 100-level options offered annually, the completion of any one of which enables progression to higher-level courses in the subject. Its enrolment is also, overwhelmingly, dominated by Pākehā students in the Bachelor of Arts degree, students whose only required encounter with biculturalism is participation in a Schedule C course. Approaching the teaching of HIST133 with a focus on the 'history of values', rather than adopting a traditional curriculum driven by historiographical debates, offers the opportunity, without introducing compulsory courses, to deepen the engagement with biculturalism for students whose experience of the graduate attribute might otherwise be fleeting.

While by no means a direct substitute for engagement with the Māori world, the type of approach described above effectively achieves three goals: the teaching of European history on its own terms; the establishment of bicultural competence and confidence; and the opening up of a new doorway onto a topic - the Māori worldview - that some students may have considered irrelevant. A process of engagement

Less Travelled: The Medieval and Early Modern World Reflected in New Zealand Collections, in: Parergon, Special Issue 32(2) (2015), pp. 1-250. For objets d'art and paintings, the only general survey is: Mary KISLER, Angels \& Aristocrats: Early European Art in New Zealand Public Collections, Auckland 2010.

58 For an introduction to an example of recorded whakapapa from the Canterbury region: Te Maire TAU, Whakapapa Books, in: Jones / MATTHEWs / CLEMENT (note 27), pp. 91-97 and 236 (quote: p. 95). See also: Hirini Moko MEAD, Tikanga Māori. Living by Māori Values, Wellington 2003. 
with Māori perspectives and an exploration of the history of values has the added benefit of potentially enabling Aotearoa-based medieval historians to generate new questions about their own field stimulated by an encounter with Māori concepts, questions they might otherwise not have asked. One early example of this is the increasing number of student-led projects at Canterbury - often employing the Canterbury Roll as a source - with a focus on digging deeper into European conceptions of genealogy and its significance for medieval society.

$\star \star \star$

The appalling events that took place in Christchurch on 15 March 2019 are a reminder that establishing a deeper understanding of medieval Europe is as important in Aotearoa New Zealand as it is elsewhere in the world. The best means of contesting the use of medieval imagery by white supremacists is to provide society with the tools to ensure that such views are not able to go unchallenged. More generally, the medieval also remains relevant to those interested in understanding New Zealand's unique colonial past and its constitutional and legal arrangements. Yet, it is the emphasis placed upon the importance of promoting a concept of biculturalism unique to New Zealand society, that, paradoxically, makes the study of the European Middle Ages most relevant in a Pacific nation. It is certainly possible to continue to teach the Middle Ages in Aotearoa much as they are taught in Europe and North America. Yet doing so risks the subject becoming less and less relevant as New Zealand society moves further away from its colonial roots. In order to realize fully the relevance of their subject in Aotearoa, medievalists need to embrace different approaches. Those approaches should favour engagement with Māori culture over participation in historiographical debates whose agendas are often shaped in very different environments.

It is to be hoped that, by embracing an agenda shaped by Aotearoa, New Zealand's medievalists are, in turn, able to bring new and unique perspectives to the wider community of medieval scholars. Whakapapa offers only one example of the way in which bicultural points of comparison can be raised in the course of studying medieval history. Topics are many and varied. They range from the process by which a predominantly oral culture transitioned into a written culture, to the way in which customary title - a concept understood as take whenua in the Māori world - developed into 'legal', documented forms of land tenure. The study of medieval Europe remains, then, relevant for the opportunity that it offers to introduce a generation of students to the graduate attribute of cultural competence and confidence. At the same time, the teaching of European history can itself be enriched by a comparative approach that has the potential to introduce new questions. 



\title{
How to be a Time Traveller: Exploring Venice with a Fifteenth-Century Pilgrimage Guide
}

\begin{abstract}
In 1462, an English pilgrim called William Wey visited Venice as the first stage of his itinerary to the Holy Land and defined the city as "the most holy place" for its exceptional architecture and closeness to God. In the present day, millions of tourists every year can potentially experience the same environment as William Wey did in the fifteenth century. This chapter investigates how a fifteenth-century pilgrimage guide may still be used as a unique means to explore a popular destination such as Venice. Indeed, medieval pilgrimage guides offer, on the one hand, unusual itineraries of the most visited medieval places and on the other, the possibility of a new understanding of the symbolic and religious perception of important historical buildings that are still well preserved. Both tourists and civic authorities stand to benefit from understanding how our medieval predecessors understood the urban environment we have inherited from them. Religious symbolism and its deep connection with relics, churches and places of worship typical of medieval experience has declined rapidly over the centuries and it is often absent from our perception and cultural understanding of our surroundings.

This research uses the case study of a medieval pilgrimage-guide to Venice to demonstrate the relevance of such texts as modern travel and civic planning sources. Field research was undertaken based on the reconstruction of a pilgrimage itinerary in present-day Venice according to the indications provided by William Wey in his guide. This chapter analyses the results of this reconstruction and argues that not only can the medieval itinerary be rediscovered, but it serves as an eye-opening experience that allows visitors and residents to see the city with new perspectives, perspectives that mean, amongst other features, that we understand our own moment to be fleeting and laden with its own ideological approach to viewing the buildings.
\end{abstract}

Keywords: travel, Venice, tourism, pilgrimage, architecture, symbolism, itinerary, travel narrative, religious celebration, doge

\section{Introduction}

The way people travel around the world has changed significantly since the Middle Ages, not only because of the ease with which it is possible to travel long distances in a few hours but also because people's attitudes towards the experience of travel

\footnotetext{
Laura Grazia Di Stefano, University of Nottingham, University Park, Nottingham, NG7 2RD, UK, distefano.laura@hotmail.it 
have changed. Travel has become mostly a leisure or business activity rather than a spiritual or political necessity and (with the exception of places such as Mecca or Rome) the majority of contemporary travellers no longer are cognisant of any deep connection with destinations familiar to medieval travellers. Yet, it remains possible for modern tourists to regain an historical insight into the places they visit and to appreciate how medieval travellers would have experienced the same environments. The use of fifteenth-century travel guides, such as that written for Venice by the English pilgrim William Wey in 1462, may be helpful to retrieve the symbolic and spiritual connection with places as they were understood by medieval travellers. ${ }^{1}$ This would allow visitors to explore well-known places from a new point of view.

Among the many locations visited during the Middle Ages, Venice is particularly suitable for this type of assessment because, although some of the most important buildings have been renovated with new artistic styles, the city's urbanism remains practically unchanged since the medieval period, offering the visitor opportunities for a 'realistic' recreation of the experience of a medieval traveller. Every year, millions of tourists walk the same path that William Wey did in $1462 .^{2}$

Of course, the spiritual context within which the medieval men and women journeyed to the Holy Land is not a prominent characteristic of current tourism and the strictly symbolic and religious perception of important historical buildings that was typical of medieval travellers and their culture is generally absent for contemporary visitors to historic locations. At the time of William Wey, people travelled principally for political or diplomatic missions, for religious reasons, or for trade. The idea of wandering for tourism was still far from being acceptable for medieval men and women, especially for those in search for redemption. It was considered inappropriate for ecclesiastics to travel for pleasure, exploration, and the enjoyment of new vistas. ${ }^{3}$ That being said, the dissemination of travel narratives was not alone a means of advising those who might follow the pilgrim trail; it also took place in order to entertain those unable to make such journeys.

A crucial feature of the medieval experience of an urban landscape was the fact that symbolism provided a shared international means of communication during the period, especially in regard to a popular understanding of Christian sacred art and rituals for travellers far from their countries. Nowadays, symbolism no longer has the same relevance and impact that it had in the Middle Ages. Visitors to modern cities are more culturally diverse and a shared religion is far from being the

1 For a similar approach with regard to England and Rome, see Ian MORTIMER, The Time Traveller's Guide to Medieval England. A Handbook for Visitors to the Fourteenth Century, London 2012; Debra J. BIRCH, Pilgrimage to Rome in the Middle Ages. Continuity and Change, Rochester 2000.

2 In 2012, Venice welcomed more than twenty-five million tourists, see Claire CoLOMB / Johannes Novy, Protest and Resistance in the Tourist City, New York 2017, p. 171.

3 See Christian K. ZACHER, Curiosity and Pilgrimage. The Literature of Discovery in FourteenthCentury England, London 1976. 
only reason why someone would visit a sacred place. Thus, the symbolic reading of the architecture around the contemporary traveller is largely under-appreciated. Yet, some knowledge of the meaning for the medieval mind of the surviving art can still be valuable for modern tourists because, as Mircea ELIADE has stated, "the symbol, the myth and the image are of the very substance of the spiritual life, [...] they may become disguised, mutilated or degraded but never extirpated". ${ }^{4}$ A part of that medieval spirituality and religious reading of Venice's architecture can still be retrieved with the help of late medieval narratives reporting not only the pilgrim's daily experiences but also their perception of the city. One author who assigned to Venice an original symbolic role in his pilgrimage narrative was William Wey.

William Wey was an English pilgrim who travelled to the Holy Land twice, in 1458 and 1462. An account of his travels survives in what is now Oxford, Bodleian Library, MS Bodley 565. During both his journeys William passed through Venice, although only the account relating to the 1462 pilgrimage includes a description of his Venetian stay. This itinerary, written in 1462, offers one of the most complete descriptions of Venice during the peak period of pilgrimage to the Holy Land. Using this account alongside six other similar texts and field research, this chapter will point towards the value of this material in providing a neglected perspective on a modern appreciation of the cities we have inherited from our medieval forebears. ${ }^{5}$

\section{Venice, a City for Pilgrimage}

Understanding the pilgrim's experience in medieval Venice is meaningful to contextualize with a spiritual framework the extent of changes experienced by the city. In fact, while the architectural change is often evident and understood as a natural response to a busy urban environment, religious and spiritual changes, such as an increase in the city's significance for pilgrims is of relevance too. Medieval Venice is known for the extent of its mercantile trade network across Europe and the Eastern Mediterranean Sea. Little scholarly attention has been paid to the fact that Venice, being one of the

\footnotetext{
4 Mircea Eliade, Images and Symbols. Studies in Religious Symbolism, Princeton / NJ 1961, p. 11. 5 Francis DAVEY, The Itineraries of William Wey, Oxford 2010; cf. most recently on Wey: Pnina ARAD, Pilgrimage, Cartography, and Devotion: William Wey's Map of the Holy Land, in: Viator 43(1) (2012), pp. 301-322. The other itineraries considered in this chapter are Bernhard von Breydenbach, Peregrinationes. Un viaggiatore del quattrocento a Gerusalemme e in Egitto, ed. Gabriella BARTOLINI / Giulio CAPORALI, Rome 1999; Viaggio in Terrasanta di Santo Brasca, 1480 con l'itinerario di Gabriele Capodilista, 1458, ed. Anna Laura Momigliano LePSCHY, Milan 1966; Mary Margaret Newett, Canon Pietro Casola's Pilgrimage to Jerusalem in the Year 1494, Manchester 1907; Felix Fabri, Evagatorium in Terrae Sanctae, Arabiae et Egypti peregrinationem, 3 vols., ed. Konrad Dietrich HASSLER (Bibliothek des literarischen Vereins in Stuttgart 2-4), Stuttgart 1843-1849.
} 
biggest European cities of the later medieval period, increased the promotion of its religious value and sacred architecture in connection with the pilgrimage phenomenon. ${ }^{6}$

Furthermore, the enormous increase in pilgrim visitors in the later fifteenth century contributed to the city's need to affirm its religious identity within the pilgrimage route. Indeed, from the thirteenth century, Venice was not only the main administrator of sea-transportation to the Holy Land but the city's leaders also promoted its religious locations through organized city itineraries aimed at the entertainment of pilgrim visitors in advance of their embarkation for Jerusalem.

Traces of these itineraries survive in some fifteenth-century pilgrimage accounts, demonstrating that pilgrims considered Venice an additional place in which to gain indulgences and visit relics during their journey to Palestine. Venice was to all intents and purposes a fascinating merchant city and religious destination and its attractions became even more relevant during the fifteenth century. With its many parishes and different traditions, the itinerary followed by pilgrims in Venice during the late fifteenth century was not much different from that generally undertaken by modern tourists when they visit historic churches and buildings positioned strategically in the different sestieri (there are six of these zones in Venice: San Polo, San Marco, Cannaregio, Dorsoduro, Castello, Santa Croce, and Giudecca). For example, the German pilgrim Felix Fabri, who visited Venice in 1480, thought that Venice was "the most beautiful city ever seen in and out of the Christian world". ${ }^{7}$ In his narrative, the 'Evagatorium in Terrae Sanctae', Fabri listed twelve main reasons why Venice was worth a visit and his list retains its relevance for a modern audience. According to Fabri, Venice was worth a visit for the history of its foundation; for its inhabitants; for its unique and longstanding form of government; for its Christianity; for its relics; for its precious treasures; for the possibility of finding everything one might need; for its income and trade; for its entertainment; because of its wise senators who had granted to the city long-lasting peace and stability; for the fact that princes and prestigious religious figures went there often; and because the city has gained privileges and graces. ${ }^{8}$ Although some of these reasons may be considered old-fashioned, the draw of Venice's history, its inhabitants, and its 'entertainment' are still high among the reasons why tourists visit the lagoon today.

A modern visitor will also be drawn by the possibility of experiencing luxury hotels, Italian cuisine, Murano glass, the Biennale exhibition, and the celebrations for the Carnival. These attractions may hide from modern tourists a symbolic

6 In this regard see Deborah HowARD, Venice \& the East. The Impact of the Islamic World on Venetian Architecture, 1100-1500, London 2000, pp. 189-215 (“The Pilgrim City”), and Élisabeth CROUZET-PAVAN, Récits, images et mythes. Venise dans l'iter hierosolomytain (XIV $-\mathrm{XV}^{\mathrm{e}}$ siècles), in: Mélanges de l'École française de Rome. Moyen-Age, Temps modernes 96(1) (1984), pp. 489-535. 7 Domenico ZASSo, Venezia nel MCDLXXXVIII. Descrizione Di Felice Fabri Da Ulma, Venice 1881, pp. 21-22.

8 Ibid., p. 22. 
understanding of the city and its architecture on historic and religious levels. Yet it is possible to retrieve a strong connection with the medieval past by using medieval travel guides to help tourists understand their destination through the eyes of fifteenth-century travellers. In order to do this, a close reading of the medieval travel guides has to be undertaken, with a sensitivity to the motivations of the authors. Medieval travellers, especially pilgrims, typically organized their itinerary to accomplish their religious duties (such as the collection of indulgences or a visit to certain relics or monastic houses). Venetian guides, called tholomagi, were appointed by the government to assist pilgrims with their movements around the city. It is likely these guides suggested to pilgrims a 'standard' itinerary of the city that was adjusted according to the pilgrims' wishes to visit certain churches or relics. There is evidence that Franciscans in Venice had a vital role in helping pilgrims with their itinerary both in Venice and the Holy Land. While it is clear that the order promoted pilgrimage to Jerusalem through specific guides or booklets the same has not been established for Venice. ${ }^{9}$ Nevertheless, there is often an element of tourism in at least a part of the itineraries they describe in the texts studied here. This arises from the fact that these visits focussed on the best-known attractions of Venice, such as the doge's palace, the island of Murano, and the Arsenal. ${ }^{10}$

Unlike merchants and members of the nobility, pilgrims did not always express their political and military interests openly. Because of the religious nature of pilgrimage, they were cautious in expressing a type of curiosity that might be judged inappropriate to their religious status. ${ }^{11}$ For this reason descriptions of places considered today as tourist attractions, such as the doge's palace or the Arsenal, appear in the background of their narratives and are observed through a devotional filter. For instance, William Wey described the Arsenal, heart of the military power of Venice, as "a large area where they build galleys to defend our Faith". ${ }^{2}$ Bernhard von Breydenbach

9 See Michele CAmpopiano, Islam, Jews and Eastern Christianity in Late Medieval Pilgrims' Guidebooks: Some Examples from the Franciscan Convent of Mount Sion, in: Al-Masaq: Islam and the Medieval Mediterranean 24(1) (2012), pp. 75-89.

10 Visiting the doge's palace was, however, a privilege that was reserved to a certain category of pilgrims, who often received an invitation from the doge himself; the visit was then probably accompanied by a dinner with the doge in person. For an example, see the narrative of Roberto Sanseverino, who travelled in 1458 (the same year as William Wey): Roberto da SANSEVERINO, Viaggio in Terra Santa, ed. Gioacchino MARUFFI, Bologna 1888.

11 A broader discussion on the evolution of pilgrimage into religious tourism is available in Luigi TOMASI, Homo Viator. From Medieval Pilgrimage to Religious Tourism via the Journey, in: William H. Swatos / Luigi Tomasi (eds.), From Medieval Pilgrimage to Religious Tourism. The Social and Cultural Economics of Piety (Religion in the Age of Transformation), Westport / CT 2002, pp. 2-24. For a general introduction to pilgrimage: Hilda F. M. PREscoTt, Jerusalem Journey. Pilgrimage to the Holy Land in the Fifteenth Century, London 1954, and Nicole CHAREYRON, Pilgrims to Jerusalem in the Middle Ages, New York 2005.

12 DAVEY (note 5), p. 118. 
depicted the doge as a saint on earth representative of the virtues and graces of a "holy city". ${ }^{13}$ In the minds of medieval pilgrims, politics and consequently military organization, were strictly connected to religion. Indeed, according to Breydenbach the successful political organization of Venice was the result of the city's deep devotion to God. ${ }^{14}$ Therefore, what appears as a present-day tourist's itinerary of the best known Venetian sights was, in the fifteenth century, part of an extended religious pathway admiring the piety and commitment of Venice towards Christianity.

A list of the churches visited by pilgrims in the fifteenth century (Table 1) shows the possible itinerary undertaken by the pilgrims while in Venice. From the middle of the fifteenth century, pilgrims seem to have visited roughly the same locations. Some of the differences in their itineraries might be attributed to various reasons, including the cultural background of the pilgrim, the public availability of an increasing number of relics during the later years of the fifteenth century, the pilgrim's knowledge of the city, the weather conditions, and, most likely, their personal wealth. This last factor is probably the most important to consider. Going on pilgrimage was not only dangerous but very expensive and Venetians, as the main providers of overseas passage, took advantage of their privileged position to transform religious devotion into a business.

To facilitate the entertainment of pilgrims in the city, Venetians organized guided tours, events, and celebrations like the traditional Sposalizio del Mare ("Marriage of the Sea") or the procession of Corpus Christi. ${ }^{15}$ Pilgrims were not, however, allowed to wander alone around Venice. There was a risk of getting lost or ending up in some of the off-limits zones of the city (it is likely, for example, that pilgrims were authorized to visit only the de-militarized areas of the Arsenal such as the production warehouses or the galley-sheds as Breydenbach, Casola, and Wey themselves indicate in their narratives). ${ }^{16}$

Public rituals encapsulated the façade that Venice exhibited to the world. They reflected the Venetian aspiration that their great city be remembered by its visitors as a unique symbol of medieval Christianity. The pilgrims' first encounter with the grandiosity of Venice was probably experienced during the doge's entrance through the canals of the lagoon, which took place with great pomp aboard the Bucintoro, a special ornate galley used for public celebrations. Ascension Day was the first public appearance of the doge during the period of the spring voyage and the first occasion for pilgrims to see him in person. The celebration ritual during Ascension Day - the 'Marriage of the Sea' - was a public remembrance of Venice's naval power during the Dalmatian conquest.

13 Bernhard von Breydenbach (note 5), pp. 24-25.

14 Ibid.

15 About this topic see Edward MurR, Civic Ritual in Renaissance Venice, Princeton / NJ 1981.

16 DAVEY (note 5), p. 118; NEWETt (note 5), pp. 139-140; Bernhard von Breydenbach (note 5), p. 23. 
It is uncertain when the 'Marriage of the Sea' became part of the rituals of Ascension Day. The first public celebration enacted aboard the Bucintoro occurred only in 1311 when the Senate approved the construction of a navilium ducentorum hominum. ${ }^{17}$ Brunetti argued that the known civic ritual of the later Middle Ages

Table 1: List of the Venetian churches visited or mentioned by fifteenth-century pilgrims.

\begin{tabular}{|c|c|c|}
\hline $\begin{array}{l}\text { William Wey } \\
1458\end{array}$ & $\begin{array}{l}\text { Roberto Sanseverino } \\
1458\end{array}$ & $\begin{array}{l}\text { Felix Fabri } \\
1480\end{array}$ \\
\hline 1. San Marco & 1. San Marco & 1. San Marco \\
\hline 2. San Geremia & 2. Santi Apostoli & 2. San Gregorio \\
\hline 3. San Giovanni di Rialto & 3. San Nicola & 3. San Piero Martire \\
\hline 4. San Giovanni in Bragora & & 4. San Domenico \\
\hline 5. San Salvatore & & 5. San Giovanni e Paolo \\
\hline 6. Santa Maria Formosa & & 6. San Nicola \\
\hline 7. San Silvestro & & 7. Santa Maria delle Grazie \\
\hline 8. San Girolamo & & 8. Santa Maria dei Miracoli \\
\hline 9. San Pietro Castello & & 9. San Pietro di Castello \\
\hline 10. S. Elena & & 10. San Zaccaria \\
\hline 11. S. Zaccaria & & 11. San Giovanni (monastery) \\
\hline 12. S. Daniele & & 12. San Rocco \\
\hline 13. S. Lorenzo & & 13. San Bartolomeo \\
\hline 14. S. Giuliano & & 14. Santa Maria della Misericordia \\
\hline 15. S. Canciano & & 15. Santa Maria Formosa \\
\hline 16. Santi Gervasio e Protasio & & 16. San Antonio \\
\hline (San Trovaso) & & 17. San Geremia \\
\hline 17. S. Nicolò & & 18. Santissima Trinità \\
\hline 18. S. Basilio & & 19. Santo Stefano \\
\hline 19. S. Giorgio & & 20. San Canziano \\
\hline 20. S. Aponal & & 21. Santa Maria del Carmine \\
\hline 21. S. Servolo & & 22. Santa Marta \\
\hline 22. S. Maria e Donato & & \\
\hline 23. San Domenico & & \\
\hline 24. San Francesco della Vigna & & \\
\hline 25. Santi Cosma e Damiano & & \\
\hline 26. San Lio & & \\
\hline 27. San Clemente & & \\
\hline 28. San Marcuola & & \\
\hline 29. San Cipriano & & \\
\hline 30. San Secondo & & \\
\hline
\end{tabular}

17 It is believed that Bucintoro was a distortion of the word ducentorum. In fact, the ship was able to carry about two hundred men aboard, see Giustina Renier MicHIEL, Origine delle feste veneziàne, vol. 1, Venice 1852, p. 193. 
Table 1 (continued)

\begin{tabular}{lll}
\hline Santo Brasca & Bernhard von & Pietro Casola \\
1480 & Breydenbach & 1494 \\
& 1483 &
\end{tabular}

1. San Marco

2. Santi Giovanni e Paolo

3. San Francesco

4. San Bartolomeo

5. San Francesco la Vigna

6. San Antonio

7. San Salvatore

8. Sant' Elena

9. San Blasio

10. San Canziano

11. Crociferi (Santa Maria Assunta)

12. San Daniele

\section{San Marco}

2. San Giorgio

3. Sant' Elena

4. San Nicola

5. Crociferi (Santa Maria Assunta)

6. Santa Marina

7. Santa Lucia

8. San Zaccaria
1. San Marco

2. Sant' Elena

3. San Antonio

4. San Cristoforo

5. San Giorgio

6. San Andrea

7. San Francesco della Vigna

8. Santa Maria dei Servi

9. Monastero della Carità

10. Santa Maria del Carmine (monastery)

11. San Salvatore

12. San Nicola

13. Santa Madonna dell'Orto

14. San Giorgio in Alga

15. San Zaccaria

16. San Pietro di Castello

17. Santi Apostoli

merged with a former and much simpler religious celebration known as benedictio maris, possibly carried out at the time of the Dalmatian conquest in the year $1000 .^{18}$ On the other hand, the ritual of the desponsatio was included in the custom much later and attributed to the visit of Pope Alexander III to Venice in the twelfth century. ${ }^{19}$ Over time, what was originally a religious benediction before an official departure of the Venetian galleys from the Arsenal gradually disappeared in favour of a much more mundane display of authority. In fact, the celebration for the Sensa (Ascension), which lasted between one and two weeks before and after the final parade of the Bucintoro through the canals of the lagoon, started with the organization of the Fiera della Sensa ("Sensa fair") considered an additional occasion for pilgrims to experience Venetian culture. Indeed, the Sensa fair was a major occasion for pilgrims to find souvenirs, do shopping, and discover sophisticated products specific to Venice, such as manuscripts and (later in the fifteenth century) early printed books, all in the same place. On the occasion of the fair, merchants and artists from and outside Venice gathered in St Mark's square. Stalls were mounted all over the piazza to

18 Mario BrunetTI, Sposalizio del Mare, in: Enciclopedia Italiana, vol. 32 (1936), pp. 416-417. 19 Ibid. 
display a countless number of objects (such as paintings, books, Murano glass, carved wood, ornaments, spices, etc.) and it seems the fair was so popular that it attracted more than 100,000 people annually. ${ }^{20}$

Although the fair was a major attraction and undoubtedly contributed to the remaking of the city as an exotic and fascinating place in the eyes of the newly-arrived visitors, the focus of the celebration was not the fair itself but the parade of the Doge aboard the Bucintoro and its symbolic religious and political significance. On the eve of the Ascension Day, the Bucintoro was moved out of the Arsenal in order to be admired by people before the official parade. ${ }^{21}$ Fabri described the vessel as, "a great ship fashioned like a tabernacle, painted, covered with gilding and shrouded with silken hangings". ${ }^{22}$ Before the parade, a religious procession accompanying the doge to the Bucintoro did not fail to remind pilgrims of the sacredness of that moment.

The ceremony is described as full of pomp and so noisy that Fabri stated that it "seems to shake the very sea," with all the city's bells ringing, trumpets, cannons, and over five thousand vessels celebrating the passage of the doge from the Arsenal to the church of St Nicholas on the Lido. ${ }^{23}$ The final stage of the celebration was the Sposalizio. The doge, as a propitiatory rite to inaugurate a new naval season, threw a ring towards the sea as a symbol of the annual 'marriage'. CROUZET-PAVAN, in her study of the myths of Venice, argued this moment represented for pilgrims a symbol of the 'maritime adventure' they were embarking upon. ${ }^{24}$ Although CROUZET-PAVAN's hypothesis may be plausible within a context of celebration, none of the pilgrims who left an account of his stay in Venice during the fifteenth century discussed the Bucintoro as a symbol of the upcoming maritime journey. On the contrary, with the exception of Felix Fabri, descriptions of Ascension Day are generally very brief. For example, Santo Brasca, who travelled to the Holy Land in 1480, described his participation in the Sensa as: "I went to see the marriage of waters beyond the walls where the doge was in the Bucintoro with many other citizens' boats and beautifully adorned women. It was certainly something great and magnificent to see.”25

This celebration was perceived differently from pilgrim to pilgrim. For instance, William Wey preferred to highlight the background linked to the symbolism of the

20 A recent study by Evelyn WELCH offers a wider perspective in relation to Italian medieval fairs and investigates the changes in the Sensa fair over the centuries, see Evelyn S. WeLCH, Shopping in the Renaissance: Consumer Cultures in Italy 1400-1600, Yale 2005, pp. 166-184.

21 L’Omnibus raccolta di letture popolari di storia, letteratura belle arti, curiosità, vol. 1, Venice 1854, p. 173.

22 Aubrey SteWART, The Book of the Wanderings of Brother Felix Fabri, vol. 1 (The Library of the Palestine Pilgrims' Text Society), London 1896, p. 98.

23 For the description of the feast see ibid., pp. 98-99.

24 Crouzet-Pavan (note 6), p. 532.

25 Preterea andai a vedere sposare el mare fuora de le castelle ove gli era il duce nel Bucintoro con tante barche de citadini et done ornatissime, che certo era grandissima magnificentia a vedere; see Santo Brasca (note 5), p. 49. 
'Marriage of the Sea' by narrating how the events involving Pope Alexander and the Doge Sebastiano Ziani led to the recognition of Venice as the city-symbol of the Christian faith instead of describing the ceremony itself in detail as Fabri did. ${ }^{26}$ What emerges from all these accounts is the intention of Venice to mark herself as a unique spot on the pilgrimage route, one that offered pilgrims a type of spirituality that was very different from the one they would experience in Jerusalem. That spirituality revolved around the figure of the doge as the legitimate representative of the Christian faith on Earth. The doge was perceived, in fact, as one of the closest emissaries of God on Earth. Therefore, everything organized by him and the city's holy government was the result of this sanctity and the highest expression of his Christian faith.

Bernhard von Breydenbach affirms there were no right words to praise the glory, piety, and sanctity of the doge, who in his eyes was a prince surrounded by the wise members of the Senate and a most judicious person to enact the saintly laws of Venice. ${ }^{27}$ Nevertheless, except for a few 'lucky' pilgrims who met the doge personally in his palace, the city's ruler remained, for the majority of visitors, a sort of symbolic figure who represented the start and the end of the Venetian stay before the journey to the Holy Land.

Venice's religious significance had always been of central importance to the Republic since the translatio of St Mark's body in 828. It developed in a completely different way from that of Jerusalem, being focussed on three main points: the figure of the doge, the civic celebrations, and the display of wealth as a sign of the city's sovereignty and as a symbol of the divine providence. In this regard, the early modern French Humanist Guillaume Postel stated that Venice was an eternal city blessed by the divine and this perennitas was shown in Venice's use of gold and in the art and glass symbols of the city's wealth. ${ }^{28}$

Furthermore, Postel described Venice as a "perfect government, most sacred regalitas and true Jerusalem". ${ }^{29}$ Postel's sixteenth-century view brilliantly summarized what Venice aspired to be not only within the pilgrimage route but also within Christianity itself. Indeed, despite its role the city did not aspire to be another Jerusalem through mimesis or devotion but, to the contrary, it wished to be considered the 'true' Jerusalem because of its unicity, geographical position, government,

26 William Wey dedicates an entire paragraph to explaining the origins of the 'Marriage of the Sea' through the legend of Pope Alexander III and Emperor Frederick, see DAVEY (note 5), pp. 120-122, and the Latin version of the text in The Itineraries of William Wey, Fellow of Eton College, to Jerusalem, A. D. 1458 and A. D. 1462; and to Saint James of Compostella, A. D. 1456. From the original manuscript in the Bodleian library, ed. Bulkeley BANDINEL / George WiLLIAMS, London 1861, pp. 87-88.

27 Bernhard von Breydenbach (note 5), pp. 24-25.

28 Marion L. KunTz, Guillaume Postel e l'idea di Venezia come la magistratura più perfetta, in: Marion L. KunTz (ed.), Postello, Venezia e il suo mondo, Florence 1988, pp. 163-178, here p. 175. 29 Ibid., p. 173. 
and wealth, all of which had been obtained by divine will. ${ }^{30}$ The inner religious devotion spread in the city since its foundation found its definitive dimension in the course of the fifteenth century. Venice's peculiar role as counterpart of Jerusalem and key provider of maritime services to the Holy Land widely contributed to making the city an important religious attraction in its own right. From a certain point of view, Venice had to respond to the pilgrims' need to be welcomed and guided though their journey. This came through the organization of city tours. When organized privately for small groups of pilgrims, these were likely to have been expensive. This price may not have included additional expenses such as alms and indulgence costs.

Modern tourists can be considered more fortunate than those who visited Venice during the Middle Ages: most of the Venetian churches are now free to enter (an exception to this are the churches of the Circuito Chorus, that is the Basilica di Santa Maria dei Frari, Chiesa di Santa Maria Formosa, Chiesa di San Polo, etc.). Felix Fabri reached some of the churches listed in Table 1 by navigating the canals, probably accompanied by a Venetian guide; Pietro Casola also stated clearly that he, and his companion, paid a fee to visit the Venetian churches. ${ }^{31}$ Differences in religious itineraries are likely due to the individual pilgrims' requests and their willingness to spend extra money on alms and indulgences in more or less complicated itineraries. The next section will consider some of these differences in more detail.

\section{Venice as Seen in William Wey's Narration}

In considering which of the available itineraries offers the most in terms of reappraising our view of present-day tours of Venice, Wey's stands out. Although those of Santo Brasca, Felix Fabri, and Pietro Casola appear as three of the most complete tours in terms of the number of churches visited, their visits were tailored specifically for their personal needs and included stopovers at monastic houses that no longer exist and meetings with certain religious contacts that are not relevant to any modern route. For instance, Felix Fabri states more than once that he went to certain churches to meet some confrères he already knew in Venice, possibly from previous travels. ${ }^{32}$ On the other hand, Roberto Sanseverino's route is not sufficiently complex because its length is very limited and his travel is known to have been politically-oriented. Bernhard von Breydenbach's narration, on the other hand, suggests an itinerary determined by the prestige of the relics held by Venice's

30 Sante GraciotTI, Venezia nell'utopia mitico-religiosa tra Cinque e Seicento (nei ditorni Jacopo Brocardo), in: Sante GRACIOTTI (ed.), Mito e antimito di Venezia nel bacino adriatico: secoli XV-XIX (Media et Orientalis Europa 1), Venice 2001, pp. 149-167, here p. 157.

31 ZASSO (note 7), pp. 17-18; NEWETT (note 5), p. 135.

32 ZASso (note 7), pp. 14-18. 
churches. While of great value in that it highlights Venice's religious relevance, an itinerary based on it might be problematic for a modern visitor due to possible restrictions on the accessibility of the relics today. Most of those Bernhard listed are either no longer available or difficult to see because they are kept out of public view (that is, inside the altar or in specific reliquaries). ${ }^{33}$

Although it is not clear whether William Wey personally undertook the route suggested in his account, the order in which the churches are listed and their location in the city indicates an actual pilgrimage itinerary which included a large number of the churches throughout the territory of Venice. It has to be noted that the description and history of the list of churches provided by Wey is slightly inaccurate. It appears mis-remembered, as if the pilgrim received oral information about the city's sights and then reported this information at a later date when writing up his account.

William divides the churches of Venice according to two criteria. On the one hand, he mentions seven churches which he believed to be founded by St Magnus. On the other hand, he mentions those churches possessing notable relics. The list of churches founded by St Magnus, however, contains several mistakes. For example, the number of churches founded by the saint was eight and not seven as Wey suggested. Nor does the list provided by Wey correspond to the actual churches founded by St Magnus himself. Specifically, the churches of St Giacomo di Rialto and St Silvestro are listed by Wey among those founded by St Magnus but these have been confused with the church of St Zaccaria and the church of Santi Apostoli. The separation of those seven churches from the general list may suggest Wey attributed a special significance to them yet the confusion in their names suggests a misunderstanding or error of memory.

Despite these caveats, William demonstrates an emotional investment in his description of Venice that sheds light on a symbolic interpretation of Venetian religious architecture that has been lost today. Before investigating of how Wey's itinerary is relevant, it is necessary to be as clear as possible about the background of the author and his purpose in creating the text.

Everything that is known about Willelmus Wey (or William Weye) can be found in the studies made by Bulkeley BANDINEL for the Roxburghe edition of his work in 1857 and from the more recent work of Francis DAVEY. ${ }^{34}$ With the exception of his confirmed fellowship at Exeter College, Oxford, from 1430 until 1442, and at Eton College, from 1441 to $1467,{ }^{35}$ all other personal information about Wey's life remains

33 Bernhard von Breydenbach (note 5), pp. 18-20.

34 See above, notes 5 and 26.

35 See Davey (note 5), p. 10, and William Wey (note 26), pp. i-ii. This edition is mainly known as 'Roxburghe'. The presence of William Wey at Exeter College is confirmed by a register of 1429, while his Eton fellowship is recorded in a register of 1447, see 'Socii Collegii Regal. Etonensis' in: Thomas HARWOOD, Alumni Etonenses. Or, a Catalogue of the Provosts \& Fellows of Eton College \& King's College, Cambridge, from the Foundation in 1443 to the Year 1797: With an Account of Their 
either unknown or contradictory. DAvEY provides possible dates for his birth (1407 in Devon) and death (30 November 1476) that are not, however, accompanied by any documentary proof, except a mention in the register of Exeter College. Furthermore, DAVEY suggests that Wey died in his seventieth year, while in the Roxburghe edition it seems that at the same age the author was consecratus ad modum peregrinorum, for his last pilgrimage in $1462 .^{36}$

Licences granted by King Henry VI and Pope Pius II allowed William to travel to the Holy Land in 1458 and 1462 despite his collegial duties. ${ }^{37}$ In both versions of his pilgrimage William started his voyage from Venice. In the first account Wey depicts Venice only briefly giving the impression he considered the city exclusively in terms of his port of departure. Conversely, the second account is more detailed and Venice itself acquires a more overtly religious character. ${ }^{38}$ There is little information about Venice in the first pilgrimage account. Here he stressed the logistical information about the journey, such as the changing of money and the expenses and necessary provisions for the sea-voyage. The account of 1462 seems to be written from a different perspective. Venice has not lost the characteristics of the mercantile city described by Wey in 1458 but four years after his first Venetian encounter, the maritime republic appears in a new, 'sacred' light. Indeed, Venice is described as an important religious stage within the itinerary to the Holy Land.

The map below (Figure 1) shows those churches (probably) visited by Wey in Venice during his stay in $1462 .{ }^{39}$ It is likely that a tour of all these churches took up to one month to complete in the Middle Ages due to the fact that part of Venice was marshy and the different parts of the city were not as well connected as they are today. Indeed, the current distance between the church of San Girolamo and the church of St Elena is about three miles and can be covered by walking for about an hour. In the fifteenth century, the connection between these two opposite sides of the city might not have been as effective as it is today. This may have lengthened the travel time considerably. Furthermore, visits to religious institutions were a spiritual investment for pilgrims for the purposes of collecting indulgences, praying, offering alms, and meeting members of the religious houses and churches. Therefore, it is

Lives \& Preferments, Collected from Original Mss. and Authentic Biographical Works, Birmingham 1797, pp. 51-52, and C. William BOASE, Register of the Rectors, Fellows, and Other Members of the Foundation of Exeter College, Oxford. With a History of the College and Illustrative Documents, Oxford 1894, pp. lxx-lxxi, 36.

36 See William Wey (note 26), p. v.

37 For the King's licence see Eton College Archives, Eton College Register 1457-1536, fol. 18r (46); for the papal licence see 'Lateran Regesta, Vol. DLXXX, f. 244' in the Calendar of Papal Registers Relating to Great Britain and Ireland, vol. 12: 1458-1471, ed. Jessie Alfred TwEMLow, London 1933, pp. 160-163.

38 See DAVEY (note 5), pp. 22-29.

39 Fig. 1 follows the subdivision of the itinerary into four sub-categories indicating the churches as mentioned in his account. Some of these churches (orange icons) no longer exist. 

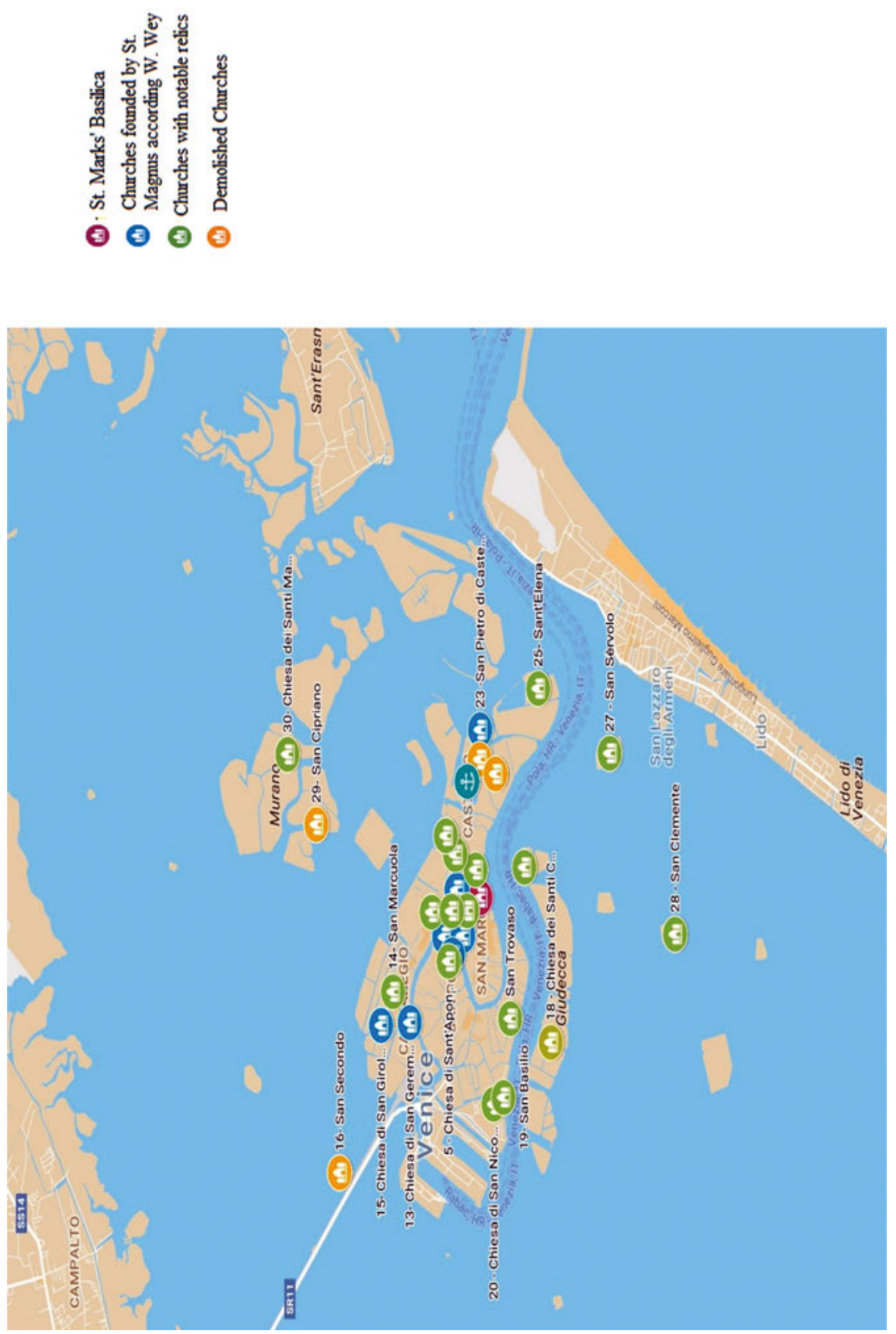

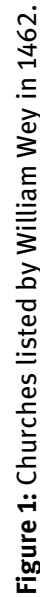


likely that a tour of the Venetian churches would not have been conducted as rapidly as it would be today; it probably only involved one to three institutions per day. ${ }^{40}$

The first nine churches mentioned by Wey establish the practicality of his suggestions for visitors to the present-day Venetian territory (Figure 2). Following the order to be found in Wey, the itinerary starts from the church of St Mark (1) continues to the church of San Geremia (2), before returning to the sestiere of St Mark to visit the churches listed from number 3 to 7 . The last two churches on the list, San Girolamo (8) and San Pietro di Castello (9), are situated at two opposite sides of Venice and needed to be visited separately because of their distance.

The completion of the itinerary takes five days. The route is not a continuous one, nor practical for the modern tourist because Wey listed the churches not according to their proximity but following a different criterion. For example, while the churches numbered eight and two in Figure 2 would be visited on the same day if distance were the only consideration, Wey placed them in a different order. Indeed, from the perspective of medieval religious men, an itinerary of this type would have expressed a deeper religious connection with the Bible. St Mark's basilica, a masterpiece of Byzantine artistic expression in Italy, was perceived by Wey as the fulcrum of the city's piety. It was a sacred place linked directly to God, a place where it was possible to receive full remission of sins and admire an emblematic connection of Venice with the heavenly Jerusalem. ${ }^{41}$ Walking inside St Mark's with his eyes on the sparkling and domed golden roof, Wey describes the Basilica as a representation of Jerusalem in Venice: "[...] and the high altar was of silver and gold as the Church of St Mark's was built as the Christian temple in Jerusalem."42

Undeniably, St Mark's basilica is one of the best Italian examples of the visual expression of Christian symbolism, having in its structure all the characteristics of a sacred divine epiphany. The golden mosaics covering the basilica's roof illustrate episodes from the Revelation of St John the Divine, which might have inspired Wey to symbolically connect Venice to John's verses. ${ }^{43}$ One of the basilica's vaults shows the seven churches of Asia in a mosaic. The following text introduces the scene: "Order to observe gradually the things I announce rightly" (Quae refero recte gradibus servare jubete). This phrase appears above the painting of the angels holding in their hands the seven churches of Asia and it introduces the archway of the Last Judgement as it is described in Revelation. By separating seven churches from the rest of the Venetian itinerary Wey created a parallel between these Venetian churches

40 Felix Fabri claimed he had visited two institutions in one day, see ZASso (note 7), p. 18

41 See Xavier BARRAl I Altet, Contro l'arte romanica? Saggio su un passato reinventato, Milan 2009, p. 202.

42 William Wey (note 26), p. 84: [...] et summum altare erat de argento deaurato, et ecclesia sancti Marci edificata ad modum templi Christianorum in Jerusalem.

43 William Wey (note 26), p. 84, already used the numerology of John to describe the main altar of St Mark's basilica. 

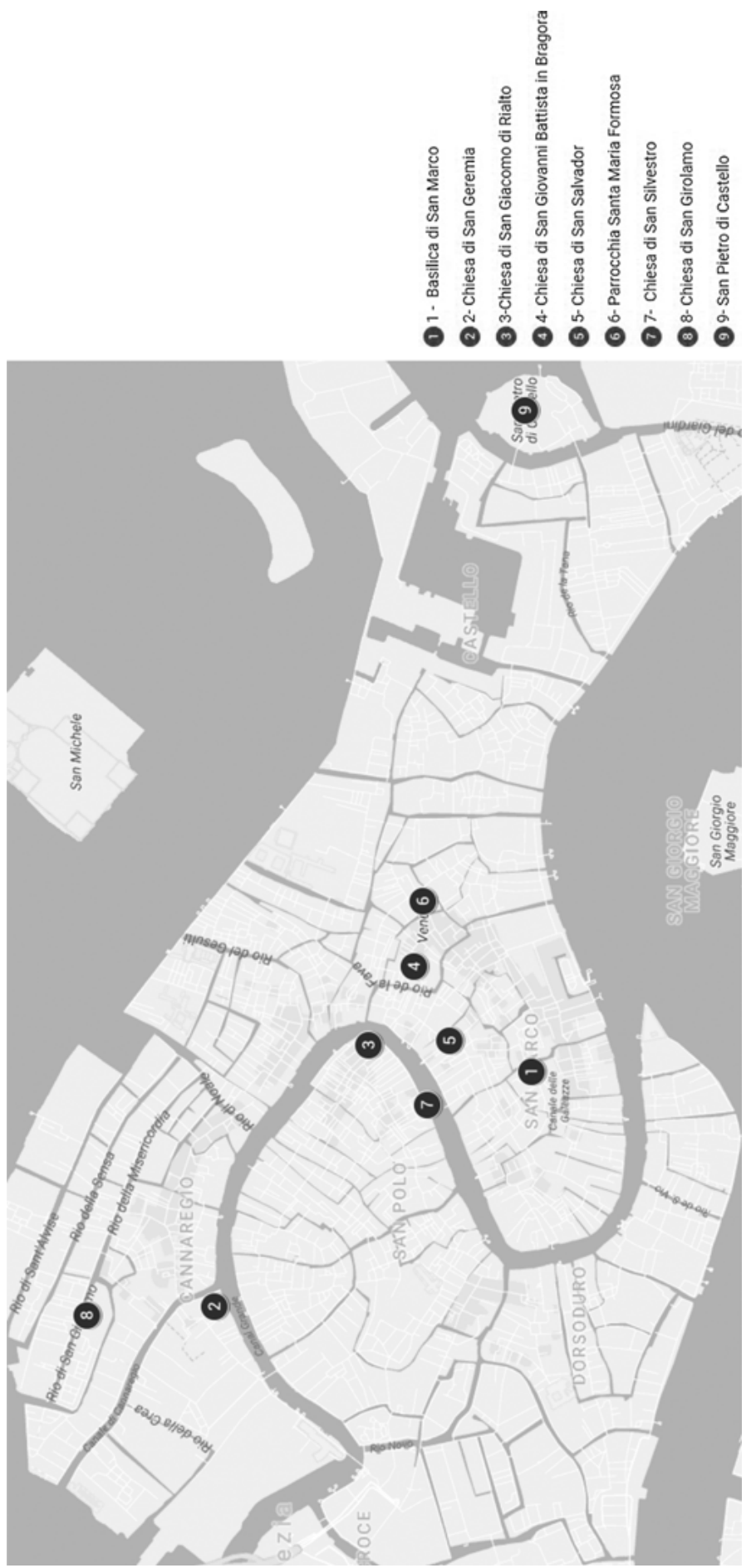

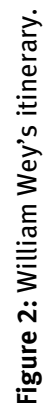


and the seven churches of Asia, possibly inspired by the images seen in the basilica. The possibility arises that Wey consciously adjusted the number of churches founded by St Magnus from eight to seven to establish a greater sense of their sacredness.

The churches of St Magnus share certain peculiarities with the ones described by John. The churches of Asia were not merely religious buildings but they had a similar significance for the community as the seven - in reality eight - churches of Venice had for Venetians. The legend of St Magnus states he was guided by God, the Apostles, and the Holy Virgin to complete the construction of the churches, just as Christ instructed John of Patmos to found the seven churches of Asia. ${ }^{44}$ Secondly, as with those listed in the Book of Revelation, the Venetian churches had specific virtues that made them relevant in the eyes of the pilgrim. For example, the church of Santa Maria Formosa was important for its sanctity as miracles happened there often and the doge of Venice visited it to redeem the sins of the citizens. The church of San Pietro di Castello, at that time the cathedral of Venice, held the throne of the apostle Peter. ${ }^{45}$ It is unclear if Wey deliberately sought to create a parallel between the symbolic association of the Venetian churches and those listed in the Book of Revelation or a Venetian guide made the claim that the churches of St Magnus were as sacred as the famous biblical ones, thereby misleading pilgrims in order to promote the sacredness of Venice.

Wey's decision to highlight the connection of Venice with Scripture, however, does not necessarily mean the actual route followed by medieval pilgrims reflected the order given in his text. Rather he was stressing that a symbolic appreciation of a small part of the pilgrim's path may add to the creation of a religious experience in Venice. Something similar occurred in Wey's explanation of the 'Marriage of the Sea'. It can be regarded as the author's peculiar way of highlighting the sacredness of Venice for his readers. In fact, although Wey's route does not reflect the actual itinerary of the churches of St Magnus, his interpretation of the mosaics in St Mark's and their possible connection with the other churches in Venice offers an interesting perspective on the impact that Venetian architecture had on medieval travellers, revealing a precious key to understanding the city's symbolism from a medieval standpoint.

After completing the itinerary according to the order indicated by William Wey, one clear conclusion can be reached, which is that from the perspective of a modern tourist a simple correspondence between the medieval text and a new itinerary would not be practical and would be very time consuming. The churches are too far

\footnotetext{
44 For more information about the history of St Magnus see Gianbattista MERLo, Vita di san Magno vescovo di Oderzo poi di Eraclea patrono della città di Venezia e specialmente della parrocchia del SS. Salvatore, Venice 1860; Revelation 1:11.

45 To the eyes of the pilgrim, this might appear particularly striking given that one of the churches of Asia, Pergamum, was said to be located on the 'seat of Satan', see DAvEY (note 5), p. 122; Clyde E. FANT / Mitchell G. REDDISH, Lost Treasures of the Bible. Understanding the Bible Through Archaeological Artifacts in World Museums, Cambridge 2008, pp. 390-391.
} 
apart and the route excludes most of the relevant Venetian religious architecture. The reintegration of a 'St Magnus itinerary' in a broader Venetian exploration, however, which includes all the remaining churches mentioned by Wey (and the other fifteenth-century pilgrims) would conform in a practical way to the manner in which, historically, Venetians organized their local religious tours (Table 2).

A visit plan based on the specific zones or linked to a particular event would be more practical in terms of time and coherence. The churches situated in the sestiere of San Marco and those near Rialto were certainly the most visited and best known by pilgrims, however, the presence of specific relics held by churches outside the tourist zone was probably the principal reason to organize tours in decentralized sestieri of Venice such as Castello, Cannaregio, or Dorsoduro.

In zones such as that of Cannaregio, which in the medieval period was mostly frequented by residents and was in some parts marshy, it was possible to visit churches holding relics considered of interest, such as the body of St Magnus or the bones of Saints Sergio and Bacco. ${ }^{46}$ Moreover, during organized visits to the Arsenal, pilgrims seized the opportunity to visit those religious institutions distant from the city centre such as the Basilica of St Pietro di Castello, situated on the little island of San Pietro di Castello, or the monastery of San Domenico. Such a route is feasible for the modern tourist, who would find it much easier and less time consuming to discover the medieval pilgrims' path according to the division by sestieri (Table 2). This would give the tourist an opportunity to insert in their itineraries other significant medieval locations such as the Arsenal in the sestiere of Castello, the doge's palace, the Marciana Library, and the Fondaco dei Tedeschi in the sestiere of St Mark's. Moreover, each summer Venice still celebrates the Sensa with a (mundane) remembrance of the medieval 'Marriage of the Sea' in front of the Church of St Nicolò al Lido. Although the doge, symbolic icon of this celebration, is no longer centre stage (replaced by the mayor in the current celebration), it would be an excellent initiative to accompany this festivity with additional tours to rediscover the paths travelled in what once was considered a 'city for pilgrims', especially for those tourists interested in learning more about the symbolic and religious sides of Venice.

\section{Conclusions}

Venice can still tell us much about the medieval period and about the pilgrimage experience in particular. With the exception of a few institutions such as the monastery of San Domenico and the churches of San Daniele, San Secondo, and San Cipriano the itinerary followed by fifteenth-century pilgrims before their journey to the Holy Land is

46 For more information about the churches of Venice see Flaminio CoRnARo, Notizie storiche delle Chiese e Monasteri di Venezia e di Torcello, Padua 1758. 


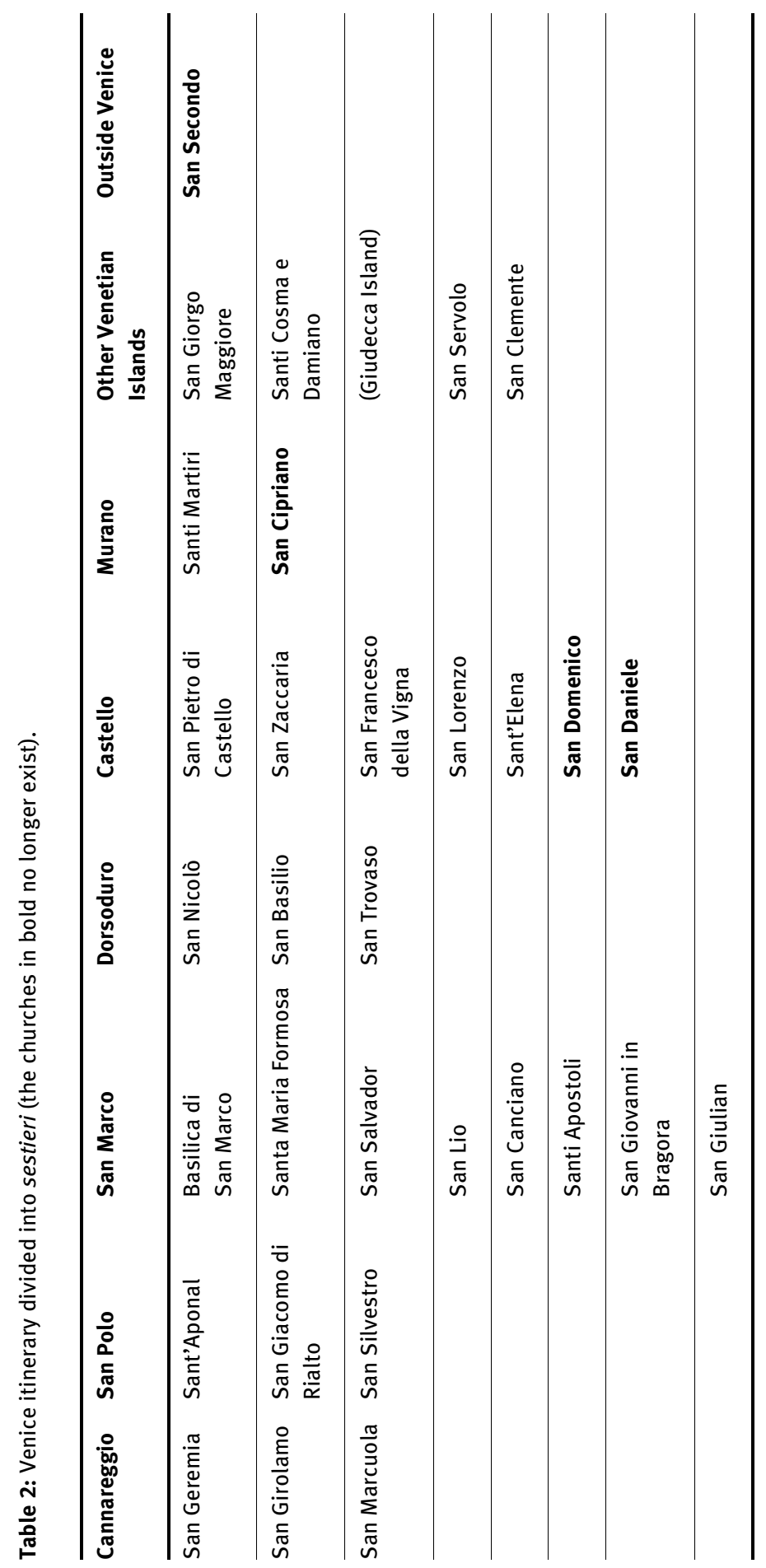


still viable and probably easier to complete than five centuries ago. Echoes from a medieval golden age resound everywhere in Venice. But are present-day tourists able to hear them without support and promotion by the Venetian authorities?

One outcome of this study is that it highlights the way in which the experience of being in Venice has changed since the Middle Ages. This is not because most of the churches and historic buildings have been physically replaced, but rather because what made this city a key destination during the medieval period has been completely forgotten by current civic institutions. In the fifteenth century, Venetian citizens were the heartbeat of the lagoon. The promotion of the city's history and its military, political, and religious unity by its inhabitants headed by the significant figure of the doge created a powerful 'myth' of Venice and a religious symbolism, which survives in countless medieval records. Fifteenth-century travel guides allow us to discover not only that it is still possible to wander as a medieval pilgrim in Venice but highlights that the medieval sense of the spiritual significance of the buildings has been lost. Indeed, although the greater part of the aforementioned churches are open to the general public, Venetians no longer welcome visitors themselves and/or involve them in discovering the history and medieval relevance of these institutions. Personal interactions have been replaced by information posters, posters that inform tourists about 'history' but not 'mentality'.

These changes have played a part in the 'disappearance' of Venetian natives and residents from the lagoon, which is a well-known problem for Venice's administration..$^{47}$ Alarming data suggests the likely emergence of a new ghost city by 2030 that will see Venice resemble a theme park rather than the city described by William Wey as the "most holy place". ${ }^{48}$ The thriving past of a multicultural, vibrant Venice attracts millions of tourists every year. A religious, symbolic understanding of the medieval city, adapted to the necessities of modern tourists, can still be discovered thanks to the material available in the medieval itinerary. Promoted by a collaboration between Venetian residents, Venice's institutions, and academia, this material can serve as a reminder of how radically our reading of the environment has changed with respect to the medieval past and this, in turn, could inform new tours and new content for tourists to engage with. Nevertheless, without the support of the local political and cultural institutions in the promotion of the historical understanding of the city and its medieval connections the gradual loss of this symbolic memory is inevitable.

47 The rise in living costs has forced Venetians to move to other locations such as nearby Mestre. On the vanishing of Venetian residents see Cathy NEwmAn, Vanishing Venice, in: National Geographic (August 2009), online: https://www.nationalgeographic.com/magazine/2009/08/ven ice/ (last accessed 15/05/2019), and Roberto BiAnchin, Venezia nel 2030: una città vuota niente abitanti ma solo turisti, in: La Repubblica (25 August 2006), online: http://www.repubblica.it/2006/ 08/sezioni/cronaca/2030-venezia-vuota/2030-venezia-vuota/2030-venezia-vuota.html (last accessed 15/05/2019).

48 Davey (note 5), p. 120. 
Klaus Oschema

\title{
Heaven Can Tell ... Late Medieval Astrologers as Experts - and what they can Teach us about Contemporary Financial Expertise
}

\begin{abstract}
In taking action, or rather in making the decision to act, humans are inevitably confronted with a fundamental dilemma: actions taken in the present seek to bring about consequences in an immediate or distant future, but that future is, by definition, unknown and unknowable. That even the present is characterized by a high degree of complexity can lead to the establishment of a particular group: experts or expert advisers. Experts are individuals credited with specific knowledge and who are relied upon in order to make informed decisions or solve particular problems. While many authors consider the development of cultures of expertise to be a uniquely modern phenomenon that responds to the increasing complexity of social organisation, this chapter argues that late medieval astrologers can be described as 'experts', and that their activities can be analysed fruitfully as being part of an 'expert culture'. In order to appreciate fully the characteristics and workings of this culture, medievalists have to rely upon insights and findings derived from the Social Sciences. While an interdisciplinary dialogue benefits research on medieval subjects, I argue that the analysis of premodern 'expert culture' can (and must) inform reflexions on the role of experts in modern societies. Based on drawing a comparison between modern financial experts and late medieval astrologers, I argue that analysis of the latter enables us to better understand our reliance on experts as an act of belief rather than as an outcome of supposedly rational calculation.
\end{abstract}

Keywords: expert culture, science, astrology, economics, forecast, prognostication, failure

\section{Prelude}

In order to demonstrate the potential and relevance of Medieval Studies for contemporary society, it seems helpful to start in the present. Many people would certainly agree that the years after 1989/90 have seen the development of an increasingly complex world on several levels. The previous, more or less clear-cut political order that saw a capitalist 'West' confront the communist 'East' has been rapidly transformed

\footnotetext{
Klaus Oschema, Geschichte des Mittelalters (insb. des späten Mittelalters), Ruhr-Universität Bochum, Historisches Institut, Universitätsstr. 150, 44801 Bochum, Germany, klaus.oschema@rub.de 
into a profoundly complex multitude of political entities with varying and sometimes unclear political orientations and affiliations. Intensified economic exchange on a global scale has benefitted large numbers of consumers, but has equally created problematic side-effects such as the economic 'migrations' of large corporations that seek to minimize their tax obligations while siting manufacturing facilities in locations where they can fabricate their products at cheaper rates (and where regulations are often less strict). International travel has vastly expanded, making people more mobile, but also distributing pathogens more efficiently (such as the 'pig-flu' and the 'bird-flu') and fostering tensions than can be interpreted, depending on one's perspective, in religious or social terms. In the aftermath of the events of 9/11/2001 that played a decisive role for many ensuing political and cultural developments, both of these dimensions converged. To cut a long story short: the world 'we' live in has become awfully complex and complicated (especially since this 'we' obviously refers to radically divergent realities, depending on the individual chance of being born into a well-off family in Switzerland or a poor family elsewhere!).

In order to 'navigate' this increasingly complicated world, contemporary societies and their members rely on a specific group: experts! Experts are the people who are recognized to have deeper insights than the average person in their particular area of expertise, and thus are supposed to be able to help us to better understand specific contexts or problems and to master successfully specific tasks. ${ }^{1}$ This approach is by no means neutral and exclusively concerned with providing us with a better sense of the world we inhabit. It rather fulfils essential and very practical functions, allowing us to take informed decisions in the present - and in order to do so, experts frequently offer prognostications about the future. ${ }^{2}$

1 Among the vast body of pertinent recent publications I would mention only Stephen P. TURNER, The Politics of Expertise (Routledge Studies in Social and Political Thought 82), New York, London 2013, who analyses the political implications of experts' prominent role; the contributions in Karl Anders Ericsson / Neil Charness / Paul J. Feltovich / Robert R. Hoffmann (eds.), The Cambridge Handbook of Expertise and Expert Performance, Cambridge, New York 2006, mostly focus on questions concerning the improvement and practical application of expertise. For a critical analysis see already Anthony GIDDENS, The Consequences of Modernity, Cambridge 1990.

2 See e. g. Dan Gardner, Future Babble. Why Expert Predictions Fail - and Why We Believe Them Anyway, Toronto 2010; Philip E. TetLock, Expert Political Judgment: How Good Is It? How Can We Know?, Princeton / NJ 2005; ID. / Dan GARDNER, Superforecasting. The Art and Science of Prediction, London 2016 (orig. New York 2015). For a specific model see Denis LovERIDGE, Foresight. The Art and Science of Anticipating the Future, New York 2009. A short critical analysis is provided by Fernand GoBET, Understanding Expertise. A Multi-Disciplinary Approach, London 2016, pp. 185-192. In the present study, I reserve the notion "forecast" / "forecasting" for modern procedures of financial and economic descriptions of probable future developments. As my argument will hopefully make clear, however, the differences between "modern forecasts" and "premodern prognostications" are not clear enough to warrant a precise distinction (which is, in fact, also reflected in the variable use of "forecast", "prediction", and "prognostication" in the cited literature). 
But the increasing importance of experts also entails a profound unease with the complexity of the modern world and the necessity of relying on expert counsel in a broad range of situations, from tax declarations and pension schemes to political decisions. This unease originates from a feeling of helplessness when confronted with the unclear consequences of individual actions, but also with the experience of experts' failures that can be witnessed in the media. 'Western' societies are thus facing a paradoxical situation: relying more and more on experts on the one hand, on the other hand they develop an 'anti-expert'-stance that underlines the importance of lay-people and 'common sense'. The experts' position is thus frequently criticized as being unmerited, since it allegedly results from purely formal criteria, like the possession of a diploma. ${ }^{3}$ This attitude resonates with the anti-intellectual stance adopted in political discourse in countries like France, Switzerland, or Hungary, and probably also contributed to the election of Donald J. Trump as president of the USA in November 2016.

Leaving genuine politics aside, ${ }^{4}$ a specific group of experts furnishes a telling example of symbolic actions that invite us to reconsider our depiction of 'modern' society as being based on principles such as rationality: since the financial crisis that erupted in 2007, several studies have demonstrated that financial and economic expertise effectively has very limited value when it comes to the prognostication of future developments, ${ }^{5}$ even though this is the main interest of the experts' clients and readers. ${ }^{6}$ We seek advice in order to decide in which form we should invest the money we put aside for use in the (often distant) future, for example for pension plans. But if the success-rate of forecasts drops far enough, tossing a coin would be equally efficient. ${ }^{7}$

3 For this criticism see e. g. Marc E. FITCH, Shmexperts. How Ideology and Power Politics are Disguised as Science, Washington / DC 2015. Adding to the paradox, the popularized presentation of scientific insights leads laypeople to underestimate the complexity of research and its findings, see Lisa SCHARRER / Yvonne RUPIEPER / Marc STADTLER / Rainer BROMME, When Science Becomes Too Easy. Science Popularization Inclines Laypeople to Underrate their Dependence on Experts, in: Public Understanding of Science (2016), online (DOI): http://journals.sagepub.com/doi/10.1177/ 0963662516680311 (last accessed 15/05/2019).

4 The need to rely on experts can in fact entail serious (theoretical and practical) difficulties for democratic processes and structures, see TURNER (note 1), pp. 3-5.

5 See note 2 and several studies by Markus SpIwoKs, e. g. ID. / Johannes ScheIER / Oliver HEIn, On Assessing Economic Forecasts. An Evaluation of Predictions on GDP, Industrial Production and Private Consumer Spending Trends in Twelve Industrial Nations, in: Advances in Management and Applied Economics 4(2) (2014), pp. 49-68.

6 See, however, Jens BECKER, Imagined Futures. Fictional Expectations and Capitalist Dynamics, Cambridge / MA 2016, who underlines the systemic value of predictions, which contribute to creating a set of expectations and a general orientation towards expected (i. e. future) growth, that characterizes capitalist mentality as a whole.

7 For the low success of financial forecasts see e. g. Markus SPIwoKs, The Golden Mean Fallacy and Financial Market Forecasting, in: European Journal of Social Sciences 6(3) (2008), pp. 433-441, or ID. / 
This is not the place to present a long list of either anecdotal or more systematic evidence for the long series of failing financial and economic forecasts, although this would provide some very amusing material. ${ }^{8}$ Suffice to say that the leading experts did not see the crisis of 2007 coming - and once it had arrived, they failed to recognize its dimensions, let alone provide satisfying explanations and justifications for their failure. ${ }^{9}$ Moreover, in spite of the apparent disappointment in this particular case, few individual experts - not to mention their entire profession suffered sustained and far-reaching consequences.

There are, of course, good reasons for this, since the failure of forecasts is not equivalent to the uselessness of the experts' assessment of the present. But the particular combination of failure and continuing practice as someone who is recognized as being an authority in predicting the future invites the medievalist to have a closer and comparative look at a phenomenon that belongs to her or his own area of expertise: the rise of astrologers as experts and scientific advisers to rulers in the fourteenth and fifteenth centuries. Even though I would not want to put modern financial and economic experts on a par with these astrologers, ${ }^{10}$ I would like to argue that their practices, as well as their social roles, resemble each other to such a degree that it warrants a comparative analysis, which in turn can shed new light on both subjects. If this really is the case, however, it implies a high degree of

Oliver HEIN, Die Währungs-, Anleihen- und Aktienmarktprognosen des Zentrums für Europäische Wirtschaftsforschung. Eine empirische Untersuchung des Prognoseerfolges von 1995 bis 2004, in: AStA - Wirtschafts- und Sozialstatistisches Archiv 1(1) (2007), pp. 43-52. See also BECKER (note 6), pp. 217-244.

8 See e. g. GARDNER (note 2).

9 Ibid., pp. 13-14; BECKER (note 6), p. 222. I would like to thank H. Darrel RUTKIN for pointing out the analogy with the situation in 1524-1525: while a large number of astrologers predicted a great flood that failed to materialize, none of them seems to have foreseen the Peasants' War of 1525, see Ottavia Niccolì, Prophecy and People in Renaissance Italy, Princeton 1990, and Heike TALKEnBERger, Sintflut. Prophetie und Zeitgeschehen in Texten und Holzschnitten astrologischer Flugschriften 1488-1528 (Studien und Texte zur Sozialgeschichte der Literatur 26), Tübingen 1990. It is interesting to note that Johannes Carion, who enjoyed the reputation of being an extremely successful astrologer, did not predict a flood for 1524, see Frank Ulrich PRIETZ, Das Mittelalter im Dienst der Reformation: Die 'Chronica' Carions und Melanchthons von 1532. Zur Vermittlung mittelalterlicher Geschichtskonzeptionen in die protestantische Historiographie (Veröffentlichungen der Kommission für geschichtliche Landeskunde in Baden-Württemberg. Reihe B: Forschungen 192), Stuttgart 2014, p. 469. On the continuing importance of astrology in the 16th century see, e. g., Claudia Brosseder, Im Bann der Sterne. Caspar Peucer, Philipp Melanchthon und andere Wittenberger Astrologen, Berlin 2004.

10 Even though the comparison has become increasingly common in recent years, see, for example, for Babylonian diviners and astrologers Stefan M. MAUL, Die Wahrsagekunst im Alten Orient, Munich 2013, p. 319, and for medieval astrologers Monica AzzolinI, The Duke and the Stars. Astrology and Politics in Renaissance Milan, Cambridge / MA, London 2013, pp. 63-64, 125. Cf. also Ann Geneva, Astrology and the Seventeenth Century Mind. William Lilly and the Language of the Stars, Manchester, New York 1995, pp. xv-xvi. 
relevance of medieval studies, since they apparently can help us to better understand the workings of our own societies in a very concrete way.

\section{A Science and its Representatives - Remarks on Late Medieval Astrology}

For the sake of brevity, I will not discuss in detail whether or not late medieval astrologers ${ }^{11}$ can indeed adequately be described and understood as 'experts' and as practitioners of a 'science'. Recent research frequently uses the former notion; ${ }^{12}$ as to the latter, they themselves formulated corresponding claims, thus distinguishing themselves from other varieties of prognosticators. Moreover, even their adversaries frequently categorized astrology as 'science' (scientia/science) rather than an 'art' (ars), ${ }^{13}$ and modern historians of science have long recognized the importance of late medieval and early modern astrology for the development of modern science. ${ }^{14}$

Besides these summary arguments, astrologers' classification as experts and practitioners of a science can equally be justified with structural observations,

11 In contrast to modern usage, medieval authors do not systematically distinguish on the terminological level between the notions of "astronomy" and "astrology", see, for example, Steven VANDEN BROECKE, The Limits of Influence. Pico, Louvain, and the Crisis of Renaissance Astrology (Medieval and Early Modern Science 4), Leiden, Boston 2003, pp. 7-27; for the factual distinction in university curricula, see John NoRTH, Astronomy and Astrology, in: Michael H. SHANK / David C. LINDBERG (eds.), Medieval Science (The Cambridge History of Science 2), Cambridge 2013, pp. 456-484, here pp. 458-459. See also H. Darrel RutKIN, Understanding the History of Astrology (and Magic) Accurately: Methodological Reflections on Terminology and Anachronism, in: Philosophical Readings 7(1) (2015), pp. 42-54, esp. pp. 45-46, who underlines that "[f]rom Ptolemy on, the disciplinary distinction both conceptually and in practice was well understood" (quote p. 46). Since my interest lies in the practice of experts who give advice on the basis of astrological data (in the modern sense), I will consistently call my protagonists "astrologers".

12 See e. g. Darin Hayton, The Crown and the Cosmos. Astrology and the Politics of Maximilian I, Pittsburgh / PA 2015, pp. 64, 68, 116 and passim; Anthony GRAFTon, Cardano's Cosmos. The Worlds and Works of a Renaissance Astrologer, Cambridge / MA, London 1999.

13 On the relationship between the concepts see e. g. the contributions in Ingrid CRAEMERRuegenberg / Andreas SpeER (eds.), Scientia und ars in Hoch- und Spätmittelalter (Miscellanea Mediaevalia 22), Berlin, New York 1994. On the question of terminology see e. g. the justification of a broad definition in Michael H. SHANK / David C. LinDBERG, Introduction, in: SHANK / LINDBERG (note 11), pp. 1-26, here pp. 5-8. The fundamental evolution of the very notion of "science" is demonstrated by Stephan MeIER-Oeser / Helmut HüHn / Helmut Pulte, Wissenschaft, in: Historisches Wörterbuch der Philosophie, vol. 12 (2004), cols 902-948.

14 See Brendan Dooley, Astrology and Science, in: ID. (ed.), A Companion to Astrology in the Renaissance (Brill's Companions to the Christian Tradition 49), Leiden, Boston 2014, pp. 233-266, esp. pp. 233-235. Cf. also NoRTH (note 11), and Edward GRANT, The Foundations of Modern Science in the Middle Ages: Their Religious, Institutional, and Intellectual Contexts, Cambridge 1996. 
which also legitimize the comparison with modern financial experts. If we consider intellectual practices to be 'scientific' that rely (for a specific context) on empirical data and analyse them according to a set of methodological procedures and a specific theoretical framework, medieval astrologers certainly qualify: ${ }^{15}$ their data is furnished by celestial movements, which they either observe directly or reconstruct with the help of astronomical tables and mathematical procedures. This data was then organized in an astrological chart that graphically represented the celestial bodies and their positions. (The use of graphic means of representation and the registration of the empirical data in mathematical terms, i. e. numbers, probably contributed significantly to the recognition of astrology as a 'scientific' practice. ${ }^{16}$ )

While readers will hopefully agree with the argument up to this point, things become more problematic with the decisive following step: based (amongst others) on the idea of an intimate macrocosm-microcosm-relationship, astrologers held (and hold) that celestial bodies affect terrestrial events. ${ }^{17}$ Even if (for the Middle Ages) the precise mechanism of the relationship is rarely discussed in detail beyond the general concepts of theories of the elements and the humours, its assumed effects have been amply noted and categorized by a range of authors who acquired authoritative rank. Astrologers in late medieval Latin Europe were influenced by authorities from the Greco-Roman past as well as by Arab authors, whose

15 SHANK / LINDBERG (note 13), p. 6.

16 The persuasive force of graphical presentation is illustrated (in the form of a guidebook) by Gerald E. JonES, How to Lie with Charts, Lincoln / NE 2000; cf. Thomas F. PATTERSON, Jr. / Jonathan G. LEONARD, E-Graphing: Perfection, Paradox or Persuasion, in: Theo BAstiaEnS / Saul CARLINER (eds.), Proceedings of E-Learn: World Conference on E-Learning in Corporate, Government, Healthcare, and Higher Education, Chesapeake / VA 2007, pp. 2077-2085; Aner TAL / Brian WANSINK, Blinded with Science. Trivial Graphs and Formulas Increase Ad Persuasiveness and Belief in Product Efficacy, in: Public Understanding of Science 25(1) (2016), pp. 117-125. On the medieval use of diagrams see recently Henrike HAUG / Christina LECHTERMAnN / Anna RATHMANn-LuTz (eds.), Diagramme im Gebrauch (Das Mittelalter 22[2]), Berlin, Boston 2017.

17 Cf. briefly Nicolas CAMPION, Astrology, in: Anne L. C. RunEHov / Lluis OvIEDo (eds.), Encyclopedia of Sciences and Religions, Dordrecht, New York 2013, pp. 143-148; for a sociological analysis of contemporary practices in France see Arnaud ESQUERRE, Prédire. L'astrologie au XXI ${ }^{\mathrm{e}}$ siècle en France, Paris 2013. See also Kocku VON STUCKRAD, Geschichte der Astrologie. Von den Anfängen bis zur Gegenwart, Munich 2003, esp. ch. 5 (“Entwicklungslinien der modernen Astrologie”). I am very grateful to H. Darrel RUTKIN for pointing out that the theoretical foundations for astrological expertise are much more complex than a simple analogy between macrocosm and microcosm; however, I feel that for my present argument, which does not seek to develop a synthetical view of astrological theory, the abbreviated presentation might suffice. For more detailed information see, e. g., H. Darrel RUTKIN, Astrology, in: Lorraine DASTON / Katharine PARK (eds.), The Cambridge History of Science, vol. 3: Early Modern Science, Cambridge 2008, pp. 542-563, esp. pp. 546-547, and ID., How to Accurately Account for Astrology's Marginalization in the History of Science and Culture: The Central Importance of an Interpretive Framework, in: Early Science and Medicine 23 (2018), pp. 217-243 (with further bibliographical references). I would like to thank the author for providing me with a copy of this most recent article. 
works were translated in large numbers from the twelfth century onwards. Among the most important, we find authors like Alcabitius, Ptolemy, Albumasar, Messahalla, and Haly Abenragel. ${ }^{18}$

Beyond their scientific methodology and their knowledge of pertinent authorities, astrologers also had to fulfil further requirements in order to be recognized as qualified members of their group: they themselves had to convey their results in a specific form, which included the use of a learned vocabulary and of the wellestablished idiom of scientific discourse, i. e. Latin (at least until the mid-fifteenth century). ${ }^{19}$ If we can apply modern observations on the sociology of expertise and the recognition of scientific status, ${ }^{20}$ we are forced to surmise that outward appearance equally played a role: the astrologers' attire and the signs of their trade, like books or an astrolabe, were certainly not unimportant. ${ }^{21}$ This assumption can at least indirectly be corroborated by the observation that the yearly publication of a

18 For a quantitative approach see David JUSTE, The Impact of Arabic Sources on European Astrology: Some Facts and Numbers, in: Agostino PARAVICINI BAGLIANI (ed.), The Impact of Arabic Sciences in Europe and Asia (Micrologus 24), Florence 2016, pp. 173-194. For a more general presentation see Jean-Patrice BoudET, Entre science et nigromance. Astrologie, divination et magie dans l'occident médiéval, $\mathrm{XII}^{\mathrm{e}}-\mathrm{XV}^{\mathrm{e}}$ siècle, Paris 2006; see also Dag Nikolaus HASSE, Success and Suppression. Arabic Sciences and Philosophy in the Renaissance (I Tatti studies in Italian Renaissance history), Cambridge / MA, London 2016, on the complicated relation between Arabic science and Renaissance thinking.

19 The first prognostications in the vernacular appear in the early 15th century, but they remain exceptional. The oldest example of a judicium in French (for 1415) can be found in Paris, Bibliothèque nationale de France, ms. lat. 7443 , fol. $43^{\mathrm{r}}-48^{\mathrm{v}}$, see Jean-Patrice BouDET, Un jugement astrologique en français sur l'année 1415, in: Jacques PAVIOT / Jacques VERGER (eds.), Guerre, pouvoir et noblesse au Moyen Âge. Mélanges en l'honneur de Philippe Contamine, Paris 2000, pp. 111-120; on the manuscript see Jean-Patrice BoudET, Lire dans le ciel. La bibliothèque de Simon de Phares, astrologue du $\mathrm{XV}^{\mathrm{e}}$ siècle (Les publications de Scriptorium 10), Brussels 1994, pp. 113-151, here p. 114 (judicium in early 15th c. hand) and p. 119 (oldest judicium in French). Philippe ConTAmine, Les prédictions annuelles astrologiques à la fin du Moyen Âge: genre littéraire et témoin de leur temps, in: Histoire sociale, sensibilités collectives et mentalités. Mélanges Robert Mandrou, Paris 1985, pp. 191-204, here pp. 196-197, presents several French judicia, the oldest of which dates from 1438. The growing importance of texts in the vernacular can be seen in the production of printed texts from the 1490s onwards, see (for early modern Germany) Jonathan GREEN, Printing and Prophecy. Prognostication and Media Change 1450-1550, Ann Arbor 2012, pp. 112, 123. For further studies on early modern almanacs and prognostications see Elide CASALI, Le spie del cielo: Oroscopi, lunari e almanacchi nell'Italia moderna, Turin 2003 (Italy), and Bernard S. CAPP, Astrology and the Popular Press: English Almanacs 1500-1800, London 1979 (England).

20 Beyond the numerous contributions which focus on discourse analysis, including questions of authority and power, the pertinent literature remains surprisingly sparse. See, however, Harald A. MIEG, Social and Sociological Factors in the Development of Expertise, in: ERICSSON et al. (note 1), pp. 743-760, here p. 746. For a helpful analysis from the perspective of rhetoric see Johanna E. ARTELIUS, The Rhetoric of Expertise, Lanham / MD 2011.

21 A detailed study of this dimension remains a desideratum; I currently prepare a pertinent research-project at the Ruhr-University Bochum. 
judicium anni, which was part of the obligations of the professors of astrology at the University of Bologna in the fifteenth century, could in fact become the occasion of a public performance. ${ }^{22}$

Unfortunately, this performative dimension of the astrologers' role as experts, whose voice was heard and who were paid for their advice, is notoriously hard to analyse, since most of the sources that contain pertinent information were written by their adversaries. ${ }^{23}$ While we do not have detailed 'manuals' for astrologers that would give advice on how to dress and to behave in order to be taken seriously, ${ }^{24}$ their opponents in the competition for social and discursive recognition sometimes present quite astute observations. Even if authors like Henry of Langenstein, Nicole Oresme, or Laurens Pignon in late fourteenth- and early fifteenth-century France and Burgundy mostly focussed on the logical and theological problems of astrology, they did not ignore opportunities to denigrate their adversaries by accusing them of all sorts of fraudulent practices. ${ }^{25}$ In so doing, they left us with valuable quasipsychological insights while also furnishing important material on astrologers' practices. And this is true, even if the polemical position adopted in such critiques makes the data difficult to evaluate.

22 For more details on this particular genre see below, note 52. The public presentation of these short annual prognostications is mentioned by Alexandre TUR, Hora introitus solis in Arietem. Les prédictions astrologiques annuelles latines dans l'Europe du XV $\mathrm{XV}^{\mathrm{e}}$ siècle (1405-1484), Paris (unpubl. PhD-thesis, Université d'Orléans) 2018, pp. 284-285. I am very grateful to the author for kindly providing me with a copy of his work. The fact that the professor of astrology had to publish such a judicium on a yearly basis is attested by the statutes of the University of Bologna from 1405, see briefly Klaus OschemA, Zukunft gegen Patronage? Spätmittelalterliche astrologische Prognostiken und die Kontaktaufnahme mit Mäzenen, in: Bernd BASTERT / Andreas BIHRER / Tino REUVEKAMPFELBER (eds.), Mäzenaten im Mittelalter aus europäischer Perspektive. Von historischen Akteuren zu literarischen Textkonzepten (Encomia Deutsch 4), Göttingen 2017, pp. 267-291, here p. 271.

23 At least this is the current state of our knowledge. Hopefully, future research on yet unpublished material will unearth additional sources; see also the preceding note.

24 Existing textbooks focus on astrological practice itself, i. e. the interpretation of celestial phenomena. In the context of astrological magic, the 'Picatrix' explains how to dress and to behave when conjuring the aid of individual planets; these prescriptions are a functional part of the ritual itself, however, not a para-scientific performative strategy to convince the public, see Picatrix. The Latin version of Ghāyat Al-Hakim, ed. David PINGREE (Studies of the Warburg Institute 39), London 1986, pp. 140-145 (III ix). More general on the 'performative' dimension of expertise in the premodern period see Frank REXroth / Teresa SchröDER-STAPPER (eds.), Experten, Wissen, Symbole. Performanz und Medialität vormoderner Wissenskulturen (Historische Zeitschrift. Beihefte N.F. 71), Munich 2018.

25 Most recently on late medieval criticism of astrology Carl Philipp Emanuel NothAFт, Vanitas vanitatum et super omnia vanitas: The Astronomer Heinrich Selder and a Newly Discovered Fourteenth-Century Critique of Astrology, in: Erudition and the Republic of Letters 1 (2016), pp. 261-304; see also Klaus Oschema, Unknown or Uncertain? Astrologers, the Church, and the Future in the Late Middle Ages, in: Sibylle Baumbach / Lena HenningSen / Klaus Oschema (eds.), The Fascination with Unknown Time, London, New York 2017, pp. 93-114. 
The most prominent feature that characterizes astrologers as a group, however, is probably their academic qualification: far from being practiced in obscure circles, astrology rapidly became a subject of university curricula during the late Middle Ages. Its place in the academic system was in the Faculty of Arts, where the quadrivium of arithmetic, geometry, music (or harmony), and astronomy encompassed the mathematical disciplines, but also questions of natural philosophy. ${ }^{26}$ In addition, pertinent knowledge equally played an important role in the study of medicine, where it was considered necessary for the choice of therapies and for determining the right moment of their application. ${ }^{27}$ Towards the end of the Middle Ages, the majority of astrologers at court were often employed as physicians and disposed of a university education or even a formal degree as a master of arts or a medical doctor. ${ }^{28}$ The integration of astrology into academic teaching is in some cases attested to by the existence of pertinent teaching positions and explicit references in the curricula. ${ }^{29}$

Astrology and its practitioners thus represented a well-integrated and widely accepted feature of late medieval culture, in spite of the existing controversies: we can find numerous astrologers as advisers in courtly contexts, and even though their role for a broader public in urban and rural settings is less well-documented, some indications show that the broader population equally sought their advice. ${ }^{30}$ The subjects of this advice had virtually no limits: they ranged from the right choice of a partner and the propitious moment for marriage (including the first intercourse) ${ }^{31}$ to the right

26 See Jean-Yves Gulllaumin, La place de l'astronomie dans le quadrivium de Boèce, in: Bernard RibÉMOnT (ed.), Observer, lire, écrire le ciel au Moyen Âge, Paris 1991, pp. 115-126; John D. NORTH, The Faculty of Arts: the "Quadrivium", in: Hilde DE RidDER-SymoENS (ed.), A History of the University in Europa, vol. 1: Universities in the Middle Ages, Cambridge 1992, pp. 337-359. For the importance of 'natural philosophy' and the teaching of Aristotelian texts, see RuTKIN, How to Accurately Account (note 17), pp. 220-221, 224, who underlines the intricate relation between "natural philosophy" and the "divine/metaphysical realm".

27 See Anna Akasoy / Charles Burnett / Ronit Yoeli-Tlalim (eds.), Astro-Medicine: Astrology and Medicine, East and West (Micrologus' Library 25), Florence 2008.

28 See briefly BOUDET (note 18), pp. 296-297.

29 For Bologna see, e. g., Monica Azzolini, The Political Uses of Astrology: Predicting the Illness and Death of Princes, Kings and Popes in the Italian Renaissance, in: Studies in History and Philosophy of Biological and Biomedical Sciences 41 (2010), pp. 135-145, here pp. 140-141, and BOUDET (note 18), pp. 288-290, 302.

30 See, e. g., Sophie PAGE, Richard Trewythian and the Uses of Astrology in Late Medieval England, in: Journal of the Warburg and Courtauld Institutes 64 (2001), pp. 193-228. One indication for a broad reception is, of course, the early and impressive success of pertinent texts in print, see, e. g., GREEN (note 19).

31 For the example of Frederick III's marriage with Isabel of Aragón see Daniel Carlo PANGERL, Sterndeutung als naturwissenschaftliche Methode der Politikberatung. Astronomie und Astrologie am Hof Kaiser Friedrichs III. (1440-1493), in: Archiv für Kulturgeschichte 92(2) (2010), pp. 309-327. 
moment to start a journey, to begin a war, to lay the foundations of a city, and to the correct treatment for an illness. ${ }^{32}$

Based on the idea that foresight allowed for preparation, a locus classicus since the Hellenistic period, ${ }^{33}$ everybody could profit from pertinent information - particularly rulers. It is thus scarcely surprising that the widespread pseudo-Aristotelian 'Secretum Secretorum' explicitly invited the prince (in this case Alexander the Great, who received instructions from his teacher Aristotle) not to do anything without the advice of an astrologer, whenever possible. ${ }^{34}$ This passage not only attests to the presence of the idea in late medieval advice literature. It reminds us, furthermore, that pertinent knowledge was not only embodied by explicitly astrological writings - which, for example, represented approximately $20 \%$ of the library of King Charles V of France ${ }^{35}$ - but was also embedded in more widespread and, at first glance, inconspicuous works.

Of course, astrologers (who, as we saw, often were practising physicians) were not the only counsellors of princes: in fact, the sometimes fervent criticism and ridicule they encountered expresses the competition for the princes' ear, and the 'urban marketplace' probably saw equal rivalries. While some clerical enmity might be explained by earnest scientific and religious concerns, at least part of it resulted from the authors' preoccupation with retaining their roles as advicegiving authorities. ${ }^{36}$ Other groups of counsellors - noblemen, but also professionals like lawyers - might equally have resented the astrologers' rise from the

32 In astrological practice, these different kinds of information are discussed in well-distinguished genres: apart form the already mentioned judicia anni, which are mainly based on an individual year's 'revolution', contemporary astrologers distinguished 'nativities', 'elections', and 'interrogations', see briefly RUTKIN, Understanding the History of Astrology (note 11), p. 46, and ID., Astrology (note 11), pp. 543-544.

33 See Ptolemy, Tetrabiblos, ed. and transl. Frank Egleston RoBbins (Loeb Classical Library 435), Cambridge / MA, London 1940, pp. 20-35 (I 3); the text was made available to Latin authors through the translation by William of Moerbeke, Claudii Ptolemaei Liber iudicialium, ed. Gudrun VuilLEMin-DiEM / Carlos STEEL, Louvain-la-Neuve 2015, pp. 165-169 (c. 3), but the dictum was also transmitted via numerous other compilations. On the reception of Ptolemy in the medieval Latin West in general, see Patrick GaUTIER Dalché, La géographie de Ptolémée en Occident $\left(\mathrm{IV}^{\mathrm{e}}-\mathrm{XVI}^{\mathrm{e}}\right.$ siècle) (Terrarum orbis 9), Turnhout 2009.

34 Roger Bacon, Secretum secretorum (cum glossis et notulis), ed. Robert STEELE (Opera hactenus inedita Rogeri Baconi 5), Oxford 1920, p. 60 (I 22): O Rex clementissime, si fieri potest, non surgas nec sedeas nec comedas nec bibas et nichil penitus facias sine consilio viri periti in arte astrorum. On the 'Secretum' see most recently Catherine GaUlLIER-Bougassas / Margaret BRIDGES / Jean-Yves TilLIETTE (eds.), Trajectoires européennes du 'Secretum secretorum' du Pseudo-Aristote $\left(\mathrm{XIII}^{\mathrm{e}}-\mathrm{XVI}^{\mathrm{e}}\right.$ siècle) (Alexander redivivus 6), Turnhout 2015.

35 BOUDET (note 18), p. 304.

36 See, e. g., for Oresme Joan Cadden, Charles V, Nicole Oresme, and Christine de Pizan. Unities and Uses of Knowledge in Fourteenth-Century France, in: Edith Sylla / Michael McVAuGH (eds.), Texts and Contexts in Ancient and Medieval Science. Studies on the Occasion of John E. Murdoch's Seventieth Birthday, Leiden, New York, Cologne 1997, pp. 208-244, here pp. 235-236. 
thirteenth century onwards, but they have left fewer traces of their concerns. Even if the general picture remains patchy, due not only to the ambivalence of our sources but also to a long-lasting neglect of the question in modern research, ${ }^{37}$ we can assume that astrologers played an important role in late medieval culture in general, and as advisors in courtly contexts in particular.

\section{Asking the Obvious Question: What about Predictions that Failed?}

Acknowledging the astrologers' importance helps us considerably to better understand medieval (and more generally premodern) culture, but it also raises numerous questions. In this short article, I will limit my discussion to one of the most frequently asked questions - a question that might seem quite self-evident, but that can actually serve as an excellent example to illustrate how inquiries into medieval and modern phenomena resonate and can mutually illuminate each other: What about failure ${ }^{38}$ While belief in astrology or in astrology's scientific character is in fact still widespread in contemporary western societies, ${ }^{39}$ 'rational' modern thinking assumes that astrology does not work because it cannot (in the absence of causal effects of the stars on Earth). Astrologers' predictions are thus bound to fail. Even though the modern 'default' position might merit some qualification as far as certain details are concerned, ${ }^{40}$ let us assume that it is (and was) indeed impossible to draw meaningful conclusions about events on earth from the observation of the stars. As a consequence, the astrologers' clients must have been constantly disappointed, and in the face of this, we have to explain their continual reliance on astrological

37 Recent publications considerably broaden our knowledge, but they mostly focus on individual regional contexts, see e. g. Azzolini (note 10) (Milan), Michael A. RYAN, A Kingdom of Stargazers. Astrology and Authority in the Late Medieval Crown of Aragon, Ithaca /NY 2011 (Aragón), BouDET (note 18) (France), Laura A. Smoller, History, Prophecy, and the Stars. The Christian Astrology of Pierre d'Ailly, 1350-1420, Princeton 1994 (France), Hilary M. CAREY, Courting Disaster. Astrology at the English Court and University in the Later Middle Ages, London 1992 (England), Gerd MENTGEN, Astrologie und Offentlichkeit im Mittelalter (Monographien zur Geschichte des Mittelalters 53), Stuttgart 2005 (German courts), HAYTON (note 12) (Maximilian I).

38 The following passages partly overlap with my presentation in Klaus OSCHEMA, Irren ohne zu scheitern. Warum (spät-)mittelalterliche Astrologen nicht immer Recht haben mussten, in: Marian FüsSEL / Frank REXRoth / Inga SchÜRMANN (eds.), Praktiken und Räume des Wissens. Expertenkulturen in Geschichte und Gegenwart, Göttingen 2019, pp. 145-171.

39 ESQUERRE (note 17), pp. 19-24; see also Nick AlluM, What Makes Some People Think Astrology Is Scientific?, in: Science Communication 33(3) (2011), pp. 341-366.

40 See e. g. the infamous criticism by Paul FEYERABEND, Science in a Free Society, London 1978, pp. 91-96 (“The Strange Case of Astrology”). 
expertise. Based on this fundamental question, we can make a series of important observations.

First of all, the evidence for failure is far less abundant than one might think. Of course, we can find a number of mostly anecdotal passages in chronicles and literary texts, where critical authors indulge in mocking descriptions of astrologers' failure. Hence it is with a certain delight that Rolandino of Padova ( +1276$)$, a fervent adversary of Ezzelino da Romano, denigrates the latter as a tyrannical noblemen close to Emperor Frederick II and the worthy target of a papal crusade. According to Rolandino, Ezzelino consulted not only one but several astrologers before going to war with Milan in 1259, in order to choose the right moment for his endeavour. The outcome of the campaign - Ezzelino was injured and captured, dying shortly after the battle - underlines the author's critical stance towards astrology. ${ }^{41}$ Numerous further anecdotes made astrologers the target of ridicule; ${ }^{42}$ moreover, some adversaries of astrological practices describe in detail the fraudulent strategies astrologers used to convince their audience and acquire the favour of potential patrons. Particularly illuminating insight is furnished by Nicole Oresme, who was active at the court of Charles V of France in the second half of the fourteenth century. Oresme not only explained, based on religious and on logical arguments, why precise and individual predictions concerning human behaviour could not be made on the basis of astrological observation, but he effectively identified a series of 'psychological' tricks astrologers resorted to. These included ambivalent prognostications, which were open to later reinterpretation, as well as the use of information drawn from non-astrological sources in order to formulate predictions. ${ }^{43}$ Much of this material is, however, formulated from an explicitly inimical position and its analysis should be undertaken with caution. Evidence for the disappointment of clients who would have complained about failing prognostications or asked for explanations, is much sparser. ${ }^{44}$

Secondly, we thus have to distinguish between cases in which we can only assume that astrologers' clients should have become aware of one or more predictions' failure and other instances in which this failure was actually made explicit. Concerning the first category, Monica Azzolini provided revealing material in her masterly analysis of the reliance of the fifteenth-century dukes of Milan on astrological advice. Of particular interest is Duke Ludovico "il Moro" (r. 1494-1499), who consulted his astrologer, Ambrogio Varesi da Rosate, on a frequent basis. It seems that Ludovico often heeded Ambrogio's advice, for example on the propitious

41 See briefly MENTGEN (note 37), pp. 191-192.

42 Cf. already Theodore O. WEDEL, The Mediæval Attitude Toward Astrology, Particularly in England, New Haven, London 1920, pp. 82-87.

43 See, for example, Stefano CAROTI, Nicole Oresme: Quaestio contra divinatores horoscopios, in: Archives d'histoire doctrinale et littéraire au Moyen Âge (1976), pp. 201-310, here pp. 265-266, 307. 44 For an exceptional example see below, pp. 203-204. 
moment to begin a journey, even if this meant delaying the departure and - as scoffing observers commented - to travel finally under inclement weather conditions. ${ }^{45}$ But several of Ambrogio's predictions were clearly off: he gave erroneous dates in his predictions about the arrival of German envoys in 1493 and about the death of Pope Innocent VIII in $1492 .{ }^{46}$ But this did not discourage Ludovico from relying on his advice, possibly because the Duke tolerated a certain margin of error. ${ }^{47}$ In fact, one might ask if the Duke was actually conscious of these failures at all? As research on modern forecasts has shown, their consumers are usually not very interested in evaluating their validity in retrospect. ${ }^{48}$

An extraordinary example of the second category is furnished by the case of "Doctor Erhard Storch", a canon of the cathedral at Chur (in modern-day Switzerland) in the late fifteenth century. ${ }^{49}$ Unfortunately the material is only known to us via the 'Diarium' compiled by a contemporary priest and historiographer at Basel, Johannes Knebel, ${ }^{50}$ but there is little reason to question its authenticity. Storch is in several respects an interesting figure, not least because he was the only cleric in the entire bishopric of Chur who held a doctoral degree in medicine - an interesting combination, since clerics were generally forbidden to practice medicine. ${ }^{51}$ At the same time, his education might explain how he acquired the astrological knowledge that he drew upon in 1477, when he redacted a prognostication (probably a so-called judicium anni $)^{52}$ for the following year and published his text by attaching it to the cathedral's

45 Azzolini (see note 10), p. 174.

46 Ibid., pp. 184-185 (German envoys) and pp. 192-194 (death of Innocent VIII).

47 Ibid., p. 194. For an analogous example concerning a prediction by Paul of Middelburg at the court of Urbino in 1482 see Stephan HEILEN, Astrology at the Court of Urbino Under Federico and Guidobaldo da Montefeltro, in: Jean-Patrice Boudet / Martine Ostorero / Agostino PARAvicinI BAGLIANI (eds.): De Frédéric II à Rodolphe II. Astrologie, divination et magie dans les cours (XIII ${ }^{\mathrm{e}}$ XVII ${ }^{\mathrm{e}}$ siècle) (Micrologus' Library 85), Florence 2017, pp. 313-368, here pp. 344-345.

48 See TetLock / Gardner, Superforecasting (see note 2), pp. 52-64, who also underline the theoretical problems in evaluating the quality of forecasts.

49 Oskar VASella, Magister Artium Dr. med. Erhard Storch, Kanonikus von Chur. Das Schicksal eines Astrologen (1466-1495), in: Zeitschrift für schweizerische Kirchengeschichte / Revue d'histoire ecclésiastique suisse 53 (1959), pp. 267-289.

50 Johannes Knebel, Diarium, 2 vols., ed. Wilhelm VISCHER (Basler Chroniken 2-3), Leipzig 1880-1887, here vol. 2, pp. 251-253; on the author see Regula Schmid KeELING, Knebel, Johannes, in: Dictionnaire historique de la Suisse 7 (2008), cols 343-344. Cf. for Knebel's interest in astrology MENTGEN (note 37), pp. 266-267.

51 VASELLA (note 49), p. 268.

52 The genre appears in the late 14th century, becoming very popular toward the end of the 15th century, see the very thorough and detailed analysis by TUR, Hora introitus solis in Arietem (note 22). Cf. also briefly OsCHEMA, Zukunft gegen Patronage? (note 22), pp. 268-270; Alexandre TuR, Hartmann Schedel, collectionneur et copiste de prédictions astrologiques annuelles, in: Bulletin du bibliophile (2015), pp. 278-296, and ID., À l'entrée du Soleil en Bélier. Les prédictions astrologiques annuelles latines dans l'Europe du XV ${ }^{\mathrm{e}}$ siècle (1405-1484), Paris (unpubl. thesis, École nationale des chartes) 2014, online: http://theses.enc.sorbonne.fr/2014/tur (last accessed 15/05/2019). TUR's 
door. But his predictions failed to materialize: amongst other things he had announced the possible death of - or at least great danger to - one of the "two great lights of the Romans" (duo luminaria magna Romanorum), ${ }^{53}$ which could only be understood as an allusion to the pope and the emperor. Both survived the critical year, however, and Johannes Hopper, the provost of the cathedral church, asked for an explanation - an unusual course of action. Storch replied with a detailed letter that Knebel copied out in its entirety. ${ }^{54}$ Instead of presenting excuses for his failure, the astrologer rather gave an explanation that amounted to the principle 'trash in, trash out': in the absence of exact information on the protagonists' ascendant, Storch claimed, his predictions necessarily contained a certain margin of error, as was often the case when astrologers were asked questions but not furnished with sufficiently precise data. ${ }^{55}$ But even in spite of this problem, as he proudly underlined, some of his predictions had in fact come true, which demonstrated the enormous value and capacity of the science he practiced. ${ }^{56}$ Once again, this observation coincides with what we know about modern experts' reactions to criticism: they tend to insist on their validity, trying to claim at least partial success, rather than admitting failures that might challenge their entire model. ${ }^{57}$

Finally, a central skill of many astrologers consisted in their capacity to manoeuvre in the shallows of diverging expectations, partly by relying on the communicative strategies that have already been mentioned: their clients obviously had an interest in receiving advice that was as precise, detailed, and concrete as possible, in order to act and decide adequately. This expectation was a strong incentive for astrologers to provide suitable information, if they wanted to claim relevance. At

contributions are particularly important since most of the pertinent material has to be consulted in manuscripts and early prints: judicia anni have long been neglected in modern research and thus rarely been edited. For a notable exception see Fabrizio Bònol / Giuseppe BEZzA / Salvo DE MEIS / Cinzia Colavita (eds.), I pronostici di Domenico Maria da Novara, Florence 2012. I would like to thank H. Darrel Rutkin for bringing this edition to my attention.

53 Johannes Knebel (note 50), vol. 2, p. 251.

54 See note 50; VASELLA (note 49), pp. 273-277, provides a detailed paraphrase.

55 Johannes Knebel (note 50), vol. 2, p. 251: questioni vestre michi heri et nudiustercius proposite, videlicet cur astrologi tam sepe errare videntur, cum dicant rem aliquam tali tempore venturam, que tamen non evenire solet, satisfaciendo dico, quod hoc ideo accidit, quia gradum aliquando ascendentis precisum nativitatis vel intronizacionis ignorant. Cf. for an analogous argument John of Glogovia, Judicium anni 1476, in Munich, Bayerische Staatsbibliothek, Clm 647, fols. $21^{\mathrm{r}}-43^{\mathrm{v}}$, here fol. $37^{\mathrm{v}}$ : statum sanctissimi describere non possum, cum nec eius genitura nec sius intronisacio mihi cognita sit. See also Igor de Russia, Judicium anni 1478, in Munich, Bayerische Staatsbibliothek, Clm 647, fols. $102^{\mathrm{r}}-126^{\mathrm{r}}$, here fol. $106^{\mathrm{r}}$ : Quamquam de statu patris sanctissimi pontifici Sixti quarti judicare sit ambigium admodumque difficile cum sue sanctissime paternitatis nedum nativitas verum etiam intronizatio est incognita.

56 Johannes Knebel (note 50), vol. 2, p. 251: et quamquam aliqua eclipsis accidencia cesaree majestati evenerunt.

57 See GARDNER (note 2), pp. 203-210. 
the same time, however, several reasons induced them to remain more perfunctory: from a pragmatic perspective - and Oresme's criticism explicitly formulated this observation as a reproach - general, ambivalent, or even obscure prognostications were easier to defend after the fact, since their author could claim to have been right, whatever the outcome. ${ }^{58}$ But self-restrictions were also advisable for other reasons. A prominent discourse amongst astrologers themselves underlined the limitations of their science: according to pseudo-Ptolemy's 'Centiloquium', astrological judgements should always remain "universal” (i. e. general), advice that became a locus classicus in the pertinent literature. ${ }^{59}$ In addition to the scientific reasoning that stood behind this idea, Christian theology imposed further limitations: if individual actions could be predicted, this would imply that they were predestined and that individuals did not have a choice in their actions. Without free will, however, the Christian dogma concerning guilt and sin, which relied on the attribution of responsibility, would have been profoundly challenged. ${ }^{60}$ If they wanted to steer clear from conflicts with the church, astrologers were thus well-advised to limit their prognostications to general judgements.

But the conundrum remained, and astrologers frequently gave in to the temptation to become more precise and detailed, not least in order to highlight their ability. John Ashenden, for example, a fourteenth-century astrologer at Oxford, referred to his former successes in his voluminous 'Summa judicialis de accidentibus mundi' (1347/48, reworked c. 1365), where he proudly claimed to have predicted correctly the arrival of the Black Death in England as one of the dire consequences of the conjunction of Saturn and Jupiter in $1345 .{ }^{61}$ Possibly spurred on by this achievement, Ashenden became quite specific in a judgement on the Great Conjunction of Jupiter and Saturn in 1365, concluding that the king of England

58 CAROTI (note 43), pp. 265-266

59 The Latin text is not yet available in a critical edition. For the relevant passage in Plato of Tivoli's translation see Jean-Patrice BOUDET, Astrology between Rational Science and Divine Inspiration. The Pseudo-Ptolemy's Centiloquium, in: Stefano RAPISARDA / Erik NiblaEuS (eds.), Dialogues Among Books in Medieval Western Magic and Divination (Micrologus' Library 65), Florence 2014, pp. 49-75, here p. 62: Astrologus non debet dicere rem specialiter sed universaliter.

60 For a presentation of this discussion, which partly refers back to St Augustine, see Jan R. VEenstra, Magic and Divination at the Courts of Burgundy and France. Text and Context of Laurens Pignon's Contre les devineurs (1411) (Brill's Studies in Intellectual History 83), Leiden, New York, Cologne 1998, pp. 184-189.

61 John Ashenden, Summa judicialis de accidentibus mundi, Venice 1489, fol. 192: Omnes autem isti effectus contigerunt ex illis coniunctionibus magnis predictis sicut ostendebatur in principio huius anni 1345 in his quæ scripsimus in pronosticationibus earumdem coniunctionum. On Ashenden and his 'Summa' see Keith V. SNEDEGAR, John Ashenden and the Scientia Astrorum Mertonensis. With an Edition of Ashenden's Pronosticationes, 2 vols., Oxford (PhD, unpubl.) 1988, and CAREY (note 37), pp. 73-78, 85-91. 
would receive the kingdom of France. ${ }^{62}$ In the immediate aftermath of the overwhelming English military success against the French at Poitiers (1356) and with King John II of France in captivity, many contemporaries would probably not have considered this prediction to be improbable, even if it only partially came true for Henry $\mathrm{V}$ in the early fifteenth century. From a strictly systematic perspective, however, it formulated a quite specific outcome, although Ashenden refrained from describing individual actions. ${ }^{63}$

In order to defend themselves against religious or theological reproach, astrologers often referred to yet another phenomenon that also helped in the defence against accusations of failure: especially in judicia anni, a kind of 'everyday literature' in this field, we repeatedly find the assertion that the author did his best to interpret the stellar signs according to tradition and astrological authorities. In spite of this effort, God could obviously always choose to alter the train of events. ${ }^{64}$ This argument, often accompanied by the assurance that nothing heretical was intended, did not actually address the problem of human free will, but it guaranteed God's free choice and omnipotence. At the same time, it provided an efficient defence against the reproach of failure - who was to blame the astrologer if God decided to intervene?

\section{Consequences? Medieval and Modern ...}

The vast range of implications resulting from this small sample of observations cannot be analysed in detail here, but the limited selection already furnishes telling material that allows us to gauge the potential of comparative approaches to medieval and modern expertise. To start with, one might underline what could be called the 'precision-conundrum': when it comes to forecasts, which are inevitably prone to be proven wrong as events unfold, the different social actors behave according to profoundly different interests. While their clients ask for detailed and precise information, the experts have an interest in leaving a certain margin for interpretation in order to be able to defend their prognostications later on. If they want to remain

62 John Ashenden, Pronosticatio coniunctionis magne Saturni et Jovis anno Christi 1365, Oxford, Bodleian Library, ms Digby 176, fols. $42^{\mathrm{r}}-49^{\mathrm{v}}$, here fol. $47^{\mathrm{r}}$. The treatise can be dated to 1357 , see CAREY (note 37), p. 87. For an instructive presentation of the theory on conjunctions, esp. the fundamental importance of 'Great Conjunctions' of Saturn and Jupiter, see John D. NoRTH, Astrology and the Fortune of Churches, in: Centaurus 24(1) (1980), pp. 181-211, and briefly Smoller (note 37), p. 19-22.

63 For Ashenden's strategy to steer clear of too precise predictions see CAREY (note 37), pp. 75-76. 64 See e. g. Johannes Laet de Borchloen, Iudicium anni 1478, Munich, Bayerische Staatsbibliothek, Clm 647 , fols. $88^{\mathrm{v}}-101^{\mathrm{v}}$, here fol. $90^{\mathrm{r}}$ : Et noverit vestre illustrissime pater mee fore mentis et intencionis de subscriptis, quod in eventum quo quis me maligno harum reprehendere molitus fuerit (quod Deus avertat) quod Deus omnipotens creator planetarum omniam supernaturaliter inmutare posset, addendo vel minuendo. 
interesting to their clients or audience, however, they need to at least conjure up the impression of relevance by, for example, providing details and by claiming a high degree of certainty. While modern experts mainly rely on the notion of probability in order to navigate between precise indications and the attempt to provide for a margin of error, late medieval astrologers accomplished a comparable effect by (a) referring to God's capacity to change the natural course of events, (b) to the deficient quality of the data they received for their calculations, and (c) to the conjectural nature of astrological predictions (as opposed to the astronomical calculations they were based on). At the same time, they ceaselessly underlined the fact that they practised a science, which was prone to produce reliable results. ${ }^{65}$ Even though their techniques partly differ, modern and medieval experts alike (mostly) successfully create the appearance of providing a secure basis for decision making. Both also profit from underlying effects in human cognition, since we often tend to ascribe a higher degree of certainty to information than the individual authors actually claim. ${ }^{66}$

Late medieval criticism of astrology contains many motifs that sound familiar when considered alongside the modern discourse about experts. Seen from this perspective, inquiries into the perception of astrologers as late medieval experts provide evidence for historical precedents of insights into the working of the human mind and into the haziness of communication. ${ }^{67}$ But they do more than that: if medievalists want to understand the mechanisms at play in these contexts adequately, they have much to learn from insights provided by the Social Sciences. Their results actually force us to recognize that human behaviour and attitudes are often characterized by irrational features: to mention but one example, humans are easily convinced by the presence of supposed arguments, even if these do not logically relate to the matter at hand. ${ }^{68}$ In addition, our thoughts and conclusions are heavily influenced by secondary, incidental, and non-related input or information. ${ }^{69}$ In sum, this implies that not every seemingly fraudulent behaviour is actually fraudulent,

65 See, for example, the introductory remarks by Cecco d'Ascoli, In spheram mundi, in: Lynn Thorndike (ed.), The Sphere of Sacrobosco and its Commentators, Chicago 1949, pp. 343-412, here p. 346: sub excellentiori modo per scientiam stellarum habetur futurorum cognitio veritatis.

66 On pertinent effects see TETLOCK / GARDNER, Superforecasting (note 2), pp. 137-143, here p. 140: "But the way people think, they seem to translate a high probability into 'this will happen'." (The authors quote Robert Rubin, a former Treasury secretary.)

67 See, for example, the comments by Oresme (see note 43).

68 Ellen J. LANGER / Arthur Blank / Benzion ChANOwITZ, The Mindlessness of Ostensibly Thoughtful Action: The Role of "Placebic" Information in Interpersonal Interaction, in: Journal of Personality and Social Psychology 36(6) (1978), pp. 635-624; cf. Daniel T. WiLlingham, When Can You Trust the Experts? How to Tell Good Science from Bad in Education, San Francisco 2012, pp. 31-32. See more generally Daniel Kahneman, Thinking, Fast and Slow, New York 2011.

69 For a detailed presentation see Hugo MERCIER / Dan SPERBER, The Enigma of Reason. A New Theory of Human Understanding, London 2017. 
since (in the astrologers' case) both the astrologers and their clients might have been equally convinced they were engaged in an earnest and serious endeavour. Consequently, reliance on astrological advice cannot be interpreted simply as a sign of superstition and naive credulity; it rather expresses the desire to act on the grounds of the best available information.

While these observations considerably modify our ideas of an important aspect of late medieval culture - arguing for the existence of a 'culture of expertise' in this period $^{70}$ - they also invite us to reflect anew about our own practices in relation to experts and expertise. As the events of the financial crisis that escalated in 2007 demonstrated, the information of an important group of economic and financial experts was, to say the least, of limited value. Moreover, many of these experts did not suffer any sustained negative consequences of their failure - and at this point late medieval and modern phenomena begin to mutually illuminate each other: the fact that failure does not make a decisive difference can also partly be explained with features that characterize human thinking and perception, including a certain confirmation bias, the tendency to suppress data that conflicts with our basic convictions, and the lack of interest in evaluating past forecasts. ${ }^{71}$ A comparative look at medieval and modern expertise in prognostication can make us realise that both rely heavily on belief in spite of their claims to a scientific character, which are underlined by their empirical basis, their mathematical approaches, and their elaborate set of rules for interpretation. In this sense, the analysis of a medieval phenomenon - by means of modern social scientific theories and insights - enables us to develop new critical perspectives on our own world and its workings and on our well-established, albeit erroneous, self-description as 'rational' ${ }^{72}$ It seems to me that this opening of a new perspective on contemporary phenomena, which is based on the identification of common cultural traits on a structural level, constitutes a clear argument for the relevance of research in Medieval Studies.

70 For a brief definition see Philip KnäBle, Einleitung, in: ID. / Marian FÜSSEL / Nina ElSEMANN (eds.), Wissen und Wirtschaft. Expertenkulturen und Märkte vom 13. bis 18. Jahrhundert, Göttingen 2017, pp. 9-30, here pp. 11-12; see also Frank ReXrotH, Systemvertrauen und Expertenskepsis. Die Utopie vom maßgeschneiderten Wissen in den Kulturen des 12. bis 16. Jahrhunderts, in: ID. / Björn REICH / Matthias RoICK (eds.), Wissen, maßgeschneidert. Experten und Expertenkulturen im Europa der Vormoderne (Historische Zeitschrift. Beihefte N.F. 57), Munich 2012, pp. 12-44. The figure of the 'expert' has recently been repeatedly discussed in medieval studies; see, for example, the contributions to Thomas BÉNATOUÏL / Isabelle DRAELANTS (eds.), Expertus sum. L'Expérience par les sens dans la philosophie médiévale (Micrologus' Library 40), Florence 2011; Hedwig RöcKELEIN / Udo FRIEDRICH (eds.), Experten der Vormoderne zwischen Wissen und Erfahrung (Das Mittelalter 17[2]), Berlin 2012; SHMESP (ed.), Experts et expertise au Moyen Âge. Consilium quaeritur a perito (Histoire ancienne et médiévale 116), Paris 2012.

71 See note 2.

72 See GoBEt (note 2), pp. 85-86, on the notion of "bounded rationality". 
But the potential insights go even further, because it would be short-sighted to simply dismiss the failing experts and their services as useless: even though their predictions are inevitably flawed, since the future is fundamentally unpredictable, they go a long way in helping the individual to ameliorate her or his vision of the respective present, precisely because they strive to deliver a diagnosis that is as complete as possible in order to lay out the panorama of future developments. In doing so, and moreover in a systematic way, they inform their readers or listeners about things that they should take into consideration before making up their minds. This effect becomes very clear when we look at the systematic writings of late medieval astrologers. Recognizing this goes a long way towards developing a new perspective on late medieval culture, one that is different from the established 'superstition narrative'. At the same time, this insight, which can be formulated in a clear way for this distant period, can open our eyes to the effects that play out in the present day: accepting the forecasts of financial or economic experts amounts to an act of belief. In addition, the lay of the land they develop in order to produce a basis for the prognosis can still furnish a valuable overview and important insights. So, in the end, analysing the features of an expert culture that is distant in time can actually help us to better understand our present in a very concrete way. 



\title{
Elva Johnston
}

\section{Eoin MacNeill's Early Medieval Ireland: A Scholarship for Politics or a Politics of Scholarship?}

\begin{abstract}
Eoin MACNEILL (1867-1945) was the first academic historian of early medieval Ireland; he is frequently considered to be the founder of the discipline of early Irish history. He was also a prominent nationalist activist, a revolutionary, and a minister in the first Irish Free State government. This paper will consider the shared inspirations for MACNEILL the politician and MACNEILL the scholar. In particular, it will focus on MACNEILL's belief that the medieval past of Ireland was the making of its national character and the foundation of its right to independence from the British Empire. This brought him into conflict with the great unionist historian of Norman Ireland, Goddard Henry ORPEN. Their debate, revolving around contested pasts, proved to be troublesome for later generations of historians who were concerned to write an Irish history free of political bias. But MACNEILL was no mere propagandist. He was passionately devoted to the writing of source-driven history, one reliant upon core research skills in language and palaeography. He believed history should be scientific but not necessarily, or even ideally, value-free. This paper will examine these issues, primarily through the lens of MACNEILL's career up to the formation of the Irish Free State (1922) and subsequent Civil War (1922-1923). It will show the extent to which his disagreements with ORPEN, as well as MACNEILL's efforts to accurately delineate the early Irish past for scholars and, crucially, the wider public, were tied to his conviction that understanding the medieval was always relevant for contemporary societies.
\end{abstract}

Keywords: Eoin MacNeill, revisionism, nationalism, Irish Manuscripts Commission, tribalism, Gaelic Ireland, Goddard Henry Orpen, Normans, British Empire, presentism, public history

\section{Eoin MACNeILL: Scholar and Politician}

In early medieval Ireland, Fer Dá Chrích, man of two districts, was a common saint's name. ${ }^{1}$ It could refer to someone associated with two places or careers. In either sense,

1 There are at least eleven examples of this name in the medieval Irish martyrologies alone. For convenience, see The Martyrology of Tallaght from the Book of Leinster and MS. 5100-4 in the

Elva Johnston, School of History, University College Dublin, Belfield Dublin 4, Ireland, elva.johnston@ucd.ie

Ә Open Access. (C 2020 Elva Johnston, published by De Gruyter. (c) BY-NC-ND This work is licensed under a Creative Commons Attribution-NonCommercial-NoDerivatives 4.0 International License. 
this serves as a metaphor for the complex life of Eoin MACNEILL, one frequently treated as bifurcated between politics and scholarship, for he was a politician and an academic historian. This dual role raises questions about the integrity of academic history and its relationship to political action and even propaganda, one which has proved troubling to later generations of Irish scholars, especially those who identified as 'revisionists'. These revisionists consciously argued for a historical scholarship free from nationalist impulses and grounded in historical documentation. The Northern Irish 'Troubles', with their heavy confluence of religious, linguistic and ethnic identities, shaped by rival understandings of the past, problematized the role of academic historians; they came to question the primacy of national narratives in shaping scholarship. At the same time, historiographical approaches, which largely emphasized empiricism and the ideal of value-free history, created a seeming division between contemporary scholars and previous generations of historians. History was defined as a science, associated with modernity and progress. ${ }^{3}$ The scholars of the late nineteenth and early twentieth centuries were sometimes portrayed as slaves to highly presentist and politicized histories, shaped around the ultimate goal of Irish independence from British rule. ${ }^{4}$ Nonetheless, as this paper will show, the debates of former generations, including those engaged in by Eoin MACNEILL, continue to echo in the present.

Eoin MACNEILL's career was strikingly varied; he was a man of many faces. MACNEILL was a Gaelic revivalist, an Irish Volunteer, a Free State minister, a bureaucrat and an academic, an establishment voice and an insurgent. ${ }^{5}$ He was born in Antrim and died in Dublin, his birth-place divided from the new state by the Border between the Irish State and the United Kingdom. To those outside of early

Royal Library, Brussels, ed. Richard I. BEST / Hugh J. LAWLER (Henry Bradshaw Society 68), London 1931, pp. 28, 44, 47, 63, 67, 69, 77. Crích literally means 'boundary' (see the 'electronic Dictionary of the Irish Language' [eDIL], s.v. crích, online: http://www.dil.ie/12912; last accessed 15/05/2019), but also commonly refers to the territory incorporated within boundaries.

2 The revisionist debate influenced most areas of Irish history. The best introduction is Ciarán BRADY (ed.), Interpreting Irish History. The Debate on Historical Revisionism, 1938-1994, Dublin 1994; its influence on early Irish studies is clear in Kim McCone / Katherine Simms (eds.), Progress in Medieval Irish Studies, Maynooth 1996; Jonathan M. Wooding, Reapproaching the Pagan Celtic Past - Anti-Nativism, Asterisk Reality and the Late-Antiquity Paradigm, in: Studia Celtica Fennica 6 (2009), pp. 61-74, provides useful commentary.

3 See for instance, Robert Dudley EdWARDS, An Agenda for Irish History, 1978-2018, in: Irish Historical Studies 81(22) (1978), pp. 3-19.

4 This gap is very much emphasized in Roy F. FosTeR, The Story of Ireland: An Inaugural Lecture Delivered before the University of Oxford on 1 December 1994, Oxford 1995.

5 The best short introductions to MACNEILL's career are Patrick MAUME, MacNeill, Eoin (1867-1945), in: Oxford Dictionary of National Biography (2004), online: http://www.oxforddnb.com/view/article/ 34813 (last accessed 15/05/2019); ID. / Thomas CHARLES-EDwARDS, MacNeill, Eoin (John), in: Dictionary of Irish Biography (2013), online: http://dib.cambridge.org/viewReadPage.do?articleId=a5283 (last accessed 15/05/2019). See also Michael TIERNEY, Eoin MacNeill: Scholar and Man of Action 1867-1945, ed. Francis X. MARTIN, Oxford 1980. 
medieval scholarship, he is best known for two controversial roles: the infamous Countermanding Order to halt the mobilisation of the Irish Volunteers, which became part of the mythology of the Easter Rising of 1916, and his ineffectual performance as the Free State's representative on the Irish Boundary Commission of 1924-1925. ${ }^{6}$ It had been expected that the Boundary Commission would create more equitable Border arrangements but it dashed these hopes. These disappointed hopes seem to have scarred MACNEILL. Despite urging, his time on the Commission did not form part of the material that MACNEILL dictated for his memoir, although there are other gaps in it as well. ${ }^{7}$ Nonetheless, MACNEILL was one of the most influential cultural politicians of his generation. In particular, his contribution to the founding of the Irish Manuscripts Commission (IMC) in 1928, for which he served as first Chair, was immense. ${ }^{8}$ It was driven by his commitment to making the primary sources of Irish history available. ${ }^{9}$ He envisaged the IMC as an Irish Monumenta Germaniae Historica, founded in the early nineteenth century and still active to this day. ${ }^{10}$ MACNEILL, it seems, was always determined to make the medieval relevant. He believed that the Irish needed to know their own past and that this past put them on a par with the other peoples of Europe. ${ }^{11}$ Knowing the past was the prelude to, and the shaper of, present actions. Thus, the past was inherently political, in the sense that it could be presented as the fore-runner to current aspirations. For MACNEILL, it never simply existed in its own right.

Despite these intersections of politics and scholarship, there is a limited appreciation of the extent to which they were bound together in MACNEILL's mind. For instance,

\footnotetext{
6 The standard study remains Geoffrey J. HAND, MacNeill and the Boundary Commission, in: Francis X. MARTIN / Francis J. BYRNE (eds.), The Scholar Revolutionary: Eoin MacNeill, 1867-1945, and the Making of the New Ireland, Shannon 1973, pp. 199-275; see also Francis X. MARTIN, Eoin MacNeill on the 1916 Rising, in: Irish Historical Studies 12(47) (1961), pp. 34-40; Enda STAunTon, The Boundary Commission Debacle 1925: Aftermath and Implications, in: History Ireland 4(2) (1996), pp. 42-45.

7 Eoin MacNeill: Memoir of a Revolutionary Scholar, ed. Brian Hughes, Dublin 2016, p. xiii.

8 Deirdre McMahon / Michael Kennedy, Reconstructing Ireland's Past: A History of the Irish Manuscripts Commission, Dublin 2009, pp. 1-94.

9 See for example Eoin MACNEILL, The Fifteenth Centenary of Saint Patrick. A Suggested Form of Commemoration, in: Studies: An Irish Quarterly Review 13(50) (1924), pp. 177-188; ID., A School of Irish Church History, in: Studies: An Irish Quarterly Review 21(81) (1932), pp. 1-6.

10 McMahon / Kennedy (note 8), pp. 6-7. For the MGH see David Knowles, Great Historical Enterprises, London 1965, pp. 65-97; Horst FunRmann, "Sind eben alles Menschen gewesen": Gelehrtenleben in 19. und 20. Jahrhundert. Dargestellt am Beispiel der Monumenta Germaniae Historica und ihrer Mitarbeiter, Munich 1996. Isabelle GuYOT-BACHY / Jean-Marie MoEGLIN (eds.), La naissance de la médiévistique. Les historiens et leurs sources en Europe (XIX ${ }^{\mathrm{e}}$-début du XX siècle) (École Pratique des Hautes Études, Sciences Historiques et Philologiques 5 / Hautes études médievales et modernes 107), Geneva 2015 (on the MGH esp. Gerhard Schmitz, Les Monumenta Germaniae Historica, in: ibid., pp. 299-313).

11 Eoin MaCNEILL, Celtic Ireland, Dublin 1921, repr. Dublin 1981, pp. xi-xv.
} 
MACNEILL's memoir juxtaposes his study of the Irish language, under the direction of the Jesuit scholar Edmund Hogan, with a consideration of the Parnell Crisis. ${ }^{12}$ This crisis split constitutional Irish nationalism and created bitterness for a generation. For MACNEILL, neither one can, nor should, be appreciated in isolation of the other. Yet, his scholarly work is frequently treated as the youthful prologue and tired epilogue to the hurly-burly of the nationalist political activism that continues to define his image in the grand narratives of Irish history. ${ }^{13}$ Indeed, these activities were heavily informed by scholarship, one with which few historians of the modern Irish state are deeply familiar. Tellingly, the zenith of his political involvement in nationalist politics, between 1913-1925, was arguably the most creative phase of his career as a historian. This shows, very clearly, the tight connection between MACNEILL the activist and MACNEILL the academic. Both originated in the same wellspring. To take an example: in November 1913 MACNEILL published "The North Began” in "An Claidheamh Soluis”, an article that served as a catalyst for the formation of the Irish Volunteers. ${ }^{14}$ It is probably the piece for which MACNEILL is best known among non-specialists. In the same year his important edition of the poems of the eleventh-century pseudohistorical writer Flann Mainistrech, an edition still used, appeared, as well as other key papers. ${ }^{15}$ Several of MACNEILL's most significant works date from the revolutionary era, more broadly, including his paper on the Laud Genealogies (1915), the formulation of the rule of dynastic succession (1919) and his ground-breaking article on status and franchise (1923), ones which transformed the very parameters of early medieval Irish scholarship. $^{16}$

This MACNEILL, the scholar, has been more generously appreciated than the politician. In a striking summation of his contribution to the foundation and popularisation of the discipline of early Irish History, Francis John BYRNE declared: "To MacNeill belongs the credit of having dragged Celtic Ireland practically single-handed from the

12 Hughes (note 7), pp. 18-19. It should be noted, though, that the memoir was primarily designed to showcase MACNEILL's public career.

13 The classic statement is Robert Dudley EDWARDS, Professor MacNeill, in: MARTIN / BYRNE (note 6), pp. 279-297, here p. 289.

14 Eoin MacNeILL, The North Began, in: An Claidheamh Soluis, 1 November 1913, p. 6. The article is republished in The Irish Volunteers, 1913-1915. Recollections and Documents, ed. Francis X. MARTIN, Dublin 1963, pp. 57-61.

15 Poems by Flann Mainistrech on the Dynasties of Ailech, Mide and Brega, ed. Eoin MAcNEILL, in: Archivium Hibernicum 2 (1913), pp. 37-99. MACNEILL's publications are usefully collated in Francis X. MARTIN, The Writings of Eoin MacNeill, in: Irish Historical Studies 6(21) (1948), pp. 44-62, and ID., Appendix 1: The Published Writings of Eoin MacNeill, in: ID. / BYRNE (note 6), pp. 325-353.

16 Eoin MACNEILL, On the Reconstruction and the Date of the Laud Genealogies, in: Zeitschrift für Celtische Philologie 10 (1915), pp. 81-96; ID., The Irish Law of Dynastic Succession, in: Studies: An Irish Quarterly Review 8(31) (1919), pp. 367-382, and 8(32) (1919), pp. 640-663; ID., Ancient Irish Law: The Law of Status or Franchise, in: Proceeding of the Royal Irish Academy 36 (1923), pp. 265-316. See the assessment by Francis John BYRnE, MacNeill the Historian, in: MARTIN / BYRNE (note 6), pp. 15-36. 
antiquarian mists into the light of history [...]."17 It must be remembered, too, that MACNEILL was not working in isolation. He contributed to a constellation of scholarship in the burgeoning and interdisciplinary field of Celtic studies, the world of the likes of Kuno Meyer and Douglas Hyde. ${ }^{18}$ Throughout, he was engaged in what he believed was an important struggle to liberate the Irish past from derogatory accusations of barbarism, a fight with a long history as MACNEILL himself was aware. ${ }^{19}$ How did MACNEILL balance this urgent political need with historical accuracy? What did he contribute to early medieval Irish history and, perhaps more importantly, to making it relevant to his public? Does his legacy still continue?

\section{Politics and the Writing of Early Irish History}

Given the complexity of MACNEILL's career, these questions are best addressed through highlighting particular aspects of his activities, although this is not to deny the relevance of other material. This paper will mainly centre on the years before MACNEILL became a government minister in 1922, at which point his focus shifted towards a more practical realisation of educational and cultural goals. ${ }^{20}$ First, however, it is necessary to outline how MACNEILL came to view the relevance of early medieval Ireland for the present. There can be no doubt that MACNEILL was fascinated with the complexity of early medieval social organisation and, for him, it provided alternative socio-political models to those of his own time. These, he argued, were based on limited bureaucracy, strong local relationships and a loose overlordship, exercised by the national monarch at Tara, which did little to interfere with day to day existence, a view that he continued to hold throughout his life. ${ }^{21}$ It is hard not to imagine MACNEILL was responding to his own experiences, creating a utopian vision of the

17 BYRNE (note 16), p. 17.

18 The interconnections between the scholars of this era are increasingly appreciated, especially as more archival material becomes available. See, for example, Seán Ó LuING, Kuno Meyer, 1858-1919: A Biography, Dublin 1991; ID., Celtic Studies in Europe and Other Essays, Dublin 2000; Dáibhí Ó CRÓINín, Letters of Kuno Meyer to Douglas Hyde, 1896-1919, in: Studia Hibernica 42 (2016), pp. 1-64; Regina Uí Chollatáin, Eoin MacNeill: Scholar and Revivalist, online: http://histo ryhub.ie/eoin-macneill-revivalist (last accessed 15/05/2019). MAcNEILL's own appreciation of his debt to Edmund Hogan is insightful. See his remarks in Contribution by Professor Eoin MacNeILl, M.A., D.Litt, in: A Page of Irish History: Story of University College, Dublin 1883-1909, Compiled by Fathers of the Society of Jesus, Dublin 1930, pp. 186-194.

19 Eoin MACNEILl, Phases of Irish History, Dublin, 1919, repr. Dublin, 1968, esp. pp. 300-304. It is worth remembering, as well, the frequent racial stereotyping of the Irish in the popular British press in MACNEILL's formative years, see Robert F. Foster, Paddy and Mr Punch, in: ID. (ed.), Paddy and Mr Punch: Connections in Irish and English History, London 1993, pp. 171-194.

20 McMahon / KenNEDy (note 8), pp. 1-20.

21 Representative examples include MACNEILL (note 11), pp. 93-111; ID. (note 19), pp. 271-275. 
past in the process. Tellingly, he remarked that "a centralised authority is an instrument of civilisation, not an essential", as the state should "serve the civilisation of the people, not [...] dominate it". ${ }^{22}$ He contrasted early Irish institutions with what he viewed as the inequalities of feudalism, introduced by the Normans alongside foreign rule. $^{23}$ Yet, like the Vikings before them, he argued, the Normans eventually integrated with the native inhabitants, contributing handsomely to the ancestral tree of the modern Irish population in the process. ${ }^{24}$ MACNEILL, perhaps wisely given his own areas of expertise, generally confined his comments to pre-Norman society, emphasising its sophistication, rather than dealing in detail with the Normans in Ireland. ${ }^{25}$ For instance, he was at great pains to show that Irish society was not tribal. ${ }^{26}$ MACNEILL, living as he did in a colonialist context, assumed that tribal had a pejorative meaning to be aligned with barbarism, anarchy and savagery. ${ }^{27}$ While the term, ultimately, did come to be used in a much less loaded way among early Irish scholars, especially under the influence of anthropological studies, ${ }^{28}$ its potentially negative Eurocentric weight is still problematic. It sometimes functions as a rhetorical device to flatten the complexity of non-European societies, ${ }^{29}$ or, of those in the past; 'tribe' and 'tribal' can serve as a verbal shorthand indicating that particular groups or cultures are at a lower rung in the supposed ladder of social evolution. It was an issue that greatly concerned MACNEILL, as he believed it to be the underpinning of a discourse that denied the Irish the right to political self-determination.

This complex of ideas, political and academic, was central to one of the defining debates of MACNEILL's career, one where interpretations of the medieval were so politically weighted that they are as revealing of current politics as they are of scholarly de-

22 Eoin MacNEILL, Early Irish Laws and Institutions, Dublin 1935, pp. 48-49; see also his suggestion on p. 74 that the worship of the bureaucratic state is satanic.

23 MACNEILL (note 11), pp. 152-176; ID. (note 19), pp. 292-299.

24 MacNeill (note 19), pp. 265-266, 273, 322-356.

25 Exceptions include ibid., pp. 300-322, but this is largely devoted to disagreements with Goddard Henry Orpen.

26 MACNEILL (note 11), pp. 152-176; ID. (note 19), pp. 289-299; ID. (note 22), pp. 1-11.

27 MACNEILL (note 11), pp. 152-154; ID. (note 19), esp. pp. 289-290, although it should be noted that MACNEILL himself is dismissive of the "Australian or Central African aborigines". See also ID. (note 22), p. 16.

28 Daniel A. Binchy, Secular Institutions, in: Myles Dillon (ed.), Early Irish Society, Dublin 1954, pp. 52-65, here p. 62; Francis John BYRNE, Tribes and Tribalism in Early Ireland, Ériu 22 (1971), pp. 128-166; ID. (note 16), pp. 26-27.

29 Archie MAFEJE, The Ideology of “Tribalism”, in: The Journal of Modern African Studies 9(2) (1971), pp. 253-261; Vail LEROY (ed.), The Invention of Tribalism in Southern Africa, London 1989; Felicitas BECKER, Vernacular Ethnic Stereotypes: Their Persistence and Change in South-East Tanzania, ca. 1890-2003, in: Alexander KEESE (ed.), Ethnicity and the Long-Term Perspective: The African Experience (CEAUP Studies on Africa 1), Berne 2010, pp. 93-126. 
siderata. It brought him into conflict with another great Irish medieval historian, his contemporary Goddard Henry ORPEN, a scholar of an unapologetically unionist persuasion. ${ }^{30}$ Nonetheless, ORPEN's magnum opus, "Ireland under the Normans", published in four volumes between 1911-1920, is justly regarded as a seminal work to which scholars still turn. ${ }^{31}$ Its faults, particularly in regard to ORPEN's prejudices towards the native Irish, who he portrays as feckless and incapable of self-government, have been judged to be of less importance than the depth of his scholarship and his dedication to the use of primary source material. ${ }^{32}$ Indeed, there has been some effort to rehabilitate ORPEN's view of the native Irish but it is unconvincing and runs contrary to his own words. ${ }^{33}$ He was a man of his time, as much as MACNEILL, and no amount of effort will turn him into a contemporary historian, nor should it. On the other hand, the same appreciation of context should be extended to MACNEILL, whose critique of ORPEN has been characterized as unfair, vindictive, and an incitement to hatred in Seán DuFFY's heated reassessment of ORPEN's contribution to Irish medieval studies. ${ }^{34}$

Why was ORPEN's work so problematic for MACNEILL and what does it tell us about his views of the meaning of the past for the present? One obvious answer lies in ORPEN's dismissal of the culture of pre-Norman Ireland as a dead-end; a dead-end, moreover, that made the Norman invasion of the island at once welcome and inevitable. ${ }^{35}$ For many readers this interpretation could stand in for the present as much as the past. It is no coincidence that the first chapter of "Ireland under the Normans" is entitled "Anarchic Ireland: Ninth to Eleventh Centuries". ${ }^{36}$ The native Irish propensity for anarchy is a long-running theme for ORPEN. The following quotation, taken from an extended description of pre-Norman Ireland, is representative:

The Chieftain, if he did not fight merely for his own hand, had no higher conception of duty than to increase the power of his clan; with this object in view, he was stayed by no scruples. The clansman, while ready to lay down his life for his chief, felt no enthusiasm for the national cause. The sentiment 'for country', in any sense more extended than his own tribal territory was alike to him and his chief unknown. ${ }^{37}$

30 A useful introduction is Philip BuLL, Orpen, Goddard Henry, in: Dictionary of Irish Biography (2014), online: http://dib.cambridge.org/viewReadPage.do?articleId=a7127 (last accessed 15/05/ 2019).

31 Goddard Henry ORPEN, Ireland under the Normans, 1169-1333, 4 vols., Oxford 1911 (vols. 1 and 2), 1920 (vols. 3 and 4); repr. in a single volume Dublin 2005.

32 See especially Seán DuFFY, Historical Revisit: Goddard Henry Orpen, Ireland under the Normans, 1169-1333 (1911-1920), in: Irish Historical Studies 32(126) (2000), pp. 246-259.

33 Ibid., pp. 255-256.

34 Ibid., pp. 248-251.

35 ORPEN (note 31), vol. 1, p. 20.

36 Ibid., pp. 19-38.

37 Ibid., p. 35. 
Here, ORPEN introduces a number of ideas that were politically loaded in the context of 1911, the year the first two volumes of "Ireland under the Normans" appeared. It was a time when a dynamic cultural nationalism, often expressed through a renewed interest in the Irish past and in the Irish language, made for a heady atmosphere rife with political possibilities. ${ }^{38}$ ORPEN's barbarous Irish clansmen, roaming an uncultivated landscape with barely the accoutrements of civilisation, were antithetical to these currents. Furthermore, he describes these clans as tribal and localized, lacking any moral impetus beyond their own self-interest. For ORPEN, then, the Irish defeated by the Normans were not inhabitants of a separate kingdom, but primitives for whom conquest was ultimately beneficial. It brought the Irish under the tutelage of their betters. As Orpen remarked: "Until the coming of the Normans - and then only partially - the Irish never felt the direct influence of a race more advanced than herself". ${ }^{39}$ His paternalistic view of the native Irish could not be more obvious.

MACNEILL's negative response may seem predictable. Yet, this was initially relatively muted and balanced by his appreciation of ORPEN's demonstrable strengths as a meticulous scholar and fine writer. Thus, in his review, published in the "Journal of the Royal Society of Antiquaries of Ireland” in 1911, he praises ORPEN’s clarity highly. He further suggests that as both Norman and Gael were ancestors of the modern Irish, their achievements deserve equal attention and celebration. ${ }^{40}$ He does criticize details of the work, particularly ORPEN's treatment of 'Laudabiliter', the Papal Bull issued in favour of an invasion of Ireland by Henry II, even now an object of scholarly dispute concerning its authenticity and contents. ${ }^{41}$ Undoubtedly, his greatest censure was reserved for ORPEN's limited understanding of pre-Norman Ireland, especially its institutions, resulting in a "very decided bias". ${ }^{42}$ This bias was lost on other reviewers who did not have MACNEILL's expertise in early medieval Irish social organisation. For instance, the British medieval historian James Tait remarked that an "impartial reader"

38 The secondary literature on this period is vast and no footnote could do it justice. MaCNEILL's own role within the Gaelic revival is discussed in Donal MCCARTNEY, MacNeill and Irish-Ireland, in: MARTin / Byrne (note 6), pp. 75-97; see also Regina Uí Chollatâin, An Claidheamh Soluis agus Fáinne an Lae 1899-1932, Dublin 2004. The broader contexts form the subject of Robert F. FosTER, Vivid Faces: The Revolutionary Generation in Ireland, 1890-1923, London 2015. The role of the reading public is emphasized in Andrew MURPHY, Ireland, Reading and Cultural Nationalism, 1790-1930: Bringing the Nation to Book, Cambridge 2018. I would like to thank my colleague Frank Bouchier-Hayes for bringing this useful study to my attention.

39 ORPEN (note 31), vol. 1, p. 105.

40 Eoin MACNEILL, Ireland under the Normans, 1169-1126. By Goddard Henry ORPEN, in: Journal of the Royal Society of Antiquaries of Ireland 1(3) (1911) p. 277.

41 The general scholarly consensus (if it can be termed as such) is that while 'Laudabiliter' is likely genuine, the presentation of it by Gerald of Wales is highly misleading. See Anne J. DuGGaN, The Power of Documents: The Curious Case of Laudabiliter, in: Brenda Bolton / Christine MEEK (eds.), Aspects of Power and Authority in the Middle Ages, Turnhout 2007, pp. 251-275.

42 MACNeILL (note 40), p. 281, 
would agree with ORPEN that an "anarchic Ireland" needed the "discipline" of Norman civilisation. ${ }^{43}$

There can be no doubt that MACNEILL's assessment of ORPEN's work hardened over time and became largely negative in tone. By 1918, when MACNEILL delivered a series of well-attended public lectures in the Rotunda in Dublin, his critique was far more trenchant, although it broadly followed the critical points outlined in his review of seven years previously. ${ }^{44}$ There are a number of contributing factors. Not only had MACNEILL's political circumstances changed, as described in his own memoir, but so had those of the country, with Sinn Féin riding high in public opinion. ${ }^{45}$ The idea of an independent Ireland in the past, in the present, and in the future, came together in a creative maelstrom of academic research shot through with political conviction. As MACNEILL stated, he now felt in a position to present the "main results of many years of study" to the public for the first time. ${ }^{46}$ And, of course, the fact that MACNEILL was giving his opinion in a public forum, to a large crowd in a heightened political environment, was a very different matter from writing a review in an academic journal. It would be surprising if they were stylistically identical. The result was "Phases of Irish History”, MACNEILL's most substantial popular book, published in 1919 but based almost directly on the lectures delivered in the Rotunda. While the majority of the lectures focussed on MACNEILL's research into early Irish society, its history and its institutions, he devoted considerable attention to ORPEN's portrayal of pre-Norman Ireland and to what he deemed its political significance. ${ }^{47}$ For instance, he remarked of ORPEN that:

When I see the eulogist of Anglo-Norman feudalism in Ireland sitting in judgment upon the political institutions of a people which he has never studied and does not at all understand, I call to mind the estimate formed by 'the ancient philosophers of Ireland' about Victorius of Aquitaine - that he was deserving of compassion rather than of ridicule. ${ }^{48}$

MACNEILL, however, did not take his own advice and he wrote, and spoke, at great length in opposition to ORPEN who seems to have become emblematic for him of a

43 James TAIT, Ireland under the Normans, 1169-1216. By G. H. ORPEN, in: The English Historical Review 27(105) (1912), pp. 144-147.

44 These lectures were originally intended to be held in Molesworth Hall but when this fell through, Bulmer Hobson arranged the Rotunda. See MACNEILL's comments in his memoir: HUGHES (note 7), pp. 95-96.

45 MACNEILL was conscious of this as shown in ibid., pp. 89-96. The spectacular turnaround in Sinn Féin's fortunes is detailed in Michael LAFFAN, Resurrection of Ireland: The Sinn Féin Party 1916-1923, Cambridge 1999.

46 Hughes (note 7), p. 95.

47 MacNeILL (note 19), esp. pp. 300-322.

48 Ibid., p. 240. 
scholarship emphasising early Irish backwardness. ${ }^{49}$ This was especially significant as the national character of the early Irish past was of primary importance to him at this stage. In contrast to ORPEN's language of political primitivism, he offered one of complexity, cultural unity and high achievement. ${ }^{50}$ For those listening to him in the Rotunda, MACNEILL painted a vision of a once and future Ireland.

Yet, while ORPEN and MACNEILL may have differed on their evaluations of early Ireland, they were both products of British society and had internalized many of its political assumptions. In MACNEILL's case this subconsciously shaped his reading of early Irish institutions. A useful example is his influential analysis of the sociopolitical communities known as tuatha. These tuatha, ORPEN's tribes and MACNEILL's tributary kingdoms, were the basic units from which most forms of political and legal authority flowed, existing within a complex hierarchy of mutual interdependence. ${ }^{51}$ For the early Irish, a tuath simultaneously comprised a people and its territory. In "Phases of Irish History", MACNEILL compares the dóer-thuatha ("unfree peoples / kingdoms") to the subjects of British India; sóer-thuatha ("free peoples / kingdoms") are in a form of dominion status, analogous to the "existing autonomous dominions of the British Empire". ${ }^{2}$ In their turn, the free peoples are subject to their provincial overkings who, themselves, are loosely joined under the 'national monarchy' of Tara. MACNEILL idealized what he believed to be the natural political organisation in Ireland, a pentarchy of five connected but largely independent kingdoms, each containing a multitude of self-regulating communities. ${ }^{53}$

It is worth noting that while MACNEILL's direct comparison of early Ireland with the British Empire may have been inspired by the need to make the medieval relevant for his audience, it also provided the basic framework for his own understanding of the political shape of pre-Norman Ireland; it functions as more than a simple analogy. MACNEILL read early medieval Irish through a presentist lens. Arguably, his understanding of the past tells us a great deal about his aspirations for the present and future. MACNEILL's early medieval Ireland was a perfected British Empire on a smaller canvas, with its bureaucracy replaced by a network of communities joined through interpersonal relationships. It emphasized the importance of the smaller unit, still a defining characteristic in modern Irish social and political life. ${ }^{54}$ Intriguingly, MACNEILL's model suggests that his view of political independence was relative rather than

49 This context is explored in Heather LAIRD, Time and the Irish: An Analysis of the Temporal Frameworks Employed by Sir Henry Maine, Eóin MacNeill, and James Connolly in their Writings on Early Modern Ireland, in: Proceedings of the Harvard Celtic Colloquium 28 (2008), pp. 128-141.

50 See for instance MACNEILL (note 19), pp. 222-248 ("The Golden Age").

51 BYRNE (note 24); Elva JoHNSTON, Literacy and Identity in Early Ireland, Woodbridge 2013, pp. 69-89, which emphasizes their change over time.

52 MaCNeILL (note 19), pp. 275-277.

53 Ibid., pp. 274-299; ID. (note 11), pp. 96-113.

54 The complex role of small-scale territorial division is discussed in Paul MACCOTTER, Medieval Ireland: Territorial, Political and Economic Divisions, Dublin 2008. See also Elizabeth FitzPATRICK / 
absolute. ${ }^{55}$ How much of this originated in his reading of the medieval Irish sources? How did this reading flow from his political opinions? The two are so intertwined that it is difficult to be certain beyond acknowledging the extent to which they nourished each other, truly a scholarship for politics and a politics of scholarship.

But, MACNEILL was also capable of criticising aspects of early Irish society; it was far from perfect. Indeed, one of his complaints against ORPEN was that he lacked a critical faculty, too often emphasising the colourful and the epic because of his emotional attachment to the Normans. ${ }^{56}$ For instance, MACNEILL wrote disapprovingly of the early Irish learned classes as "conservative, inadaptable, unproviding", representing the "fatal weakness" of their culture, a judgement which has been remarkably long-lasting despite its flaws. ${ }^{57}$ However, MACNEILL could be guilty of special-pleading. His sensitivity to assumptions of Irish barbarism was such that he sometimes distorted the obvious meaning of sources. A good example is his treatment of forms of servitude. These were of economic and social significance in early medieval Irish society and functioned within a spectrum of a highly unequal distribution of rights according to class, gender and individual. ${ }^{58}$ MACNEILL argued that slavery was initially a pre-Christian institution which was only re-established under Norse influence. ${ }^{59}$ In reality, slavery, especially debt-bondage, was an ubiquitous feature of pre-Viking society and certainly did not require foreign inspiration, even if the Vikings gave it greater economic impetus. This inconvenient truth was airbrushed by MACNEILL. In fact, a detailed reading of MACNEILL's scholarship shows him at his best when not on the defensive. In these cases, his dedication to historical accuracy, based firmly on the primary sources, is predominant. This is one of the reasons that his brilliant deconstruction of the medieval Irish pseudo-histories as entirely artificial, showing them to be medieval inventions, has stood the test of time. ${ }^{60}$

Raymond GILlESPIE (eds.), The Parish in Medieval and Early Modern Ireland: Community, Territory and Building, Dublin 2006.

55 This is also clear in MACNEILL's comments in his memoir about the period in which 'Phases in Irish History’ was delivered. See HuGHEs (note 7), pp. 96-97.

56 MACNEILl (note 40), pp. 276, 281.

57 MacNeill (note 19), p. 355. The view is echoed in Francis John BYRNE, Senchas: The Nature of the Gaelic Historical Tradition, in: John G. BARRY (ed.), Historical Studies IX: Papers Read Before the Irish Conference of Historians, Cork, 29-31 May 1971, Belfast 1974, pp. 137-159.

58 Fergus KelLy, A Guide to Early Irish Law, Dublin 1988, pp. 68-98.

59 MacNeIll (note 11), p. 110. See also Paul Holm, The Slave Trade of Dublin, Ninth to Twelfth Centuries, in: Peritia 5 (1986), pp. 317-42, who emphasizes the new commercial aspects of Viking slave trading in Irish contexts.

60 See, for example, MACNEILl (note 11), pp. 25-42; ID. (note 19), pp. 90-92; ID., A Pioneer of Nations, in: Studies: An Irish Quarterly Review 11(41) (1911), pp. 13-28, and 11(42) (1911), pp. $435-446$. 


\section{Beyond Apathy and Antipathy: MACNEILL and the Limits of History}

Seán DUFFY has remarked of the disagreement between MACNEILL and ORPEN that it is "most unfortunate that a scholar of Eoin MacNeill's integrity and stature should have let emotions enter the historical debate in this way [.. .]". ${ }^{61}$ This comment touches on an important issue about MACNEILL's view of the purpose of history. MACNEILL as a historian was not only what we would now term an academic scholar. He was also a public historian and invested a great deal of time in communicating his subject to a wide audience, through public lectures, radio broadcasts and writing. MACNEILL was passionate about this, emphasising that the Irish should know their own history at first hand and that their story was one of the people, not simply of great men. ${ }^{62}$ Only on this basis could they understand their society and, through understanding, change it for the better. Knowledge of history was instrumental; it was certainly not value free. MACNEILL did not place emphasis on the "spirit of cold detachment", much prized by a later generation of scholars, especially the revisionists mentioned at the beginning of this paper. ${ }^{63}$ This does not mean, however, that MACNEILL believed that the historian should function as a propagandist or even give free range to emotional interpretations, the very fears which drove revisionist historiography. As we have seen, he criticized ORPEN for being too emotionally engaged with the objects of this research. Moreover, MACNEILL explicitly regarded historical research as based on scientific principles and likened his apprenticeship with the great scholar Edmund Hogan to working in a laboratory. ${ }^{64}$ In lectures delivered in University College Dublin he stated: “Ancient Ireland, as it happens, is no vacant region for free speculation. The material for its study are remarkably copious, and the method of its study must be by way of research, analysis, and synthesis."65

However, MACNEILL's view of history was not simply empiricist, although empiricism was foundational to it. ${ }^{66}$ Emotional apperception was also part of the equation; it was the faculty through which historians engaged with the past and, furthermore, engaged their audiences in that past. Emotion, tempered and led by knowledge, bridged the past and present, making the medieval relevant for the researcher and the public. In his foreword to "Phases in Irish History" MACNEILL suggested that "[n]either apathy nor antipathy can ever bring out the truth of history" ${ }^{67}$ This gnomic phrase distils that

61 DuFFy (note 32), p. 250.

62 The transcript of a radio broadcast, given by MACNEILL, reproduced in MCMAHON / KENNEDY (note 8), pp. 89-90, is an especially clear statement of this viewpoint.

63 EDWARDS (note 13), p. 286, castigates MACNEILL on this point.

64 MACNEILL (note 14), p. 191.

65 ID. (note 11), p. 144.

66 Ibid., pp. xiv-xv. See also the overview provided by BYRNE (note 16), pp. 15-36.

67 MACNEILL (note 19), p. vi. 
complex attitude. This contrasts with the search for objective 'fairness', envisaged as an absence of emotion, that has animated much revisionist scholarship. ${ }^{68}$

MACNEILL took his role as a public historian very seriously. His writing is clear; he has no problems translating technical terms into simpler equivalents and he deploys rhetoric well, shifting cadences when he wished to connect politically or emotionally with his audience. For example, in "Phases of Irish History", a discussion of sixthcentury Ireland develops into a heightened evocation of clashing empires, with a not altogether subtle nod to Ireland's own political position in 1918. He even remarks:

[...] and I rejoice, I am sure we all rejoice, to see, in these days of clashing and crashing empires, that the clear idea of nationality, as if by the wonderful recreative power that is in nature, is rising in the esteem of good men all over the world, above and beyond the specious and seductive appeal of what has been called 'the wider patriotism'. In this regard, too, our own country in that most remarkable period of its history may furnish something of a model. ${ }^{69}$

At the same time, he warned his audience against believing comforting mythologies that linked the ancient Irish with biblical history. ${ }^{70}$ The Irish were not a "Chosen People'; they were only special, insofar as every other people had its own value. Disentangling legend from fact was crucial in understanding the past.

MACNEILL's commitment to the transformative power of public history has often been viewed as preventing him from completing book-length research. Thus, modern scholars lament that MACNEILL never produced a monograph or sustained study, such as ORPEN's masterpiece. ${ }^{71}$ His three longer works, "Celtic Ireland", "Phases of Irish History", and "Early Irish Laws and Institutions" are all fix-ups of public lecture series, reprinted with minimal changes, apart from introductory matter written specially for the printed editions. ${ }^{72}$ It is certainly true that none of these volumes gather MACNEILL's many insights into a single all-encompassing interpretation of early medieval Irish society. But, it is also worth considering MACNEILL's stated opinion that the writing of a truly impartial national history was impossible ${ }^{73}$ he situated his work as either establishing critical foundations for further studies or as correctives to misunderstandings,

68 See for instance, Ciarán BRADY, Constructive and Instrumental: The Dilemma of Ireland's First 'New Historians, in: ID. (note 2), pp. 3-34; Alfred MARKEY, Revisionisms and the Story of Ireland. From Sean O’Faolain to Roy Foster, in: Estudios Irlandeses 0 (2005), pp. 91-101.

69 MACNEILL (note 19), p. 227.

70 Ibid., p. 91.

71 BYRNE (note 16), p. 35, remarks that "[h]e (MacNeill) never seems to have had the ambition to complete a definitive work".

72 MaCNeILl (note 11), pp. xi-xv; ID. (note 19), p. vi; ID. (note 22), pp. 5-55, is the longest by some measure.

73 His comments on this matter are usefully collected in Mairéad CAREw, Eoin MacNeill and the Promotion of Celtic Studies in North America, online: http://historyhub.ie/eoin-macneill-celticstudies-america (last accessed 15/05/2019). 
both academic and popular. Furthermore, specialized research needed to continue. As he pointed out in his preface to "Celtic Ireland", written in 1921:

There is still work for many pioneers to do [...] As things are, it would be a vain ambition to seek the credit of having said "the last word" on almost any matter of Irish antiquity; but on almost any, in some respect there is still the first word to be said. ${ }^{74}$

This was combined with a conviction that writing an over-arching narrative of Irish history was impossible to complete without bias, especially for a single person. In this context, MACNEILL's support of collaborative projects, under the auspices of the IMC, ${ }^{75}$ is the closest he could come to moving through that space beyond apathy and antipathy. Significantly, perhaps, despite a growing ecology of textbooks and monographs, early Irish history still lacks a singular grand narrative, although the value of one would rightly be questioned by modern scholars. It could be argued that MACNEILL was realistic: the reaches of the early Irish past were only accessible through painstaking individual research combined with group projects. Nevertheless, MACNEILL's public lectures do articulate his vision of history far more clearly than anything to be found in his more obviously specialist works, which tend to be tightly focussed, lacking the discursiveness of his talks. They are for scholars. But, MACNEILL understood that history was of cultural importance for all society. For him, making the medieval relevant was a duty and this is where, apart from specialist works, MACNEILL's vision as a scholar, still resonates.

Yet, there are other factors that need to be considered. MACNEILL's debate with ORPEN hardened a contrast between an early medieval Ireland, ending abruptly and artificially with the arrival of the Normans in 1169, and a medieval Ireland of natives and newcomers. Even now, relatively few historians of one period, cross-over substantially to the other, despite the clear connections between the two. ${ }^{76}$ This has truncated scholarly understandings of a complex period of Irish history and has tended to make early Ireland appear sui generis, self-enclosed and immeasurably remote. Moreover, contemporary scholars of Irish history remain wary of bias and emotion, distrusting their power to twist the past. This fear is justified yet, in the process, it is arguable that something has been lost. Few current scholars of early medieval Ireland connect with popular audiences with the same regularity, and to the same extent, as MACNEILL. In their place, popular romanticized studies of a 'Celtic' world predominate, recycling those same fantastical mythologies that Eoin MACNEILL, himself, had long ago disproved.

74 MACNEILL (note 11), p. xiv.

75 MCMAHON / KenNEDY (note 8), pp. 1-94.

76 There are, of course, exceptions, especially in the area of Church reform. For instance, MarieTherese FlanAGAN is equally at home in pre- and post-Norman Ireland, see for a representative study ID., The Transformation of the Irish Church in the Twelfth Century, Woodbridge 2010. More recently, Donnchadh Ó CORRÁIN, The Irish Church, its Reform and the English Invasion, Dublin 2017, covers some similar ground. 


\title{
What's in a Word? Naming 'Muslims' in Medieval Christian Iberia
}

\begin{abstract}
This chapter underlines the various ways in which closer study of the Middle Ages can be relevant to some aspects of Western attitudes towards Islam, past and present. Taking the variability of the terminology used to name Muslims in medieval Iberia as a case study, the paper examines how the nomenclature used to designate Muslims was in specific instances influenced by understandings of Islamic ethnic and political complexities, as represented in works by medieval Hispanic writers and records of the decisions and deeds of leading Christian political figures. Understanding Islam to be a constellation of peoples had an impact on the responses of medieval Spaniards to local Muslim communities and leaders. Such nuanced understandings could also foster notably co-operative political relationships and arrangements. Analysing in particular the refinement of pre-Islamic Christian models for nomenclature with the Hispanic introduction of new designations during the first half of the twelfth century, the chapter shows that Christian authors could conceive of the Islamic world not just as a totalized vision of an abstract enemy, but also as a juxtaposition of peoples, and of political identifications in particular. These distinctions challenge the commonly held idea of the Middle Ages as a period of only crude intercultural understandings. They resonate with contemporary debates surrounding the place of Islam in the so-called modern world, a debate too often fed by a monolithic appreciation of what it is to be a Muslim.
\end{abstract}

Keywords: Western views of Islam, medieval Iberia, ethnonyms, Andalusis

"Messire! Un sarrasin! Messire, un sarrasin dans une chariotte du diable!" ("Sire! A Saracen! Sire, a Saracen in a devil's chariot!”). This line from the 1993 French film 'Les Visiteurs'1 is intended to illustrate the crude if not comic credulity commonly attributed to medieval people. The comedy featured the nobleman Godefroy de Montmirail (Jean Reno) and his squire Jacquouille (Christian Clavier), whom a sorcerer's spell transported from the twelfth century to the twentieth. In their attempts to find a way back to their home, the protagonists faced many challenges, including the unexpected appearance of a post-office van driven by a black-skinned employee

1 Les Visiteurs, dir. Jean-Marie Poiré, perf. Christian Clavier, Jean Reno, Valérie Lemercier, France, 1993, film.

Hélène Sirantoine, SOPHI - Department of History, Quadrangle A14, The University of Sydney, NSW 2006, Australia, helene.sirantoine@sydney.edu.au 
(Théophile Moussa Sowié). Terrified both by the man's skin colour and the internal combustion engine, Jacquouille - as the audience was meant to believe - could only identify both through his own knowledge base. This involved concluding, apparently inevitably, the materialization of a "Sarrasin!" was 'devilish'.

The line made millions of spectators heartily laugh in 1993. When I saw the film as a teenager I, myself, was far from imagining that the Saracens would become, years later, recurrent characters in my professional life as an historian of medieval Iberia! It might even have been the first time I heard the term, and today I do not remember with clarity whether I reacted to the scene or simply laughed along with the rest of the audience. I certainly recall that we had read Corneille's 'Le Cid' at school and I might have associated the 'Saracens' with the 'Moors' whom the Castilian hero Rodrigue chivalrously fought in the seventeenth-century play. Did I then laugh at the archaism of the term? Or at the caricatured rendering of French public services behind the appearance of a debonair post-office employee whose startled verbal reaction at the sight of the threatening "Visiteurs" was uttered with a strong sub-Saharan African accent? I am honestly not sure that my reflections were particularly deep at the time. Was I even aware of how bitterly that scene - the spectators' laughter, and my own poor appreciation of a characteristically xenophobic form of French humour - resonated with many French people in a context of post-colonial racism $?^{2}$ After all, it was not that different from another line that I had heard repeated time and time again in the 'real world' of the news, of adult conversations, and even in my school playground. "Rentre chez toi, sale arabe” (“Go home, you filthy Arab!”) was not a quotation from a comic film, but the appalling reality suffered by many among the descendants of North-African immigrants, spontaneously harassed by some of their fellow citizens who held them responsible for the creeping economic crisis. ${ }^{3}$ This xenophobic attitude towards the parts of the French population of African-immigrant origins, wherever their forebears came from, evolved in its turn at the very end of the twentieth and in the first decade of the twenty-first century. It partially moved from a racial focus to become more centred on religious and cultural questions, and French debates concerning identity crystallized around "le problème musulman" ("the Muslim problem"). ${ }^{4}$ In this context, it is not rare for French Muslims to be held collectively responsible for the terrorist attacks that have plunged the country repeatedly into mourning. Conflating elements of racism, xenophobia, and islamophobia, the use some made of the designations 'Arabs' or 'Muslims' contain not only questionable assumptions, but also the idea that the communities they name, conceived as monolithic, do not belong. That is, they are othered, as they were in the Middle Ages.

2 Sylvie Chalaye, Nègres en images, Paris 2002.

3 Gérard NoIRIEL, Immigration, antisémitisme et racisme en France. Discours publics, humiliations privées, Paris 2007.

4 Abdellali HaJjat / Marwan MoнAmmed, Islamophobie. Comment les élites françaises fabriquent le 'problème musulman', Paris 2013. 
As they were in the Middle Ages? Over the last three decades, medievalists have repeatedly claimed a place and relevance for their field in the debates that have shaken - and that continue to resonate in - the public sphere of many Western countries regarding the place of Islam in the so-called modern world. Refuting the overly simple theory of a "clash of civilizations" zation of the world from the sixteenth century, medievalists have established their period as the age when multifaceted and complex relations between Europe and the Islamic world began. ${ }^{6}$ Complementing the recurrent calls to avoid generalizations when it comes to Western (mis)conceptions of Islam, they shed light on how the Middle Ages were a formative period in the construction of prejudices against Muslims. ${ }^{7}$ In reflecting on the racism present in contemporary Western societies, they have also questioned their own intellectual practices and have condemned the phenomenon of 'scholarly islamophobia'. ${ }^{8}$ The Middle Ages therefore emerge as a period of history essential for productive considerations regarding "Islam and the West", 9 whether as a point of departure, comparison, or for explication of Western attitudes.

This chapter aims to pursue this reflection on the enduring relevance of the Middle Ages to contemporary perceptions of Islam by extending the investigation into the discursive field of the terminology used to describe the peoples of Islam, and how it impacted on the perception of the Muslim world. It departs from the observation that medievalists often focus their enquiries on how medieval people envisaged Islam in its religious dimensions, neglecting the co-existing contemporary understandings of the Islamic world in its secular aspects. ${ }^{10}$ This constraint is certainly understandable because it corresponds to the Christian representations of the world that characterize most of the evidence for the period. However, it also

5 Samuel P. Huntington, The Clash of Civilizations and the Remaking of World Order, New York 1996.

6 Synthesis in Henry LaUREnS / John V. Tolan / Gilles Veinstein, L'Europe et l'Islam. Quinze siècles d'histoire, Paris 2009 (Engl. trans.: Europe and the Islamic World, Princeton / NJ 2013).

7 Among others, see John V. Tolan, Islam in the Mirror of our Phantasms, in: Nilüfer GöLE (ed.), Islam and Public Controversy in Europe, Farnham 2013, pp. 113-22.

8 See the edited volume by Philippe BürTGEN et al. (eds.), Les Grecs, les Arabes et nous. Enquête sur l'islamophobie savante, Paris 2009, that followed the publication of the monograph by Sylvain Gouguenheim, Aristote au Mont-Saint-Michel. Les racines grecques de l'Europe chrétienne, Paris 2008, in which the author denied the role of the Islamic world in the transmission of Greek philosophy to medieval Latin Christendom.

9 To repeat the title of one of the earliest works on Western perceptions of Islam, written by Norman DANIEL, Islam and the West. The Making of an Image, Edinburgh 1960.

10 See Marie-Thérèse D'ALVERNY, La connaissance de l'Islam en Occident du IX ${ }^{\mathrm{e}}$ au milieu du XII ${ }^{\mathrm{e}}$ siècle, in: Charles BuRNETT (ed.), La connaissance de l'Islam dans l'Occident médiéval, Aldershot 1994, pp. 577-602, who symptomatically stated at the very beginning of her article that "[she would] limit [her] study to the knowledge of Islam as a religion, and this is already a vast subject" ("Nous limiterons notre étude à la connaissance de l'Islam en tant que religion, et ceci est déjà un sujet bien vaste"). 
tends to confine reflection and limit its transportability into discussions and debates today. Within such limits, the Middle Ages remain an 'age of faith' in which Muslims were an archetypal enemy of Christendom. As a consequence, the period occasionally becomes the focus of anachronistic examinations of modern notions of tolerance and intolerance. Decentring our approach to look at how medieval people observed the world that they shared with Muslims ${ }^{11}$ allows for more intersectional comparisons, and offers a further example of the relevance of the medieval period for a contemporary audience. Taking the example of medieval Iberia as a case study of inter-cultural encounter, and focussing in particular on sources from the twelfth century, this chapter argues that medieval people could adopt a plurality of viewpoints on Islam, that were not always based on religious antagonism or uniformizing comprehension. Indeed, medieval Christians in Iberia engaged with diverse discursive strategies in their identification of Muslims.

A caricature, and problematic in terms of race discourse, as it was and remains, the line from 'Les Visiteurs' nevertheless referred to a historical reality: in the medieval Latin West, 'Saracen' was one of the most commonly used words to designate not only a Muslim person, but potentially any person physically or geographically associated with the empire of Islam. ${ }^{12}$ Modern scholars have frequently discussed the various potential etymological roots of the term. ${ }^{13}$ In the mind of medieval Christians, its meaning was clearly inherited from an early ethnology based on the evidence of the Bible. Commenting on biblical genealogies in the fourth century, Saint Jerome among others, explained how "Ishmaelites and Hagarenes [are] now called Saracens, having falsely taken for themselves the name of Sarah in order to be seen as descending from a lawful woman rather than from a slave". ${ }^{14}$ He had in mind the people considered by Christian authors as the descendants of Ishmael, first son of the patriarch Abraham and his servile wife, Hagar. Not satisfied with their shameful origin, the Ishmaelites or Hagarenes had tried, according to this Church Father, to mitigate it by appropriating the name of Abraham's legitimate wife, Sarah. The term 'Saracen' thus conveys a pejorative implication of deceit. Other Christian authors from pre-Islamic times, writing on the ethno-geographical history of their world, associated Saracens with the tribes of the pagan Arabs, and this nomenclature passed into the medieval West through

11 For such an approach, see Hélène SiRANTOINE, Histories of the Islamic World in the Chronicles of the Kingdom of León (End-Ninth to Mid-Twelfth Centuries), in: Parergon 35(2) (2018), pp. 119-145. Elements of the ideas presented here are based on the argument developed in this article.

12 Norman DANIEL, The Arabs and Mediaeval Europe, London 1975, p. 53; Philippe SÉNAC, L'Occident médiéval face à l'Islam. L'Image de l'autre, 2nd ed. Paris 2000, p. 14.

13 Irfān SHAHÎD / Clifford Edmund BosworTH, Saracens, in: Encyclopaedia of Islam, Second Edition (published online 2012), online (DOI): http://dx.doi.org/10.1163/1573-3912_islam_COM_1003 (last accessed 15/05/2019).

14 Jerome, Commentariorum in Hiezechielem libri XIV, ed. Francis GLORIE (Corpus Christianorum. Series Latina 75), Turnhout 1964, p. 335 (VIII 28): Ismaelitas et Agarenos, qui nunc Saraceni appellantur, assumentes sibi falso nomen Sarae quo scilicet de ingenua et domina uideantur esse generate. 
writers such as Isidore of Seville (d. 636) in his 'Etymologies' ${ }^{15}$ From there, when the time came to name the followers of the new movement arisen in Arabia in the midseventh century, a discursive frame of reference was already prepared for use. Later on, the terms 'Saracens', 'Hagarenes', and 'Ishmaelites', in the expression of European writers, denoted an assimilation between Arabs and Muslims, and these identifications that had begun as ethnonyms acquired a religious dimension. They also tended to impose a monolithic depiction of the Islamic world, based on a biblical framework interpreted with pejorative implications.

Although the Iberian Peninsula was the place of a more direct encounter between the Islamic world and Latin Christendom as a consequence of the westward expansion of the dār al-Islām, authors originating from the Hispanic Christian kingdoms were generally no exceptions to the ethnographic-commentarial habits described above, which are all apparent in the medieval documentation. ${ }^{16}$ But, from the early Middle Ages, they were combined with a store of other terms employed in a variety of contexts. For example, the biblical analogy was expanded upon in the Asturian 'Chronicle of Alfonso III' (early tenth century), ${ }^{17}$ where Muslims, in addition to Saracens and Ishmaelites, were also designated as Chaldeans. With this term, the author reminded his audience of the scriptural misfortunes suffered by the people of Israel, and presented the Asturians as the heirs of the Chosen People. ${ }^{18}$ In other writings, emphasis was drawn to the paganism that, it was assumed, characterized Saracens. Thus, the Mozarabic cleric Eulogius of Córdoba (d. 857), in his various treatises written in defence of voluntary martyrdom, was scrupulous in referring to Muslims as pagani, ethnici, and gentiles. ${ }^{19}$ We also know of some diplomatic occurrences of a term transliterated from the Arabic muslim under the Latin form muzlemite at the turn of the millennium. ${ }^{20}$

Admittedly, other terms appeared in Iberian sources that signal a recognition of ethnic distinctions within the otherwise purportedly uniform Muslim community.

15 John V. Tolan, Saracens. Islam in the Medieval European Imagination, New York 2002, pp. 10-12.

16 See Dolores Oliver PÉREZ, Sarraceno: su etimología e historia, in: Al-Qantara 15(1) (1994), pp. 99-130, whose article proposes an overview of the denominations adopted by Christian Spaniards to designate Muslims up to the 13th century.

17 Chronicle of Alfonso III, ed. Juan GIL, in: Crónicas Asturianas, ed. Juan GIL, trans. José L. Moralejo, and study by Ignacio RuIZ DE LA PEÑA, Oviedo 1985, pp. 113-149.

18 Kenneth B. Wolf, Conquerors and Chroniclers of Early Medieval Spain, Liverpool 1990, pp. 58-59.

19 Eulogius of Córdoba, Memoriale Sanctorum, Documentum Martyriale, and Apologeticus Martyrum, ed. Juan GIL, in: Corpus Scriptorum Muzarabicorum (Manuales y Anejos de "Emerita” 28), ed. Juan GIL, Madrid 1973, vol. 2, pp. 363-495.

20 See Maurilio PÉREZ GonZÁlez (ed.), Lexicon latinitatis Medii Aevi regni Legionis (s. VIII-1230). Imperfectum (Corpus Christianorum. Continuatio Mediaeualis. Medieval Latin dictionaries 3), Turnhout 2010, p. 498. 
Arabes and Mauri in particular were used in early Iberian texts to distinguish, respectively, the Arab and Berber populations that had settled in the peninsula after its conquest. Such is the case in the 'Mozarabic Chronicle of 754', which is attentive to the resentment felt by the Berbers/Mauri against the Arab ruling elite. ${ }^{21}$ However, with time 'Arabs' was less frequently resorted to, or lost its ethnologic specificity. It was only with the 'Historia Arabum' written by the archbishop of Toledo, Rodrigo Jiménez de Rada, in the mid-thirteenth century that it regained clearer currency. For 'Moors', which became, on the contrary, widely used, the meaning was variable. $^{22}$ In the 'Primera Crónica General', promoted by King Alfonso X of CastileLeón (1252-1284), 'Moors' referred either to those identified as the Arabs from Arabia in early Christian ethnology, or to the Berbers originating from Mauritania who had rebelled against the Arabs in eighth-century al-Andalus. But it could also be employed as a synonym for Hagarenes and thus point to Muslims in general. ${ }^{23}$ In all, the variety employed in medieval Iberian texts to name Muslim populations creates the impression of a great confusion of terms, at least when these terms are taken together by the modern reader.

It has been argued that, in historiographical material at least, this confusion could be attributed to a historical methodology that favoured in many instances the compilation of previous writings that were not always standardized. However, a decisive and more important reason was the ignorance with which Iberian Christian historiographers regarded their Islamic foe, whom they nevertheless regularly alluded to in their stories. Behind the Saracens, the Moors and the Arabs, medieval people were only given to see the archetype of 'them', notwithstanding the respective identifications or allegiances to the Fatimid caliphate, the Cordoban emirate, or an autonomous pirate base. It was a strategic ignorance, insofar as unifying the Islamic world behind a totalizing designation was also an instrument for defining the valorous and virtuous Christian power that combatted it from the Iberian Peninsula. However, such purposes did not prevent Hispanic historians from underlining the significant internal rivalries that weakened Islamic political unity, especially in its Western parts. The discursive emphasis on both a totalist unity and on precarious fragmentation within the Muslim world, which was in operation through various scribal strategies, must therefore be conceived as twinned

21 Continuatio isidoriana hispana = Crónica mozárabe de 754, ed. and trans. José Eduardo LÓPEZ PEREIRA, León 2009.

22 Évariste LÉvi-ProvençAl / Frédéric DE LA ChAPELLE, Moors, in: Encyclopaedia of Islam, First Edition 1913-1936 (published online 2012), online (DOI): http://dx.doi.org/10.1163/1573-3912_islam_ SIM_5262 (last accessed 15/05/2019).

23 Bernard RICHARD, L'Islam et les musulmans chez les chroniqueurs castillans du milieu du Moyen Âge, in: Hespéris-Tamuda 12 (1971), pp. 107-132, here p. 118. 
aspects of a rhetoric employed to glorify the actions of Iberian Christian historical figures as defenders of both territory and faith. ${ }^{24}$

Once one considers that both the confusion and the genericism observed in the designation of Muslims in Iberian Christian sources could be the result of a calculated (un)awareness, the possibility of other terminological strategies appears a fruitful field of investigation. From such a perspective, a closer look at what could otherwise be interpreted as exceptions in Hispanic sources from the twelfth century reveals their abiding discursive potential and the eruption of characterizations and differentiations of Muslims based on a variety of ethno-political identities.

In this regard, the introduction of a new term among the range of those available to Iberian writers to refer to Muslims can be considered the result of such strategies. Sources from the period testify to the introduction of the ethnonym 'Moabites'. ${ }^{25}$ The term itself comes again from the Bible as a historico-genealogical resource: in the 'Book of Genesis' Moab is the son whom Lot fathered with his elder daughter, and from there became associated with the eponymous kingdom of Moab, located on the eastern side of the Dead Sea, whose inhabitants featured as foes to Old Testament Israel in various instances. In his 'Dialogue against the Jews', written sometime between 1106 and 1135, the Hispanic polemicist Petrus Alfonsi specifically identified the Moabites with the followers of Prophet Muhammad. ${ }^{26} \mathrm{~A}$ few years later, Renallo, author of the 'Life of Saint Olegarius', bishop of Barcelona from 1116, then of Tarragona from 1118 until his death in 1137, offered a synthesis of the new and old biblical genealogies. In a passage where we follow the count of Barcelona, Ramon Berengar III (d. 1131), over a tour of Italy to obtain support in his fight against Islam, we see him stopping at Genoa and requesting the assistance of the city "against the sons of Hagar and Moab". ${ }^{27}$

However, in many Iberian sources, the term is believed to have been used rather to refer to the Almoravids specifically, the Berber dynasty that took power in the Maghreb in the second half of the eleventh century, and later proceeded to conquer and rule over al-Andalus from 1086-1147. In addition to the biblical explanation behind this choice of ethnonym, we must consider the phonetic proximity of the Latin $\mathrm{Mo}(h)$ abitae with the Arabic al-murābit (pl. al-murābitūn) as a determining restriction for the term's significance. The reason behind this restriction might also have had to do with the name given in Latin sources to the Almoravid golden coins

24 Ibid., pp. 118, 122.

25 Meritxell BRU, Posar un nom. Els Almoràvits com a Moabites a finals del segle XI, in: Faventia 31 (2009), pp. 129-149.

26 Ibid., pp. 135-136.

27 Vita Beati Ollegarii, ed. Martin AurELl, in: ID., Prédication, croisade et religion civique: Vie et Miracles d'Oleguer († 1137), évêque de Barcelone, in: Revue Mabillon 10 (1999), pp. 113-168, here p. 127: Adversus filios Agar et Moab. 
circulating in the Iberian Peninsula from the last decade of the eleventh century, namely, the morabetinos. ${ }^{28}$

Moabitae, referring to the Almoravids, therefore cohabitated with more traditional terms with a similarly wide meaning and currency. Its status is not entirely clear in the case of the 'Historia Compostellana', a text written at the instigation of the archbishop of Santiago de Compostela, Diego Gelmirez (d. 1140). ${ }^{29}$ Chronicling the history of the Compostelan see but above all the episcopate of his sponsor, the 'Historia' dedicated many lines to the repeated warring between Christians and Muslims during this period. The latter were most of the time designated as Sarraceni, Hismaelitae, and sometimes Agareni. But the authors also named the Moabitae, whom a passage identified as Maur ${ }^{30}$ whilst another stated that, "the heat of the sun [had] made them similar to the Ethiopians". ${ }^{31}$ It might not be realistic to conclude that usage of the term was systematically restricted to designating the Almoravids in this text. ${ }^{32}$ The evidence provided by the 'Historia Roderici' is stronger. In this anonymous Latin chronicle, recounting the glorious deeds of the famous Cid (d. 1099) and composed at an unknown date during the twelfth century, ${ }^{33}$ 'Saracens' refers to Muslims in general. But among the terminology used, gens Moabitarum or more simply Moabite is often juxtaposed to Hysmaelite, with the Ishmaelites presented as having to collaborate with or submit to the new leading Islamic power of the 'barbaric' Moabites, of whom the context allows identification with the Almoravids. ${ }^{34}$ This juxtaposition suggests that the Moabites were not just a particular group within a whole, defined as 'the Ishmaelites', but rather that both terms were referring to a specific group. In this perspective, if Moabite referred to the Almoravids, to what group were the Ishmaelites assimilated? It must be noted that, in one instance at least, the Ishmaelites were presented as originating 'from Hispania' ${ }^{35}$ Could it be that this text relating the descendants of Ishmael to the Muslims of Spain acknowledged a specific national identity for the Andalusis? Another chronicle certainly did, albeit through a different use of vocabulary.

28 BRU (note 25), pp. 136-138.

29 Historia Compostellana, ed. Emma FALQUE (Corpus Christianorum. Continuatio Mediaeualis 70), Turnhout 1988.

30 Ibid., II, XVI: Moabitarum siue Maurorum.

31 Ibid., I, XXIX: Moabite, quos estus solis facit Ethiopibus similes.

32 Contra: Historia Compostelana, trans. Emma FALQUE (Akal. Clásicos Latinos Medievales 3), Madrid 1994, pp. 132-133, n. 315 and 321.

33 On the dating of the 'Historia Roderici' see the balance of hypotheses offered in Alberto MONTANER Frutos / Ángel Escobar CHICo (eds.), Carmen Campidoctoris o Poema latino del Campeador, Madrid 2001, pp. 77-87. Alberto MONTANER proposes a late date around 1190 for the composition of the text.

34 See the evidence compiled by BRU (note 25), pp. 138-139.

35 Historia Roderici vel Gesta Roderici Campidocti, ed. Emma Falque, in: Chronica Hispana Saeculi XII. Pars 1 (Corpus Christianorum. Continuatio Mediaeualis 71), Turnhout 1990, pp. 1-98, here ch. 33.22: Omnes alii reges Yspanie Ysmaelitarum. 
The 'Chronica Adefonsi Imperatoris' (henceforward CAI) was written between 1147 and 1149 by a cleric close to King Alfonso VII of Castile-León (1126-1157), and probably at his instigation. ${ }^{36}$ The chronicle is dedicated to the narration of his reign, from Alfonso's accession to the throne in 1126 to the preparations for the siege of Almería in 1147. Within the historiographical panorama of its time, this text testifies to a revival of interest in the Islamic world, ${ }^{37}$ especially its western parts whose contemporary dynamics are clearly described. ${ }^{38}$ In particular, the chronicler understood and competently rendered the change of rule in al-Andalus in the early twelfth century. In the title to Book II the chronicler specified that he aimed to narrate "the conflicts and battles which he [Alfonso VII] [...] had with King 'Alī, with his son Tāshufin, and with the other kings and princes of the Moabites and Hagarenes". ${ }^{39}$ The ensuing first chapter elaborated on this title, setting the historical context of the narrative:

Departing from the natural order of things, let us come to deal with the wars which in times past were particularly hard-fought for the Christians. After the death of King Alfonso [VI, in 1109], [...] King 'Alī, who was the most powerful among the Saracens, and who as king of Marrakesh ruled over the Moabites, and on this side of the sea over the Hagarenes far and wide, and over many islands and peoples of the sea, like a serpent thirsting in the summer heat, raised his head and, as if he would triumph everywhere after the death of such a great man, summoned all the princes, commanders and soldiers of the Moabites together with a great army of Arab mercenaries, and many thousands of horsemen, crossbowmen and great companies of foot-soldiers, as numerous as the sand which is upon the sea shore. Having received advice from his experts, he gathered an army and crossed the sea with his son Tāshufin and went to Seville. ${ }^{40}$

36 Chronica Adefonsi Imperatoris, ed. Antonio MAYA SÁNCHEZ, in: Chronica Hispana Saeculi XII. Pars 1 (Corpus Christianorum. Continuatio Mediaeualis 71), Turnhout 1990, pp. 109-248; an introduction to the chronicle and an assessment of its place within the historiographical production of the time can be read along with the English translation of the text - from which all the translated excerpts cited in this chapter are borrowed - in Simon BARTON / Richard FLETCHER (trans.), The World of El Cid. Chronicles of the Spanish Reconquest. Selected Sources Translated and Annotated, Manchester, New York 2000, pp. 148-263.

37 See Simon BARTon, Islam and the West. A View from Twelfth-Century León, in: ID. / Peter LineHAN (eds.), Cross, Crescent and Conversion. Studies on Medieval Spain and Christendom in memory of Richard Fletcher, Leiden, Boston 2008, pp. 153-74.

38 For the analysis of CAI that follows, see SIRANTOINE (note 11), pp. 141-148.

39 CAI (note 36), II, praef.: DE DISSENSIONIBVS ET PRELIIS QVE HABVIT IPSE [. . ] CVM REGE ALI ET CVM FILIO SVO TEXVFINO ET CVM CETERIS REGIBVS ET PRINCIPIBVS MOABITARVM ET AGARENORVM.

40 CAI (note 36), II 1: OMISSO NATVRALI ORDINE AD EA, QVE OLIM CHRISTIANIS ASPERRIMA FVERE BELLA, TRACTANDA VENIAMVS. Post obitum regis domni Adefonsi, [.. .] rex Ali maximus Sarracenorum, qui rex Marrocorum dominabatur Moabitis et ex ista parte maris Agarenis longe lateque aliisque multis et maris insulis et nationibus, sicut serpens estu sitiens extulit caput et quasi post mortem summi uiri ubique triumphaturus conuocauit omnes principes et duces et milites Moabitarum et magnum exercitum conductitium Arabum et multa milia militum, balistorum et magnas multitudines peditum sicut 
In this passage, which exemplifies a strategy adopted throughout the text, we observe that the chronicler made use of terminology inspired by the Bible to designate Muslims: they were 'Saracens' and 'Hagarenes', two denominations not unusual at that stage, and 'Moabites', a more recent addition to the nomenclature, as we have seen. However, the author also reappropriated this terminology to shed light on the politico-ethnic variety of the Muslims with whom Alfonso VII dealt during his reign. Indeed, a clear distinction is made between the Moabites, here evidently designating the Almoravids from the Maghreb ruled by 'King 'Alī', that is Emir 'Alī ibn Yùsuf (1106-1143), and the Hagarenes, acknowledged specifically as the Muslims "on this side of the sea", that is the Andalusis whom the Almoravids overpowered progressively from 1086 onward. Whereas the term 'Hagarene' worked as a synonym for 'Saracens' in previous texts, it was redefined in the CAI to apply only to the Muslims of Hispania, whilst 'Saracens' continued to refer to Muslims in a universalizing way. ${ }^{41}$ Later in the text, the chronicler even added one more group to this panorama: the Berber Almohads, whose rise to power in the Maghreb between 1120 and 1147 was similarly depicted quite accurately. They first appeared in a chapter relating that King 'Alī had "to make war on the Muzmutos and the king of the Assyrians, called Abdelnomen, who attacked his territories without interruption". ${ }^{42}$ This designation of the Almohad leader 'Abd al-Mu'min as "king of the Assyrians", recalling the biblical Nebuchadnezzar, ${ }^{43}$ allowed for a continuation of the scriptural tradition for which the author seemed to have particular enthusiasm. ${ }^{44}$ But on the other hand, the term Muzmuti had no relation to biblical genealogies, and was a phonetic rendition of 'Masmuda', referring to the Berber tribes who first supported the Almohad movement. ${ }^{45}$ In this case, the direct influence of the Arabic language on the Christian perspective should be acknowledged.

Interestingly enough, this attention to both a distinction between Muslims from Berber and Andalusi descent, and the phonetico-linguistic precision in identifying them, also made its way into Alfonso VII's diplomatic records, around the same period when the CAI was composed. From the mid-1130s, his chancery developed a habit of

arena que est in litore maris et, habito usuque industrium consilio, congregauit exercitum et transfretando uenit in Sibiliam et cum eo filius eius Texufinus.

41 Ron BARKAI, Cristianos y musulmanes en la España medieval. El Enemigo en el espejo, Madrid 1984, pp. 140-141.

42 CAI (note 36), II 10: Ad facienda prelia contra Muzmutos et regem Asiriorum nomine Abdelnomen, qui expugnabat partes eius sine intermissione.

43 BARTON / FLETCHER (note 36), pp. 208-209, note 25.

44 Maurilio PÉREZ GonZÁLEZ, Influencias clásicas y bíblicas en la 'Chronica Adefonsi Imperatoris', in: ID. (ed.), Actas del I congreso nacional de latín medieval, León 1995, pp. 349-355.

45 BARKAI (note 41), p. 141. 
incorporating into the dating of its records short narrations ${ }^{46}$ showcasing the king's glorious deeds: the reception of a new vassal, for example, or the visits of papal legates, royal marriages, conquests or military expeditions in al-Andalus, and so forth. ${ }^{47}$ From 1146 onward, it is not rare to encounter in these records references to Berber Muslims and/or their leaders. Thus, during the second half of 1146, three diplomas reminded their readers that they were issued "during the year when the Emperor [Alfonso VII] acquired Córdoba and made Abengania, prince of the Moabites, his vassal" ${ }^{48}$ We can recognize here the Almoravid governor of al-Andalus Yahyā ibn Gāniya (d. 1148), who rallied Alfonso VII to face the rebellions weakening al-Andalus at a time when the Almoravid dynasty was threatened in the Maghreb by the rising Almohads. ${ }^{49}$ A few years later, a military campaign launched again against Córdoba recently overrun by the Almohads - provided the opportunity to repeat on sixteen occasions, from August 1150 to August 1151, that the records were written "in the same year when the Emperor fought the Muzmutos over Córdoba and defeated them". 50 'Hagarenes', however, are absent from Alfonso VII's diplomatic collection. And yet, two records from July 1150 testify to the fact that Andalusis were nevertheless recognized as a specific ethno-cultural group, at least in the mind of the scribe who drafted the records. Both alluded in their dating formula to the same campaign, mentioning the Muzmuti / Almohads. But this time, these were not alone: "This charter was made when the Emperor had Córdoba surrounded and fought there against three thousands Muzmutos and many other Indeluciis [Induluciis in the earliest record, HS], and he defeated them." ${ }^{51}$ Whereas the author of the CAI had resorted to a strategy of redefining the biblical terminology to characterize Muslims from Hispania, the scribe responsible for these records chose to build on the possibilities offered by local languages, using a word that was obviously transliterated from Arabic to acknowledge

46 Amaia ARIZALETA, who studied these formulas for the reign of Alfonso VIII of Castile (11581214), called these texts 'diplomatic micro-narrations', see Amaia ARIZALETA, Les Clercs au palais. Chancellerie et écriture du pouvoir royal. Castille, 1157-1230 (Les Livres d'e-Spania), Paris 2010, ch. 3, § 78-99, online: http://e-spanialivres.revues.org/154 (last accessed 15/05/2019).

47 Hélène SiRANTOINE, Imperator Hispaniae. Les Idéologies impériales dans le royaume de León, Madrid 2012, pp. 323-324, 336-337.

48 Anno quo predictus imperator Cordubam acquisiuit et principem moabitarum Abinganiam sibi uassallum fecit. See Bernard F. REILLY, The Kingdom of León-Castilla under King Alfonso VII, 1126-1157, Philadelphia 1998, annotated guide to Alfonso VII's documents, pp. 323-398, docs. 531, 538, and 540. In a fourth record, Abengania is labelled princeps Maurorum (ibid., doc. 532.)

49 Ibid., pp. 92-93.

50 Or similar formulations, see ibid., docs. 670, 679, 681-682, 684, 688-690, 699-703, 705, 707-708.

51 Facta carta quando imperator tenebat Cordubam circumdatam et pugnauit cum XXX milia muzmudis et cum aliis multis indeluciis super eam et deuicit eos. See Hélène SIRANTOINE, Sobre las primeras fuentes de los términos ‘Andaluz' y ‘Andalucía’. Cum Aliis Multis Indeluciis y Alandaluf, unas ocurrencias documentales y cronísticas a mediados del siglo XII, in: Anaquel de Estudios Árabes 15 (2004), pp. 185-190. 
the ethno-political status of the 'Andalusis'. Did he himself incorporate this new term into the Latin nomenclature? Did he read it somewhere? There is no way to answer these questions, but it is worth noting that no earlier or later diplomatic occurrences of the word are known to this day.

All of these examples manifest a certain consistent tendency among some Iberian authors and scribes from the twelfth century. They were willing to conceive of a Muslim community that was not necessarily a uniform whole, but comprised various groups, themselves constituting a diverse range of ethno-political entities. The chronological coincidence raises in its turn a series of questions. The first relates to the reason why this tendency arose in Iberian documentation at this specific time. Various factors might have served as contextual but also technical triggers. On the broad scale of Latin Christendom, this period - coinciding with the opening of the crusades era - was marked by not only a broader interest in the Islamic world, but also a concerted effort to understand its complexity, though one informed by the aim of refuting Islam or repelling the territorial advance of its followers. ${ }^{52}$ Christian Spaniards were no strangers to that movement, and on the local Iberian scale the impact of the successive Berber invasions likely reinforced combative dispositions. But they might also have benefitted from a technical specificity, which was a result of this movement towards better understanding. The Iberian Peninsula was an enclave where many intellectuals gathered to learn from both the Hellenic sciences, which the Arabs had preserved, and the scientific production of the Arab-Muslim world itself. ${ }^{53}$ It was there that translators made this work available to a Latin audience, ${ }^{54}$ and translation methodologies might therefore have impacted on the terminology used to refer to Muslims. ${ }^{55}$ In all, more interaction, whether military or intellectual, generated a clearer view and a willingness to name Muslims accurately.

Another question however remains that of the purpose of these tendencies in the Iberian documentation. If, as we underlined earlier, the monolithic term 'Saracen' could be deployed to enhance the glory of the Christians who faced such a tremendous enemy, was there some benefit in distinguishing Berbers and Andalusis among

52 Richard W. Southern, Western Views of Islam in the Middle Ages, Cambridge 1962, ch. 2: "The Century of Reason and Hope"; Tolan (note 15), chs. 5 and 6.

53 Marie-Thérèse D’Alverny / Charles BurnetT, La Transmission des textes philosophiques et scientifiques au Moyen Âge (Collected Studies Series 463), Aldershot 1994.

54 Charles BuRnETt, The Translating Activity in Medieval Spain, in: Salma K. JAYYUSI / Manuela MARÍN (eds.), The Legacy of Muslim Spain, Leiden 1992, pp. 1036-1058.

55 This possibility was pointed out to me by Charles BURNETT, whom I want to thank warmly. It is well known that Christian Iberian sources named Hispania the territory which in Arabic was called al-Andalus, see José Antonio MaravalL, El concepto de España en la Edad Media, Madrid 1954. However, there is evidence that during the twelfth century this latter designation made its way into the Latin, then vernacular, range of toponyms, see SiRANTOINE (note 51). Work remains to be done to locate the origins of such evolution in the translating activity set in Spain. 
their ranks? The testimony of the CAI is particularly revealing in this respect. In this account of Alfonso VII's reign, an important role is given to a certain "King Zafadola", i. e. Sayf al-Dawla, "of the most illustrious lineage of the kings of the Hagarenes". ${ }^{56}$ Last representative of the Huddid family that once ruled the taifa of Zaragoza, he was dispossessed of his kingdom by the Almoravids in $1110 .{ }^{57}$ The chronicle narrated how Zafadola then became a close collaborator with Alfonso VII against the Almoravids, and in the end the leader of the Hagarene resistance against them. Reporting a dialogue that supposedly took place between the Hagarene / Andalusi leaders and Zafadola, the chronicler wrote:

When the princes, commanders and all the Hagarene people saw that miseries were multiplied [...] they said: 'What can we do, since we shall not be able to withstand war with the emperor and his commanders?' Some of them replied saying: 'The Moabites eat the fat of the land, they take away our possessions and our gold and silver from us, and they oppress our wives and children. Let us fight against them [...] for we have no part in King Tāshufin's palace neither have we inheritance in the sons of 'Alī and of his father Yūsuf.' Others said: 'First of all, let us make a peace agreement with the emperor of León and Toledo, and let us give him royal tribute, just as our fathers gave it to his fathers.' This seemed good in their eyes and they agreed to make ready for war against the men of Marrakesh. [...] Sending messengers, they called upon King Zafadola and all the lineage of the kings of the Hagarenes to come and make war on the Moabites. ${ }^{58}$

This dialogue emphasized an Andalusi nation threatened by the Almoravid foreigners, ${ }^{59}$ and even credits some legitimacy to the Andalusi presence in the Peninsula. But it was also clear that this recognition worked only as long as the Hagarenes submitted to Alfonso VII. Now, the latter was king of Castile-León, but, as can be seen in the excerpts cited here, he also claimed the title of 'Emperor of all Hispania'. He was even crowned emperor in May 1135, during a ceremony that Zafadola himself attended, among many other people, according to the CAI. ${ }^{60}$ The attention dedicated by the author of the CAI to the Western Islamic world and the distinction he maintained

56 CAI (note 36), I 27: Et erat rex ex maximo semine regum Agarenorum.

57 On Zafadola, see Francisco GARCíA FITZ, Relaciones políticas y guerra. La Experiencia castellanoleonesa frente al Islam. Siglos XI-XIII, Seville 2002, pp. 82-98.

58 CAI (note 36), II 93: Videntes ergo principes et duces et omnis populus Agarenorum multiplicata mala [...] dixerunt: 'Quid faciemus, quia non poterimus substinere bellum imperatoris et ducum eius?' Responderunt nonnulli eorum dicentes: 'Moabite medulas terre comedunt et possesiones nostras, aurum et argentum nobis tollunt, uxores nostras et filios nostros opprimunt. Pugnemus ergo contra eos et occidamus eiiciamusque dominium a nobis, quia non est nobis pars in domo regis Texufini neque hereditas in filiis Ali et patris eius Iuzeph'. Alii autem dicebant: 'Faciamus in primis pactum et pacem cum imperatore Legionis et Toleti et demus ei tributa regalia, sicut patres nostri dederunt patribus suis'. Quod bonum uisum est in oculis eorum et ut essent parati in prelio contra Marrochinos. [. . .] Et mittentes uocabant regem Zafadolam et omne semen regum Agarenorum, ut uenirent et bellarent contra Moabitas.

59 See also CAI (note 36), I 27 and 41.

60 See CAI (note 36), I 70, and SiRANTOINE (note 47), ch. 8. 
between various Muslim ethno-political entities were therefore part of the broader narrative of the 'Hispanic empire' in which the Andalusis had a role to play, as long as they accepted client status under the 'imperial' authority. In doing so, the CAI was nevertheless one step ahead of the 'Historia Roderici', that merely identified an Andalusi community through a fragile restriction of the meaning of the term 'Ishmaelites'. The CAI, on the other hand, was incorporating the Andalusis into the Hispanic history and narrative implicitly. The Almoravids and Almohads, both groups that had recently arisen in the Maghreb, were external enemies; but the Andalusi community, settled in Iberia for a long time, shared a sense of Hispanic identity which made it possible for them to belong, with more or less negotiation, in the Iberian imperium that Alfonso VII wished to federate. They had to be subdued, but they were also shown as having a rightful place in the Iberian Peninsula.

The various cases presented in this chapter illustrate how inventive medieval Spaniards could be when it came to the terms used to characterize Islam and its followers. They were able to conceive Islam as a single world, unified by a religious law and populated by Saracens and / or Moors, but also as a polity comprising of many peoples, territories, and ultimately identities. Iberian sources from the twelfth century show that chroniclers and scribes, in parallel with the traditional vision of enmity towards Saracens, aimed also to distinguish categories of peoples among them: the Berber 'Moabites' and 'Muzmuti', the 'Hagarenes', or Indeluci. These distinctions could be and certainly were utilized, and in the CAI they awarded an expedient legitimacy to the Andalusi community that served the chronicler's political agenda. But these examples also challenge the commonly held idea of the Middle Ages as an age of reductive understandings of Muslims, and they undermine the misguided, simplistic idea of a clash of civilizations; such a thesis bears little relevance to conditions in both the past and present.

Zafadola's supposed speech stating his and his Andalusi people's Iberian belonging singularly echoes the distressed replies that some French Muslims feel compelled to reply when they are urged to 'go home': "But this is my home." These words, then and now, show that totalizing perceptions of what it means to be Muslim, past and present, are the result of discourses assumed more or less consciously by societies, and, further, that societies can also choose to refine discourses or adopt alternatives, with sharper distinction and sage discretion, if not assimilation and co-operation, as their guide. 


\title{
The Enduring Power of the Cult of Relics - an Irish Perspective
}

\begin{abstract}
As the cult of saints became increasingly important to the Christian religion during the latter stages of the Roman Empire, so too the veneration of relics became a central element of Christian piety. The urge to physically touch, kiss, or just be in the presence of saintly remains survives to this day. The estimated 250,000 British and Irish visitors to the relics of St Anthony of Padua in 2013, and the millions that attended the tours of St Thérèse's relics to Ireland, in 2001, 2009, and 2012, offers us an insight into the enduring power with which saintly remains have been invested in Ireland. ${ }^{1}$ Indeed, the widespread media coverage of the discovery by Irish police in April 2018 of the heart of St Laurence O'Toole, stolen from Dublin's Christ Church Cathedral six years earlier, indicates an ongoing fascination with the cult of relics. This chapter explores how and why the cult of relics became a key element in the functioning of the Christian church in early medieval Ireland, as elsewhere, and in the Church's interaction with society. Furthermore, it will question whether it was the Church's control of the cult that ensures its longevity or whether the Church simply tapped into an essential part of human existence. Through an examination of the veneration of relics in Ireland, this study will shed light on the lasting appeal of the cult and what implications this has for our perceptions of religion in our modern, secular, global society.
\end{abstract}

Keywords: relics, cult of saints, Catholic Church, popular devotion, St Patrick, early Irish law, hagiography

\section{The Nature of Relics}

Relics are a manifestation of the cult of saints. ${ }^{2}$ They are regarded as extensions of the saint's body and share its sacred quality. Proximity here is key. Saints had grown closer

1 Audrey HeAly / Eugene MCCAFFrey, St Thérèse in Ireland. Official Diary of the Irish Visit, April-July 2001, Dublin 2001, p. 10.

2 For what follows, and the cults of relics and saints in general, see Peter BRown, The Rise and Function of the Holy Man in Late Antiquity, in: Journal of Roman Studies 61 (1971), pp. 80-101; Nicole HERRMANn-MASCARD, Les Reliques des Saints. Formation Coutumière d'un Droit, Paris 1975; Martin HeInZELmann, Translationsberichte und andere Quellen des Reliquienkultes (Typologie des

Niamh Wycherley, NUI Postdoctoral Fellow in Irish/Celtic Studies, Moore Institute for Research in the Humanities and Social Studies, National University of Ireland, University Road, Galway, Ireland, niamh.wycherley@gmail.com 
to Christ through death and this intimacy could be shared with those on earth who nurtured relationships with the saints. The tangibility of relics ensured the appeal of the cult. Through the perceived intervention of the saint they belonged to, relics were used for many purposes, for example, to heal the sick, to effect favourable changes in weather, and to ensure victory in battle. In Late Antiquity relics were used as diplomatic gifts to facilitate the nurturing of relationships and alliances, creating a social as well as geographical network of solidarity, obligation, and reciprocity. The use of relics in church and secular politics became a key feature of the cult of relics throughout the medieval era, as well as into the early modern and modern periods. In the Middle Ages the circulation of relics bridged distances and differences between territories, expedited the creation of military networks, and smoothed relations between princes. ${ }^{3}$ Part of the appeal of relics is their ability to transcend boundaries of time and place. The physical connection and interaction between pilgrim and relic could effectively collapse the temporal and spatial distance to the saint. The thaumaturgic power of relics was only one element in the cult. "Their ability to substitute for public authority, protect and secure the community, determine the relative status of individuals and churches, and provide for the community's economic prosperity", ${ }_{4}^{4}$ ensured a lasting role for relics within the medieval Church and society.

The cult of relics is not just a medieval phenomenon. It is still a force in popular devotion, despite waning support for the church in increasingly secularized and multicultural societies such as Ireland. Space precludes an overview of the various forms of modern relic-related devotion here. Such behaviour persists, however, in most world religions, ${ }^{5}$ and in 'secular' or celebrity cults, ${ }^{6}$ and this suggests that, from an

Sources du Moyen Âge Occidental 33), Turnhout 1979; Peter BRown, The Cult of the Saints. Its Rise and Function in Latin Christianity, Chicago 1981; Patrick J. GEARY, Furta Sacra. Thefts of Relics in the Central Middle Ages, rev. ed. Princeton 1990; Arnold AnGENEndT, Heilige und Reliquien. Die Geschichte ihres Kultes vom frühen Christentum bis zur Gegenwart, 2nd rev. ed. Munich 1997; James HowaRD-Johnston / Paul Antony HaYwaRd (eds.), The Cult of Saints in Late Antiquity and the Middle Ages. Essays on the Contribution of Peter Brown, Oxford 1999.

3 David Rollason, Relic-Cults as an Instrument of Royal Policy c. 900-c. 1050, in: Anglo-Saxon England 15 (1986), pp. 91-103, here pp. 93-96.

4 Patrick J. GeARY, Living with the Dead in the Middle Ages, Ithaca / NY 1994, pp. 205-206.

5 See Caroline Walker Bynum, Christian Materiality. An Essay on Religion in Late Medieval Europe, New York 2011, pp. 273-279; Brannon WHEELER, Mecca and Eden. Ritual, Relics and Territory in Islam, Chicago 2006; Josef W. MeRI, The Cult of Saints Among Muslims and Jews in Medieval Syria (Oxford Oriental Monographs), Oxford 2002; Brian D. RuPPERT, Jewels in the Ashes. Buddha Relics and Power in Early Medieval Japan, London 2000; David OwnBy / Vincent GoOsSAERT / Ji ZHE (eds.), Making Saints in Modern China, Oxford 2017; Robert H. SCHARF, On the Allure of Buddhist Relics, in: Representations 66 (1999), pp. 75-99; John S. STRONG, Relics of the Buddha, Princeton 2004, pp. 2-5; Gregory SCHOPEN, Bones, Stones, and Buddhist Monks. Collected Papers on the Archaeology, Epigraphy, and Texts of Monastic Buddhism in India, Honolulu 1997.

6 For modern and secular cults see Peter Jan MARgry (ed.), Shrines and Pilgrimage in the Modern World. New Itineraries into the Sacred, Amsterdam 2008; James F. HoPGOOD (ed.), The Making of 
anthropological perspective, the tangibility of the cult of relics clearly satisfies some basic human need or desire. It is certainly intelligible in the context of Emile DURKHEIM's theory of all forms of religion as "social cement".

Despite the universality of the appeal of relics, it is only in the last fifty years that the cult of relics has become a distinct subject in studies of the cult of the saint. ${ }^{8}$ In particular, there has been a recent upsurge in interest in the cult of relics stimulated by a plethora of dedicated museum exhibits. ${ }^{9}$ The public and interactive nature of museums provides a valuable point of contact between the academic community and the general populace, and the success of these exhibitions reflects the interest of both groups in the cult of relics. Most notable was "Treasures of Heaven", displayed in 2011 in the Cleveland Museum of Art, the Walters Art Museum, Baltimore, and in the British Museum, London. ${ }^{10}$ These recent major exhibitions of relics and reliquaries have called in to question the meaning of the cult in the modern age. Two key themes have emerged; one on the dichotomy between relics as talismanic objects and as objects of art and a second on whether there is a distinction between the secular and religious in relation to the cult.

These are both important issues. Today, the original religious importance of relics is sometimes thought to be unintelligible to modern sensibilities. The varying accounts and newspaper reviews of the "Treasures of Heaven" exhibit, however, indicate that to some it was a secular experience and to others a religious one. ${ }^{11}$ The

Saints. Contesting Sacred Ground, Tuscaloosa 2005; Sarah M. MISEMER, Secular Saints. Performing Frida Kahlo, Carlos Gardel, Eva Perón, and Selena, Woodbridge 2008; Lyman L. JoHNSON (ed.), Death, Dismemberment, and Memory. Body Politics in Latin America, Albuquerque 2004; Nina Tumarkin, Lenin Lives! The Lenin Cult in Soviet Russia, Cambridge / MA 1997; Steve A. Smith, Bones of Contention. Bolsheviks and the Struggle against Relics 1918-1930, in: Past and Present 204 (2009), pp. 155-194.

7 Emile DurkHEIM, The Elementary Forms of the Religious Life, ed. Joseph W. SwaIN, London 1968, p. 47.

8 In addition to notes above, especially note 2, see Edina Bozóky, La politique des reliques de Constantin à Saint Louis, Paris 2006; Julia M. H. SмIтH, Portable Christianity. Relics in the Medieval West (c. 700-c. 1200), in: Proceedings of the British Academy 181 (2012), pp. 143-167; Robert BARTLETT, Why Can the Dead Do Such Great Things? Saints and Worshippers from the Martyrs to the Reformation, Princeton 2013; Marika RäSÄNEN / Gritje HARTMANN / Earl J. RichARDS (eds.), Relics, Identity, and Memory in Medieval Europe (Europa Sacra 21), Turnhout 2016.

9 For a review see Andrew ButTeRfield, What Remains, in: New Republic, August 18 (2011), pp. 26-31.

10 Martina Bagnoli et al. (eds.), Treasures of Heaven. Saints, Relics, and Devotion in Medieval Europe, Baltimore 2010; James RoBINSON / Lloyd DE BEER / Anna HARNDEN (eds.), Matter of Faith: An Interdisciplinary Study of Relics and Relic Veneration in the Medieval Period (British Museum Research Publication 195), London 2014; Cynthia HaHN / Holger A. KLEIN (eds.), Saints and Sacred Matter. The Cult of Relics in Byzantium and Beyond (Dumbarton Oaks Byzantine Symposia and Colloquia), Washington 2015.

11 For example, contrast Karen ARMSTRONG, Bones, Hairs and Blood, online: https://www.theguar dian.com/commentisfree/2011/jun/30/relics-pilgrims-medieval-cult-martyrs (last accessed 15/05/ 
enduring devotional significance of the items, for some, is proven by the fact that, as a result of repeated kissing and touching, the display cases required extra cleaning. ${ }^{12}$ This underlines a key issue within the cult of relics: there is no inherent value in the actual items regarded as relics. As Patrick GEARY has argued, the worth of relics is a social construct based on a communal acceptance that these remains belonged to an individual intimately connected to a higher power, and that this individual's essence survives in the relics. ${ }^{13}$ Those who argue that a particular relic cannot be authentic and deride those who 'are duped' by a greedy church, fundamentally misunderstand this crucial point about the cult of relics. ${ }^{14}$ It is the people and their faith that imbue these objects with power and potency. There appears to be juxtaposition between the appeal of tangible items like relics - that can provide reassurance and facilitate intercession - and the deliberate use, and sometimes exploitation, of this belief by the authorities. Academic discourse needs to take these two different but linked modes of veneration into account. ${ }^{15}$

Throughout the Middle Ages there was no scholarly consensus or legal codification of types of relics, or on the theological meaning of the cult in itself. Julia SMITH has shown that, even when the cult was at its pre-Reformation height, there was a disjuncture between learned treatises and devotional practices. ${ }^{16}$ Relic theory is still being worked out. Recently, Steven HOOPER has proposed a new tripartite theoretical framework which includes images as an integral component of the cult of relics and discards the previous dichotomy between the religious and the secular. ${ }^{17}$ I agree with HOOPER that "classifying art and celebrity memorabilia as relics", allows us to better understand recent behaviour. ${ }^{18} \mathrm{I}$ am not convinced, however, that the relationship of people to celebrity memorabilia is the same as seeking divine intervention via holy relics. Relics are believed to hold power as a direct link to an

2019), who argues the exhibition can teach us about faith and belief in a modern world, with Waldermar JANUSZCZAK, The Hand of God, online: https://www.thetimes.co.uk/article/the-hand-ofgod-mzmlxg0g2ck (last accessed 15/05/2019), who deemed the exhibition as only of art historical value.

12 Steven Hooper, Bodies, Artefacts and Images. A Cross-Cultural Theory of Relics, in: RoBinson / DE BEER / HARNDEN (note 10), pp. 188-199, here p. 194.

13 GEARY (note 4), p. 201.

14 John Calvin was one of the most famous proponents of this view. For discussion see Alexandra WaLSham, Skeletons in the Cupboard. Relics after the English Reformation, in: Past and Present 206 (supplement 5) (2010), pp. 121-143.

15 Simon YarRow, Miracles, Belief and Christian Materiality: Relic'ing in Twelfth-Century Miracle Narratives, in: Matthew M. MESLEY / Louise E. Wilson (eds.), Contextualizing Miracles in the Christian West, 1100-1500, Oxford 2014, pp. 41-62, provides an instructive example of a sympathetic approach to understanding relic-oriented religion.

16 Julia M. H. Smith, Relics. An Evolving Tradition in Latin Christianity, in: HAHN / KLEIN (note 10), pp. 41-60.

17 Steven Hooper, A Cross-Cultural Theory of Relics, in: World Art 4 (2014), pp. 175-207.

18 HOOPER (note 12), p. 198. 
intercessory saint who can act as representative at the resurrection. Can the same be said for modern celebrity heroes? Alexandra WALSHAM emphasizes, in her analysis of relics in post-Reformation Protestant England, that relics were treasured as keepsakes with spiritual and emotional significance rather than for material and miraculous properties. "The problem was that the potential for slippage between souvenir and sacramental, sign and receptacle of supernatural virtue was high."19

Investigations into efficacy and belief, such as Steven JusTicE's examination of the purpose of incredible miracle stories in Medieval hagiography, presuppose that the Medieval mindset was one fundamentally distinct from our own. ${ }^{20}$ Considering the continued popularity of some medieval relic sites, however, and the creation of new object-focussed cults, whether religious or otherwise, it may not be helpful to regard the cult of relics in the Middle Ages as different from the veneration of relics today. ${ }^{21}$ An examination of the evidence for early Ireland indicates that the cult was anything but monolithic, and developed in response to the needs of particular communities and individuals. ${ }^{22}$

\section{The Irish Case}

The earliest written evidence for relics in Ireland is a statement in Cummian's letter on the paschal controversy, written c. 632. Cummian, possibly a bishop of Clonfert on the Shannon, contends that the relics of the holy martyrs brought back from Rome authenticated the Roman edict regarding the correct dating of Easter, which was of dispute at the time. In case of any doubters, Cummian verified his argument by actually testing the efficacy of the relics, and, of course, they duly produced miracles: "We saw with our own eyes a totally blind girl opening her eyes at these relics, and a paralytic walking and many demons cast out." ${ }^{23}$ This evidence is significant. Not only does Cummian defend at length the superiority of Rome, he also indicates the

19 WaLsham (note 14), p. 136.

20 Stephen JusticE, Did the Middle Ages Believe in Their Miracles? in: Representations 103 (2008), pp. 1-29.

21 See Rubén C. LoIS GonzÁLEz, The Camino de Santiago and its Contemporary Renewal: Pilgrims, Tourists and Territorial Identities, in: Culture and Religion 14 (2013), pp. 8-22; Lisa BITEL, Our Lady of the Rock: Vision and Pilgrimage in the Mojave Desert, Ithaca / NY 2015.

22 For further details and references for all of the following content on the cult of relics in early Ireland, see Niamh WYCHERLEY, The Cult of Relics in Early Medieval Ireland (Studies in the Early Middle Ages 43), Turnhout 2015.

23 Cummian's Letter De Controversia Paschali and the De Ratione Computandi, ed. Maura WALSH / Dáibhí Ó CRÓINín, Toronto 1988, pp. 94-95, 11. 286-288: Uidimus oculis nostris puellam caecam omnino ad has reliquias oculos aperientem, et paraliticum ambulantem, et multa demonia eiecta. 
respect afforded to Roman martyrial relics, a theme which was to continue in Irish documentary sources in the following centuries.

In his 'collection' of stories about Patrick, composed c. 690, Tírechán, reveals the extent to which the cult of relics had taken hold in Ireland by the late seventh century. ${ }^{24}$ His account of the travels of Patrick is a veritable goldmine of evidence for the veneration of bodily remains. His numerous references to the location of the bones of holy men, such as Assicus and Mucneus, suggest that the Irish countryside was beginning to be defined by the cult of relics at this time. ${ }^{25}$ He also makes an important claim that Patrick gave his disciple Sachellus, "a portion of the relics of Peter and Paul, Stephen, and Lawrence, which are in Armagh". ${ }^{26}$ Regardless of how and when the Church of Armagh actually attained these relics, it was clearly using them to strengthen its political position, via Tírechán, in the late seventh century. In another episode, Tírechán recounts how Patrick ordained Olcán and granted him Roman relics in Dunseverick, Co. Antrim. ${ }^{27}$ He was concerned with establishing which churches 'belonged' to Patrick. He creates an image of an Irish countryside interspersed with relics, bestowed by Patrick and his disciples on the churches they founded. This reflects the strategic function of saintly remains in authenticating claims and ascertaining the jurisdiction of churches. In general, relics are an important element in Tírechán's efforts to establish the primacy of Patrick as the founding saint in Ireland.

In the seventh century, Armagh, which claimed to have been established by Patrick in the fifth century, was vying to be recognized as the leading Irish church. Armagh focussed on establishing Patrick as the greatest saint in Ireland and the apostle of the Irish. The biggest threat to Armagh's primacy was from Kildare. The cult of relics, of corporeal remains in particular, played an essential role in this major political dispute in the early Irish Church. In his prologue to his 'Life of Brigit', written c. $675,{ }^{28}$ Cogitosus declared that Kildare was, "the head of almost all the Irish churches with supremacy over all the monasteries of the Irish and its paruchia extends over the whole land of Ireland, reaching from sea to sea". ${ }^{29}$ He supported these claims by exalting the relics of his patrons, Brigit, founder of Kildare, and Conláed,

24 Tírechán, Collectanea, in: The Patrician Texts in the Book of Armagh, ed. and trans. Ludwig BIELER (Scriptores Latini Hiberniae 10), Dublin 1979, pp. 122-167.

25 Ibid., p. 134 (14.6), 140 (22.4), 156-157 (42.7).

26 Ibid., p. 122 (3.5): partem de reliquís Petri et Pauli, Laurentii et Stefani quae sunt in Machi.

27 Ibid., pp. 160-161 (48.3).

28 Thomas M. Charles-Edwards, Early Christian Ireland, Cambridge 2000, p. 438. Despite disagreement among scholars regarding a precise dating, the 'Life' can be confidently ascribed to the second half of the seventh century.

29 Cogitosus, Vita S. Brigitae, ed. Jean BolLAND et al., Acta Sanctorum, 3rd ser., 1 February, Paris 1863, pp. 135-141, here p. 135 (2): caput pene omnium Hibernensium Ecclesiarum, et culmen praecellens omnia monasteria Scottorum, cujus parochial per totam Hibernensem terram diffusa, a mari usque ad mare extensa est. Cogitosus, Life of Saint Brigit, trans. Sean ConNolly / Jean-Michel PICARD, in: Journal of the Royal Society of Antiquaries of Ireland 117 (1987), pp. 5-27, here p. 11 (Preface, 4). 
her bishop. He describes them, "laid on the right and left of the ornate altar and resting in tombs adorned with a refined profusion of gold, silver, gems and precious stones". ${ }^{30}$ The grandeur of the tombs, their prime positions on either side of the altar, and the sumptuousness of the adornments, leave us in no doubt that the veneration of the corporeal remains of Brigit and Conláed was crucial to the church of Kildare. This is explicitly stated by Cogitosus, who marvelled at the large crowds drawn into Kildare by the tombs of its patrons. ${ }^{31}$ The presence of the corporeal remains of the founder drew many pilgrims and much revenue into the church, which was vitally important for the monastery's political position.

Cogitosus's grand description of these ornate tombs clearly embarrassed Armagh, given its lack of any bodily remains for Patrick. However, Armagh did boast other relics. In the mid seventh-century quasi-legal text the 'Liber Angeli' Armagh supported its claims for superiority by emphasizing that it, "ought to be venerated in honour of the relics of the principal martyrs Peter and Paul, Stephen, Lawrence, and the others". ${ }^{32}$ For, although Armagh could not claim the bones of Patrick, it did possess the blood of Jesus Christ in a "sacred linen cloth". ${ }^{33}$ This 'battle for supremacy' appears to have been decided by an Armagh-Kildare pact appended to the 'Liber Angeli' in which Armagh is evidently granted primacy. ${ }^{34}$ Given the statements of Cogitosus, Tírechán and the 'Liber Angeli', it is clear that relics played a key role in the rivalry between the two churches. ${ }^{35}$

Churches promoted the cult of their saints by commissioning hagiography, taking relics on tours or circuits, and of course, by the creation of shrines and reliquaries. Indeed, a key legacy of the cult of relics in medieval Ireland is the material evidence, which has helped define Ireland's landscape and cultural heritage. The pilgrimage sites and routes dotted around the country and the opulent metalwork reliquaries on display in museums have contributed to Ireland's fame as the 'island of saints and scholars'. ${ }^{36}$ The layout of many early Christian monasteries accommodated and enticed pilgrims seeking to venerate the tombs of the saints and to seek miraculous intervention by the saint on their behalf. Dating to perhaps as early as

30 Cogitosus (note 29), p. 141 (37): a dextris et a sinistris altaris decorati, in monumentis posita, ornatis vario cultu auri et argenti et gemmarum pretiosi lapidis [. . . ] requiescunt.

31 Ibid., p. 141 (39).

32 Liber Angeli, in: BIELER (note 24), pp. 184-191, here p. 186 (19): uenerari debet honore summorum martyrum Petri et Pauli, Stefani Laurendi et caeterorum.

33 Ibid., p. 186 (19).

34 Ibid., pp. 190-191 (Appendix XI, 3.32).

35 For further discussion see WYCHERLEY (note 22), esp. pp. 46-53, 69-72.

36 The literature on the archaeology of the cult of relics is extensive. In addition to the following notes, see, for example, Tomás Ó CARRAGÁIN, The Architectural Setting of the Cult of Relics in Early Medieval Ireland, in: Journal of the Royal Society of Antiquaries of Ireland 133 (2003), pp. 130-176; Karen OvERBEY, Sacral Geographies: Saints, Shrines, and Territory in Medieval Ireland (Studies in the Visual Cultures of the Middle Ages 2), Turnhout 2012. 
c. $600 \mathrm{CE}$, slab or 'A' shaped shrines are possibly earliest material evidence for the cult of relics in Ireland. ${ }^{37}$ There is a clear similarity between these shrines and the martyria of the first few centuries of Christianity, and it could be argued that these were an Irish version of the Mediterranean cella memoriae - the cell or enclosure around the accessible tomb with its corporeal relic. ${ }^{38}$ Holes in the slab shrines at Killabuonia, Killoluiag, and Kilpeacan (and the window in the later shrine at Bovevagh, Co. Derry) correspond to the fenestella or cataracta of more monumental continental tombs. ${ }^{39}$ These openings provided access for the faithful to observe the holy relics and intensified the intimate relationship between saint and pilgrim. They also would have facilitated the insertion of items such as pieces of material termed brandea which pilgrims could 'dip' into the sacred space.

Early Christians could supplement veneration at the tombs of the saints during their lifetime by being buried next to the saints after death. The faithful desired to be buried near the saint to ensure proximity to his resurrection on the day of judgement, thus increasing their own chances of a similar fate. This custom of burial $a d$ sanctos increased at such a rate in the early Christian Church that the most desired burial sites were a source of markedly unholy quarrelling. ${ }^{40}$ The Irish evidence also indicates a developing concern about overcrowding because attempts were made to preserve the integrity of cemeteries and holy places. ${ }^{41}$ The division of ecclesiastical sites into inner and outer enclosures became the norm in early Ireland, as revealed by aerial surveys. ${ }^{42}$ Excavations reveal a pattern of an important shrine at the centre and the people buried outwards from this core.

Elizabeth O'BRIEN's analysis of the transition of Irish burial from pagan to Christian practices highlights that burial near the bones of the saint became a substitute for burial near the graves of the ancestors. ${ }^{43}$ Burial ad sanctos reflects the assimilation of native and Christian ideas governing the manner in which bones could legitimate sites. This is corroborated by the eighth-century collection of Irish

37 Charles Thomas, The Early Christian Archaeology of North Britain, London 1971, pp. 143-144.

38 Françoise HENRY, Early Monasteries, Beehive Huts, and Dry-Stone Houses in the Neighbourhood of Caherciveen and Waterville, Co. Kerry, in: Proceedings of the Royal Irish Academy 58 C (1957), pp. 45-166, here p. 155; THOMAS (note 37), pp. 140-141.

39 Nancy EDWARDS, The Archaeology of Early Medieval Ireland, London 1990, p. 131.

40 See Yvette Duval, Auprès des saints corps et âme. L'inhumation 'ad sanctos' dans la chrétienté d'Orient et d'Occident du III $^{\mathrm{e}}$ au VII ${ }^{\mathrm{e}}$ siècle, Paris 1988.

41 Thomas Fanning, Excavation of an Early Christian Cemetery and Settlement at Reask, in: Proceedings of the Royal Irish Academy 81 C (1981), pp. 67-172, here pp. 74-79.

42 Leo Swan, Monastic Proto-towns in Early Medieval Ireland. The Evidence of Aerial Photography, Plan Analysis and Survey, in: Howard B. CLARKE / Anngret SIMMS, The Comparative History of Urban Origins in Non-Roman Europe (BAR International Series 255 [i]), Oxford 1985, pp. 77-102, here p. 99.

43 Elizabeth O’BrIEn, Pagan and Christian Burial in Ireland during the First Millennium AD. Continuity and Change, in: Nancy EdWARDS / Alan LANE (eds.), The Early Church in Wales and the West, Oxford 1992, pp. 130-137, here pp. 134-136. 
church canons, the 'Collectio Canonum Hibernensis', which preserves the importance of ancestral cemeteries: "Man or woman should be buried in their paternal cemetery. For it is said: 'cursed is everyone who is not buried in the grave of his fathers'." 44 The Church effectively promoted the Christian saint as a replacement for the ancestor by fitting his burial into this ready-made cultural matrix.

The custom of burial ad sanctos in early Ireland also reveals important insights into the growing complicity between secular and ecclesiastical elites. Burial in the immediate vicinity of the saint was reserved for the most respected figures in the community - both religious and lay. The poem on the graves of the kings at Clonmacnoise glorifies the interment of important lay Christians, such as kings, within this inner sanctum. ${ }^{45}$ In the 'Life of Munnu' of Taghmon burial in the vicinity of the saint was considered a rare privilege. ${ }^{46}$ In this text the saint grants this honour to the donor of the land and stresses that all buried in the graveyard were assured of heaven. ${ }^{47}$ Indeed, Máire HERBERT's analysis of burial ad sanctos in early Irish hagiography reveals the levels of political interference in the location of saintly burials. She shows that burial privileges were bestowed on secular powers in return for grants to churches. ${ }^{48}$ Theories underpinning the veneration of relics fed into complex issues concerning jurisdiction over land and burial. Eighth-century legal texts such as the 'Collectio Canonum Hibernensis', 'Córus Bésgnai', and 'Ríagail Phátraic' reveal that the church was attempting to legislate and charge for burial at this time.

\section{The Formal Use of Relics}

The devotional activity surrounding the cult of relics led to the increasing employment of relics in the operations and framework of the Church. This is particularly well attested in the fundamental function of relics in church consecration, which

44 Die Irische Kanonensammlung, ed. Helmut WASSERSCHLEBEN, 2nd rev. ed. Leipzig 1885, p. 56 (18.2): Vir sive mulier in suo paterno sepulcro sepeliatur. Dicitur enim: Maledictus omnis homo, qui non sepelitur in sepulcro patrum suorum.

45 R. I. BEST, The Graves of the Kings at Clonmacnoise, in: Ériu 2 (1904), pp. 163-171 (perhaps composed by Conaing Buidhe O'Mulconry in the thirteenth century).

46 Vitae Fintani seu Munnu, in: Vitae Sanctorum Hiberniae, ed. W. W. HeIST, Brussels 1965, pp. 198-209. Possibly dating to before the year 800, according to Richard SHARPE, Medieval Irish Saints' Lives, Oxford 1991, here p. 334.

47 Vitae Fintani seu Munnu (note 46), pp. 203-04 (20-21).

48 Máire HERBERT, Hagiography and Holy Bodies: Observations on Corporeal Relics in Pre-Viking Ireland, in: L’Irlanda e gli Irlandesi nell'alto Medioevo: Spoleto, 16-21 aprile 2009 (Settimane di studio della Fondazione Centro Italiano di Studi sull'Alto Medioevo 57), Spoleto 2010, pp. 239-57, here pp. 249-254. 
was popularized by Ambrose, bishop of Milan, in the late fourth century. ${ }^{49}$ In many cases the relics used were those disseminated from Rome, to bind churches to it and to solidify certain Roman agreements and edicts. Around the turn of the fifth century the letters of Avitus of Vienne testify to the use of Roman relics in the dedication and consecration of churches in Gaul. ${ }^{50}$ By the eighth century relics were essential for the consecration of a church. In 787, the Seventh Ecumenical Council in Nicaea forbade the consecration of a church without a relic, under pain of "being deposed". ${ }^{51}$ The cult of relics, thus, became rooted in the community's Eucharistic worship.

The Irish material indicates that relics were also an essential requirement in the foundation of churches in early Ireland. Evidence to support this can be found in a myriad of sources. The 'Collectio Canonum Hibernensis', for example, provides extensive sanctions to conserve the purity of places consecrated by saints' relics. ${ }^{52}$ Furthermore, the 'Annals of Ulster' record that when Bishop Colmán and his Irish monks left Lindisfarne after their defeat at the Synod of Whitby, they brought with them relics and founded a church on Inishbofin. ${ }^{53}$ The implication is clearly that the relics and the foundation of the church were intimately connected. According to the mid-ninth-century 'Virtutes Fursei', at his departure from Louth in 626 Fursa brought with him to Francia not only relics (pignora) of Patrick, but also those of local patron saints Beoán and Meldán, amongst others. ${ }^{54}$ With these relics Fursa built a church in thirty days, in honour of the twelve apostles. Similarly, the eighthcentury law text 'Bretha Nemed Toísech' states that the qualifications of a good church included both the tomb of a righteous man, presumably the founding saint,

49 See, for example, Saint Ambrose. Letters, trans. Mary M. BeyEnKA (The Fathers of the Church 26), Washington 1954, p. 376 (Epistle 61); Alan THACKER, Loca Sanctorum. The Significance of Place in the Study of the Saints, in: ID. / Richard SHARPE (eds.), Local Saints and Local Churches in the Early Medieval West, Oxford 2002, pp. 1-43, here pp. 5-11.

50 Ian Wood, The Audience of Architecture in Post-Roman Gaul, in: Lawrence A. S. ButLER / Richard K. MORRIS (eds.), The Anglo-Saxon Church. Papers on History, Architecture, and Archaeology in Honour of Dr H. M. Taylor (Council of British Archaeology Research Report 60), London 1986, pp. 74-79.

51 The Canons of the Holy and Ecumenical Seventh Council, in: The Seven Ecumenical Councils of the Undivided Church. Their Canons and Dogmatic Decrees [...], trans. Henry PerCIVAL (A Select Library of Nicene and Post-Nicene Fathers of the Christian Church, 2nd ser. 14), Oxford, New York 1971, pp. 555-570, here p. 560 (Canon 7).

52 Collectio Canonum Hibernensis (note 44), pp. 176-177 (44.6-9).

53 The Annals of Ulster (ad 1131). Part I. Text and Translation, ed. and trans. Seán MAC AIRT / Gearóid MAC NiocaILl, Dublin 1983, sub anno 668: Nauigatio Columbani episcopi cum reliquis sanctorum ad Insolam Uaccae Albae, in qua fundauit aeclesiam.

54 Virtutes Fursei, ed. Bruno KruSCH / Wilhelm Levison, in: Passiones Vitaeque Sanctorum Aevi Merowingici (MGH SRM 4), Hannover 1913, pp. 440-449, here p. 447 (19); Jean-Michel PICARD, Le culte des reliques en Irlande (VII ${ }^{\mathrm{e}}-\mathrm{IX}^{\mathrm{e}}$ siècle), in: Edina BozóKY / Anne-Marie HelVÉTIUS (eds.), Les reliques. Objets, cultes, symbols (Hagiologia 1), Turnhout 1999, pp. 39-55, here p. 49. 
and the relics of saints, which may have been placed inside the church as part of the consecration rite. ${ }^{55}$

Once relics were in place within the church, they became part of the official emblems or insignia, and as such were used to represent that church's position and status. Insignia, meaning symbols or badges of office, became a specific type of relic that represented a particular saint or church. The authority of insignia is preserved by 'Cáin Adamnáin', ${ }^{56}$ which protects "the immunity of the church, her familia, her insignia and her sanctuaries". ${ }^{57}$ Furthermore, the text stresses that the insignia or relics of churches merit particular protection and if they are damaged or violated in any manner, regardless of the location of the insignia at the time, a full fine is incurred. ${ }^{58}$ The 'Liber Angeli' promoted the insignia of Patrick as superior to all others: "Whosoever insults or violates the consecrated insignia of Patrick, shall pay twofold." 59

Relics effectively symbolized the saint and his church. If they were disrespected in any manner this was equivalent to slighting the actual saint, which would require proper retribution. In 809, the 'Annals of Ulster' record "the murder of Dúnchú, superior of the community of Tullylish beside the shrine of Patrick in the abbot's house". ${ }^{60}$ We are informed later in the same year that the repercussion of this act was an attack by Áed son of Niall. ${ }^{61}$ The reaction of the community was in response not just to the killing of Dúnchú but also to the perpetration of this act next to the shrine of Patrick. It was a gross violation to commit such a crime in a sacred space. It showed contempt not only for Patrick but also for his Church of Armagh. As political patron of Armagh it was a matter of honour for Áed to retaliate against such a base crime of disrespect, as it was a clear affront to his authority. This episode is part of the complex political wrangling that characterized Áed's kingship. An earlier incident of disrespect towards Armagh was the assault by the notorious Donnchad of Meath in 789 on the insignia of Armagh (the Staff of Jesus

55 The First Third of Bretha Nemed Toísech, ed. Liam BREATNACH, in: Ériu 40 (1989), pp. 1-40, here pp. 8-9, 11 (3): Cair: cis n-é dagfolad sóertho ecalso? Ní hansae: martarlaic fíréoin, reilgi nóeb, scriptuir déodae, airchinnech etail.

56 The written text survives probably in ninth-century form and seeks to explain the law of Adomnán (Lex Innocentium) promulgated at the Synod of Birr in c. 697.

57 Cáin Adamnáin. An Old-Irish Treatise on the Law of Adamnan, ed. Kuno MEYER, Oxford 1905, p. 24 (34): sóire ecalsi Dé cona muintir 7 a fethlaib > a termnaib. The Law of Adomnán: A Translation, trans. Máirín Ní DHonNCHAdHA, in: Thomas O’LoUghlin (ed.), Adomnán at Birr, AD 697. Essays in commemoration of the Law of the Innocents, Dublin 2001, pp. 53-68, here p. 62.

58 Cáin Adamnáin (note 57), p. 26 (36): Is óghdíri nach eclais fria sárughud a fethtaltae, cip port $i$ ndéntur.

59 Liber Angeli (note 32), pp. 188-189 (26): Item quicumque contempserit aut uiolauerit insignia consecrata eiusdem agii, id est Patricii, duplicia soluet.

60 Annals of Ulster (note 53), sub anno 809: Occisio Dunchon principis Telcha Leiss hi fail scrine Patraicc i tigh abad Telcha Liss.

61 Ibid., sub anno 809. 
and relics of Patrick) at a gathering. ${ }^{62}$ Like Áed, Donnchad was very astute at harnessing the power of relics and appreciating their various uses. These are just a couple of examples of the profanation of relics, and they provide an interesting insight into the alliances and maintenance of power within the Irish Church and society.

The political use of relics is well attested in the cult of relics in the church as a whole and became increasingly integral to the interactions between the Irish church and secular elites from the eighth and ninth centuries onwards. Relics would be present at the making of agreements and swearing of oaths and they were taken on tour to promote the cult of a particular saint, to seek intercession, and to exact tribute for his church. For example, the 'Annals of Ulster' states sub anno 734 that "the relics of Peter, Paul, and Patrick were taken on tour to execute the law". ${ }^{63}$ Relic circuits provided an opportunity for the collection of revenue. The extent to which this was the primary objective of these circuits has been a matter of debate. ${ }^{64}$ The timing of some relic circuits coincided with famines or the outbreak of disease and there may have been genuine concern for the well-being of the population at a time of undoubted difficulty and hardship.

Nevertheless, revenue collection was certainly an important facet of these tours. The early Irish law texts 'Cóic Conara Fugill' and 'Berrad Airechta' both make reference to the "earnings of a reliquary" (tuillem menistrech) ${ }^{65}$ Another legal text, 'The Heptads' includes the "earnings of reliquaries" (tuillem meinistri), ${ }^{66}$ among its list of the rights that cannot be recovered by distraint. ${ }^{67}$ The phrase is glossed as "i. e. pay for protection by the relic, i. e. which is earned by the relics that are carried about, i. e. of tithes and first fruits and alms". ${ }^{68}$ The circuit of relics combines two of the key elements intrinsic to the success of the cult of relics: faith and authority. For the relics of a particular saint to contain any real power and longevity lay Christians needed to believe in their

62 Ibid., sub anno 789.

63 Ibid.: Commotatio martirum Petir 7 Phoil 7 Phatraicc ad legem perficiendam. For a discussion of relic circuits and the use of relics for oath taking see WyCHERLEY (note 22), chs. 5, 6.

64 See, for example, Felim Ó BRIAIN, Hagiography of Leinster, in: John RYAN (ed.), Féilsgríbhinn Eóin Mhic Néill, Dublin 1940, pp. 454-464, here p. 457; Kathleen Hughes, The Church in Early Irish Society, London 1966, pp. 168-169; Colmán ETCHINGHAM, Church Organisation in Ireland AD 6501000, Maynooth 1999, ch. 5.3.

65 Cóic Conara Fugill, ed. and trans. Rudolf ThURNEYSEN, Berlin 1926, pp. 21, 55 (16, 127); Corpus Iuris Hibernici, ed. Daniel A. BinchY, 6 vols., Dublin 1978, vol. 2, p. 591, 1l. 9-13; Berrad Airechta. An Old Irish Tract on Suretyship, ed. Robin Chapman STACEY, in: Thomas M. CHARLES-EDWARdS / Morfydd E. OwEN / Dafydd B. WALTERS (eds.), Lawyers and Laymen: Studies in the History of Law Presented to Professor Dafydd Jenkins on his Seventy-Fifth Birthday, Cardiff 1986, pp. 210-233, here p. 210.

66 Corpus Iuris Hibernici (note 65), vol. 1, p. 40, 1. 10.

67 Ibid., vol. 1, p. 39, 1. 30.

68 Ibid., vol. 1, p. 40, 1l. 13-14: i. log ar comairce don minn i. imtuillit na minna biit for aister i. do .x. maduib primittib $_{7}$ almsanaib. 
intercessory power. The relics also needed to be an effective resource for the church and secular elite to be adequately promoted.

The multiplicity, and various use, of terms for relics in early Ireland indicates that the cult of relics was complex and that there was no exclusive approach or definitive theory. At the very least, it is clear that Medieval Irish writers were continually interrogating the specificities of relics. ${ }^{69}$ Despite this multiplicity, a close analysis of the uses of these terms often fails to reveal distinct meanings. It is difficult to disentangle, for example, terms such as creatura, cretair, benedictio, meinistir, and chrismale, all of which relate to the liturgical use of relics in Medieval Ireland. This difficulty in defining terms for relics is echoed in studies of the material manifestation of the cult, which suggest that medieval reliquaries created a distance between relic and pilgrim, rather than facilitating an intimate connection. ${ }^{70}$ Access to relics was strictly regulated by the Church, which used these precious objects to consolidate its authority. ${ }^{71} \mathrm{~A}$ similar obfuscation of relics is revealed by Christopher JONES's analysis of Old English terms for relics. He claims that terms such as reliquias and haligdom "occlude and elide, collectivize and largely depersonalize the "holies' that they contain". ${ }^{72}$ While the sheer variety of terms used for relics in Medieval Irish texts would suggest an attempt at illumination, a detailed analysis of the terms for relics in Medieval Ireland may reveal similar results to those put forward by JonES for Anglo-Saxon England.

\section{Conclusions - Modern Relevance of The Cult of Relics?}

From this very general and brief examination of the cult of relics in early medieval Ireland, we can observe a few important themes emerging. We can see that relics were more than just holy items to be revered by the faithful, they were administrative tools used in the day-to-day running of the Church. The evolution of relics into insignia and official emblems became a useful tool at the Church's disposal in its interaction with lay society. The sources also convey a clear sense of the political use of

69 There are over thirty terms relating to the cult of relics in Medieval Irish sources, in HibernoLatin (for example, reliquiae, insignia, benedictio, martyr, creatura, scrinium, eulogia, capsella, basilica), native vernacular Irish (for example, mind, taise, cretair, fethal, fert, cumtach) and Irish Latin loan-words (for example, reilic, bennacht, martirum, lecht, meinistir, scrín, ruam).

70 Cynthia HAHN, Metaphor and Meaning in Early Medieval Reliquaries, in: Giselle DE NIE /Karl F. MORRISON / Marco Mostert (eds.), Seeing the Invisible in Late Antiquity and the Early Middle Ages (Utrecht Studies in Medieval Literacy 14), Turnhout 2005, pp. 239-263.

71 Robyn Malo, The Pardoner's Relics (and Why They Matter the Most), in: Chaucer Review 43 (2008), pp. 82-102.

72 Christopher A. JonES, Old English Words for Relics of the Saints, in: Florilegium 26 (2009), pp. 85-129, here p. 90. 
relics to attain and maintain influence by clerical and secular elites and an understanding by these elites that relics were vehicles with which to 'control' the faithful in general. An important element here is that relics were symbols of authority and power. We must not, however, adopt an overly cynical view of the role of relics in early medieval Ireland, or indeed, in general. The enduring power of the cult, despite recent criticism of the hierarchy, power, and control of the Catholic Church, reflects the inherent appeal of relics to the lay community. Part of the success of the cult of relics in early Ireland was the fact that many aspects of the cult fitted well into preexisting beliefs concerning the active role of the ancestor and his or her remains in society.

It is difficult to ascertain the exact details of the progression of relics from being objects of popular devotion to becoming political tools of the power brokers in medieval society. Indeed, given the discussion above, it would seem that a more useful approach is to view these two elements as simultaneous and inextricably linked. While many individuals do not engage in the veneration of relics, the cult is a fairly consistent feature of religion across varying time periods, faiths and geographical locations. An examination of the medieval cult of relics indicates that the Church facilitated and accommodated an existing need. The Church harnessed, rather than created, the cults of saints and relics. While some cults were 'invented' by ambitious church leaders, such as Ambrose of Milan, others evolved at a local level out of the commemoration of a respected religious community leader or an inspiring devout individual. But the relative 'success' or fame of a cult is often as a result of effective promotion by elites.

It is clear that the role of the saint as patron and mediator is at the very core of the appeal of the cult. The case of the heart of Laurence O'Toole provides an instructive example. In an era of declining church attendance, why did the return of this stolen relic attract so much media attention ${ }^{73}$ Given the discussion above, the answer could have its roots in the historical significance of Laurence O'Toole as defender of Dublin's interests in the twelfth century, one of the most difficult periods in the city's history. Assistant Garda Commissioner Pat Leahy spoke of his pleasure at returning the relic to its "rightful place among the people of Dublin". ${ }^{74}$ The heart of Laurence O'Toole, therefore, represents the heart of Dublin itself, and the crime was perpetuated against the community as a whole. Indeed, Christ Church Cathedral, as a monument, represents Dublin, and is one the city's most famous landmarks and tourist attractions.

73 There are other such cases, such as the theft and retrieval of St Manchán's shrine in Boher, Co. Offaly, in 2012.

74 Ken Foy, 'Deadly Curse' Forces Thieves to Return Relic, in: Irish Independent Newspaper, April 27th, 2018. 
In an increasingly secularized age, some argue that celebrities have replaced medieval saints as patrons. ${ }^{75}$ Modern technology facilitates the fostering of perceived relationships with celebrities and social media provides a forum in which fans can communicate directly with the subjects of their devotion. The recent live broadcast of the royal wedding of Prince Harry and Meghan Markle on May 19th, 2018, promoted a virtual familiarity between the royal couple and the general public. A countless number of viewers dressed up as wedding guests for the event or hosted wedding viewing parties, replete with formal invitations and wedding cake. This indicates a desire by these viewers to be an active part of the intimate ceremony. Hours after the wedding some official guests auctioned their gift bags online. ${ }^{76}$ This sort of intimacy can be attained on a permanent basis at the Hollywood Forever cemetery in Los Angeles, where burial plots are priced according to proximity to celebrity graves - a modern secular version of burial ad sanctos. ${ }^{77}$

Perhaps the most important lesson to be learned from an examination of the medieval evidence, in particular in relation to early Ireland, is that there is dialectic at play between the veneration of relics as a popular act and one fashioned by elites. This dialectic transfers to the modern day, with the substitution of commercial considerations for those of the medieval abbot and aristocracy. Jan GEISBUSCH has shown how in recent years Catholic relics have been alienated from traditional institutional settings and traded through the internet, especially via auction sites like eBay, which appears as an arena on constructing and contesting religious significance through sacred objects. ${ }^{78}$ Pilgrimage to holy sites must be supported by an institutional framework and infrastructure, which is inevitably created and maintained by governments and organisations that profit from the phenomenon. For example, one can only visit the grave of Elvis because his family at Graceland, supported by the local authority and community, motivated by varying degrees of commercialism, have accommodated visitors. Again, this is not to underplay the devotional significance of these items and sites to certain individuals or to exaggerate the mercenary aspects of the cult. In order to fully appreciate the relevance of the cult of relics today, we must acknowledge that popular devotion and commercial or institutional promotion are two sides of the one coin. If we frame our analysis of the veneration of relics within a singular model, in which the 'official' and 'popular' are co-dependant, we can better understand the enduring appeal of the cult.

75 See Fred INGLIS, A Short History of Celebrity, New Jersey 2010; see also note 6 above.

76 See also Cara BARRETT, In-Depth: The Sale of Paul Newman's Rolex Daytona. The Most Expensive Wristwatch Ever, online: https://www.hodinkee.com/articles/paul-newman-rolexdaytona-auction-most-expensive-watch-ever (last accessed 15/05/2019).

77 Chris Rojek, Celebrity, London 2001, p. 60.

78 Jan Geisbusch, For Your Eyes Only? The Magic Touch of Relics, in: Sandra H. Dudley (ed.), Museum Objects: Experiencing the Properties of Things (Leicester Readers in Museum Studies), London, New York 2012, pp. 202-213. 



\title{
Ben Jervis \\ Resilience and Society in Medieval \\ Southampton: An Archaeological Approach to Anticipatory Action, Politics, and Economy
}

\begin{abstract}
Resilience is a key theme in contemporary urban studies, with researchers seeking to understand what it is that makes some urban communities better equipped to cope with trauma than others. However, this scholarship rarely draws on historical examples to understand how resilience might emerge over the long term. This chapter introduces key concepts relating to resilience and the ways in which communities are able to anticipate trauma and applies these ideas to understanding the resilience of the community of medieval Southampton. Southampton faced a number of traumatic events in the fourteenth and fifteenth centuries, not least the Black Death and a French raid in 1338. Evidence from archaeological excavations in the city is drawn upon to consider the different ways that members of Southampton's community were able to protect their interests, build resilience and anticipate trauma, and the implications of their actions for urban development. The chapter demonstrates how the idea of resilience can be used to provide deeper insights into the political structure of medieval towns, and also assesses how archaeological evidence might be used to further develop and test concepts which are more typically used in understanding the modern city.
\end{abstract}

Keywords: resilience, anticipation, community, urban, port, medieval, Southampton

Resilience is an important concept across the humanities and social sciences, although its meaning is contested. Developing from origins in the natural sciences, in basic terms resilience is the ability of a system to 'bounce back' from some form of trauma (either caused within the system or from the intervention of some externality), either to its previous state or through adaptation. ${ }^{1}$ The importance of adaptation has been repeatedly stressed, as it is the means through which systems build the capacity to resist similar traumas in the future. ${ }^{2}$ As the concept of resilience has

1 Neil ADGER, Social and Ecological Resilience: Are They Related?, in: Progress in Human Geography 24 (3) (2000), pp. 347-364, here p. 349; Fran NoRRIs / Susan SteVEns / Betty PFEFFERBAUM / Karen WyCHE / Rose Pfefferbaum, Community Resilience as a Metaphor, Theory, Set of Capacities and Strategy for Disaster Readiness, in: American Journal of Community Psychology 41 (2008), pp. 127-150.

2 Kevin Fox Gotham / Richard Campanella, Towards a Research Agenda on Transformative Resilience. Challenges and Opportunities for Post-Trauma Urban Ecosystems, in: Critical Planning, Summer 2010 (2010), pp. 8-23, here p. 12.

Ben Jervis, School of History, Archaeology \& Religion, Cardiff University, John Percival Building, Colum Drive, Cardiff, UK, CF10 3EU, jervisb@cardiff.ac.uk

Ә Open Access. (C) 2020 Ben Jervis, published by De Gruyter. (c) BY-NC-ND This work is licensed under a Creative Commons Attribution-NonCommercial-NoDerivatives 4.0 International License. 
received increasing use in the social sciences, it has been continuously re-defined and re-imagined. As will be discussed below, many approaches seek to develop generalising models and rules for understanding societal resilience, whilst others, such as the geographer Ben Anderson, ${ }^{3}$ see resilience building as a contextual and complex set of processes. The use of an historical case study, where we can trace socio-economic processes and assess their implications, allows a contribution to be made to this debate, by reflecting upon the extent to which general rules appear applicable and exploring theoretical frameworks which might prove useful for understanding resilience today.

In this chapter I draw on contemporary political discourse to explore the relationship between ideas of adaptability and resilience, arguing that these are different but related concepts which emerge through the performance of social relations. ${ }^{4}$ This relationship between social structure, adaptability and resilience is examined through the consideration of the medieval town of Southampton (Figure 1), which, in the fourteenth and fifteenth centuries, suffered from a range of traumatic and disruptive events, including a raid by the French, the disruption of supply lines due to warfare and sheep murrain and the Black Death. My approach is grounded in 'assemblage theory', a means of approaching the past which stresses the historical contingency of social relations and their unpredictable unfolding. Importantly, it is an approach in which we can define the town not as a fixed spatial entity but as a socio-spatial process, of a community of people, things, materials and ideas in flux, which is both affective upon and effected by external processes. ${ }^{5}$

\section{Modelling Resilience: General Rules}

The notion that resilience exists as a set of general rules can be seen as a product of the concept's origins in the natural sciences, where it was used to explore the ways in which ecological systems are able to recover from external trauma. From a socioeconomic perspective, this approach is best exemplified in studies of economic resilience, which seek to develop an understanding of which factors allow an economic system to exhibit resilience, to recover quickly from trauma.

A link between social organisation and adaptability is demonstrated in research within contemporary society. SIMMIE and MARTIN argue that regions pass through an economic cycle of specialisation and, as the economy becomes more specialized, resilience decreases as there is less adaptive capacity; as regions become more

3 Ben Anderson, What Kind of Thing is Resilience?, in: Politics 35(1) (2015), pp. 60-66.

4 Chris ZeBrowsKI, The Nature of Resilience, in: Resilience 1(3) (2013), pp. 159-173, here p. 170.

5 See also Ben JERVIS, Assemblage Urbanism. Becoming Urban in Late Medieval Southampton, in: Archaeological Dialogues 25(2) (2018), pp. 135-160. 


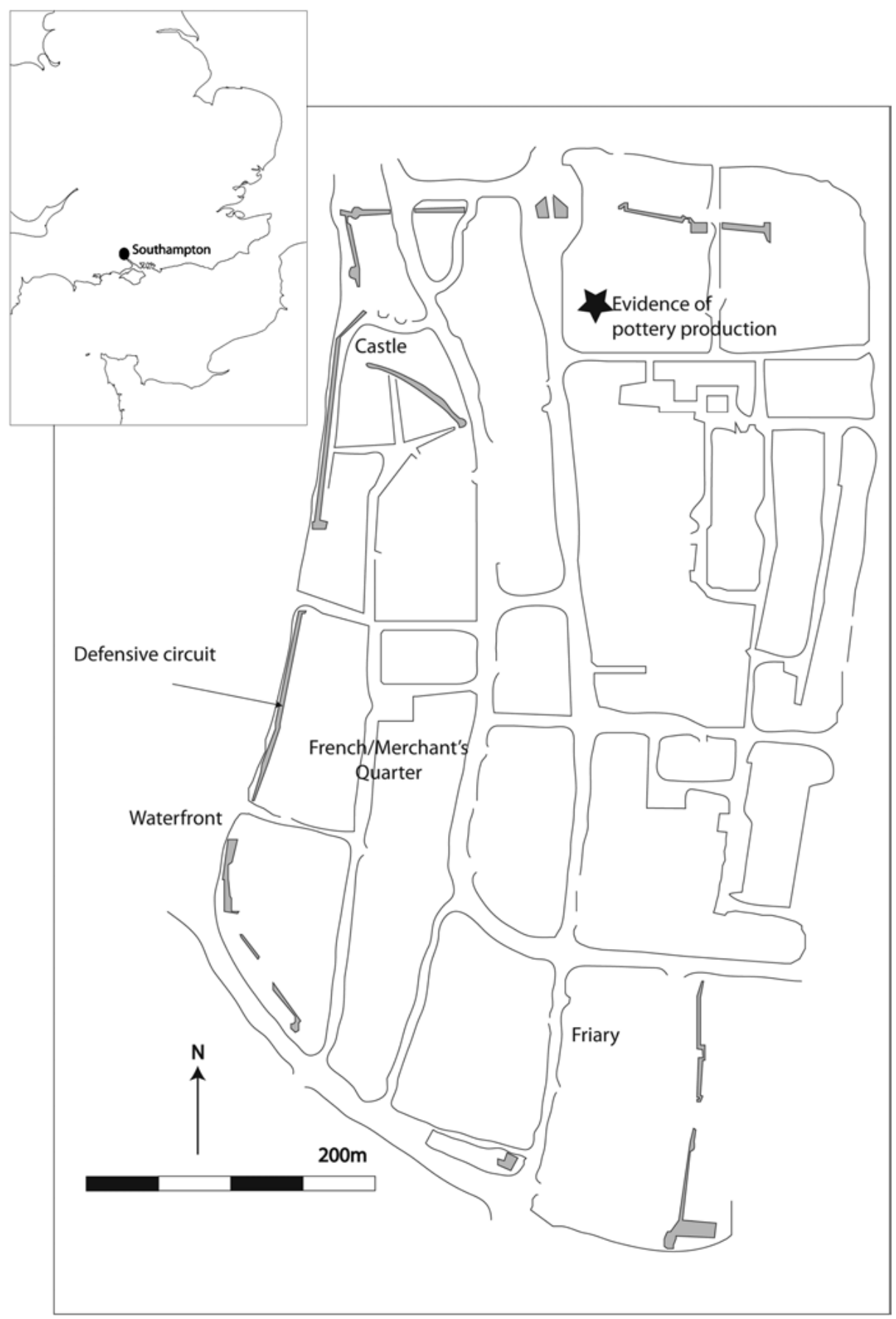

Figure 1: Map of medieval Southampton, showing key locations mentioned in the text. Image: Ben Jervis. 
homogenized in their economic base, they become less resilient. ${ }^{6}$ Generally, more economically, ecologically, or socially diverse systems are considered resilient, as they are more flexible in their ability to adapt to change; however whilst diversity can build resilience through widening access to resources and spreading risk, it might also create conflict and weaken social ties. ${ }^{7}$ Considering the resilience of cities, CHELLERI sees resilience as emerging at the intersection of economic, political, social and environmental networks, proposing that changes in one of these subsystems may have implications for the whole, which can be countered through adaptation. ${ }^{8}$ Thinking about adaptability and resilience therefore requires us to think about towns and cities as networks, with the key to resilience lying in the ability to maintain connections, which might be achieved through diversification of environments or economies, decentralising social and political systems to spread risk, allowing it to return to its basic state whilst at the same time responding to change. ${ }^{9}$

Within this chapter archaeological evidence is used to explore the question of resilience. Similar models based upon systems approaches have long been utilized within archaeology, particularly to explore questions of societal collapse, allowing archaeologists to model general societal pre-conditions for success or failure (although such approaches have not been prevalent within British medieval archaeology), demonstrating the potential for exploring resilience through archaeological data. ${ }^{10} \mathrm{~A}$ similar approach, based on empirical comparison of multiple societies has been developed by CURTIS in an important study of pre-industrial agricultural societies. ${ }^{11}$ Through empirical study he identifies a relationship between the organisation of resources and political strategies and the ability of a community to adapt to crisis. He hypothesizes that communities which are egalitarian are likely to be less vulnerable than those with a more polarized power structure. This resilience may be achieved through adopting

6 James SimmiE / Ron MARTIN, The Economic Resilience of Regions. Towards an Evolutionary Approach, in: Cambridge Journal of Regions, Economy and Society 3 (2010), pp. 27-43; Laura EsTÉVEZMAURIZ / Jimeno FonSECA / Claudiu ForGaCI / Nils BJÖRLInG, The Liveability of Spaces. Performance and/or Resilience? Reflections on the Effects of Spatial Heterogeneity in Transport and Energy Systems and the Implications of Urban Environmental Quality, in: International Journal of Sustainable Built Environment 6(1) (2017), pp. 1-8, online (DOI): http://dx.doi.org/10.1016/j.ijsbe.2016.10.001 (last accessed 15/05/2019).

7 Fox Gotham / Campanella (note 2), p. 14

8 Lorenzo CHELleri, From the "Resilient City" to Urban Resilience. A Review Essay on Understanding and Integrating the Resilience Perspective for Urban Systems, in: Documents d'Anàlisi Geogràfica 58(1) (2012), pp. 287-306.

9 ADGER (note 1).

10 See Patricia McAnANy / Norman YoffEE (eds.), Questioning Collapse. Human Resilience, Ecological Vulnerability, and the Aftermath of Empire, Cambridge 2009; Ronald K. FAULSEIT (ed.), Beyond Collapse. Archaeological Perspectives on Resilience, Revitalisation, and Transformation in Complex Societies, Carbondale 2015, for recent studies and reviews.

11 Daniel CuRTIS, Coping with Crisis. The Resilience and Vulnerability of Pre-Industrial Settlements, Farnham 2014. 
risk-avoidance strategies or repetition of adopting flexible regimes, to adapt to new challenges. In contrast, the coercive or short-termist approaches taken in societies where elites seek to exploit the land for profit is likely to result in vulnerability.

Models of resilience have developed over time with, in particular, a realisation that the ability to adapt is critical, so as not to make a society repeatedly vulnerable to the same trauma; an observation made particularly acutely in studies undertaken in the aftermath of Hurricane Katrina. Such realisations have led to resilience studies developing in new directions, focussing on the adaptive capacity of societies, with particular attention being paid to specific contextual factors rather than general explanatory models. It is within this discourse that the current contribution can be most comfortably situated. It is my contention that any similarities between medieval and modern societies must be proven rather than assumed and, therefore, that the application of general models developed for contemporary society may mask real similarities and differences between the structures of medieval and modern society. Furthermore, their application to medieval evidence may also provide a means to test to the universal applicability of such models, which, in turn, may impact the contexts in which they can be applied today. Whilst much contemporary political discourse around this subject is linked to the way in which a dogma of resilience has developed as a means of protecting the neo-liberal social order of the twentieth and twenty-first centuries, ${ }^{12}$ the basic premise that communities take steps to protect what they believe to be important to their social well-being, and that their paths may be hindered by other interest groups, is one which might be tested through historical or archaeological data, to reveal a range of behaviours which might help us better understand the nature of resilient and sustainable societies. $^{13}$

\subsection{From Systematic Resilience to Adaptation and Anticipation}

In a recent summary of the study of resilience in modern political discourse, ANDERSON has argued that the term is utilized in a variety of different ways, as dogma, power dynamic or policy, for example, with its use intended to have different consequences and arising from different historical processes. ${ }^{14}$ He proposes that rather than homogenising resilience through the development of generalising models, we must embrace this diversity, to understand what kind of a thing

12 Brad Evans / Julian ReID, Dangerously Exposed. The Life and Death of the Resilient Subject, in: Resilience 1(2) (2013), pp. 83-98; Kristina DIPROSE, Resilience is Futile, in: Soundings 58 (2015), pp. 44-56.

13 NoRRIs et al. (note 1), p. 139.

14 ANDERSON (note 3). 
resilience might be in different circumstances, in other words that it is contextually variable. In basic terms resilience is a form of anticipatory action. Whereas adaptability is the capacity of a place to change, resilience implies the use of some strategy to respond to a perceived vulnerability. By exploring these strategies, we can, therefore, seek to understand what was deemed vulnerable and requiring protection by different groups within a society, and the ability that they had to effect some change.

Following ANDERSON a range of different forms of anticipatory action can be taken. ${ }^{15}$ Trauma might be pre-empted, with measures being taken to stop it from ever happening, precautions might be taken to prevent it or limit its effects or communities may accept that an anticipated shock might occur and be prepared for it. If we acknowledge the importance of anticipatory action, we implicitly accept that the futures which unfold are historically contingent, and that certain futures might be formed or prevented through action in different places or times. It may seem obvious that the future emerges from the past, but the critical point is that futures cannot be entirely planned; they emerge in unpredictable ways, which are shaped, in various ways, by patterns of behaviour and natural processes. Resilience therefore becomes a specific utilisation of knowledge; that something is vulnerable and that steps can be taken to make it less so. Threats are emergent; they may arise from social or natural processes, they may have certain implications because of their intersection with other processes. An earthquake is only a threat if these geological processes intersect with the socio-economic processes of everyday life, for example. Resilience therefore implies the identification of something as having value and of a community as having some power to take measures to protect it. ${ }^{16}$

Resilience might be specifically linked to the concept of preparedness, it implies a recognition that something is vulnerable and cannot be entirely protected; rather than prevention it becomes a way of resisting the world, of resisting a possible future. If we perceive of a world unfolding from social relations it might be perceived as a series of potentially dangerous events, which must be anticipated if the social order is to be protected. ${ }^{17} \mathrm{~A}$ difference can, therefore, be identified between the capacity to adapt, which relates to the ways in which a system is structured, and resilience, a socially constructed response to a perceived vulnerability. ${ }^{18} \mathrm{My}$ aim here is to move away from an essentialist position which sees a system as resilient, to explore how vulnerability and resilience emerge from social relations and

15 ID., Preemption, Precaution, Preparedness. Anticipatory Action and Future Geographies, in: Progress in Human Geography 34(6) (2010), pp. 777-798.

16 Ibid., p. 782.

17 Evans / ReID (note 12), p. 83.

18 Gabriella Christmann / Oliver IBERT, Vulnerability and Resilience in Socio-Spatial Perspective. A Social-Scientific Approach, in: Raumforschung und Raumordnung 70(4) (2012), pp. 259-272, here p. 261. 
are processes which might be performed at different scales, with varying and potentially conflicting implications. As SoENS states, "societal resilience and vulnerability of people are clearly two different things"19; whilst infrastructure and institutions may survive this does not mean that communities are not affected by trauma in a variety of ways, which, in some cases, may be due to the restrictions on adaptability caused by those same institutions. Whereas adaptability arises from the nature of the relations which form a social system, resilience emerges from the manipulation of these relations, by moving or distancing elements of it or by taking measures to transform relations. ${ }^{20}$ Therefore, adaptability is imminent within social relations, but resilience is necessarily prior to these relations, as a form of pre-emptive historical action which surfaces in certain performances of the present. ${ }^{21}$ Critically, it is a resistance to the natural adaptability of systems, which might emerge in such a way that it over-writes the existing system; as such resilience is a strategy taken to counter a double threat - of destruction by shock and destruction by unmanaged and unpredictable adaptation. In what follows, I suggest that the archaeological and historical evidence from the Middle Ages offers an opportunity to examine the long-term consequences of anticipatory behaviour, in a way that studies of this behaviour in contemporary societies cannot. Therefore, the aim of this analysis is not to simply test general rules and models but, rather, to reveal the implications of anticipatory behaviour which might allow us to better understand the unintended consequences of resilience building today.

\section{Adaptability, Social Structure and the Middle Ages: An Assemblage Approach}

By focussing on a historical case study, it is possible to use the archaeological context as a laboratory for exploring the implications of these ideas, and of analytical approaches which might help us to better understand the relational character of adaptability and resilience. By understanding a wide variety of ways in which resilience emerges, we become better able to develop strategies to deal with trauma and understand the implications of this behaviour over a period of a century or more, something which is unachievable through a focus on modern situations where decision making processes are ongoing and it is only possible to think about their implications in a hypothetical sense.

19 Tim Soens, Resilient Societies, Vulnerable People: Coping with North Sea Floods Before 1800, in: Past \& Present 241(1) (2018), pp. 143-177, here p. 175.

20 Ibid., p. 167; ESTEVEZ-MAURIZ et al. (note 6), p. 6.

21 Kevin Grove, Agency, Affect, and the Immunological Politics of Disaster Resilience, in: Environment and Planning D: Society and Space 32(2) (2014), pp. 240-256, here p. 245. 
The case study presented here is that of fourteenth- and fifteenth-century Southampton, a major medieval port town in southern England. From an economic perspective, Southampton was remarkably homogeneous. Although there was small scale craft manufacture, with archaeological evidence for iron working and pottery manufacture for example, the economy was principally focussed on trade and servicing merchants. ${ }^{22}$ In the thirteenth century this trade was, itself, particularly homogenous, with wool from Southampton's wider region being the principal export, and wine from Gascony being the principal import. ${ }^{23}$ Generalising models of resilience would, therefore, suggest that Southampton was likely to be highly vulnerable to the political and ecological crises of the fourteenth century, which cut off access to Gascony and impacted the wool yield. ${ }^{24}$

Historical data reveal, however, that Southampton did not fail, but was able to adapt and recover. Although trade was depressed through the middle and later parts of the fourteenth century, Southampton was able to restore its position as an important port in the fifteenth century, largely due to its importance as a landing place for Italian merchants, who exported wool initially to Flanders and later to the Mediterranean, and as a point of entry for exotic goods from eastern trade routes. ${ }^{25}$ The terrier, a survey of property in the town dated to 1454 , but detailing the occupation and ownership of plots over several decades, reveals only a small number of vacant plots despite the devastation of the French raid of 1338, which is reflected in the archaeological record in the form of deposits of burnt demolition debris, and the Black Death in the later fourteenth century. ${ }^{26}$ The population of Southampton likely dropped after the Black Death, although exact figures are not available, limiting the demand for housing, whilst works to the town wall made certain areas which had once been occupied as merchant dwelling less attractive, with them becoming open gardens (potentially widening the biodiversity of the town and increasing food security). ${ }^{27}$ Archaeological evidence demonstrates quick rebuilding in timber rather than stone, including the development of new plots, potentially as speculative rental properties. ${ }^{28}$ Historically, Southampton's burgesses had a high degree of political autonomy, formalized in a charter of 1199. It is clear from their

22 Colin PlatT, Medieval Southampton: The Port and Trading Community, London 1973, pp. 45-46; Duncan BRown, Pottery in Medieval Southampton, c. 1066-1540, York 2002, pp. 128-129.

23 Platt (note 22), pp. 69-77.

24 ADGER (note 1), p. 351

25 Aldwyn RuDDock, Italian Merchants and Shipping in Southampton 1270-1600, Southampton 1951, pp. 151-152.

26 Lawrence Burgess, The Southampton Terrier of 1454, London 1976; Colin PlatT / Richard Coleman-Smith, Excavations in Medieval Southampton 1953-1969, Leicester 1975, p. 37; Richard Brown / Alan HaRdy, Trade and Prosperity, War and Poverty. An Archaeological and Historical Investigation into Southampton's French Quarter, Oxford 2011.

27 Platt / Coleman-Smith (note 26), p. 294.

28 Ibid., pp. 232-246. 
petitions to the crown for relief and the reduction of fee farm, as well as disputes with merchants from other towns that they employed protectionist strategies to sustain a degree of income and limit their burden in times of hardship. ${ }^{29}$ Burgesses held some land outside of the town and were also able to influence their hinterland by providing opportunities for trade and entering into financial arrangements with local producers. ${ }^{30}$ Southampton had a distinct advantage over other local market towns due to the variety of imported goods available, although many of these would only be in the reach of a small number of households in the wider region. We can see, however, in the steps taken by Southampton merchants attempts to secure relations with its wider region and foreign traders, exploiting their position as holding access to the major port for the region.

At a superficial level at least, Southampton seems to have been equipped to absorb the traumas of the fourteenth century, with its trade axis changing towards the Mediterranean, making it an important connection between Italian markets and the southern English cloth industry, both by exporting their products and importing dyestuffs essential for its growth and development. ${ }^{31}$ Rather than seeking to apply general rules to understand how adaptable Southampton was to crisis, my approach here is to explore the nature of resilience and the strategies employed within Southampton and beyond, and to highlight their implications for strategies of resilience today. Within the context of medieval studies, such an approach has further value in re-opening debates over the occurrence of an urban crisis in the later fourteenth and early fifteenth centuries from a new perspective, building on previous conclusions that towns cannot be considered alone but must be examined within their region, an endeavour well suited to the relational approach to adaptability and resilience advocated here. ${ }^{32}$

Recent approaches in urban history, archaeology and geography have sought to move beyond an essentialist approach to the urban, to explore how cities emerge as spatially situated social processes. ${ }^{33}$ Following scholars such as DELEUzE and GuATTARI and DELANDA they see the city as existing as a coagulation of flows, a

29 PlatT (note 22), pp. 119-120.

30 Ibid., p. 253.

31 Michael Hicks, English Inland Trade 1430-1540. Southampton and its Region, Oxford 2015, pp. 154-158.

32 Alan DyER, Decline and Growth in English Towns 1400-1640, Cambridge 1991; Ben JERVIS, Decline or Transformation? Archaeology and the Late Medieval Urban 'Decline' in Southern England, in: The Archaeological Journal 174(1) (2017), pp. 211-243.

33 See, e. g., Dorothy BRANTZ, Assembling the Multitude. Questions about Agency in the Urban Environment, in: Urban History 44(1) (2017), pp. 130-136; Ben JERVIS, Assemblage Theory and Town Foundation in Medieval England, in: Cambridge Archaeological Journal 26(3) (2016), pp. 381-395; Colin MCFARLANE, The City as Assemblage. Dwelling and Urban Space, in: Environment and Planning D: Society and Space 29 (2011), pp. 649-671; Ben JERVIS, Assemblage Thought and Archaeology, Abingdon 2018. 
process of 'territorialisation' in which the city as an entity is formed at the affective intersection of flows of people, goods, resources, materials, ideas and capital, for example. ${ }^{34}$ The city does not exist as such, but occurs as an ongoing process, with the 'mineralisation' of these flows creating the concrete urban landscape as the site of re-occurring social interactions, which necessarily requires it to extend beyond its physical limits. ${ }^{35}$ Urban ecosystems are, therefore, more than the environment of the city itself, but include the wider surroundings, the region which is instigated in the performance of the city. ${ }^{36}$ Such an approach also acknowledges that human agency is not the only form of power within the city. Instead, agency is generated in the coming together of flows, ${ }^{37}$ with the non-human having power to stimulate the emergence of new urban futures or to decay the structures put in place by mechanism of bureaucracy, be that through the decay of materials or the colonisation of open spaces by plant species or the spread of microbial disease. ${ }^{38}$ Whereas adaptability emerges in these different relations, resilience becomes the manipulation of these flows, the management of this potency, to protect specific ways of urban being.

The concept of vibrant materials, particularly drawing on the work of Jane BENNETT, ${ }^{39}$ is increasingly important in archaeological scholarship, and is one with which medieval people might have been sympathetic. Fundamentally this concept requires us to be aware of the power that materials might have over us, meaning that the world is not shaped by human intentionality alone, but by interaction between human and material forces. Medieval examples such as the use of humeral theory in agricultural practices, an approach based in scientific knowledge, and measures taken to prevent the exhaustion of resources such as crop rotation and flood defence measures all demonstrate an ability to manage natural forces. ${ }^{40} \mathrm{We}$ might also see such an appreciation of the power of the material in in the use of apotropaic objects, for example the burial of pilgrim souvenirs to protect a

34 Gilles Deleuze / Felix Guattari, A Thousand Plateaus, London 1987; Manuel DeLandA, A Thousand Years of Nonlinear History, New York 1997.

35 DELANDA (note 34), pp. 26-28; MCFARLANE (note 33), p. 663.

36 DELANDA (note 34), p. 108

37 Astrid van Oyen, Historicising Material Agency. From Relations to Relational Constellations, in: Journal of Archaeological Method and Theory 23(3) (2016), pp. 354-378; BRANTz (note 33).

38 Tim EDEnsor, Vital Urban Materiality and its Multiple Absences. The Building Stone of Central Manchester, in: Cultural Geographies 20(4) (2012), pp. 447-465; Matthew GANDY, Unintentional Landscapes, in: Landscape Research 41(4) (2016), pp. 433-440.

39 Jane BenNETT, Vibrant Matter. A Political Ecology of Things, Durham / NC 2010.

40 Richard Jones / Holly Miller / Naomi SykES, Is it Time for an Elemental (Re)Turn in Archaeology?, in: Archaeological Dialogues 23(2) (2016) pp. 175-192, here p. 183; Rainer SCHREG, Ecological Approaches in Medieval Rural Archaeology, in: European Journal of Archaeology 7(1) (2014), pp. 3-119; Christopher GERRARD / David PETLEY, A Risk Society? Environmental Hazards, Risk and Resilience in Medieval Europe, in: Natural Hazards 69(1) (2013), pp. 1051-1079. 
household or bless the fields. ${ }^{41}$ Rather than focus on these acts as religious, or to simply identify them as 'ritual' behaviour, we can propose that these were anticipatory measures, taken to protect specific ways of life, measures which can also be seen more concretely and explicitly in the endowment of parish churches, religious institutions and chantries. ${ }^{42}$

In his analysis of urban development in medieval Europe, DELANDA identifies two extremes of urban assemblage. ${ }^{43}$ The first is the meshwork, which we might view as a true 'assemblage' of interconnected participants, which come together in unpredictable ways. Within these assemblages past connections open the potential for future ones. Such assemblages occupy a 'smooth' space, in which flows are free to entangle with each other in promiscuous and unpredictable ways, with little control exerted over them. DELANDA suggests that such meshwork assemblages are characteristic of 'gateway' cities, such as ports. These places exist as islands, coagulations of flows from distant places, over which they exert little control. The opposite is the hierarchy, emerging through a homogenising process of stratification. In such cities, components are sorted and bonded together through bureaucratic mechanisms, which can be likened to the sorting and cementing of sediment in the process of rock formation. These might be perceived of as occupying a space which is striated, preventing flows from moving in some directions; 'coding' them to interact in specific ways to lead to futures which, whilst not entirely predictable, are managed. ${ }^{44}$ In both cases futures are historically contingent and unpredictable, but within the hierarchy futures are anticipated and worked upon more explicitly. Such cities may exert control by homogenising the environment around them, either directly or indirectly, becoming central places. Such a theoretical approach finds a degree of historical legitimacy. In his study of economic development in northern Europe in the early medieval period, LOVELUCK contrasts the comparative freedom of coastal areas with inland areas, and sees the growth of ports as an attempt by authorities to exert power over trading activity, whilst acknowledging the need to create urban centres in which merchants had the freedom to accrue capital, receiving protection in return. ${ }^{45}$ From our perspective, adaptability is a characteristic of the meshwork, whilst resilience emerges from stratification, a manipulation of flows to create a homogenized and predictable future, rather than the messy and unpredictable one emerging from an adaptive meshwork.

41 William ANDERson, Blessing the Fields? A Study of Late Medieval Ampullae from England and Wales, in: Medieval Archaeology 54 (2010), pp. 180-203.

42 GeRRARD / PetLey (note 40).

43 DeLanda (note 34), pp. 26-28.

44 Grove (note 21), pp. 247-248.

45 Christopher Loveluck, Northwest Europe in the Early Middle Ages c. AD 600-1150, Cambridge 2013, pp. 302-303. 
In contemporary discussions of the implications of resilience in neoliberal societies it is this stratified element that is emphasized, resilience becoming perceived negatively as a means of maintaining a subjugating status quo. A parallel can be drawn here with the perception of medieval society as rigidly hierarchical. The behaviour of medieval communities was constrained, to varying degrees, by the interests of the elite, although it should be noted that resistance, as exemplified by events such as the peasants' revolt, also constrained elite action. By acknowledging the presence of meshwork elements within medieval society resilience can become something more positive, a means through which communities might overcome some perceived disadvantage, in the medieval context, this might equate to those outside of the seigniorial or urban elite being able to shape their future, providing a counter-narrative to that of subservience, deference, and subjugation. ${ }^{46}$ By exploring the relationship between these different elements of the urban assemblage in historical perspective we can, therefore, potentially contribute alternative ways of looking at the relationships between different forms of power and adaptive capacities in both past and contemporary societies, and view resilience not as a means of power being exerted through a hierarchy, but rather as emerging out of a range of behaviours performed across society.

Meshwork and hierarchy sit on a continuum, the reality being that some cities exhibit more, or less, meshwork elements. Importantly, the dominance of these elements will vary as social relations unfold; hierarchies may become de-stratified as they are 'over-coded' by other processes, perhaps an unanticipated process or one which was insufficiently or ineffectively prepared for, whilst these processes also occur at multiple scales. Cities must constantly change to adapt to threats (through the embracing of meshwork characteristics), but also be stratified to ensure that certain structures are in place to maintain urban society. ${ }^{47}$ Cities are assemblages of assemblages, such as households, themselves heterogeneous bundles of people, things and connections which cause them to 'overflow' the space with which they are associated. ${ }^{48}$ Processes of stratification, of seeking to control the vibrant flows of matter and energy which constitute life, may occur at multiple scales and tension between these scales may also lead to specific processes of anticipation and preparedness emerging at the expense of others. It is these specific processes, and their implications for understanding adaptive behaviour, which are the focus of the remainder of this paper.

46 GROVE (note 21), p. 245.

47 ESTEVEZ-MAURIZ et al. (note 6), p. 5.

48 Michel Callon, Actor-Network Theory - The Market Test, in: John LAw / John HANSARD (eds.), Actor Network Theory and After, Oxford 1999, pp. 181-195. 


\section{Resilience at the Microscale}

DELANDA highlights how medieval towns and cities were microbial laboratories. ${ }^{49}$ Disease could spread quickly, as seen by the rapid spread of plague, with the effect of 'over-coding' existing social structures, breaking down existing structures and creating opportunities for new ones to emerge, as is particularly seen in the changes to the organization of the rural economy in the fifteenth century. ${ }^{50}$ Whilst the understanding of the causes of disease was undeveloped, there was an acceptance of the need for good hygiene to prevent its spread. The capacity to spread disease is a quality of waste matter. Archaeological evidence demonstrates the occurrence of worms, spread through exposure to human excrement and food waste attracted disease carrying rodents for example. ${ }^{51}$ Measures were taken to remove waste from the centre of the town, where limitations on space and the proximity of residents combined to make waste management a key concern. Archaeological excavations reveal extensive excavations of pits in backyards across Southampton. These were dug for a variety of purposes, including as cess pits, and were often back-filled with a range of domestic waste. ${ }^{52}$

By studying the ways in which these pits were filled, the case can be made that processes of vulnerability and resilience building were being played out. A range of analyses demonstrate that waste was not dumped in pits in a haphazard manner, but was structured. Sterile layers, of shell or earth, were deposited. Analysis of fly pupae show that pits were sealed, preventing further insect infestation. ${ }^{53}$ What we are seeing here is an attempt to neutralize the potent elements of this waste matter, to homogenize what had been a diverse mix of objects, food waste and natural substances through a process of stratification; of sorting it into a mulch of waste and cementing its position through burial. ${ }^{54}$ At the micro-level this process was one of managing potential futures, of categorising and disposing of the products of historical processes to prevent them from lingering and playing a role in the future. Rather than relying on an ability to adapt to disease, measures were taken to

49 DELANDA (note 34), p. 110.

50 Bruce CAmpBell, The Great Transition. Climate, Disease and Society in the Late Medieval World, Cambridge 2016.

51 Andrew Jones, Southampton French Quarter 1382 Specialist Report Download E6: Intestinal Parasites, online: https://library.thehumanjourney.net/51/1/SOU_1382_Specialist_report_down load_E6.pdf (last accessed 15/05/2019).

52 Platt / Coleman-Smith (note 26); Brown / HaRdy (note 26), pp. 281-284.

53 David Smiтh, Southampton French Quarter 1382 Specialist Report Download E9: Mineralised and waterlogged fly pupae, and other insects and artropods, online: https://library.thehumanjour ney.net/52/1/SOU_1382_Specialist_report_download_E9.pdf (last accessed 15/05/2019).

54 See also Roos VAN OOSTEN, The Dutch Great Stink: The End of the Cesspit Era in Pre-Industrial Towns of Leiden and Haarlem, in: European Journal of Archaeology 19(4) (2016), pp. 704-727, for a long-term consideration of urban waste management. 
anticipate and prevent its occurrence. Through the repetition of such processes across the town, combined with the enacting of municipal regulations on waste management, ${ }^{55}$ we can see resilience to the threat of disease emerging at the microscale, through individual interactions with waste matter and anticipation of its potential consequences.

Despite these measures, disease was a critical issue in the medieval town. ${ }^{56}$ Humans and microbes co-evolved, humans developing immunity to one strain as new ones developed. It is here that we can bring in to focus the idea that resilience exists as a resistance to the world, as an acknowledgement that risks cannot be entirely removed but that steps can be taken to prepare for and pre-empt them. Disease would always be a risk, but by taking measures to prevent its spread, by acknowledging a source of vulnerability, resilience could be built in some form. What we see in waste management is the removal of vibrant matter from the urban assemblage as a conscious effort to exert some control over an anticipated, but unpredictable future. Importantly this can be characterized as a 'bottom-up' strategy, in which societal power emerges out of multiple performances of anticipatory behaviour distinctive to the urban environment - a widespread enacting of knowledge to manage a future over which the whole community had a stake.

\section{The Politics of Resilience}

Vulnerability to the affect of waste emerged through the processes of urban life. In this case that vulnerability was the result of the proximity and density of people and the redundancy of waste, when, in the countryside, the latter was a valuable source of manure. Resilience and vulnerability are therefore negotiated through and emerge from relations with a human and nonhuman urban world, through which the process of urban assemblage both takes shape in the present and produces relations which shape the future. ${ }^{57} \mathrm{~A}$ focus on a more specific instance of vulnerability and resilience reveals further how the priorities of stakeholders within the town might cause resilience to emerge as a point of tension and rupture between scales of power.

The process of resilience can reveal dynamics of power and serve to re-enforce inequalities. The anticipation of attack caused significant tension between the crown and Southampton's burgess community. Potential weaknesses in Southampton's defences were highlighted in 1321 when a fleet from Winchelsea landed and burnt two

55 Paul StUder (ed.), The Oak Book of Southampton of c. A. D. 1300, Southampton 1910.

56 Carole RAwCLIfFE, Urban Bodies. Communal Health in Late Medieval English Towns and Cities, Woodbridge 2013.

57 ZEBROWSKI (note 4), p. 161. 
ships. The seaward defences of Southampton consisted of an earthen rampart and palisade. Whilst it is unclear as to what extent the defences had been built in stone by the French raid of 1338, the town clearly had defensive weaknesses. The context of the raid was ongoing war with France, and the vulnerability of Southampton as a target either for raids or as a landing place was clearly recognized by the crown. Works were undertaken to the castle in the first decade of the fourteenth century and in 1326 a grant was made of a new toll to fund the town wall. In 1337 a string of warning beacons was erected along the south coast and for the decades after the raid periodic surveys of the defences were required. ${ }^{58}$ The raid of 1338 exposed a vulnerability which had been identified by the crown, who had taken measures to enable the strengthening of the defences of the town. This anticipatory action may never have prevented an attack, but could have mitigated its impact. As it was, the raiding party experienced little resistance, the gates had been barred but were easily broken through. The crown's inability to strengthen the defences came from the strong position of the burgesses, indeed following the raid the town was effectively placed under martial law to prevent looting and anticipate further attacks.

It was though surely in the interests of the burgesses to invest in the defence of Southampton. After all, their livelihoods depended upon the ability of goods to flow through the port. It is here that the burgesses are revealed as displaying a particularly self-destructive form of self-interest. They were reluctant to defend the waterfront as it would hinder trade and lower the value of their properties. ${ }^{59}$ Their concern was with the persistence of the everyday rhythms of port life, the ability to move goods to and from the quayside, to continue to trade in an efficient manner. They anticipated that a defensive scheme would impact upon their ability to do this, and, rather than adapting, they resisted the fortification of the waterfront in stone, even, it would seem, after defensive frailties had been highlighted in 1321.

Tension over the defences continued into the fifteenth century. Little care was taken by the burgesses in routinely maintaining the wall. In places, it was too thin to be fit for purpose, either to withstand bombardment or to offer a platform from which to defend the town. ${ }^{60}$ Periodically this vulnerability would be highlighted by royal surveys and measures taken to attempt to strengthen the defences, which were followed through to varying levels of effect.

We can see here how, depending upon the social relations in which people were enrolled, the wall and quayside afforded different things, ${ }^{61}$ and brought about different forms of vulnerability. For the crown, with its knowledge of the political

58 Platt (note 22), pp. 107-108.

59 Ibid., pp. 108-109.

60 Platt / Coleman-Smith (note 26), pp. 146-149.

61 Affordance is taken here to be a recognized capacity of a thing, emerging through knowledgeable interaction; see Carl KNAPPETT, Thinking Through Material Culture, Philadelphia 2005, pp. 45-47. 
situation and understanding of warfare the quay was periodically a point of vulnerability, for the merchants it was a place central to their lifestyle and the defences literally introduced a barrier to them trading in the most efficient manner. Furthermore, the periodic nature of the threat meant that vulnerability was not uniformly recognized, but acted upon episodically, allowing the defences to degrade, whether through the failure to maintain the stonework or the filling of ditches with domestic waste, with resilience having to be enacted as a process every time a threat was identified.

The example of the wall demonstrates how resilience building can introduce conflict. The aim is not to directly protect the physical structure of the town, but the social relations which flow through it and which it affords. ${ }^{62}$ Competing interests value these relations in different ways, and seek to protect them by identifying where they were vulnerable. Therefore, the overall resilience of the town itself came to be limited by the interests of certain groups and fluctuates with the power that these various groups are able to develop and exert. Royal action introduced vulnerability to the functioning of the port and the wealth of the merchants, whilst the political situation made the port vulnerable, but in a way, which could easily be written off as paranoia. Whilst this example is specific, it is a characteristic of resilience strategies that there is a trade-off and it is the values of a dominant group which are best catered for. The negligence displayed in relation to the defence of Southampton may have served the short-term interests of the mercantile burgesses, but placed the rest of Southampton's townspeople at risk. Political action may highlight or strengthen inequalities, and even limit the potential for recovery. ${ }^{63}$ In this tension we can reveal uneven power dynamics within the town, which arise from the historical freedoms and authority given to the burgesses by the crown.

The French raid had an uneven impact; houses around the waterfront, largely occupied by merchants, suffered the most extreme damage, whilst households in the east of the town were less directly affected. They were, however, exposed to the economic downturn which warfare and disease had brought about and for which the raid was a catalyst at the local scale. However, whereas the merchant burgesses can be shown to have sought to stratify the town through regulation and undertook actions which homogenized the economy of Southampton, the eastern part of the town exhibits greater diversity. Plots had substantial gardens and households were engaged in various craft activities. Whilst they may have provided labour around the quayside, their livelihood was more diverse than that of the mercantile households. These households appear as a heterogeneous element within the townscape, and may have been able to adapt, directing their efforts towards subsistence and continuing to produce goods for the local market which persisted despite a

62 GROVE (note 21), pp. 243-244.

63 Fox Gotham / Campanella (note 2), pp. 16-17. 
downturn in international trade. Pottery, of a type which appears to have emerged as a short-term replacement for types no longer available, was produced here as well. ${ }^{64}$ Although the burgesses utilized bureaucracy to seek to bring a specific form of urban order about, and were able to resist external power, we can see that meshwork elements persisted within the town. Whereas the merchants had to invest significant capital in rebuilding their homes and the quay facilities, and expend political capital in bringing Italian trade back to the port, within these meshwork elements life adapted more easily thanks to its heterogeneity. We should not, however, make the mistake of writing off the positive impacts of stratification. ${ }^{65}$ Bureaucratic tools are tools for persistence, allowing governance and Southampton's port function to persist, although they might also reify inequality by seeking to maintain a socio-economic and political status quo in the town; a trait which is characteristic of the rigidly hierarchical nature of medieval society.

This example demonstrates the implications of competing political interests for anticipatory behaviour. We can see that the ability to build resilience is historically contingent, here underpinned by charters granting burgesses power which constrained that ability of the crown to protect its interests. We can see how the interests of those in power are served by decisions about resilience building at certain scales, but also that less hierarchical and more heterogeneous elements of urban communities may display greater adaptability. This is not to say that these elements were unable to build resilience, but the scale at which they could act upon potential vulnerability was determined through historical processes. Whilst steps to build resilience opened or closed potential trajectories of unfolding, the adaptability of these marginalized elements of the urban community allowed them to act on this emerging future, by participating in urban processes, such as manufacture for the local market. Decision making, political interest and the form of urban assemblages therefore combine in messy ways to determine the ways in which the town unfolds, with resilience (or attempts at building resilience) having effects which are implicated in the future emergence of the town. This is a critical observation, as power over the future is not something in the hands of an identifiable urban elite, but emerges out of the ability of different sections of urban society to adapt and respond, creating possibilities for those who are marginal within formal power structures to play a role in shaping urban futures. It becomes clear that power is not imposed upon urban society, but rather, emerges in different forms out of particular everyday interactions, a phenomenon which is difficult to account for in generalising models of resilience which conceptualize power in more limited terms.

64 BROWN (note 22), pp. 18-19.

65 Delanda (note 34); Deleuze / GuatTari (note 34). 


\section{Southampton in the World}

An assemblage approach calls on us to consider the ways in which towns, as social processes, extend beyond their physical limits. The social relations which constitute Southampton are contingent both on performances of agricultural and commercial activity in its hinterland and on the performance of long-distance trade. Urban ecosystems are, therefore, more than the flora and fauna of the urban landscape, but extend into the agricultural hinterland. ${ }^{66}$ As ADGER demonstrates, resilience is dependent both on natural and political factors. ${ }^{67}$ Towns have implications for their hinterland. Towns which DELANDA might identify as 'hierarchical', 68 that is having a rigid structure, might be seen as exploiting a defined hinterland and, in turn, striating it through the management of the urban market. In contrast, gateway towns, such as ports, might draw on a wide hinterland. It is unclear how much direct influence Southampton had on its hinterland, but it had implications for decisions taken in the management of agricultural resources. Towns, or commerce in general, have the effect of limiting biodiversity and reducing the length of food chains, focussing on the conversion of biomass into energy for human consumption, be that in the form of grain or the conversion of plants into animal protein. ${ }^{69}$ Grain was imported to Southampton both from its hinterland and through its coastal contacts, with some being exported to the continent, particularly to provision troops in France. Here though, I wish to focus on another implication of the performance of Southampton, the performance of pastoral agriculture.

Although at the centre of our study, Southampton, and England in general, were at the periphery of an economic system which was focussed on the Italian economic powerhouses of Genoa and Venice. ${ }^{70}$ Trade with Genoese, Florentine and later Venetian merchants was critical to Southampton's development. ${ }^{71}$ Although they do not seem to have invested directly in pastoral husbandry, these merchants bought up stocks of wool to be processed into cloth in the Flemish cities in the thirteenth century and, later, exported cloth produced in Southampton's wider hinterland. Importantly, Southampton was not only a conduit for finished cloth, but also for dyestuffs imported by the Italians. ${ }^{72}$

66 DeLanda (note 34), p. 108.

67 ADGER (note 1), p. 354.

68 DeLanda (note 34).

69 Ibid., p. 108.

70 Janet ABu-Lughod, Before European Hegemony. The World System AD 1250-1350, Oxford 1989; Ben JERvis, Assembling the Archaeology of the Global Middle Ages, in: World Archaeology 49(5) (2017), pp. 666-680.

71 RudDOCK (note 25).

72 Hicks (note 31), pp. 156-157. 
By the fifteenth century, Southampton's trade was largely in the hands of foreign merchants, with Southampton's burgesses investing in shipping but largely providing hospitality and undertaking overland trade. ${ }^{73}$ Southampton therefore occupied a precarious position, reliant on the continuing interest of foreign merchants and the sustainable management of pastoral resources. The impact of sheep murrain on wool exports is well documented, and had implications for the prosperity of Flemish cloth producing centres. However, its impact on Southampton as a port is less clear, there was still a demand for wool and it commanded a high price, with it likely being the domestic rather than export market which lost out. ${ }^{74}$

By the fifteenth century, the principal wool producing landlord within Southampton's hinterland, the bishops of Winchester, had changed their agricultural strategy. Benefitting from a decline in population and adjusting to a rise in wages, sheep husbandry increased. A focus was placed on the processing of wool into cloth in the towns on the Winchester estate, with this finished product being exported through Southampton. Similar developments occurred across southern England. ${ }^{75}$ The typical narrative is one of simple economics, pasture became more profitable than arable stimulating a change. Whilst there is undoubtedly truth to this, we can also view this shift in terms of resilience. The placement of embargos on trade with Flanders, as well as sheep murrain, had revealed vulnerabilities in the supply chain. By taking charge of cloth production and increasing the size of flocks, landowners could build resilience by stockpiling wool, whilst also leasing pasture to farmers who could take on some of the risk of sheep husbandry.

These measures had implications for Southampton, over which its burgesses had little, if any, control. Resource management decisions were intended to address perceived vulnerability, seeking to secure a supply of wool and a maximisation of profit through the trade in cloth. Critically, these management decisions did not simply arise from local processes, they were stimulated by the spread of infestation, firstly of animals and later of people, and a demand for cloth which derived from eastern markets via Italian merchants. Here then we can see that attempts at building resilience outside of the core of the town still had implications for it, with pastoral husbandry, although a rural activity, becoming an element of an urban ecosystem, focussed not on Southampton but the Italian cities.

Here we can see Southampton as a gateway town, demonstrating meshwork characteristics. Rather than burgesses homogenising the hinterland to build resilience, we see this process arising from land management by the Bishop and his staff. Rather, Southampton's merchants adapted, they invested in quay facilities, provided hospitality and built links with foreign merchants. By being implicated in

73 Platt (note 22), pp. 152-153.

74 Ibid., pp. 154-155.

75 John Hare, The Bishop and the Prior. Demesne Agriculture in Medieval Hampshire, in: The Agricultural History Review 54(2) (2006), pp. 187-212. 
this trade, the leading burgesses' interests were aligned with these powers, meaning there was little short-term gain to be had in heterogenising the socio-spatial processes of the town. Here we can see Southampton as marginal and vulnerable. Whilst its interests were aligned with those of its trading partners it persisted as a port, with resilience coming from decisions taken outside, but with implications for, the urban population. The burgesses didn't control trade, but exhibit adaptability as they developed their capacity to provide hospitality and facilitate trade, as well as building partnerships through overland trade. However, the subsequent decline of Southampton in the sixteenth century clearly demonstrates the vulnerability introduced by this lack of control and short-term approach to economic growth. ${ }^{76}$

This example demonstrates how the fortunes of towns do not lie only in the decisions taken by their residents. By exploring the ways in which towns play a part in wider networks it is possible to examine how they were impacted by decisions taken outside, as land owners and powerful Italian merchants identified vulnerabilities and made changes to the supply chain to build resilience. This created spaces in which Southampton could display meshwork characteristics, but in which it was homogenized by external forces, making its existence, or at least its position in the urban hierarchy, precarious. ${ }^{77}$ One only has to think of the decline of cities focussed on single industries, such as Detroit, to understand how this resonates in contemporary society. But, despite sixteenth-century decline, port operations in Southampton persisted, albeit at a lower intensity. Infrastructure, networks and knowledge were not lost, but the port community adapted to prevailing conditions. The ability to build on experience and networks emphasizes the importance of everyday performance and the emergence of alternative forms of power, derived from these 'bottomup' interactions. Indeed, whilst the picture in twenty-first-century Detroit is often portrayed as bleak, some analysis shows that the persistence of knowledge and networks creates opportunities for innovation and adaptation. ${ }^{78}$ By exploring how communities like that of Southampton were able to adapt and persist over the long term, particularly through processes which exist outside of the hierarchical structures of power, contemporary cities can be more confident in their ability to recover, not through repetition but through adaptation, through a concern not with forcing hegemonic structure to persist, but instead allowing urban processes to emerge and adapt, to create spaces for innovation, recovery and alternative forms of power.

76 Platt (note 22) p. 223.

77 ZEBRowsKI (note 4), p. 168.

78 Robert MAXWELL, After the Car. Navigating the Archaeology of Abandonment in Detroit, Michigan, in: Post-Medieval Archaeology 46(2) (2012), pp. 347-352; Thomas J. Hannigan / Marcello Cano-Kollmann / Ram Mudambi, Thriving Innovation Amidst Manufacturing Decline. The Detroit Auto Cluster and the Resilience of Local Knowledge Production, in: Industrial and Corporate Change 24(3) (2015), pp. 613-634. 


\section{Conclusion}

By seeking to explore how the community of medieval Southampton acted in anticipatory ways, the archaeological and historical evidence reveals the inherent link between resilience, power and agency and demonstrates the value of an approach which is contextual, rather than reliant on a generalising model. Rather, if we are to generalize, an approach based on the mapping of social relations, may prove fruitful for understanding the character and emergence of resilience. This corresponds with developments in contemporary political analysis, geography and economics which have considered that resilience is an articulation of adaptability, which arises from social relations and can be characterized as a means of anticipating the future. The historical practices revealed show that power is emergent from sets of relations between people and the World, and that adaptation and resilience can, therefore, emerge at multiple scales and in ways which need not directly reflect the formal power dynamic within a town. My core point is to show that resilience is not a simple process, but is enacted simultaneously by different groups at various scales, potentially with conflicting imperatives. Approaches inspired by assemblage theory and related frameworks are increasingly common in archaeological theory and the social sciences, but we must be careful to understand the implications of assemblage thought, arising from its origins in radical politics as a means of creating the potential for transformation, both in contemporary society and in our understanding of the past not as awaiting discovery but as an ongoing, emergent process in the present; its goal not being to create a theory compatible with our knowledge of the past but to produce new knowledge which makes us alive to the possibilities of the past and of the future. ${ }^{79}$

A focus on resilience building allows us to think about how power emerges and is enacted over an emergent future, and provides potential both for understanding how past societies worked on potential futures, and how we may shape our own futures through a stronger awareness of the nature of power and its relationship to anticipatory action and adaptive capacity. The form that this power takes, whether it is over people, vibrant materials or agricultural resources, may vary, but wherever vulnerability is acted upon, the process of resilience building will have wider implications; potentially serving to marginalize the interests of other groups, or directing the ways in which they might be able to adapt. It is critical that we are alive to these implications, so as to better equip contemporary society to deal with challenges, particularly by exploring the potential to enfranchise those who are marginalized by over-arching power structures and facilitating, rather than restricting, their agency in shaping the future. Such reflection on the role of resilience building

79 Bertie Russell / Andre Pusey / Paul Chatterton, What Can an Assemblage Do? Seven Propositions for a More Strategic and Politicized Assemblage Thinking, in: City 15(5) (2011), pp. 577-583. 
in contemporary politics and the implications that power dynamics might have beyond their intended consequences, will better equip us to develop theoretical tools which allow us to traverse the constructed distinction between past and present, to work on both, not to reproduce power dynamics but to reveal and transform them in ways which allow agency to be re-distributed in productive ways to build more nuanced pasts and which enfranchise communities in anticipating their future. ${ }^{80}$

80 GRove (note 21), p. 246. 
Pierre Monnet

\title{
Studying the Middle Ages: Historical Food for Thought in the Present Day
}

\begin{abstract}
Why study the Middle Ages? The answers this question yields concern more than simply medievalists: they generate reflections regarding the usefulness of science or intellectual engagement in any given society. Answering the question includes critical reflection on periodization in general and, in particular, on the public's understanding of what is termed (for better or worse) 'the Middle Ages'. The relevance of studying the period has been justified in many ways. It allows, for example, a comparison of social dynamics and the gathering of insights into the role of religion. Equally, it enables investigation of modes of rule and the organization of communities. Ultimately, it enables us to better understand modernity itself. Yet while many arguments concern a better understanding of the contemporary world, they do not necessarily justify the necessity of incorporating medieval comparisons. The current consensus (at least in French medieval studies) is to study the Middle Ages as a society in its own right. There is an additional understanding that the specific problems raised by this period should be placed in a broader chronological and spatial context. These critical reflections invite deeper considerations, which are, in turn, useful in developing our sense of democracy, our understanding of society, and in the development of a historical science that is conscious of the current tendencies to 're-politicize' history. This chapter argues that this leads to invaluable insights into the workings of any discipline concerned with the perception of time and change.
\end{abstract}

Keywords: Medieval Studies, History and Theory, periodization, modernity, ideology, epistemology, interdisciplinarity, humanities, France

\section{Turning back - and broadening the question}

To raise the question of the interest and relevance of studying and teaching the Middle Ages means, first, to presuppose that there should be debate on the matter and, secondly, that what we call 'the Middle Ages' constitutes a well-defined and clearly

Note: Translated by Bruce L. Venarde (Pittsburgh), Chris Jones (Christchurch, NZ), and Klaus OsChemA (Bochum).

Pierre Monnet, Directeur d'études (EHESS, Paris), Directeur de l'Institut Franco-Allemand / Sciences Historiques et Sociales (IFRA / SHS), Goethe-Universität, Norbert-Wollheim-Platz 1, IG-Farben Haus, Postfach 42, 60629 Frankfurt / Main, Germany, monnetpierre@gmail.com 
conceptualized subject. The simple affirmation that the Middle Ages 'exist' at all needs to be the starting point for any reflection that seeks to answer the question of whether studying the period constitutes either a 'useful' or 'useless' endeavour. Each of our initial assumptions, however, must be considered to be problematic. The difficulties they raise are closely intertwined. ${ }^{1}$ The twofold nature of the initial question, which appears to be simple only at the most superficial first glance, presupposes two assumptions that might in turn have dangerous or undesirable side-effects: firstly, that the Middle Ages 'exist' and, secondly, that the fact of their existence enables us to ask, in a meaningful way, whether studying them is either 'useful' or 'useless'.

The underlying logic of these initial assumptions and their consequences demand explicit elucidation, not least because the very label 'Middle Ages' derives from a specific understanding. Introduced by humanists in the sixteenth century, its inventors sought to discredit the entire period that came between the fall of Roman civilization and their own. The term has been repeated continually ever since. Its success and persistent use up to our own day should in fact be considered surprising: it is a persistence that has survived shifts in chronology as well as the arrival of new chrononyms that flank the so-called 'Middle Ages' such as 'Renaissance' and 'Late Antiquity'.'

My argument will focus first and foremost on phenomena that concern 'history' as an institutionalized academic discipline. There are two principle reasons that might lead scholars of the 'Middle Ages', a particular unit in the system of academic periodization of history, to try and justify the usefulness of studying the object of

1 For a first approach to the possibilities and limits of considering the Middle Ages through modern heuristic categories, see the collection of notes "De l'usage de ..." published online in the francophone medievalists' platform Menestrel, online: http://www.menestrel.fr/spip.php?rubrique397\&lang= fr (last accessed 15/05/2019). See also Alain GUERREAU, L'avenir d'un passé incertain. Quelle histoire du Moyen Âge au XXI" siècle?, Paris 2001, pp. 251-274 (“Fréquenter les concepts”).

2 Jacques Le GofF, Faut-il vraiment découper l'histoire en tranches?, Paris 2014. On the matter of traditional and novel periodizations, see Olivier Dumoulin / Raphaël VALÉRY (eds.), Périodes. La construction du temps historique, Paris 1991; Stéphane GIBERT / Jean LE BiHAN / Florian MAZEL (eds.), Découper le temps. Actualité de la périodisation en histoire, Rennes 2014; Reinhart HeRzoG / Reinhart Koselleck (eds.), Epochenschwelle und Epochenbewusstsein (Poetik und Hermeneutik 12), Munich 1987; Revue d'histoire du XIX ${ }^{\mathrm{e}}$ siècle 25 (2002) (special issue: "Le temps et les historiens"). See also Paul BACOT / Laurent Douzou / Jean-Paul HonORÉ, Chrononymes. La politisation du temps, in: Mots. Les langages du politique 87 (2008), pp. 5-12. For additional consultation, see the table of contents of the journal "Temporalités" on this subject, notably 8 (2008) (special issue: "Les temporalités dans les sciences sociales"); see also Jean LEDUC, La construction du temps chez les historiens universitaires français de la seconde moitié du XX $\mathrm{X}^{\mathrm{e}}$ siècle, in: Temporalités 1 (2004), pp. 80-97. Most recently Bernhard JUSSEN has repeatedly argued for the replacement of the notion 'Middle Ages', see e. g. ID., Richtig denken im falschen Rahmen? Warum das "Mittelalter" nicht in den Lehrplan gehört, in: Geschichte in Wissenschaft und Unterricht 67(9-10) (2016), pp. 558-576, and ID., Wer falsch spricht, denkt falsch. Warum Antike, Mittelalter und Neuzeit in die Wissenschaftsgeschichte gehören, in: Spekulative Theorien, Kontroversen, Paradigmenwechsel. Streitgespräch in der wissenschaftlichen Sitzung der Versammlung der Berlin-Brandenburgischen Akademie der Wissenschaften am 25. November 2016 (Debatte 17), Berlin 2017, pp. 38-52. 
their specialization (and sometimes even to justify its very existence). In the first place, there is an intellectual and heuristic benefit: scrutinizing the very motivations that lead individuals to doubt either a period's existence or the usefulness of studying it helps us to clarify, in an interesting way, the relationship between modern and pre-modern periods and cultures. The so-called 'exoticism', 'strangeness', 'alterity', 'barbarism', 'intolerance', and 'violence' of the Middle Ages - to mention but a few of the highly charged notions that frequently appear and which are often invoked in trying the case of this allegedly dismal and backwards period - are more revealing about the prejudices and fantasies of our own times than about any specific moment of the past. And for this reason alone, the prejudice of the judges would suffice to legitimize studying the Middle Ages: study enables us to get a clearer idea of the distortions. In the second place, the arguments that are and can be mobilized in order to 'explain' the Middle Ages come under the heading of a reflexive epistemology that is always beneficial.

\section{The Problems of Time and Periodization}

We can agree that for the above two reasons the medievalists' Middle Ages has no more need than any other period to defend itself; yet, by the same token, nor do specialists in this period have any more reason to evade the question than those working in other periods. The question raised at the beginning of this chapter is therefore directed to all periods and other demarcations of historical time which are fixed and rationalized a posteriori for academic, ideological, and institutional purposes. The question either has merit for all fields or for none. The simple explanation for this is that the relationship of our societies to time and history has changed. This is because the social need of history, as a discipline, has evolved. ${ }^{3}$ History itself - as science, practice, and writing - has changed (for starters, as a result of the internet). ${ }^{4}$ To make the 'non-present present', comprehensible, and in certain respects necessary, ${ }^{5}$ functions that both collide and coincide with the contemporaneousness of the non-contemporary, is something that properly concerns the whole field of history or, to echo Marc BLOCH, ${ }^{6}$ all processes of historical reflection and understanding that are connected to the modes of functioning and of the transformation of structures of a

3 Gérard NOIRIEL, Sur la "crise" de l'histoire, Paris 1996.

4 Jean-Philippe GENET / Andrea ZORZI (eds.), Les historiens et l'informatique. Un métier à réinventer (Collection de l'École Française de Rome 444), Rome 2011.

5 Valentin GroebneR, Das Mittelalter hört nicht auf. Über historisches Erzählen, Munich 2008.

6 Marc Bloch, Apologie pour l'histoire, ou Métier d'historien, ed. Étienne Bloch, 2nd ed. Paris 1997 (orig. 1941/42). Recall that the first famous words of the book concern the utility, relevance, legitimacy, or the necessity of history: "Daddy, tell me what history is good for?" ("Papa, explique-moi donc à quoi sert l'histoire?”) (Ibid., p. 69.) 
society. Applying this perspective actually makes History nothing less than the science of social change over time. And, as such, History can claim to be part of a broad range of 'pure' scientific endeavour, that is scientific activity that is not driven by the goal of obtaining profit. In this, as part of the Humanities and the Social Sciences, History is a science precisely because it is historical and thus focusses first and foremost on human actors, individual and collective. Taking into account a certain form of nostalgia and attachment to the past and the approaches imposed by certain media and the seductive nature of everything 'medieval' (real and imagined) for a wide range of different modern ideologies, we can understand why the Middle Ages, more than any other period, seem, at the end of the twentieth century and the beginning of the twenty-first, to be particularly vulnerable to dangerous ideological exploitation. The increasing importance of this exploitation is highlighted dramatically by the way in which the Middle Ages has recently changed its status from being a 'showcase' period to become a pleasantly exotic world. As such, it has been 're-imported' into the present day, where it has become part of political strategies that seek to use it as an ideological tool. This phenomenon is particularly apparent in situations where the Middle Ages are introduced as the matrix of a western, Christian civilization, which is purportedly simultaneously 'under attack' by Muslim fundamentalism while at the same time endangered by processes of globalization. The latter are in turn interpreted as the death of the nation-state and the end of Europe's special character and exceptional nature. In this sense, the prominent exploitation of the Middle Ages as an ideological resource - a practice that can conveniently be called 'medievalism, ${ }^{\text {, }}$ - reveals that the problems that might induce a critical debate of medieval history's value and the status of medieval studies, are part and parcel of a democratic crisis, ${ }^{8}$ a crisis that affects the loss of our contemporary sense of political meaning. The methods and research principles of medievalists themselves, on the other hand, have less to do with current issues.

Specialists of this period, historians whose chronological framework has become very flexible and might in fact be considered to cover the entire time between the end of Antiquity and the turn of the nineteenth century, are confronted with a series of dramatic developments: the globalization of history and the new subjects it introduces (including prominent and ubiquitous calls to 'de-Europeanize' history), the overwhelming domination of contemporary history (which goes hand in hand with a regime of historicity marked by the domination of presentism), ${ }^{9}$ an increasing social

7 Janos M. BAK / Jörg JARNUT / Pierre MONNET / Bernd SCHNEIDMÜLLER (eds.), Gebrauch und Missbrauch des Mittelalters, 19.-21. Jahrhundert / Uses and Abuses of the Middle Ages, 19th-21th Century / Usages et mésusages du Moyen Âge du XIX ${ }^{\mathrm{e}}$ au XXI ${ }^{\mathrm{e}}$ siècle (Mittelalter-Studien 17), Munich 2009.

8 Tommaso di Carpegna Falconieri, Médiéval et militant. Penser le contemporain à travers le Moyen Âge, Paris 2015.

9 Jérôme BASCHET, L'histoire face au présent perpétuel. Quelques remarques sur la relation passé / futur, in: François HaRtog / Jacques Revel (eds.), Les usages politiques du passé, Paris 2001, 
demand - something, as I noted above, that is increasingly exploited and used as a political instrument - addressed to the entire body of historians in the context of public and patrimonial debates over sites of memory, and, no less significantly, the major thematic and methodologic reorientations in the study of medieval society that have occurred in recent decades. Like it or not, specialists have recently engaged in, voluntarily or involuntarily, a self-reflective exercise concerning their approach to, and the object of, their knowledge. This is obviously a development that should be welcomed.

\section{How to use a Social Science}

From the guild of medievalists themselves came a series of rather cautious reassessments. These remained strictly historiographical and methodological, and were primarily addressed to other professional or academic historians. ${ }^{10}$ Beyond these, several attempts have been made to respond to the question of the necessity and relevance of the study of the Middle Ages - or, at the very least, a certain understanding of the medieval - not only in academia but in society in general. Many of these latter, with a readership that stretches beyond a narrow circle of colleagues and specialists in mind, have tried consciously to demonstrate the usefulness of the Middle Ages by underlining their contemporary relevance. ${ }^{11}$

Numerous other attempts have tried to locate an argument for relevance on the general scientific and cultural specificity of the subject or the terrain called the

pp. 55-74; François Hartog, Régimes d'historicité. Présentisme et expériences du temps, Paris 2003.

10 An excellent overview of the debate is Joseph MORSEL / Christine Ducourtieux, L'histoire (du Moyen Âge) est un sport de combat ... Réflexions sur les finalités de l'Histoire du Moyen Âge destinées à une société dans laquelle même les étudiants d'Histoire s'interrogent, (s. 1.) 2007, online: https://halshs.archives-ouvertes.fr/halshs-00290183 (last accessed 15/05/2019). On the German side, see Michael BoRGoLTE (ed.), Mittelalterforschung nach der Wende 1989 (Historische Zeitschrift. Beiheft. N.F. 20), Munich 1994; Hans-Werner GOETZ (ed.), Moderne Mediävistik: Stand und Perspektiven der Mittelalterforschung, Darmstadt 1999; ID. (ed.), Die Aktualität des Mittelalters (Herausforderungen 10), Bochum 2000; ID. / Jörg JARNUT (eds.), Mediävistik im 21. Jahrhundert. Stand und Perspektiven der internationalen und interdisziplinären Mittelalterforschung (MittelalterStudien 1), Munich 2003; Peter MoRAw / Rudolf SCHIEFFER (eds.), Die deutschsprachige Mediävistik im 20. Jahrhundert (Vorträge und Forschungen 62), Ostfildern 2005. On the French side, see Jacques LE GoFF / Guy Lobrichon (eds.), Le Moyen Âge aujourd'hui, Paris 1997; SHMESP (ed.), Être historien du Moyen Âge au XXI ${ }^{\text {e }}$ siècle, Paris 2008. For a comparative Franco-German approach, see Otto Gerhard OEXLE / Jean-Claude SchmitT (eds.), Les tendances actuelles de l'histoire du Moyen Âge en France et en Allemagne, Paris 2003.

11 Gerd Althoff (ed.), Die Deutschen und ihr Mittelalter. Themen und Funktionen moderner Geschichtsbilder vom Mittelalter, Darmstadt 1992; Joachim HeINZLE (ed.), Modernes Mittelalter. Neue Bilder einer populären Epoche, Frankfurt / Main 1990; Horst FuhrmanN (ed.), Überall ist Mittelalter. Von der Gegenwart einer vergangenen Zeit, Munich 1996. 
Middle Ages. In this regard, one might cite Johannes FRIED's book, which justifies the relevance of the Middle Ages for the present by highlighting the existence of a medieval 'knowledge society' that cultivated the intrinsic unity of all fields of knowledge. According to FRIED, it was this particular structure, which represents the complete opposite of the present day with its fragmentation of the sciences, different fields of knowledge, and perspectives, that actually gave birth to modern 'knowledge' and science. ${ }^{12}$ Jérôme BASCHET's study of the global social dynamic of the Middle Ages within the paradigm of the ecclesio-feudal order - that is, a style of domination characterized by a logic of service and salvation which controls and dominates through a new combination of the spiritual and the corporeal - proceeds in a different mode but in a similar spirit. BASCHET analyses the cultural techniques that were deployed to command nature, the historicization of time, and Christian universalism. In so doing, he underlines how all these elements combine and simultaneously become the condition and the legacy of the West in its initiatives of colonial conquest. ${ }^{13}$

In both the above instances we might note that the exposition is not placed under any heading that involves the 'usefulness' of the Middle Ages as defined by the period's capacity to explain the present day. This distinguishes both approaches from the multitude of other works which usually do just that. One example of the latter done in a particularly bad way concerns the 'crusades' and 'holy war' in cases where authors assess both in the context of a supposed clash of civilizations and religion between the Christian West and Islam. ${ }^{14}$ Instead of proposing analogies that are as easy to draw as they are erroneous, FRIED and BASCHET underline the necessity of taking into account the specificities and dynamics of the Middle Ages in order to understand with precision, by comparison or imitation - and in BASCHET's case by creation and rupture - why our present has become what it is and why it maintains a troubled relationship with the Middle Ages in particular. This is a relationship that the late Otto Gerhard OEXLE described as a cleft or a split. ${ }^{15}$ More recently, a collection of essays has attempted to move beyond the simple justification of studying the Middle Ages by way of underlining their relationship to the present.

12 Johannes FrIED, Die Aktualität des Mittelalters, Stuttgart 2002.

13 Jérôme BASCHET, La civilisation féodale. De l'an mil à la colonisation de l'Amérique, Paris 2006. 14 It is not unimportant that the latest significant scandal involving the Middle Ages and medievalists to be reported in the French media dates back to the polemics triggered in 2008 (and lasting until 2011) by the appearance of Sylvain GouguenheIM, Aristote au Mont-Saint-Michel, Paris 2008, a book about the translation and transmission - or not - of the works of Aristotle by the Greek or Muslim world, and therefore about the major - or minor - role of the intervention of Arabic in the importation and acculturation of a whole portion of classical political literature in the European and Latin culture of the Middle Ages. For some elements of the ensuing controversy, see e. $g$. Philippe BÜtTGEn / Alain DE LibERA / Marwan RASHED / Irène Rosier-CATACH (eds.), Les Grecs, les Arabes et nous. Enquête sur l'islamophobie savante, Paris 2009.

15 Otto Gerhard OeXLE, Das entzweite Mittelalter, in: ALTHOFF (note 11), pp. 7-28. 
Here the period is understood as the 'object' of scientific scrutiny. These scholars have tried to rehabilitate the Middle Ages' epistemological and heuristic status as an indispensable link in a long-term social dynamic in the West, one which cannot be ignored if we want to understand the latter's development. This allows us to speak of the study of this period in terms of real 'necessity'. In the course of a longterm development that unfolds from the fifth to the eighteenth century, the relationships between individuals, family/kin, space, and religion were fundamentally restructured in comparison with what preceded and what followed. ${ }^{16}$ In this sense the authors of this collective work respond to the question of 'why study the Middle Ages' not primarily by exploring 'how' (practices, writing, sources, etc.) or with a 'because' answer. Rather, they claim, and wholeheartedly embrace, the idea that 'medieval history' should have the status of an Historical Science. Its practice can tell us much about the relationship between History and the Social Sciences, between past and present, and about the fundamental structural elements of a complex human society. On the basis of this approach, the term 'Middle Ages' can be replaced by 'medieval society'.

If one wanted to summarize a 'French' voice - if such a thing even exists (and it has to legitimize itself by way of comparison with other historiographical traditions in Europe) - in a debate that seeks to elucidate the reasons one might put forward in order to argue in favour of the legitimacy and necessity of the study of the Middle Ages, we might identify a set of characteristics. Since this chapter seeks to retain the experimental nature that underlies the entire present volume, I will briefly discuss these reasons in an approach that combines critique and comparison.

\section{Some Suggestions}

These characteristics notably include:

1) the persistent but nevertheless not always accepted recognition that we still do not really know how to work in a comparative way, that is between countries, periods, etc.,

2) the belief that history remains an entity that consists of a chronological unit, of a fixed set of concepts, and tools,

3) the precocious integration, by the Annales School, of anthropological and sociological issues (analysing and understanding 'the social' by all available methods, in other words: treating the Middle Ages as a 'laboratory'),

4) the status of historical science (including the medieval period), which is secured through the structures that ensure the training of elites for the (French)

16 Didier Méhu / Neri de Barros Almeida / Marcelo CÂndido da Silva (eds.), Pourquoi étudier le Moyen Âge? Les médiévistes face aux usages sociaux du passé, Paris 2012. 
Republic and which, in turn, stress the study of history as a project of national identity and as an instrument of democratic acculturation, and

5) the general integration of History as a discipline and as a general way of thinking in an ideological field that can be characterized as progressive rather than conservative. This leads, to put it briefly, to an interpretation of the long-term process that some have chosen to call 'European exceptionalism' or 'divergence' as the original model. It would thus constitute a non-replicable and nonreproducible model of the organization of parental, spatial, and economic links in the service of a specific social and cultural constellation that was, from an anthropological perspective, based on domination over people and land. The links in question would include the types of resource use, remunerated labour, levies on a free but controlled peasantry, household autonomy, urbanization, organization of the monotheist sacred in the dimension of space, monetarization of the economy without monetarization of economic decision-making, articulation of body and spirit based on a specific relationship between culture and nature, and the historicization of time.

\section{'De-medievalizing' the Problem}

In order to answer the question of whether a historical science devoted to the Middle Ages is relevant we should avoid arguing on a purely ontological level, even if this dimension can still play a role, by affirming that 'the study of the Middle Ages is essential because the Middle Ages exist'. Nor can the answer be teleological; Marc BLOCH would have spoken of the "idol of origins", meaning either a period for which one feels nostalgia for a lost time or an era from which Europe did well to free itself though rejection. Finally, we cannot rely exclusively on the argument that studying the Middle Ages contributes to a better understanding of our own present and its phenomena of stratification, its relationship to the religious, or its specific construction of politics and identity. After all, one suspects it is not so much the content of each of these positions that is important today, but rather their combination, their public and academic implications, and their integration into a scientific project that is conscious of the triple specificity and the triple historicity of its objects, its methodology, and its subjects. This project must be attentive to the profound changes that affect the study of history and that arise from the questions that historians choose to ask, but also to history's uses, its techniques (notably the widespread electronic access to sources and the online publication of research results), and its public. For there exist multiple 'Middle Ages', not only in the sense of an historiography, of a period, of a professional discipline, of a specific critical methodology that governs the handling and interpretation of the sources, and of a narrative, but also in the sense of concepts, of a teaching method, and of the uses of the past. These plural, parallel, and competing definitions, carry within themselves one or more contradictions whose very unmasking is actually 
part and parcel of the definition of the subject and therefore its legitimacy. Politicians and the media, to the contrary, would rather that we seek the best ways to essentialize history and to arrange it in a streamlined narrative.

How should we react to these multiple and ideologically motivated expectations? On a very first level, our argument should be based on the assumption that historical knowledge is indivisible (if not unique). Otherwise, we risk reviving internal divisions between the different periods and the academics who represent them, and thereby elevating the importance of one period over another. If we take the initial assertion seriously, it will inevitably lead to the conviction that medievalists possess a wide and open field of enquiry that they can cultivate at the crossroads of Anthropology, the Humanities, and Social Sciences, while their work remains organized around the fundamental need to understand the social production of change in a given period. In order to plead in favour of the relevance of the Middle Ages, a second argument might be added, which fundamentally relies on the unity of the problems that are raised by the observation of history or asked by historians. This unity exists no matter what the individual research question is, whether we work on the history of women, of the individual, of power, of coercion, of rituals, and so on. In all these cases, serious research can never focus exclusively on the Middle Ages, yet it cannot afford to ignore the period either!

Once this preliminary framework is established, the problem of the relevance of medieval studies encourages us to revisit the question of what we might call 'secondary' characteristics of the period. Which elements make the Middle Ages specific and unique, so that the period can neither be merged with another nor exchanged with it, whether that other is its predecessor or successor? In addition, we might ask which mental and structural patterns were characteristic of the Middle Ages and its organization of the social field.

\section{Changing the Vocabulary}

Asking these questions and discussing the answers can have two results. Firstly, it might lead us to rename the 'Middle Ages'. Rather, we might start to talk about 'medieval society', as, for example, Joseph MORSEL has proposed. MORSEL systematically argues for a label that invites attention to a double orientation, temporal and social. ${ }^{17}$ Secondly, we might begin to realize that what we collectively refer to as the

17 Joseph MoRSEL, L'Histoire (du Moyen Âge) est un sport de combat ... deux ans après: retour sur une tentative de légitimation sociale, in: MÉHU / DE BARROS ALMEIDA / CÂNDIDO DA SILVA (note 16), pp. 61-92. In fact, one might also justify the study of the Middle Ages because it makes us aware of the importance of long-term processes when our own societies are currently heavily dominated by a fixation on the short term. 
'Middle Ages' represents nothing more (but also nothing less) than the only period in history that is complete, (more or less clearly) delimited, and documented, and which enables us to observe the beginning and the end of a unique and original social process. This process is characterized by specific parameters that involve the place of religious institutions, the mode of production and work, and the organization of political powers, to name but the most obvious. Thus, the real question is, whether the Middle Ages are 'relevant' because of the specific way in which medievalists analyse medieval society - and because of the relationship between this approach to (or its integration into) a broader practice of understanding change that emanates from the Social Sciences.

In other words, if the 'house of the Middle Ages' is on fire and medievalists are 'firefighters' who may either save it or bury its remains, the cause of the flames themselves lies in reasons that far surpass any intrinsic quality ascribed to the period. Instead, their true origins concern our more general relationship to the past: they include the social demands which confront historians in the twenty-first century, demands that differ from those that faced their nineteenth-century counterparts at a time when History was first constituted as an academic and scientific discipline. The status of the humanities - and more broadly, of the intellectual - has changed in a society that has become addicted to the instant and to technology. Finally, global systems of values and representations have changed.

\section{A Central Question: What do we Lose and What do we Gain?}

In view of all of these points, the relevance of the Middle Ages must be reconsidered not despite but because of these new factors and the environment they create. That relevance must be rethought as part of an intellectual exercise and therefore of an activity that wholeheartedly acknowledges its ideological character. In fact, from this perspective, nothing could be worse than a renewal of scholarly demand for autonomy and learned isolation. The meaning of this exercise is not at its core attached to a chronology composed of dates (for example 410-1492, from the 'fall' of Rome to the 'discovery' of America). Instead, it is rather generated by the questions it brings forth and by the problems it focusses on. The questions concern a subject that occupies a specific place in space and time and whose development was characterized by accidents. This latter should be underlined against all attempts to create erroneous continuities and teleological interpretations. The problems cannot be boiled down to the deadly triptych of 'altérité, identité, européanité' - alterity, identity, and 'Europeanness'. From this perspective the real focus of our reflections about the relevance of the Middle Ages should lie in considering the question of the added scientific value of medieval studies in relation to other historical and social projects: What do we 
lose and what do we gain if we either ignore or try to understand ten to fifteen centuries of history? How do the processes of identification and separation between the Middle Ages and ourselves play out today? How can we argue for the usefulness and relevance of the Middle Ages without falling into the tyranny of a utilitarian discourse that unconsciously condemns medievalists to navigate exclusively between the poles of continuity and alterity?

On the whole, there is obviously no inherent or overarching obligation to study the Middle Ages. The only exception to that statement might be professional medievalists themselves, who do have an immediate (and very material) interest in saving either jobs that are threatened by budget-cuts or certain budgetary elements in specific contexts and institutions. Today, medievalists are in fact confronted with criticism or at least with questions that are addressed to their community as a whole and that concern their subject of study. The very existence of this criticism and of these questions should be reason enough to pause and to listen - we should neither challenge nor dismiss the concerns raised and the underlying motivations connected with them out of hand. ${ }^{18}$ Instead, our real concern should be to try and find, together, the reasons why the observation of a world that has disappeared furnishes helpful 'food for thought' in our present. We should work this out in cooperation, while practising history as a Social Science and as a Cultural Science. The world of the Middle Ages has all but disappeared entirely. Yet the period actually imposes itself on us because it represents at least ten centuries of spatial and social transformation that spans an entire continent. And it furnishes 'food for thought' because it strengthens our sense of history, our sense of democracy, our understanding of society, which is inevitably multiple and complex in nature. But all of this is only true as long we continue to approach the Middle Ages as an historical science that is conscious of the repoliticization of history, of its imperative for self-reflection, of the common interests it shares with other disciplines and of approaches to the perception of time and change.

18 Of course, one could, sooner or later, do away with the 'medieval' discipline, university chairs, or 'medieval' institutes. Yet doing so could erase neither what happened during the period itself nor the relationship that contemporary people necessarily have with it. 



\section{Notes on Contributors}

Erin Connelly recently completed her CLIR postdoctoral fellowship in Data Curation in Medieval Studies at the Schoenberg Institute for Manuscript Studies, University of Pennsylvania Libraries. Her interests involve medieval medical texts, complex networks, and the relevance of medieval medicine for modern infections (ancientbiotics). She collaborates on a wide range of interdisciplinary projects. Among her publications is the volume New Approaches to Disease, Disability and Medicine in Medieval Europe (2018).

Julien Demade is a researcher (chargé de recherche) in Medieval History at the Centre National de la Recherche Scientifique and a member of the Laboratoire de Médiévistique occidentale de Paris at the Université Paris 1 Panthéon-Sorbonne. His work focusses on late medieval economic history and economic and social theory. His publications include Les embarras de Paris, ou l'illusion techniciste de la politique des déplacements (2015) and Produire un fait scientifique. Beveridge et le comité international d'histoire des prix (2018).

Laura Grazia Di Stefano recently obtained her PhD in History from the University of Nottingham. Her work focusses on Venice's organization of pilgrimage to the Holy Land during the late Middle Ages. She also specializes in the codicology and palaeography of medieval texts. Among her recent publications is "An Overlooked Manuscript of the Italian Mandevillian Tradition: Florence, Biblioteca Medicea Laurenziana, MS Ashburnham n. 1699 'Viaggio di Giovanni Mandevilla tradotto in Italiano"”, in: Manuscripta 61(1) (2017), pp. 1-20.

Jörg Feuchter teaches Medieval History at Humboldt University Berlin and is a researcher at the Berlin-Brandenburg Academy of Sciences and Humanities, where he is head of the Academy-hosted project "Regesta Imperii - Regesten Kaiser Friedrichs III. (1440-1493)". Feuchter has worked on a broad range of topics, including medieval politics regarding religious minorities (heretics, Jews), pre-modern political culture (political oratory in representative assemblies), and scientific approaches to the past (Genetic History). He was one of the conveners of the first scientific conference bringing together geneticists, historians, and archaeologists in Germany. His publications include Ketzer, Konsuln und Büßer: Die städtischen Eliten von Montauban vor dem Inquisitor Petrus Cellani (1236/1241) (2007).

Freya Harrison is an Associate Professor of Microbiology at the University of Warwick. Her research focusses on understanding and treating chronic bacterial infections. She led the reconstruction and testing of Bald's eyesalve and her group is exploring other historical remedies for sources of natural product antibiotics. She has published widely on the microbiology of antibiotic-resistant biofilm infections and the development of lab methods for studying chronic bacterial pathogens in in vivo-like conditions.

Ben Jervis is Lecturer in Archaeology at Cardiff University. His research develops new materialist approaches to the study of medieval material culture and urbanism. He is the author of Pottery and Social Life in Medieval England: Towards a Relational Approach (2014) and Assemblage Thought and Archaeology (2019). He is editor of the journal Medieval Ceramics. 
Elva Johnston is an Associate Professor in the School of History, University College Dublin, with a research focus on Late Antique and Early Medieval Ireland. Her monograph, Literacy and Identity in Early Medieval Ireland (2013), was awarded the Irish Historical Research Prize (2015) for the best new work of Irish historical research. She is a general editor of Peritia: The Journal of the Medieval Academy of Ireland and a member of the Irish Manuscripts Commission.

Chris Jones, FSA is an Associate Professor at the University of Canterbury, New Zealand. His work focusses upon medieval France and political thought. Among his publications are the monograph Eclipse of Empire? Perceptions of the Western Empire and Its Rulers in Late Medieval France (2007), the edited collection John of Paris: Beyond Royal and Papal Power (2015), and the Canterbury Roll Project (2017). He is the current President of the Australian \& New Zealand Association for Medieval \& Early Modern Studies Inc. (ANZAMEMS).

Tobias Kluge heads a junior research group at the Institute of Environmental Physics at Heidelberg University that is part of the Heidelberg Graduate School of Fundamental Physics (HGSFP). The group's work focusses on understanding isotope systems and their application to palaeoclimate research.

Conor Kostick is a Research Fellow with the Department of History, Trinity College Dublin, working on the Climates of Conflict in Ancient Babylonia (CLICAB) project. He has authored or edited eighteen books, including The Social Structure of the First Crusade (2008).

Frank Ludlow is Assistant Professor of Medieval Environmental History in the Department of History, Trinity College Dublin. He has previously been a Marie Sklodowska-Curie Individual Fellow in the Department of History, Trinity College Dublin, a Postdoctoral Fellow at Yale University, a Carson Fellow at the Rachel Carson Center for Environment and Society at LMU Munich, and he held an Environmental Fellowship at Harvard University.

Pierre Monnet is Directeur d'études at the École des Hautes Études en Sciences Sociales in Paris (from 2005) and director of the Institut Franco-Allemand de Sciences Historiques et Sociales at the GoetheUniversität Frankfurt (from 2011), where he also teaches as Adjunct Professor. His research focusses on the history of late medieval cities and political systems in Europe. His recent publications include Villes d'Allemagne au Moyen Âge (2004), the edited collection Bouvines 1214-2014: Histoire et mémoire d'une bataille / Eine Schlacht zwischen Geschichte und Erinnerung (2016), and Charles IV (1316-1378). Un empereur en Europe (2020, forthcoming).

Klaus Oschema is Professor in (Late) Medieval History at the Ruhr-University Bochum. His work focusses on late medieval court culture (France, Burgundy), political and social practices, and medieval perceptions of the world in a transcultural perspective. He has published Bilder von Europa im Mittelalter (2013) and Freundschaft und Nähe im spätmittelalterlichen Burgund (2006). He was Gerda-Henkel-Member at the Institute for Advanced Study in Princeton, New Jersey (20162017) and is a Member of the Konstanzer Arbeitskreis für mittelalterliche Geschichte (since 2019). He is a board-member of the German Mediävistenverband e.V.

Maximilian Schuh is a Lecturer in Medieval History at the Freie Universität Berlin. His research focusses on the history of universities in the Holy Roman Empire and the environmental history of fourteenth-century England. His publications include Aneignungen des Humanismus. Institutionelle und individuelle Praktiken an der Universität Ingolstadt im 15. Jahrhundert (2013). 
Hélène Sirantoine is a Senior Lecturer at the University of Sydney. She researches Iberian medieval history, with a particular focus on the written culture of the kingdom of Castile and León up to the mid-thirteenth century. Her publications include the monograph Imperator Hispaniae: les idéologies impériales dans le royaume de León (IXe-XII ${ }^{e}$ siècles) (2012), and the edited collections Chartes et cartulaires comme instruments de pouvoir: Péninsule ibérique et Occident chrétien $\left(V_{I I I}{ }^{e} X I I^{e}\right.$ s.) (2013, with Julio Escalona) and Epistola 2. La Lettre diplomatique. Écriture épistolaire et actes de la pratique dans l'Occident latin médiéval (2018).

Madi Williams, Ngāti Kuia, Ngāti Koata, Ngāti Apa ki te Rā Tō is a PhD candidate at the University of Canterbury, New Zealand. Her research is focussed on Māori and indigenous perceptions of the past and tribal histories. She is currently preparing a volume on Polynesia, 900-1600 (forthcoming with ARC-Humanities Press).

Niamh Wycherley is currently the NUI (National University of Ireland) Postdoctoral Fellow in Irish / Celtic Studies, and is situated at the Moore Institute, NUI Galway. Her research focusses on the terminology and language of relics in Medieval Ireland. She won the NUI Publication Prize in Irish History 2017 for her monograph The Cult of Relics in Early Medieval Ireland (2015). 



\section{Index}

A Thesaurus of Old English 125

Abenragel $\rightarrow$ Haly Abenragel

Adger, Neil 272

Adomnan of lona 64

Adso of Montier-en-Der 64

Áed, son of Niall 249-250

Albumasar 196

Alcabitius 196

Alexander III, pope 178,180

Alexander the Great 200

Alfonso VI, king of Castile-León 233

Alfonso VII, king of Castile-León 233-235, 237-238

Alfonso X, king of Castile-León 230

'Alī ibn Yūsuf, sultan of Morocco 234

Allgäu, southern Germany 40

Alt-Right 9

Ambrogio Varesi da Rosate 202

Ambrose, saint, bishop of Milan 248, 252

An Claidheamh Soluis 214

Anderson, Ben 259-260

Annales School 283

Annals of Ulster 249-250

ANZAMEMS (Australian and New Zealand Association for Medieval and Early Modern Studies) 26

Ardern, Jacinda, Prime Minister, Aotearoa New Zealand 152

Aristotle 199-200

Armagh, Ireland 244, 249-250

Assicus 244

Avitus of Vienne 248

Azzolini, Monica 202

Bacco, saint 188

Baillie, Mike 60-61, 67

Bald's Leechbook 118-130

Baltimore, Walters Art Museum, USA 241

Bandinel, Bulkeley 182

Barcelona, Spain 231

Baschet, Jérôme 282

Basel, Switzerland 32, 203

Baumeisterbuch 40-41

Beijing Normal University, China 49

Bell, Avril 161

Bennett, Jane 263

Beoán, saint 248
Beowulf 10

Berlin Wall 8

Bernhard von Breydenbach 175-176, 178, 180, 182

Berrad Airechta 250

Bierbaumer, Peter 125

Black Death (see also: Justinian Plague) 100-102, 205, 256, 262

Blainey, Geoffrey 155

Bloch, Marc 12, 279

Bologna, University of, Italy 197

Boston, Grand Summit Hotel, USA 49

Boucheron, Patrick 28

Bovevagh, Co. Derry, Ireland 246

Bracton, Henry de $\rightarrow$ Henry de Bracton

Bragg, Melvyn 20

Branagh, Kenneth, actor and director 2

Brennessel, Barbara 120

Bretha Nemed Toîsech 248

Brigit, saint 244-245

British Academy 26, 133

British Museum $\rightarrow$ London

Brunetti, Mario 178

Bucintoro 178-179

Burckhardt, Jacob 4

Burke, Peter 4

Butterfield, Herbert 166

Byrne, Francis John 214

Cáin Adamnáin 249

Canterbury Roll Project 167-168

Canterbury, University of, Aotearoa New Zealand 156, 162-165, 167-169

Celtic Ireland 223-224

Centiloquium 205

Charles V, king of France 200, 202

Chelleri, Lorenzo 258

Chinese Academy of Social Sciences 49

Christchurch, Aotearoa New Zealand 2, 152, 154, 157, 162, 169

Chronica Adefonsi Imperatoris 233-235, 237-238

Chronicle of Alfonso III 229

Chur, Switzerland 203

Clavier, Christian, actor 225

Cleveland Museum of Art, USA 241

Clonmacnoise, Ireland 247

Ә Open Access. (C) 2020 Chris Jones, Conor Kostick, Klaus Oschema, published by De Gruyter. (c) BY-NC-ND This work is licensed under a Creative Commons Attribution-NonCommercial-NoDerivatives 4.0 International License. https://doi.org/10.1515/9783110546316-016 
Cogitosus 244-245

Cóic Conara Fugill 250

Coke, Sir Edward 158

Collectio Canonum Hibernensis 247-248

Colmán, bishop 248

Conláed, bishop of Kildare 244-245

Conquest of Paradise, song 154

Conrad of Megenberg 4

Conway, Kellyanne 3-5

Córdoba, Spain 230, 235

Corneille, Pierre 226

Córus Bésgnai 247

Crouzet-Pavan, Élisabeth 179

Crusaders (rugby team, Christchurch, Aotearoa New Zealand) 11, 154-158

Crusaders (rugby team, UK) 155

Crutzen, Paul 48, 50

Cummian 243

Curry, Olaf 54

Curtis, Daniel 258

Davey, Francis 182-183

Dead Sea 231

DeLanda, Manuel 263, 265, 267, 272

Deleuze, Gilles 263

Detroit, USA 274

Deutsch, Lorànt 20

Di Carpegna Falconieri, Tommaso 29

Diabetes UK 123, 134

Dialogue against the Jews 231

Dictionary of Old English Plant Names 124-125

Dictionary of Old English Web Corpus 124

Diego Gelmîrez, archbishop of Santiago de Compostela 232

Donnchad of Meath 249-250

Drout, Michael D. C. $120,127,134$

Dublin, Ireland 14, 212, 219, 252

Dublin, Ireland, Christ Church Cathedral 252

Dublin, Ireland, University College 222

Duffy, Seán 217, 222

Dúnchú, superior of Tullylish 249

Dunedin, Aotearoa New Zealand 154

Dunseverick, Co. Antrim, Ireland 244

Durkheim, Emile 241

Dye-3 (ice core site, Greenland) 60

Early Irish Laws and Institutions 223

Easter Rising, 1916, Ireland 213

Edward III, king of England 158
El Niño-Southern Oscillation 56

Eliade, Mircea 173

Elizabeth II, queen of the UK, Head of the Commonwealth 159

Erhard Storch, canon of Chur cathedral, Switzerland 203

Etna, Sicily, Italy 46

Eton College 182-183

Etymologies 229

Eulogius of Córdoba 229

Evagatorium in Terrae Sanctae 174

Ezzelino da Romano 202

Fabri, Felix $\rightarrow$ Felix Fabri

Febvre, Lucien 16

Felix Fabri 174, 177, 179-181

Fiera della Sensa 178

Fisher's Exact Test 126

Flann Mainistrech 214

Flexner, Abraham 14-15

Fränkische Alb, northern Bavaria 36

Franklin, Benjamin 47

Frederick II, Holy Roman emperor, king of Sicily and Jerusalem 202

Fried, Johannes 282

Fursa 248

Game of Thrones, TV-series 2

Geary, Patrick J. 18, 104, 106, 242

Geisbusch, Jan 253

Genesis, biblical book 231

Genoa, Italy 231, 272

GICC05 (Greenland Ice Core Chronology 2005) 60-61

GISP2 (Greenland Ice Sheet Project 2) 59-60

Glanvill(e) $\rightarrow$ Ranulf de Glanvill

Glaser, Rüdiger 37

Glasgow, University of, Scotland 145

Gordon Research Conferences 49

Graceland, Memphis / TN, USA 253

Gravel, Robyn 120

Green, Monica H. 102

GRIP (Greenland Ice Core Project) 60

Groebner, Valentin 11

Guattari, Felix 263

Hallyday, Johnny, singer and actor 139

Haly Abenragel 196

Hamilton, William Rowan 14-15 
Hautes Etudes Commerciales (HEC), Paris 141 Henry II, king of England 218

Henry V, king of England 206

Henry VI, king of England 183

Henry de Bracton 158

Henry of Langenstein 198

Herbert, Máire 247

Hermann of Reichenau 73

Highlanders (rugby team, Dunedin, Aotearoa New Zealand) 154

Historia Arabum 230

Historia Compostellana 232

Historia Roderici 232, 238

Hogan, Edmund 213, 222

Hölloch, cave in southern Germany 40-41

Hollywood Forever, cemetery, Los Angeles, USA 253

Holy Roman Empire 31-32

Hooper, Steven 242

Hugh Capet, king of France 138

Hugo, Victor, poet 139

Hurricane Katrina 259

Hyde, Douglas 215

Imperial Laws Application Act, 1988, Aotearoa New Zealand 158

Inishboffin, Ireland 248

Institute for Advanced Study (IAS), Princeton / NJ, USA 14

International Medieval Congress, Leeds,

UK 26, 28

Ireland under the Normans 217

Irish Boundary Commission 213

Irish Manuscripts Commission 213

Isidore of Seville 229

Jackson, Peter, director 2

Jerome, saint 228

Jerusalem 175, 180-181, 185

Joan of Arc 138

Johannes Hopper, provost of Chur Cathedral, Switzerland 204

Johannes Knebel, cleric at Basel, Switzerland 203-204

John II, king of France 205-206

John Arderne 128

John Ashenden, astrologer 205-206

John of Patmos, evangelist 187
Journal of the Royal Society of Antiquaries of Ireland 218

Justice, Steven 243

Justinian Plague 94, 101

Keith, David 49

Keutsch, Frank 49

Killabuonia, Ireland 246

Killoluiag, Ireland 246

Kilpeacan, Ireland 246

Kipfmueller, Kurt 70-71

Kleine Teufelshöhle, cave near Nuremberg 36

Krakatau, volcano, Indonesia 47, 67

Lakagîgar, volcano, Iceland 47

Laudabiliter, papal bull 218

Laurence 0'Toole, saint, archbishop of Dublin, Ireland 252

Laurens Pignon 198

Lawrence, Mark G. 50

Lawrence, saint 244-245

Le Cid, play by Pierre Corneille 226

Leahy, Pat 252

Les Visiteurs, film (1993) 225-226, 228

Liber Angeli 245, 249

Life of Brigit 244

Life of Munnu 247

Life of St Olegarius 231

Life of St Columba 64

Lindisfarne, monastery, UK 248

London, British Museum 241

Loveluck, Christopher 265

Ludovico “il Moro", duke of Milan 202-203

Lylye of Medicynes 127, 130

Magna Carta 157-159

Magnus, saint $182,187,188$

Mark, saint 180

Markle, Meghan 253

Marochetti, Carlo 155

Martel, Charles 10

Martin, George R. R. 2

Martin, Ron 256

McAneney, Jonny 67

McCarthy, Daniel 92

Mecca 171

Mediävistenverband 26

Meldán, saint 248

Messahalla 196 
Meyer, Kuno 217

Milan, Italy 202, 248, 252

Miracles of St Mansuy 64

Monumenta Germaniae Historica 213

Morris, William 155

Morsel, Joseph 285

Mount St Helens / WA, USA 67

Mountfort, Benjamin 154-155

Mozarabic Chronicle of 754230

Mucneus 244

Nash, Ogden 25

National Research Council, USA 66

NEEM S1 (North Greenland Eemian Ice Drilling) 67

NGRIP (North Greenland Ice Core Project) 60

Nicaea, Ecumenical Council of 787248

Nicole Oresme 198, 202, 204

Nördlingen, southern Germany 32

North Atlantic Oscillation 56

Nottingham, University of, UK 26, 134

Nuremberg, southern Germany 32, 34-43

Nussbaum, Martha 22

O’Brien, Elizabeth 246

Oexle, Otto Gerhard 7-8, 282

Olcán 244

Olympic Games 139

Orpen, Goddard Henry 216-223

Oxford, Exeter College, UK 182-183

Oxford, University of, UK 144, 146, 205

Parnell Crisis, Ireland 213-214

Pasteur, Louis 139

Patrick, saint 244-245, 248-250

Paul, saint 244-245, 250

Peasants' Revolt, 1381266

Pegnitz, river, southern Germany 34-43

Peter, saint 244-245, 250

Peters, Winston, Deputy Prime Minister, Aotearoa New Zealand 161

Petitfils, Jean-Christian 20

Petrus Alfonsi 231

Phases of Irish History 219-220, 222-223

Pietro Casola 178, 181

Pius II, pope 183

Plague $\rightarrow$ Justinian Plague; Black Death

Pliny the Elder 47

Plutarch 47
Poitiers, battle, 1356205

Postel, Guillaume 180

Presley, Elvis, singer and actor 253

Primera Crónica General 230

Prince Harry 253

Pseudo-Apuleius Herbarius 128

Pseudo-Aristotle 200

Pseudo-Ptolemy 205

Ptolemy 196

Ramon Berengar III, count of Barcelona 231

Ranke, Leopold von 6, 29

Ranulf de Glanvill 158

Renallo, bishop of Barcelona 231

Reno, Jean, actor 225

Revelation, biblical book 185, 187

Reynolds, Jesse 54

Riagail Phátraic 247

Rice, Geoffrey 156

Roberto Sanserverino 177, 181

Rodrigo Jiménez de Rada, archbishop of Toledo 230

Rolandino of Padova 201-202

Rome, Italy 171, 243, 248, 286

Royal Society APEX Award 129

Sachellus 244

Salzer, Matthew 71

Samalas, volcano, Indonesia, eruption 125769,92

Saracens (rugby club, UK) 155

Saunders, J. J. 156

Sayf al-Dawla, ruler of Rueda, Spain 237

Schick, Carol 164

Sebastiano Ziani, doge of Venice 180

Secretum Secretorum 200

Sergio, saint 188

SHMESP (Société des Historiens Médiévistes de l'Enseignement Supérieur Public), France 15

Sigl, Michael 61

Simmie, James 256

Sinn Féin 219

Smith, Julia 242

Sorbonne, Paris 139

Southampton, UK 256, 262-264, 267-274

Sowié, Théophile Moussa, actor 225

Sposalizio del Mare 177-178, 187-188 
Statute of Westminster, 1275158

Staufen dynasty 32

Stephen, saint 244-245

Storch, Erhard $\rightarrow$ Erhard Storch

Strasbourg University, France 139

Sullivan, Keith 161

Summa judicialis de accidentibus mundi 205

Super Rugby League, Aotearoa New Zealand 154

Taghmon 247

Tait, James 219

Tambora, volcano, Indonesia, eruption 181567

Tara, Ireland 215

Tarragona, Spain 231

Tertiary Education Strategy 2014-2019 (New Zealand Ministry of Education Te Tāhuhu o Te Mātauranga) 13

The Heptads 250

Thor, film (2011) 2

Tirechán 244-245

Todd, Chuck 5

Tolkien, J. R. R. 2

Treasures of Heaven, exhibition 241-242

Treaty of Waitangi $\rightarrow$ Waitangi

Trump, Donald 3, 193

Tucher, Endres 40

Tullylish, Ireland 249

Vangelis, band 154

Varesi da Rosate, Ambrogio $\rightarrow$ Ambrogio Varesi da Rosate

Venice 171-190, 272

Venice, Arsenal 175, 177-179, 188

Venice, Doge's Palace 175, 180, 188

Venice, Marciana Library 188

Venice, Murano 174-175, 179

Venice, piazza San Marco 178, 185, 188

Venice, San Cipriano 176, 188-189

Venice, San Daniele 176-177, 188

Venice, San Domenico 176, 188-189

Venice, San Geremia 176, 185, 189
Venice, San Giacomo di Rialto 182, 189

Venice, San Girolamo 183, 185, 189

Venice, San Marco 185-187

Venice, San Nicolò (St Nicholas on the Lido) 176, 179, 188-189

Venice, San Pietro di Castello 176-177, 185, 187-189

Venice, San Polo 174, 181, 189

Venice, San Secondo 176, 188-189

Venice, San Silvestro 176, 182, 189

Venice, San Zaccaria 176-177, 182, 189

Venice, Santa Maria dei Frari 181

Venice, Santa Maria Formosa 176, 181, 187, 189

Venice, Sant'Elena 176-177, 183, 189

Venice, Santi Apostoli 176-177, 182, 189

Venice, Santo Brasca 178, 179, 181

Verbeek, Rogier D. M. 47

Victorius of Aquitaine 219

Virgil, poet 46

Virtutes Fursei 248

Waitangi, Treaty of, 1840 158, 160-162, 165

Walsham, Alexandra 247

Wassergüß in Nürnberg 37-39

Weill, Kurt 25

Westminster, Palace of, UK 155

Whitby, Synod of, 664248

White, Hayden 16

William Wey 171-190

Winchelsea, UK 268

Winchester, UK 273

World View Enterprises 49

Yaḥyā ibn Gāniya, governor of al-Andalus 235

Youyou, Tu 130

Zaragosa 237

Zhejijang University, Hangzhou, China 49

Zidane, Zinedine, footballer and coach 139

Zoolithen Cave, cave, southern Germany 36-37 
